\title{
Lewis Base Activation of Lewis Acids: Catalytic, Enantioselective Vinylogous Aldol Reactions
}

Scott E. Denmark and John R. Heemstra, Jr.

Department of Chemistry, University of Illinois Urbana-Champaign, Urbana, Illinois 61801

\section{SUPPORTING INFORMATION}

Table of Contents

Page

General Experimental S1

Literature Preparations $S 2$

Experimental Procedures S4

Preparations of Silyl Dienol Ethers S4

Preparations of Bissilyl Dienol Ethers S8

Preparations of Conjugated $\mathrm{N}, \mathrm{O}$-Silyl Ketene Acetals S14

Vinylogous Aldol Additions of Silyl Dienol Ethers $S 25$

Vinylogous Aldol Additions of Bissilyl Dienol Ethers $S 40$

Vinylogous Aldol Additions of Conjugated $\mathrm{N}, \mathrm{O}$-Silyl Ketene Acetals 557

Preparation of tert-Butyldimethylsilyl Ether $\mathbf{8 6}$

S116

Preparations of Methyl Ketone $\mathbf{8 7}$

$S 118$

Determination of the Absolute Configuration of the Vinylogous Aldol Adducts

S120

Calculated Structure of the Aldehyde-Silyl cation Complex (Figure 7)

$S 130$

References

$S 135$

${ }^{1}$ H NMR Spectra

$\mathrm{S} 137$

\section{General Experimental}

All reactions were performed in oven-dried $\left(140{ }^{\circ} \mathrm{C}\right)$ or flame-dried glassware under an atmosphere of dry $\mathrm{N}_{2}$ or Argon. All reaction temperatures correspond to internal temperatures measured by Teflon-coated thermocouples unless otherwise noted. Reaction solvents including dichloromethane (HPLC Grade), diethyl ether (BHT stabilized HPLC Grade) and tetrahydrofuran (HPLC Grade) were dried by percolation through two columns packed with neutral alumina under a positive pressure of argon. Reaction solvent acetonitrile was used as 
received. Solvents for chromatography and filtration were: diethyl ether, hexane (ACS grade), ethyl acetate (technical grade, distilled from $\mathrm{K}_{2} \mathrm{CO}_{3}$ ), pentane (ACS grade), dichloromethane (technical grade, distilled from $\mathrm{CaCl}_{2}$ ), $\mathrm{MeOH}$ (ACS grade, distilled from $\mathrm{K}_{2} \mathrm{CO}_{3}$ ). Column chromatography was performed using SiliaFlash P60 (40-63 $\mu 60$ Å pore size).

${ }^{1} \mathrm{H}$ NMR, ${ }^{13} \mathrm{C}$ NMR, ${ }^{19} \mathrm{~F}$ NMR spectra were recorded at $400 \mathrm{MHz},{ }^{1} \mathrm{H} ; 100 \mathrm{MHz},{ }^{13} \mathrm{C}, 376$ $\mathrm{MHz},{ }^{19} \mathrm{~F}$, and $500 \mathrm{MHz},{ }^{1} \mathrm{H} ; 126 \mathrm{MHz},{ }^{13} \mathrm{C}$. Spectra were referenced to residual chloroform (7.26 ppm, ${ }^{1} \mathrm{H}, 77.00 \mathrm{ppm},{ }^{13} \mathrm{C}$ ) and ${ }^{19} \mathrm{~F}$ spectra were referenced externally to $\mathrm{C}_{6} \mathrm{~F}_{6}$. Chemical shifts are reported in ppm, multiplicities are indicated by s (singlet), d (doublet), $t$ (triplet), $q$ (quartet), p (pentet), h (hextet), m (multiplet) and br (broad). Coupling constants, $J$, are reported in Hertz. ${ }^{1} \mathrm{H}$ NMR and ${ }^{13} \mathrm{C}$ NMR assignments are corroborated by $2 \mathrm{D}$ experiments (COSY, HMBC, HMQC, and HETCOR). Spectra are available on request from denmark@scs.uiuc.edu. EI, CI, and FI mass spectra are reported in the form of $(\mathrm{m} / \mathrm{z})$. Infrared spectra (IR) are reported in $\mathrm{cm}^{-1}$ with indicated relative intensities: s (strong, 67-100\%); m (medium, 34-66\%); w (weak, 0-33\%). Melting points (mp) were determined in sealed tubes and are corrected. Kugelrohr distillation temperatures reported are air bath temperatures (ABT). Rotary evaporations were performed at $30{ }^{\circ} \mathrm{C}$ and $14 \mathrm{mmHg}$. Analytical thin-layer chromatography was performed on silica gel $60 \mathrm{~F}_{254}$ TLC plates. Visualization was accomplished with UV(254), and potassium permanganate $\left(\mathrm{KMnO}_{4}\right)$, staining solutions.

Optical rotation data was obtained on a digital polarimeter and are reported as follows: concentration ( $c=g / 100 \mathrm{~mL}$ ), and solvent. Analytical supercritical fluid chromatography (CSPSFC) was performed with packed-column SFC with built-in photometric detector (220 nm) using Daicel Chiralpak OD, OJ, OB, AD and AS columns as well as a Regis Whelk-O1 column. Ozonolyses were performed with a 1 slpm flow rate. Fourier transform IR analysis was performed using a ReactIR 1000 purchased from ASI Applied Systems INC., 8223 Coverleaf Drive, Suite 120, Millersvile, MD 21108. Reactions were monitored using 5/8" Dicomp probe fitted to an MCT detector. Acquisitions were recorded using software version 3.0.

Dienol ethers 32c, 32d, 33a, 33c, 43, 81, and 82 were too unstable to obtain full characterization and the assignments of these structures should be considered tentative. Similarly, minor products $\mathbf{1 7}, \mathbf{3 9}, \alpha \mathbf{- 5 0}, \alpha \mathbf{- 5 1}$, and $\mathbf{8 5}$ were not isolated in quantities sufficient for full characterization and the assignments of these structures should be considered tentative. 


\section{Literature Preparations}

The preparation of 1-trimethylsilyloxy-1,3-cyclohexadiene (10) followed the procedure described by Fleming et. al. ${ }^{1}$

The preparation of $(R, R)-N, N^{\prime}$-bis[4,5-dihydro-3,5-dimethyl-4-(3H-dinaphtho[2,1$\mathrm{d}: 1$ ',2'-f][1,3,2]-2-oxo-diazaphosphephepino)]- $N, N^{\prime}$-dimethyl-1,5-pentanediamine $\quad((R, R)-3)$, $(R, R)-N, N$ '-bis[4,5-dihydro-3,5-dimethyl-4-(3H-dinaphtho[2,1-d:1',2'-f][1,3,2]-2-oxodiazaphosphephepino)]-N,N'-dimethyl-1,4-butanediamine $((R, R)-35)$, and $(R, R)-N, N^{\prime}$-bis[4,5dihydro-3,5-dimethyl-4-(3H-dinaphtho[2,1-d:1',2'-f][1,3,2]-2-oxo-diazaphosphephepino)]- $N, N^{\prime}$ dimethyl-1,6-hexaneanediamine $((R, R)-36)$, followed the procedure described by Denmark and Wynn. $^{2}$

The preparation of $(R)$-1,3-dimethyl-2,3-dihydro-2-piperidinyl-dinaphtho-[2,1-c:1'2'-e]1H-[1,3,2]diazaphosphepine 2-oxide $\quad((R)-37), \quad(4 R, 5 R)-1,3-D i m e t h y l-4,5-d i p h e n y l-1-(1-$ piperidinyl)-1,3,2-diazaphospholidine 2-Oxide $((R, R)-\mathbf{3 8})$ followed the procedure described by Denmark et. $a .^{3}$

The preparation of 2-butenoic acid dimethylamide, 2-butenoic acid diethylamide, 1[(2E)-1-oxo-2-butenyl]piperidine, 4-[(2E)-1-oxo-2-butenyl]morpholine, 4-[(2E)-1-oxo-2-methyl2-butenyl]morpholine, and 4-[1-oxo-3-methyl-2-butenyl]morpholine, 4-[(2E)-1-oxo-2pentenyl]morpholine followed the procedure described by Ongoka et. al. ${ }^{4}$

2-tert-Butyldimethylsilyoxyacetaldehyde, ${ }^{5} \quad$ 2-benzyloxyacetaldehyde, ${ }^{6} \quad$ 3-tertbutyldimethylsilyoxypropionaldehyde, ${ }^{7} \quad 3$-benzyloxypropionaldehyde, ${ }^{8}$ 3allyloxypropionaldehyde, ${ }^{9}$ 3-benzoyloxypropionaldehyde, ${ }^{10}$ 3-pivoyloxypropionaldehyde, ${ }^{11}$ 6benzyloxyhexanal ${ }^{12}$ were prepared by literature methods. 


\section{Experimental Procedures.}

\section{Preparations of Silyl Dienol Ethers}

\section{Representative Procedure 1. Enolization of $\alpha, \beta$-Unsaturated Ketones to Form Silyl Dienol} Ethers. Preparation of (Z)-1-(Phenylbuta-1,3-dienyloxy)trimethylsilane (6) (Scheme 3)

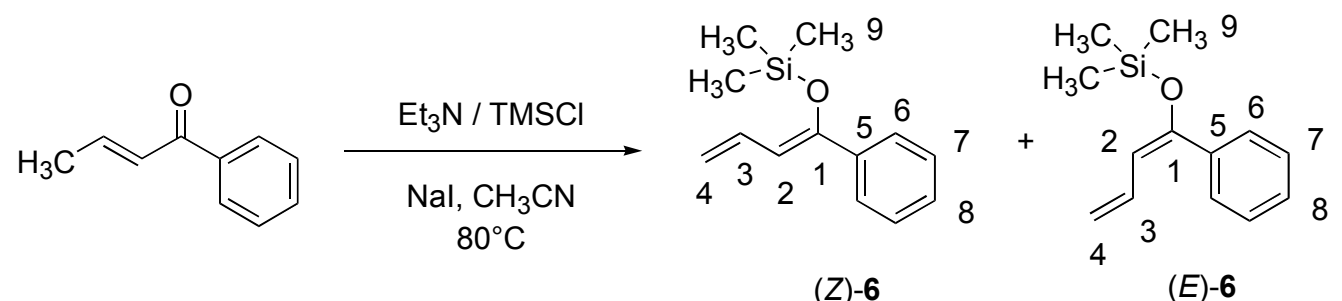

To a flame-dried 100-mL, 3-necked, round-bottomed flask fitted with a magnetic stir bar, thermocouple, gas inlet tube, and septum was added $2.85 \mathrm{~g}$ (20.0 mmol, 1.0 equiv) of 1-phenyl2-buten-1-one, $3.46 \mathrm{~mL}$ (24.8 mmol, 1.24 equiv) of $\mathrm{Et}_{3} \mathrm{~N}$ and $3.15 \mathrm{~mL}$ (24.5 mmol, 1.24 equiv) of TMSCl. Then, a solution of $3.72 \mathrm{~g}$ (24.8 mmol, 1.24 equiv) of $\mathrm{NaI}$ in $25 \mathrm{~mL}$ of $\mathrm{CH}_{3} \mathrm{CN}$ was added slowly dropwise over 5 min via cannula. The resulting solution was then placed in an oil bath at $80{ }^{\circ} \mathrm{C}$ and stirred for $6 \mathrm{~h}$. The mixture was cooled to $\mathrm{rt}$ and $50 \mathrm{~mL}$ of cold pentane was added. The organic layer was then separated and the aqueous layer was washed with pentane (3 x $50 \mathrm{~mL})$. The combined organic extracts were washed with $\mathrm{H}_{2} \mathrm{O}(2 \times 50 \mathrm{~mL}), \mathrm{CuSO}_{4}$ (sat. aq.) $(2 \times 50 \mathrm{~mL})$, and brine $(50 \mathrm{~mL})$, dried over $\mathrm{Na}_{2} \mathrm{SO}_{4}(10 \mathrm{~g})$, filtered and the filtrate concentrated in vacuo. The resulting residue was purified by bulb-to-bulb distillation to yield $4.135 \mathrm{~g}(95 \%$, $Z: E, 60: 40)$ of 6 as a clear, colorless oil. ${ }^{13}$

Data for 6:

bp: $\quad 60{ }^{\circ} \mathrm{C}(0.05 \mathrm{mmHg}, \mathrm{ABT})$

${ }^{1}$ H NMR: $\quad\left(500 \mathrm{MHz}, \mathrm{CDCl}_{3}\right)$

$7.53(\mathrm{dt}, J=7.3,1.7,2 \mathrm{H},(Z)-\mathrm{HC}(6)), 7.42$ (dt, $J=7.1,1.7,2 \mathrm{H},(E)-\mathrm{HC}(6))$, 7.37-7.31 (m, $6 \mathrm{H},(Z)-\mathrm{HC}(7)$ and $(E)-\mathrm{HC}(7,8), 7.28-7.25(\mathrm{~m}, 1 \mathrm{H},(Z)-\mathrm{HC}(8))$, $6.74(\mathrm{dt}, J=17.1,10.5,1 \mathrm{H},(Z)-\mathrm{HC}(3)), 6.48(\mathrm{dt}, J=16.7,10.8,1 \mathrm{H},(E)-\mathrm{HC}(3))$, $6.06(\mathrm{~d}, J=10.7,1 \mathrm{H},(Z)-\mathrm{HC}(2)), 5.78(\mathrm{~d}, J=11.0,1 \mathrm{H},(E)-\mathrm{HC}(2)), 5.22(\mathrm{~d}, J=$ 17.1, $1 \mathrm{H},(Z)-\mathrm{HC}(4)), 5.10(\mathrm{~d}, J=16.8,1 \mathrm{H},(E)-\mathrm{HC}(4)), 5.03(\mathrm{~d}, J=10.3,1 \mathrm{H}$, $(Z)-\mathrm{HC}(4)), 4.85$ (d, $J=11.3,1 \mathrm{H},(E)-\mathrm{HC}(4)), 0.19$ (s, $\left.9 \mathrm{H},(E)-\mathrm{H}_{3} \mathrm{C}(9)\right), 0.17$ (s, $\left.9 \mathrm{H},(Z)-\mathrm{H}_{3} \mathrm{C}(9)\right)$ 


\section{NOE ${ }^{1} \mathrm{H}$ NMR: $\left(500 \mathrm{MHz}, \mathrm{CDCl}_{3}\right)$}

Irradiation at $6.06 \mathrm{ppm}((Z)-\mathrm{HC}(2))$ enhanced signal at $7.53 \mathrm{ppm}((\mathrm{Z})-\mathrm{HC}(6))$ and $5.22 \mathrm{ppm}((Z)-\mathrm{HC}(4))$. Irradiation at $6.48 \mathrm{ppm}((\mathrm{E})-\mathrm{HC}(3))$ enhanced signal at $7.42 \mathrm{ppm}((E)-\mathrm{HC}(6))$ and $4.85 \mathrm{ppm}((E)-\mathrm{HC}(4))$

${ }^{13} \mathrm{C} \mathrm{NMR}: \quad\left(126 \mathrm{MHz}, \mathrm{CDCl}_{3}\right)$

$152.9((E)-\mathrm{C}(1)), 150.4((Z)-\mathrm{C}(1)), 138.2((Z)-\mathrm{C}(5)), 137.3(E-\mathrm{C}(5)), 133.6((E)-$ $\mathrm{C}(3)), 131.9((Z)-\mathrm{C}(3)), 128.7((E)-\mathrm{C}(6)), 128.3((E)-\mathrm{C}(8)), 128.1((Z)-\mathrm{C}(7))$, $128.0((Z)-\mathrm{C}(8)), 127.9((E)-\mathrm{C}(7)), 125.5((Z)-\mathrm{C}(6)), 114.5((Z)-\mathrm{C}(4)), 113.4((E)-$ $\mathrm{C}(4)), 112.6((Z)-\mathrm{C}(2)), 112.0((Z)-\mathrm{C}(2)), 0.5((Z)-\mathrm{C}(9)), 0.3((E)-\mathrm{C}(9))$

IR: (neat)

3086 (w), 3059 (w), 3037 (w), 3012 (w), 2961 (m), 2900 (w), 2360 (w), 2342 (w), 1950 (w), 1890 (w), 1783 (w), 1689 (m), 1670 (w), 1628 (s), 1590 (w), 1573 (w), 1492 (m), 1447 (m), 1416 (m), 1330 (s), 1308 (m), 1284 (m), 1253 (s), 1210 (s), 1174 (m), 1115 (s), 1067 (s), 1028 (m), 996 (m), 948 (m), 922 (m), 888 (s), 845 (s), $791(\mathrm{~m}), 759(\mathrm{~s}), 732(\mathrm{~m}), 697(\mathrm{~s}), 666(\mathrm{~m}), 651(\mathrm{w}), 629(\mathrm{w})$

MS: $\quad(\mathrm{EI}, 70 \mathrm{eV})$

219 (12), $218\left(\mathrm{M}^{+}, 51\right), 217$ (35), 203 (30), 210 (13), 129 (68), 128 (27), 127 (11), 115 (14), 105 (23), 77 (25), 75 (43), 74 (12), 73 (100)

HRMS: $\quad$ Calcd for $\mathrm{C}_{13} \mathrm{H}_{18} \mathrm{OSi}: 218.1127$, found: 218.1126

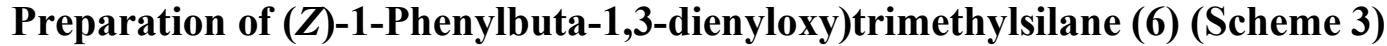
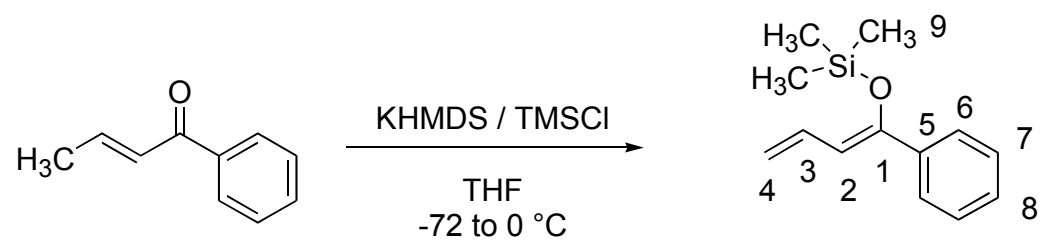

(Z)-6

To a flame-dried 50-mL, 3-necked, round-bottomed flask fitted with a magnetic stir bar, thermocouple, gas inlet tube, and septum was added $1.10 \mathrm{~g}$ (5.5 mmol, 1.1 equiv) of potassium hexamethyldisilazide and $25 \mathrm{~mL}$ of THF. The solution was cooled to $-72{ }^{\circ} \mathrm{C}$ and then $731 \mathrm{mg}$ (5.0 mmol, 1.0 equiv) of 1-phenyl-2-buten-1-one was added slowly dropwise over 1 min via syringe. The resulting orange solution was stirred for $20 \mathrm{~min}$ at $-72{ }^{\circ} \mathrm{C}$ prior to addition of a solution of $703 \mu \mathrm{L}$ (5.5 mmol, 1.1 equiv) of TMSCl via syringe. The dry ice bath was then 
removed and the solution was allowed to warm to $0{ }^{\circ} \mathrm{C}$. The yellow solution was then concentrated in vacuo, and the resulting residue was taken up in $50 \mathrm{~mL}$ of pentane. The yellow precipitate which is formed was then filtered through a pad of Celite on a glass frit and the filtrate was concentrated in vacuo. The residue was purified by bulb-to-bulb distillation to afford $805 \mathrm{mg}(74 \%, Z: E, 99: 1)$ of 6 as a clear, colorless oil. ${ }^{13}$

Data for $(Z)-6$ :

bp: $\quad 60{ }^{\circ} \mathrm{C}(0.05 \mathrm{mmHg}, \mathrm{ABT})$

${ }^{1} \mathrm{H}$ NMR: $\quad\left(500 \mathrm{MHz}, \mathrm{CDCl}_{3}\right)$

7.53 (dt, $J=8.4,1.6,2$ H, HC(6)), 7.34-7.30 (m, 2 H, HC(7)), 7.28-7.25 (m, 1 H, $\mathrm{HC}(8)), 6.73$ (dt, $J=17.1,10.5,1 \mathrm{H}, \mathrm{HC}(3)), 6.05$ (d, $J=10.7,1 \mathrm{H}, \mathrm{HC}(2)), 5.24-$ 5.20 (m, $1 \mathrm{H}, \mathrm{HC}(4))$, 5.04-5.01 (m, $1 \mathrm{H}, \mathrm{HC}(4)), 0.17$ (s, $\left.9 \mathrm{H}, \mathrm{H}_{3} \mathrm{C}(9)\right)$

${ }^{13} \mathrm{C} \mathrm{NMR}: \quad\left(126 \mathrm{MHz}, \mathrm{CDCl}_{3}\right)$

150.4 (C(1)), 138.3 (C(5)), 131.9 (C(3)), 128.1 (C(7)), 128.0 (C(8)), 125.5 (C(6)), $114.5(\mathrm{C}(4)), 112.0(\mathrm{C}(2)), 0.5(\mathrm{C}(9))$

\section{Preparation of ((Z)-2,2-Dimethylhexa-3,5-dien-3-yloxy)trimethylsilane (7) (Scheme 3)}

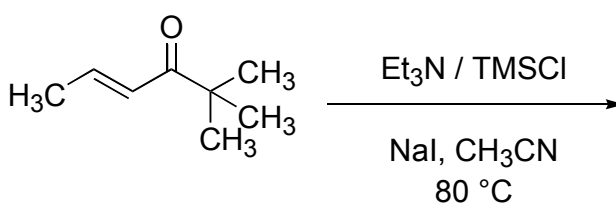

Following Representative Procedure 1, 5.048 g (40.0 mmol, 1.0 equiv) of 2,2-dimethyl-4hexen-3-one was combined with $6.91 \mathrm{~mL}\left(50.0 \mathrm{mmol}, 1.25\right.$ equiv) of $\mathrm{Et}_{3} \mathrm{~N}, 6.91 \mathrm{~mL}$ (50.0 mmol, 1.25 equiv) of TMSCl, and $7.43 \mathrm{~g}$ (50.0 mmol, 1.20 equiv) of $\mathrm{NaI}$ to yield, after bulb-to-bulb distillation, $7.497 \mathrm{~g}(95 \%, Z: E, 89: 11)$ of 7 as a clear, colorless oil.

Data for 7:

bp: $\quad 55^{\circ} \mathrm{C}(8 \mathrm{mmHg}, \mathrm{ABT})$

${ }^{1} \mathrm{H} \mathrm{NMR}: \quad\left(500 \mathrm{MHz}, \mathrm{CDCl}_{3}\right)$

$6.81(\mathrm{dt}, J=16.6,10.9,0.11 \mathrm{H},(E)-\mathrm{HC}(5)) 6.50(\mathrm{dt}, J=17.1,10.5,0.89 \mathrm{H},(Z)$ $\mathrm{HC}(5)), 5.39$ (d, $J=10.5,0.89 \mathrm{H},(Z)-\mathrm{HC}(4)), 5.34(\mathrm{~d}, J=11.5,0.11 \mathrm{H}(E)-$ $\mathrm{HC}(4)), 5.03(\mathrm{dd}, J=17.1,2.0,0.89 \mathrm{H},(Z)-\mathrm{HC}(6)), 4.89-4.84$ (m, $1 \mathrm{H},(Z)-\mathrm{HC}(6)$ 
and $(E)-\mathrm{HC}(6)), 4.76(\mathrm{dd}, J=10.0,2.0,0.11 \mathrm{H},(E)-\mathrm{HC}(6)), 1.20(\mathrm{~s}, 1 \mathrm{H},(E)-$ $\left.\mathrm{H}_{3} \mathrm{C}(1)\right), 1.08$ (s, $\left.8 \mathrm{H},(Z)-\mathrm{H}_{3} \mathrm{C}(1)\right), 0.25$ (s, $\left.8 \mathrm{H},(Z)-\mathrm{H}_{3} \mathrm{C}(7)\right), 0.21$ (s, $1 \mathrm{H},(E)-$ $\left.\mathrm{H}_{3} \mathrm{C}(7)\right)$

NOE ${ }^{1} \mathrm{H}$ NMR: $\left(500 \mathrm{MHz}, \mathrm{CDCl}_{3}\right)$

Irradiation at $1.08 \mathrm{ppm}((Z)-\mathrm{HC}(1))$ enhanced signal at $5.39 \mathrm{ppm}((\mathrm{Z})-\mathrm{HC}(4))$ and $0.25 \mathrm{ppm}((Z)-\mathrm{HC}(7))$. Irradiation at $1.20 \mathrm{ppm}((E)-\mathrm{HC}(1))$ enhanced signal at $6.81 \mathrm{ppm}((E)-\mathrm{HC}(5))$ and $0.21 \mathrm{ppm}(E)-\mathrm{HC}(7))$

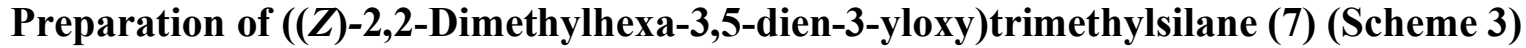
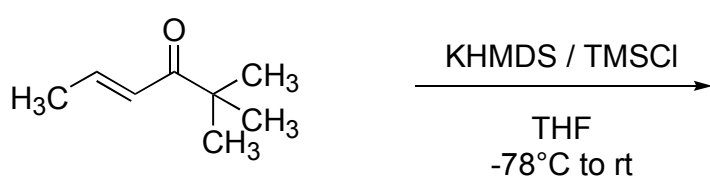

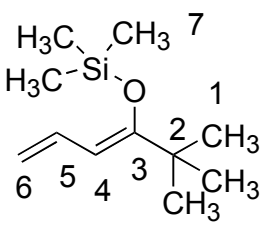

(Z)-7

To a flame-dried 50-mL, 3-necked, round-bottomed flask fitted with a magnetic stir bar, thermocouple, gas inlet tube, and septum was added $1.10 \mathrm{~g}$ (5.5 mmol, 1.1 equiv) of potassium hexamethyldisilazide and $25 \mathrm{~mL}$ of THF. The solution was cooled to $-72{ }^{\circ} \mathrm{C}$ and then $631 \mathrm{mg}$ (5.0 mmol, 1.0 equiv) of 2,2-dimethyl-4-hexen-3-one was added slowly dropwise over 1 min via syringe. The resulting reddish-orange solution was stirred for $20 \mathrm{~min}$ at $-72{ }^{\circ} \mathrm{C}$ prior to addition of a solution of $703 \mu \mathrm{L}$ (5.5 mmol, 1.1 equiv) of TMSCl via syringe. The dry ice bath was then removed and the solution was allowed to warm to rt. The clear solution was then concentrated in vacuo, and the resulting residue was taken up in $50 \mathrm{~mL}$ of pentane. The yellow precipitate that is formed was then filtered through a pad of Celite on a glass frit and the filtrate was concentrated in vacuo. The residue was purified by bulb-to-bulb distillation to afford $864 \mathrm{mg}(87 \%, Z: E$, $>99: 1)$ of 7 as a clear, colorless oil.

\section{Data for $(Z)-7$ :}

bp: $\quad 55^{\circ} \mathrm{C}(8 \mathrm{mmHg}, \mathrm{ABT})$

${ }^{1}$ H NMR: $\quad\left(500 \mathrm{MHz}, \mathrm{CDCl}_{3}\right)$

$6.50(\mathrm{dt}, J=17.1,10.5,1 \mathrm{H}, \mathrm{HC}(5)), 5.39$ (d, $J=10.5,1 \mathrm{H}, \mathrm{HC}(4)), 5.05-5.01$ (m, $1 \mathrm{H}, \mathrm{HC}(6))$, 4.87-4.84 (m, $1 \mathrm{H}, \mathrm{HC}(6)), 1.08$ (s, $\left.9 \mathrm{H}, \mathrm{H}_{3} \mathrm{C}(1)\right), 0.25$ (s, $9 \mathrm{H}$, $\left.\mathrm{H}_{3} \mathrm{C}(7)\right)$ 
${ }^{13} \mathrm{C} \mathrm{NMR}: \quad\left(126 \mathrm{MHz}, \mathrm{CDCl}_{3}\right)$

$161.2(\mathrm{C}(3)), 132.5(\mathrm{C}(5)), 112.2(\mathrm{C}(6)), 106.3(\mathrm{C}(4)), 36.5(\mathrm{C}(2)), 28.4(\mathrm{C}(1))$, $1.1(\mathrm{C}(7))$

IR: (neat)

$3086(\mathrm{w}), 3066$ (w), 2959 (s), 2906 (m), $2870(\mathrm{w}), 2362$ (w), $1781(\mathrm{w}), 1716(\mathrm{w})$,

1641 (s), 1595 (w), 1481 (m), 1460 (w), 1417 (m), 1391 (w), 1358 (w), 1315 (s),

1291 (m), 1254 (s), 1221 (m), 1190 (s), 1103 (s), 1029 (m), 994 (m), 963 (m), 930

(s), $888(\mathrm{~s}), 846(\mathrm{~s}), 758(\mathrm{~m}), 718(\mathrm{w}), 676(\mathrm{~m}), 646(\mathrm{w}), 610(\mathrm{w})$

MS: $\quad(\mathrm{EI}, 70 \mathrm{eV})$

$198\left(\mathrm{M}^{+}, 27\right), 183(51), 141$ (10), 75 (36), 73 (100), 57 (13)

HRMS: $\quad$ Calcd for $\mathrm{C}_{11} \mathrm{H}_{22} \mathrm{OSi}: 198.1440$, found: 198.1439

\section{Preparations of Bissilyl Dienol Ethers}

Representative Procedure 2. Enolization of 1,3-Diketones to form Bissilyl Dienol Ethers. Preparation of 2,4-Bis(trimethylsilyloxy)-1,3-pentadiene (32a) (Figure 3)<smiles>CC(=O)CC(C)=O</smiles>

30

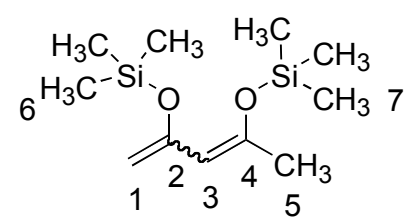

$32 a$

To a flame-dried, 250-mL, 3-necked, round-bottomed flask equipped with a magnetic stir bar, reflux condenser, septum and 125-mL addition funnel was added $2.57 \mathrm{~mL}$ (25.0 mmol, 1.0 equiv) of acetylacetone (30), $7.14 \mathrm{~mL}$ (51.25 mmol, 2.05 equiv) of $\mathrm{Et}_{3} \mathrm{~N}$ and $50 \mathrm{~mL}$ of $\mathrm{Et}_{2} \mathrm{O}$. The solution was cooled to $0{ }^{\circ} \mathrm{C}$ (bath temperature). The addition funnel was charged with 9.28

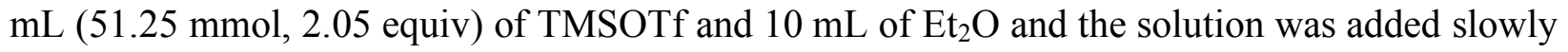
dropwise over $15 \mathrm{~min}$. The resulting biphasic solution was stirred for $1 \mathrm{~h}$ at $0{ }^{\circ} \mathrm{C}$ prior to addition of $50 \mathrm{~mL}$ of cold $\mathrm{H}_{2} \mathrm{O}$. The organic layer was separated and aqueous layer washed with pentane $(3 \times 50 \mathrm{~mL})$. The combined organic extracts were washed with $\mathrm{NaHCO}_{3}$ (sat aq) $(50 \mathrm{~mL}), \mathrm{H}_{2} \mathrm{O}$ $(50 \mathrm{~mL})$, brine $(75 \mathrm{~mL})$, dried of $\mathrm{K}_{2} \mathrm{CO}_{3}(10 \mathrm{~g})$, filtered and the filtrate was concentrated in vacuo. The residue was purified by bulb-to-bulb distillation to afford $5.765 \mathrm{~g}(94 \%, Z: E, 55: 45)$ of $32 \mathbf{a}$ as a clear, colorless oil. ${ }^{14}$ 


\section{Data for 32a:}

bp: $\quad 55^{\circ} \mathrm{C}(0.2 \mathrm{mmHg}, \mathrm{ABT})$

${ }^{1} \mathrm{H}$ NMR: $\quad\left(500 \mathrm{MHz}, \mathrm{CDCl}_{3}\right)$

$5.20(\mathrm{~s}, 0.45 \mathrm{H},(E)-\mathrm{HC}(3)), 4.75(\mathrm{~s}, 0.45 \mathrm{H},(E)-\mathrm{HC}(1)), 4.73$ (s, $0.55 \mathrm{H},(Z)-$ $\mathrm{HC}(3)), 4.32$ (d, $J=1.2,0.45 \mathrm{H},(E)-\mathrm{HC}(1)), 4.14$ (s, $0.55 \mathrm{H},(Z)-\mathrm{HC}(1)), 4.10$ (s, $0.55 \mathrm{H},(Z)-\mathrm{HC}(1)), 2.01\left(\mathrm{~s}, 1.75 \mathrm{H},(E)-\mathrm{H}_{3} \mathrm{C}(5)\right), 1.85$ (s, $\left.1.25 \mathrm{H},(Z)-\mathrm{H}_{3} \mathrm{C}(5)\right)$, $0.24\left(\mathrm{~s}, 4.95 \mathrm{H},(Z)-\mathrm{H}_{3} \mathrm{C}(6)\right), 0.22\left(\mathrm{~s}, 4.05 \mathrm{H},(E)-\mathrm{H}_{3} \mathrm{C}(6)\right), 0.21(\mathrm{~s}, 4.05 \mathrm{H},(E)-$ $\left.\mathrm{H}_{3} \mathrm{C}(7)\right), 0.20\left(\mathrm{~s}, 4.95 \mathrm{H},(Z)-\mathrm{H}_{3} \mathrm{C}(7)\right)$

\section{Preparation of 2,4-Bis(tert-butyldimethylsilyloxy)-1,3-pentadiene (32b) (Figure 3)}<smiles>CC(=O)CC(C)=O</smiles>

30

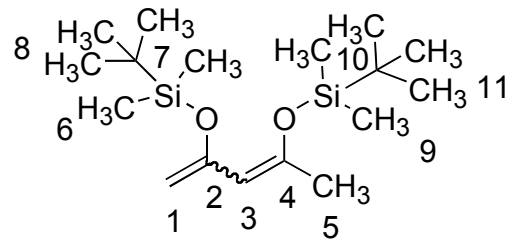

$32 b$

Following Representative Procedure 2, $2.05 \mathrm{~mL}(20 \mathrm{mmol})$ of acetylacetone (30) was combined with $6.13 \mathrm{~mL}$ (44 mmol, 2.2 equiv) of $\mathrm{Et}_{3} \mathrm{~N}$, and $9.19 \mathrm{~mL}$ (40 mmol, 2.0 equiv) of TBSOTf to yield, after bulb-to-bulb distillation, $6.245 \mathrm{~g}(95 \%, Z: E, 55: 45)$ of 32b as a clear, colorless oil.

Data for 32b:

bp: $\quad 90{ }^{\circ} \mathrm{C}(0.05 \mathrm{mmHg}, \mathrm{ABT})$

${ }^{1} \mathrm{H} \mathrm{NMR}: \quad\left(500 \mathrm{MHz}, \mathrm{CDCl}_{3}\right)$

$5.16(\mathrm{~s}, 0.45 \mathrm{H},(Z)-\mathrm{HC}(3)), 4.79(\mathrm{~s}, 0.55 \mathrm{H},(E)-\mathrm{HC}(1)), 4.68$ (s, $0.45 \mathrm{H},(E)-$ $\mathrm{HC}(3)), 4.39$ (d, $J=1.5,0.55 \mathrm{H},(E)-\mathrm{HC}(1)), 4.19$ (s, $0.55 \mathrm{H},(Z)-\mathrm{HC}(1)), 4.09$ (s, $0.55 \mathrm{H},(Z)-\mathrm{HC}(1)), 2.00\left(\mathrm{~d}, J=0.4,1.75 \mathrm{H},(Z)-\mathrm{H}_{3} \mathrm{C}(5)\right), 1.87$ (d, $J=0.4,1.25 \mathrm{H}$, $\left.(E)-\mathrm{H}_{3} \mathrm{C}(5)\right), 0.95-0.92\left(\mathrm{~m}, 18 \mathrm{H},(E)-\mathrm{H}_{3} \mathrm{C}(8),(Z)-\mathrm{H}_{3} \mathrm{C}(8),(E)-\mathrm{H}_{3} \mathrm{C}(11),(Z)-\right.$ $\left.\mathrm{H}_{3} \mathrm{C}(11)\right), 0.19-0.13\left(\mathrm{~m}, 12 \mathrm{H},(E)-\mathrm{H}_{3} \mathrm{C}(6),(Z)-\mathrm{H}_{3} \mathrm{C}(6),(E)-\mathrm{H}_{3} \mathrm{C}(9),(Z)-\mathrm{H}_{3} \mathrm{C}(9)\right)$

NOE ${ }^{1} \mathrm{H}$ NMR: $\left(500 \mathrm{MHz}, \mathrm{CDCl}_{3}\right.$ )

Irradiation at $4.79 \mathrm{ppm}(\mathrm{HC}(3))$ enhanced signal at $2.01 \mathrm{ppm}(\mathrm{HC}(5))$

${ }^{13} \mathrm{C} \mathrm{NMR}: \quad\left(126 \mathrm{MHz}, \mathrm{CDCl}_{3}\right)$

$154.8((Z)-\mathrm{C}(2)), 152.7((Z)-\mathrm{C}(4)), 152.3((E)-\mathrm{C}(2)), 150.6((E)-\mathrm{C}(4)), 108.6((Z)-$ 
C(3)), $106.8((E)-\mathrm{C}(3)), 94.2((E)-\mathrm{C}(1)), 93.5((Z)-\mathrm{C}(1)), 25.87,25.86,25.8,25.6$, $18.29,18.26,18.1,18.0,-3.2,-4.37,-4.42,-4.5$

IR: (neat)

3119 (w), 2958 (s), 2931 (s), 2887 (m), 2859 (s), 2805 (w), 2742 (w), 2712 (w), 2647 (w), 2263 (w), 1687 (w), 1654 (s), 1618 (m), 1473 (s), 1464 (m), 1437 (m), 1382 (s), 1362 (m), 1334 (s), 1254 (s), 1198 (s), 1173 (s), 1025 (s), 1004 (s), 938 (m), $877(\mathrm{~m}), 838(\mathrm{~s}), 811(\mathrm{~s}), 780(\mathrm{~s}), 747$ (w), $697(\mathrm{~m}), 671(\mathrm{w})$

MS: $\quad(\mathrm{EI}, 70 \mathrm{eV})$

$328\left(\mathrm{M}^{+}, 6\right), 313$ (22), 271 (14), 216 (12), 215 (23), 173 (26), 158 (13), 157 (90), 149 (23), 147 (23), 133 (37), 75 (24), 73 (100), 59 (11), 57 (15)

HRMS: $\quad$ Calcd for $\mathrm{C}_{17} \mathrm{H}_{36} \mathrm{O}_{2} \mathrm{Si}_{2}: 328.2254$, found: 328.2250

Preparation of 2,4-Bis(triethylsilyloxy)-1,3-pentadiene (32c) (Figure 3)<smiles>CC(=O)CC(C)=O</smiles>

30

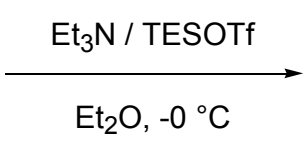

$\mathrm{Et}_{2} \mathrm{O},-\mathrm{O}^{\circ} \mathrm{C}$

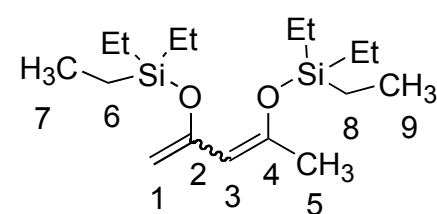

32c

Following Representative Procedure 2, $2.05 \mathrm{~mL}(20 \mathrm{mmol})$ of acetylacetone (30) was combined with $6.13 \mathrm{~mL}$ (44 mmol, 2.2 equiv) of $\mathrm{Et}_{3} \mathrm{~N}$, and $9.05 \mathrm{~mL}$ (40 mmol, 2.0 equiv) of TESOTf to yield, after bulb-to-bulb distillation, $6.484 \mathrm{~g}(98 \%, Z: E, 55: 45)$ of 32c as a clear, colorless oil.

Data for 32c:

bp: $\quad 150{ }^{\circ} \mathrm{C}(0.05 \mathrm{mmHg}, \mathrm{ABT})$

${ }^{1} \mathrm{H}$ NMR: $\quad\left(500 \mathrm{MHz}, \mathrm{CDCl}_{3}\right)$

5.19 (s, $0.46 \mathrm{H},(Z)-\mathrm{HC}(3)), 4.80(\mathrm{~s}, 0.54 \mathrm{H},(E)-\mathrm{HC}(1)), 4.71$ (dd, $J=1.7,0.7$, $0.54 \mathrm{H},(E)-\mathrm{HC}(3)), 4.36(\mathrm{~d}, J=1.7,0.54 \mathrm{H},(E)-\mathrm{HC}(1)), 4.15$ (s, $0.46 \mathrm{H},(Z)-$ $\mathrm{HC}(1)), 4.05$ (s, $0.46 \mathrm{H},(Z)-\mathrm{HC}(1)), 2.03$ (s, $\left.1.35 \mathrm{H},(Z)-\mathrm{H}_{3} \mathrm{C}(5)\right), 1.88$ (s, $1.65 \mathrm{H}$, $\left.(E)-\mathrm{H}_{3} \mathrm{C}(5)\right), \quad 1.02-0.96\left(\mathrm{~m}, 18 \mathrm{H},(E)-\mathrm{H}_{3} \mathrm{C}(7),(Z)-\mathrm{H}_{3} \mathrm{C}(7), E\right)-\mathrm{H}_{3} \mathrm{C}(9),(Z)-$ $\left.\mathrm{H}_{3} \mathrm{C}(9)\right), 0.77-0.66\left(\mathrm{~m}, 12 \mathrm{H},(E)-\mathrm{H}_{3} \mathrm{C}(6),(Z)-\mathrm{H}_{3} \mathrm{C}(6),(E)-\mathrm{H}_{3} \mathrm{C}(8),(Z)-\mathrm{H}_{3} \mathrm{C}(8)\right)$ 


\section{Preparation of 2,4-Bis(triisoproylsilyloxy)-1,3-pentadiene (32d) (Figure 3)}<smiles>CC(=O)CC(C)=O</smiles>

30

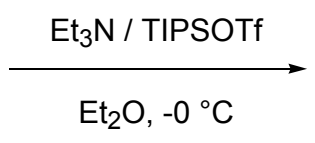

$\mathrm{t}_{2} \mathrm{O},-0^{\circ} \mathrm{C}$

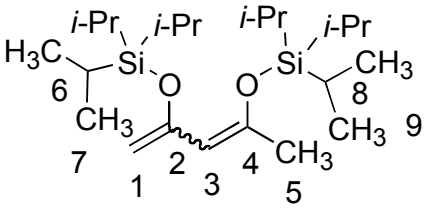

32d

Following Representative Procedure 2, $0.257 \mathrm{~mL}(2.5 \mathrm{mmol})$ of acetylacetone (30) was combined with $0.767 \mathrm{~mL}$ (5.5 mmol, 2.2 equiv) of $\mathrm{Et}_{3} \mathrm{~N}$, and $1.4 \mathrm{~mL}$ (5.5 mmol, 2.1 equiv) of TIPSOTf to yield, after bulb-to-bulb distillation, $0.910 \mathrm{~g}(88 \%, Z: E, 55: 45)$ of $\mathbf{3 2 d}$ as a clear, colorless oil.

Data for 32d:

bp: $\quad 150{ }^{\circ} \mathrm{C}(0.05 \mathrm{mmHg}, \mathrm{ABT})$

${ }^{1} \mathrm{H} \mathrm{NMR}: \quad\left(500 \mathrm{MHz}, \mathrm{CDCl}_{3}\right)$

5.19 (s, $0.55 \mathrm{H},(Z)-\mathrm{HC}(3)), 4.82$ (s, $0.45 \mathrm{H},(E)-\mathrm{HC}(1)), 4.71$ (dd, $J=1.7,0.9$, $0.45 \mathrm{H},(E)-\mathrm{HC}(3)), 4.39$ (d, $J=1.7,0.45 \mathrm{H},(E)-\mathrm{HC}(1)), 4.18(\mathrm{~s}, 0.55 \mathrm{H},(Z)-$ $\mathrm{HC}(1)), 4.03$ (s, $0.55 \mathrm{H},(Z)-\mathrm{HC}(1)), 2.06$ (d, $\left.J=0.6,1.75 \mathrm{H},(Z)-\mathrm{H}_{3} \mathrm{C}(5)\right), 1.92$ (s, $\left.1.25 \mathrm{H},(E)-\mathrm{H}_{3} \mathrm{C}(5)\right), 1.24-1.13\left(\mathrm{~m}, 6 \mathrm{H},(E)-\mathrm{H}_{3} \mathrm{C}(6),(Z)-\mathrm{H}_{3} \mathrm{C}(6), E\right)-\mathrm{H}_{3} \mathrm{C}(8),(Z)-$ $\left.\mathrm{H}_{3} \mathrm{C}(8)\right), 1.11-1.05$ (m, $\left.36 \mathrm{H},(E)-\mathrm{H}_{3} \mathrm{C}(7),(Z)-\mathrm{H}_{3} \mathrm{C}(7),(E)-\mathrm{H}_{3} \mathrm{C}(9),(Z)-\mathrm{H}_{3} \mathrm{C}(9)\right)$

\section{Preparation of (2Z/4Z)-3,5-Bis(trimethylsilyloxy)-2,5-heptadiene (33a) (Figure 3)}

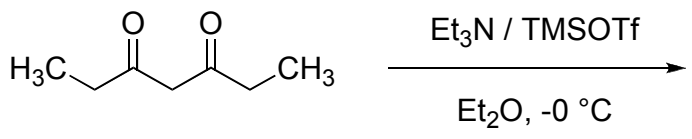

31

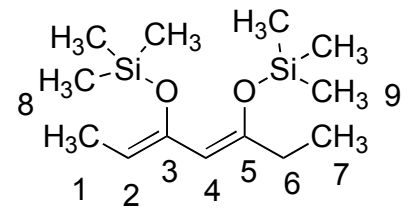

$33 a$

Following Representative Procedure 2, $2.71 \mathrm{~mL}(20 \mathrm{mmol})$ of 3,5-heptanedione (31) was combined with $6.13 \mathrm{~mL}$ (44 mmol, 2.2 equiv) of $\mathrm{Et}_{3} \mathrm{~N}$, and $7.14 \mathrm{~mL}$ (40 mmol, 2.0 equiv) of TMSOTf to yield, after bulb-to-bulb distillation, $5.246 \mathrm{~g}$ (96\%, 2Z,4Z:minor isomers, 90:10) of 33a as a clear, colorless oil.

Data for 33a:

bp: $\quad 90{ }^{\circ} \mathrm{C}(0.05 \mathrm{mmHg}, \mathrm{ABT})$

${ }^{1} \mathrm{H}$ NMR: $\quad\left(500 \mathrm{MHz}, \mathrm{CDCl}_{3}\right)$

$5.20(\mathrm{q}, J=7.0,1 \mathrm{H}, \mathrm{HC}(2)), 4.75(\mathrm{~d}, J=0.5,1 \mathrm{H}, \mathrm{HC}(4)), 2.07$ (q, $J=7.5,2 \mathrm{H}$, 
$\left.\mathrm{H}_{2} \mathrm{C}(6)\right), 1.60\left(\mathrm{~d}, J=6.8,3 \mathrm{H}, \mathrm{H}_{3} \mathrm{C}(1)\right)$, 1.06-1.01 (m, $\left.3 \mathrm{H}, \mathrm{H}_{3} \mathrm{C}(7)\right), 0.20$ (s, $9 \mathrm{H}$, $\left.\mathrm{H}_{3} \mathrm{C}(8)\right), 0.17$ (s, $\left.9 \mathrm{H}, \mathrm{H}_{3} \mathrm{C}(9)\right)$

Preparation of (2Z,4Z)-3,5-Bis(tert-butyldimethylsilyloxy)-2,4-heptadiene (33b) (Figure 3)

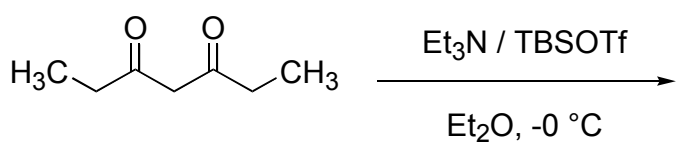

31

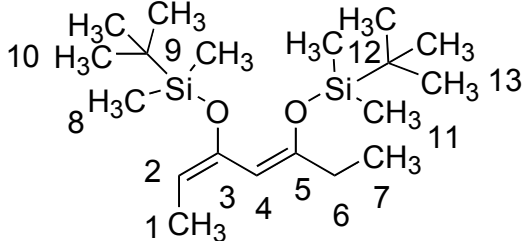

$33 b$

Following Representative Procedure 2, $2.71 \mathrm{~mL}(20 \mathrm{mmol})$ of 3,5-heptanedione (31) was combined with $6.13 \mathrm{~mL}$ (44 mmol, 2.2 equiv) of $\mathrm{Et}_{3} \mathrm{~N}$, and $9.19 \mathrm{~mL}$ (40 mmol, 2.0 equiv) of TBSOTf to yield, after bulb-to-bulb distillation, $6.01 \mathrm{~g}(84 \%, 2 Z, 4 Z$ :minor isomers, 90:10) of $\mathbf{3 3 b}$ as a clear, colorless oil.

Data for $(2 Z, 4 Z)-33 \mathbf{b}$ :

bp: $\quad 150{ }^{\circ} \mathrm{C}(0.1 \mathrm{mmHg}, \mathrm{ABT})$

${ }^{1} \mathrm{H}$ NMR: $\quad\left(500 \mathrm{MHz}, \mathrm{CDCl}_{3}\right)$

5.12 (q, $J=6.9,1 \mathrm{H}, \mathrm{HC}(2)), 4.73$ (s, $1 \mathrm{H}, \mathrm{HC}(4)), 2.09$ (q, $\left.J=7.4,2 \mathrm{H}, \mathrm{H}_{2} \mathrm{C}(6)\right)$, $1.61\left(\mathrm{~d}, J=6.8,3 \mathrm{H}, \mathrm{H}_{3} \mathrm{C}(1)\right), 1.08-1.02$ (m, $\left.3 \mathrm{H}, \mathrm{H}_{3} \mathrm{C}(7)\right), 0.96$ (s, $\left.9 \mathrm{H}, \mathrm{H}_{3} \mathrm{C}(10)\right)$ ), 0.94 (s, 9 H, $\left.\mathrm{H}_{3} \mathrm{C}(13)\right), 0.15$ (s, $\left.6 \mathrm{H}, \mathrm{H}_{3} \mathrm{C}(8)\right), 0.11$ (s, $\left.6 \mathrm{H}, \mathrm{H}_{3} \mathrm{C}(11)\right)$

NOE ${ }^{1} \mathrm{H}$ NMR: $\left(500 \mathrm{MHz}, \mathrm{CDCl}_{3}\right)$

Irradiation at $4.73 \mathrm{ppm}\left(\mathrm{H}_{3} \mathrm{C}(4)\right)$ enhanced signals at $5.12 \mathrm{ppm}(\mathrm{HC}(2))$ and 2.09 $\left(\mathrm{H}_{2} \mathrm{C}(6)\right.$.

${ }^{13}$ C NMR: $\quad\left(126 \mathrm{MHz}, \mathrm{CDCl}_{3}\right)$ 153.5 (C(5)), $145.0(\mathrm{C}(3)), 106.1(\mathrm{C}(2)), 105.4$ (C(4)), 30.2 (C(6)), 25.9 (C(10), $25.8(\mathrm{C}(13)), 18.3(\mathrm{C}(9)), 18.2$ (C(12)), 11.8 (C(7)), $10.8(\mathrm{C}(1)),-3.6(\mathrm{C}(8)),-3.9$ $(\mathrm{C}(12))$

IR: (neat) 2959 (s), 2931 (s), 2896 (s), 2859 (s), 2740 (w), 2711 (w), 2361 (w), 1655 (w), 1591 (w), 1473 (s), 1464 (s), 1406 (m), 1390 (m), 1362 (s), 1323 (m), 1301 (s), 1289 (s), 1255 (s), 1199 (s), 1168 (s), 1103 (m), 1076 (s), 1045 (s), 1004 (s), 938 (s), $904(\mathrm{~m}), 880(\mathrm{~m}), 839(\mathrm{~s}), 811(\mathrm{~s}), 778(\mathrm{~s}), 704(\mathrm{w}), 697(\mathrm{~m}), 623(\mathrm{w})$ 
MS: $\quad(E I, 70 \mathrm{eV})$

357 (13), $356\left(\mathrm{M}^{+}, 35\right), 341$ (12), 328 (16), 327 (54), 299 (27), 271 (35), 225 (16),

185 (38), 149 (25), 147 (55), 133 (16), 95 (15), 75 (20), 59 (10), 57 (10)

HRMS: $\quad$ Calcd for $\mathrm{C}_{19} \mathrm{H}_{40} \mathrm{O}_{2} \mathrm{Si}_{2}: 356.2567$, found: 356.2567

Preparation of (2Z/4Z)-3,5-Bis(triethylsilyloxy)-2,4-heptadiene (33c) (Figure 3)

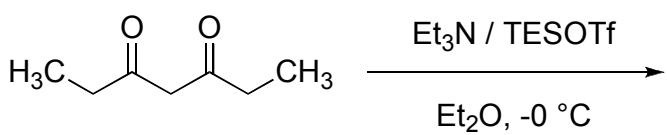

31

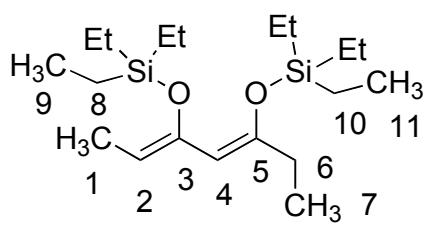

$33 c$

Following Representative Procedure 2, $2.71 \mathrm{~mL}(20 \mathrm{mmol})$ of 3,5-heptanedione (31) was combined with $6.13 \mathrm{~mL}$ (44 mmol, 2.2 equiv) of $\mathrm{Et}_{3} \mathrm{~N}$, and $9.05 \mathrm{~mL}$ (40 mmol, 2.0 equiv) of TESOTf to yield, after bulb-to-bulb distillation, $6.955 \mathrm{~g}$ (97\%, 2Z,4Z:minor isomers, 90:10) of 33c as a clear, colorless oil.

Data for 33c:

bp: $\quad 90{ }^{\circ} \mathrm{C}(0.05 \mathrm{mmHg}, \mathrm{ABT})$

${ }^{1} \mathrm{H} \mathrm{NMR}: \quad\left(500 \mathrm{MHz}, \mathrm{CDCl}_{3}\right)$

$5.21(\mathrm{q}, J=6.8,1 \mathrm{H}, \mathrm{HC}(2)), 4.69$ (s, $1 \mathrm{H}, \mathrm{HC}(4)), 2.10$ (q, $\left.J=7.3,2 \mathrm{H}, \mathrm{H}_{2} \mathrm{C}(6)\right)$, $1.62\left(\mathrm{~d}, J=6.8,3 \mathrm{H}, \mathrm{H}_{3} \mathrm{C}(1)\right), 1.04$ (t, $\left.J=7.3,3 \mathrm{H}, \mathrm{H}_{3} \mathrm{C}(7)\right), 1.01-0.91$ (m, $18 \mathrm{H}$, $\left.\mathrm{H}_{3} \mathrm{C}(9), \mathrm{H}_{3} \mathrm{C}(11)\right), 0.73-0.63$ (m, $\left.\left.12 \mathrm{H}, \mathrm{H}_{2} \mathrm{C}(8)\right), \mathrm{H}_{2} \mathrm{C}(10)\right)$ 
Preparations of Conjugated $N, O$-Silyl Ketene Acetals From $\alpha, \beta$-Unsaturated Amides.

Representative Procedure 2. Enolization of $\alpha, \beta$-Unsaturated Amides to Form Conjugate N,O-Silyl Ketene Acetals. Preparation of (Z)-[1-(tert-Butyldimethylsilanyloxy)-1,3butadienyl]dimethylamine (41) (Figure 4)

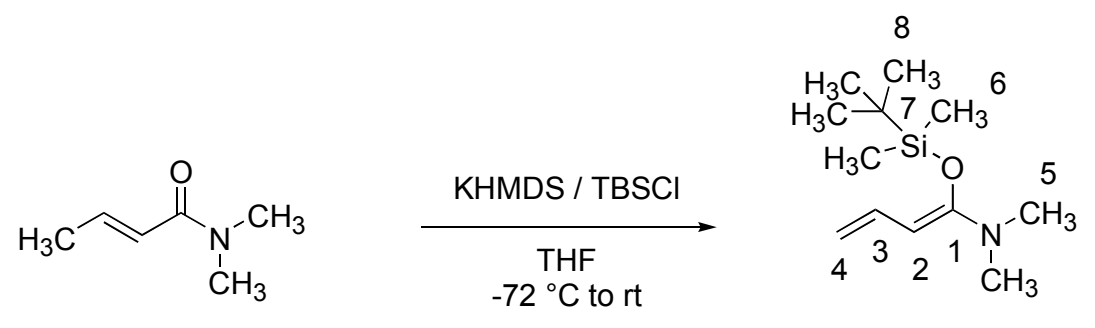

41

To a flame-dried 200-mL, 3-necked, round-bottomed flask fitted fitted with a magnetic stir bar, thermocouple, gas inlet tube, and septum, was added $1.13 \mathrm{~g}(10 \mathrm{mmol})$ of 2-butenoic acid dimethylamide and $50 \mathrm{~mL}$ of THF. The solution was cooled to $-72{ }^{\circ} \mathrm{C}$ and then a solution of $2.19 \mathrm{~g}$ ( $1.1 \mathrm{mmol}, 1.1$ equiv) of potassium hexamethyldisilazide in $20 \mathrm{~mL}$ THF was added slowly dropwise over 5 min via syringe. The resulting yellow solution was stirred for $30 \mathrm{~min}$ at $-72{ }^{\circ} \mathrm{C}$ prior to addition of a solution of $1.66 \mathrm{~g}$ (11 mmol, 1.1 equiv) of TBSCl in 10 of THF via syringe. The dry ice bath was then removed and the solution was allowed to warm to $0{ }^{\circ} \mathrm{C}$. The yellow solution was then concentrated in vacuo, and the resulting residue was taken up in $50 \mathrm{~mL}$ of pentane. The yellow precipitate which is formed was then filtered through a pad of Celite and the filtrate was concentrated in vacuo. The residue was purified by bulb-to-bulb distillation to afford $1.738 \mathrm{~g}(77 \%)$ of $\mathbf{4 1}$ as a clear, colorless oil.

Data for $(Z)-\mathbf{4 1}$ :

bp: $\quad 60{ }^{\circ} \mathrm{C}(0.01 \mathrm{mmHg}, \mathrm{ABT})$

${ }^{1} \mathrm{H}$ NMR: $\quad\left(500 \mathrm{MHz}, \mathrm{CDCl}_{3}\right)$

$6.54(\mathrm{dt}, J=17.1,10.5,1 \mathrm{H}, \mathrm{HC}(3)), 4.79$ (dd, $J=17.1,2.2,1 \mathrm{H}, \mathrm{HC}(4)), 4.61$ (d, $J=10.7,1 \mathrm{H}, \mathrm{HC}(2)), 4.53(\mathrm{dd}, J=10.5,2.3,1 \mathrm{H}, \mathrm{HC}(4)), 2.58$ (s, $\left.6 \mathrm{H}, \mathrm{H}_{3} \mathrm{C}(5)\right)$, 1.00 (s, $\left.9 \mathrm{H}, \mathrm{H}_{3} \mathrm{C}(8)\right), 0.16$ (s, $\left.6 \mathrm{H}, \mathrm{H}_{3} \mathrm{C}(6)\right)$

NOE ${ }^{1} \mathrm{H}$ NMR: $\left(500 \mathrm{MHz}, \mathrm{CDCl}_{3}\right)$

Irradiation at $3.58 \mathrm{ppm}\left(\mathrm{H}_{3} \mathrm{C}(5)\right)$ enhanced signal at $4.61 \mathrm{ppm}(\mathrm{HC}(2))$ 
${ }^{13}$ C NMR: $\quad\left(126 \mathrm{MHz}, \mathrm{CDCl}_{3}\right)$

$155.5(\mathrm{C}(1)), 133.4(\mathrm{C}(3)), 105.6(\mathrm{C}(4)), 89.2(\mathrm{C}(2)), 39.5(\mathrm{C}(5)), 25.7(\mathrm{C}(8))$, $18.3(\mathrm{C}(7)),-4.6(\mathrm{C}(6))$

IR: (neat)

3083 (m), 3060 (m), 3013 (m), 2955 (s), 2932 (s), 2886 (m), 2859 (s), 2793 (m), 1631 (s), 1474 (s), 1461 (s), 1438 (m), 1419 (s), 1390 (m), 1346 (s), 1298 (m), $1281(\mathrm{~m}), 1254(\mathrm{~s}), 1195(\mathrm{~s}), 1145(\mathrm{~s}), 1125(\mathrm{~s}), 1102(\mathrm{~m}), 1055(\mathrm{~m}), 1023(\mathrm{~s})$, 1005 (m), 996 (m), 944 (m), 881 (s), 839 (s), 825 (s), 810 (s), 782 (s), 739 (m), $679(\mathrm{~m}), 655(\mathrm{~m}), 642(\mathrm{~m})$

MS: $\quad(E I, 70 \mathrm{eV})$

228 (18), $227\left(\mathrm{M}^{+}, 85\right), 212$ (51), 171 (32), 170 (71), 157 (15), 156 (100), 147

(12), 130 (14), 96 (19), 81 (13), 75 (13), 73 (52), 59 (12), 57 (19)

HRMS: Calcd for $\mathrm{C}_{12} \mathrm{H}_{25}$ NOSi: 227.1705, found: 227.1694

Preparation of (Z)-[1-(tert-Butyldimethylsilanyloxy)-1,3-butadienyl]diethylamine (42) (Figure 4)

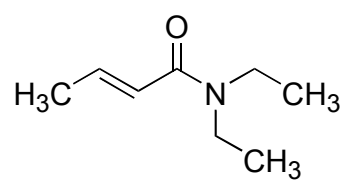

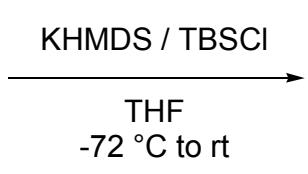

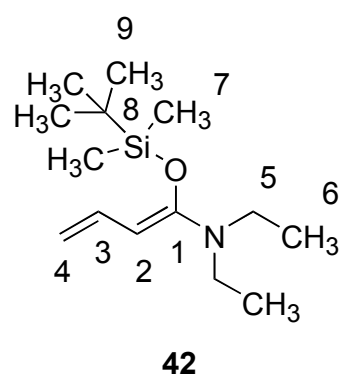

42

Following Representative Procedure 3, $1.41 \mathrm{~g}$ (10 mmol) of 2-butenoic acid diethylamide was combined with $2.19 \mathrm{~g}$ ( $1.1 \mathrm{mmol}, 1.1$ equiv) of potassium hexamethyldisilazide, and $1.66 \mathrm{~g}$ (11 mmol, 1.1 equiv) of TBSCl to yield, after bulb-to-bulb distillation, $2.27 \mathrm{~g}(89 \%)$ of $\mathbf{4 2}$ as a clear, colorless oil.

Data for $(Z)-\mathbf{4 2}$ :

bp: $\quad 90{ }^{\circ} \mathrm{C}(0.05 \mathrm{mmHg}, \mathrm{ABT})$

${ }^{1}$ H NMR: $\quad\left(500 \mathrm{MHz}, \mathrm{CDCl}_{3}\right)$

$6.58(\mathrm{dt}, J=17.1,10.5,1 \mathrm{H}, \mathrm{HC}(3)), 4.76(\mathrm{dd}, J=17.2,1.9,1 \mathrm{H}, \mathrm{HC}(4)), 4.62$ (d, $J=10.7,1 \mathrm{H}, \mathrm{HC}(2)), 4.53(\mathrm{dd}, J=10.3,2.3,1 \mathrm{H}, \mathrm{HC}(4)), 3.00$ (q, $J=7.1,4 \mathrm{H}$, $\left.\mathrm{H}_{2} \mathrm{C}(5)\right), 1.02$ (t, $\left.J=7.1,6 \mathrm{H}, \mathrm{H}_{3} \mathrm{C}(6)\right), 0.99$ (s, $\left.9 \mathrm{H}, \mathrm{H}_{3} \mathrm{C}(9)\right), 0.15$ (s, $6 \mathrm{H}$, 
$\left.\mathrm{H}_{3} \mathrm{C}(7)\right)$

NOE ${ }^{1} \mathrm{H}$ NMR: $\left(500 \mathrm{MHz}, \mathrm{CDCl}_{3}\right)$

Irradiation at $3.00 \mathrm{ppm}\left(\mathrm{H}_{2} \mathrm{C}(5)\right)$ enhanced signal at $4.62 \mathrm{ppm}(\mathrm{HC}(2))$ and 1.02 $\operatorname{ppm}\left(\mathrm{H}_{3} \mathrm{C}(6)\right)$

${ }^{13} \mathrm{C} \mathrm{NMR}: \quad\left(126 \mathrm{MHz}, \mathrm{CDCl}_{3}\right)$

153.1 (C(1)), 133.7 (C(3)), 104.8 (C(4)), 91.5 (C(2)), 42.0 (C(5)), $25.8(\mathrm{C}(9))$, $18.3(\mathrm{C}(8)), 11.4(\mathrm{C}(6)),-4.5(\mathrm{C}(7))$

IR: (neat)

3083 (m), 3057 (w), 3013 (m), 2961 (s), 2932 (s), 2896 (m), 2859 (s), 1631 (s), 1591 (m), 1473 (m), 1464 (m), 1449 (w), 1418 (s), 1390 (m), 1370 (s), 1343 (m), 1309 (m), 1282 (m), 1252 (s), 1238 (s), 1181 (m), 1126 (s), 1096 (w), 1071 (m), 1058 (m), 1036 (s), 1005 (m), 994 (m), 945 (m), 922 (m), 839 (s), 807 (s), 781 (s), $738(\mathrm{w}), 680(\mathrm{~m}), 657(\mathrm{w}), 642(\mathrm{w})$

MS: $\quad(\mathrm{EI}, 70 \mathrm{eV})$

256 (22), 255 (M+, 88), 254 (14), 241 (19), 240 (97), 226 (14), 199 (34), 198 (48), 185 (19), 184 (100), 171 (16), 170 (36), 156 (12), 144 (12), 124 (21), 100 (15), 95 (11), 75 (22), 73 (91), 68 (16), 67 (20), 59 (21), 57 (13)

HRMS: $\quad$ Calcd for $\mathrm{C}_{14} \mathrm{H}_{29} \mathrm{NOSi}$ : 255.2018, found: 255.2016

\section{Preparation of (Z)-1-[1-(tert-Butyldimethylsilanyloxy)-1,3-butadienyl]pyrrolidine} (Figure 4)

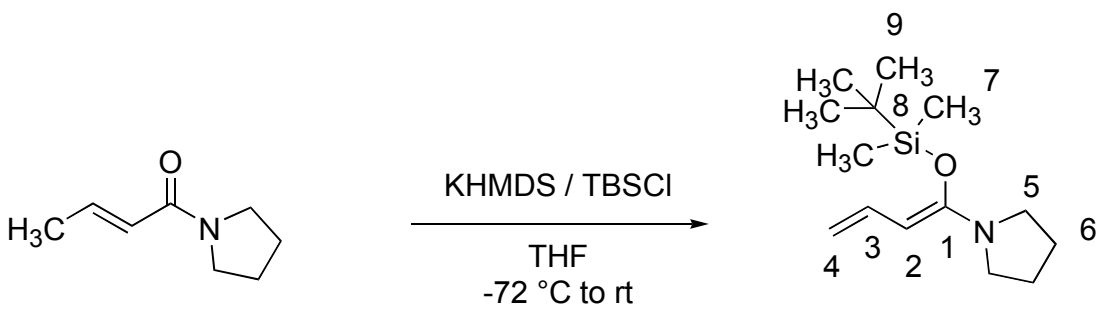

43

Following Representative Procedure 3, $1.53 \mathrm{~g}$ (10 mmol) of 1-[(2E)-1-oxo-2butenyl]pyrrolidine was combined with $2.19 \mathrm{~g}$ (1.1 mmol, 1.1 equiv) of potassium hexamethyldisilazide, and $1.66 \mathrm{~g}$ (11 mmol, 1.1 equiv) of TBSCl to yield, after bulb-to-bulb distillation, $1.012 \mathrm{~g}(40 \%)$ of $\mathbf{4 3}$ as a clear, colorless oil. 
Data for $(Z)-\mathbf{4 3}$ :

bp: $\quad 100{ }^{\circ} \mathrm{C}(0.05 \mathrm{mmHg}, \mathrm{ABT})$

${ }^{1}$ H NMR: $\quad\left(500 \mathrm{MHz}, \mathrm{CDCl}_{3}\right)$

$6.52(\mathrm{dt}, J=17.1,10.5,1 \mathrm{H}, \mathrm{HC}(3)), 4.68$ (dd, $J=17.2,2.2,1 \mathrm{H}, \mathrm{HC}(4)), 4.48$ (d, $J=10.5,1 \mathrm{H}, \mathrm{HC}(2)), 4.39$ (dd, $J=10.3,2.2,1 \mathrm{H}, \mathrm{HC}(4)), 3.11-3.08$ (m, $4 \mathrm{H}$, $\left.\mathrm{H}_{2} \mathrm{C}(5)\right)$, 1.84-1.81 (m, 4 H, $\left.\mathrm{H}_{2} \mathrm{C}(6)\right), 1.00$ (s, 9 H, $\left.\mathrm{H}_{3} \mathrm{C}(9)\right), 0.19$ (s, $6 \mathrm{H}, \mathrm{H}_{3} \mathrm{C}(7)$ )

NOE ${ }^{1} \mathrm{H}$ NMR: $\left(500 \mathrm{MHz}, \mathrm{CDCl}_{3}\right)$

Irradiation at 3.11-3.08 ppm $\left(\mathrm{H}_{2} \mathrm{C}(5)\right)$ enhanced signal at $4.48 \mathrm{ppm}(\mathrm{HC}(2))$ and 1.84-1.81 ppm $\left(\mathrm{H}_{2} \mathrm{C}(6)\right)$

${ }^{13} \mathrm{C} \mathrm{NMR}: \quad\left(126 \mathrm{MHz}, \mathrm{CDCl}_{3}\right)$

$153.0(\mathrm{C}(1)), 133.8$ (C(3)), $102.3(\mathrm{C}(4)), 84.8$ (C(2)), 47.6 (C(5)), $25.8(\mathrm{C}(9))$, $25.0(\mathrm{C}(6), 18.3(\mathrm{C}(8)),-4.1(\mathrm{C}(7))$

IR: (neat)

3374 (w) 3081 (w), 3058 (w), 2955 (s), 2931 (s), 2884 (s), 2858 (s), 1624 (s), 1472 (s), 1463 (m), 1421 (s), 1389 (m), 1362 (s), 1297 (m), 1254 (s), 1227 (m), 1191 (m), 1058 (s), 1005 (m), 940 (m), 914 (m), 882 (s), 839 (s), 810 (s), 781 (s), $738(\mathrm{w}), 672(\mathrm{~m}), 646(\mathrm{w})$

Preparation of (Z)-1-[1-(tert-Butyldimethylsilanyloxy)-1,3-butadienyl]piperidine (Figure 4)

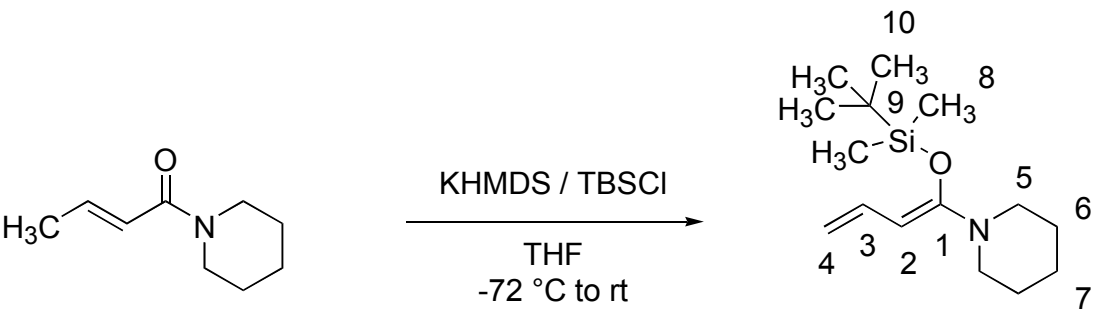

44

Following Representative Procedure 3, $1.531 \mathrm{~g}$ (10 mmol) of 1-[(2E)-1-oxo-2butenyl]piperidine was combined with $2.19 \mathrm{~g}(1.1 \mathrm{mmol}, 1.1$ equiv $)$ of potassium hexamethyldisilazide (1.1 mmol, 1.1 equiv), and $1.66 \mathrm{~g} \mathrm{(11} \mathrm{mmol,} 1.1$ equiv) of TBSCl to yield, after bulb-to-bulb distillation, $2.138 \mathrm{~g}(80 \%)$ of 44 as a clear, colorless oil.

Data for $(Z)-\mathbf{4 4 :}$

bp: $\quad 100{ }^{\circ} \mathrm{C}(0.05 \mathrm{mmHg}, \mathrm{ABT})$ 
${ }^{1}$ H NMR: $\quad\left(500 \mathrm{MHz}, \mathrm{CDCl}_{3}\right)$

6.57 (dt, $J=17.1,10.5,1 \mathrm{H}, \mathrm{HC}(3)), 4.83$ (ddd, $J=17.2,2.2,0.5,1 \mathrm{H}, \mathrm{HC}(4))$, 4.66 (d, $J=10.5,1 \mathrm{H}, \mathrm{HC}(2)$ ), 4.58 (ddd, $J=10.3,2.2,0.5,1 \mathrm{H}, \mathrm{HC}(4)), 2.85-$ 2.79 (m, $\left.4 \mathrm{H}, \mathrm{H}_{2} \mathrm{C}(5)\right), 1.59-1.48$ (m, $6 \mathrm{H}, \mathrm{H}_{2} \mathrm{C}(6), \mathrm{H}_{2} \mathrm{C}(7)$ ), 0.99 (s, $9 \mathrm{H}$, $\left.\mathrm{H}_{3} \mathrm{C}(10)\right), 0.16\left(\mathrm{~s}, 6 \mathrm{H}, \mathrm{H}_{3} \mathrm{C}(8)\right)$

NOE ${ }^{1} \mathrm{H}$ NMR: $\left(500 \mathrm{MHz}, \mathrm{CDCl}_{3}\right)$

Irradiation at $2.85 \mathrm{ppm}\left(\mathrm{H}_{2} \mathrm{C}(5)\right)$ enhanced signal at $4.66 \mathrm{ppm}(\mathrm{HC}(2))$ and 1.59$1.48 \mathrm{ppm}\left(\mathrm{H}_{2} \mathrm{C}(6,7)\right)$

${ }^{13} \mathrm{C}$ NMR: $\quad\left(126 \mathrm{MHz}, \mathrm{CDCl}_{3}\right)$ $156.0(\mathrm{C}(1)), 133.3(\mathrm{C}(3)), 106.7(\mathrm{C}(4)), 91.0(\mathrm{C}(2)), 49.1$ (C(5)), 25.8 (C(10)), $25.4(\mathrm{C}(6), 24.4(\mathrm{C}(7), 18.3(\mathrm{C}(9)),-4.5(\mathrm{C}(8))$

IR: (neat)

3083 (w), 3057 (w), 2935 (s), 2858 (s), 2809 (m), 1634 (s), 1594 (m), $1471(\mathrm{~m})$, 1453 (m), 1444 (m), 1418 (s), 1381 (m), 1370 (s), 1344 (s), 1308 (m), 1274 (w), 1253 (s), 1214 (s), 1183 (w), 1156 (w), 1132 (s), 1057 (s), 1034 (m), 999 (s), 991 (s), $869(\mathrm{~s}), 829(\mathrm{~s}), 815(\mathrm{~m}), 781(\mathrm{~s}), 734(\mathrm{w}), 683(\mathrm{w}), 668(\mathrm{w}), 647$ (w)

MS: (EI, $70 \mathrm{eV})$

268 (26), 267 (M+ , 90), 266 (19), 253 (22), 252 (97), 212 (10), 211 (40), 210 (40), 197 (19), 196 (100), 183 (16), 182 (11), 168 (10), 147 (26), 142 (11), 138 (10), 136 (22), 84 (17), 75 (31), 73 (86), 69 (12), 68 (10), 59 (26), 57 (72), 56 (13), 55 (16)

HRMS: $\quad$ Calcd for $\mathrm{C}_{15} \mathrm{H}_{29} \mathrm{NOSi}$ : 267.2018, found: 267.2016 
Preparation of (Z)-1-[1-(tert-Butyldimethylsilanyloxy)-1,3-butadienyl]morpholine

(Figure 4)

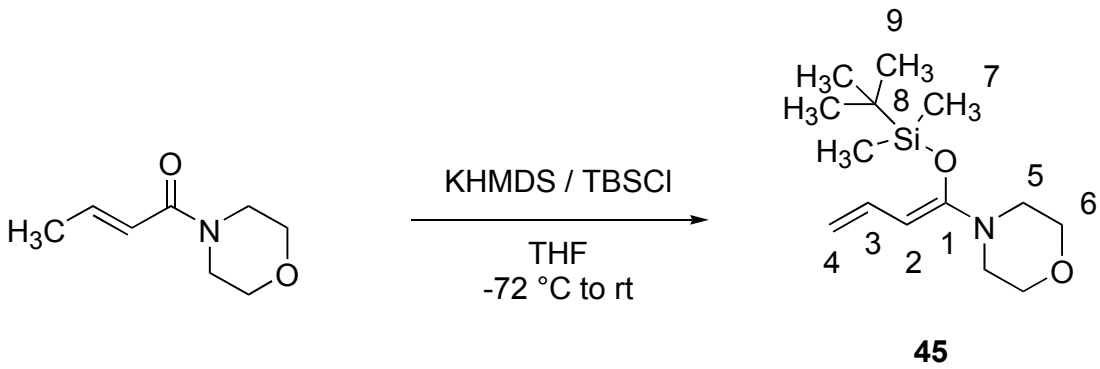

Following Representative Procedure 3, $1.55 \mathrm{~g}$ (10 mmol) of 4-[(2E)-1-oxo-2butenyl]morpholine was combined with $2.19 \mathrm{~g}$ (1.1 mmol, 1.1 equiv) of potassium hexamethyldisilazide, and $1.66 \mathrm{~g}$ (11 mmol, 1.1 equiv) of TBSCl to yield, after bulb-to-bulb distillation, $2.11 \mathrm{~g}(\mathbf{7 8 \%})$ of $\mathbf{4 5}$ as a clear, colorless oil.

Data for $(Z)-45$ :

bp: $\quad 100{ }^{\circ} \mathrm{C}(0.04 \mathrm{mmHg}, \mathrm{ABT})$

${ }^{1} \mathrm{H}$ NMR: $\quad\left(500 \mathrm{MHz}, \mathrm{CDCl}_{3}\right)$

$6.54(\mathrm{dt}, J=17.1,10.5,1 \mathrm{H}, \mathrm{HC}(3)), 4.87$ (dd, $J=17.1,2.2,1 \mathrm{H}, \mathrm{HC}(4)), 4.68$ (d, $J=10.5,1 \mathrm{H}, \mathrm{HC}(2)), 4.64$ (dd, $J=10.3,2.2,1 \mathrm{H}, \mathrm{HC}(4)), 3.71-3.66$ (m, $4 \mathrm{H}$, $\left.\mathrm{H}_{2} \mathrm{C}(6)\right)$ ) 2.90-2.88 (m, 4 H, $\left.\mathrm{H}_{2} \mathrm{C}(5)\right), 0.99$ (s, 9 H, $\left.\mathrm{H}_{3} \mathrm{C}(9)\right), 0.17$ (s, $6 \mathrm{H}, \mathrm{H}_{3} \mathrm{C}(7)$ )

NOE ${ }^{1} \mathrm{H}$ NMR: $\left(500 \mathrm{MHz}, \mathrm{CDCl}_{3}\right.$ )

Irradiation at 2.90-2.88 ppm $\left(\mathrm{H}_{2} \mathrm{C}(5)\right)$ enhanced signal at $4.68 \mathrm{ppm}(\mathrm{HC}(2))$ and 3.71-3.66 ppm $\left(\mathrm{H}_{2} \mathrm{C}(6)\right)$

${ }^{13} \mathrm{C} \mathrm{NMR}: \quad\left(126 \mathrm{MHz}, \mathrm{CDCl}_{3}\right)$

154.8 (C(1)), $132.6(\mathrm{C}(3)), 108.0(\mathrm{C}(4)), 91.8(\mathrm{C}(2))$, $66.5(\mathrm{C}(6)), 48.4(\mathrm{C}(5))$, $25.8(\mathrm{C}(9)), 18.2(\mathrm{C}(8)),-4.5(\mathrm{C}(7))$

IR: (neat)

3083 (w), 3060 (w), 2959 (m), 2931 (m), 2894 (m), 2857 (m), 2829 (m), 1636 (s), 1595 (m), 1473 (m), 1462 (m), 1454 (m), 1419 (m), 1390 (w), 1371 (m), 1362 (m), 1347 (s), 1312 (w), 1297 (w), 1283 (w), 1260 (m), 1218 (s), 1270 (s), 1183 (m), 1121 (s), 1063 (s), 1012 (m), 945 (m), 926 (w), 876 (s), 835 (s), 808 (m), 782 (s), $735(\mathrm{w}), 691(\mathrm{w}), 674(\mathrm{~m}), 648(\mathrm{w}), 629(\mathrm{w})$ 
MS: $\quad(E I, 70 \mathrm{eV})$

270 (28), $269\left(\mathrm{M}^{+}, 100\right), 255$ (10), 254 (47), 228 (37), 226 (13), 214 (15), 213

(22), 212 (29), 199 (10), 198 (46), 189 (11), 183 (27), 182 (13), 170 (12), 168

(13), 155 (10), 154 (11), 147 (25), 75 (53), 73 (56), 59 (14), 57 (28), 56 (11)

HRMS: $\quad$ Calcd for $\mathrm{C}_{14} \mathrm{H}_{27} \mathrm{NO}_{2} \mathrm{Si}: 269.1811$, found: 269.1805

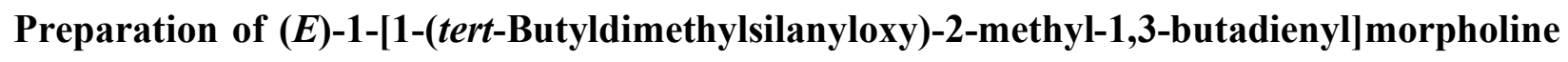
(72) (Figure 5)
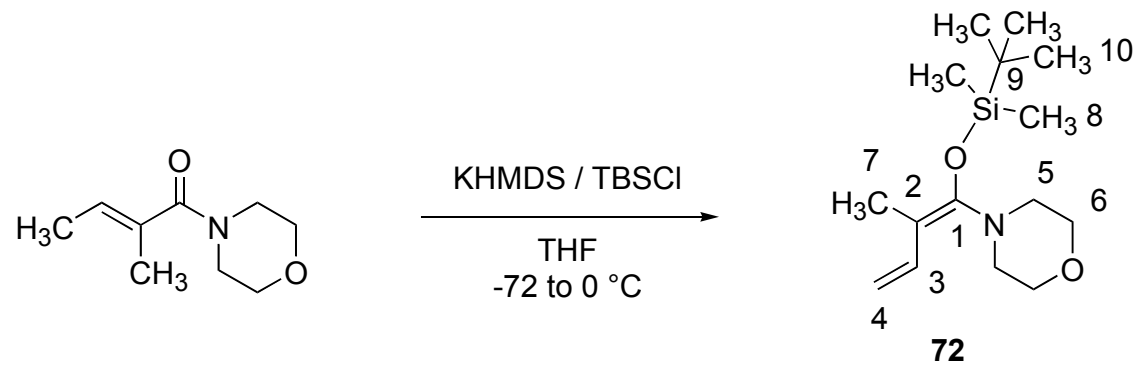

Following Representative Procedure 3, 1.69 g (10 mmol) of 4-[(2E)-1-oxo-2-methyl-2butenyl]morpholine was combined with $2.19 \mathrm{~g}(1.1 \mathrm{mmol}, 1.1 \mathrm{equiv})$ of potassium hexamethyldisilazide, and $1.66 \mathrm{~g}$ (11 mmol, 1.1 equiv) of TBSCl to yield, after bulb-to-bulb distillation, $2.51 \mathrm{~g}(89 \%, E: Z, 72: 28)$ of 72 as a clear, colorless oil.

\section{Data for $(E)-72$ :}

bp: $\quad 130{ }^{\circ} \mathrm{C}(0.05 \mathrm{mmHg}, \mathrm{ABT})$

${ }^{1} \mathrm{H}$ NMR: $\quad\left(500 \mathrm{MHz}, \mathrm{CDCl}_{3}\right)$

$6.80(\mathrm{dd}, J=17.5,10.9,1 \mathrm{H}, \mathrm{HC}(3)), 4.89(\mathrm{dd}, J=17.5,1.6,1 \mathrm{H}, \mathrm{HC}(4)), 4.81$ (dd, $J=11.0,1.7,1 \mathrm{H}, \mathrm{HC}(4)), 3.72-3.70$ (m, 4 H, $\left.\mathrm{H}_{2} \mathrm{C}(6)\right)$ ), 2.94-2.92 (m, $4 \mathrm{H}$, $\left.\mathrm{H}_{2} \mathrm{C}(5)\right), 1.68$ (s, $\left.3 \mathrm{H}, \mathrm{H}_{3} \mathrm{C}(7)\right), 0.99$ (s, $\left.9 \mathrm{H}, \mathrm{H}_{3} \mathrm{C}(10)\right), 0.20$ (s, $6 \mathrm{H}, \mathrm{H}_{3} \mathrm{C}(8)$ )

NOE ${ }^{1} \mathrm{H}$ NMR: $\left(500 \mathrm{MHz}, \mathrm{CDCl}_{3}\right)$

Irradiation at $1.68 \mathrm{ppm}\left(\mathrm{H}_{3} \mathrm{C}(7)\right)$ enhanced signal at $4.88 \mathrm{ppm}(\mathrm{HC}(4)), 0.99 \mathrm{ppm}$ $\left(\mathrm{H}_{3} \mathrm{C}(10)\right)$ and $0.20 \mathrm{ppm}\left(\mathrm{H}_{3} \mathrm{C}(8)\right)$

${ }^{13} \mathrm{C} \mathrm{NMR}: \quad\left(126 \mathrm{MHz}, \mathrm{CDCl}_{3}\right)$

151.7 (C(1)), 136.0 (C(3)), 108.0 (C(4)), 104.9 (C(2)), 67.2 (C(6)), 49.7 (C(5)), $26.0(\mathrm{C}(10)), 18.5(\mathrm{C}(9)), 12.2(\mathrm{C}(7)),-3.2(\mathrm{C}(8))$

IR: (neat) 3088 (w), 3015 (w), 2957 (s), 2931 (s), 2892 (s), 2857 (s), 1628 (s), 1473 (m), 
1462 (s), 1420 (m), 1389 (m), 1362 (s), 1343 (m), 1328 (m), 1299 (m), 1281 (s), 1260 (m), 1195 (s), 1171 (s), 1070 (s), 1052 (m), 1029 (m), 1006 (s), 971 (s), 939 (w), $923(\mathrm{~m}), 874(\mathrm{~s}), 838(\mathrm{~s}), 780(\mathrm{~s}), 691(\mathrm{~m}), 668(\mathrm{~m}), 621(\mathrm{w})$

MS: $\quad(\mathrm{EI}, 70 \mathrm{eV})$ $283\left(\mathrm{M}^{+}, 26\right), 268$ (32), 242 (37), 212 (28), 188 (13), 185 (27), 168 (13), 154 (15), 149 (13), 147 (29), 143 (12), 133 (12), 114 (15), 86 (14), 83 (19), 82 (12), 75 (83), 74 (11), 73 (100), 70 (21), 59 (25), 58 (13), 57 (84), 56 (37), 55 (35), 54 (18), 53 (21)

HRMS: $\quad$ Calcd for $\mathrm{C}_{15} \mathrm{H}_{29} \mathrm{NO}_{2} \mathrm{Si}$ : 283.1968, found: 283.1962

\section{Preparation of (Z)-1-[1-(tert-Butyldimethylsilanyloxy)-3-methyl-1,3-butadienyl]morpholine} (73) (Figure 5)
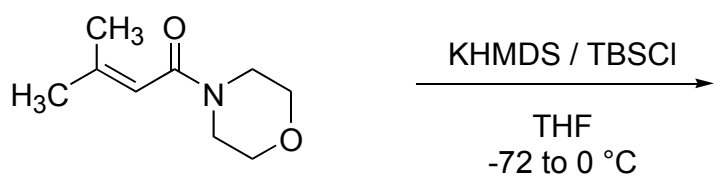

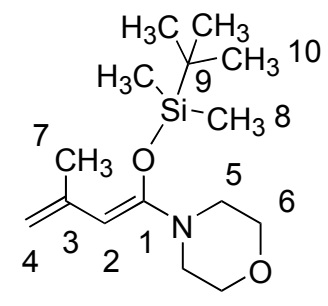

73

Following Representative Procedure 3, 1.69 g (10 mmol) of 4-[(2E)-1-oxo-3-methyl-2butenyl]morpholine was combined with $2.19 \mathrm{~g}$ (1.1 mmol, 1.1 equiv) of potassium hexamethyldisilazide, and $1.66 \mathrm{~g}$ (11 mmol, 1.1 equiv) of TBSCl to yield, after bulb-to-bulb distillation, $2.32 \mathrm{~g}(82 \%, Z: E$, 95:5) of 73 as a clear, colorless oil.

Data for $(Z)-73$ :

bp: $\quad 130{ }^{\circ} \mathrm{C}(0.05 \mathrm{mmHg}, \mathrm{ABT})$

${ }^{1} \mathrm{H}$ NMR: $\quad\left(500 \mathrm{MHz}, \mathrm{CDCl}_{3}\right)$

$4.96(\mathrm{dd}, J=2.7,0.7,1 \mathrm{H}, \mathrm{HC}(4)), 4.72$ (dd, $J=2.8,1.5,1 \mathrm{H}, \mathrm{HC}(4)), 4.34$ (s, 1 $\mathrm{H}, \mathrm{HC}(2))$, 3.72-3.70 (m, $\left.4 \mathrm{H}, \mathrm{H}_{2} \mathrm{C}(6)\right)$ ), 2.85-2.83 (m, $\left.4 \mathrm{H}, \mathrm{H}_{2} \mathrm{C}(5)\right), 1.87$ (s, $3 \mathrm{H}$, $\left.\mathrm{H}_{3} \mathrm{C}(7)\right), 0.95$ (s, $\left.9 \mathrm{H}, \mathrm{H}_{3} \mathrm{C}(10)\right), 0.18$ (s, $\left.6 \mathrm{H}, \mathrm{H}_{3} \mathrm{C}(8)\right)$

NOE ${ }^{1} \mathrm{H}$ NMR: $\left(500 \mathrm{MHz}, \mathrm{CDCl}_{3}\right.$ )

Irradiation at $4.34 \mathrm{ppm}(\mathrm{HC}(2))$ enhanced signal at 2.84-2.82 ppm $\left(\mathrm{H}_{2} \mathrm{C}(5)\right)$ and 4.96 ppm (HC(4)) 
${ }^{13}$ C NMR: $\quad\left(126 \mathrm{MHz}, \mathrm{CDCl}_{3}\right)$

$154.5(\mathrm{C}(1)), 139.6(\mathrm{C}(3)), 110.7(\mathrm{C}(4)), 92.4(\mathrm{C}(2)), 66.5(\mathrm{C}(6)), 49.5(\mathrm{C}(5))$, $26.1(\mathrm{C}(10)), 24.4(\mathrm{C}(7)), 18.2(\mathrm{C}(9)),-3.8(\mathrm{C}(8))$

IR: (neat)

3078 (w), 2960 (s), 2931 (s), 2894 (s), 2857 (s), 2826 (s), 1640 (s), 1472 (m), 1462 (m), 1454 (s), 1409 (m), 1390 (m), 1371 (s), 1362 (s), 1299 (m), 1260 (s), $1212(\mathrm{~m}), 1197(\mathrm{~s}), 1171(\mathrm{~m}), 1121(\mathrm{~s}), 1077(\mathrm{~s}), 1015(\mathrm{~m}), 970(\mathrm{~s}), 938(\mathrm{w}), 927$ (w), 902 (m), 881 (s), 841 (s), 826 (s), 810 (s), 781 (s), 741 (w), 722 (w), 688 (w), $668(\mathrm{w}), 630(\mathrm{w})$

MS: $\quad(E I, 70 \mathrm{eV})$ $283\left(\mathrm{M}^{+}, 14\right), 268$ (37), 226 (20), 212 (44), 168 (13), 127 (10), 83 (26), 82 (13), 75 (34), 73 (100), 59 (34), 57 (64), 56 (19), 55 (24), 54 (12), 53 (18)

HRMS: $\quad$ Calcd for $\mathrm{C}_{15} \mathrm{H}_{29} \mathrm{NO}_{2} \mathrm{Si}$ : 283.1968, found: 283.1964

Preparation of (Z)-1-[1-(Trimethylsilanyloxy)-3-methyl-1,3-butadienyl]morpholine (81) (Table 14, entry 2)

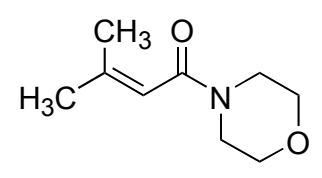

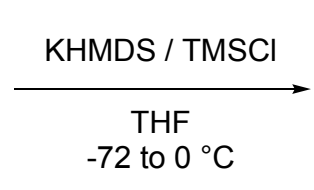

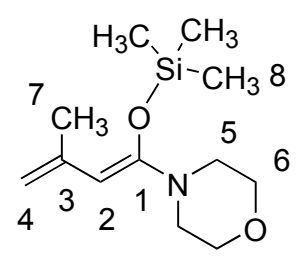

81

Following Representative Procedure 3, 0.846 g (5 mmol) of 4-[(2E)-1-oxo-3-methyl-2butenyl]morpholine was combined with $1.10 \mathrm{~g}$ (5.5 mmol, 1.1 equiv) of potassium hexamethyldisilazide, and $0.696 \mathrm{~mL}$ ( $5.5 \mathrm{mmol}, 1.1$ equiv) of TMSCl to yield, after bulb-to-bulb distillation, $1.03 \mathrm{~g}(85 \%, Z: E, 95: 5)$ of $\mathbf{8 1}$ as a clear, colorless oil.

Data for $(Z)-81$ :

bp: $\quad 100{ }^{\circ} \mathrm{C}(0.05 \mathrm{mmHg}, \mathrm{ABT})$

${ }^{1}$ H NMR: $\quad\left(500 \mathrm{MHz}, \mathrm{CDCl}_{3}\right)$

4.96 (dd, $J=2.7,0.7,1 \mathrm{H}, \mathrm{HC}(4)), 4.72$ (dd, $J=2.8,1.5,1 \mathrm{H}, \mathrm{HC}(4)), 4.34$ (s, 1 $\mathrm{H}, \mathrm{HC}(2))$, 3.72-3.70 (m, 4 H, $\left.\mathrm{H}_{2} \mathrm{C}(6)\right), 2.85-2.83$ (m, 4 H, $\left.\mathrm{H}_{2} \mathrm{C}(5)\right), 1.87$ (s, $3 \mathrm{H}$, $\left.\mathrm{H}_{3} \mathrm{C}(7)\right), 0.21$ (s, $9 \mathrm{H}, \mathrm{H}_{3} \mathrm{C}(8)$ ) 
Preparation of (Z)-1-[1-(Triisopropylsilanyloxy)-3-methyl-1,3-butadienyl]morpholine (82) (Table 14, entry 3)
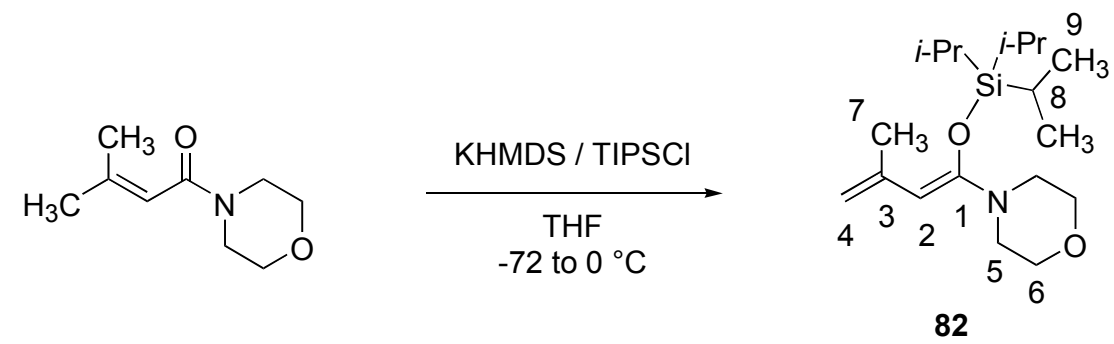

Following Representative Procedure 3, 0.846 g (5 mmol) of 4-[(2E)-1-oxo-3-methyl-2butenyl]morpholine was combined with $1.10 \mathrm{~g}(5.5 \mathrm{mmol}, 1.1$ equiv) of potassium hexamethyldisilazide, and $1.18 \mathrm{~g}$ (5.5 mmol, 1.1 equiv) of TIPSCl to yield, after bulb-to-bulb distillation, $1.597 \mathrm{~g}(98 \%, Z: E, 95: 5)$ of $\mathbf{8 2}$ as a clear, colorless oil.

Data for $(Z)-\mathbf{8 2}$ :

bp: $\quad 140{ }^{\circ} \mathrm{C}(0.05 \mathrm{mmHg}, \mathrm{ABT})$

${ }^{1} \mathrm{H} \mathrm{NMR}: \quad\left(500 \mathrm{MHz}, \mathrm{CDCl}_{3}\right)$

$4.96(\mathrm{dd}, J=2.7,0.7,1 \mathrm{H}, \mathrm{HC}(4)), 4.72(\mathrm{dd}, J=2.8,1.5,1 \mathrm{H}, \mathrm{HC}(4)), 4.34$ (s, 1 $\mathrm{H}, \mathrm{HC}(2))$, 3.72-3.70 (m, 4 H, $\left.\mathrm{H}_{2} \mathrm{C}(6)\right)$ ), 2.85-2.83 (m, 4 H, $\left.\mathrm{H}_{2} \mathrm{C}(5)\right), 1.87$ (s, $3 \mathrm{H}$, $\left.\mathrm{H}_{3} \mathrm{C}(7)\right), 1.21-0.81\left(\mathrm{~m}, 21 \mathrm{H}, \mathrm{H}_{3} \mathrm{C}(9), \mathrm{HC}(8)\right)$

Preparation of (1Z,3Z)-1-[1-(tert-Butyldimethylsilanyloxy)-1,3-pentadienyl]morpholine (74) (Figure 5)

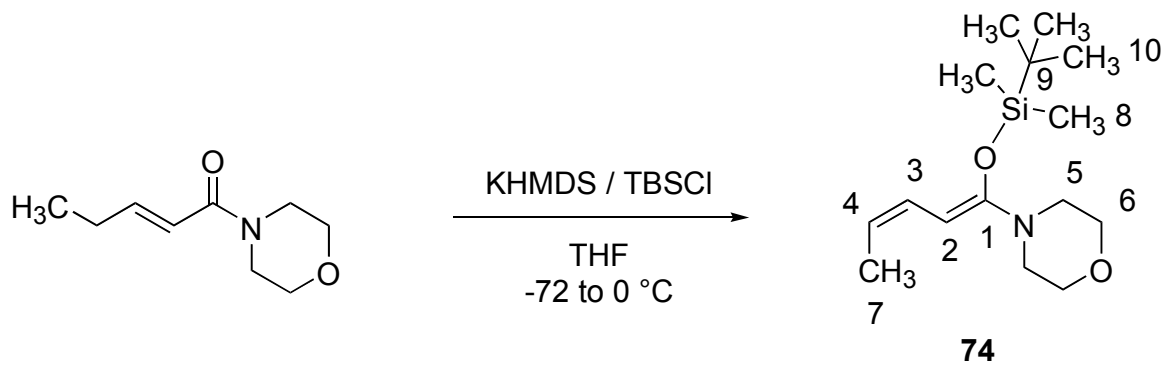

Following Representative Procedure 3, 1.69 g (10 mmol) of 4-[(2E)-1-oxo-2pentenyl]morpholine was combined with $2.19 \mathrm{~g}(1.1 \mathrm{mmol}, 1.1$ equiv $)$ of potassium hexamethyldisilazide, and $1.66 \mathrm{~g}$ (11 mmol, 1.1 equiv) of TBSCl to yield, after bulb-to-bulb distillation, $2.526 \mathrm{~g}(89 \%, 1 Z, 3 Z$ :minor isomers, 90:10) of $\mathbf{7 4}$ as a clear, colorless oil.

Data for (1Z,3Z)-74:

bp: $\quad 150{ }^{\circ} \mathrm{C}(0.05 \mathrm{mmHg}, \mathrm{ABT})$ 
${ }^{1}$ H NMR: $\quad\left(500 \mathrm{MHz}, \mathrm{CDCl}_{3}\right)$

6.21-6.16 (m, $1 \mathrm{H}, \mathrm{HC}(3))$, 5.17-5.10 (m, $1 \mathrm{H}, \mathrm{HC}(4)), 4.75$ (d, $J=11.0,1 \mathrm{H}$, $\mathrm{HC}(2)$ ), 3.72-3.70 (m, $4 \mathrm{H}, \mathrm{H}_{2} \mathrm{C}(6)$ ), 2.91-2.89 ( $\mathrm{m}, 4 \mathrm{H}, \mathrm{H}_{2} \mathrm{C}(5)$ ), 1.68 (dd, J = 7.1, 1.7, $\left.3 \mathrm{H}, \mathrm{H}_{3} \mathrm{C}(7)\right), 0.98$ (s, $\left.9 \mathrm{H}, \mathrm{H}_{3} \mathrm{C}(10)\right), 0.16$ (s, $6 \mathrm{H}, \mathrm{H}_{3} \mathrm{C}(8)$ )

NOE ${ }^{1} \mathrm{H}$ NMR: $\left(500 \mathrm{MHz}, \mathrm{CDCl}_{3}\right)$

Irradiation at $4.75 \mathrm{ppm}(\mathrm{HC}(2))$ enhanced signal at 2.90-2.89 ppm ( $\mathrm{HC}(5))$, and $1.69 \mathrm{ppm}\left(\mathrm{H}_{3} \mathrm{C}(7)\right)$

${ }^{13} \mathrm{C} \mathrm{NMR}: \quad\left(126 \mathrm{MHz}, \mathrm{CDCl}_{3}\right)$

$154.5(\mathrm{C}(1)), 124.9(\mathrm{C}(3)), 117.9(\mathrm{C}(4)), 86.1(\mathrm{C}(2)), 66.5(\mathrm{C}(6)), 48.6(\mathrm{C}(5))$, $25.8(\mathrm{C}(10)), 18.2(\mathrm{C}(9)), 13.2(\mathrm{C}(7)),-4.5(\mathrm{C}(8))$

IR: (neat)

3033 (w), 2959 (s), 2931 (s), 2894 (s), 2857 (s), 2827 (m), 1645 (s), 1604 (s), $1560(\mathrm{w}), 1473$ (s), 1454 (s), 1415 (m), 1390 (m), 1373 (s), 1362 (s), 1342 (s), 1310 (m), 1297 (m), 1253 (s), 1214 (s), 1203 (s), 1195 (s), 1178 (m), 1122 (s), 1076 (s), 1036 (m), 987 (s), 929 (m), 874 (s), 838 (s), 809 (s), 782 (s), 714 (s), $689(\mathrm{~m}), 667(\mathrm{~m}), 644(\mathrm{w})$

MS: $\quad($ EI, $70 \mathrm{eV})$

284 (26), 283 (M+100), 282 (11), 268 (18), 255 (10), 254 (44), 242 (17), 226 (32), 212 (28), 198 (22), 168 (10), 147 (11), 75 (24), 73 (77), 59 (16)

HRMS: $\quad$ Calcd for $\mathrm{C}_{15} \mathrm{H}_{29} \mathrm{NO}_{2} \mathrm{Si}$ : 283.1968, found: 283.1966 


\section{Vinylogous Aldol Additions of Silyl Dienol Ethers}

Representative Procedure 4. Addition of Acyclic $\alpha, \beta$-Unsaturated Ketone-Derived Silyl Dienol Ethers to Aldehydes. Preparation of $(+)-(5 R, 2 E)-5-H y d r o x y-1,5-d i p h e n y l-2-p e n t e n-$ 1-one (11) (Table 1, entry 1)<smiles>C=CC=C(O[Na])c1ccccc1</smiles>

6<smiles>O=Cc1ccccc1</smiles>

$-\mathrm{Pr}_{2} \mathrm{NEt}(0.2$ equiv) $\mathrm{CH}_{2} \mathrm{Cl}_{2}, 0.5 \mathrm{M}$

$-50{ }^{\circ} \mathrm{C}, 24 \mathrm{~h}$

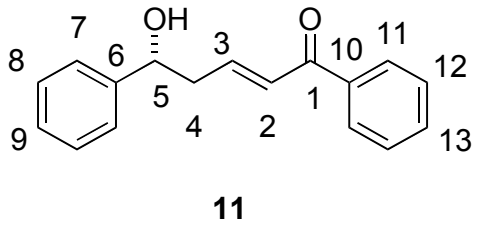

11

Diisopropylethylamine ( $35 \mu \mathrm{L}, 0.2 \mathrm{mmol}, 0.2$ equiv) was added via syringe to a flamedried, 5-mL, Schlenk flask under Ar containing a solution of $42 \mathrm{mg}$ (0.05 mmol, 0.05 equiv) of bisphosphoramide $(R, R)-3 \mathrm{CH}_{2} \mathrm{Cl}_{2}(2 \mathrm{~mL})$. To this solution was added $102 \mu \mathrm{L}(1.0 \mathrm{mmol}, 1.0$ equiv) of benzaldehyde in one portion and the reaction mixture was cooled to $-50{ }^{\circ} \mathrm{C}$ over 15 min. To the resulting solution was added $172 \mu \mathrm{L}$ (1.1 mmol, 1.1 equiv) of $\mathrm{SiCl}_{4}$ in one portion. Then, $284 \mu \mathrm{L}$ (1.2 mmol, 1.2 equiv) of 6 was added dropwise over $1 \mathrm{~min}$ via syringe. The resulting mixture was stirred at $-50{ }^{\circ} \mathrm{C}$ for $24 \mathrm{~h}$ whereupon $3.0 \mathrm{~mL}$ of chilled $\mathrm{CH}_{2} \mathrm{Cl}_{2}$ was added before the cold reaction mixture was poured into a rapidly stirring solution of $1 / 1$ sat. aq. $\mathrm{NaHCO}_{3} /$ sat. aq. $\mathrm{KF}(25 \mathrm{~mL})$ at $0{ }^{\circ} \mathrm{C}$. This biphasic mixture was stirred vigorously for $1 \mathrm{~h}$ before being filtered through Celite on a glass frit. The phases were then separated and the aqueous layer was washed with $\mathrm{CH}_{2} \mathrm{Cl}_{2}(3 \times 40 \mathrm{~mL})$. The combined organic extracts were dried over $\mathrm{Na}_{2} \mathrm{SO}_{4}(5 \mathrm{~g})$, filtered and the filtrate was concentrated in vacuo. The ratio of $\gamma / \alpha$-addition products was determined to be $>99 / 1$ by ${ }^{1} \mathrm{H}$ NMR $(500 \mathrm{MHz})$ analysis of the crude reaction mixture. The residue was purified by column chromatography $\left(\mathrm{SiO}_{2}(25 \mathrm{~g}), 3 \mathrm{~cm}\right.$ diam., hexanes/EtOAc, 4/1 to yield $201 \mathrm{mg}(80 \%)$ of $(+)-11$ as a thick, colorless oil.

\section{Data for $(+)-11$ :}

${ }^{1} \mathrm{H}$ NMR: $\quad\left(500 \mathrm{MHz}, \mathrm{CDCl}_{3}\right)$

$7.88(\mathrm{~d}, J=7.1,2 \mathrm{H}, \mathrm{HC}(11)),(\mathrm{dt}, J=7.5,1.5,1 \mathrm{H}, \mathrm{HC}(13)), 7.43(\mathrm{t}, J=7.62 \mathrm{H}$, $\mathrm{HC}(12))$, 7.39-7.35 (m, 4 H, HC(7,8)), 7.32-7.28 (m, 1 H, HC(9)), 7.06-7.00 (m, 1 H, HC(3)), 6.91 (dt, $J=15.4,1.3,1 \mathrm{H}, \mathrm{HC}(2)), 4.90$ (dd, J = 7.7, 5.1, $1 \mathrm{H}, \mathrm{HC}(5))$, 2.83-2.71 (m, 2 H, HC(4)), 2.31 (br s, $1 \mathrm{H}, \mathrm{OH})$ 
${ }^{13}$ C NMR: $\quad\left(125 \mathrm{MHz}, \mathrm{CDCl}_{3}\right)$

$190.7(\mathrm{C}(1)), 145.0(\mathrm{C}(3)), 143.5(\mathrm{C}(6)), 137.6$ (C(10)), 132.8 (C(13)), 128.6 $(\mathrm{C}(11)), 128.6(\mathrm{C}(8)), 128.6(\mathrm{C}(2)$ or $\mathrm{C}(12)), 128.5(\mathrm{C}(2)$ or $\mathrm{C}(12)), 127.9(\mathrm{C}(9))$, $125.8(\mathrm{C}(7)), 73.2(\mathrm{C}(5)), 42.5(\mathrm{C}(4))$

IR: (neat)

4057 (w), 3430 (m), 3061 (w), 3030 (w), 2894 (w), 2360 (w), $2340(\mathrm{w}), 1964$ (w), 1901 (w), 1817 (w), 1668 (m), 1652 (m), 1621 (m), 1598 (m), 1578 (w), 1494 (w), 1448 (m), 1418 (w), 1344 (m), 1285 (m), 1226 (m), 1180 (w), 1020 (m), 987 (m), $915(\mathrm{w}), 894(\mathrm{w}), 834(\mathrm{w}), 764(\mathrm{~m}), 698(\mathrm{~m}), 667(\mathrm{~m})$

MS: $\quad\left(\mathrm{CI}, \mathrm{CH}_{4}\right)$

$253\left(\mathrm{M}^{+}+\mathrm{H}, 17\right), 236$ (10), 235 (51), 175 (18), 148 (11), 147 (100), 146 (43), 145

(11), 107 (71), 105 (79), 79 (13)

Opt. Rot.: $\quad[\alpha]_{\mathrm{D}}{ }^{24}+14.40^{\circ}(\mathrm{c}=1.00, \mathrm{EtOH})$

TLC: $\quad R_{f} 0.30$ (hexanes/EtOAc, 3/2) [UV (254 nm)]

SFC: $\quad(R)-11, t_{\mathrm{R}} 3.04 \min (99.0 \%) ;(S)-11, t_{\mathrm{R}} 4.06 \min (1.0 \%)$ (Chiralpak AD, 175 psi, $40{ }^{\circ} \mathrm{C}, 20.0 \% \mathrm{MeOH}$ in $\mathrm{CO}_{2}, 3.0 \mathrm{~mL} / \mathrm{min}, 220 \mathrm{~nm}$ )

Analysis: $\quad \mathrm{C}_{17} \mathrm{H}_{16} \mathrm{O}_{2}(252.31)$

Calcd: $\quad$ C, 80.93; H, 6.39\%

Found: $\quad$ C, $80.63 ; \quad H, 6.33 \%$

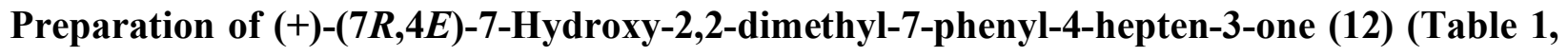
entry 2)
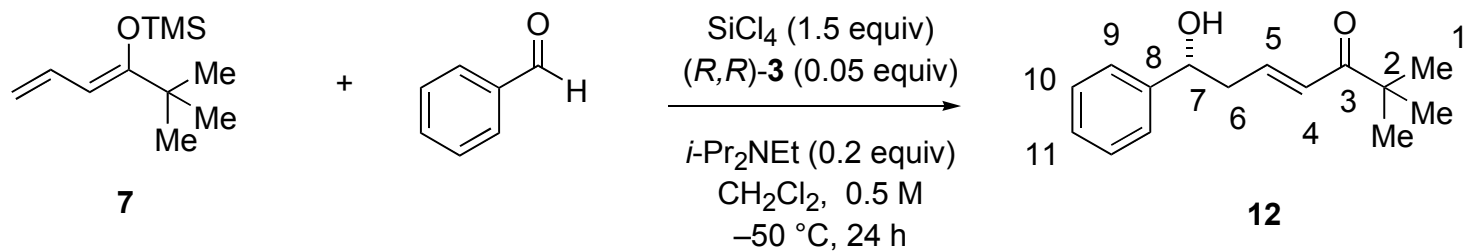

Following Representative Procedure 4, $102 \mu \mathrm{L}(1.0 \mathrm{mmol})$ of benzaldehyde was combined with $42 \mathrm{mg}(0.05 \mathrm{mmol}, 0.05$ equiv) of bisphosphoramide $(R, R)-3,35 \mu \mathrm{L}(0.2 \mathrm{mmol}$, 0.2 equiv) of diisopropylethylamine, $172 \mu \mathrm{L}\left(1.5 \mathrm{mmol}, 1.5\right.$ equiv) of $\mathrm{SiCl}_{4}$ and $290 \mu \mathrm{L}(1.2$ mmol, 1.2 equiv) of 7 to yield, after column chromatography $\left(\mathrm{SiO}_{2}(20 \mathrm{~g}), 2 \mathrm{~cm}\right.$ diam., hexanes/EtOAc 3/1) to yield $218 \mathrm{mg}(94 \%)$ of $(+)-\mathbf{1 2}$ as a white solid. The ratio of $\gamma / \alpha$-addition 
products was determined to be $>99 / 1$ by ${ }^{1} \mathrm{H}$ NMR $(500 \mathrm{MHz})$ analysis of the crude reaction mixture.

Data for $(+)-\mathbf{1 2}$ :

mp: $\quad 49-50{ }^{\circ} \mathrm{C}$ (benzene)

${ }^{1} \mathrm{H}$ NMR: $\quad\left(500 \mathrm{MHz}, \mathrm{CDCl}_{3}\right)$

7.38-7.34 (m, 4 H, HC(9,10)), 7.30-7.27 (m, 1 H, HC(11)), 6.94-6.88 (m, 1 H, $\mathrm{HC}(5)), 6.53$ (dt, $J=15.3,1.4,1 \mathrm{H}, \mathrm{HC}(4)), 4.84$ (dd, J = 7.6, 5.4, $1 \mathrm{H}, \mathrm{HC}(7))$, 2.72-2.61 (m, $\left.2 \mathrm{H}, \mathrm{H}_{2} \mathrm{C}(6)\right), 2.02$ (br s, $\left.1 \mathrm{H}, \mathrm{OH}\right), 1.11$ (s, $9 \mathrm{H}, \mathrm{H}_{3}(\mathrm{C}(1)$ )

${ }^{13} \mathrm{C} \mathrm{NMR}: \quad\left(125 \mathrm{MHz}, \mathrm{CDCl}_{3}\right)$

204.2 (C(3)), 143.5 (C(8)), 142. 6 (C(5)), 128.6 (C(10)), 127.8 (C(11)), 127.0 (C(4)), 125.8 (C(9)), 73.1 (C(7)), 42.8 (C(2)), 42.2 (C(6)), 26.0 (C(1))

IR: $\quad\left(\mathrm{CHCl}_{3}\right)$

4059 (w), 3436 (m), 3087 (w), 3063 (w), 3016 (m), 2970 (s), 2934 (m), 2906 (m), 2871 (m), 2444 (w), 1951 (w), 1879 (w), 1809 (w), 1686 (s), 1624 (s), 1494 (m), 1478 (s), 1455 (m), 1396 (m), 1367 (m), 1334 (m), 1295 (m), 1218 (m), 1178 (w), 1102 (m), 1082 (m), 1066 (m), 1047 (m), 1028 (m), 992 (m), 940 (w), 866 (w), $844(\mathrm{w}), 756(\mathrm{~s}), 700(\mathrm{~s}), 667(\mathrm{~m}), 630(\mathrm{w})$

MS: $\quad\left(\mathrm{CI}, \mathrm{CH}_{4}\right)$

$233\left(\mathrm{M}^{+}+\mathrm{H}, 4\right), 215$ (26), 155 (10), 129 (13), 127 (59), 126 (25), 109 (15), 107 (91), 105 (13), 85 (37), 79 (20), 69 (21), 63 (16), 57 (100), 55 (12)

Opt. Rot.: $[\alpha]_{\mathrm{D}}^{24}+6.12^{\circ}(\mathrm{c}=0.95, \mathrm{EtOH})$

TLC: $\quad R_{f} 0.34$ (hexanes/EtOAc, 3/2) [UV (254 nm)]

SFC: $\quad(R)-12, t_{\mathrm{R}} 5.63 \min (99.4 \%) ;(S)-12, t_{\mathrm{R}} 6.41 \min (0.6 \%)$ (Chiralpak AD, 150 psi, $40{ }^{\circ} \mathrm{C}, 3.5 \% \mathrm{MeOH}$ in $\mathrm{CO}_{2}, 3.5 \mathrm{~mL} / \mathrm{min}, 220 \mathrm{~nm}$ )

Analysis: $\quad \mathrm{C}_{15} \mathrm{H}_{20} \mathrm{O}_{2}(232.32)$

Calcd: $\quad$ C, $77.55 ; \quad H, 8.68 \%$

Found: $\quad \mathrm{C}, 77.58 ; \quad \mathrm{H}, 8.72 \%$ 


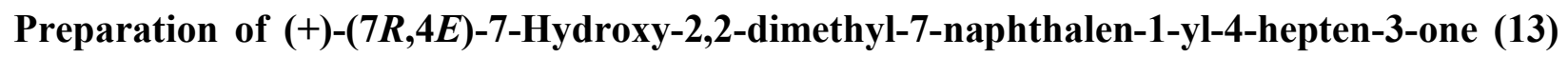
(Table 1, entry 3)
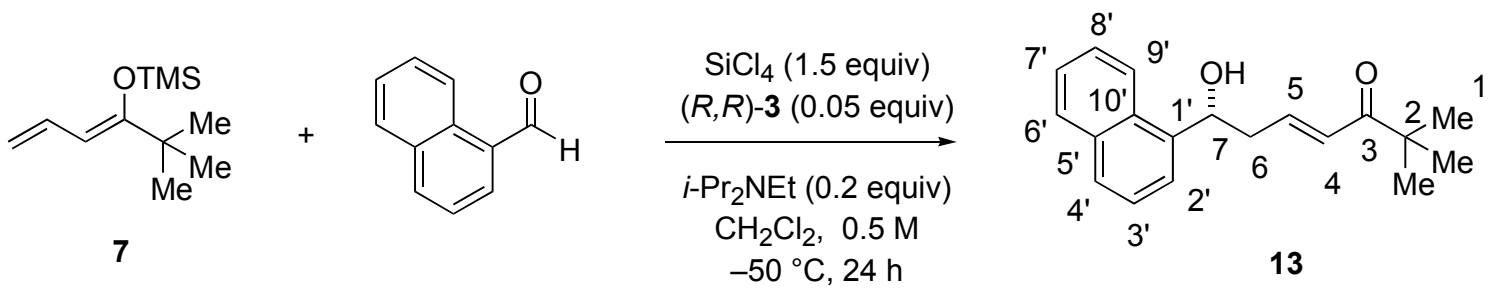

Following Representative Procedure 4, $136 \mu \mathrm{L}(1.0 \mathrm{mmol})$ of 1-naphthaldehyde was combined with $42 \mathrm{mg}(0.05 \mathrm{mmol}, 0.05$ equiv) of bisphosphoramide $(R, R)-3,35 \mu \mathrm{L}(0.2 \mathrm{mmol}$, 0.2 equiv) of diisopropylethylamine, $172 \mu \mathrm{L}\left(1.5 \mathrm{mmol}, 1.5\right.$ equiv) of $\mathrm{SiCl}_{4}$ and $290 \mu \mathrm{L}(1.2$ mmol, 1.2 equiv) of 7 to yield, after column chromatography $\left(\mathrm{SiO}_{2}(20 \mathrm{~g}), 2 \mathrm{~cm}\right.$ diam., pentane $\left./ \mathrm{Et}_{2} \mathrm{O} 2 / 1\right)$ to yield $239 \mathrm{mg}(85 \%)$ of $(+)-13$ as a thick, clear oil. The ratio of $\gamma / \alpha$-addition products was determined to be $>99 / 1$ by ${ }^{1} \mathrm{H}$ NMR $(500 \mathrm{MHz})$ analysis of the crude reaction mixture.

Data for $(+)-13$ :

${ }^{1}$ H NMR: $\quad\left(500 \mathrm{MHz}, \mathrm{CDCl}_{3}\right)$

8.07 (d, $\left.J=8.3,1 \mathrm{H}, \mathrm{HC}\left(9^{\prime}\right)\right), 7.89$ (d, $\left.J=8.8,1 \mathrm{H}, \mathrm{HC}\left(6^{\prime}\right)\right), 7.80$ (d, $J=8.1,1 \mathrm{H}$, HC(4')), 7.67 (d, $J=7.1,1$ H, HC(2')), 7.56-7.47 (m, 3 H, HC(3', 7',8'), 7.087.02 (m, 1 H, HC(5)), 6.57 (dd, $J=15.3,1.4,1$ H, HC(4)), 5.64 (dd, J = 8.0, 4.4, 1 $\mathrm{H}, \mathrm{HC}(7)), 2.92-2.75$ (m, $\left.2 \mathrm{H}, \mathrm{H}_{2} \mathrm{C}(6)\right), 2.11$ (br s, $\left.1 \mathrm{H}, \mathrm{OH}\right), 1.11$ (s, $9 \mathrm{H}, \mathrm{H}_{3} \mathrm{C}(1)$ )

${ }^{13} \mathrm{C} \mathrm{NMR}: \quad\left(125 \mathrm{MHz}, \mathrm{CDCl}_{3}\right)$

204.3 (C(3)), 143.1 (C(5)), 139.1 (C(1')), 133.7 (C(5’)), 130.0 (C(10’)), 129.0 (C(6’)), 128.1 (C(4')), 126.8 (C(4)), 126.1 (C(8')), 125.5 (C(7’)), 125.4 (C(3’)), 122.9 (C(2’)), 122.8 (C(9’)), $69.7(\mathrm{C}(7)), 42.8$ (C(2)), 41.2 (C(6)), $26.0(\mathrm{C}(1))$

IR: (neat)

3437 (s), 3052 (m), 2968 (s), 2932 (s), 2906 (m), 2870 (m), 2719 (w), 2416 (w), 2249 (w), 1945 (w), 1814 (w), 1687 (s), 1621 (s), 1599 (m), 1512 (m), 1477 (s), 1464 (m), 1423 (m), 1395 (s), 1366 (s), 1326 (s), 1295 (m), 1266 (m), 1222 (m), 1163 (m), 1143 (w), 1104 (s), 1080 (s), 1051 (s), 1005 (s), 987 (s), 968 (s), 939 (m), 910 (s), 864 (m), 801 (s), 779 (s), 733 (s), 647 (m), 631 (m)

MS: $\quad(\mathrm{EI}, 70 \mathrm{eV})$ $282\left(\mathrm{M}^{+}, 3\right), 158$ (13), 157 (100), 130 (10), 129 (86), 128 (49), 127 (33), 126 (59), 
69 (23), 57 (27)

Opt. Rot.: $\quad[\alpha]_{\mathrm{D}}{ }^{24}+57.11^{\circ}(\mathrm{c}=1.10, \mathrm{EtOH})$

TLC: $\quad R_{f} 0.49$ (hexanes/EtOAc, 3/2) [UV (254 nm)]

SFC: $\quad(S)-13, t_{\mathrm{R}} 3.59 \min (1.1 \%) ;(R)-13, t_{\mathrm{R}} 4.81 \mathrm{~min}(98.9 \%)$ (Chiralpak OD, 125 psi, $40{ }^{\circ} \mathrm{C}, 17.5 \% \mathrm{MeOH}$ in $\mathrm{CO}_{2}, 3.0 \mathrm{~mL} / \mathrm{min}, 220 \mathrm{~nm}$ )

Analysis: $\quad \mathrm{C}_{19} \mathrm{H}_{22} \mathrm{O}_{2}(282.38)$
Calcd:
C, 80.82;
$\mathrm{H}, 7.85 \%$

Found:

C, 80.70;

$\mathrm{H}, 7.83 \%$

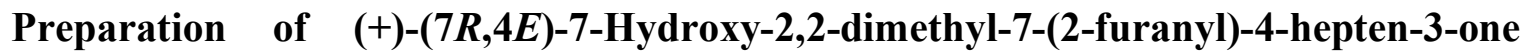

(Table 1, entry 4)
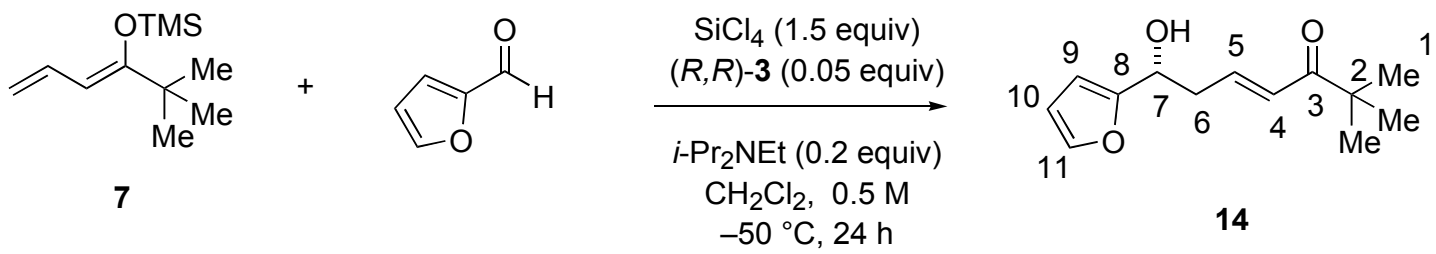

Following Representative Procedure 4, $84 \mu \mathrm{L}(1.0 \mathrm{mmol})$ of 2-furfuraldehyde was combined with $42 \mathrm{mg}$ (0.05 mmol, 0.05 equiv) of bisphosphoramide $(R, R)-3,35 \mu \mathrm{L}(0.2 \mathrm{mmol}$, 0.2 equiv) of diisopropylethylamine, $172 \mu \mathrm{L}\left(1.5 \mathrm{mmol}, 1.5\right.$ equiv) of $\mathrm{SiCl}_{4}$ and $290 \mu \mathrm{L}(1.2$ mmol, 1.2 equiv) of 7 to yield, after column chromatography $\left(\mathrm{SiO}_{2}(20 \mathrm{~g}), 2 \mathrm{~cm}\right.$ diam., pentane/ $\left.\mathrm{Et}_{2} \mathrm{O} 2 / 1\right)$ to yield $199 \mathrm{mg}(90 \%)$ of $(+)-14$ as a waxy solid. The ratio of $\gamma / \alpha$-addition products was determined to be $>99 / 1$ by ${ }^{1} \mathrm{H}$ NMR $(500 \mathrm{MHz})$ analysis of the crude reaction mixture.

Data for $(+)-14$ :

${ }^{1} \mathrm{H} \mathrm{NMR}: \quad\left(500 \mathrm{MHz}, \mathrm{CDCl}_{3}\right)$

$7.38(\mathrm{dd}, J=1.7,0.9,1 \mathrm{H}, \mathrm{HC}(11)), 6.89$ (dt, $J=15.4,7.5,1 \mathrm{H}, \mathrm{HC}(5)), 6.58$ (dt, $J=15.3,1.3,1 \mathrm{H}, \mathrm{HC}(4)), 6.33(\mathrm{dd}, J=3.2,1.7,1 \mathrm{H} \mathrm{HC}(10)), 6.26(\mathrm{~d}, J=3.2,1$ H, HC(9)), 4.85 (t, $J=6.6,1 \mathrm{H}, \mathrm{HC}(7)), 2.80-2.76$ (m, $\left.2 \mathrm{H}, \mathrm{H}_{2} \mathrm{C}(6)\right), 2.02$ (br s, 1 $\mathrm{H}, \mathrm{OH}), 1.13\left(\mathrm{~s}, 9 \mathrm{H}, \mathrm{H}_{3} \mathrm{C}(1)\right)$

${ }^{13} \mathrm{C} \mathrm{NMR}: \quad\left(125 \mathrm{MHz}, \mathrm{CDCl}_{3}\right)$

$204.1(\mathrm{C}(3)), 155.4(\mathrm{C}(8)), 142.2$ (C(11)), 141.7 (C(5)), 127.1 (C(4)), 110.2 (C(10)), 106.5 (C(9)), 66.5 (C(7)), 42.8 (C(2)), 38.5 (C(6)), 26.0 (C(1)) 
IR: (neat)

3428 (s), 3122 (m), 3055 (w), 2969 (s), 2935 (s), 2908 (m), 2872 (m), 2301 (w), 1760 (m), 1688 (s), 1624 (s), 1569 (w), 1505 (m), 1478 (s), 1465 (s), 1396 (s), 1367 (s), 1329 (s), 1295 (m), 1223 (m), 1148 (s), 1069 (s), 1009 (s), 884 (m), 865 (m), $813(\mathrm{~m}), 792(\mathrm{~m}), 742(\mathrm{~s})$

MS: $\quad\left(\mathrm{CI}, \mathrm{CH}_{4}\right)$ $223\left(\mathrm{M}^{+}+\mathrm{H}, 3\right), 206$ (16), 205 (100), 127 (44), 126 (30), 109 (11), 97 (92), 85 (16), 69 (16), 57 (47)

Opt. Rot.: $\quad[\alpha]_{\mathrm{D}}^{24}+3.80^{\circ}(\mathrm{c}=1.00, \mathrm{EtOH})$

TLC: $\quad R_{f} 0.34$ (hexanes/EtOAc, 3/2) [UV (254 nm)]

SFC: $\quad(R)-14, t_{\mathrm{R}} 5.73 \min (95.8 \%) ;(S)-14, t_{\mathrm{R}} 6.63 \min (4.2 \%)$ (Chiralpak AD, 150 psi, $40{ }^{\circ} \mathrm{C}, 2.5 \% \mathrm{MeOH}$ in $\mathrm{CO}_{2}, 3.0 \mathrm{~mL} / \mathrm{min}, 220 \mathrm{~nm}$ )

Analysis: $\quad \mathrm{C}_{13} \mathrm{H}_{18} \mathrm{O}_{3}(222.28)$

Calcd: $\quad$ C, $70.24 ; \quad H, 8.16 \%$

Found: $\quad$ C, $69.89 ; \quad H, 8.20 \%$

\section{Preparation of (-)-(7R,4E)-7-Hydroxy-2,2-dimethyl-7-(2-thienyl)-4-hepten-3-one (15)} (Table 1, entry 5)<smiles></smiles>

7

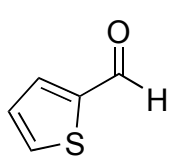

(n)
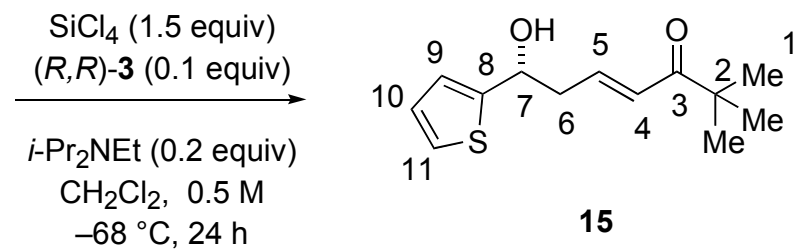

Following Representative Procedure 4, $94 \mu \mathrm{L}$ (1.0 mmol) of 2-thiophenecarboxaldehyde was combined with $84 \mathrm{mg}(0.1 \mathrm{mmol}, 0.1$ equiv) of bisphosphoramide $(R, R)-3,35 \mu \mathrm{L}(0.2$ mmol, 0.2 equiv) of diisopropylethylamine, $172 \mu \mathrm{L}\left(1.5 \mathrm{mmol}, 1.5\right.$ equiv) of $\mathrm{SiCl}_{4}$ and $290 \mu \mathrm{L}$ (1.2 mmol, 1.2 equiv) of 7 to yield, after column chromatography $\left(\mathrm{SiO}_{2}(20 \mathrm{~g}), 2 \mathrm{~cm}\right.$ diam., hexanes/EtOAc 4/1) a solid which was recrystallized from hexanes $(3 \mathrm{~mL})$ at $-20{ }^{\circ} \mathrm{C}$ to yield 119 $\mathrm{mg}(50 \%)$ of $(-)-\mathbf{1 5}$ as white needles. The ratio of $\gamma / \alpha$-addition products was determined to be $>99 / 1$ by ${ }^{1} \mathrm{H}$ NMR $(500 \mathrm{MHz})$ analysis of the crude reaction mixture.

\section{Data for (-)-15:}

mp: $\quad 49-51^{\circ} \mathrm{C}$ (hexanes) 
${ }^{1} \mathrm{H}$ NMR: $\quad\left(500 \mathrm{MHz}, \mathrm{CDCl}_{3}\right)$

7.27-7.25 (m, $1 \mathrm{H}, \mathrm{HC}(11))$, 6.99-6.93 (m, $2 \mathrm{H}, \mathrm{HC}(9,10)), 6.89$ (dt, J= 15.4, 7.4, $1 \mathrm{H}, \mathrm{HC}(5)), 6.58$ (dt, $J=15.1,1.5,1 \mathrm{H}, \mathrm{HC}(4)), 5.09$ (dd, $J=7.0,6.1,1 \mathrm{H}$, $\mathrm{HC}(7)$ ), 2.82-2.71 (m, 2 H, $\left.\mathrm{H}_{2} \mathrm{C}(6)\right), 2.12$ (br s, $\left.1 \mathrm{H}, \mathrm{OH}\right), 1.13$ (s, 9 H, $\mathrm{H}_{3} \mathrm{C}(1)$ )

${ }^{13} \underline{\mathrm{C} \mathrm{NMR}}: \quad\left(125 \mathrm{MHz}, \mathrm{CDCl}_{3}\right)$

204.3 (C(3)), 147.4 (C(8)), 141.9 (C(5)), 127.2 (C(4)), 126.7 (C(10)), 124.8 (C(11)), 124.0 (C(9)), 67.0 (C(7)), 42.8 (C(2)), 42.2 (C(6)), 26.0 (C(1))

IR: $\quad\left(\mathrm{CHCl}_{3}\right)$

3436 (w), 3109 (w), 3017 (m), 2971 (m), 2934 (w), 2906 (w), $2871(\mathrm{w}), 2401$ (w), 2361 (w), 2341 (w), 1686 (s), 1624 (s), 1534 (m), 1478 (m), 1464 (w), 1440 (w), 1396 (m), 1367 (m), 1321 (w), 1295 (w), 1216 (s), 1151 (w), 1100 (m), 1066 (m), $1038(\mathrm{~m}), 1007$ (m), $988(\mathrm{~m}), 934(\mathrm{w}), 896(\mathrm{w}), 853(\mathrm{w}), 833(\mathrm{w}), 758(\mathrm{~s}), 702(\mathrm{~s})$, $668(\mathrm{~m})$

MS: $\quad(\mathrm{FI})$

239 (15), $238\left(\mathrm{M}^{+}, 100\right)$

Opt. Rot.: $[\alpha]_{\mathrm{D}}^{24}-5.26^{\circ}(\mathrm{c}=1.00, \mathrm{EtOH})$

TLC: $\quad R_{f} 0.33$ (hexanes/EtOAc, 3/2) [UV (254 nm)]

SFC: $\quad(R)-15, t_{\mathrm{R}} 5.63 \min (93.8 \%) ;(S)-15, t_{\mathrm{R}} 6.33 \min (6.2 \%)$ (Chiralpak AD, 150 psi, $40{ }^{\circ} \mathrm{C}, 5.0 \% \mathrm{MeOH}$ in $\left.\mathrm{CO}_{2}, 2.75 \mathrm{~mL} / \mathrm{min}, 220 \mathrm{~nm}\right)$

Analysis: $\quad \mathrm{C}_{13} \mathrm{H}_{18} \mathrm{O}_{2} \mathrm{~S}(238.35)$

Calcd: $\quad$ C, 65.51; $\quad$ H, 7.61\%

Found: $\quad$ C, $65.30 ; \quad$ H, $7.66 \%$ 
Preparation of $(-)-(7 R, 2 E)-7-H y d r o x y-2,2-d i m e t h y l-9-p h e n y l-4,8-n o n a d i e n-3-o n e$

(Table 1, entry 6)

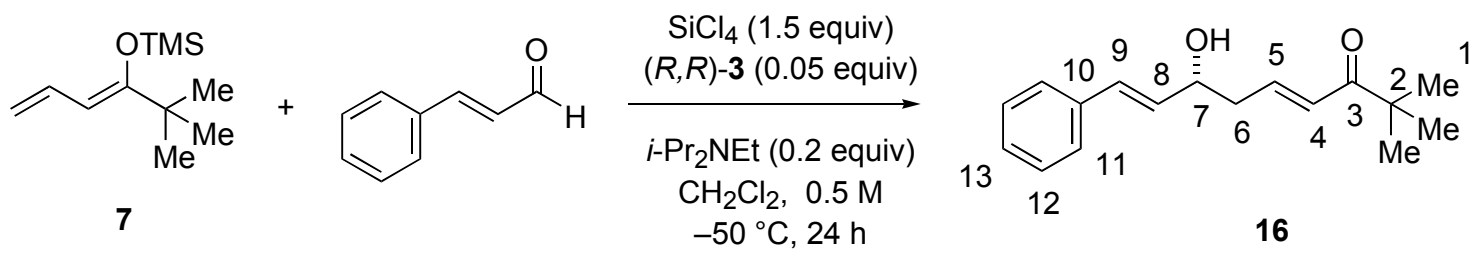

Following Representative Procedure 4, $126 \mu \mathrm{L}(1.0 \mathrm{mmol})$ of cinnamaldehyde was combined with $42 \mathrm{mg}$ (0.05 mmol, 0.05 equiv) of bisphosphoramide $(R, R)-3,35 \mu \mathrm{L}(0.2 \mathrm{mmol}$, 0.2 equiv) of diisopropylethylamine, $172 \mu \mathrm{L}$ (1.5 mmol, 1.5 equiv) of $\mathrm{SiCl}_{4}$ and $290 \mu \mathrm{L}(1.2$ mmol, 1.2 equiv) of 7 to yield, after column chromatography $\left(\mathrm{SiO}_{2}(20 \mathrm{~g}), 2 \mathrm{~cm}\right.$ diam., pentane/ $\left.\mathrm{Et}_{2} \mathrm{O} 2 / 1\right)$ to yield $211 \mathrm{mg}(82 \%)$ of (-)-16 as a white solid. The ratio of $\gamma / \alpha$-addition products was determined to be $>99 / 1$ by ${ }^{1} \mathrm{H}$ NMR $(500 \mathrm{MHz})$ analysis of the crude reaction mixture.

Data for (-)-16:

mp: $\quad 47-48{ }^{\circ} \mathrm{C}$ (benzene)

${ }^{1} \mathrm{H} \mathrm{NMR}: \quad\left(500 \mathrm{MHz}, \mathrm{CDCl}_{3}\right)$

7.37 (d, $J=7.1,2$ H, HC(11)), 7.32 (t, $J=7.5,2$ H, HC(12)), 7.27-7.24 (m, 1 H, HC(13)), 6.96 (dt, $J=15.1,7.6,1 \mathrm{H}, \mathrm{HC}(5))$, 6.64-6.60 (m, $2 \mathrm{H}, \mathrm{HC}(4,9)), 6.23$ (dd, $J=15.9,6.6,1 \mathrm{H}, \mathrm{HC}(8)), 4.84$ (dd, $J=7.6,5.4,1 \mathrm{H}, \mathrm{HC}(7)), 2.56$ (t, $J=7.1$ $\left.2 \mathrm{H}, \mathrm{H}_{2} \mathrm{C}(6)\right), 1.82$ (br s, $\left.1 \mathrm{H}, \mathrm{OH}\right), 1.15$ (s, $9 \mathrm{H}, \mathrm{H}_{3} \mathrm{C}(1)$ )

${ }^{13} \mathrm{C} \mathrm{NMR}: \quad\left(125 \mathrm{MHz}, \mathrm{CDCl}_{3}\right)$

204.1 (C(3)), 142.4 (C(5)), 136.3 (C(10)), 131.0 (C(8)), 130.9 (C(9)), 128.6 (C(12)), 127.9 (C(13)), 127.1 (C(4)), 126.5 (C(11)), 71.5 (C(7)), 42.8 (C(2)), 40.5 (C(6)), $26.1(\mathrm{C}(1))$

\section{IR: $\quad\left(\mathrm{CHCl}_{3}\right)$}

3440 (w), 3082 (w), 3058 (m), 3016 (m), 2969 (s), 2932 (m), 2905 (w), 2870 (w), 2401 (w), 2361 (w), 2340 (w), 1948 (w), 1877 (w), 1685 (s), 1623 (s), 1578 (w), 1493 (w), 1477 (m), 1463 (w), 1449 (m), 1395 (m), 1366 (m), 1330 (m), 1294 (w), 1216 (s), 1091 (m), 1060 (m), 1030 (m), 1002 (m), 968 (s), 890 (w), 849 (w), 753 (s), 694 (s), 667 (m), 620 (w) 
MS: $\quad(\mathrm{FI}, 70 \mathrm{eV})$

$259(21), 258\left(\mathrm{M}^{+}, 100\right)$

Opt. Rot.: $\quad[\alpha]_{\mathrm{D}}{ }^{24}-27.42^{\circ}(\mathrm{c}=0.90, \mathrm{EtOH})$

TLC: $\quad R_{f} 0.39$ (hexanes/EtOAc, 3/2) [UV (254 nm)]

SFC: $\quad(R)-16, t_{\mathrm{R}} 2.93 \min (99.7 \%) ;(S)-16, t_{\mathrm{R}} 3.62 \min (0.3 \%)$ (Chiralpak OD, 125 psi, $40{ }^{\circ} \mathrm{C}, 15.0 \% \mathrm{MeOH}$ in $\mathrm{CO}_{2}, 3.0 \mathrm{~mL} / \mathrm{min}, 220 \mathrm{~nm}$ )

Analysis: $\quad \mathrm{C}_{17} \mathrm{H}_{22} \mathrm{O}_{2}(258.36)$

Calcd: $\quad$ C, $79.03 ; \quad H, 8.58 \%$

Found: $\quad$ C, $79.00 ; \quad H, 8.71 \%$

\section{Preparation of (7R,4E)-7-Hydroxy-2,2-dimethyl-9-phenyl-4,8-nonadien-3-one (17) (Table 1, entry 6)}

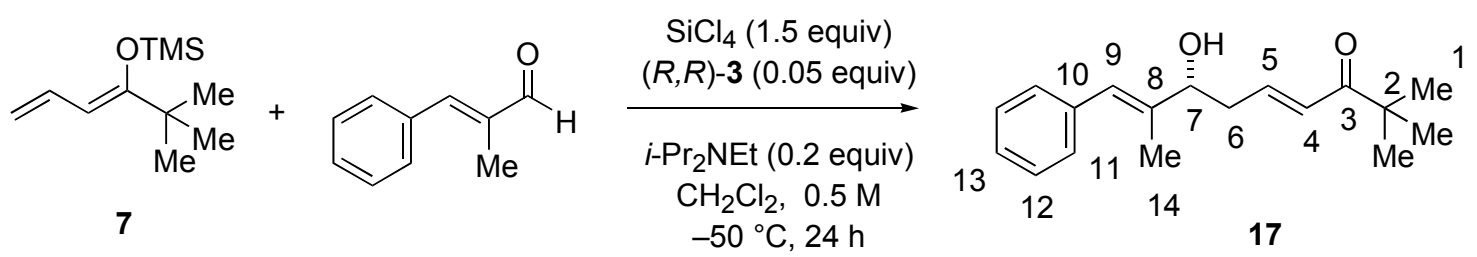

Following Representative Procedure 4, $70 \mu \mathrm{L}(0.5 \mathrm{mmol})$ of 2-methylcinnamaldehyde was combined with $21 \mathrm{mg}(0.025 \mathrm{mmol}, 0.05$ equiv) of bisphosphoramide $(R, R)-3,18 \mu \mathrm{L}(0.1$ mmol, 0.2 equiv) of diisopropylethylamine, $86 \mu \mathrm{L}\left(0.75 \mathrm{mmol}, 1.5\right.$ equiv) of $\mathrm{SiCl}_{4}$ and $145 \mu \mathrm{L}$ ( $0.6 \mathrm{mmol}, 1.2$ equiv) of 7 to yield, after column chromatography $\left(\mathrm{SiO}_{2}(14 \mathrm{~g}), 2 \mathrm{~cm}\right.$ diam., pentane $\left./ \mathrm{Et}_{2} \mathrm{O} 1 / 1\right)$ to yield $33 \mathrm{mg}(24 \%)$ of 17 as a clear, colorless oil. The ratio of $\gamma / \alpha$-addition products was determined to be $>99 / 1$ by ${ }^{1} \mathrm{H}$ NMR $(500 \mathrm{MHz})$ analysis of the crude reaction mixture.

Data for 17:

${ }^{1} \mathrm{H} \mathrm{NMR}: \quad\left(500 \mathrm{MHz}, \mathrm{CDCl}_{3}\right)$

7.35-7.32 (m, 2 H, HC(11)), 7.26-7.21 (m, 3 H, HC(12,13)), 6.95 (dt, $J=15.1$, 7.3, $1 \mathrm{H}, \mathrm{HC}(5)), 6.62$ (dt, $J=15.4,1.5,1 \mathrm{H}, \mathrm{HC}(4)), 6.54$ (s, $1 \mathrm{H}, \mathrm{HC}(9)), 4.34$ $(\mathrm{t}, J=6.6,1 \mathrm{H}, \mathrm{HC}(7)), 2.57\left(\mathrm{t}, J=7.1,2 \mathrm{H}, \mathrm{H}_{2} \mathrm{C}(6)\right), 1.89(\mathrm{~d}, J=1.2,3 \mathrm{H}$, $\mathrm{HC}(14)), 1.72$ (br s, $1 \mathrm{H}, \mathrm{OH}), 1.15$ (s, $9 \mathrm{H}, \mathrm{H}_{3} \mathrm{C}(1)$ )

TLC: $\quad R_{f} 0.41$ (hexanes/EtOAc, 3/2) [UV (254 nm)] 
SFC: $\quad(R)-17, t_{\mathrm{R}} 3.31 \min (64.7 \%) ;(S)-17, t_{\mathrm{R}} 3.66 \min (35.3 \%)$ (Chiralpak OD, 125 psi, $40{ }^{\circ} \mathrm{C}, 11.0 \% \mathrm{MeOH}$ in $\mathrm{CO}_{2}, 3.0 \mathrm{~mL} / \mathrm{min}, 220 \mathrm{~nm}$ )

Preparation of $(-)-(7 R, 4 E)-7-H y d r o x y-2,2-d i m e t h y l-9-p h e n y l-4-n o n e n-8-y n-3-o n e \quad(18)$ (Table 1, entry 8)

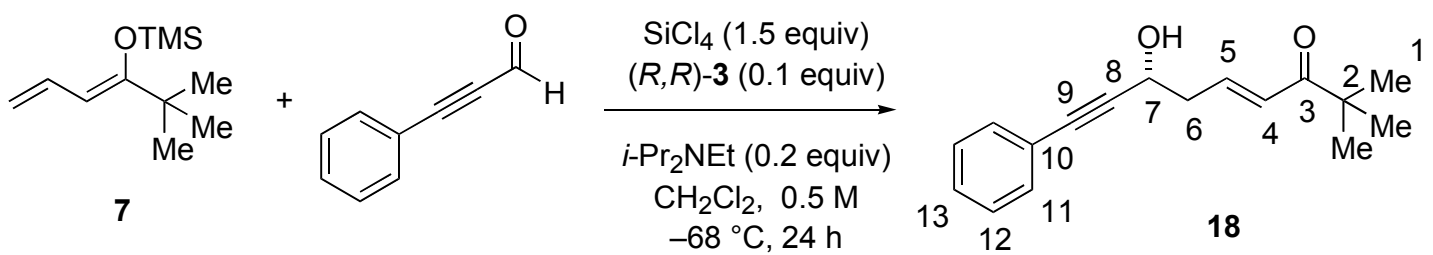

Following Representative Procedure 4, $122 \mu \mathrm{L}(1.0 \mathrm{mmol})$ of 3-phenyl-2-propynal was combined with $84 \mathrm{mg}(0.1 \mathrm{mmol}, 0.1$ equiv) of bisphosphoramide $(R, R)-3,35 \mu \mathrm{L}(0.2 \mathrm{mmol}, 0.2$ equiv) of diisopropylethylamine, $172 \mu \mathrm{L}\left(1.5 \mathrm{mmol}, 1.5\right.$ equiv) of $\mathrm{SiCl}_{4}$ and $290 \mu \mathrm{L}(1.2 \mathrm{mmol}$, 1.2 equiv) of 7 at $-68{ }^{\circ} \mathrm{C}$ to yield, after column chromatography $\left(\mathrm{SiO}_{2}(20 \mathrm{~g}), 2 \mathrm{~cm}\right.$ diam., hexanes/EtOAc 6/1) to yield $102 \mathrm{mg}(40 \%)$ of (-)-18 as a clear oil. The ratio of $\gamma / \alpha$-addition products was determined to be $>99 / 1$ by ${ }^{1} \mathrm{H}$ NMR $(500 \mathrm{MHz})$ analysis of the crude reaction mixture.

Data for (-)-18:

${ }^{1} \mathrm{H} \mathrm{NMR}: \quad\left(500 \mathrm{MHz}, \mathrm{CDCl}_{3}\right)$

7.43-7.41 (m, 2 H, HC(11)), 7.35-7.29 (m, 3 H, HC(12,13)), 7.02 (dt, $J=15.4$, 7.5, $1 \mathrm{H}, \mathrm{HC}(5)), 6.69(\mathrm{dt}, J=15.4,1.2,1 \mathrm{H}, \mathrm{HC}(4)), 4.75$ (t, $J=6.1,1 \mathrm{H}$, $\mathrm{HC}(7)), 2.73$ (dt, $\left.J=6.1,1.2,2 \mathrm{H}, \mathrm{H}_{2} \mathrm{C}(6)\right), 1.65$ (br s, $\left.1 \mathrm{H}, \mathrm{OH}\right), 1.16$ (s, $9 \mathrm{H}$, $\left.\mathrm{H}_{3} \mathrm{C}(1)\right)$

${ }^{13} \mathrm{C} \mathrm{NMR}: \quad\left(125 \mathrm{MHz}, \mathrm{CDCl}_{3}\right)$

204.1 (C(3)), 141.1 (C(5)), 131.7 (C(11)), 128.6 (C(13)), 128.3 (C(12)), 127.5 (C(4)), 122.2 (C(10)), 88.8 (C(8)), 85.8 (C(9)), 61.6 (C(7)), 42.9 (C(2)), 40.7 (C(6)), $26.1(\mathrm{C}(1))$

IR: $\quad\left(\mathrm{CHCl}_{3}\right)$

3405 (s), 3079 (m), 3057 (m), 3033 (m), 3021 (m), 2966 (s), 2932 (s), 2906 (s), 2870 (s), 2718 (w), $2336(w), 2232$ (w), 2205 (w), 1959 (w), $1884(w), 1681($ s), 1621 (s), 1599 (s), 1573 (m), 1489 (s), 1477 (s), 1464 (s), 1443 (s), 1395 (s), 1366 (s), 1325 (s), 1292 (s), 1221 (m), 1199 (m), 1176 (m), 1102 (s), 1070 (s), 1035 (s), 
1005 (s), 953 (s), 919 (m), 885 (m), 864 (m), 845 (m), 819 (m), 789 (m), 757 (s), $692(\mathrm{~s}), 669(\mathrm{~m})$

MS: $\quad\left(\mathrm{CI}, \mathrm{CH}_{4}\right)$

$257\left(\mathrm{M}^{+}+\mathrm{H}, 4\right), 239$ (31), 183 (15), 155 (21), 131 (53), 127 (36), 126 (10), 105 (39), 103 (22), 85 (27), 57 (100)

Opt. Rot:: $[\alpha]_{\mathrm{D}}{ }^{24}-15.96^{\circ}(\mathrm{c}=0.99$, EtOH $)$

TLC: $\quad R_{f} 0.39$ (hexanes/EtOAc, 3/2) [UV (254 nm)]

SFC: $\quad(R)-18, t_{\mathrm{R}} 1.90 \min (83.9 \%) ;(S)-18, t_{\mathrm{R}} 3.60 \min (16.1 \%)$ (Chiralpak OD, 125 psi, $40{ }^{\circ} \mathrm{C}, 17.5 \% \mathrm{MeOH}$ in $\mathrm{CO}_{2}, 3.00 \mathrm{~mL} / \mathrm{min}, 220 \mathrm{~nm}$ )

Analysis: $\quad \mathrm{C}_{17} \mathrm{H}_{20} \mathrm{O}_{2}(256.34)$

Calcd: $\quad$ C, $79.65 ; \quad H, 7.86 \%$

Found: $\quad$ C, $79.68 ; \quad H, 7.72 \%$

\section{Representative Procedure 5. Addition of Cyclic Ketone-Derived Silyl Dienol Ether 10 to}

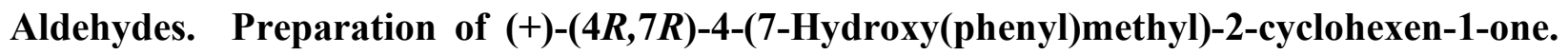
(20) (Table 2, entry 1)

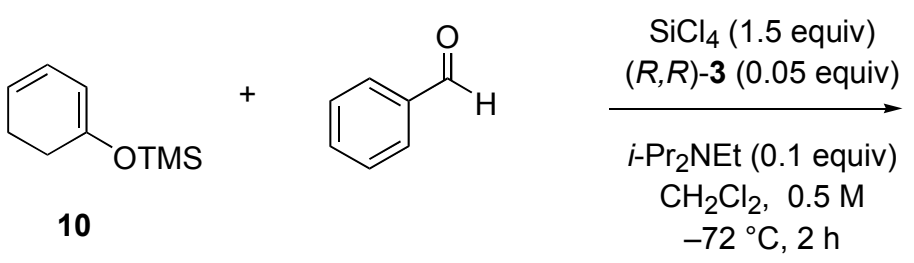

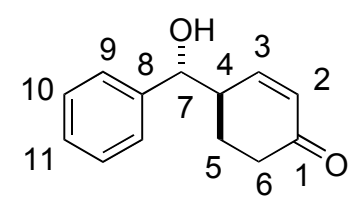

20

Diisopropylethylamine (18 $\mu \mathrm{L}, 0.1 \mathrm{mmol}, 0.1$ equiv) was added via syringe to a flamedried, 5-mL, Schlenk flask under $\mathrm{N}_{2}$ containing a solution of $42 \mathrm{mg}$ (0.05 mmol, 0.05 equiv) of bisphosphoramide $(R, R)-3$ in $\mathrm{CH}_{2} \mathrm{Cl}_{2}(2 \mathrm{~mL})$. To this solution was added $102 \mu \mathrm{L}(1.0 \mathrm{mmol})$ of benzaldehyde in one portion. To the resulting solution was added $172 \mu \mathrm{L}$ (1.5 mmol, 1.5 equiv) of $\mathrm{SiCl}_{4}$ in one portion and the reaction mixture was cooled to $-72{ }^{\circ} \mathrm{C}$ over $15 \mathrm{~min}$. Then, 224 $\mu \mathrm{L}$ (1.2 mmol, 1.2 equiv) of $\mathbf{1 0}$ was added dropwise over $1 \mathrm{~min}$. The resulting mixture was stirred at $-72{ }^{\circ} \mathrm{C}$ for $2 \mathrm{~h}$ whereupon $3.0 \mathrm{~mL}$ of chilled $\mathrm{CH}_{2} \mathrm{Cl}_{2}$ was added before the cold reaction mixture was poured into a rapidly stirring solution of $1 / 1$ sat. aq. $\mathrm{NaHCO}_{3} /$ sat. aq. $\mathrm{KF}(25 \mathrm{~mL})$ at $0{ }^{\circ} \mathrm{C}$. This biphasic mixture was stirred vigorously for $1 \mathrm{~h}$ before being filtered through Celite on a glass frit. The phases were then separated and the aqueous layer was washed with $\mathrm{CH}_{2} \mathrm{Cl}_{2}$ $(3 \times 40 \mathrm{~mL})$. The combined organic extracts were dried over $\mathrm{Na}_{2} \mathrm{SO}_{4}$, filtered and the filtrate 
was concentrated in vacuo. The ratio of $\gamma / \alpha$-addition products was determined to be $>99 / 1$ by ${ }^{1} \mathrm{H}$ NMR $(500 \mathrm{MHz})$ analysis of the crude reaction mixture. The residue was purified by column chromatography $\left(\mathrm{SiO}_{2}(25 \mathrm{~g}), 3 \mathrm{~cm}\right.$ diam., pentane/Et $2 \mathrm{O}, 1 / 1$ to yield $182 \mathrm{mg}(90 \%)$ of $(+)-20$ as a thick, colorless oil, solidified upon standing. The diastereomeric ratio was determined to be anti/syn, $97.5 / 2.5$ by SFC analysis. The spectroscopic data for $\mathbf{2 0}$ matched those in the literature. $^{15}$

Data for $(+)-($ anti)-20:

${ }^{1} \mathrm{H}$ NMR: $\quad\left(500 \mathrm{MHz}, \mathrm{CDCl}_{3}\right)$

7.43-7.32 (m, 5H, HC(9,10,11)), 7.25 (dt, $J=10.3,1.7,1 \mathrm{H}, \mathrm{HC}(3)), 6.09$ (dd, $J=$ 10.3, 2.4, 1 H, HC(2)), 4.59 (dd, J = 7.8, 3.2, 1 H, HC(7)), 2.78-2.73 (m, 1 H, $\mathrm{HC}(4))$, 2.49-2.21 (m, $1 \mathrm{H}, \mathrm{HC}(6)), 2.35-2.28$ (m, $1 \mathrm{H}, \mathrm{HC}(6)), 2.03$ (br s, 1H, $\mathrm{OH}), 1.75-1.68\left(\mathrm{~m}, 2 \mathrm{H}, \mathrm{H}_{2} \mathrm{C}(5)\right)$

${ }^{13} \mathrm{C} \mathrm{NMR}: \quad\left(125 \mathrm{MHz}, \mathrm{CDCl}_{3}\right)$

200.0 (C(1)), 151.6 (C(3)), 142.2 (C(8)), 129.8 (C(2)), 128.6 (C(10)), 128.1

(C(11)), 126.2 (C(9)), 76.5 (C(7)), $43.6(\mathrm{C}(4)), 36.7$ (C(6)), 25.8 (C(5))

Opt. Rot.: $\quad[\alpha]_{\mathrm{D}}^{24}+114.38^{\circ}(\mathrm{c}=1.00, \mathrm{EtOH})$

TLC: $\quad R_{f} 0.10$ (pentane/Et $\left.{ }_{2} \mathrm{O}, 1 / 1\right)$ [UV $\left.(254 \mathrm{~nm})\right]$

SFC: $\quad(4 S, 7 S)-20 t_{\mathrm{r}} 6.52 \mathrm{~min}(2.5 \%)$; $(4 R, 7 R)-\mathbf{2 0} \mathrm{t}_{\mathrm{r}} 9.65 \mathrm{~min}(97.5 \%)$ (Chiralpak OJ, 150 psi, $40{ }^{\circ} \mathrm{C}, 6.0 \% \mathrm{MeOH}$ in $\mathrm{CO}_{2}, 2.75 \mathrm{~mL} / \mathrm{min}, 220 \mathrm{~nm}$ )

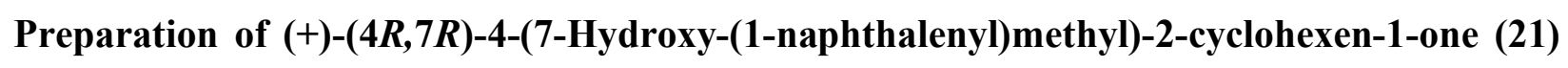
(Table 2, entry 2)

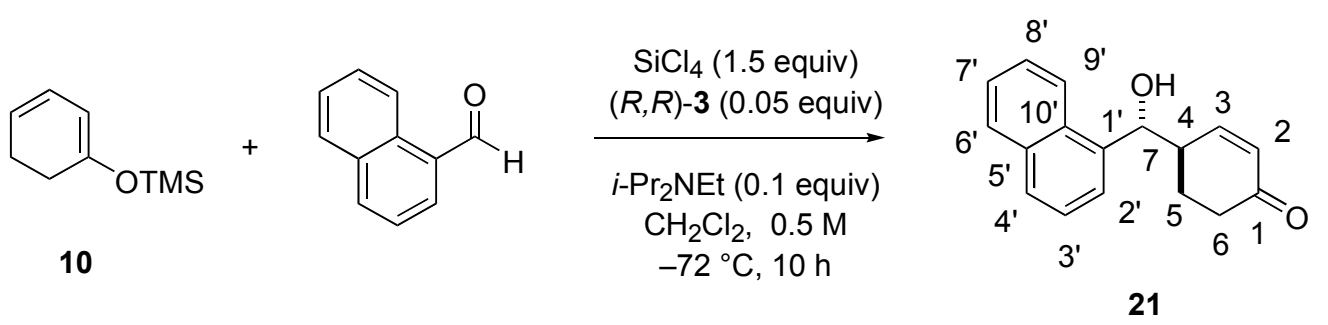

Following Representative Procedure 5, $136 \mu \mathrm{L}(1.0 \mathrm{mmol})$ of 1-naphthaldehyde was combined with $42 \mathrm{mg}$ ( $0.05 \mathrm{mmol}, 0.05$ equiv) of bisphosphoramide $(R, R)-3,35 \mu \mathrm{L}(0.2 \mathrm{mmol}$, 0.2 equiv) of diisopropylethylamine, $172 \mu \mathrm{L}\left(1.5 \mathrm{mmol}, 1.5\right.$ equiv) of $\mathrm{SiCl}_{4}$ and $224 \mu \mathrm{L}(1.2$ mmol, 1.2 equiv) of $\mathbf{1 0}$ for $10 \mathrm{~h}$ to yield, after column chromatography $\left(\mathrm{SiO}_{2}(20 \mathrm{~g}), 2 \mathrm{~cm}\right.$ diam., 
Pentane $\left./ \mathrm{Et}_{2} \mathrm{O} 2 / 1\right)$ to yield $202 \mathrm{mg}(80 \%)$ of $(+)-21$ as a white foam. The ratio of $\gamma / \alpha$-addition products was determined to be $>99 / 1$ by ${ }^{1} \mathrm{H}$ NMR $(500 \mathrm{MHz})$ analysis of the crude reaction mixture. The diastereomeric ratio was determined to be anti/syn, 89.0/11.0 by SFC analysis.

Data for $(+)-($ anti $)-21$ :

${ }^{1} \mathrm{H} \mathrm{NMR}: \quad\left(500 \mathrm{MHz}, \mathrm{CDCl}_{3}\right)$

8.13 (d, $\left.J=8.3,1 \mathrm{H}, \mathrm{HC}\left(9^{\prime}\right)\right), 7.89$ (d, $\left.J=8.8,1 \mathrm{H}, \mathrm{HC}\left(6^{\prime}\right)\right), 7.85$ (d, $J=8.3,1 \mathrm{H}$, HC(4')), 7.69 (d, J= 7.1, 1 H, HC(2’)), 7.57-7.51 (m, 3H, HC(3', 7’, 8')), 7.25 (dd, $J=10.3,1.5,1 \mathrm{H}, \mathrm{HC}(3)), 6.11(\mathrm{dd}, J=10.4,2.6,1 \mathrm{H}, \mathrm{HC}(2)), 5.40$ (d, $J=6.6,1$ H, HC(7)), 3.08-3.03 (m, 1 H, HC(4)), 2.51 (td, $J=16.7,4.3,1$ H, HC(6)), 2.30 (ddd, $J=16.8,11.5,5.2,1 \mathrm{H}, \mathrm{HC}(6)), 2.13$ (br s, $1 \mathrm{H}, \mathrm{OH}), 1.99-1.91$ (m, $1 \mathrm{H}$, $\mathrm{HC}(5)), 1.86-1.82$ (m, $1 \mathrm{H}, \mathrm{HC}(5))$

${ }^{13} \mathrm{C} \mathrm{NMR}: \quad\left(125 \mathrm{MHz}, \mathrm{CDCl}_{3}\right)$

200.0 (C(1)), 151.4 (C(3)), 137.8 (C(1')), 133.8 (C(5’)), 130.4 (C(10’)), 129.8

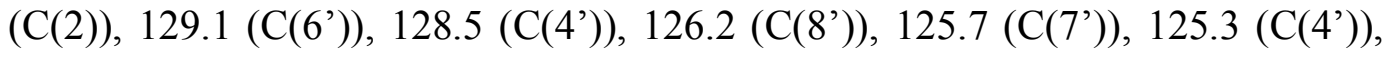
124.0 (C(2’)), 122.9 (C(9’)), 73.4 (C(7)), 42.8 (C(4)), 36.9 (C(6)), 26.5 (C(5))

IR: (neat)

3417 (s), 3058 (m), 3011 (m), 2954 (m), 1666 (s), 1597 (m), 1509 (m), 1393 (m), 1352 (m), 1332 (m), 1256 (m), 1216 (m), 1140 (m), 1092 (m), 1048 (m), 1015 (m), $861(\mathrm{~m}), 848(\mathrm{~m}), 805(\mathrm{~m}), 784(\mathrm{~s}), 756(\mathrm{~s}), 666(\mathrm{~m}), 632(\mathrm{~m})$

MS: (ESI)

$253\left(\mathrm{M}^{+}+\mathrm{H}, 12\right), 236(21), 235$ (100), 157 (54)

Opt. Rot.: $\quad[\alpha]_{\mathrm{D}}{ }^{24}+89.08^{\circ}(\mathrm{c}=0.90, \mathrm{EtOH})$

TLC: $\quad R_{f} 0.20$ (hexanes/EtOAc, 3/2) [UV (254 nm)]

SFC: $\quad(4 S, 7 S)-21 t_{\mathrm{r}} 2.50 \min (5.0 \%)$; $(4 R, 7 R)-21 \mathrm{t}_{\mathrm{r}} 5.08 \mathrm{~min}(95.0 \%)$; (Chiralpak OJ, $125 \mathrm{psi}, 40^{\circ} \mathrm{C}, 20.0 \% \mathrm{MeOH}$ in $\mathrm{CO}_{2}, 4.0 \mathrm{~mL} / \mathrm{min}, 220 \mathrm{~nm}$ )

HRMS: $\quad$ Calcd for $\mathrm{C}_{17} \mathrm{H}_{17} \mathrm{O}_{2}: 253.1229$, found: 253.1224 
Preparation of (-)-(4R,7R)-4-(7-Hydroxy-(9-phenyl-8-propenyl))-2-cyclohexen-1-one (22) (Table 2, entry 3)

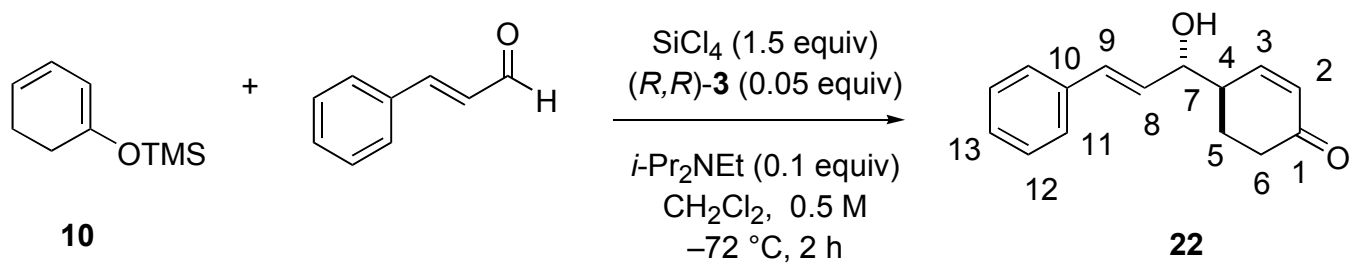

Following Representative Procedure 5, $126 \mu \mathrm{L}(1.0 \mathrm{mmol})$ of cinnamaldehyde was combined with $42 \mathrm{mg}$ ( $0.05 \mathrm{mmol}, 0.05$ equiv) of bisphosphoramide $(R, R)-3,35 \mu \mathrm{L}(0.2 \mathrm{mmol}$, 0.2 equiv) of diisopropylethylamine, $172 \mu \mathrm{L}\left(1.5 \mathrm{mmol}, 1.5\right.$ equiv) of $\mathrm{SiCl}_{4}$ and $224 \mu \mathrm{L}(1.2$ mmol, 1.2 equiv) of $\mathbf{1 0}$ for $2 \mathrm{~h}$ to yield, after column chromatography $\left(\mathrm{SiO}_{2}(20 \mathrm{~g}), 2 \mathrm{~cm}\right.$ diam., hexanes/EtOAc $2 / 1)$ to yield $173 \mathrm{mg}(76 \%)$ of (-)-22 as a thick, clear oil. The ratio of $\gamma / \alpha-$ addition products was determined to be $>99 / 1$ by ${ }^{1} \mathrm{H}$ NMR $(500 \mathrm{MHz})$ analysis of the crude reaction mixture. The diastereomeric ratio was determined to be anti/syn, 98.0/2.0 by SFC analysis.

Data for (-)-(anti)-22:

${ }^{1} \mathrm{H}$ NMR: $\quad\left(500 \mathrm{MHz}, \mathrm{CDCl}_{3}\right)$

$7.41(\mathrm{~d}, J=7.8,2 \mathrm{H}, \mathrm{HC}(11)), 7.34$ (t, $J=7.3,2 \mathrm{H}, \mathrm{HC}(12))$, 7.30-7.27 (m, $J=$ 7.3, 1.2, $1 \mathrm{H}, \mathrm{HC}(13)), 7.16(\mathrm{ddd}, J=10.3,2.3,1.6,1 \mathrm{H}, \mathrm{HC}(3)), 6.67$ (d, $J=$ 15.9, $1 \mathrm{H}, \mathrm{HC}(9)), 6.26(\mathrm{dd}, J=15.9,6.8,1 \mathrm{H}, \mathrm{HC}(8)), 6.10(\mathrm{ddd}, J=10.3,2.4$, $0.7,1 \mathrm{H}, \mathrm{HC}(2)), 4.23$ (t, $J=6.8,1 \mathrm{H}, \mathrm{HC}(7)), 2.69-2.63$ (m, $1 \mathrm{H}, \mathrm{HC}(4)), 2.55$ (dt, $J=16.8,4.2,1 \mathrm{H}, \mathrm{HC}(6)), 2.39$ (ddd, $J=16.8,13.2,5.0,1 \mathrm{H}, \mathrm{HC}(6), 2.14-$ 2.08 (m, 1 H, HC(5)), 1.90-1.82 (m, 1 H, HC(5)), 1.71 (br s, 1 H. OH)

${ }^{13} \mathrm{C} \mathrm{NMR}: \quad\left(125 \mathrm{MHz}, \mathrm{CDCl}_{3}\right)$

199.9 (C(1)), 151.1 (C(3)), 136.0 (C(10)), 132.3 (C(9)), 130.2 (C(2)), 129.6 (C(8)), 128.7 (C(12)), 128.1 (C(13)), 126.5 (C(11)), 75.0 (C(7)), 42.3 (C(4)), 36.9 (C(6)), $25.5(\mathrm{C}(5))$

IR: (neat)

3417 (s), 3082 (m), 3058 (m), 3028 (m), 2953 (m), 2872 (m), 2247 (w), 1954 (w), 1883 (w), 1812 (w), 1682 (s), 1651 (s), 1600 (m), 1578 (m), 1494 (s), 1450 (s), 1415 (s), 1391 (s), 1351 (s), 1331 (s), 1255 (s), 1217 (s), 1178 (s), 1140 (m), 1110 (s), 1071 (s), 1037 (s), 969 (s), 913 (m), 879 (m), 843 (m), 752 (s), 695 (s) 
MS: $\quad(\mathrm{FI})$

$228\left(\mathrm{M}^{+}, 40\right), 211(15), 210(100)$

Opt. Rot.: $\quad[\alpha]_{\mathrm{D}}{ }^{24}-52.73^{\circ}(\mathrm{c}=1.43, \mathrm{EtOH})$

TLC: $\quad R_{f} 0.16$ (hexanes/EtOAc, 3/2) [UV (254 nm)]

SFC: $\quad(4 R, 7 R)-22 \mathrm{t}_{\mathrm{r}} 4.91 \mathrm{~min}(84.5 \%)$; $(4 S, 7 S)-22 \mathrm{t}_{\mathrm{r}} 6.47 \mathrm{~min}(15.5 \%)$ (Chiralpak OD, $125 \mathrm{psi}, 40{ }^{\circ} \mathrm{C}, 20.0 \% \mathrm{MeOH}$ in $\mathrm{CO}_{2}, 3.0 \mathrm{~mL} / \mathrm{min}, 220 \mathrm{~nm}$ )

Analysis: $\quad \mathrm{C}_{15} \mathrm{H}_{16} \mathrm{O}_{2}(228.29)$

Calcd: $\quad$ C, $78.92 ; \quad$ H, $7.06 \%$

Found: $\quad$ C, $79.03 ; \quad H, 7.06 \%$

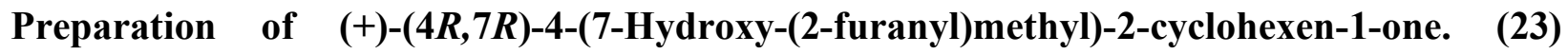
(Table 2, entry 4)
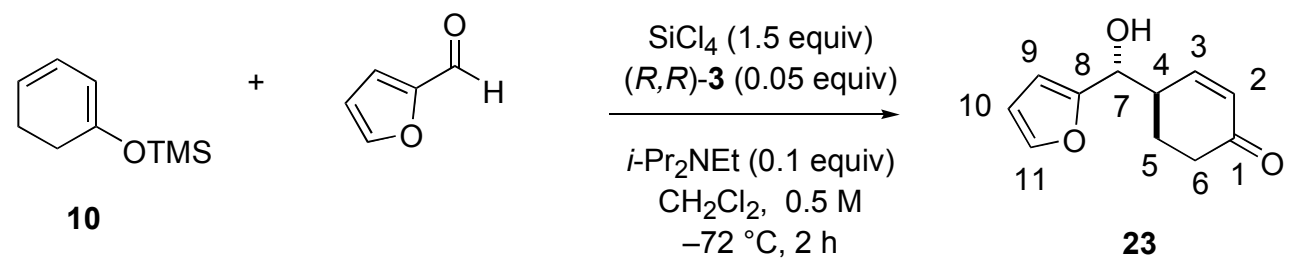

Following Representative Procedure 5, $84 \mu \mathrm{L}(1.0 \mathrm{mmol})$ of 2-furfuraldehyde was combined with $42 \mathrm{mg}$ (0.05 mmol, 0.05 equiv) of bisphosphoramide $(R, R)-3,35 \mu \mathrm{L}(0.2 \mathrm{mmol}$, 0.2 equiv) of diisopropylethylamine, $172 \mu \mathrm{L}$ (1.5 mmol, 1.5 equiv) of $\mathrm{SiCl}_{4}$ and $224 \mu \mathrm{L}(1.2$ mmol, 1.2 equiv) of $\mathbf{1 0}$ to yield, after column chromatography $\left(\mathrm{SiO}_{2}(20 \mathrm{~g}), 2 \mathrm{~cm}\right.$ diam., hexanes/EtOAc 3/2) to yield $180 \mathrm{mg}(94 \%)$ of $(+)-23$ as clear oil. The ratio of $\gamma / \alpha$-addition products was determined to be $>99 / 1$ by ${ }^{1} \mathrm{H}$ NMR $(500 \mathrm{MHz})$ analysis of the crude reaction mixture. The diastereomeric ratio was determined to be anti/syn, 81.5/18.5 by SFC analysis.

Data for $(+)-($ anti)-23:

${ }^{1} \mathrm{H} \mathrm{NMR}: \quad\left(500 \mathrm{MHz}, \mathrm{CDCl}_{3}\right)$

7.41 (t, $J=1.5,1 \mathrm{H}, \mathrm{HC}(11)), 7.35$ (t, $J=2.0,1 \mathrm{H}, \mathrm{HC}(3)), 6.38$ (dd, $J=3.2,2.0$, $1 \mathrm{H}, \mathrm{HC}(10)), 6.33$ (d, $J=3.2,1 \mathrm{H}, \mathrm{HC}(9)), 6.10$ (dd, $J=10.3,2.4,1 \mathrm{H}, \mathrm{HC}(2))$, 4.64 (dd, $J=7.5,5.0,1 \mathrm{H}, \mathrm{HC}(7)), 2.98-2.94$ (m, 1H, HC(4)), 2.51 (dt, $J=16.8$, 4.4, $1 \mathrm{H}, \mathrm{HC}(6)), 2.38$ (ddd, $J=16.8,12.9,5.1, \mathrm{HC}(6)), 2.03$ (d, $J=5.1,1 \mathrm{H}$, $\mathrm{OH}), 1.90-1.74(\mathrm{~m}, 2 \mathrm{H}, \mathrm{HC}(5))$ 
${ }^{13} \mathrm{C} \mathrm{NMR}: \quad\left(125 \mathrm{MHz}, \mathrm{CDCl}_{3}\right)$

199.9 (C(1)), 154.4 (C(8)), 151.1 (C(3)), 142.4 (C(11)), 130.2 (C(2)), 110.3

(C(10)), 107.5 (C(9)), 70.1 (C(7)), 41.5 (C(4)), 36.7 (C(6)), 25.4 (C(5))

IR: (neat)

3405 (s), 3147 (m), 3120 (m), 3039 (w), 2953 (m), 2875 (m), 2361 (w), 2343 (w), 2079 (w), 1667 (s), 1505 (s), 1453 (m), 1416 (s), 1391 (s), 1353 (s), 1326 (s), 1258 (s), 1219 (s), 1177 (s), 1148 (s), 1068 (s), 1042 (s), 1011 (s), 971 (s), 939 (m), $918(\mathrm{~s}), 884(\mathrm{~s}), 853(\mathrm{~s}), 816(\mathrm{~s}), 745(\mathrm{~s}), 683(\mathrm{~m})$

MS: $\quad\left(\mathrm{CI}, \mathrm{CH}_{4}\right)$

$193\left(\mathrm{M}^{+}+\mathrm{H}, 3\right), 175$ (25), 97 (100), 96 (14)

Opt. Rot.: $\quad[\alpha]_{\mathrm{D}}{ }^{24}+58.18^{\circ}(\mathrm{c}=1.05, \mathrm{EtOH})$

TLC: $\quad R_{f} 0.19$ (hexanes/EtOAc, 3/2) [UV (254 nm)]

SFC: $\quad(4 S, 7 S)-23 \mathrm{t}_{\mathrm{r}} 5.77 \mathrm{~min}(18.5 \%)$; $(4 R, 7 R)-23 \mathrm{t}_{\mathrm{r}} 7.14 \mathrm{~min}(81.5 \%)$ (Chiralpak OJ, $125 \mathrm{psi}, 40{ }^{\circ} \mathrm{C}, 5.0 \% \mathrm{MeOH}$ in $\mathrm{CO}_{2}, 2.5 \mathrm{~mL} / \mathrm{min}, 220 \mathrm{~nm}$ )

Analysis: $\quad \mathrm{C}_{11} \mathrm{H}_{12} \mathrm{O}_{3}(192.21)$

Calcd: $\quad$ C, 68.74; H, 6.29\%

Found: $\quad$ C, $68.59 ; \quad$ H, 6.34\%

\section{Vinylogous Aldol Additions of Bissilyl Dienol Ethers}

Preparation of (-)-(2R)-2,3-Dihydro-6-methyl-2-phenylpyran-4-one (34) (Table 3, entry 1)
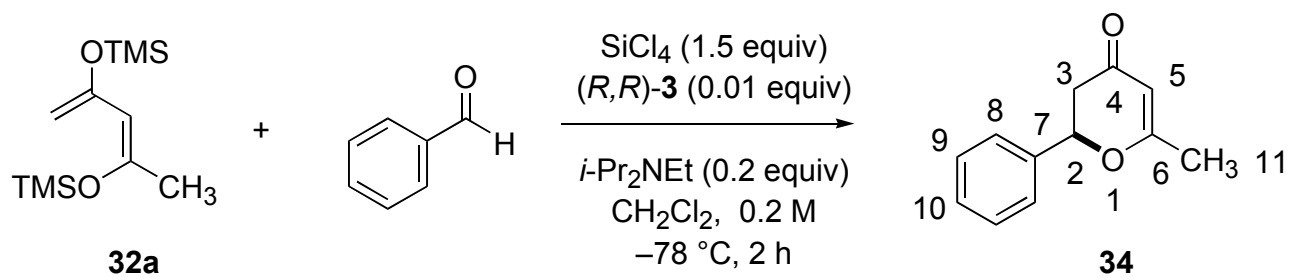

Diisopropylamine (18 $\mu \mathrm{L}, 0.1 \mathrm{mmol}, 0.2$ equiv) was added via syringe to a flame-dried, 20-mL, 2-necked, round bottomed flask fitted with a magnetic stir bar, gas inlet tube, and septum under $\mathrm{N}_{2}$ containing a solution of $5 \mathrm{mg}(0.005 \mathrm{mmol}, 0.01$ equiv) of bisphosphoramide $(R, R)-3$ in $\mathrm{CH}_{2} \mathrm{Cl}_{2}(2 \mathrm{~mL})$. To this solution was added $51 \mu \mathrm{L}(0.5 \mathrm{mmol})$ of benzaldehyde in one portion. The resulting solution was cooled to $-78{ }^{\circ} \mathrm{C}$ (bath temperature) over 15 min and to the reaction mixture was added $86 \mu \mathrm{L}(0.75 \mathrm{mmol}, 1.5$ equiv $)$ of $\mathrm{SiCl}_{4}$ in one portion. Then, $147 \mathrm{mg}(0.6$ 
mmol, 1.2 equiv) of 32a was added dropwise over $5 \mathrm{~min}$. The resulting mixture was stirred at $78{ }^{\circ} \mathrm{C}$ for $2 \mathrm{~h}$ whereupon $3.0 \mathrm{~mL}$ of chilled $\mathrm{CH}_{2} \mathrm{Cl}_{2}$ was added before the cold reaction mixture was poured into a rapidly stirring solution of $1 / 1$ sat. aq. $\mathrm{NaHCO}_{3} /$ sat. aq. $\mathrm{KF}(25 \mathrm{~mL})$ at $0{ }^{\circ} \mathrm{C}$. This biphasic mixture was stirred vigorously for $3 \mathrm{~h}$ after which the aqueous layer was washed with $\mathrm{CH}_{2} \mathrm{Cl}_{2}(3 \times 30 \mathrm{~mL})$. The combined organic extracts were dried over $\mathrm{Na}_{2} \mathrm{SO}_{4}(5 \mathrm{~g})$ filtered through Celite on a glass frit, and the filtrate was concentrated in vacuo. The residue was dissolved in $10 \mathrm{~mL}$ of $\mathrm{CH}_{2} \mathrm{Cl}_{2}$ and cooled in an ice water bath for $15 \mathrm{~min}$ and to the reaction mixture 10 drops of TFA was added. The resulting mixture was stirred at $\mathrm{rt}$ for $16 \mathrm{~h}$ whereupon $10 \mathrm{ml}$ of sat. aq. $\mathrm{NaHCO}_{3}$ added. This biphasic mixture was stirred for $10 \mathrm{~min}$ after which the aqueous layer was washed with $\mathrm{CH}_{2} \mathrm{Cl}_{2}(3 \times 20 \mathrm{~mL})$. The combined organic extracts were dried over $\mathrm{Na}_{2} \mathrm{SO}_{4}(5 \mathrm{~g})$, filtered through Celite on a glass frit, and the filtrate was concentrated in vacuo. The resulting residue was purified by column chromatography $\left(12 \mathrm{~g} \mathrm{SiO}_{2}, 2 \mathrm{~cm}\right.$ diam., pentane/ $\left.\mathrm{Et}_{2} \mathrm{O}, 1 / 1\right)$ to yield $83 \mathrm{mg}(95 \%)$ of $\mathbf{3 4}$ as a clear oil. The spectroscopic data for 34 matched those in the literature. ${ }^{16}$

Data for 34:

${ }^{1}$ H NMR: $\quad\left(500 \mathrm{MHz}, \mathrm{CDCl}_{3}\right)$

7.44-7.37 (m, $5 \mathrm{H}, \mathrm{HC}(8,9,10)), 5.44$ (s, $1 \mathrm{H}, \mathrm{CH}(5)), 5.39$ (dd, $J=14.3,3.2$ $\mathrm{HC}(2)) ; 2.82(\mathrm{dd}, J=16.8,14.4,1 \mathrm{H}, \mathrm{HC}(3)) ; 2.60$ (dd, $J=16.8,3.4, \mathrm{HC}(3))$; $2.08\left(\mathrm{~s}, 3 \mathrm{H}, \mathrm{H}_{3} \mathrm{C}(11)\right)$

TLC: $\quad R_{f} 0.29$ (hexanes/EtOAc, 4/1) [UV (254 nm)]

SFC: $\quad(S)-34 \mathrm{t}_{\mathrm{r}} 2.24 \min (37.9 \%) ;(R)-34 \mathrm{t}_{\mathrm{r}} 2.47 \min (62.1 \%)$; (Chiralpak OD, 150 psi, $40{ }^{\circ} \mathrm{C}, 11.0 \% \mathrm{MeOH}$ in $\mathrm{CO}_{2}, 3.0 \mathrm{~mL} / \mathrm{min}, 220 \mathrm{~nm}$ )

\section{Preparation of (2R)-2,3-Dihydro-6-methyl-2-phenylpyran-4-one (34) (Table 3, entry 2)}

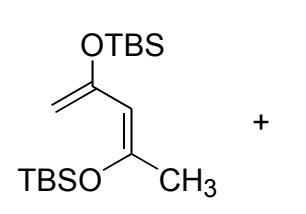

32b
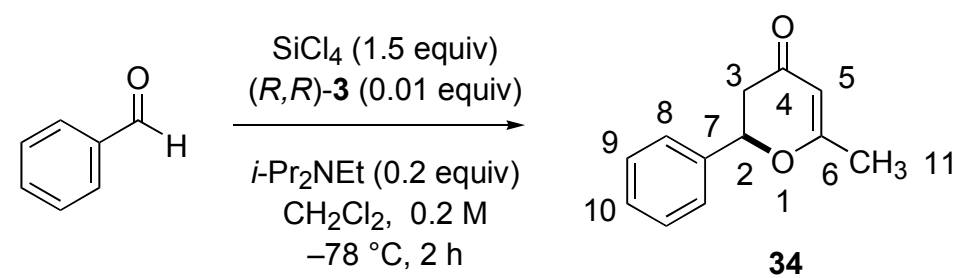

Diisopropylamine (18 $\mu \mathrm{L}, 0.1 \mathrm{mmol}, 0.2$ equiv) was added via syringe to a flame-dried, 20-mL, 2-neck, round bottomed flask fitted with a magnetic stir bar, gas inlet tube, and septum under $\mathrm{N}_{2}$ containing a solution of $5 \mathrm{mg}(0.05 \mathrm{mmol}, 0.01$ equiv $)$ of bisphosphoramide $(R, R)-3$ in 
$\mathrm{CH}_{2} \mathrm{Cl}_{2}(2 \mathrm{~mL})$. To this solution was added $51 \mu \mathrm{L}(0.5 \mathrm{mmol})$ of benzaldehyde in one portion. The resulting solution was cooled to $-78{ }^{\circ} \mathrm{C}$ (bath temperature) over $15 \mathrm{~min}$ and to the reaction mixture was added $86 \mu \mathrm{L}(0.75 \mathrm{mmol}, 1.5$ equiv $)$ of $\mathrm{SiCl}_{4}$ in one portion. Then, $197 \mathrm{mg}(0.6$ mmol, 1.2 equiv) of $\mathbf{3 2 b}$ was added dropwise over $5 \mathrm{~min}$. The resulting mixture was stirred at $78{ }^{\circ} \mathrm{C}$ for $2 \mathrm{~h}$ whereupon $3.0 \mathrm{~mL}$ of chilled $\mathrm{CH}_{2} \mathrm{Cl}_{2}$ was added before the cold reaction mixture was poured into a rapidly stirring solution of $1 / 1$ sat. aq. $\mathrm{NaHCO}_{3} /$ sat. aq. $\mathrm{KF}(25 \mathrm{~mL})$ at $0{ }^{\circ} \mathrm{C}$. This biphasic mixture was stirred vigorously for $3 \mathrm{~h}$ after which the aqueous layer was washed with $\mathrm{CH}_{2} \mathrm{Cl}_{2}(3 \times 30 \mathrm{~mL})$. The combined organic extracts were dried over $\mathrm{Na}_{2} \mathrm{SO}_{4}(5 \mathrm{~g})$ filtered through Celite on a glass frit, and the filtrate was concentrated in vacuo. The residue was dissolved in $10 \mathrm{~mL}$ of $\mathrm{CH}_{2} \mathrm{Cl}_{2}$ and cooled in an ice water bath for $15 \mathrm{~min}$ and to the reaction mixture 10 drops of TFA was added. The resulting mixture was stirred at $\mathrm{rt}$ for $16 \mathrm{~h}$ whereupon $10 \mathrm{ml}$ of sat. aq. $\mathrm{NaHCO}_{3}$ added. This biphasic mixture was stirred for $10 \mathrm{~min}$ after which the aqueous layer was washed with $\mathrm{CH}_{2} \mathrm{Cl}_{2}(3 \times 20 \mathrm{~mL})$. The combined organic extracts were dried over $\mathrm{Na}_{2} \mathrm{SO}_{4}(5 \mathrm{~g})$, filtered through Celite on a glass frit, and the filtrate was concentrated in vacuo. The resulting residue was purified by column chromatography $\left(13 \mathrm{~g} \mathrm{SiO}_{2}, 2 \mathrm{~cm}\right.$ diam., pentane/ $\left.\mathrm{Et}_{2} \mathrm{O}, 1 / 1\right)$ to yield $82 \mathrm{mg}(94 \%)$ of $\mathbf{3 4}$ as a clear oil. The spectroscopic data for 34 matched those in the literature. ${ }^{16}$

Data for 34:

${ }^{1}$ H NMR: $\quad\left(500 \mathrm{MHz}, \mathrm{CDCl}_{3}\right)$

7.44-7.36 (m, $5 \mathrm{H}, \mathrm{HC}(8,9,10)), 5.43(\mathrm{~s}, 1 \mathrm{H}, \mathrm{CH}(5)), 5.38(\mathrm{dd}, J=14.2,3.2$ $\mathrm{HC}(2)), 2.81(\mathrm{dd}, J=16.7,14.4,1 \mathrm{H}, \mathrm{HC}(3)), 2.61$ (dd, $J=16.8,3.3, \mathrm{HC}(3))$, 2.09 (s, $\left.3 \mathrm{H}, \mathrm{H}_{3} \mathrm{C}(11)\right)$

TLC: $\quad R_{f} 0.29$ (hexanes/EtOAc, 4/1) [UV (254 nm)]

SFC: $\quad(S)-34 t_{\mathrm{r}} 2.23 \min (25.2 \%) ;(R)-34 \mathrm{t}_{\mathrm{r}} 2.46 \min (74.8 \%)$; (Chiralpak OD, 150 psi, $40{ }^{\circ} \mathrm{C}, 11.0 \% \mathrm{MeOH}$ in $\mathrm{CO}_{2}, 3.0 \mathrm{~mL} / \mathrm{min}, 220 \mathrm{~nm}$ ) 


\section{Representative Procedure 6. Addition of Bissilyl Dienol Ethers to Conjugated Aldehydes.} Preparation of (-)-(2R)-2,3-Dihydro-6-methyl-2-phenylpyran-4-one (34) (Table 3, entry 3)
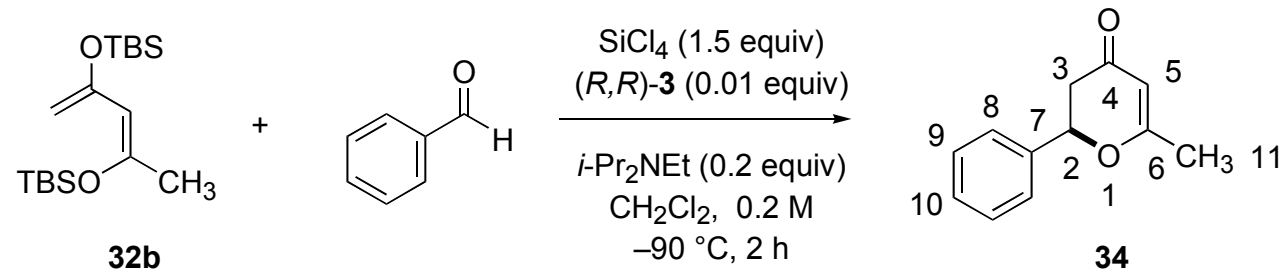

Diisopropylamine (18 $\mu \mathrm{L}, 0.1 \mathrm{mmol}, 0.1$ equiv) was added via syringe to a flame-dried, 20-mL, 2-necked, rounded bottom flask fitted with a magnetic stir bar, thermocouple, gas inlet tube, and septum under $\mathrm{N}_{2}$ containing a solution of $9 \mathrm{mg}(0.01 \mathrm{mmol}, 0.01$ equiv) of bisphosphoramide $(R, R)-3$ in $\mathrm{CH}_{2} \mathrm{Cl}_{2}(2 \mathrm{~mL})$. To this solution was added $102 \mu \mathrm{L}(1.0 \mathrm{mmol})$ of benzaldehyde in one portion. The resulting solution was cooled to $-90{ }^{\circ} \mathrm{C}$ over $15 \mathrm{~min}$ and to the reaction mixture was added $172 \mu \mathrm{L}(1.5 \mathrm{mmol}, 1.5$ equiv $)$ of $\mathrm{SiCl}_{4}$ in one portion. Then, $394 \mathrm{mg}$ (1.2 mmol, 1.2 equiv) of $\mathbf{3 2 b}$ was added dropwise over $5 \mathrm{~min}$. The resulting mixture was stirred at $-90{ }^{\circ} \mathrm{C}$ for $2 \mathrm{~h}$ whereupon $3.0 \mathrm{~mL}$ of chilled $\mathrm{CH}_{2} \mathrm{Cl}_{2}$ was added before the cold reaction mixture was poured into a rapidly stirring solution of $1 / 1$ sat. aq. $\mathrm{NaHCO}_{3} /$ sat. aq. $\mathrm{KF}(25 \mathrm{~mL})$ at $0{ }^{\circ} \mathrm{C}$. This biphasic mixture was stirred vigorously for $3 \mathrm{~h}$ after which the aqueous layer was washed with $\mathrm{CH}_{2} \mathrm{Cl}_{2}(3 \times 50 \mathrm{~mL})$. The combined organic extracts were dried over $\mathrm{Na}_{2} \mathrm{SO}_{4}(5 \mathrm{~g})$ filtered through Celite on a glass frit, and the filtrate was concentrated in vacuo. The residue was dissolved in $10 \mathrm{~mL}$ of $\mathrm{CH}_{2} \mathrm{Cl}_{2}$ and cooled in an ice water bath for $15 \mathrm{~min}$ and to the reaction mixture 10 drops of TFA was added. The resulting mixture was stirred at $\mathrm{rt}$ for $16 \mathrm{~h}$ whereupon $10 \mathrm{ml}$ of sat. aq. $\mathrm{NaHCO}_{3}$ added. This biphasic mixture was stirred for $10 \mathrm{~min}$ after which the aqueous layer was washed with $\mathrm{CH}_{2} \mathrm{Cl}_{2}(3 \times 20 \mathrm{~mL})$. The combined organic extracts were dried over $\mathrm{Na}_{2} \mathrm{SO}_{4}(5 \mathrm{~g})$, filtered through Celite on a glass frit, and the filtrate was concentrated in vacuo. The resulting residue was purified by column chromatography $\left(30 \mathrm{~g} \mathrm{SiO}_{2}, 2 \mathrm{~cm}\right.$ column diam., hexanes/EtOAc, 2/1). The product-containing fractions were combined and the solvent was removed in vacuo to yield $165 \mathrm{mg}(88 \%)$ of (-)-34 as a clear oil. The spectroscopic data for 34 matched those in the literature. ${ }^{16}$

\section{Data for (-)-34:}

${ }^{1} \mathrm{H}$ NMR: $\quad\left(500 \mathrm{MHz}, \mathrm{CDCl}_{3}\right)$

7.44-7.36 (m, $5 \mathrm{H}, \mathrm{HC}(8,9,10)), 5.43(\mathrm{~s}, 1 \mathrm{H}, \mathrm{CH}(5)), 5.38(\mathrm{dd}, J=14.2,3.2$ $\mathrm{HC}(2)), 2.81(\mathrm{dd}, J=16.7,14.4,1 \mathrm{H}, \mathrm{HC}(3)), 2.610$ (dd, $J=16.8,3.3, \mathrm{HC}(3))$, 


$$
\left.2.09 \text { (s, } 3 \mathrm{H}, \mathrm{H}_{3} \mathrm{C}(11)\right)
$$

${ }^{13} \mathrm{C} \mathrm{NMR}: \quad\left(125 \mathrm{MHz}, \mathrm{CDCl}_{3}\right)$

$192.1(\mathrm{C}(5)), 174.1$ (C(6)), 138.1 (C(7)), 128.7 (C(8,9)), 126.1 (C(8)), 105.1 (C(5)), 80.7 (C(2)), 42.3 (C(3)), $21.0(\mathrm{C}(11))$

Opt. Rot.: $\quad[\alpha]_{\mathrm{D}}{ }^{24}-48.00^{\circ}\left(\mathrm{c}=1.15, \mathrm{CH}_{2} \mathrm{Cl}_{2}\right)$

TLC: $\quad R_{f} 0.28$ (hexanes/EtOAc, 4/1) [UV (254 nm)]

SFC: $\quad(S)-34 \mathrm{t}_{\mathrm{r}} 1.86 \min (19.9 \%) ;(R)-34 \mathrm{t}_{\mathrm{r}} 2.02 \min (80.1 \%)$; (Chiralpak OD, 150 psi, $40{ }^{\circ} \mathrm{C}, 15.0 \% \mathrm{MeOH}$ in $\mathrm{CO}_{2}, 3.0 \mathrm{~mL} / \mathrm{min}, 220 \mathrm{~nm}$ )

\section{Preparation of (2R)-2,3-Dihydro-6-methyl-2-phenylpyran-4-one (34) (Table 3, entry 4)}

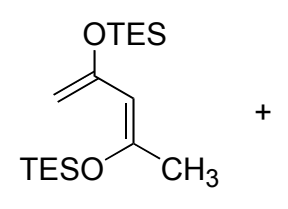

32c

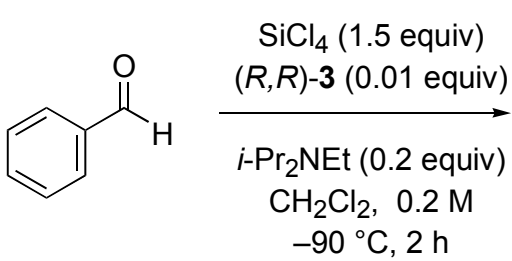

$-90{ }^{\circ} \mathrm{C}, 2 \mathrm{~h}$

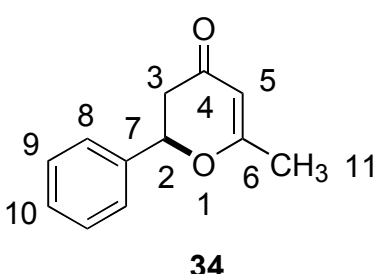

34

Following Representative Procedure $6,51 \mu \mathrm{L}(0.5 \mathrm{mmol})$ of benzaldehyde was combined with $5 \mathrm{mg}$ (0.005 mmol, 0.01 equiv) of bisphosphoramide $(R, R)-3,18 \mu \mathrm{L}(0.1 \mathrm{mmol}, 0.2$ equiv) of diisopropylethylamine, $86 \mu \mathrm{L}\left(0.75 \mathrm{mmol}, 1.5\right.$ equiv) of $\mathrm{SiCl}_{4}$ and $197 \mu \mathrm{L}(0.6 \mathrm{mmol}, 1.2$ equiv) of 32c to yield, after column chromatography $\left(\mathrm{SiO}_{2}(12 \mathrm{~g}), 2 \mathrm{~cm}\right.$ diam., pentane/Et $\left.\mathrm{O}_{2} \mathrm{O} 1 / 1\right)$ to yield $67 \mathrm{mg}(77 \%)$ of $\mathbf{3 4}$ as a white solid. The spectroscopic data for $\mathbf{3 4}$ matched those in the literature. $^{16}$

\section{Data for 34:}

${ }^{1} \mathrm{H} \mathrm{NMR}: \quad\left(500 \mathrm{MHz}, \mathrm{CHCl}_{3}\right)$

7.44-7.34 (m, $5 \mathrm{H}, \mathrm{HC}(8,9,10)), 5.44$ (s, $1 \mathrm{H}, \mathrm{CH}(5)), 5.38$ (dd, $J=14.2,3.3$ $\mathrm{HC}(2)), 2.83(\mathrm{dd}, J=16.7,14.2,1 \mathrm{H}, \mathrm{HC}(3)), 2.60$ (dd, $J=16.8,3.2, \mathrm{HC}(3))$, $2.10\left(\mathrm{~s}, 3 \mathrm{H}, \mathrm{H}_{3} \mathrm{C}(11)\right)$

TLC: $\quad R_{f} 0.28$ (hexanes/EtOAc, 4/1) [UV (254 nm)]

SFC: $\quad(S)-34 \mathrm{t}_{\mathrm{r}} 4.67 \mathrm{~min}(38.8 \%) ;(R)-34 \mathrm{t}_{\mathrm{r}} 5.31 \mathrm{~min}(61.2 \%)$; (Chiralpak OD, 125 psi, $40{ }^{\circ} \mathrm{C}, 3.5 \% \mathrm{MeOH}$ in $\mathrm{CO}_{2}, 3.0 \mathrm{~mL} / \mathrm{min}, 220 \mathrm{~nm}$ ) 


\section{Preparation of (2R)-2,3-dihydro-6-methyl-2-phenylpyran-4-one (218) (Table 3, entry 5)}<smiles>C=C(/C=C(/C)[OH2+])O[Na]</smiles>

32d<smiles>O=Cc1ccccc1</smiles>

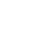

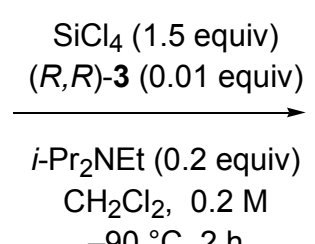

$-90^{\circ} \mathrm{C}, 2 \mathrm{~h}$

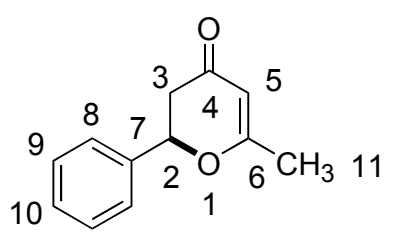

34

Following Representative Procedure $6,51 \mu \mathrm{L}(0.5 \mathrm{mmol})$ of benzaldehyde was combined with $5 \mathrm{mg}$ ( $0.005 \mathrm{mmol}, 0.01$ equiv) of bisphosphoramide $(R, R)-3,18 \mu \mathrm{L}(0.1 \mathrm{mmol}, 0.2$ equiv) of diisopropylethylamine, $86 \mu \mathrm{L}\left(0.75 \mathrm{mmol}, 1.5\right.$ equiv) of $\mathrm{SiCl}_{4}$ and $248 \mathrm{mg}(0.6 \mathrm{mmol}, 1.2$ equiv) of 32d to yield, after column chromatography ( $\mathrm{SiO}_{2}(12 \mathrm{~g}), 2 \mathrm{~cm}$ diam., pentane/Et $\left.\mathrm{O}_{2} \mathrm{O} 1 / 1\right)$ to yield $72 \mathrm{mg}(83 \%)$ of $\mathbf{3 4}$ as a white solid. The spectroscopic data for $\mathbf{3 4}$ matched those in the literature. $^{16}$

Data for 34:

${ }^{1}$ H NMR: $\quad\left(500 \mathrm{MHz}, \mathrm{CDCl}_{3}\right)$

7.44-7.34 (m, $5 \mathrm{H}, \mathrm{HC}(8,9,10)), 5.44$ (s, $1 \mathrm{H}, \mathrm{CH}(5)), 5.38$ (dd, $J=14.2,3.3$ $\mathrm{HC}(2)), 2.83(\mathrm{dd}, J=16.7,14.2,1 \mathrm{H}, \mathrm{HC}(3)), 2.60$ (dd, $J=16.8,3.2, \mathrm{HC}(3))$, 2.10 (s, $\left.3 \mathrm{H}, \mathrm{H}_{3} \mathrm{C}(11)\right)$

TLC: $\quad R_{f} 0.28$ (hexanes/EtOAc, 4/1) [UV (254 nm)]

SFC: $\quad(S)-34 \mathrm{t}_{\mathrm{r}} 4.67 \min (38.8 \%) ;(R)-34 \mathrm{t}_{\mathrm{r}} 5.31 \mathrm{~min}(61.2 \%)$; (Chiralpak OD, 125 psi, $40{ }^{\circ} \mathrm{C}, 3.5 \% \mathrm{MeOH}$ in $\mathrm{CO}_{2}, 3.0 \mathrm{~mL} / \mathrm{min}, 220 \mathrm{~nm}$ )

\section{Preparation of (2R)-2,3-Dihydro-6-methyl-2-phenylpyran-4-one (34) (Table 3, entry 6)}

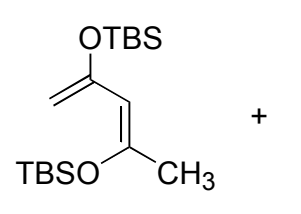

$32 b$

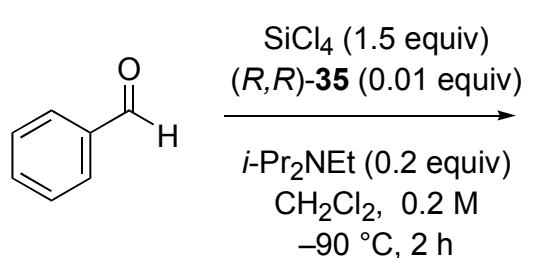

$-90{ }^{\circ} \mathrm{C}, 2 \mathrm{~h}$

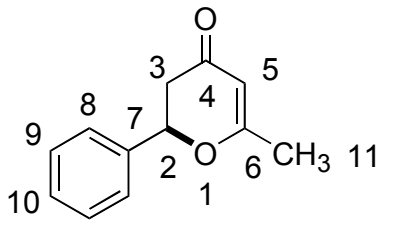

34

Following Representative Procedure $6,51 \mu \mathrm{L}(0.5 \mathrm{mmol})$ of benzaldehyde was combined with $4 \mathrm{mg}$ (0.005 mmol, 0.01 equiv) of bisphosphoramide $(R, R)-35,18 \mu \mathrm{L}(0.1 \mathrm{mmol}, 0.2$ equiv) of diisopropylethylamine, $86 \mu \mathrm{L}\left(0.75 \mathrm{mmol}, 1.5\right.$ equiv) of $\mathrm{SiCl}_{4}$ and $197 \mathrm{mg}(0.6 \mathrm{mmol}, 1.2$ equiv) of 32b to yield, after column chromatography $\left(\mathrm{SiO}_{2}(12 \mathrm{~g}), 2 \mathrm{~cm}\right.$ diam., pentane/Et $\left.\mathrm{O}_{2} \mathrm{O} / 1\right)$ to yield $66 \mathrm{mg}(76 \%)$ of $\mathbf{3 4}$ as a white solid. The spectroscopic data for $\mathbf{3 4}$ matched those in the literature. $^{16}$ 


\section{Data for 34:}

${ }^{1}$ H NMR: $\quad\left(500 \mathrm{MHz}, \mathrm{CDCl}_{3}\right)$

7.44-7.34 (m, $5 \mathrm{H}, \mathrm{HC}(8,9,10)), 5.44(\mathrm{~s}, 1 \mathrm{H}, \mathrm{CH}(5)), 5.38(\mathrm{dd}, J=14.2,3.3$ $\mathrm{HC}(2)), 2.83(\mathrm{dd}, J=16.7,14.2,1 \mathrm{H}, \mathrm{HC}(3)), 2.60$ (dd, $J=16.8,3.2, \mathrm{HC}(3))$, $2.10\left(\mathrm{~s}, 3 \mathrm{H}, \mathrm{H}_{3} \mathrm{C}(11)\right)$

TLC: $\quad R_{f} 0.28$ (hexanes/EtOAc, 4/1) [UV (254 nm)]

SFC: $\quad(S)-34 \mathrm{t}_{\mathrm{r}} 4.67 \mathrm{~min}(12.5 \%)$; $(R)-34 \mathrm{t}_{\mathrm{r}} 5.31 \mathrm{~min}(87.5 \%)$; (Chiralpak OD, 125 psi, $40{ }^{\circ} \mathrm{C}, 3.5 \% \mathrm{MeOH}$ in $\mathrm{CO}_{2}, 3.0 \mathrm{~mL} / \mathrm{min}, 220 \mathrm{~nm}$ )

\section{Preparation of (2R)-2,3-Dihydro-6-methyl-2-phenylpyran-4-one (34) (Table 3, entry 7)}

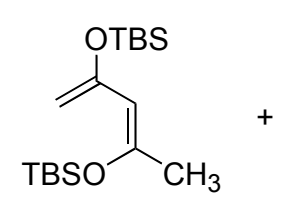

$32 b$

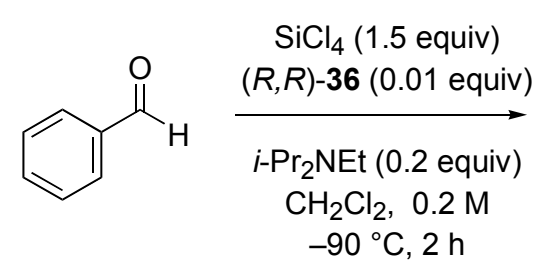

$-90{ }^{\circ} \mathrm{C}, 2 \mathrm{~h}$

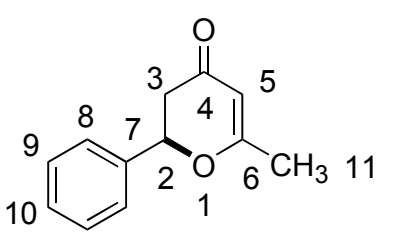

34

Following Representative Procedure $6,51 \mu \mathrm{L}(0.5 \mathrm{mmol})$ of benzaldehyde was combined with $5 \mathrm{mg}$ ( $0.005 \mathrm{mmol}, 0.01$ equiv) of bisphosphoramide $(R, R)-36,18 \mu \mathrm{L}(0.1 \mathrm{mmol}, 0.2$ equiv) of diisopropylethylamine, $86 \mu \mathrm{L}\left(0.75 \mathrm{mmol}, 1.5\right.$ equiv) of $\mathrm{SiCl}_{4}$ and $197 \mathrm{mg}(0.6 \mathrm{mmol}, 1.2$ equiv) of 32b to yield, after column chromatography ( $\mathrm{SiO}_{2}(12 \mathrm{~g}), 2 \mathrm{~cm}$ diam., pentane/Et $\left.\mathrm{O}_{2} \mathrm{O} 1 / 1\right)$ to yield $70 \mathrm{mg}(80 \%)$ of $\mathbf{3 4}$ as a white solid. The spectroscopic data for $\mathbf{3 4}$ matched those in the literature. $^{16}$

Data for 34:

${ }^{1} \mathrm{H}$ NMR: $\quad\left(500 \mathrm{MHz}, \mathrm{CHCl}_{3}\right)$

7.45-7.34 (m, $5 \mathrm{H}, \mathrm{HC}(8,9,10)), 5.42(\mathrm{~s}, 1 \mathrm{H}, \mathrm{CH}(5)), 5.38(\mathrm{dd}, J=14.2,3.3$ $\mathrm{HC}(2)), 2.83(\mathrm{dd}, J=16.7,14.2,1 \mathrm{H}, \mathrm{HC}(3)), 2.62(\mathrm{dd}, J=16.9,3.2, \mathrm{HC}(3))$, 2.07 (s, $\left.3 \mathrm{H}, \mathrm{H}_{3} \mathrm{C}(11)\right)$

TLC: $\quad R_{f} 0.28$ (hexanes/EtOAc, 4/1) [UV (254 nm)]

SFC: $\quad(S)-34 \mathrm{t}_{\mathrm{r}} 4.51 \mathrm{~min}(15.0 \%) ;(R)-34 \mathrm{t}_{\mathrm{r}} 5.13 \min (85.0 \%)$; (Chiralpak OD, 125 psi, $40{ }^{\circ} \mathrm{C}, 3.5 \% \mathrm{MeOH}$ in $\mathrm{CO}_{2}, 3.0 \mathrm{~mL} / \mathrm{min}, 220 \mathrm{~nm}$ ) 
Preparation of (2R)-2,3-Dihydro-6-methyl-2-phenylpyran-4-one (34) (Table 3, entry 8)
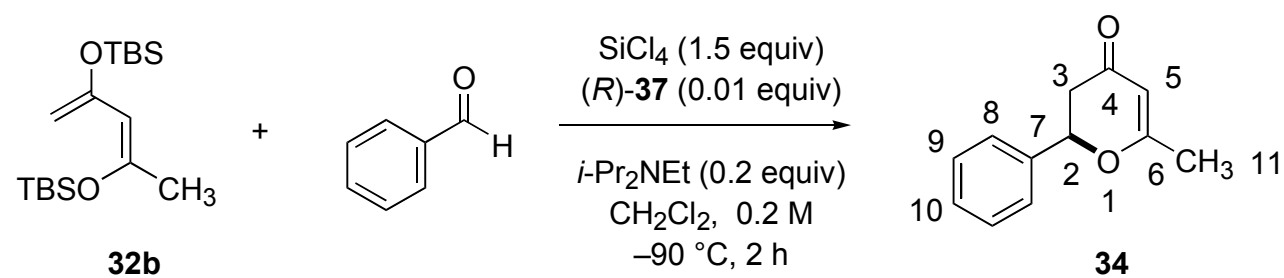

Following Representative Procedure $6,51 \mu \mathrm{L}(0.5 \mathrm{mmol})$ of benzaldehyde was combined with $5 \mathrm{mg}$ ( $0.005 \mathrm{mmol}, 0.01$ equiv) of bisphosphoramide $(R)-37,18 \mu \mathrm{L}(0.1 \mathrm{mmol}, 0.2$ equiv) of diisopropylethylamine, $86 \mu \mathrm{L}\left(0.75 \mathrm{mmol}, 1.5\right.$ equiv) of $\mathrm{SiCl}_{4}$ and $197 \mathrm{mg}(0.6 \mathrm{mmol}, 1.2$ equiv) of 32b to yield, after column chromatography ( $\mathrm{SiO}_{2}(12 \mathrm{~g}), 2 \mathrm{~cm}$ diam., pentane/Et $\left.2 \mathrm{O} 1 / 1\right)$ to yield $50 \mathrm{mg}(57 \%)$ of $\mathbf{3 4}$ as a white solid. The spectroscopic data for $\mathbf{3 4}$ matched those in the literature. $^{16}$

Data for 34:

${ }^{1} \mathrm{H}$ NMR: $\quad\left(500 \mathrm{MHz}, \mathrm{CDCl}_{3}\right)$

7.44-7.34 (m, $5 \mathrm{H}, \mathrm{HC}(8,9,10)), 5.44$ (s, $1 \mathrm{H}, \mathrm{CH}(5)), 5.38$ (dd, $J=14.2,3.3$ $\mathrm{HC}(2)), 2.83(\mathrm{dd}, J=16.7,14.2,1 \mathrm{H}, \mathrm{HC}(3)), 2.60$ (dd, $J=16.8,3.2, \mathrm{HC}(3))$, 2.10 (s, $\left.3 \mathrm{H}, \mathrm{H}_{3} \mathrm{C}(11)\right)$

TLC: $\quad R_{f} 0.29$ (hexanes/EtOAc, 4/1) [UV (254 nm)]

SFC: $\quad(S)-34 \mathrm{t}_{\mathrm{r}} 4.67 \mathrm{~min}(17.2 \%)$; $(R)-34 \mathrm{t}_{\mathrm{r}} 5.31 \mathrm{~min}(82.8 \%)$; (Chiralpak OD, 125 psi, $40{ }^{\circ} \mathrm{C}, 3.5 \% \mathrm{MeOH}$ in $\mathrm{CO}_{2}, 3.0 \mathrm{~mL} / \mathrm{min}, 220 \mathrm{~nm}$ )

\section{Preparation of (2R)-2,3-Dihydro-6-methyl-2-phenylpyran-4-one (34) (Table 3, entry 9)}

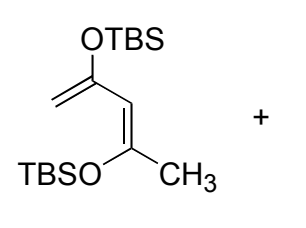

$32 b$

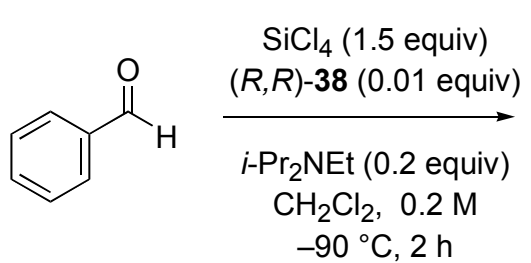

$-90{ }^{\circ} \mathrm{C}, 2 \mathrm{~h}$

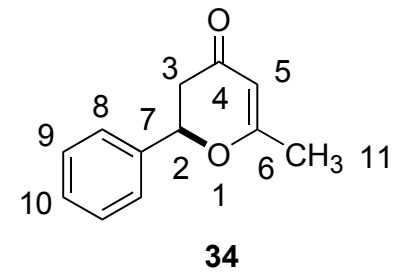

34

Following Representative Procedure $6,51 \mu \mathrm{L}(0.5 \mathrm{mmol})$ of benzaldehyde was combined with $3 \mathrm{mg}$ ( $0.005 \mathrm{mmol}, 0.01$ equiv) of bisphosphoramide $(R, R)-38,18 \mu \mathrm{L}(0.1 \mathrm{mmol}, 0.2$ equiv) of diisopropylethylamine, $86 \mu \mathrm{L}\left(0.75 \mathrm{mmol}, 1.5\right.$ equiv) of $\mathrm{SiCl}_{4}$ and $197 \mathrm{mg}(0.6 \mathrm{mmol}, 1.2$ equiv) of 32b to yield, after column chromatography ( $\mathrm{SiO}_{2}(12 \mathrm{~g}), 2 \mathrm{~cm}$ diam., pentane/Et ${ }_{2} \mathrm{O}$ 1/1) to yield $85 \mathrm{mg}(98 \%)$ of $\mathbf{3 4}$ as a white solid. The spectroscopic data for $\mathbf{3 4}$ matched those in the literature. $^{16}$ 


\section{Data for 34:}

${ }^{1} \mathrm{H} \mathrm{NMR}: \quad\left(500 \mathrm{MHz}, \mathrm{CDCl}_{3}\right)$

7.44-7.34 (m, $5 \mathrm{H}, \mathrm{HC}(8,9,10)), 5.44(\mathrm{~s}, 1 \mathrm{H}, \mathrm{CH}(5)), 5.38$ (dd, $J=14.2,3.3$ $\mathrm{HC}(2)), 2.83(\mathrm{dd}, J=16.7,14.2,1 \mathrm{H}, \mathrm{HC}(3)), 2.60$ (dd, $J=16.8,3.2, \mathrm{HC}(3))$, $2.10\left(\mathrm{~s}, 3 \mathrm{H}, \mathrm{H}_{3} \mathrm{C}(11)\right)$

TLC: $\quad R_{f} 0.29$ (hexanes/EtOAc, 4/1) [UV (254 nm)]

SFC: $\quad(S)-34 \mathrm{t}_{\mathrm{r}} 4.67 \mathrm{~min}(38.8 \%) ;(R)-34 \mathrm{t}_{\mathrm{r}} 5.31 \mathrm{~min}(61.2 \%)$; (Chiralpak OD, 125 psi, $40{ }^{\circ} \mathrm{C}, 3.5 \% \mathrm{MeOH}$ in $\mathrm{CO}_{2}, 3.0 \mathrm{~mL} / \mathrm{min}, 220 \mathrm{~nm}$ )

\section{Representative Procedure 7. Vinylogous Aldol Additions of Bissilyl Dienol Ethers 32a-c to} Hydrocinnamaldehyde. Preparation of (2S)-2,3-Dihydro-6-methyl-2-phenylethylpyran-4one (39) (Table 4, entry 1)
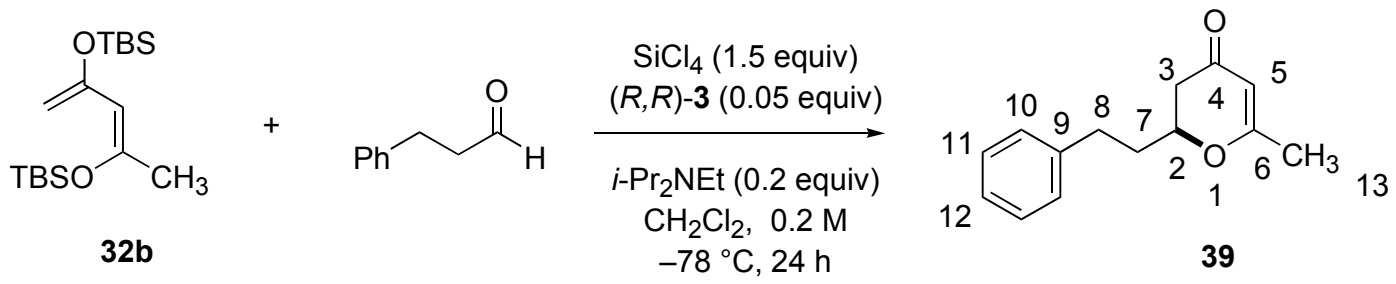

Diisopropylamine (18 $\mu \mathrm{L}, 0.1 \mathrm{mmol}, 0.1$ equiv) was added via syringe to a flame-dried, 20-mL, 2-necked, rounded bottom flask fitted with a magnetic stir bar, gas inlet tube and septum under $\mathrm{N}_{2}$ containing a solution of $21 \mathrm{mg}(0.025 \mathrm{mmol}, 0.05$ equiv $)$ of bisphosphoramide $(R, R)-3$ in $\mathrm{CH}_{2} \mathrm{Cl}_{2}(2 \mathrm{~mL})$. To this solution was added $66 \mu \mathrm{L}(0.5 \mathrm{mmol})$ of hydrocinnamaldehyde in one portion. The resulting solution was cooled to $-78{ }^{\circ} \mathrm{C}$ (bath temperature) over $15 \mathrm{~min}$ and to the reaction mixture was added $86 \mu \mathrm{L}(0.75 \mathrm{mmol}, 1.5$ equiv $)$ of $\mathrm{SiCl}_{4}$ in one portion. Then, $197 \mathrm{mg}$ ( $0.6 \mathrm{mmol}, 1.2$ equiv) of $\mathbf{3 2 b}$ was added dropwise over $5 \mathrm{~min}$. The resulting mixture was stirred at $-78{ }^{\circ} \mathrm{C}$ for $24 \mathrm{~h}$ whereupon $3.0 \mathrm{~mL}$ of chilled $\mathrm{CH}_{2} \mathrm{Cl}_{2}$ was added before the cold reaction mixture was poured into a rapidly stirring solution of $1 / 1$ sat. aq. $\mathrm{NaHCO}_{3} /$ sat. aq. $\mathrm{KF}(25 \mathrm{~mL})$ at $0{ }^{\circ} \mathrm{C}$. This biphasic mixture was stirred vigorously for $3 \mathrm{~h}$ after which the aqueous layer was washed with $\mathrm{CH}_{2} \mathrm{Cl}_{2}(3 \times 30 \mathrm{~mL})$. The combined organic extracts were dried over $\mathrm{Na}_{2} \mathrm{SO}_{4}(5 \mathrm{~g})$ filtered through Celite on a glass frit, and the filtrate was concentrated in vacuo. The residue was dissolved in $10 \mathrm{~mL}$ of $\mathrm{CH}_{2} \mathrm{Cl}_{2}$ and cooled in an ice water bath for $15 \mathrm{~min}$ and to the reaction mixture 10 drops of TFA was added. The resulting mixture was stirred at $\mathrm{rt}$ for $16 \mathrm{~h}$ whereupon $10 \mathrm{ml}$ of sat. aq. $\mathrm{NaHCO}_{3}$ added. This biphasic mixture was stirred for $10 \mathrm{~min}$ after which the 
aqueous layer was washed with $\mathrm{CH}_{2} \mathrm{Cl}_{2}(3 \times 20 \mathrm{~mL})$. The combined organic extracts were dried over $\mathrm{Na}_{2} \mathrm{SO}_{4}(5 \mathrm{~g})$, filtered through Celite on a glass frit, and the filtrate was concentrated in vacuo. The resulting residue was purified by column chromatography (12 $\mathrm{g} \mathrm{SiO}_{2}, 2 \mathrm{~cm}$ column diam., pentane/ $\left.\mathrm{Et}_{2} \mathrm{O}, 1 / 1\right)$. The product-containing fractions were combined and the solvent was removed in vacuo to yield $23 \mathrm{mg}(21 \%)$ of 39 as a clear, colorless oil.

Data for 39:

${ }^{1}$ H NMR: $\quad\left(500 \mathrm{MHz}, \mathrm{CHCl}_{3}\right)$

7.32-7.29 (m, 2 H, HC(11)), 7.23-7.19 (m, 3 H, HC(10,12)), 5.32 (s, $1 \mathrm{H}, \mathrm{CH}(5))$, 4.38-4.32 (m, $1 \mathrm{H}, \mathrm{HC}(2), 2.86-2.73$ (m, 2 H, H $2 \mathrm{C}(8))$, 2.48-2.35 (m, $2 \mathrm{H}, \mathrm{HC}(3))$, 2.22-2.12 (m, 1 H, HC(7)), 2.02 (s, 3 H, H $\left.{ }_{3} \mathrm{C}(13)\right)$, 1.99-1.92 (m, 2 H, HC(7))

TLC: $\quad R_{f} 0.28$ (hexanes/EtOAc, 4/1) [UV (254 nm)]

SFC: $\quad(R)-39 \mathrm{t}_{\mathrm{r}} 2.67 \min (30.0 \%) ;(S)-39 \mathrm{t}_{\mathrm{r}} 3.43 \min (70.0 \%)$; (Chiralpak OD, 125 psi, $40{ }^{\circ} \mathrm{C}, 15.0 \% \mathrm{MeOH}$ in $\mathrm{CO}_{2}, 3.0 \mathrm{~mL} / \mathrm{min}, 220 \mathrm{~nm}$ )

Preparation of (2S)-2,3-Dihydro-6-methyl-2-phenylethylpyran-4-one (39) (Table 4, entry 2)
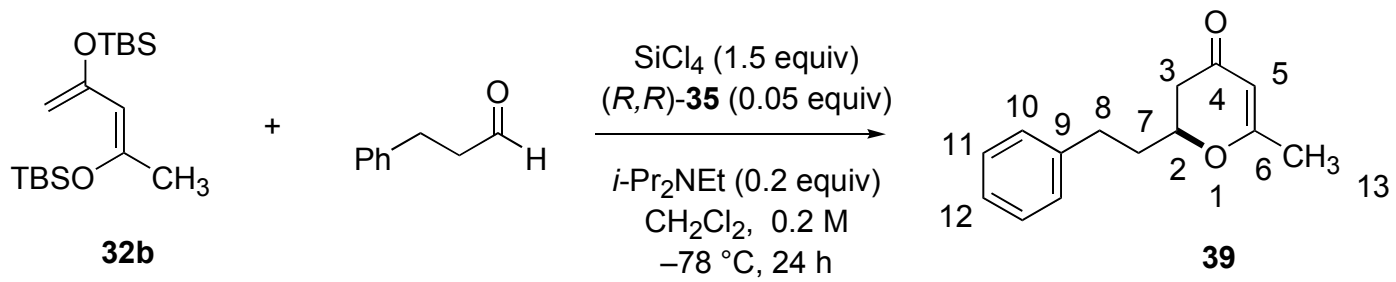

Following Representative Procedure 7, $66 \mu \mathrm{L}(0.5 \mathrm{mmol})$ of hydrocinnamaldehyde was combined with $21 \mathrm{mg}(0.025 \mathrm{mmol}, 0.05$ equiv) of bisphosphoramide $(R, R)-35,18 \mu \mathrm{L}(0.1$ mmol, 0.2 equiv) of diisopropylethylamine, $86 \mu \mathrm{L}\left(0.75 \mathrm{mmol}, 1.5\right.$ equiv) of $\mathrm{SiCl}_{4}$ and $197 \mathrm{mg}$ ( 0.6 mmol, 1.2 equiv) of $\mathbf{3 2 b}$ to yield, after column chromatography $\left(\mathrm{SiO}_{2}(13 \mathrm{~g}), 2 \mathrm{~cm}\right.$ diam., pentane/ $\left.\mathrm{Et}_{2} \mathrm{O} 1 / 1\right)$ to yield $23 \mathrm{mg}(21 \%)$ of 39 as a clear, colorless oil.

\section{Data for 39:}

${ }^{1} \mathrm{H}$ NMR: $\quad\left(500 \mathrm{MHz}, \mathrm{CHCl}_{3}\right)$

7.32-7.28 (m, 2 H, HC(11)), 7.23-7.19 (m, 3 H, HC(10,12)), 5.32 (s, 1 H, CH(5)), 4.38-4.32 (m, 1 H, HC(2), 2.86-2.72 (m, 2 H, H 2 C(8)), 2.48-2.35 (m, 2 H, HC(3)), 2.22-2.13 (m, $1 \mathrm{H}, \mathrm{HC}(7)), 2.01$ (s, $\left.3 \mathrm{H}, \mathrm{H}_{3} \mathrm{C}(13)\right)$, 1.98-1.91 (m, $\left.2 \mathrm{H}, \mathrm{HC}(7)\right)$

TLC: $\quad R_{f} 0.28$ (hexanes/EtOAc, 4/1) [UV (254 nm)]

SFC: $\quad(R)-39 \mathrm{t}_{\mathrm{r}} 2.66 \min (37.0 \%)$; $(3 S)-39 \mathrm{t}_{\mathrm{r}} 3.41 \min (63.0 \%)$; (Chiralpak OD, 125 psi, 
$40{ }^{\circ} \mathrm{C}, 15.0 \% \mathrm{MeOH}$ in $\left.\mathrm{CO}_{2}, 3.0 \mathrm{~mL} / \mathrm{min}, 220 \mathrm{~nm}\right)$

Preparation of (2S)-2,3-Dihydro-6-methyl-2-phenylethylpyran-4-one (39) (Table 4, entry 3)<smiles></smiles>

32b

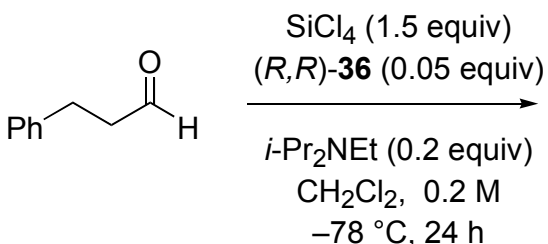

$-78^{\circ} \mathrm{C}, 24 \mathrm{~h}$

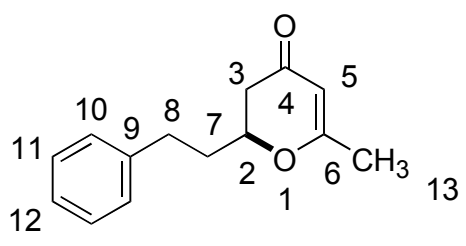

39

Following Representative Procedure 7, $66 \mu \mathrm{L}(0.5 \mathrm{mmol})$ of hydrocinnamaldehyde was combined with $21 \mathrm{mg}(0.025 \mathrm{mmol}, 0.05$ equiv) of bisphosphoramide $(R, R)-36,18 \mu \mathrm{L}(0.1$ mmol, 0.2 equiv) of diisopropylethylamine, $86 \mu \mathrm{L}\left(0.75 \mathrm{mmol}, 1.5\right.$ equiv) of $\mathrm{SiCl}_{4}$ and $197 \mathrm{mg}$ (0.6 mmol, 1.2 equiv) of 32b to yield, after column chromatography $\left(\mathrm{SiO}_{2}(13 \mathrm{~g}), 2 \mathrm{~cm}\right.$ diam., pentane/ $\left.\mathrm{Et}_{2} \mathrm{O} 1 / 1\right)$ to yield $14 \mathrm{mg}(13 \%)$ of 39 as a clear, colorless oil.

\section{Data for 39:}

${ }^{1} \mathrm{H}$ NMR: $\quad\left(500 \mathrm{MHz}, \mathrm{CHCl}_{3}\right)$

7.32-7.28 (m, 2 H, HC(11)), 7.23-7.19 (m, 3 H, HC(10,12)), 5.32 (s, 1 H, CH(5)), 4.38-4.32 (m, 1 H, HC(2), 2.86-2.72 (m, 2 H, H 2 C(8)), 2.48-2.35 (m, 2 H, HC(3)), 2.22-2.13 (m, 1 H, HC(7)), 2.01 (s, 3 H, H $\left.{ }_{3} \mathrm{C}(13)\right)$, 1.98-1.91 (m, 2 H, HC(7))

TLC: $\quad R_{f} 0.28$ (hexanes/EtOAc, 4/1) [UV (254 nm)]

SFC: $\quad(R)-39 \mathrm{t}_{\mathrm{r}} 2.63 \min (46.1 \%)$; $(S)-39 \mathrm{t}_{\mathrm{r}} 3.38 \mathrm{~min}(53.9 \%)$; (Chiralpak OD, 125 psi, $40{ }^{\circ} \mathrm{C}, 15.0 \% \mathrm{MeOH}$ in $\mathrm{CO}_{2}, 3.0 \mathrm{~mL} / \mathrm{min}, 220 \mathrm{~nm}$ )

Preparation of (2S)-2,3-Dihydro-6-methyl-2-phenylethylpyran-4-one (39) (Table 4, entry 4)<smiles>C=C(C=C(C)O[Na])O[Na]</smiles>

$32 a$

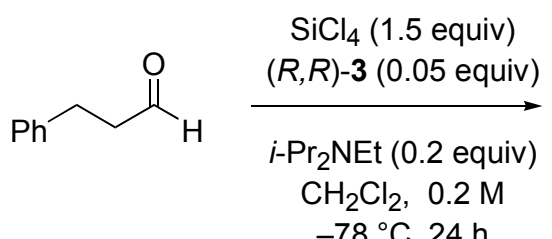

$-78^{\circ} \mathrm{C}, 24 \mathrm{~h}$

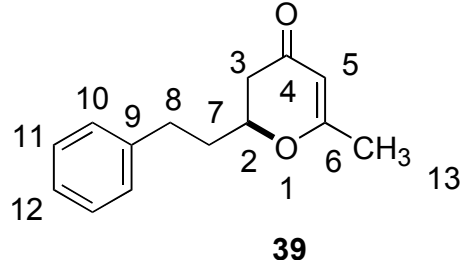

39

Following Representative Procedure 7, $66 \mu \mathrm{L}(0.5 \mathrm{mmol})$ of hydrocinnamaldehyde was combined with $21 \mathrm{mg}(0.025 \mathrm{mmol}, 0.05$ equiv) of bisphosphoramide $(R, R)-3,18 \mu \mathrm{L}(0.1 \mathrm{mmol}$, 0.2 equiv) of diisopropylethylamine, $86 \mu \mathrm{L}\left(0.75 \mathrm{mmol}, 1.5\right.$ equiv) of $\mathrm{SiCl}_{4}$ and $147 \mathrm{mg}(0.6$ mmol, 1.2 equiv) of 32a to yield, after column chromatography $\left(\mathrm{SiO}_{2}(13 \mathrm{~g}), 2 \mathrm{~cm}\right.$ diam., 
pentane/ $\left.\mathrm{Et}_{2} \mathrm{O} 1 / 1\right)$ to yield $33 \mathrm{mg}(31 \%)$ of 39 as a clear, colorless oil.

Data for 39:

${ }^{1} \mathrm{H}$ NMR: $\quad\left(500 \mathrm{MHz}, \mathrm{CHCl}_{3}\right)$

7.33-7.28 (m, 2 H, HC(11)), 7.22-7.19 (m, 3 H, HC(10,12)), 5.32 (s, $1 \mathrm{H}, \mathrm{CH}(5))$, 4.38-4.32 (m, 1 H, HC(2), 2.86-2.72 (m, 2 H, H 2 C(8)), 2.49-2.35 (m, 2 H, HC(3)), 2.21-2.13 (m, $1 \mathrm{H}, \mathrm{HC}(7)), 2.01$ (s, 3 H, H $\left.\mathrm{H}_{3}(13)\right)$, 1.98-1.91 (m, 2 H, HC(7))

TLC: $\quad R_{f} 0.28$ (hexanes/EtOAc, 4/1) [UV (254 nm)]

SFC: $\quad(R)-39 \mathrm{t}_{\mathrm{r}} 2.67 \min (46.8 \%) ;(S)-39 \mathrm{t}_{\mathrm{r}} 3.40 \min (53.2 \%)$; (Chiralpak OD, 125 psi, $40{ }^{\circ} \mathrm{C}, 15.0 \% \mathrm{MeOH}$ in $\mathrm{CO}_{2}, 3.0 \mathrm{~mL} / \mathrm{min}, 220 \mathrm{~nm}$ )

\section{Preparation of (2S)-2,3-Dihydro-6-methyl-2-phenylethylpyran-4-one (39) (Table 4, entry 5)}<smiles>C=C(C=C(C)OC#[SH])O[Na]</smiles>

32c
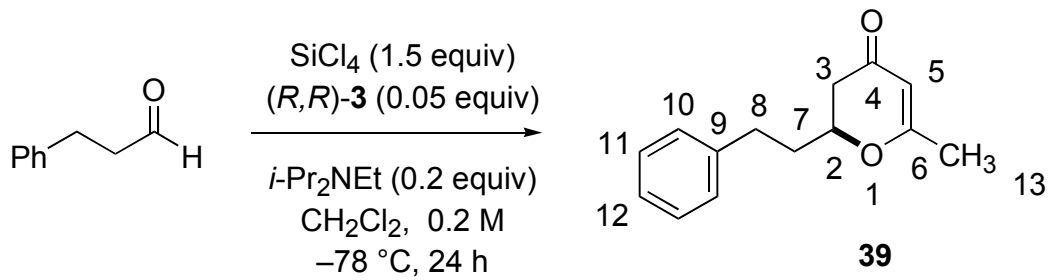

39

Following Representative Procedure 7, $66 \mu \mathrm{L}(0.5 \mathrm{mmol})$ of hydrocinnamaldehyde was combined with $21 \mathrm{mg}(0.025 \mathrm{mmol}, 0.05$ equiv) of bisphosphoramide $(R, R)-3,18 \mu \mathrm{L}(0.1 \mathrm{mmol}$, 0.2 equiv) of diisopropylethylamine, $86 \mu \mathrm{L}\left(0.75 \mathrm{mmol}, 1.5\right.$ equiv) of $\mathrm{SiCl}_{4}$ and $197 \mathrm{mg}(0.6$ mmol, 1.2 equiv) of 32c to yield, after column chromatography $\left(\mathrm{SiO}_{2}(13 \mathrm{~g}), 2 \mathrm{~cm}\right.$ diam., pentane/ $\left.\mathrm{Et}_{2} \mathrm{O} 1 / 1\right)$ to yield $20 \mathrm{mg}(19 \%)$ of 39 as a clear, colorless oil.

Data for 39:

${ }^{1}$ H NMR: $\quad\left(500 \mathrm{MHz}, \mathrm{CHCl}_{3}\right)$

7.32-7.28 (m, $2 \mathrm{H}, \mathrm{HC}(11))$ ) 7.23-7.19 (m, $3 \mathrm{H}, \mathrm{HC}(10,12)$ ), 5.32 (s, $1 \mathrm{H}, \mathrm{CH}(5))$,

4.38-4.32 (m, $1 \mathrm{H}, \mathrm{HC}(2)$, 2.86-2.72 (m, $2 \mathrm{H}, \mathrm{H}_{2} \mathrm{C}(8)$ ), 2.48-2.35 (m, $2 \mathrm{H}, \mathrm{HC}(3)$ ), 2.22-2.13 (m, $1 \mathrm{H}, \mathrm{HC}(7)), 2.01$ (s, $\left.3 \mathrm{H}, \mathrm{H}_{3} \mathrm{C}(13)\right)$ ) 1.98-1.91 (m, $2 \mathrm{H}, \mathrm{HC}(7)$ )

TLC: $\quad R_{f} 0.28$ (hexanes/EtOAc, 4/1) [UV (254 nm)]

SFC: $\quad(R)-39 \mathrm{t}_{\mathrm{r}} 2.65 \min (41.1 \%)$; (S)-39 $\mathrm{t}_{\mathrm{r}} 3.40 \min (58.9 \%)$; (Chiralpak OD, $125 \mathrm{psi}$, $40{ }^{\circ} \mathrm{C}, 15.0 \% \mathrm{MeOH}$ in $\mathrm{CO}_{2}, 3.0 \mathrm{~mL} / \mathrm{min}, 220 \mathrm{~nm}$ ) 
Preparation of (2S)-2,3-Dihydro-6-methyl-2-phenylethylpyran-4-one (39) (Table 4, entry 6)<smiles>C=C(C=[Pb])O[Na]</smiles>

32d

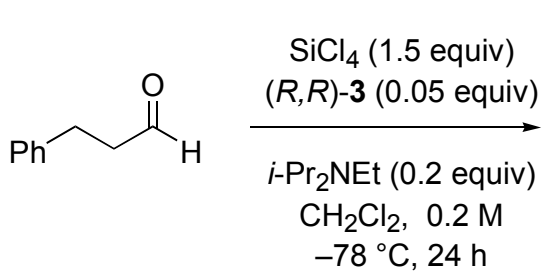

Following Representative Procedure 7, $66 \mu \mathrm{L}(0.5 \mathrm{mmol})$ of hydrocinnamaldehyde was combined with $21 \mathrm{mg}(0.025 \mathrm{mmol}, 0.05$ equiv) of bisphosphoramide $(R, R)-3,18 \mu \mathrm{L}(0.1 \mathrm{mmol}$, 0.2 equiv) of diisopropylethylamine, $86 \mu \mathrm{L}\left(0.75 \mathrm{mmol}, 1.5\right.$ equiv) of $\mathrm{SiCl}_{4}$ and $248 \mathrm{mg}(0.6$ mmol, 1.2 equiv) of 32d to yield, after column chromatography $\left(\mathrm{SiO}_{2}(13 \mathrm{~g}), 2 \mathrm{~cm}\right.$ diam., pentane/Et $\left.{ }_{2} \mathrm{O} 1 / 1\right)$ to yield $10 \mathrm{mg}(9 \%)$ of 39 as a clear, colorless oil.

\section{Data for 39:}

${ }^{1} \mathrm{H}$ NMR: $\quad\left(500 \mathrm{MHz}, \mathrm{CHCl}_{3}\right)$

7.32-7.28 (m, 2 H, HC(11)), 7.23-7.19 (m, 3 H, HC(10,12)), 5.32 (s, $1 \mathrm{H}, \mathrm{CH}(5))$, 4.38-4.31 (m, 1 H, HC(2), 2.86-2.72 (m, 2 H, H 2 C(8)), 2.48-2.36 (m, 2 H, HC(3)), 2.22-2.12 (m, $1 \mathrm{H}, \mathrm{HC}(7)), 2.00$ (s, 3 H, H3 $\mathrm{C}(13))$, 1.98-1.92 (m, 2 H, HC(7))

TLC: $\quad R_{f} 0.28$ (hexanes/EtOAc, 4/1) [UV (254 nm)]

SFC: $\quad(R)-39 \mathrm{t}_{\mathrm{r}} 2.63 \min (32.5 \%) ;(S)-39 \mathrm{t}_{\mathrm{r}} 3.35 \min (67.5 \%)$; (Chiralpak OD, 125 psi, $40{ }^{\circ} \mathrm{C}, 15.0 \% \mathrm{MeOH}$ in $\mathrm{CO}_{2}, 3.0 \mathrm{~mL} / \mathrm{min}, 220 \mathrm{~nm}$ )

\section{Preparation of (-)-(2R,3S)-6-Ethyl-2,3-dihydro-3-methyl-2-phenylpyran-4-one (40) (Table} 5, entry 1)

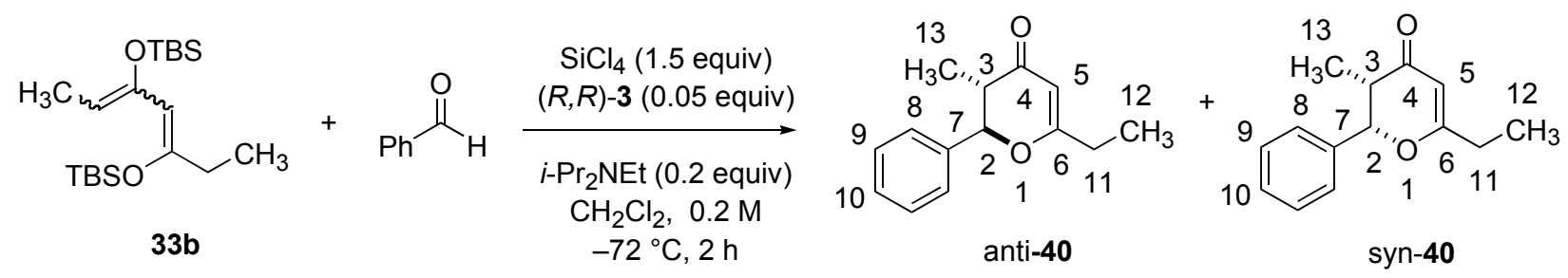

Diisopropylamine ( $35 \mu \mathrm{L}, 0.2 \mathrm{mmol}, 0.2$ equiv) was added via syringe to a flame-dried, 20-mL, schlenk flask under $\mathrm{N}_{2}$ containing a solution of $21 \mathrm{mg}(0.025 \mathrm{mmol}, 0.05$ equiv $)$ of bisphosphoramide $(R, R)-3$ in $\mathrm{CH}_{2} \mathrm{Cl}_{2}(2 \mathrm{~mL})$. To this solution was added $102 \mu \mathrm{L}(1.0 \mathrm{mmol})$ of benzaldehyde in one portion. The resulting solution was cooled to $-72{ }^{\circ} \mathrm{C}$ over $15 \mathrm{~min}$ and to the reaction mixture was added $172 \mu \mathrm{L}(1.5 \mathrm{mmol}, 1.5$ equiv $)$ of $\mathrm{SiCl}_{4}$ in one portion. Then, $394 \mathrm{mg}$ 
(1.2 mmol, 1.2 equiv) of $\mathbf{3 3 b}$ was added dropwise over $5 \mathrm{~min}$. The resulting mixture was stirred at $-72{ }^{\circ} \mathrm{C}$ for $2 \mathrm{~h}$ whereupon $3.0 \mathrm{~mL}$ of chilled $\mathrm{CH}_{2} \mathrm{Cl}_{2}$ was added before the cold reaction mixture was poured into a rapidly stirring solution of $1 / 1$ sat. aq. $\mathrm{NaHCO}_{3} /$ sat. aq. $\mathrm{KF}(25 \mathrm{~mL})$ at $0{ }^{\circ} \mathrm{C}$. This biphasic mixture was stirred vigorously for $3 \mathrm{~h}$ after which the aqueous layer was washed with $\mathrm{CH}_{2} \mathrm{Cl}_{2}(3 \times 50 \mathrm{~mL})$. The combined organic extracts were dried over $\mathrm{Na}_{2} \mathrm{SO}_{4}(5 \mathrm{~g})$ filtered through Celite on a glass frit, and the filtrate was concentrated in vacuo. The residue was dissolved in $10 \mathrm{~mL}$ of $\mathrm{CH}_{2} \mathrm{Cl}_{2}$ and cooled in an ice water bath for $15 \mathrm{~min}$ and to the reaction mixture 10 drops of TFA was added. The resulting mixture was stirred at $\mathrm{rt}$ for $16 \mathrm{~h}$ whereupon $10 \mathrm{ml}$ of sat. aq. $\mathrm{NaHCO}_{3}$ added. This biphasic mixture was stirred for $10 \mathrm{~min}$ after which the aqueous layer was washed with $\mathrm{CH}_{2} \mathrm{Cl}_{2}(3 \times 20 \mathrm{~mL})$. The combined organic extracts were dried over $\mathrm{Na}_{2} \mathrm{SO}_{4}(5 \mathrm{~g})$, filtered through Celite on a glass frit, and the filtrate was concentrated in vacuo. The anti/syn ratio was determined to be $96.0 / 4.0$ by ${ }^{1} \mathrm{H}$ NMR (500 MHz) analysis of the crude reaction mixture. The resulting residue was purified by column chromatography (30 g $\mathrm{SiO}_{2}, 2 \mathrm{~cm}$ column diam., hexanes/EtOAc, 2/1). The product-containing fractions were combined and the solvent was removed in vacuo to yield $190 \mathrm{mg}(88 \%)$ of (-)-anti-40 as a clear oil and $8 \mathrm{mg}(4 \%)$ of syn-40 as a clear oil (overall yield 92\%).

Data for (-)-anti-40:

${ }^{1}$ H NMR: $\quad\left(500 \mathrm{MHz}, \mathrm{CHCl}_{3}\right)$

7.46-7.39 (m, $5 \mathrm{H}, \mathrm{HC}(8,9,10)), 5.45$ (s, $1 \mathrm{H}, \mathrm{HC}(5)), 4.93$ (d, $J=13.2,1 \mathrm{H}$, $\mathrm{HC}(2)), 2.73$ (dt, $J=13.6,6.8,1 \mathrm{H}, \mathrm{HC}(3)), 2.32$ (q, $J=7.6,2 \mathrm{H}, \mathrm{HC}(11)), 1.16$ $(\mathrm{t}, J=7.3,3 \mathrm{H}, \mathrm{HC}(12)), 0.93(\mathrm{~d}, J=7.1,3 \mathrm{H}, \mathrm{HC}(13))$

${ }^{13} \mathrm{C} \mathrm{NMR}: \quad\left(125 \mathrm{MHz}, \mathrm{CDCl}_{3}\right)$

$192.8(\mathrm{C}(4)), 177.9(\mathrm{C}(6)), 137.7(\mathrm{C}(7)), 128.9 \mathrm{C}(10)), 128.6(\mathrm{C}(9)), 127.3(\mathrm{C}(8))$, 102.5 (C(5)), 86.7 (C(2)), 44.1 (C(3)), 27.7 (C(11)), 10.5 (C(12)), 10.3 (C(13))

IR: (neat)

3065 (w), 3035 (w), 2974 (m), 2937 (w), 2879 (w), 2361 (w), 1958 (w), 1889 (w), 1671 (s), 1641 (s), 1499 (w), 1456 (s), 1424 (w), 1395 (s), 1365 (s), 1335 (m), 1279 (m), 1234 (m), 1212 (m), 1157 (m), 1091 (m), 1077 (m), 1065 (m), 1011 (s), 971 (m), 947 (m), $916(\mathrm{w}), 900$ (w), 856 (m), 821 (m), 794 (w), 760 (s), 700 (s), $656(\mathrm{w}), 616(\mathrm{w})$ 
MS: $\quad(\mathrm{EI}, 70 \mathrm{eV})$

$216\left(\mathrm{M}^{+}, 6\right), 159(11), 119(10), 118(100), 117(38), 91$ (12)

Opt. Rot.: $\quad[\alpha]_{\mathrm{D}}{ }^{24}-51.36^{\circ}(\mathrm{c}=1.15, \mathrm{EtOH})$

TLC: $\quad R_{f} 0.25$ (hexanes/EtOAc, 4/1) [UV (254 nm)]

SFC: $\quad(2 R, 3 S)-40 t_{\mathrm{r}} 3.89 \min (83.0 \%)$; (2S,3R)-40 $\mathrm{t}_{\mathrm{r}} 4.27 \mathrm{~min}(17.0 \%)$ (Chiralpak OJ, $125 \mathrm{psi}, 40{ }^{\circ} \mathrm{C}, 1.5 \% \mathrm{MeOH}$ in $\left.\mathrm{CO}_{2}, 3.0 \mathrm{~mL} / \mathrm{min}, 220 \mathrm{~nm}\right)$

Analysis: $\quad \mathrm{C}_{14} \mathrm{H}_{16} \mathrm{O}_{2}(216.28)$

Calcd: $\quad$ C, $77.75 ; \quad H, 7.46 \%$

Found: $\quad$ C, $77.66 ; \quad H, 7.49 \%$

Data for syn-40:

${ }^{1} \mathrm{H}$ NMR: $\quad\left(500 \mathrm{MHz}, \mathrm{CHCl}_{3}\right)$

7.43-7.32 (m, $5 \mathrm{H}, \mathrm{HC}(8,9,10)), 5.48(\mathrm{~d}, J=3.2,1 \mathrm{H}, \mathrm{HC}(2)), 5.38(\mathrm{~s}, 1 \mathrm{H}$, $\mathrm{HC}(5)), 2.52$ (dq, $J=3.2,0.8,1 \mathrm{H}, \mathrm{HC}(3)), 2.40$ (q, $J=7.6,2 \mathrm{H}, \mathrm{HC}(11)), 1.21$ (t, $J=7.6,3 \mathrm{H}, \mathrm{HC}(12)), 0.90(\mathrm{~d}, J=7.3,3 \mathrm{H}, \mathrm{HC}(13))$

MS: $\quad(\mathrm{EI}, 70 \mathrm{eV})$

$216\left(\mathrm{M}^{+}, 4\right), 159(22), 119(10), 118$ (100), 117 (45), 91 (12)

TLC: $\quad R_{f} 0.17$ (hexanes/EtOAc, 4/1) [UV (254 nm)]

SFC: $\quad s y n-\mathbf{4 0} \mathrm{t}_{\mathrm{r}} 2.75 \min (48.7 \%)$; syn-40 $\mathrm{t}_{\mathrm{r}} 3.26 \min (51.3 \%)$ (Chiralpak OD, 125 psi, $40{ }^{\circ} \mathrm{C}, 5.0 \% \mathrm{MeOH}$ in $\left.\mathrm{CO}_{2}, 3.0 \mathrm{~mL} / \mathrm{min}, 220 \mathrm{~nm}\right)$

HRMS: $\quad$ Calcd for $\mathrm{C}_{14} \mathrm{H}_{17} \mathrm{O}_{2}: 217.1229$, found: 217.1230

Preparation of (2R,3S)-6-Ethyl-2,3-dihydro-3-methyl-2-phenylpyran-4-one (40) (Table 5, entry 2)
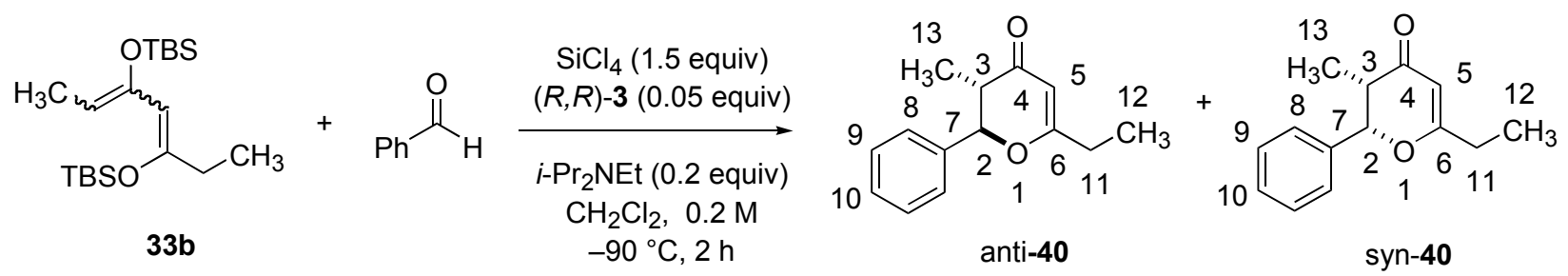

Following Representative Procedure $6,51 \mu \mathrm{L}(0.5 \mathrm{mmol})$ of benzaldehyde was combined with $21 \mathrm{mg}$ ( $0.025 \mathrm{mmol}, 0.05$ equiv) of bisphosphoramide $(R, R)-3,18 \mu \mathrm{L}(0.1 \mathrm{mmol}, 0.2$ equiv) of diisopropylethylamine, $86 \mu \mathrm{L}\left(0.75 \mathrm{mmol}, 1.5\right.$ equiv) of $\mathrm{SiCl}_{4}$ and $214 \mathrm{mg}(0.6 \mathrm{mmol}, 1.2$ 
equiv) of 33b to yield, after column chromatography (13 g SiO${ }_{2}, 2 \mathrm{~cm}$ diam., pentane/ $\left.\mathrm{Et}_{2} \mathrm{O}, 2 / 1\right)$ $77 \mathrm{mg} \mathrm{(66 \% )} \mathrm{of} \mathrm{anti-40} \mathrm{as} \mathrm{a} \mathrm{clear,} \mathrm{colorless} \mathrm{oil} \mathrm{and} 3 \mathrm{mg}(3 \%)$ of syn-40 as a clear, colorless oil (overall yield 69\%). The anti/syn ratio was determined to be $95.0 / 5.0$ by ${ }^{1} \mathrm{H} \mathrm{NMR}(500 \mathrm{MHz})$ analysis of the crude reaction mixture.

Data for anti-40:

${ }^{1} \mathrm{H}$ NMR: $\quad\left(500 \mathrm{MHz}, \mathrm{CHCl}_{3}\right)$

7.46-7.38 (m, 5 H, HC(8,9,10)), 5.45 (s, $1 \mathrm{H}, \mathrm{HC}(5)), 4.93$ (d, $J=13.2,1 \mathrm{H}$, $\mathrm{HC}(2)), 2.73$ (dt, $J=13.5,6.9,1 \mathrm{H}, \mathrm{HC}(3)), 2.32$ (q, $J=7.5,2 \mathrm{H}, \mathrm{HC}(11)), 1.15$ (t, $J=7.2,3 \mathrm{H}, \mathrm{HC}(12)), 0.93(\mathrm{~d}, J=7.1,3 \mathrm{H}, \mathrm{HC}(13))$

TLC: $\quad R_{f} 0.25$ (hexanes/EtOAc, 4/1) [UV (254 nm)]

SFC: $\quad(2 R, 3 S)-40$ t $3.76 \min (84.5 \%)$; $(2 S, 3 R)-40 t_{\mathrm{r}} 4.13 \mathrm{~min}(15.5 \%)$ (Chiralpak OJ, $125 \mathrm{psi}, 40{ }^{\circ} \mathrm{C}, 1.5 \% \mathrm{MeOH}$ in $\mathrm{CO}_{2}, 3.0 \mathrm{~mL} / \mathrm{min}, 220 \mathrm{~nm}$ )

Data for syn-40:

${ }^{1} \mathrm{H}$ NMR: $\quad\left(500 \mathrm{MHz}, \mathrm{CHCl}_{3}\right)$

7.42-7.32 (m, $5 \mathrm{H}, \mathrm{HC}(8,9,10)), 5.49(\mathrm{~d}, J=3.2,1 \mathrm{H}, \mathrm{HC}(2)), 5.40(\mathrm{~s}, 1 \mathrm{H}$, HC(5)), 2.52 (dq, $J=3.1,0.9,1 \mathrm{H}, \mathrm{HC}(3)), 2.40$ (q, $J=7.6,2 \mathrm{H}, \mathrm{HC}(11)), 1.21$ (t, $J=7.5,3 \mathrm{H}, \mathrm{HC}(12)), 0.90(\mathrm{~d}, J=7.3,3 \mathrm{H}, \mathrm{HC}(13))$

TLC: $\quad R_{f} 0.17$ (hexanes/EtOAc, 4/1) [UV (254 nm)]

SFC: $\quad s y n-40 \mathrm{t}_{\mathrm{r}} 2.68 \min (46.9 \%) ; s y n-40 \mathrm{t}_{\mathrm{r}} 3.20 \min (53.1 \%)$ (Chiralpak OD, 125 psi, $40{ }^{\circ} \mathrm{C}, 5.0 \% \mathrm{MeOH}$ in $\mathrm{CO}_{2}, 3.0 \mathrm{~mL} / \mathrm{min}, 220 \mathrm{~nm}$ )

Preparation of $(2 R, 3 S)-6-E t h y l-2,3-d i h y d r o-3-m e t h y l-2-p h e n y l p y r a n-4-o n e ~(40)$ (Table 5, entry 3)
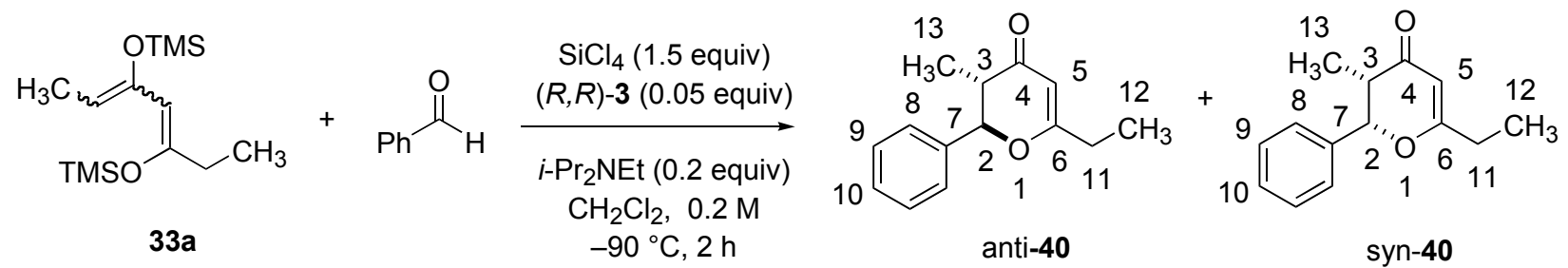

Following Representative Procedure $6,51 \mu \mathrm{L}(0.5 \mathrm{mmol})$ of benzaldehyde was combined with $21 \mathrm{mg}$ ( $0.025 \mathrm{mmol}, 0.05$ equiv) of bisphosphoramide $(R, R)-3,18 \mu \mathrm{L}(0.1 \mathrm{mmol}, 0.2$ equiv) of diisopropylethylamine, $86 \mu \mathrm{L}\left(0.75 \mathrm{mmol}, 1.5\right.$ equiv) of $\mathrm{SiCl}_{4}$ and $164 \mathrm{mg}(0.6 \mathrm{mmol}, 1.2$ 
equiv) of 33a to yield, after column chromatography (13 g SiO${ }_{2}, 2 \mathrm{~cm}$ diam., pentane/Et $\left.2 \mathrm{O}, 2 / 1\right)$ $101 \mathrm{mg} \mathrm{(93 \% )} \mathrm{of} \mathrm{anti-40} \mathrm{as} \mathrm{a} \mathrm{clear} \mathrm{oil} \mathrm{and} 3 \mathrm{mg}(3 \%)$ of syn-40 as a clear oil (overall yield $96 \%$ ). The anti/syn ratio was determined to be $95.0 / 5.0$ by ${ }^{1} \mathrm{H}$ NMR (500 MHz) analysis of the crude reaction mixture.

Data for anti-40:

${ }^{1} \mathrm{H}$ NMR: $\quad\left(500 \mathrm{MHz}, \mathrm{CHCl}_{3}\right)$

7.45-7.39 (m, $5 \mathrm{H}, \mathrm{HC}(8,9,10)), 5.45$ (s, $1 \mathrm{H}, \mathrm{HC}(5)), 4.93$ (d, $J=13.1,1 \mathrm{H}$, $\mathrm{HC}(2)), 2.73$ (dt, $J=13.6,6.8,1 \mathrm{H}, \mathrm{HC}(3)), 2.33$ (q, $J=7.5,2 \mathrm{H}, \mathrm{HC}(11)), 1.16$ (t, $J=7.2,3 \mathrm{H}, \mathrm{HC}(12)), 0.93(\mathrm{~d}, J=7.1,3 \mathrm{H}, \mathrm{HC}(13))$

TLC: $\quad R_{f} 0.25$ (hexanes/EtOAc, 4/1) [UV (254 nm)]

SFC: $\quad(2 R, 3 S)-40$ t $3.84 \mathrm{~min}(69.6 \%)$; $(2 S, 3 R)-40 \mathrm{t}_{\mathrm{r}} 4.21 \mathrm{~min}(30.4 \%)$ (Chiralpak OJ, $125 \mathrm{psi}, 40{ }^{\circ} \mathrm{C}, 1.5 \% \mathrm{MeOH}$ in $\mathrm{CO}_{2}, 3.0 \mathrm{~mL} / \mathrm{min}, 220 \mathrm{~nm}$ )

Data for syn-40:

${ }^{1}$ H NMR: $\quad\left(500 \mathrm{MHz}, \mathrm{CHCl}_{3}\right)$

7.44-7.32 (m, $5 \mathrm{H}, \mathrm{HC}(8,9,10)), 5.48(\mathrm{~d}, J=3.2,1 \mathrm{H}, \mathrm{HC}(2)), 5.39(\mathrm{~s}, 1 \mathrm{H}$, $\mathrm{HC}(5)), 2.54$ (dq, $J=3.2,0.8,1 \mathrm{H}, \mathrm{HC}(3)), 2.41$ (q, $J=7.6,2 \mathrm{H}, \mathrm{HC}(11)), 1.20$ (t, $J=7.6,3 \mathrm{H}, \mathrm{HC}(12)), 0.90(\mathrm{~d}, J=7.3,3 \mathrm{H}, \mathrm{HC}(13))$

TLC: $\quad R_{f} 0.17$ (hexanes/EtOAc, 4/1) [UV (254 nm)]

\section{Preparation of $(2 R, 3 S)-6-E$ thyl-2,3-dihydro-3-methyl-2-phenylpyran-4-one (40) (Table 5, entry 4)}
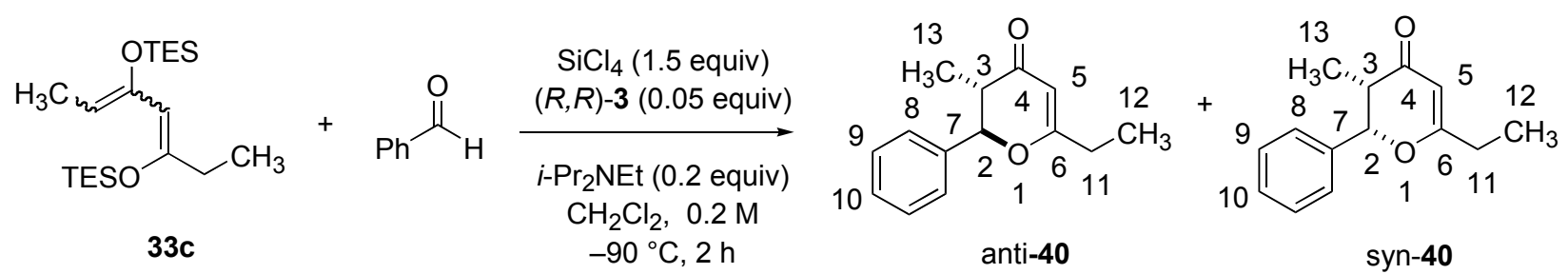

Following Representative Procedure $6,51 \mu \mathrm{L}(0.5 \mathrm{mmol})$ of benzaldehyde was combined with $21 \mathrm{mg}(0.025 \mathrm{mmol}, 0.05$ equiv) of bisphosphoramide $(R, R)-3,18 \mu \mathrm{L}(0.1 \mathrm{mmol}, 0.2$ equiv) of diisopropylethylamine, $86 \mu \mathrm{L}\left(0.75 \mathrm{mmol}, 1.5\right.$ equiv) of $\mathrm{SiCl}_{4}$ and $214 \mathrm{mg}(0.6 \mathrm{mmol}, 1.2$ equiv) of 33c to yield, after column chromatography (13 g SiO $2,2 \mathrm{~cm}$ diam., pentane/Et $\left.\mathrm{g}_{2} \mathrm{O}, 2 / 1\right)$ $88 \mathrm{mg}(81 \%)$ of anti-40 as a clear, colorless oil and $3 \mathrm{mg} \mathrm{(3 \% )}$ of syn-40 as a clear, colorless oil 
(overall yield 91\%). The anti/syn ratio was determined to be $95.0 / 5.0$ by ${ }^{1} \mathrm{H}$ NMR (500 MHz) analysis of the crude reaction mixture.

Data for anti-40:

${ }^{1}$ H NMR: $\quad\left(500 \mathrm{MHz}, \mathrm{CHCl}_{3}\right)$

7.46-7.38 (m, $5 \mathrm{H}, \mathrm{HC}(8,9,10)), 5.43$ (s, $1 \mathrm{H}, \mathrm{HC}(5)), 4.95$ (d, $J=13.2,1 \mathrm{H}$, $\mathrm{HC}(2)), 2.74$ (dt, $J=13.6,6.8,1 \mathrm{H}, \mathrm{HC}(3)), 2.31$ (q, $J=7.6,2 \mathrm{H}, \mathrm{HC}(11)), 1.16$ (t, $J=7.3,3 \mathrm{H}, \mathrm{HC}(12)), 0.92$ (d, $J=7.1,3 \mathrm{H}, \mathrm{HC}(13))$

TLC: $\quad R_{f} 0.25$ (hexanes/EtOAc, 4/1) [UV (254 nm)]

SFC: $\quad(2 R, 3 S)-40 t_{\mathrm{r}} 3.85 \mathrm{~min}(72.6 \%) ;(2 S, 3 R)-40 \mathrm{t}_{\mathrm{r}} 4.27 \mathrm{~min}(27.4 \%)$ (Chiralpak OJ, $125 \mathrm{psi}, 40{ }^{\circ} \mathrm{C}, 1.5 \% \mathrm{MeOH}$ in $\left.\mathrm{CO}_{2}, 3.0 \mathrm{~mL} / \mathrm{min}, 220 \mathrm{~nm}\right)$

Data for syn-40:

${ }^{1} \mathrm{H}$ NMR: $\quad\left(500 \mathrm{MHz}, \mathrm{CHCl}_{3}\right)$

7.43-7.32 (m, $5 \mathrm{H}, \mathrm{HC}(8,9,10)), 5.48(\mathrm{~d}, J=3.2,1 \mathrm{H}, \mathrm{HC}(2)), 5.38(\mathrm{~s}, 1 \mathrm{H}$, $\mathrm{HC}(5)), 2.52(\mathrm{dq}, J=3.2,0.8,1 \mathrm{H}, \mathrm{HC}(3)), 2.40$ (q, $J=7.6,2 \mathrm{H}, \mathrm{HC}(11)), 1.21$ (t, $J=7.6,3 \mathrm{H}, \mathrm{HC}(12)), 0.90(\mathrm{~d}, J=7.3,3 \mathrm{H}, \mathrm{HC}(13))$

TLC: $\quad R_{f} 0.17$ (hexanes/EtOAc, 4/1) [UV (254 nm)]

\section{Vinylogous Aldol Additions of Conjugated N,O-Silyl Ketene Acetals}

Preparation of (+)-(2E,5S)-5-Hydroxy-5-phenyl-2-pentenoic Acid Dimethylamide (46) (Table 6, entry 1)

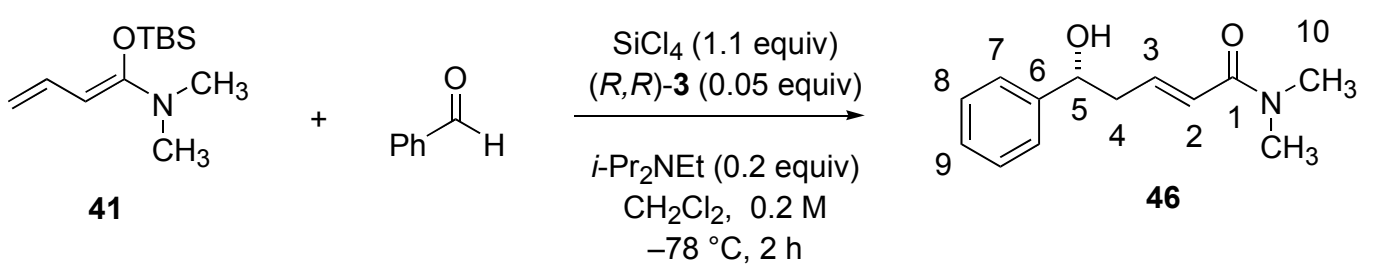

Diisopropylethylamine ( $9 \mu \mathrm{L}, 0.05 \mathrm{mmol}, 0.2$ equiv) was added via syringe to a flamedried, 5-mL, Schlenk flask under Ar containing a solution of $11 \mathrm{mg}$ (0.0125 mmol, 0.05 equiv) of bisphosphoramide $(R, R)-3$ in $\mathrm{CH}_{2} \mathrm{Cl}_{2}(1.25 \mathrm{~mL})$. To this solution was added $25 \mu \mathrm{L}(0.25$ mmol) of benzaldehyde in one portion. The reaction mixture was cooled to $-78{ }^{\circ} \mathrm{C}$ (bath temperature) in a dry ice/isopropanol bath over $15 \mathrm{~min}$ and then $32 \mu \mathrm{L}(0.275 \mathrm{mmol}, 1.1$ equiv) 
of $\mathrm{SiCl}_{4}$ was added in one portion. Then $68 \mathrm{mg}(0.3 \mathrm{mmol}, 1.2$ equiv) of 41 was added dropwise over $2 \mathrm{~min}$ via syringe to the reaction mixture. The resulting mixture was stirred at $-78{ }^{\circ} \mathrm{C}$ for 2 $\mathrm{h}$ in a dry ice/isopropanol bath whereupon $3.0 \mathrm{~mL}$ of chilled $\mathrm{CH}_{2} \mathrm{Cl}_{2}$ was added before the cold reaction mixture was poured into a rapidly stirring solution of $1 / 1$ sat. aq. $\mathrm{NaHCO}_{3} /$ sat. aq. $\mathrm{KF}$ $(25 \mathrm{~mL})$ at $0{ }^{\circ} \mathrm{C}$. This biphasic mixture was stirred vigorously for $2 \mathrm{~h}$ after which the organic layer was removed and aqueous layer was washed with $\mathrm{CH}_{2} \mathrm{Cl}_{2}(3 \times 30 \mathrm{~mL})$. The combined organic extracts were dried over $\mathrm{Na}_{2} \mathrm{SO}_{4}(3 \mathrm{~g})$, filtered and the filtrate was concentrated in vacuo. The ratio of $\gamma / \alpha$-addition products was determined to be $95 / 5$ by ${ }^{1} \mathrm{H}$ NMR (500 MHz) analysis of the crude reaction mixture. The residue was purified by column chromatography $\left(\mathrm{SiO}_{2}(15 \mathrm{~g}), 2\right.$ cm diam., EtOAc to yield $45 \mathrm{mg}(82 \%)$ of $(+)-46$ as a white solid.

Data for $(+)-\gamma-46$ :

mp: $\quad 86-87^{\circ} \mathrm{C}$

${ }^{1} \mathrm{H}$ NMR: $\quad\left(500 \mathrm{MHz}, \mathrm{CDCl}_{3}\right)$

7.37-7.26 (m, 5 H, HC(7,8,9)), 6.84 (dt, $J=15.1,7.6,1 \mathrm{H}, \mathrm{HC}(3)), 6.31$ (d, $J=$ 15.1, $1 \mathrm{H}, \mathrm{HC}(2)), 4.83(\mathrm{dd}, J=7.3,5.6,1 \mathrm{H}, \mathrm{HC}(5)), 3.01-2.98$ (m, $6 \mathrm{H}$, $\left.\mathrm{H}_{3} \mathrm{C}(10)\right)$, 2.67-2.64 (m, $\left.2 \mathrm{H}, \mathrm{H}_{2} \mathrm{C}(4)\right), 2.05$ (br s, $1 \mathrm{H}, \mathrm{OH}$ )

${ }^{13} \mathrm{C} \mathrm{NMR}: \quad\left(126 \mathrm{MHz}, \mathrm{CDCl}_{3}\right)$

$166.6(\mathrm{C}(1)), 143.7(\mathrm{C}(6)), 141.6(\mathrm{C}(3)), 128.4(\mathrm{C}(8)), 127.6(\mathrm{C}(9)), 125.8(\mathrm{C}(7))$, $123.2(\mathrm{C}(2)), 73.0(\mathrm{C}(5)), 42.4(\mathrm{C}(4)), 37.3(\mathrm{C}(10)), 35.7$ (C(10))

IR: $\quad\left(\mathrm{CHCl}_{3}\right)$

$3367(w), 3061$ (w), 3029 (w), 2935 (w), 1658 (m), 1602 (m), 1493 (w), 1453 (w), 1398 (w), 1260 (w), 1148 (w), 1057 (w), 980 (w), 912 (w), 835 (w), 755 (w), 730 (w), $700(\mathrm{~m}), 626(\mathrm{w})$

MS: $\quad\left(\mathrm{CI}, \mathrm{CH}_{4}\right)$

$220\left(\mathrm{M}^{+}+\mathrm{H}, 25\right), 203$ (17), 202 (100), 113 (17), 107 (11), 72 (11)

Opt. Rot.: $\quad[\alpha]_{\mathrm{D}}^{24}+8.98(\mathrm{c}=0.86$, EtOH)

TLC: $\quad R_{f} 0.11$ (EtOAc) [UV(254 nm)]

SFC: $\quad(R)-46, t_{\mathrm{R}} 2.76 \min (76.9 \%) ;(S)-46, t_{\mathrm{R}} 3.26 \min (23.1 \%)$ (Chiralpak AD, 125 psi, $40{ }^{\circ} \mathrm{C}, 15.0 \% \mathrm{MeOH}$ in $\mathrm{CO}_{2}, 3.0 \mathrm{~mL} / \mathrm{min}, 220 \mathrm{~nm}$ )

HRMS: Calcd for $\mathrm{C}_{13} \mathrm{H}_{18} \mathrm{NO}_{2}: 220.1338$, found: 220.1337 
Preparation of (2E,5S)-5-Hydroxy-5-phenyl-2-pentenoic Acid Diethylamide (47) (Table 6, entry 2)<smiles>C=C/C=C(\O[Sb])N(CC)CC</smiles>

42
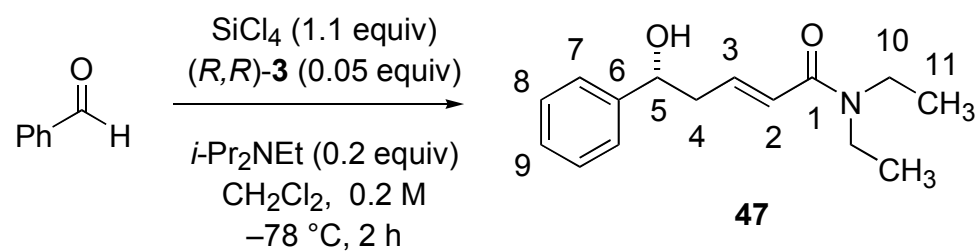

Diisopropylethylamine ( $9 \mu \mathrm{L}, 0.05 \mathrm{mmol}, 0.2$ equiv) was added via syringe to a flamedried, 5-mL, Schlenk flask under Ar containing a solution of $11 \mathrm{mg}$ ( $0.0125 \mathrm{mmol}, 0.05$ equiv) of bisphosphoramide $(R, R)-3$ in $\mathrm{CH}_{2} \mathrm{Cl}_{2}(1.25 \mathrm{~mL})$. To this solution was added $25 \mu \mathrm{L}(0.25$ mmol) of benzaldehyde in one portion. The reaction mixture was cooled to $-78{ }^{\circ} \mathrm{C}$ (bath temperature) in a dry ice/isopropanol bath over $15 \mathrm{~min}$ and then $32 \mu \mathrm{L}(0.275 \mathrm{mmol}, 1.1$ equiv) of $\mathrm{SiCl}_{4}$ was added in one portion. Then $77 \mathrm{mg}(0.3 \mathrm{mmol}, 1.2$ equiv) of $\mathbf{4 2}$ was added dropwise over 2 min via syringe to the reaction mixture. The resulting mixture was stirred at $-78{ }^{\circ} \mathrm{C}$ for 2 $\mathrm{h}$ in a dry ice/isopropanol bath whereupon $3.0 \mathrm{~mL}$ of chilled $\mathrm{CH}_{2} \mathrm{Cl}_{2}$ was added before the cold reaction mixture was poured into a rapidly stirring solution of $1 / 1$ sat. aq. $\mathrm{NaHCO}_{3} /$ sat. aq. $\mathrm{KF}$ $(25 \mathrm{~mL})$ at $0{ }^{\circ} \mathrm{C}$. This biphasic mixture was stirred vigorously for $2 \mathrm{~h}$ after which the organic layer was removed and aqueous layer was washed with $\mathrm{CH}_{2} \mathrm{Cl}_{2}(3 \times 30 \mathrm{~mL})$. The combined organic extracts were dried over $\mathrm{Na}_{2} \mathrm{SO}_{4}(3 \mathrm{~g})$, filtered and the filtrate was concentrated in vacuo. The ratio of $\gamma / \alpha$-addition products was determined to be $98 / 2$ by ${ }^{1} \mathrm{H}$ NMR (500 MHz) analysis of the crude reaction mixture. The residue was purified by column chromatography $\left(15 \mathrm{~g} \mathrm{SiO}_{2}, 2\right.$ cm diam., 3/1 hexanes/EtOAc) to yield $61 \mathrm{mg}$ (98\%) of 47 as a clear, colorless oil.

Data for $\gamma-47$ :

${ }^{1}$ H NMR: $\quad\left(500 \mathrm{MHz}, \mathrm{CDCl}_{3}\right)$

7.38-7.26 (m, $5 \mathrm{H}, \mathrm{HC}(7,8,9)), 6.88(\mathrm{dt}, J=15.1,7.4,1 \mathrm{H}, \mathrm{HC}(3)), 6.26(\mathrm{~d}, J=$ 14.9, $1 \mathrm{H}, \mathrm{HC}(2)), 4.84(\mathrm{dd}, J=7.0,5.6,1 \mathrm{H}, \mathrm{HC}(5)), 3.48-3.27$ (m, $4 \mathrm{H}$, $\mathrm{H}_{2} \mathrm{C}(10)$ ), 2.70-2.63 (m, $\left.2 \mathrm{H}, \mathrm{H}_{2} \mathrm{C}(4)\right), 2.03$ (br s, $\left.1 \mathrm{H}, \mathrm{OH}\right), 1.15-1.11$ (m, $6 \mathrm{H}$, $\left.\mathrm{H}_{3} \mathrm{C}(11)\right)$

${ }^{13} \mathrm{C} \mathrm{NMR}: \quad\left(126 \mathrm{MHz}, \mathrm{CDCl}_{3}\right)$

166.1 (C(1)), 143.9 (C(3)), 142.0 (C(6)), 128.7 (C(8)), 127.8 (C(9)), 126.1 (C(7)), 123.7 (C(2)), 73.2 (C(5)), 42.8 (C(4)), 42.5 (C(10)), 41.1 (C(10)), 15.0 (C(11)), 


\section{$13.3(\mathrm{C}(11))$}

IR: (neat)

3377 (m), 3062 (m), 3030 (m), 2978 (m), 2935 (m), 1954 (w), 1714 (m), 1694

(m), 1682 (m), 1660 (m), 1652 (m), 1645 (m), 1634 (m), 1621 (m), 1600 (m), 1547 (m), 1557 (m), 1538 (m), 1514 (w), 1486 (m), 1463 (m), 1455 (m), 1435

(m), 1382 (m), 1361 (m), 1265 (m), 1218 (m), 1175 (m), 1145 (m), 1073 (m), 1053 (m), 1027 (m), 974 (m), 915 (m), 843 (m), 757 (m), 701 (m), $651(\mathrm{~m}), 620$ (m)

MS: $\quad\left(\mathrm{CI}, \mathrm{CH}_{4}\right)$ $248\left(\mathrm{M}^{+}+\mathrm{H}, 52\right), 231$ (17), 230 (100), 141 (20), 123 (29), 107 (10), 100 (11)

TLC: $\quad R_{f} 0.25(\mathrm{EtOAc})[\mathrm{UV}(254 \mathrm{~nm})]$

SFC: $\quad(R)-47, t_{\mathrm{R}} 3.19 \min (66.2 \%) ;(S)-47, t_{\mathrm{R}} 3.53 \min (33.8 \%)$ (Chiralpak AD, 125 psi, $40{ }^{\circ} \mathrm{C}, 11.0 \% \mathrm{MeOH}$ in $\mathrm{CO}_{2}, 3.0 \mathrm{~mL} / \mathrm{min}, 220 \mathrm{~nm}$ )

HRMS: Calcd for $\mathrm{C}_{15} \mathrm{H}_{22} \mathrm{NO}_{2}$ : 248.1651, found: 248.1653

Preparation of 1-[(5S,2E)-1-Oxo-5-phenyl-5-hydroxy-2-pentenyl]pyrrolidine (48) (Table 6, entry 3)
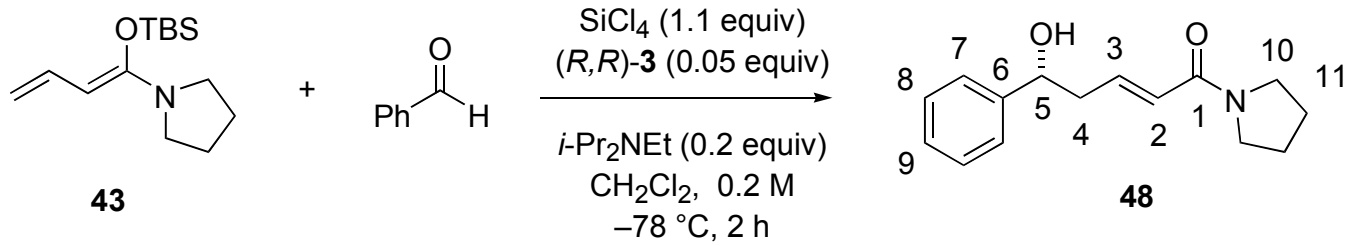

Diisopropylethylamine (18 $\mu \mathrm{L}, 0.1 \mathrm{mmol}, 0.2$ equiv) was added via syringe to a flamedried, 5-mL, Schlenk flask under Ar containing a solution of $21 \mathrm{mg}$ (0.025 mmol, 0.05 equiv) of bisphosphoramide $(R, R)-3$ in $\mathrm{CH}_{2} \mathrm{Cl}_{2}(2.5 \mathrm{~mL})$. To this solution was added $51 \mu \mathrm{L}(0.5 \mathrm{mmol})$ of benzaldehyde in one portion. The reaction mixture was cooled to $-78{ }^{\circ} \mathrm{C}$ (bath temperature) in a dry ice/isopropanol bath over $15 \mathrm{~min}$ and then $64 \mu \mathrm{L}\left(0.55 \mathrm{mmol}, 1.1\right.$ equiv) of $\mathrm{SiCl}_{4}$ was added in one portion. Then $152 \mathrm{mg}$ ( $0.6 \mathrm{mmol}, 1.2$ equiv) of $\mathbf{4 3}$ was added dropwise over 2 min via syringe to the reaction mixture. The resulting mixture was stirred at $-78{ }^{\circ} \mathrm{C}$ for $2 \mathrm{~h}$ in a dry ice/isopropanol bath whereupon $3.0 \mathrm{~mL}$ of chilled $\mathrm{CH}_{2} \mathrm{Cl}_{2}$ was added before the cold reaction mixture was poured into a rapidly stirring solution of $1 / 1$ sat. aq. $\mathrm{NaHCO}_{3} /$ sat. aq. $\mathrm{KF}(25 \mathrm{~mL})$ at $0{ }^{\circ} \mathrm{C}$. This biphasic mixture was stirred vigorously for $2 \mathrm{~h}$ after which the organic layer was 
removed and aqueous layer was washed with $\mathrm{CH}_{2} \mathrm{Cl}_{2}(3 \times 30 \mathrm{~mL})$. The combined organic extracts were dried over $\mathrm{Na}_{2} \mathrm{SO}_{4}(3 \mathrm{~g})$, filtered and the filtrate was concentrated in vacuo. The ratio of $\gamma / \alpha$-addition products was determined to be $80 / 20$ by ${ }^{1} \mathrm{H}$ NMR (500 MHz) analysis of the crude reaction mixture. The residue was purified by column chromatography $\left(15 \mathrm{~g} \mathrm{SiO}_{2}, 2 \mathrm{~cm}\right.$ diam., 19/1 EtOAc/MeOH) to yield $68 \mathrm{mg}(56 \%)$ of 48 as a white solid.

Data for 48:

mp: $\quad 98-99^{\circ} \mathrm{C}$

${ }^{1}$ H NMR: $\quad\left(500 \mathrm{MHz}, \mathrm{CDCl}_{3}\right)$

7.38-7.33 (m, 4 H, HC(7,8)), 7.29-7.26 (m, 1 H, HC(9)), 6.90 (dt, J=15.1, 7.6, 1 $\mathrm{H}, \mathrm{HC}(3)), 6.18$ (d, $J=15.1,1 \mathrm{H}, \mathrm{HC}(2)), 4.83$ (dd, $J=7.0,5.9,1 \mathrm{H}, \mathrm{HC}(5))$, 3.51-3.42 (m, $\left.4 \mathrm{H}, \mathrm{H}_{2} \mathrm{C}(10)\right)$, 2.66-2.63 (m, $\left.2 \mathrm{H}, \mathrm{H}_{2} \mathrm{C}(4)\right)$ ), 1.96-1.82 (m, $6 \mathrm{H}$, $\left.\mathrm{H}_{2} \mathrm{C}(11)\right)$

${ }^{13} \mathrm{C} \mathrm{NMR}: \quad\left(126 \mathrm{MHz}, \mathrm{CDCl}_{3}\right)$

164.7 (C(1)), 143.9 (C(6)), 141.5 (C(3)), 128.3 (C(8)), $127.4(\mathrm{C}(9)), 125.8$ (C(7)), 124.3 (C(2)), 72.8 (C(5)), 46.5 (C(10)), 45.8 (C(10)), 42.4 (C(4)), 26.0 (C(11)), $24.2(\mathrm{C}(11))$

IR: $\quad\left(\mathrm{CHCl}_{3}\right)$

3367 (m), 3086 (w), 3062 (w), 3030 (w), 2975 (m), 2953 (m), 2877 (m), 2238 (w), 1660 (s), 1601 (s), 1493 (m), 1446 (s), 1341 (m), 1306 (m), 1254 (m), 1228 (m), 1193 (m), 1173 (m), 1115 (w), 1042 (m), 974 (m), 911 (s), 862 (m), 843 (w), $814(\mathrm{w}), 731(\mathrm{~s}), 701(\mathrm{~s}), 645(\mathrm{~s})$

MS: $\quad\left(\mathrm{CI}, \mathrm{CH}_{4}\right)$

$246\left(\mathrm{M}^{+}+\mathrm{H}, 33\right), 229$ (11), 228 (58), 141 (10), 140 (100), 139 (17), 107 (35), 98 (24), 79 (11), 57 (14), 55 (13)

TLC: $\quad R_{f} 0.15(\mathrm{EtOAc})[\mathrm{UV}(254 \mathrm{~nm})]$

SFC: $\quad(R)-48, t_{\mathrm{R}} 2.93 \min (56.5 \%) ;(S)-48, t_{\mathrm{R}} 3.97 \min (43.5 \%)$ (Chiralpak AD, 125 psi, $40{ }^{\circ} \mathrm{C}, 20.0 \% \mathrm{MeOH}$ in $\mathrm{CO}_{2}, 3.0 \mathrm{~mL} / \mathrm{min}, 220 \mathrm{~nm}$ )

HRMS: $\quad$ Calcd for $\mathrm{C}_{15} \mathrm{H}_{20} \mathrm{NO}_{2}$ : 246.1494, found: 246.1497 


\section{Preparation of (+)-1-[(5S,2E)-1-Oxo-5-phenyl-5-hydroxy-2-pentenyl]piperidine (49) (Table} 6, entry 4)
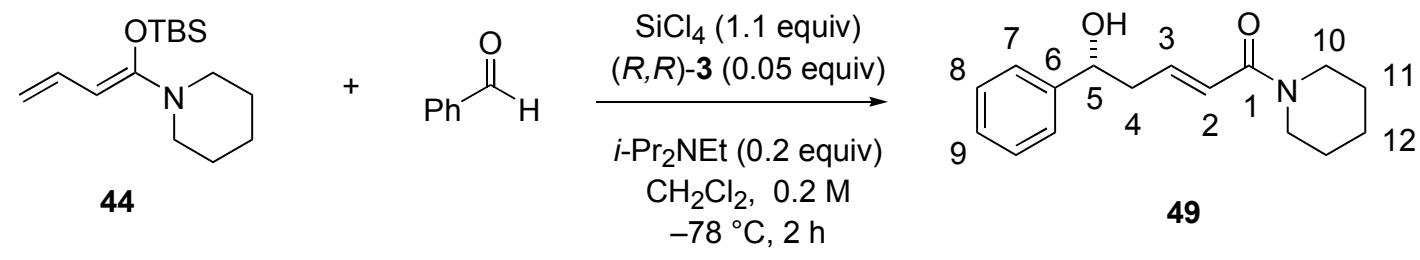

Diisopropylethylamine ( $18 \mu \mathrm{L}, 0.1 \mathrm{mmol}, 0.2$ equiv) was added via syringe to a flamedried, 5-mL, Schlenk flask under Ar containing a solution of $21 \mathrm{mg}$ (0.025 mmol, 0.05 equiv) of bisphosphoramide $(R, R)-3$ in $\mathrm{CH}_{2} \mathrm{Cl}_{2}(2.5 \mathrm{~mL})$. To this solution was added $51 \mu \mathrm{L}(0.5 \mathrm{mmol})$ of benzaldehyde in one portion. The reaction mixture was cooled to $-78{ }^{\circ} \mathrm{C}$ (bath temperature) in a dry ice/isopropanol bath over $15 \mathrm{~min}$ and then $64 \mu \mathrm{L}(0.55 \mathrm{mmol}, 1.1$ equiv $)$ of $\mathrm{SiCl}_{4}$ was added in one portion. Then $160 \mathrm{mg}$ ( $0.6 \mathrm{mmol}, 1.2$ equiv) of 44 was added dropwise over 2 min via syringe to the reaction mixture. The resulting mixture was stirred at $-78{ }^{\circ} \mathrm{C}$ for $2 \mathrm{~h}$ in a dry ice/isopropanol bath whereupon $3.0 \mathrm{~mL}$ of chilled $\mathrm{CH}_{2} \mathrm{Cl}_{2}$ was added before the cold reaction mixture was poured into a rapidly stirring solution of $1 / 1$ sat. aq. $\mathrm{NaHCO}_{3} /$ sat. aq. $\mathrm{KF}(25 \mathrm{~mL})$ at $0{ }^{\circ} \mathrm{C}$. This biphasic mixture was stirred vigorously for $2 \mathrm{~h}$ after which the organic layer was removed and aqueous layer was washed with $\mathrm{CH}_{2} \mathrm{Cl}_{2}(3 \times 30 \mathrm{~mL})$. The combined organic extracts were dried over $\mathrm{Na}_{2} \mathrm{SO}_{4}(3 \mathrm{~g})$, filtered and the filtrate was concentrated in vacuo. The ratio of $\gamma / \alpha$-addition products was determined to be $95 / 5$ by ${ }^{1} \mathrm{H}$ NMR (500 MHz) analysis of the crude reaction mixture. The residue was purified by column chromatography $\left(15 \mathrm{~g} \mathrm{SiO}_{2}, 2 \mathrm{~cm}\right.$ diam., EtOAc) to yield $126 \mathrm{mg}(98 \%)$ of $(+)-\gamma-49$ as a white solid.

Data for $(+)-49$ :

mp: $\quad 89-90{ }^{\circ} \mathrm{C}$

${ }^{1}$ H NMR: $\quad\left(500 \mathrm{MHz}, \mathrm{CDCl}_{3}\right)$

7.38-7.33 (m, 4 H, HC(7,8)), 7.29-7.27 (m, 1 H, HC(9)), 6.90 (dt, J= 15.1, 7.4, 1 $\mathrm{H}, \mathrm{HC}(3)), 6.18$ (dt, $J=15.1,1.2,1 \mathrm{H}, \mathrm{HC}(2)), 4.83$ (dd, $J=7.3,5.6,1 \mathrm{H}$, $\mathrm{HC}(5))$, 3.57-3.40 (m, 4 H, $\left.\mathrm{H}_{2} \mathrm{C}(10)\right)$ ), 2.69-2.61 (m, 2 H, $\left.\mathrm{H}_{2} \mathrm{C}(4)\right)$ ), 1.98 (br s, $1 \mathrm{H}$, $\mathrm{OH}), 1.66-1.62$ (m, $\left.2 \mathrm{H}, \mathrm{H}_{2} \mathrm{C}(12)\right), 1.54$ (br s, $4 \mathrm{H}, \mathrm{H}_{2} \mathrm{C}(11)$ )

${ }^{13} \mathrm{C} \mathrm{NMR}: \quad\left(126 \mathrm{MHz}, \mathrm{CDCl}_{3}\right)$

165.4 (C(1)), 143.9 (C(6)), 141.2 (C(3)), 128.2 (C(8)), 127.3 (C(9)), 125.8 (C(7)), 123.4 (C(2)), 72.8 (C(5)), 46.8 (C(10)), 42.9 (C(10)), 42.5 (C(4)), 26.4 (C(11)), 
$25.4(\mathrm{C}(11)), 24.4(\mathrm{C} 12))$

IR: $\quad\left(\mathrm{CHCl}_{3}\right)$

3370 (m), 3085 (w), 3062 (w), 3029 (w), 3006 (w), 2939 (s), 2857 (m), 2239 (w), 1656 (s), 1598 (s), 1493 (m), 1444 (s), 1366 (m), 1353 (m), 1254 (s), 1225 (m), 1176 (w), 1140 (m), 1125 (w), 1090 (w), 1053 (m), 1024 (m), 973 (m), 912 (m), $883(\mathrm{~m}), 808(\mathrm{w}), 731(\mathrm{~s}), 701(\mathrm{~s}), 668(\mathrm{~m}), 645(\mathrm{~m})$

MS: $\quad\left(\mathrm{CI}, \mathrm{CH}_{4}\right)$

261 (10), 260 (M+H, 55), 244 (11), 243 (18), 242 (100), 154 (61), 153 (22), 138

(11), 112 (24), 107 (48), 79 (14), 59 (15), 57 (17), 55 (14)

Opt. Rot.: $[\alpha]_{\mathrm{D}}^{24}+8.55(\mathrm{c}=0.83$, EtOH $)$

TLC: $\quad R_{f} 0.27(\mathrm{EtOAc})[\mathrm{UV}(254 \mathrm{~nm})]$

SFC: $\quad(R)-49, t_{\mathrm{R}} 3.57 \min (87.0 \%) ;(S)-49, t_{\mathrm{R}} 4.17 \mathrm{~min}(13.0 \%)$ (Chiralpak AD, $125 \mathrm{psi}$, $40{ }^{\circ} \mathrm{C}, 15.0 \% \mathrm{MeOH}$ in $\mathrm{CO}_{2}, 3.0 \mathrm{~mL} / \mathrm{min}, 220 \mathrm{~nm}$ )

HRMS: Calcd for $\mathrm{C}_{16} \mathrm{H}_{22} \mathrm{NO}_{2}: 260.1651$, found: 260.1655

Preparation of 1-[(5S,2E)-1-Oxo-5-phenyl-5-hydroxy-2-pentenyl]morpholine (50) (Table 6, entry 5)

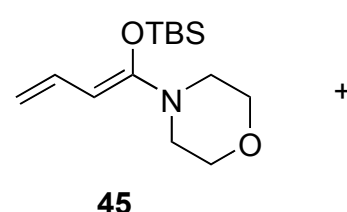

45<smiles>O=Cc1ccccc1</smiles>

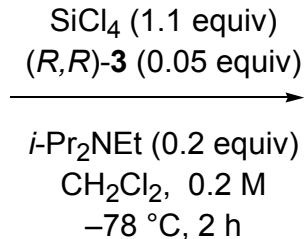

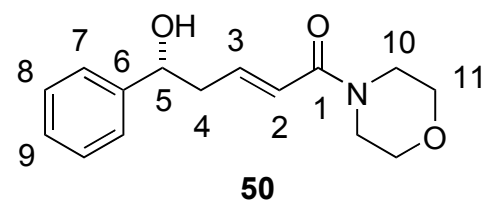

Diisopropylethylamine (18 $\mu \mathrm{L}, 0.1 \mathrm{mmol}, 0.2$ equiv) was added via syringe to a flamedried, 5-mL, Schlenk flask under Ar containing a solution of $21 \mathrm{mg}$ (0.025 mmol, 0.05 equiv) of bisphosphoramide $(R, R)-3$ in $\mathrm{CH}_{2} \mathrm{Cl}_{2}(2.5 \mathrm{~mL})$. To this solution was added $51 \mu \mathrm{L}(0.5 \mathrm{mmol})$ of benzaldehyde in one portion. The reaction mixture was cooled to $-78{ }^{\circ} \mathrm{C}$ (bath temperature) in a dry ice/isopropanol bath over $15 \mathrm{~min}$ and then $64 \mu \mathrm{L}\left(0.55 \mathrm{mmol}, 1.1\right.$ equiv) of $\mathrm{SiCl}_{4}$ was added in one portion. Then $162 \mathrm{mg}$ ( $0.6 \mathrm{mmol}, 1.2$ equiv) of 45 was added dropwise over 2 min via syringe to the reaction mixture. The resulting mixture was stirred at $-78{ }^{\circ} \mathrm{C}$ for $2 \mathrm{~h}$ in a dry ice/isopropanol bath whereupon $3.0 \mathrm{~mL}$ of chilled $\mathrm{CH}_{2} \mathrm{Cl}_{2}$ was added before the cold reaction mixture was poured into a rapidly stirring solution of $1 / 1$ sat. aq. $\mathrm{NaHCO}_{3} /$ sat. aq. $\mathrm{KF}(25 \mathrm{~mL})$ at $0{ }^{\circ} \mathrm{C}$. This biphasic mixture was stirred vigorously for $2 \mathrm{~h}$ after which the organic layer was 
removed and aqueous layer was washed with $\mathrm{CH}_{2} \mathrm{Cl}_{2}(3 \times 30 \mathrm{~mL})$. The combined organic extracts were dried over $\mathrm{Na}_{2} \mathrm{SO}_{4}(3 \mathrm{~g})$, filtered and the filtrate was concentrated in vacuo. The ratio of $\gamma / \alpha$-addition products was determined to be $>99 / 1$ by ${ }^{1} \mathrm{H}$ NMR $(500 \mathrm{MHz}$ ) analysis of the crude reaction mixture. The residue was purified by column chromatography $\left(15 \mathrm{~g} \mathrm{SiO}_{2}, 2 \mathrm{~cm}\right.$ diam., EtOAc) to yield $90 \mathrm{mg}(69 \%)$ of $\mathbf{5 0}$ as a white solid.

Data for 50:

${ }^{1}$ H NMR: $\quad\left(500 \mathrm{MHz}, \mathrm{CDCl}_{3}\right)$

7.38-7.33 (m, 4 H, HC(7,8)), 7.29-7.27 (m, 1 H, HC(9)), 6.90 (dt, J=15.1, 7.4, 1 $\mathrm{H}, \mathrm{HC}(3)), 6.18(\mathrm{dt}, J=15.1,1.2,1 \mathrm{H}, \mathrm{HC}(2)), 4.83$ (dd, $J=7.3,5.6,1 \mathrm{H}$, $\mathrm{HC}(5)$ ), 3.57-3.40 (m, 4 H, $\mathrm{H}_{2} \mathrm{C}(10)$ ), 2.69-2.61 (m, 2 H, $\mathrm{H}_{2} \mathrm{C}(4)$ ), 1.98 (br s, $1 \mathrm{H}$, $\mathrm{OH}), 1.66-1.62$ (m, $\left.2 \mathrm{H}, \mathrm{H}_{2} \mathrm{C}(12)\right), 1.54$ (br s, $\left.4 \mathrm{H}, \mathrm{H}_{2} \mathrm{C}(11)\right)$

TLC: $\quad R_{f} 0.17(\mathrm{EtOAc})[\mathrm{UV}(254 \mathrm{~nm})]$

SFC: $\quad(R)-50, t_{\mathrm{R}} 3.38 \min (95.0 \%)$; $(S)-50, t_{\mathrm{R}} 4.05 \min (5.0 \%)$ (Chiralpak OB, 125 psi, $40{ }^{\circ} \mathrm{C}, 10.0 \% \mathrm{MeOH}$ in $\mathrm{CO}_{2}, 3.0 \mathrm{~mL} / \mathrm{min}, 220 \mathrm{~nm}$ )

\section{Preparation of 4-[(5R,2E)-1-Oxo-7-phenyl-5-hydroxy-2,6-heptadienyl]morpholine} (Table 7, entry 1)

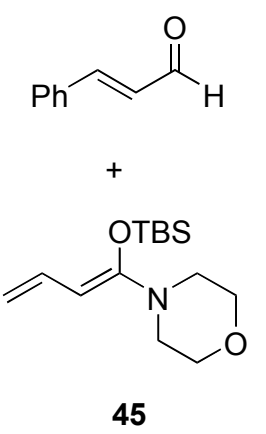

45
$\mathrm{SiCl}_{4}$ (1.1 equiv) $(R, R)-3$ (0.05 equiv)

$i-\mathrm{Pr}_{2} \mathrm{NEt}(0.2$ equiv)

$\mathrm{CH}_{2} \mathrm{Cl}_{2}, 0.2 \mathrm{M}$

$-78^{\circ} \mathrm{C}, 2 \mathrm{~h}$

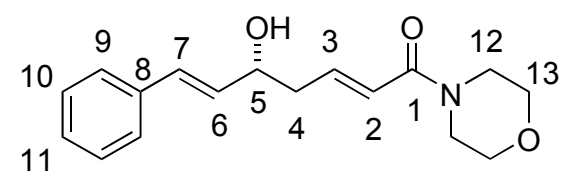

$\gamma-1,2-51$

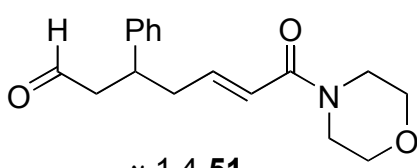

$\gamma-1,4-51$<smiles>[R5][Te]/C=C/C(O)C(C=C)C(=O)N1CCOCC1</smiles>

$\alpha-1,2-51$<smiles>C=CC(C(=O)N1CCOCC1)C(CC=O)c1ccccc1</smiles>

Diisopropylethylamine (18 $\mu \mathrm{L}, 0.1 \mathrm{mmol}, 0.2$ equiv) was added via syringe to a flamedried, 20-mL, Schlenk flask under Ar containing a solution of $21 \mathrm{mg}$ ( $0.025 \mathrm{mmol}, 0.05$ equiv) of bisphosphoramide $(R, R)-3$ in $\mathrm{CH}_{2} \mathrm{Cl}_{2}(2.5 \mathrm{~mL})$. To this solution was added $63 \mu \mathrm{L}(0.5 \mathrm{mmol}$, 1.0 equiv) of cinnamaldehyde in one portion and the reaction mixture was cooled to $-78{ }^{\circ} \mathrm{C}$ over $15 \mathrm{~min}$. To the resulting solution was added $63 \mu \mathrm{L}\left(0.55 \mathrm{mmol}, 1.1\right.$ equiv) of $\mathrm{SiCl}_{4}$ in one portion. Then, $162 \mathrm{mg}$ ( $0.6 \mathrm{mmol}, 1.2$ equiv) of 45 was added dropwise over 2 min via syringe. 
The resulting mixture was stirred at $-72{ }^{\circ} \mathrm{C}$ for $2 \mathrm{~h}$ whereupon $3.0 \mathrm{~mL}$ of chilled $\mathrm{CH}_{2} \mathrm{Cl}_{2}$ was added before the cold reaction mixture was poured into a rapidly stirring solution of $1 / 1$ sat. aq. $\mathrm{NaHCO}_{3} / \mathrm{sat}$. aq. $\mathrm{KF}(25 \mathrm{~mL})$ at $0{ }^{\circ} \mathrm{C}$. This biphasic mixture was stirred vigorously for $3 \mathrm{~h}$ after which the organic layer was removed and the aqueous layer was washed with $\mathrm{CH}_{2} \mathrm{Cl}_{2}(3 \times 30$ $\mathrm{mL})$. The combined organic extracts were dried over $\mathrm{Na}_{2} \mathrm{SO}_{4}(5 \mathrm{~g})$, filtered and the filtrate was concentrated in vacuo. The ratio of $\gamma-1,2-51 / \alpha-1,2-51 / \gamma-1,4-51 / \alpha-1,4-51$ was determined to be 97/0/1/2 by ${ }^{1} \mathrm{H}$ NMR (500 MHz) analysis of the crude reaction mixture. The residue was purified by column chromatography $\left(\mathrm{SiO}_{2}(12 \mathrm{~g}), 2 \mathrm{~cm}\right.$ diam., EtOAc $(100 \mathrm{~mL})$ to EtOAc/MeOH, 19/1 (100 mL)) to yield $131 \mathrm{mg}(91 \%)$ of $\gamma-1,2-51$ as a white solid.

Data for $\gamma-1,2-51$ :

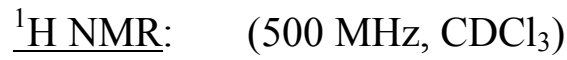

7.37 (dd, $J=8.2,1.1,2 \mathrm{H}, \mathrm{HC}(9)), 7.32$ (dt, $J=7.6,1.7,2 \mathrm{H}, \mathrm{HC}(10)) 7.25$ (tt, $J$ $=7.3,1.3,1 \mathrm{H}, \mathrm{HC}(11)), 6.91(\mathrm{dt}, J=15.1,7.3,1 \mathrm{H}, \mathrm{HC}(3)), 6.61(\mathrm{~d}, J=15.9,1$ $\mathrm{H}, \mathrm{HC}(7)), 6.32(\mathrm{dt}, J=15.1,1.4,1 \mathrm{H}, \mathrm{HC}(2)), 6.24(\mathrm{dd}, J=15.9,6.3,1 \mathrm{H}$, $\mathrm{HC}(6)), 4.47$ (dq, $J=6.6,1.2,1 \mathrm{H}, \mathrm{HC}(5)), 3.65$ (m, 8 H, $\left.\mathrm{H}_{2} \mathrm{C}(12,13)\right), 2.58-2.54$ (m, $\left.2 \mathrm{H}, \mathrm{H}_{2} \mathrm{C}(4)\right), 2.08$ (br s, $1 \mathrm{H}, \mathrm{OH}$ )

TLC: $\quad R_{f} 0.14(\mathrm{EtOAc})[\mathrm{UV}(254 \mathrm{~nm})]$

SFC: $\quad(R)-\gamma-1,2-51, t_{\mathrm{R}} 2.38 \mathrm{~min}(92.6 \%) ;(S)-\gamma-1,2-51, t_{\mathrm{R}} 4.14 \mathrm{~min}(7.4 \%)$ (Chiralpak $\mathrm{OB}, 125 \mathrm{psi}, 40{ }^{\circ} \mathrm{C}, 20.0 \% \mathrm{MeOH}$ in $\left.\mathrm{CO}_{2}, 3.0 \mathrm{~mL} / \mathrm{min}, 220 \mathrm{~nm}\right)$

\section{Preparation of 4-[(5R,2E)-1-Oxo-7-phenyl-5-hydroxy-2,6-heptadienyl]morpholine}

(Table 7, entry 2)

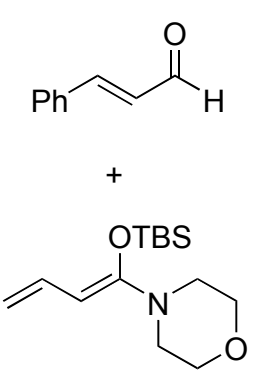

45
$\mathrm{SiCl}_{4}$ (1.1 equiv) ( $R, R)$-3 (0.02 equiv) i- $\mathrm{Pr}_{2} \mathrm{NEt}(0.2$ equiv) $\mathrm{CH}_{2} \mathrm{Cl}_{2}, 0.2 \mathrm{M}$ $-78^{\circ} \mathrm{C}, 2 \mathrm{~h}$

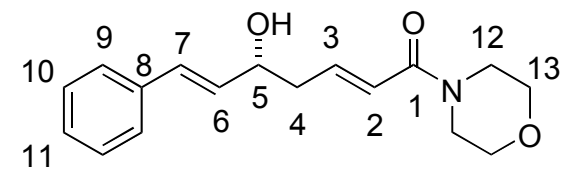

$\gamma-1,2-51$

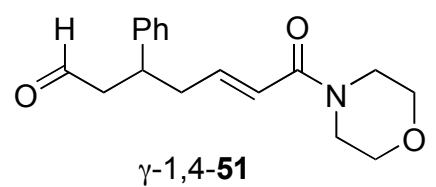<smiles>C=CC(C(=O)N1CCOCC1)C(O)/C=C/c1ccccc1</smiles>

$\alpha-1,2-51$

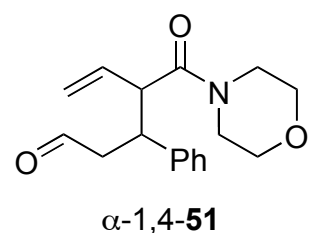

Diisopropylethylamine ( $18 \mu \mathrm{L}, 0.1 \mathrm{mmol}, 0.2$ equiv) was added via syringe to a flame- 
dried, 20-mL, Schlenk flask under Ar containing a solution of $8 \mathrm{mg}$ (0.01 mmol, 0.02 equiv) of bisphosphoramide $(R, R)-3$ in $\mathrm{CH}_{2} \mathrm{Cl}_{2}(2.5 \mathrm{~mL})$. To this solution was added $63 \mu \mathrm{L}(0.5 \mathrm{mmol}, 1.0$ equiv) of cinnamaldehyde in one portion and the reaction mixture was cooled to $-78{ }^{\circ} \mathrm{C}$ (bath temperature) over $15 \mathrm{~min}$. To the resulting solution was added $63 \mu \mathrm{L}$ (0.55 mmol, 1.1 equiv) of $\mathrm{SiCl}_{4}$ in one portion. Then, $162 \mathrm{mg}(0.6 \mathrm{mmol}, 1.2$ equiv) of 45 was added dropwise over $2 \mathrm{~min}$ via syringe. The resulting mixture was stirred at $-72{ }^{\circ} \mathrm{C}$ for $2 \mathrm{~h}$ whereupon $3.0 \mathrm{~mL}$ of chilled $\mathrm{CH}_{2} \mathrm{Cl}_{2}$ was added before the cold reaction mixture was poured into a rapidly stirring solution of $1 / 1$ sat. aq. $\mathrm{NaHCO}_{3} /$ sat. aq. $\mathrm{KF}(25 \mathrm{~mL})$ at $0{ }^{\circ} \mathrm{C}$. This biphasic mixture was stirred vigorously for $3 \mathrm{~h}$ after which the organic layer was removed and the aqueous layer was washed with $\mathrm{CH}_{2} \mathrm{Cl}_{2}(3 \times 30 \mathrm{~mL})$. The combined organic extracts were dried over $\mathrm{Na}_{2} \mathrm{SO}_{4}(5 \mathrm{~g})$, filtered and the filtrate was concentrated in vacuo. The ratio of $\gamma-1,2-51 / \alpha-1,2-51 / \gamma-1,4-51 / \alpha-1,4-51$ was determined to be $97 / 0 / 1 / 2$ by ${ }^{1} \mathrm{H}$ NMR (500 MHz) analysis of the crude reaction mixture. The residue was purified by column chromatography $\left(\mathrm{SiO}_{2}(12 \mathrm{~g}), 2 \mathrm{~cm}\right.$ diam., EtOAc $(100 \mathrm{~mL})$ to EtOAc/MeOH, 19/1 (100 mL)) to yield $140 \mathrm{mg}(97 \%)$ of $\gamma-1,2-51$ as a white solid.

Data for $\gamma-1,2-51$ :

${ }^{1}$ H NMR: $\quad\left(500 \mathrm{MHz}, \mathrm{CDCl}_{3}\right)$

$7.38(\mathrm{dd}, J=8.2,1.2,2 \mathrm{H}, \mathrm{HC}(9)), 7.32(\mathrm{dt}, J=7.6,1.8,2 \mathrm{H}, \mathrm{HC}(10)) 7.26(\mathrm{tt}, J=$ 7.3, 1.2, $1 \mathrm{H}, \mathrm{HC}(11)), 6.91$ (dt, $J=15.1,7.3,1 \mathrm{H}, \mathrm{HC}(3)), 6.61$ (d, $J=15.9,1 \mathrm{H}$, $\mathrm{HC}(7)), 6.33$ (dt, $J=15.1,1.4,1 \mathrm{H}, \mathrm{HC}(2)), 6.24$ (dd, $J=15.9,6.3,1 \mathrm{H}, \mathrm{HC}(6))$, 4.46 (dq, $J=6.6,1.2,1 \mathrm{H}, \mathrm{HC}(5)), 3.62$ (m, 8 H, $\left.\mathrm{H}_{2} \mathrm{C}(12,13)\right)$ ) 2.59-2.54 (m, $2 \mathrm{H}$, $\left.\mathrm{H}_{2} \mathrm{C}(4)\right), 2.08$ (br s, $1 \mathrm{H}, \mathrm{OH}$ )

TLC: $\quad R_{f} 0.14(\mathrm{EtOAc})[\mathrm{UV}(254 \mathrm{~nm})]$

SFC: $\quad(R)-\gamma-1,2-51, t_{\mathrm{R}} 2.40 \min (94.7 \%) ;(S)-\gamma-1,2-51, t_{\mathrm{R}} 4.16 \mathrm{~min}(5.3 \%)$ (Chiralpak $\mathrm{OB}, 125 \mathrm{psi}, 40{ }^{\circ} \mathrm{C}, 20.0 \% \mathrm{MeOH}$ in $\mathrm{CO}_{2}, 3.0 \mathrm{~mL} / \mathrm{min}, 220 \mathrm{~nm}$ ) 


\section{Preparation of 4-[(5R,2E)-1-Oxo-7-phenyl-5-hydroxy-2,6-heptadienyl]morpholine} (Table 7, entry 3)

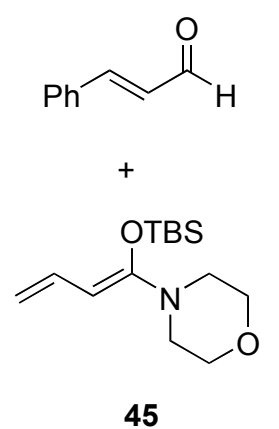

45
$\mathrm{SiCl}_{4}(1.1$ equiv) $(R, R)-3$ (0.02 equiv)

i- $\mathrm{Pr}_{2} \mathrm{NEt}(0.2$ equiv)

$\mathrm{CH}_{2} \mathrm{Cl}_{2}, 0.1 \mathrm{M}$

$-78^{\circ} \mathrm{C}, 2 \mathrm{~h}$

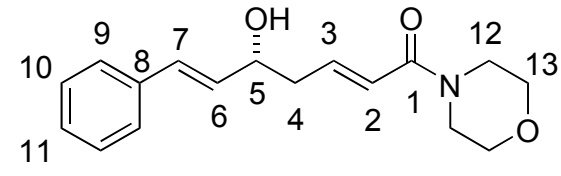

$\gamma-1,2-51$

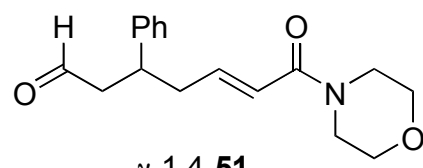

$\gamma-1,4-51$
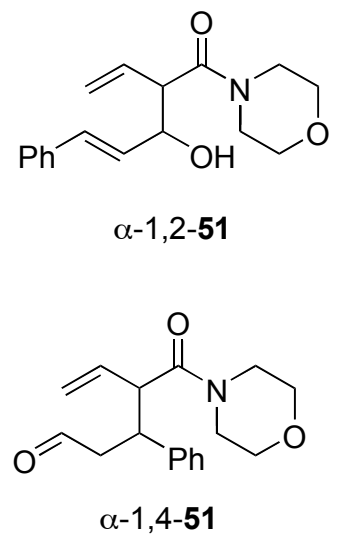

Diisopropylethylamine ( $9 \mu \mathrm{L}, 0.05 \mathrm{mmol}, 0.2$ equiv) was added via syringe to a flamedried, 20-mL, Schlenk flask under Ar containing a solution of $4 \mathrm{mg}$ (0.005 mmol, 0.02 equiv) of bisphosphoramide $(R, R)-3$ in $\mathrm{CH}_{2} \mathrm{Cl}_{2}(2.5 \mathrm{~mL})$. To this solution was added $32 \mu \mathrm{L}(0.25 \mathrm{mmol}$, 1.0 equiv) of cinnamaldehyde in one portion and the reaction mixture was cooled to $-78{ }^{\circ} \mathrm{C}$ (bath temperature) over $15 \mathrm{~min}$. To the resulting solution was added $32 \mu \mathrm{L}$ (0.275 mmol, 1.1 equiv) of $\mathrm{SiCl}_{4}$ in one portion. Then, $81 \mathrm{mg}(0.3 \mathrm{mmol}, 1.2$ equiv) of 45 was added dropwise over $2 \mathrm{~min}$ via syringe. The resulting mixture was stirred at $-78{ }^{\circ} \mathrm{C}$ for $2 \mathrm{~h}$ whereupon $3.0 \mathrm{~mL}$ of chilled $\mathrm{CH}_{2} \mathrm{Cl}_{2}$ was added before the cold reaction mixture was poured into a rapidly stirring solution of $1 / 1$ sat. aq. $\mathrm{NaHCO}_{3} /$ sat. aq. $\mathrm{KF}(25 \mathrm{~mL})$ at $0{ }^{\circ} \mathrm{C}$. This biphasic mixture was stirred vigorously for $2 \mathrm{~h}$ after which the organic layer was removed and the aqueous layer was washed with $\mathrm{CH}_{2} \mathrm{Cl}_{2}(3 \times 30 \mathrm{~mL})$. The combined organic extracts were dried over $\mathrm{Na}_{2} \mathrm{SO}_{4}(5 \mathrm{~g})$, filtered and the filtrate was concentrated in vacuo. The ratio of $\gamma-1,2-51 / \alpha-1,2-51 / \gamma-1,4-51 / \alpha-1,4-51$ was determined to be $97 / 0 / 1 / 2$ by ${ }^{1} \mathrm{H}$ NMR (500 MHz) analysis of the crude reaction mixture. The residue was purified by column chromatography $\left(\mathrm{SiO}_{2}(12 \mathrm{~g}), 2 \mathrm{~cm}\right.$ diam., EtOAc $(100 \mathrm{~mL})$ to EtOAc/MeOH, 19/1 (100 mL)) to yield $70 \mathrm{mg}(97 \%)$ of $\gamma-1,2-51$ as a white solid.

Data for $\gamma-1,2-51$ :

${ }^{1}$ H NMR: $\quad\left(500 \mathrm{MHz}, \mathrm{CDCl}_{3}\right)$

7.38 (d, $J=8.4,2 \mathrm{H}, \mathrm{HC}(9)), 7.32$ (dt, $J=7.7,1.7,2 \mathrm{H}, \mathrm{HC}(10)) 7.25$ (tt, $J=7.5$, 1.3, $1 \mathrm{H}, \mathrm{HC}(11)), 6.92(\mathrm{dt}, J=15.1,7.3,1 \mathrm{H}, \mathrm{HC}(3)), 6.61(\mathrm{~d}, J=15.9,1 \mathrm{H}$, $\mathrm{HC}(7)), 6.32$ (dt, $J=15.1,1.5,1 \mathrm{H}, \mathrm{HC}(2)), 6.24$ (dd, $J=15.9,6.3,1 \mathrm{H}, \mathrm{HC}(6))$, $4.48(\mathrm{dq}, J=6.6,1.2,1 \mathrm{H}, \mathrm{HC}(5)), 3.65$ (m, $\left.8 \mathrm{H}, \mathrm{H}_{2} \mathrm{C}(12,13)\right), 2.58-2.54$ (m, $2 \mathrm{H}$, 
$\left.\mathrm{H}_{2} \mathrm{C}(4)\right), 2.09$ (br s, $1 \mathrm{H}, \mathrm{OH}$ )

TLC: $\quad R_{f} 0.14(\mathrm{EtOAc})[\mathrm{UV}(254 \mathrm{~nm})]$

SFC: $\quad(R)-\gamma-1,2-51, t_{\mathrm{R}} 2.40 \min (95.6 \%) ;(S)-\gamma-1,2-51, t_{\mathrm{R}} 4.15 \mathrm{~min}(4.4 \%)$ (Chiralpak $\mathrm{OB}, 125 \mathrm{psi}, 40^{\circ} \mathrm{C}, 20.0 \% \mathrm{MeOH}$ in $\mathrm{CO}_{2}, 3.0 \mathrm{~mL} / \mathrm{min}, 220 \mathrm{~nm}$ )

\section{Preparation of 4-[(5R,2E)-1-Oxo-7-phenyl-5-hydroxy-2,6-heptadienyl]morpholine}

\section{(Table 7, entry 4)}

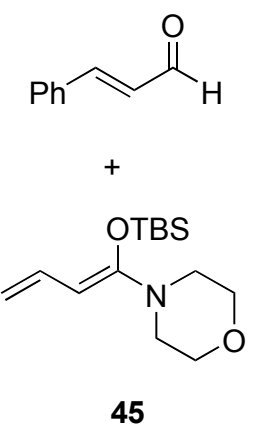

$\mathrm{SiCl}_{4}$ (1.1 equiv) $(R, R)-3$ ( 0.02 equiv)

$i-\mathrm{Pr}_{2} \mathrm{NEt}$ (0.2 equiv)

$\mathrm{CH}_{2} \mathrm{Cl}_{2}, 0.2 \mathrm{M}$

$-78{ }^{\circ} \mathrm{C}, 2 \mathrm{~h}$

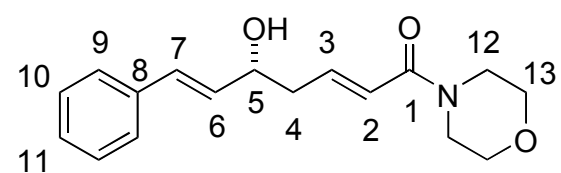

$\gamma-1,2-51$

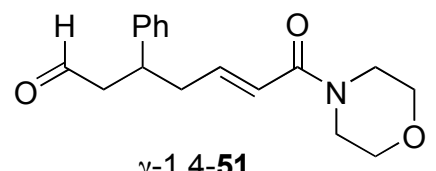<smiles>C=CC(C(=O)N1CCOCC1)C(O)/C=C/c1ccccc1</smiles>

$\alpha-1,2-51$

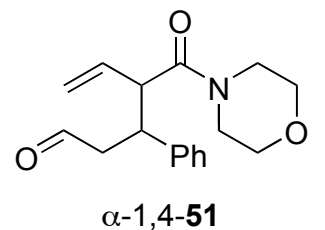

Diisopropylethylamine ( $9 \mu \mathrm{L}, 0.05 \mathrm{mmol}, 0.2$ equiv) was added via syringe to a flamedried, 20-mL, Schlenk flask under Ar containing a solution of $4 \mathrm{mg}$ (0.005 mmol, 0.02 equiv) of bisphosphoramide $(R, R)-3$ in $\mathrm{CH}_{2} \mathrm{Cl}_{2}(1.25 \mathrm{~mL})$. To this solution was added $32 \mu \mathrm{L}(0.25 \mathrm{mmol}$, 1.0 equiv) of cinnamaldehyde in one portion and the reaction mixture was cooled to $-78{ }^{\circ} \mathrm{C}$ (bath temperature) over $15 \mathrm{~min}$. To the resulting solution was added $32 \mu \mathrm{L}$ (0.275 mmol, 1.1 equiv) of $\mathrm{SiCl}_{4}$ in one portion. Then, a solution of $81 \mathrm{mg}(0.3 \mathrm{mmol}, 1.2$ equiv) of 45 in $1.25 \mathrm{~mL}$ of $\mathrm{CH}_{2} \mathrm{Cl}_{2}$ was added dropwise over 5 min via syringe. The resulting mixture was stirred at $-72{ }^{\circ} \mathrm{C}$ for $2 \mathrm{~h}$ whereupon $3.0 \mathrm{~mL}$ of chilled $\mathrm{CH}_{2} \mathrm{Cl}_{2}$ was added before the cold reaction mixture was poured into a rapidly stirring solution of $1 / 1$ sat. aq. $\mathrm{NaHCO}_{3} /$ sat. aq. $\mathrm{KF}(25 \mathrm{~mL})$ at $0{ }^{\circ} \mathrm{C}$. This biphasic mixture was stirred vigorously for $2 \mathrm{~h}$ after which the organic layer was removed and the aqueous layer was washed with $\mathrm{CH}_{2} \mathrm{Cl}_{2}(3 \times 30 \mathrm{~mL})$. The combined organic extracts were dried over $\mathrm{Na}_{2} \mathrm{SO}_{4}(5 \mathrm{~g})$, filtered and the filtrate was concentrated in vacuo. The ratio of $\gamma-1,2-$ 51/ $\alpha-1,2-51 / \gamma-1,4-51 / \alpha-1,4-51$ was determined to be $100 / 0 / 0 / 0$ by ${ }^{1} \mathrm{H}$ NMR $(500 \mathrm{MHz})$ analysis of the crude reaction mixture. The residue was purified by column chromatography $\left(\mathrm{SiO}_{2}(12 \mathrm{~g})\right.$, $2 \mathrm{~cm}$ diam., EtOAc $(100 \mathrm{~mL})$ to EtOAc/MeOH, 19/1 $(100 \mathrm{~mL}))$ to yield $70 \mathrm{mg}(97 \%)$ of $\gamma-1,2-$ 51 as a white solid. 
Data for $\gamma-1,2-51$ :

H NMR: $\quad\left(500 \mathrm{MHz}, \mathrm{CDCl}_{3}\right)$

$7.36(\mathrm{dd}, J=8.0,1.1,2 \mathrm{H}, \mathrm{HC}(9)), 7.32$ (dt, $J=7.5,1.6,2 \mathrm{H}, \mathrm{HC}(10)) 7.25$ (tt, $J$ $=7.3,1.4,1 \mathrm{H}, \mathrm{HC}(11)), 6.91(\mathrm{dt}, J=15.1,7.3,1 \mathrm{H}, \mathrm{HC}(3)), 6.61(\mathrm{~d}, J=15.9,1$ $\mathrm{H}, \mathrm{HC}(7)), 6.32(\mathrm{dt}, J=15.1,1.5,1 \mathrm{H}, \mathrm{HC}(2)), 6.24(\mathrm{dd}, J=15.9,6.3,1 \mathrm{H}$, $\mathrm{HC}(6)), 4.49$ (dq, $J=6.7,1.2,1 \mathrm{H}, \mathrm{HC}(5)), 3.67$ (m, 8 H, H $\left.\mathrm{C}_{2}(12,13)\right), 2.57-2.54$ (m, $\left.2 \mathrm{H}, \mathrm{H}_{2} \mathrm{C}(4)\right), 2.08$ (br s, $1 \mathrm{H}, \mathrm{OH}$ )

TLC: $\quad R_{f} 0.14(\mathrm{EtOAc})[\mathrm{UV}(254 \mathrm{~nm})]$

SFC: $\quad(R)-\gamma-1,2-51, t_{\mathrm{R}} 2.39 \min (96.0 \%) ;(S)-\gamma-1,2-51, t_{\mathrm{R}} 4.14 \mathrm{~min}$ (4.0\%) (Chiralpak $\mathrm{OB}, 125 \mathrm{psi}, 40{ }^{\circ} \mathrm{C}, 20.0 \% \mathrm{MeOH}$ in $\mathrm{CO}_{2}, 3.0 \mathrm{~mL} / \mathrm{min}, 220 \mathrm{~nm}$ )

\section{Preparation of 4-[(5R,2E)-1-Oxo-7-phenyl-5-hydroxy-2,6-heptadienyl]morpholine}

\section{(Table 7, entry 5)}

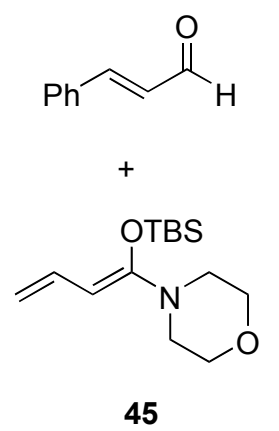

45
$\mathrm{SiCl}_{4}(1.1$ equiv) $(R, R)-3$ (0.02 equiv)

i- $\operatorname{Pr}_{2} \mathrm{NEt}(0.2$ equiv)

$\mathrm{CH}_{2} \mathrm{Cl}_{2}, 0.1 \mathrm{M}$

$-78^{\circ} \mathrm{C}, 2 \mathrm{~h}$

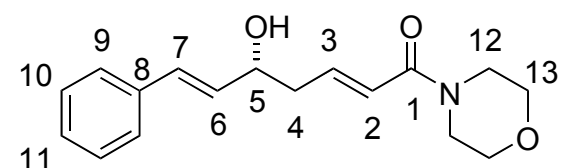

$\gamma-1,2-51$

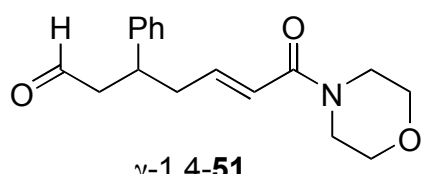<smiles>[R15]#[Y10]/C=C/C(O)C(C=C)C(=O)N1CCOCC1</smiles>

$\alpha-1,2-51$

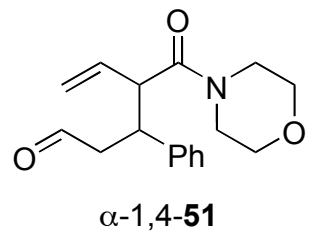

Diisopropylethylamine ( $9 \mu \mathrm{L}, 0.05 \mathrm{mmol}, 0.2$ equiv) was added via syringe to a flamedried, 20-mL, Schlenk flask under Ar containing a solution of $4 \mathrm{mg}$ (0.005 mmol, 0.02 equiv) of bisphosphoramide $(R, R)-\mathbf{2 1}$ in $\mathrm{CH}_{2} \mathrm{Cl}_{2}(2.5 \mathrm{~mL})$. To this solution was added $32 \mu \mathrm{L}(0.25 \mathrm{mmol}$, 1.0 equiv) of cinnamaldehyde in one portion and the reaction mixture was cooled to $-78{ }^{\circ} \mathrm{C}$ (bath temperature) over $15 \mathrm{~min}$. To the resulting solution was added $32 \mu \mathrm{L}$ ( $0.275 \mathrm{mmol}, 1.1$ equiv) of $\mathrm{SiCl}_{4}$ in one portion. Then, a solution of $81 \mathrm{mg}\left(0.3 \mathrm{mmol}, 1.2\right.$ equiv) of 45 in $2.5 \mathrm{~mL}$ of $\mathrm{CH}_{2} \mathrm{Cl}_{2}$ was added dropwise over $5 \mathrm{~min}$ via syringe. The resulting mixture was stirred at $-72{ }^{\circ} \mathrm{C}$ for $2 \mathrm{~h}$ whereupon $3.0 \mathrm{~mL}$ of chilled $\mathrm{CH}_{2} \mathrm{Cl}_{2}$ was added before the cold reaction mixture was poured into a rapidly stirring solution of $1 / 1$ sat. aq. $\mathrm{NaHCO}_{3} /$ sat. aq. $\mathrm{KF}(25 \mathrm{~mL})$ at $0{ }^{\circ} \mathrm{C}$. This biphasic mixture was stirred vigorously for $2.5 \mathrm{~h}$ after which the organic layer was removed and the 
aqueous layer was washed with $\mathrm{CH}_{2} \mathrm{Cl}_{2}(3 \times 30 \mathrm{~mL})$. The combined organic extracts were dried over $\mathrm{Na}_{2} \mathrm{SO}_{4}(5 \mathrm{~g})$, filtered and the filtrate was concentrated in vacuo. The ratio of $\gamma-1,2-51 / \alpha-$ 1,2-51/ $\gamma-1,4-51 / \alpha-1,4-51$ was determined to be $100 / 0 / 0 / 0$ by ${ }^{1} \mathrm{H}$ NMR (500 MHz) analysis of the crude reaction mixture. The residue was purified by column chromatography $\left(\mathrm{SiO}_{2}(12 \mathrm{~g}), 2 \mathrm{~cm}\right.$ diam., EtOAc $(100 \mathrm{~mL})$ to EtOAc/MeOH, 19/1 (100 mL)) to yield $68 \mathrm{mg}(94 \%)$ of $\gamma-1,2-51$ as a white solid.

Data for $\gamma-1,2-51$ :

${ }^{1}$ H NMR: $\quad\left(500 \mathrm{MHz}, \mathrm{CDCl}_{3}\right)$

$7.36(\mathrm{dd}, J=8.2,1.1,2 \mathrm{H}, \mathrm{HC}(9)), 7.32$ (dt, $J=7.6,1.7,2 \mathrm{H}, \mathrm{HC}(10)) 7.25$ (tt, $J$ $=7.3,1.3,1 \mathrm{H}, \mathrm{HC}(11)), 6.91(\mathrm{dt}, J=15.1,7.3,1 \mathrm{H}, \mathrm{HC}(3)), 6.61(\mathrm{~d}, J=15.9,1$ $\mathrm{H}, \mathrm{HC}(7)), 6.32$ (dt, $J=15.4,1.4,1 \mathrm{H}, \mathrm{HC}(2)), 6.24(\mathrm{dd}, J=15.7,6.3,1 \mathrm{H}$, $\mathrm{HC}(6)), 4.48$ (dq, $J=6.6,1.2,1 \mathrm{H}, \mathrm{HC}(5)), 3.66$ (m, 8 H, $\left.\mathrm{H}_{2} \mathrm{C}(12,13)\right)$, 2.59-2.53 (m, $\left.2 \mathrm{H}, \mathrm{H}_{2} \mathrm{C}(4)\right), 2.12$ (br s, $1 \mathrm{H}, \mathrm{OH}$ )

TLC: $\quad R_{f} 0.14(\mathrm{EtOAc})[\mathrm{UV}(254 \mathrm{~nm})]$

SFC: $\quad(R)-\gamma-1,2-51, t_{\mathrm{R}} 2.46 \min (98.1 \%) ;(S)-\gamma-1,2-51, t_{\mathrm{R}} 4.22 \min (1.9 \%)$ (Chiralpak $\mathrm{OB}, 125 \mathrm{psi}, 40{ }^{\circ} \mathrm{C}, 20.0 \% \mathrm{MeOH}$ in $\mathrm{CO}_{2}, 3.0 \mathrm{~mL} / \mathrm{min}, 220 \mathrm{~nm}$ )

\section{Representative Procedure 8. Vinylogous Aldol Additions of Conjugated $\mathrm{N}, \mathrm{O}$-Silyl Ketene Acetals to Conjugated Aldehydes. Preparation of (+)-4-[(5R,2E)-1-Oxo-5-phenyl-5- hydroxy-2-pentenyl]morpholine (50) (Table 8, entry 1)}

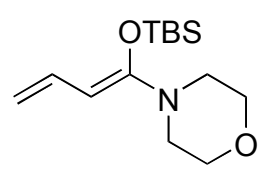

45

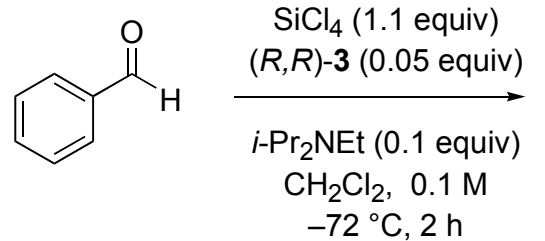

Diisopropylethylamine (18 $\mu \mathrm{L}, 0.1 \mathrm{mmol}, 0.1$ equiv) was added via syringe to a flamedried, 20-mL, Schlenk flask under Ar containing a solution of $42 \mathrm{mg}$ (0.05 mmol, 0.05 equiv) of bisphosphoramide $(R, R)-3$ in $\mathrm{CH}_{2} \mathrm{Cl}_{2}(5 \mathrm{~mL})$. To this solution was added $102 \mu \mathrm{L}(1.0 \mathrm{mmol})$ of benzaldehyde in one portion. To the resulting solution was added $126 \mu \mathrm{L}$ (1.1 mmol, 1.1 equiv) of $\mathrm{SiCl}_{4}$ in one portion and the reaction mixture was cooled to $-72{ }^{\circ} \mathrm{C}$ over $15 \mathrm{~min}$. Then, a solution of $324 \mathrm{mg}$ (1.2 mmol, 1.2 equiv) of 45 in $5 \mathrm{~mL}$ of $\mathrm{CH}_{2} \mathrm{Cl}_{2}$ was added dropwise over 5 
min via syringe. The resulting mixture was stirred at $-72{ }^{\circ} \mathrm{C}$ for $1 \mathrm{~h}$ whereupon $3.0 \mathrm{~mL}$ of chilled $\mathrm{CH}_{2} \mathrm{Cl}_{2}$ was added before the cold reaction mixture was poured into a rapidly stirring solution of $1 / 1$ sat. aq. $\mathrm{NaHCO}_{3} /$ sat. aq. $\mathrm{KF}(25 \mathrm{~mL})$ at $0{ }^{\circ} \mathrm{C}$. This biphasic mixture was stirred vigorously for $3 \mathrm{~h}$ after which the organic layer was removed and aqueous layer was washed with $\mathrm{CH}_{2} \mathrm{Cl}_{2}(3 \times 50 \mathrm{~mL})$. The combined organic extracts were dried over $\mathrm{Na}_{2} \mathrm{SO}_{4}(5 \mathrm{~g})$, filtered and the filtrate was concentrated in vacuo. The ratio of $\gamma / \alpha$-addition products was determined to be $>99 / 1$ by ${ }^{1} \mathrm{H}$ NMR $(500 \mathrm{MHz})$ analysis of the crude reaction mixture. The residue was purified by column chromatography $\left(\mathrm{SiO}_{2}(30 \mathrm{~g}), 3 \mathrm{~cm}\right.$ diam., EtOAc $(200 \mathrm{~mL})$ to EtOAc/MeOH, 19/1 (150 mL)) to yield a solid which was recrystallized by precipitation from hot EtOAc $(5 \mathrm{~mL})$ with minimal amounts of hexanes to yield $247 \mathrm{mg}(95 \%)$ of $(+)-50$ as white needles.

Data for $(+)-\mathbf{5 0}$ :

mp: $\quad 108-109^{\circ} \mathrm{C}($ EtOAc/hexanes $)$

${ }^{1} \mathrm{H}$ NMR: $\quad\left(500 \mathrm{MHz}, \mathrm{CDCl}_{3}\right)$

7.38-7.27 (m, $5 \mathrm{H}, \mathrm{HC}(7,8,9)), 6.87$ (dt, $J=15.1,7.1,1 \mathrm{H}, \mathrm{HC}(3)), 6.24$ (dt, $J=$ 15.1, 1.4, $1 \mathrm{H}, \mathrm{HC}(2)), 4.85$ (dd, $J=7.5,5.5,1 \mathrm{H}, \mathrm{HC}(5))$, 3.66-3.56 (m, $8 \mathrm{H}$, $\mathrm{H}_{2} \mathrm{C}(10,11)$ ), 2.72-2.63 (m, $\left.2 \mathrm{H}, \mathrm{H}_{2} \mathrm{C}(4)\right), 2.15$ (br s, $\left.1 \mathrm{H}, \mathrm{OH}\right)$

${ }^{13} \mathrm{C} \mathrm{NMR}: \quad\left(126 \mathrm{MHz}, \mathrm{CDCl}_{3}\right)$

165.5 (C(1)), 143.9 (C(6)), 142.5 (C(3)), 128.2 (C(8)), 127.4 (C(9)), 125.7 (C(7)), $122.3(\mathrm{C}(2)), 72.7$ (C(5)), 66.5 (C(11)), 45.9 (C(10)), 42.4 (C(4)), 42.0 (C(10))

IR: $\quad\left(\mathrm{CHCl}_{3}\right)$

3674 (w), 3647 (w), 3600 (m), 3392 (s), 3058 (m), 3063 (s), 3010 (s), 2972 (s), 2924 (s), 2902 (s), 2861 (s), 2762 (m), 2714 (m), 2686 (m), 2581 (w), 2459 (m), 2402 (m), 2360 (m), 2334 (w), 2233 (w), 2016 (w), 1952 (w), $1881(\mathrm{w}), 1812$ (w), 1759 (w), 1732 (w), 1657 (s), 1607 (s), 1493 (s), 1437 (s), 1389 (s), 1362 (s), 1302 (s), 1227 (s), 1217 (s), 1115 (s), 1068 (s), 1042 (s), 1008 (s), 977 (s), 917 (s), $893(\mathrm{~m}), 855(\mathrm{~s}), 756(\mathrm{~s}), 701(\mathrm{~s}), 667(\mathrm{~s}), 628(\mathrm{~s})$

MS: $\quad\left(\mathrm{CI}, \mathrm{CH}_{4}\right)$

$262\left(\mathrm{M}^{+}+\mathrm{H}, 29\right), 245$ (20), 244 (100), 156 (14), 155 (31), 114 (11), 107 (27)

Opt. Rot.: $\quad[\alpha]_{\mathrm{D}}{ }^{24}+10.42(\mathrm{c}=0.90, \mathrm{EtOH})$

TLC: $\quad R_{f} 0.17(\mathrm{EtOAc})[\mathrm{UV}(254 \mathrm{~nm})]$ 
SFC: $\quad(R)-50, t_{\mathrm{R}} 3.39 \min (97.1 \%) ;(S)-50, t_{\mathrm{R}} 4.11 \mathrm{~min}(2.9 \%)$ (Chiralpak OB, 125 psi, $40{ }^{\circ} \mathrm{C}, 10.0 \% \mathrm{MeOH}$ in $\left.\mathrm{CO}_{2}, 3.0 \mathrm{~mL} / \mathrm{min}, 220 \mathrm{~nm}\right)$

Analysis: $\quad \mathrm{C}_{15} \mathrm{H}_{19} \mathrm{NO}_{3}(261.32)$

Calcd: $\quad$ C, 68.94; H, 7.33; $\quad$ N, 5.36\%

Found: $\quad$ C, 68.92; $\quad$ H, 7.33; $\quad$ N, 5.36\%

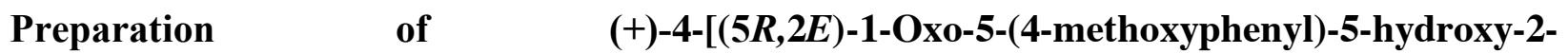
pentenyl]morpholine (52) (Table 8, entry 2)

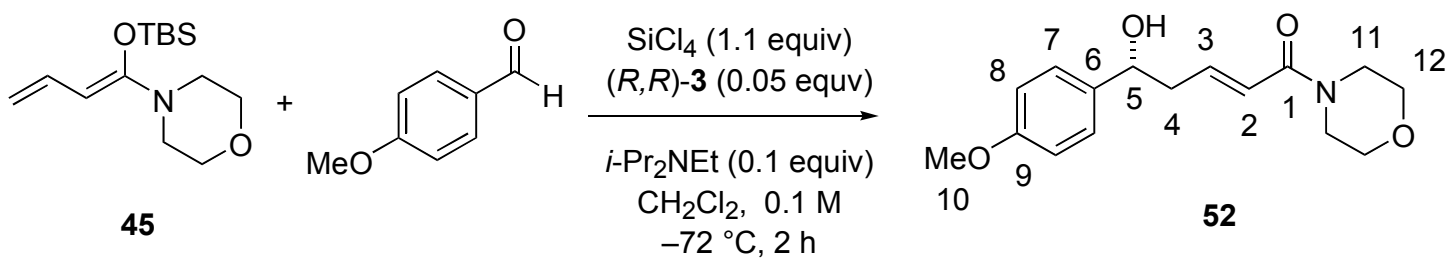

Following Representative Procedure 8, $121 \mu \mathrm{L}(1.0 \mathrm{mmol})$ of $p$-anisaldehyde was combined with $42 \mathrm{mg}(0.05 \mathrm{mmol}, 0.05$ equiv) of bisphosphoramide $(R, R)-3,18 \mu \mathrm{L}(0.1 \mathrm{mmol}$, 0.1 equiv) of diisopropylethylamine, $126 \mu \mathrm{L}\left(1.1 \mathrm{mmol}, 1.1\right.$ equiv) of $\mathrm{SiCl}_{4}$ and $324 \mathrm{mg}(1.2$ mmol, 1.2 equiv) of $\mathbf{4 5}$ to yield, after column chromatography $\left(\mathrm{SiO}_{2}(30 \mathrm{~g}), 3 \mathrm{~cm}\right.$ diam., EtOAc $(200 \mathrm{~mL})$ to EtOAc/MeOH, 19/1 $(150 \mathrm{~mL}))$ a solid which was recrystallized by precipitation from hot EtOAc $(5 \mathrm{~mL})$ with minimal amounts of hexanes to yield $277 \mathrm{mg}(95 \%)$ of (+)-52 as white crystals. The ratio of $\gamma / \alpha$-addition products was determined to be $>99 / 1$ by ${ }^{1} \mathrm{H}$ NMR (500 $\mathrm{MHz}$ ) analysis of the crude reaction mixture.

Data for $(+)-52$ :

mp: $\quad 95-96^{\circ} \mathrm{C}($ EtOAc/hexanes $)$

${ }^{1} \mathrm{H}$ NMR: $\quad\left(500 \mathrm{MHz}, \mathrm{CDCl}_{3}\right)$

7.29-7.27 (m, 2 H, HC(7)), 6.90-6.83 (m, 3 H, HC(3,8)), 6.24 (dt, $J=15.1,1.4,1$

$\mathrm{H}, \mathrm{HC}(2)), 4.80$ (dd, $J=7.6,5.4,1 \mathrm{H}, \mathrm{HC}(5)), 3.80$ (s, $\left.3 \mathrm{H}, \mathrm{H}_{3} \mathrm{C}(10)\right)$, 3.67-3.57

$\left(\mathrm{m}, 8 \mathrm{H}, \mathrm{H}_{2} \mathrm{C}(11,12)\right), 2.71-2.59$ (m, $\left.2 \mathrm{H}, \mathrm{H}_{2} \mathrm{C}(4)\right), 1.96$ (br s, $\left.1 \mathrm{H}, \mathrm{OH}\right)$

${ }^{13} \mathrm{C} \mathrm{NMR}: \quad\left(126 \mathrm{MHz}, \mathrm{CDCl}_{3}\right)$

165.5 (C(1)), 158.8 (C(9)), 142.5 (C(3)), 136.0 (C(6)), 126.9 (C(7)), 122.1 (C(2)), 113.5 (C(8)), 72.3 (C(5)), 66.5 (C(12)), 55.1 (C(10), 45.9 (C(11)), 42.2 (C(4)), $41.9(\mathrm{C}(11))$ 
IR: $\quad\left(\mathrm{CHCl}_{3}\right)$

3388 (m), 3014 (m), $2971(\mathrm{w}), 2926$ (w), 2903 (w), 2862 (w), $2839(\mathrm{w}), 2458(\mathrm{w})$, $2401(\mathrm{w}), 2058$ (w), 1887 (w), 1765 (w), 1657 (m), 1611 (s), 1514 (s), 1462 (m), 1440 (s), 1389 (m), 1362 (w), 1303 (m), 1266 (m), 1248 (s), 1217 (s), 1175 (m), 1115 (m), 1069 (w), 1037 (m), 1007 (w), 977 (w), 931 (w), 887 (w), 834 (m), 810 (w), $757(\mathrm{~s}), 667(\mathrm{~m})$

MS: $\quad(\mathrm{ESI})$

$292\left(\mathrm{M}^{+}+\mathrm{H}, 45\right), 275(20), 274$ (100), 169 (12)

Opt. Rot.: $\quad[\alpha]_{\mathrm{D}}^{24}+9.95(\mathrm{c}=0.90, \mathrm{EtOH})$

TLC: $\quad R_{f} 0.15(\mathrm{EtOAc})[\mathrm{UV}(254 \mathrm{~nm})]$

SFC: $\quad(R)-52, t_{\mathrm{R}} 4.11 \min (99.0 \%) ;(S)-52, t_{\mathrm{R}} 4.95 \min (1.0 \%)$ (Chiralpak OB, 125 psi, $40{ }^{\circ} \mathrm{C}, 12.5 \% \mathrm{MeOH}$ in $\mathrm{CO}_{2}, 3.0 \mathrm{~mL} / \mathrm{min}, 220 \mathrm{~nm}$ )

Analysis: $\quad \mathrm{C}_{16} \mathrm{H}_{21} \mathrm{NO}_{4}(291.34)$

$\begin{array}{llll}\text { Calcd: } & \text { C , 65.96; } & \text { H, 7.27; } & \text { N, 4.81\% } \\ \text { Found: } & \text { C, 65.87; } & \text { H, 7.28; } & \text { N, 4.78\% }\end{array}$

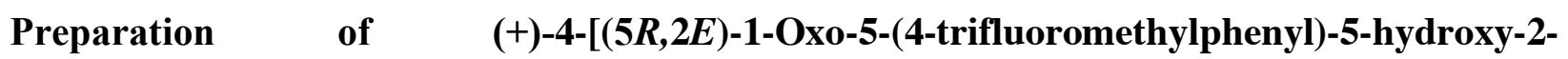
pentenyl]morpholine (53) (Table 8, entry 3)
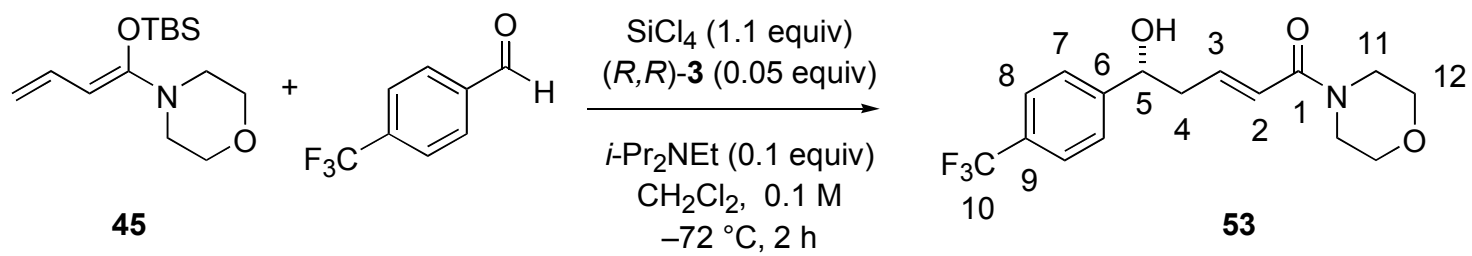

Following Representative Procedure 8, $137 \mu \mathrm{L} \quad\left(\begin{array}{llll}1.0 & \mathrm{mmol}\end{array}\right)$ of $p$ trifluoromethylbenzaldehyde was combined with $42 \mathrm{mg}(0.05 \mathrm{mmol}, 0.05$ equiv $)$ of bisphosphoramide $(R, R)-3,18 \mu \mathrm{L}(0.1 \mathrm{mmol}, 0.1$ equiv) of diisopropylethylamine, $126 \mu \mathrm{L}(1.1$ mmol, 1.1 equiv) of $\mathrm{SiCl}_{4}$ and $324 \mathrm{mg}$ (1.2 mmol, 1.2 equiv) of 45 to yield, after column chromatography $\left(\mathrm{SiO}_{2}(30 \mathrm{~g}), 3 \mathrm{~cm}\right.$ diam., EtOAc $(200 \mathrm{~mL})$ to EtOAc/MeOH, 19/1 (150 mL)) a solid which was recrystallized by precipitation from hot EtOAc $(5 \mathrm{~mL})$ with minimal amounts of hexanes to yield $306 \mathrm{mg}(93 \%)$ of (+)-53 as white crystals. The ratio of $\gamma / \alpha$-addition products was determined to be $>99 / 1$ by ${ }^{1} \mathrm{H}$ NMR (500 MHz) analysis of the crude reaction mixture. 
Data for $(+)-53$ :

mp: $\quad 122-123{ }^{\circ} \mathrm{C}($ EtOAc/hexanes $)$

${ }^{1} \mathrm{H} \mathrm{NMR}: \quad\left(500 \mathrm{MHz}, \mathrm{CDCl}_{3}\right)$

$7.62(\mathrm{~d}, J=8.1,2 \mathrm{H}, \mathrm{HC}(7)), 7.49$ (d, $J=8.3,2 \mathrm{H}, \mathrm{HC}(8)), 6.89$ (dt, $J=14.9$, 7.6, $1 \mathrm{H}, \mathrm{HC}(3)), 6.25(\mathrm{dt}, J=15.1,1.4,1 \mathrm{H}, \mathrm{HC}(2)), 4.94$ (t, $J=6.3,1 \mathrm{H}$, $\mathrm{HC}(5)), 3.67-3.58\left(\mathrm{~m}, 8 \mathrm{H}, \mathrm{H}_{2} \mathrm{C}(11,12)\right), 2.66$ (t, $\left.J=6.6,2 \mathrm{H}, \mathrm{H}_{2} \mathrm{C}(4)\right), 2.18$ (br s, $1 \mathrm{H}, \mathrm{OH})$

${ }^{13} \underline{\mathrm{C} \mathrm{NMR}}: \quad\left(126 \mathrm{MHz}, \mathrm{CDCl}_{3}\right)$

$165.5(\mathrm{C}(1)), 148.0(\mathrm{C}(6)), 142.1(\mathrm{C}(3)), 129.4$ (q, $\left.\mathrm{J}_{\mathrm{CF}}=32, \mathrm{C}(9)\right), 126.1(\mathrm{C}(7))$, $125.2\left(\mathrm{q}, \mathrm{J}_{\mathrm{CF}}=4, \mathrm{C}(8)\right), 124.0\left(\mathrm{q}, \mathrm{J}_{\mathrm{CF}}=272, \mathrm{C}(10)\right), 122.6(\mathrm{C}(2)), 72.7(\mathrm{C}(5))$, $66.5(\mathrm{C}(12)), 45.9(\mathrm{C}(11)), 42.4(\mathrm{C}(4)), 42.0(\mathrm{C}(11))$

${ }^{19}$ F NMR: $\quad\left(237 \mathrm{MHz}, \mathrm{CDCl}_{3} \mathrm{w} / \mathrm{C}_{6} \mathrm{~F}_{6}\right)$ $-62.716$

IR: $\quad\left(\mathrm{CHCl}_{3}\right)$

3678 (w), 3603 (w), 3380 (w), 3018 (m), $2975(\mathrm{w}), 2926(\mathrm{w}), 2903(\mathrm{w}), 2863(\mathrm{w})$, $2763(\mathrm{w}), 2717$ (w), 2401 (w), 2349 (w), 1925 (w), 1807 (w), 1658 (m), 1607 (m), 1518 (w), 1462 (m), 1439 (m), 1389 (w), 1362 (w), 1326 (s), 1303 (w), 1268 (m), 1216 (s), 1167 (m), 1115 (s), 1068 (s), 1042 (w), 1017 (m), 977 (w), 930 (w), 887 $(\mathrm{w}), 846(\mathrm{~m}), 767(\mathrm{~s}), 668(\mathrm{~m})$

MS: $\quad(\mathrm{EI}, 70 \mathrm{eV})$

$329\left(\mathrm{M}^{+}, 2\right), 225$ (13), 175 (64), 155 (100), 140 (46), 127 (36), 86 (25), 69 (29), $56(21)$

Opt. Rot.: $\quad[\alpha]_{\mathrm{D}}{ }^{24}+10.94(\mathrm{c}=1.00, \mathrm{EtOH})$

TLC: $\quad R_{f} 0.22(\mathrm{EtOAc})[\mathrm{UV}(254 \mathrm{~nm})]$

SFC: $\quad(R)-53, t_{\mathrm{R}} 10.42 \min (95.4 \%) ;(S)-53, t_{\mathrm{R}} 11.62 \min (4.6 \%)$ (Chiralpak OB, 200 psi, $40{ }^{\circ} \mathrm{C}, 2.0 \% \mathrm{MeOH}$ in $\mathrm{CO}_{2}, 2.0 \mathrm{~mL} / \mathrm{min}, 220 \mathrm{~nm}$ )

Analysis: $\quad \mathrm{C}_{16} \mathrm{H}_{18} \mathrm{~F}_{3} \mathrm{NO}_{3}(329.31)$

Calcd: $\quad$ C, 58.35; $\quad$ H, 5.51; $\quad$ N, 4.25\%

Found: $\quad$ C, 58.35; H, 5.60; N, 4.48\% 
Preparation of (+)-4-[(5R,2E)-1-Oxo-5-furanyl-5-hydroxy-2-pentenyl]morpholine (Table 8, entry 4)

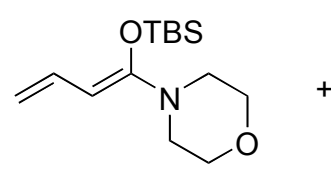

45

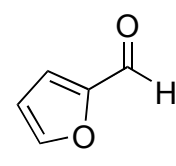

(1)

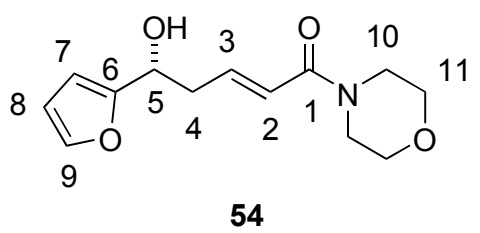

54

Following Representative Procedure $8,83 \mu \mathrm{L}(1.0 \mathrm{mmol})$ of 2-furfuraldehyde, was combined with $42 \mathrm{mg}(0.05 \mathrm{mmol}, 0.05$ equiv) of bisphosphoramide $(R, R)-3,18 \mu \mathrm{L}(0.1 \mathrm{mmol}$, 0.1 equiv) of diisopropylethylamine, $126 \mu \mathrm{L}$ (1.1 mmol, 1.1 equiv) of $\mathrm{SiCl}_{4}$, and $324 \mathrm{mg}(1.2$ mmol, 1.2 equiv) of $\mathbf{4 5}$ to yield, after column chromatography $\left(\mathrm{SiO}_{2}(30 \mathrm{~g}), 3 \mathrm{~cm}\right.$ diam., EtOAc $(200 \mathrm{~mL})$ to $\mathrm{EtOAc} / \mathrm{MeOH}, 19 / 1(150 \mathrm{~mL}))$ an oil which was crystallized from $\mathrm{Et}_{2} \mathrm{O}(4 \mathrm{~mL})$ to yield $236 \mathrm{mg}(94 \%)$ of $(+)-54$ as white crystals. The ratio of $\gamma / \alpha$-addition products was determined to be $>99 / 1$ by ${ }^{1} \mathrm{H}$ NMR $(500 \mathrm{MHz})$ analysis of the crude reaction mixture.

Data for $(+)-54:$

mp: $\quad 50-52{ }^{\circ} \mathrm{C}\left(\mathrm{Et}_{2} \mathrm{O}\right)$

${ }^{1} \mathrm{H} \mathrm{NMR}: \quad\left(500 \mathrm{MHz}, \mathrm{CDCl}_{3}\right)$

$7.38(\mathrm{dd}, J=1.7,0.7,1 \mathrm{H}, \mathrm{HC}(9)), 6.86(\mathrm{dt}, J=15.1,7.3,1 \mathrm{H}, \mathrm{HC}(3)), 6.34(\mathrm{dd}$, $J=3.2,2.0,1 \mathrm{H}, \mathrm{HC}(8)), 6.31(\mathrm{~d}, J=15.1,1 \mathrm{H}, \mathrm{HC}(2)), 6.27$ (d, J = 3.2, $1 \mathrm{H}$, $\mathrm{HC}(7)), 4.86(\mathrm{t}, J=6.6,1 \mathrm{H}, \mathrm{HC}(5)), 3.68-3.60$ (m, 8 H, $\left.\mathrm{H}_{2} \mathrm{C}(10,11)\right), 2.80-2.76$ (m, $\left.2 \mathrm{H}, \mathrm{H}_{2} \mathrm{C}(4)\right), 1.87$ (br s, $1 \mathrm{H}, \mathrm{OH}$ )

${ }^{13} \mathrm{C} \mathrm{NMR}: \quad\left(126 \mathrm{MHz}, \mathrm{CDCl}_{3}\right)$

165.5 (C(1)), 155.9 (C(6)), 141.8 (C(3)), 141.7 (C(9)), $122.4(\mathrm{C}(2)), 110.0(\mathrm{C}(8))$, $106.0(\mathrm{C}(7)), 66.5$ (C(11), 66.2 (C(5)), 45.9 (C(10)), 42.0 (C(10)), 38.7 (C(4))

IR: (neat)

3379 (s), 3146 (m), 3117 (m), 3059 (w), 2966 (m), 2903 (s), 2859 (s), 2761 (w), 2715 (w), 2361 (w), 2243 (w), 1961 (w), 1660 (s), 1614 (s), 1505 (m), 1435 (s), 1387 (m), 1362 (m), 1301 (s), 1267 (s), 1237 (s), 1195 (m), 1180 (m), 1146 (s), 1115 (s), 1068 (s), 1041 (s), 1011 (s), 978 (s), 918 (s), 884 (m), 854 (s), 812 (m), 734 (s), 700 (m), 646 (m) 
MS: $\quad\left(\mathrm{CI}, \mathrm{CH}_{4}\right)$

$252\left(\mathrm{M}^{+}+\mathrm{H}, 6\right), 235$ (17), 234 (100), 155 (23), 97 (21)

Opt. Rot.: $\quad[\alpha]_{\mathrm{D}}^{24}+8.52(\mathrm{c}=0.90, \mathrm{EtOH})$

TLC: $\quad R_{f} 0.11(\mathrm{EtOAc})[\mathrm{UV}(254 \mathrm{~nm})]$

SFC: $\quad(R)-54, t_{\mathrm{R}} 7.16 \min (93.8 \%) ;(S)-54, t_{\mathrm{R}} 8.21 \min (6.2 \%)$ (Chiralpak AD, 150 psi, $40{ }^{\circ} \mathrm{C}, 8.0 \% \mathrm{MeOH}$ in $\mathrm{CO}_{2}, 3.0 \mathrm{~mL} / \mathrm{min}, 220 \mathrm{~nm}$ )

Analysis: $\quad \mathrm{C}_{13} \mathrm{H}_{17} \mathrm{NO}_{4}(251.28)$

Calcd: $\quad$ C, 62.14; H, 6.82; $\quad$ N, 5.57\%

Found: $\quad$ C, 62.07; $\quad \mathrm{H}, 6.82 ; \quad \mathrm{N}, 5.54 \%$

Preparation of (-)-4-[(5R,2E)-1-Oxo-7-phenyl-5-hydroxy-2,6-heptadienyl]morpholine (51) (Table 8, entry 5)

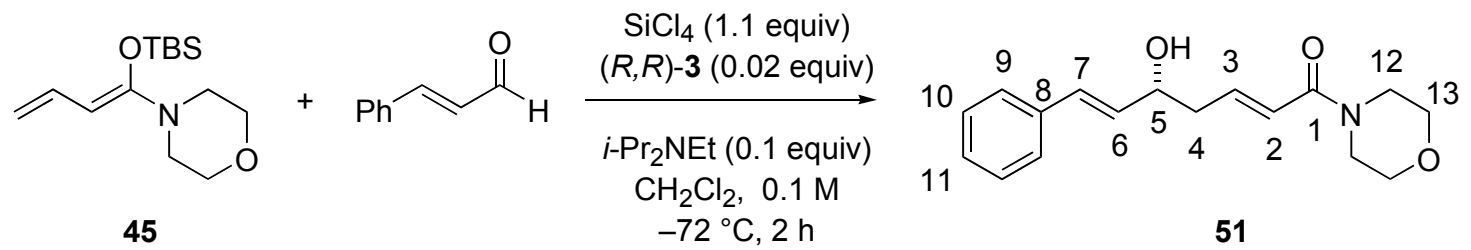

Following Representative Procedure 8, $126 \mu \mathrm{L}(1.0 \mathrm{mmol})$ of cinnamaldehyde was combined with $42 \mathrm{mg}$ (0.05 mmol, 0.05 equiv) of bisphosphoramide $(R, R)-3,18 \mu \mathrm{L}(0.1 \mathrm{mmol}$, 0.1 equiv) of diisopropylethylamine, $126 \mu \mathrm{L}\left(1.1 \mathrm{mmol}, 1.1\right.$ equiv) of $\mathrm{SiCl}_{4}$ and $324 \mathrm{mg}(1.2$ mmol, 1.2 equiv) of $\mathbf{4 5}$ to yield, after column chromatography $\left(\mathrm{SiO}_{2}(30 \mathrm{~g}), 3 \mathrm{~cm}\right.$ diam., EtOAc $(200 \mathrm{~mL})$ to EtOAc/MeOH, 19/1 $(150 \mathrm{~mL}))$ a solid which was recrystallized by precipitation from hot EtOAc $(5 \mathrm{~mL})$ with minimal amounts of hexanes to yield $270 \mathrm{mg}(94 \%)$ of (-)-51 as white crystals. The ratio of $\gamma / \alpha$-addition products was determined to be $>99 / 1$ by ${ }^{1} \mathrm{H}$ NMR (500 $\mathrm{MHz}$ ) analysis of the crude reaction mixture.

Data for (-)-51:

mp: $\quad 87-88^{\circ} \mathrm{C}($ EtOAc/hexanes $)$

${ }^{1}$ H NMR: $\quad\left(500 \mathrm{MHz}, \mathrm{CDCl}_{3}\right)$

7.37 (dd, $J=8.2,1.1,2$ H, HC(9)), 7.32 (dt, $J=7.6,1.7,2$ H, HC(10)) 7.25 (tt, $J$ $=7.3,1.3,1 \mathrm{H}, \mathrm{HC}(11)), 6.91(\mathrm{dt}, J=15.1,7.3,1 \mathrm{H}, \mathrm{HC}(3)), 6.61(\mathrm{~d}, J=15.9,1$ $\mathrm{H}, \mathrm{HC}(7)), 6.32(\mathrm{dt}, J=15.1,1.4,1 \mathrm{H}, \mathrm{HC}(2)), 6.24(\mathrm{dd}, J=15.9,6.3,1 \mathrm{H}$, 
$\mathrm{HC}(6)), 4.47$ (dq, $J=6.6,1.2,1 \mathrm{H}, \mathrm{HC}(5)), 3.65-3.45$ (m, $\left.8 \mathrm{H}, \mathrm{H}_{2} \mathrm{C}(12,13)\right), 2.58$ 2.54 (m, $\left.2 \mathrm{H}, \mathrm{H}_{2} \mathrm{C}(4)\right), 2.08$ (br s, $\left.1 \mathrm{H}, \mathrm{OH}\right)$

${ }^{13} \mathrm{C} \mathrm{NMR}: \quad\left(126 \mathrm{MHz}, \mathrm{CDCl}_{3}\right)$

165.5 (C(1)), 142.4 (C(3)), 136.4 (C(8)), 131.4 (C(6)), 130.1 (C(7)), 128.4 (C(10)), 127.5 (C(11)), 126.2 (C(9)), 122.4 (C(2)), 71.0 (C(5)), 66.5 (C(13)), 66.4 (C(13), 45.9 (C(12)), 42.0 (C(12)), 40.5 (C(4))

IR: $\quad\left(\mathrm{CHCl}_{3}\right)$

3676 (w), 3601 (w), 3383 (w), 3083 (w), 3061 (w), 3014 (m), 2925 (w), 2902 (w), 2862 (w), 2762 (w), 2716 (w), 2686 (w), 2453 (w), 2401 (w), 2231 (w), 1951 (w), $1879(\mathrm{w}), 1805$ (w), 1658 (m), 1607 (s), 1494 (w), 1460 (m), 1438 (s), 1389 (w), 1362 (w), 1302 (m), 1268 (m), 1236 (m), 1216 (s), 1115 (s), 1068 (m), 1039 (m), $968(\mathrm{~m}), 926(\mathrm{w}), 854(\mathrm{w}), 752(\mathrm{~s}), 694(\mathrm{~m}), 668(\mathrm{~m}), 628(\mathrm{w})$

MS: $\quad\left(\mathrm{CI}, \mathrm{CH}_{4}\right)$ $288\left(\mathrm{M}^{+}+\mathrm{H}, 10\right), 272$ (16), 271 (22), 270 (100), 183 (10), 156 (23), 155 (35), 133 (36), 114 (20), 88 (15), 63 (43), 62 (11), 61 (16)

Opt. Rot.: $\quad[\alpha]_{\mathrm{D}}{ }^{24}-17.23(\mathrm{c}=1.20, \mathrm{EtOH})$

TLC: $\quad R_{f} 0.14(\mathrm{EtOAc})[\mathrm{UV}(254 \mathrm{~nm})]$

SFC: $\quad(R)-51, t_{\mathrm{R}} 2.41 \min (98.2 \%) ;(S)-51, t_{\mathrm{R}} 4.16 \min (1.8 \%)$ (Chiralpak OB, 125 psi, $40{ }^{\circ} \mathrm{C}, 20.0 \% \mathrm{MeOH}$ in $\mathrm{CO}_{2}, 3.0 \mathrm{~mL} / \mathrm{min}, 220 \mathrm{~nm}$ )

Analysis: $\quad \mathrm{C}_{17} \mathrm{H}_{21} \mathrm{NO}_{3}(287.35)$

$\begin{array}{llll}\text { Calcd: } & \text { C, 71.06; } & \text { H, 7.37; } & \text { N, 4.87\% } \\ \text { Found: } & \text { C , 70.95; } & \text { H, 7.42; } & \text { N, 4.85\% }\end{array}$

Preparation of $\quad(+)-4-[(5 R, 2 E)-1-0 x 0-7-p h e n y l-6-m e t h y l-5-h y d r o x y-2,6-$ heptadienyl]morpholine (55) (Table 8, entry 6)

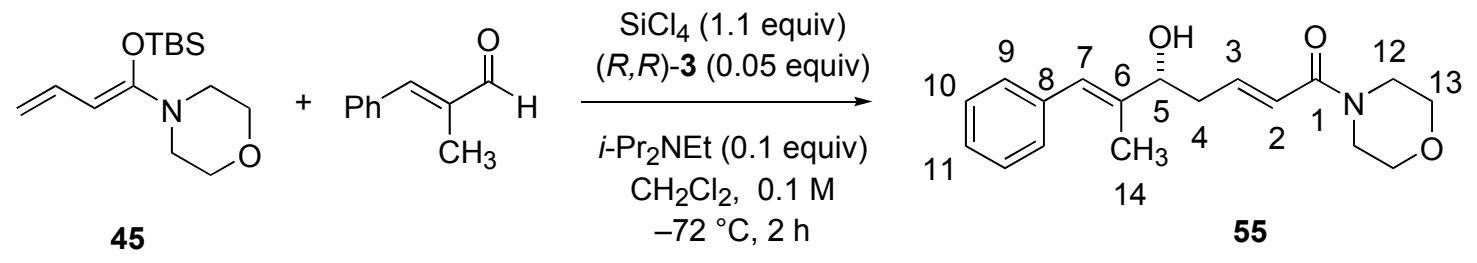

Following Representative Procedure 8, $140 \mu \mathrm{L}$ (1.0 mmol) of $\alpha$-methylcinnamaldehyde 
was combined with $42 \mathrm{mg}(0.05 \mathrm{mmol}, 0.05$ equiv) of bisphosphoramide $(R, R)-3,18 \mu \mathrm{L}(0.1$ mmol, 0.1 equiv) of diisopropylethylamine, $126 \mu \mathrm{L}\left(1.1 \mathrm{mmol}, 1.1\right.$ equiv) of $\mathrm{SiCl}_{4}$ and $324 \mathrm{mg}$ (1.2 mmol, 1.2 equiv) of 45 to yield, after column chromatography $\left(\mathrm{SiO}_{2}(30 \mathrm{~g}), 3 \mathrm{~cm}\right.$ diam., EtOAc $(200 \mathrm{~mL})$ to EtOAc/MeOH, 19/1 (150 mL)) an oil which was crystallized from $\mathrm{Et}_{2} \mathrm{O}(4$ $\mathrm{mL})$ to yield $273 \mathrm{mg}(91 \%)$ of $(+)-55$ as white crystals. The ratio of $\gamma / \alpha$-addition products was determined to be $>99 / 1$ by ${ }^{1} \mathrm{H}$ NMR $(500 \mathrm{MHz})$ analysis of the crude reaction mixture.

Data for $(+)-55$ :

mp: $\quad 79-80{ }^{\circ} \mathrm{C}\left(\mathrm{Et}_{2} \mathrm{O}\right)$

${ }^{1}$ H NMR: $\quad\left(500 \mathrm{MHz}, \mathrm{CDCl}_{3}\right)$

7.37 (dt, $J=7.6,1.3,2 \mathrm{H}, \mathrm{HC}(10)), 7.27$ (dt, $J=7.6,1.7,2 \mathrm{H}, \mathrm{HC}(9)) 7.25$ (dt, $J$ $=7.5,1.2,1 \mathrm{H}, \mathrm{HC}(11)), 6.91(\mathrm{dt}, J=15.0,7.3,1 \mathrm{H}, \mathrm{HC}(3)), 6.54$ (s, $1 \mathrm{H}, \mathrm{HC}(7))$, $6.32(\mathrm{dt}, J=15.1,1.3,1 \mathrm{H}, \mathrm{HC}(2)), 4.34$ (t, $J=6.6,1 \mathrm{H}, \mathrm{HC}(5)), 3.66-3.61$ (m, 8 $\left.\mathrm{H}, \mathrm{H}_{2} \mathrm{C}(12,13)\right), 2.59-2.55$ (m, $\left.2 \mathrm{H}, \mathrm{H}_{2} \mathrm{C}(4)\right), 2.01$ (br s, $\left.1 \mathrm{H}, \mathrm{OH}\right), 1.90$ (d, J=1.2, $\left.3 \mathrm{H}, \mathrm{H}_{3} \mathrm{C}(14)\right)$

${ }^{13} \mathrm{C} \mathrm{NMR}: \quad\left(126 \mathrm{MHz}, \mathrm{CDCl}_{3}\right)$

165.5 (C(1)), 142.8 (C(3)), 139.3 (C(6)), 137.2 (C(8)), 128.8 (C(9)), 128.0 (C(10)), 126.4 (C(11)), 125.7 (C(7)), 122.4 (C(2)), 76.1 (C(5)), 66.48 (C(13)), 66.54 (C(13), 46.0 (C(12)), 45.1 (C(12)), 38.6 (C(4)), 13.5 (C(14))

IR: (neat)

3392 (m), 3055 (m), 3023 (w), 2966 (m), 2918 (m), 2858 (m), $2714(\mathrm{w}), 2361$

(w), $2243(\mathrm{w}), 1957$ (w), 1812 (w), 1659 (s), 1606 (s), 1491 (m), 1436 (s), 1362

(m), 1301 (m), 1267 (s), 1236 (s), 1190 (m), 1116 (s), 1069 (m), 1042 (s), 1019

(m), 977 (m), $920(\mathrm{~m}), 855$ (m), $810(\mathrm{w}), 733$ (s), 701 (s), $646(\mathrm{~m}), 619(\mathrm{w})$

MS: $\quad(E I, 70 \mathrm{eV})$

$301\left(\mathrm{M}^{+}, 2\right), 155$ (66), 147 (40), 140 (30), 129 (24), 115 (10), 91 (18), 87 (11), 69

(14), 62 (100), 61 (26)

Opt. Rot.: $\quad[\alpha]_{\mathrm{D}}^{24}+0.82(\mathrm{c}=1.07, \mathrm{EtOH})$

TLC: $\quad R_{f} 0.14(\mathrm{EtOAc})[\mathrm{UV}(254 \mathrm{~nm})]$

SFC: $\quad(R)-55, t_{\mathrm{R}} 8.67 \min (75.5 \%) ;(S)-55, t_{\mathrm{R}} 10.02 \min (24.5 \%)$ (Chiralpak OB, 150 psi, $40{ }^{\circ} \mathrm{C}, 5.0 \% \mathrm{MeOH}$ in $\mathrm{CO}_{2}, 3.5 \mathrm{~mL} / \mathrm{min}, 220 \mathrm{~nm}$ )

Analysis: $\quad \mathrm{C}_{18} \mathrm{H}_{23} \mathrm{NO}_{3}(301.38)$ 

Calcd:
C, 71.73;
H, 7.69;
$\mathrm{N}, 4.65 \%$
Found:
C, 71.68;
H, 7.73;
$\mathrm{N}, 4.66 \%$

\section{Preparation of 4-[(2E)-1-Oxo-5-phenyl-5-hydroxy-2-pentenyl]morpholine (50) (Scheme 6)}

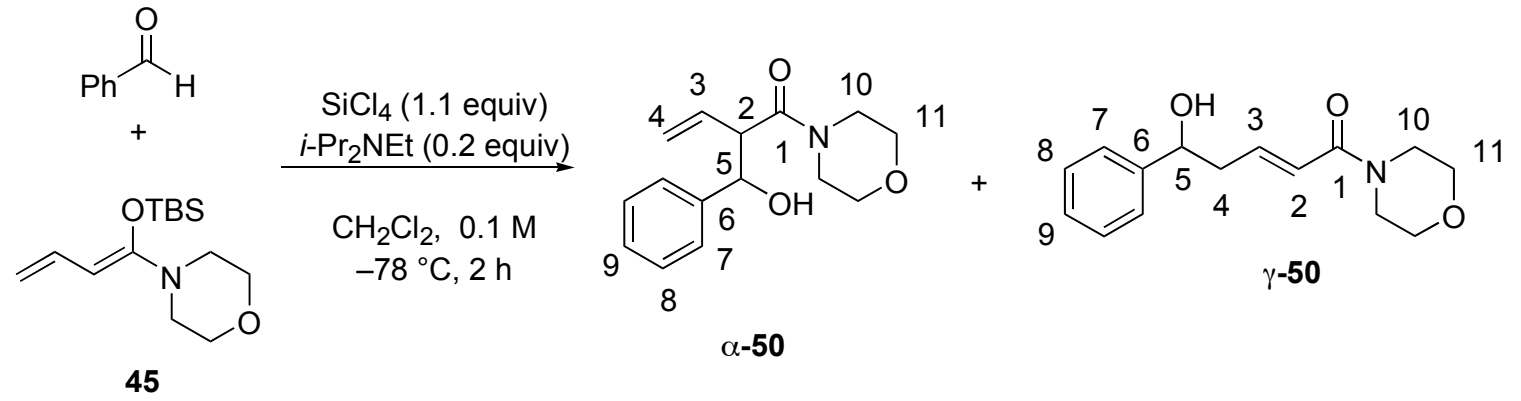

Following Representative Procedure $8,51 \mu \mathrm{L}(0.5 \mathrm{mmol})$ of benzaldehyde was combined with $18 \mu \mathrm{L}$ ( $0.1 \mathrm{mmol}, 0.2$ equiv) of diisopropylethylamine, $63 \mu \mathrm{L}$ ( $0.55 \mathrm{mmol}, 1.1$ equiv) of $\mathrm{SiCl}_{4}$ and $162 \mathrm{mg}$ (0.6 mmol, 1.2 equiv) of 45 to yield, after column chromatography $\left(\mathrm{SiO}_{2}(12\right.$ g), $2 \mathrm{~cm}$ diam., EtOAc $(150 \mathrm{~mL})$ to EtOAc/MeOH, 19/1 $(100 \mathrm{~mL}))$ to yield $48 \mathrm{mg}(37 \%)$ of $\alpha-$ $\mathbf{5 0}$ as a clear, colorless oil and $77 \mathrm{mg}(59 \%)$ of $\boldsymbol{\gamma} \mathbf{- 5 0}$ as a white solid.

Data for $\alpha-50$ :

${ }^{1} \mathrm{H}$ NMR: $\quad\left(500 \mathrm{MHz}, \mathrm{CDCl}_{3}\right)$

7.36-7.23 (m, $5 \mathrm{H}, \mathrm{HC}(7,8,9)), 5.91-5.78(\mathrm{~m}, 1 \mathrm{H}, \mathrm{HC}(3)), 5.22(\mathrm{~d}, J=10.5,1 \mathrm{H}$, HC(4)), 5.04 (d, $J=17.3,1.2,1 \mathrm{H}, \mathrm{HC}(4)), 4.94-4.91$ (m, $1 \mathrm{H}, \mathrm{HC}(5))$ 3.72-3.25 $\left(\mathrm{m}, 9 \mathrm{H}, \mathrm{HC}(2), \mathrm{H}_{2} \mathrm{C}(10,11)\right)$

MS: $\quad\left(\mathrm{CI}, \mathrm{CH}_{4}\right)$ $262\left(\mathrm{M}^{+}+\mathrm{H}, 28\right), 244$ (30), 184 (12), 157 (11), 156 (100), 155 (29), 114 (96), 107 (90), 106 (11), 105 (12), 88 (29), 79 (25), 69 (13)

TLC: $\quad R_{f} 0.32(\mathrm{EtOAc})[\mathrm{UV}(254 \mathrm{~nm})]$

Data for $\gamma-\mathbf{5 0}$ :

${ }^{1}$ H NMR: $\quad\left(500 \mathrm{MHz}, \mathrm{CDCl}_{3}\right)$

7.35-7.25 (m, $5 \mathrm{H}, \mathrm{HC}(7,8,9)), 6.84$ (dt, $J=15.0,6.9,1 \mathrm{H}, \mathrm{HC}(3))$ ), 6.22 (dt, $J=$ 15.0, 1.4, $1 \mathrm{H}, \mathrm{HC}(2)), 4.83$ (dd, $J=7.4,5.6,1 \mathrm{H}, \mathrm{HC}(5)), 3.62-3.43$ (m, $8 \mathrm{H}$, $\left.\mathrm{H}_{2} \mathrm{C}(10,11)\right), 2.69-2.59$ (m, $\left.3 \mathrm{H}, \mathrm{H}_{2} \mathrm{C}(4), \mathrm{OH}\right)$

TLC: $\quad R_{f} 0.17($ EtOAc) [UV(254 nm)] 
Preparation of 4-[(2E)-1-Oxo-7-phenyl-5-hydroxy-2,6-heptadienyl]morpholine (Scheme 6) [JRH-VIII-39]
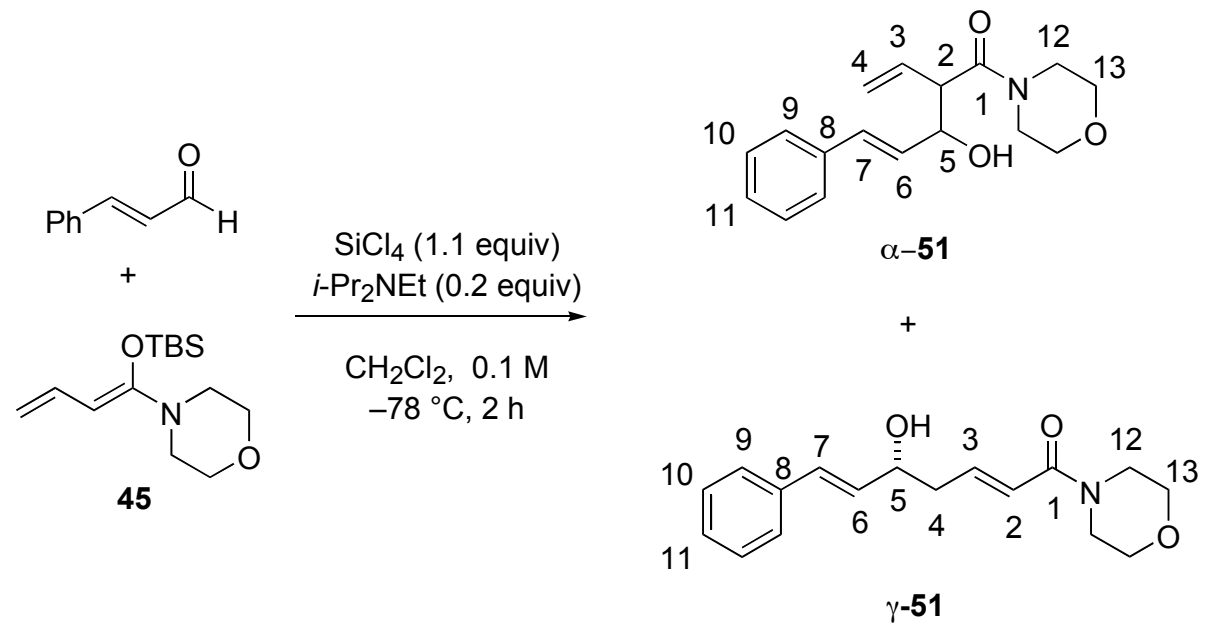

Following Representative Procedure $8,63 \mu \mathrm{L}(0.5 \mathrm{mmol})$ of cinnamaldehyde was combined with $18 \mu \mathrm{L}(0.1 \mathrm{mmol}, 0.2$ equiv) of diisopropylethylamine, $63 \mu \mathrm{L}(0.55 \mathrm{mmol}, 1.1$ equiv) of $\mathrm{SiCl}_{4}$ and $162 \mathrm{mg}$ ( $0.6 \mathrm{mmol}, 1.2$ equiv) of 45 to yield, after column chromatography $\left(\mathrm{SiO}_{2}(12 \mathrm{~g}), 2 \mathrm{~cm}\right.$ diam., EtOAc $(150 \mathrm{~mL})$ to EtOAc/MeOH, 19/1 (100 mL)) to yield $4 \mathrm{mg}(3 \%)$ of $\alpha-51$ as a clear, colorless oil and $106 \mathrm{mg}(74 \%)$ of $\gamma-\mathbf{5 1}$ as a white solid.

Data for $\alpha-51$ :

${ }^{1} \mathrm{H}$ NMR: $\quad\left(500 \mathrm{MHz}, \mathrm{CDCl}_{3}\right)$

$7.41(\mathrm{~d}, J=8.0,2 \mathrm{H}), 7.32(\mathrm{t}, J=7.5,2 \mathrm{H})) 7.27(\mathrm{t}, J=7.3,1 \mathrm{H})), 6.61(\mathrm{~d}, J=$ 15.8, $1 \mathrm{H}), 6.24(\mathrm{dd}, J=15.7,6.1,1 \mathrm{H}), 5.93-5.87$ (m, $1 \mathrm{H}), 5.31-5.19(\mathrm{~m}, 2 \mathrm{H})$, $4.57(\mathrm{t}, J=6.7,1 \mathrm{H}), 3.89-3.47(\mathrm{~m}, 9 \mathrm{H}), 3.78(\mathrm{t}, J=6.8,1 \mathrm{H})$

MS: $\quad\left(\mathrm{CI}, \mathrm{CH}_{4}\right)$ $288\left(\mathrm{M}^{+}+\mathrm{H}, 12\right), 270$ (17), 156 (68), 155 (12), 134 (10), 133 (100), 132 (10), 114 (53), 107 (18), 88 (32)

TLC: $\quad R_{f} 0.28($ EtOAc) $[\mathrm{UV}(254 \mathrm{~nm})]$

Data for $\gamma-51$ :

${ }^{1} \underline{\mathrm{H} N M R}: \quad\left(500 \mathrm{MHz}, \mathrm{CDCl}_{3}\right)$

$7.36(\mathrm{~d}, J=8.0,2 \mathrm{H}, \mathrm{HC}(9)), 7.31$ (t, $J=7.6,2 \mathrm{H}, \mathrm{HC}(10)) 7.26(\mathrm{t}, J=7.5,1 \mathrm{H}$, HC(11)), 6.90 (dt, $J=15.0,7.3,1 \mathrm{H}, \mathrm{HC}(3)), 6.61$ (d, $J=15.9,1 \mathrm{H}, \mathrm{HC}(7)), 6.32$ 
$(\mathrm{dt}, J=15.0,1.5,1 \mathrm{H}, \mathrm{HC}(2)), 6.24(\mathrm{dd}, J=15.9,6.3,1 \mathrm{H}, \mathrm{HC}(6)), 4.46$ (q, $J=$ 5.9, $1 \mathrm{H}, \mathrm{HC}(5)), 3.66-3.52\left(\mathrm{~m}, 8 \mathrm{H}, \mathrm{H}_{2} \mathrm{C}(12,13)\right), 2.55$ (t, $\left.J=6.3,2 \mathrm{H}, \mathrm{H}_{2} \mathrm{C}(4)\right)$, 2.23 (br s, $1 \mathrm{H}, \mathrm{OH}$ )

TLC: $\quad R_{f} 0.14(\mathrm{EtOAc})[\mathrm{UV}(254 \mathrm{~nm})]$

\section{Representative Procedure 9. Addition of Conjugate $\mathrm{N}, \mathrm{O}$-Ketene Acetals to Aliphatic Aldehydes. Preparation of (-)-(2E,5S)- 5-Hydroxy-7-phenyl-2-heptenoic Acid Dimethylamide (56) (Table 9, entry 1)}

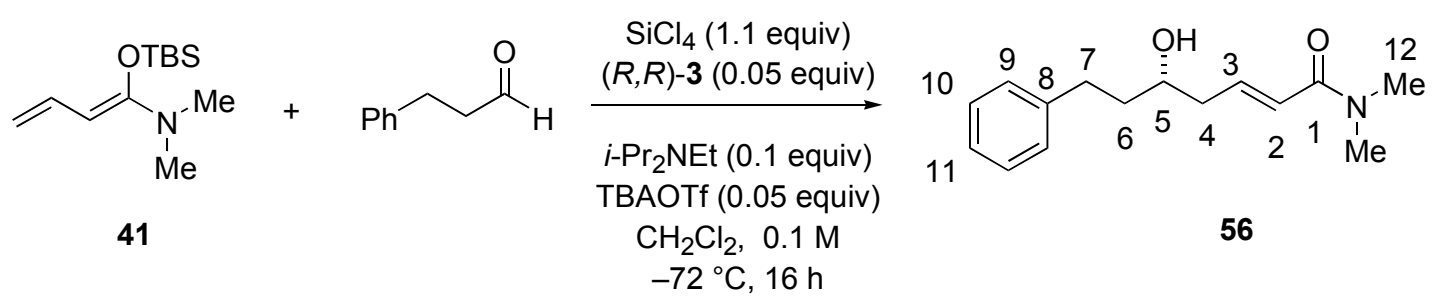

Diisopropylethylamine (18 $\mu \mathrm{L}, 0.1 \mathrm{mmol}, 0.1$ equiv) was added via syringe to a flamedried, 20-mL, Schlenk flask under Ar containing a solution of $42 \mathrm{mg}$ (0.05 mmol, 0.05 equiv) of bisphosphoramide $(R, R)-3$ and $20 \mathrm{mg}(0.05 \mathrm{mmol}, 0.05$ equiv) of tetrabutylammonium triflate in $\mathrm{CH}_{2} \mathrm{Cl}_{2}(5 \mathrm{~mL})$. To this solution was added $132 \mu \mathrm{L}(1.0 \mathrm{mmol}, 1.0$ equiv $)$ of hydrocinnamaldehyde in one portion and the reaction mixture was cooled to $-72{ }^{\circ} \mathrm{C}$ over $15 \mathrm{~min}$. To the resulting solution was added $126 \mu \mathrm{L}$ (1.1 mmol, 1.1 equiv) of $\mathrm{SiCl}_{4}$ in one portion. Then, a solution of $273 \mathrm{mg}$ (1.2 mmol, 1.2 equiv) of $41 \mathrm{in} 5 \mathrm{~mL}$ of $\mathrm{CH}_{2} \mathrm{Cl}_{2}$ was added dropwise over 5 min via syringe. The resulting mixture was stirred at $-72{ }^{\circ} \mathrm{C}$ for $16 \mathrm{~h}$ whereupon $3.0 \mathrm{~mL}$ of chilled $\mathrm{CH}_{2} \mathrm{Cl}_{2}$ was added before the cold reaction mixture was poured into a rapidly stirring solution of $1 / 1$ sat. aq. $\mathrm{NaHCO}_{3} /$ sat. aq. $\mathrm{KF}(25 \mathrm{~mL})$ at $0{ }^{\circ} \mathrm{C}$. This biphasic mixture was stirred vigorously for $3 \mathrm{~h}$ after which the organic layer was removed and the aqueous layer was washed with $\mathrm{CH}_{2} \mathrm{Cl}_{2}(3 \times 50 \mathrm{~mL})$. The combined organic extracts were dried over $\mathrm{Na}_{2} \mathrm{SO}_{4}(5 \mathrm{~g})$, filtered and the filtrate was concentrated in vacuo. The ratio of $\gamma / \alpha$-addition products was determined to be $92 / 8$ by ${ }^{1} \mathrm{H}$ NMR (500 MHz) analysis of the crude reaction mixture. The residue was purified by column chromatography $\left(\mathrm{SiO}_{2}(30 \mathrm{~g}), 3 \mathrm{~cm}\right.$ diam., EtOAc $(200 \mathrm{~mL})$ to EtOAc/MeOH, 19/1 $(150 \mathrm{~mL}))$ to yield $171 \mathrm{mg}(69 \%)$ of $(-)-56$ as a colorless oil. ${ }^{17}$ The ratio of $\gamma / \alpha$-addition products was determined to be $92 / 8$ by ${ }^{1} \mathrm{H}$ NMR (500 MHz) analysis of the crude reaction mixture. 
Data for (-)-56:

bp: $\quad 140{ }^{\circ} \mathrm{C}\left(6.5 \times 10^{-5} \mathrm{mmHg}, \mathrm{ABT}\right)$

${ }^{1}$ H NMR: $\quad\left(500 \mathrm{MHz}, \mathrm{CDCl}_{3}\right)$

7.28 (dt, $J=7.6,2.0,2 \mathrm{H}, \mathrm{HC}(10)), 7.21-7.17$ (m, $3 \mathrm{H}, \mathrm{HC}(9,11)), 6.88$ (dt, $J=$ 15.0, 7.8, $1 \mathrm{H}, \mathrm{HC}(3)), 6.34$ (dt, $J=15.0,1.3,1 \mathrm{H}, \mathrm{HC}(2))$, 3.81-3.76 (m, $1 \mathrm{H}$, $\mathrm{HC}(5)), 3.04$ (br s, $\left.6 \mathrm{H}, \mathrm{H}_{3} \mathrm{C}(12)\right), 2.82$ (dt, J = 13.9, 7.6, $\left.1 \mathrm{H}, \mathrm{HC}(7)\right), 2.69$ (dt, $J$ $=13.8,8.1,1 \mathrm{H}, \mathrm{HC}(7)), 2.47-2.33$ (m, $\left.2 \mathrm{H}, \mathrm{H}_{2} \mathrm{C}(4)\right), 2.00$ (br s, $\left.1 \mathrm{H}, \mathrm{OH}\right), 1.84-$ $1.79\left(\mathrm{~m}, 2 \mathrm{H}, \mathrm{H}_{2} \mathrm{C}(6)\right)$

${ }^{13} \mathrm{C} \mathrm{NMR}: \quad\left(100 \mathrm{MHz}, \mathrm{CDCl}_{3}\right)$

$166.6(\mathrm{C}(1)), 142.4(\mathrm{C}(3)), 142.0$ (C(8)), 128.3 (C(9)), 128.2 (C(10)), 125.6 (C(11)), 122.6 (C(12)), 69.5 (C(2)), 40.7 (C(4)), 38.6 (C(6)), $37.2(\mathrm{C}(12)), 35.6$ (C12)), $31.9(\mathrm{C}(7))$

IR: (neat)

3391 (m), 3085 (w), 3061 (w), 3026 (m), 2931 (m), 2863 (m), 2361 (w), 1951 (w), 1875 (w), 1810 (w), 1660 (s), 1605 (s), 1495 (s), 1455 (m), 1398 (s), 1261 (m), 1225 (w), 1152 (m), 1086 (m), 1053 (m), 1032 (m), 978 (m), 929 (w), 876 (w), $824(\mathrm{w}), 750(\mathrm{~m}), 701(\mathrm{~s}), 639(\mathrm{~m})$

MS: $\quad\left(\mathrm{CI}, \mathrm{CH}_{4}\right)$ 249 (16), $248\left(\mathrm{M}^{+}+\mathrm{H}, 100\right), 230$ (44), 113 (22), 98 (12), 91 (20), 72 (13), 59 (11)

Opt. Rot.: $\quad[\alpha]_{\mathrm{D}}{ }^{24}-6.48(\mathrm{c}=1.02, \mathrm{EtOH})$

TLC: $\quad R_{f} 0.11(\mathrm{EtOAc})[\mathrm{UV}(254 \mathrm{~nm})]$

SFC: $\quad(S)-56, t_{\mathrm{R}} 5.89 \min (90.9 \%) ;(R)-56, t_{\mathrm{R}} 6.37 \min (9.1 \%)$ (Chiralpak AD, 125 psi, $40{ }^{\circ} \mathrm{C}, 10.0 \% \mathrm{MeOH}$ in $\left.\mathrm{CO}_{2}, 2.5 \mathrm{~mL} / \mathrm{min}, 220 \mathrm{~nm}\right)$

HRMS: $\quad$ Calcd for $\mathrm{C}_{15} \mathrm{H}_{22} \mathrm{NO}_{2}: 248.1651$, found: 248.1649 
Preparation of (-)-(2E,5S)-5-Hydroxy-7-phenyl-2-heptenoic Acid Diethylamide (57) (Table 9, entry 2)

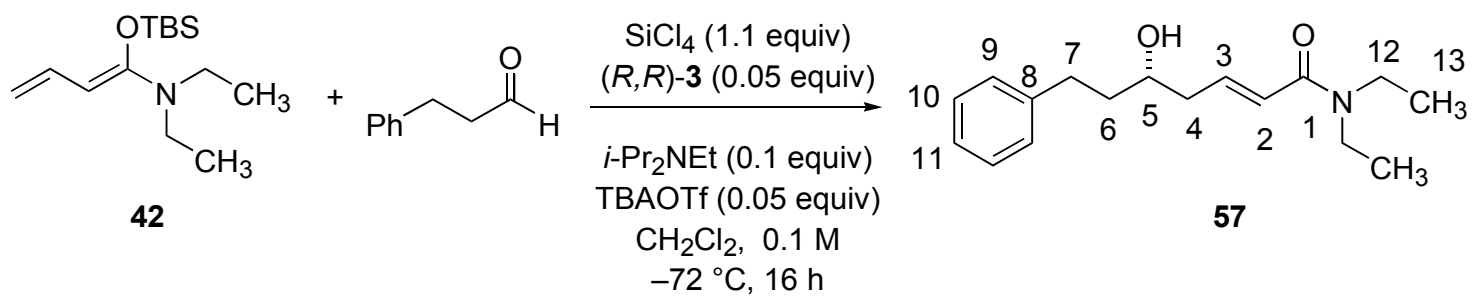

Following Representative Procedure 9, $132 \mu \mathrm{L}(1.0 \mathrm{mmol})$ of hydrocinnamaldehyde, was combined with $42 \mathrm{mg}$ ( $0.05 \mathrm{mmol}, 0.05$ equiv) of bisphosphoramide $(R, R)-3,20 \mathrm{mg}(0.05 \mathrm{mmol}$, 0.05 equiv) of tetrabutylammonium triflate, $18 \mu \mathrm{L} \quad(0.1 \mathrm{mmol}, 0.1$ equiv $)$ of diisopropylethylamine, $126 \mu \mathrm{L}\left(1.1 \mathrm{mmol}, 1.1\right.$ equiv) of $\mathrm{SiCl}_{4}$ and $307 \mathrm{mg}(1.2 \mathrm{mmol}, 1.2$ equiv) of 42 to yield after column chromatography (30 g SiO $2,3 \mathrm{~cm}$ diam., EtOAc), $215 \mathrm{mg}$ (78\%) of (-)-57 as a colorless oil. ${ }^{17}$ The ratio of $\gamma / \alpha$-addition products was determined to be $95 / 5$ by ${ }^{1} \mathrm{H}$ NMR (500 MHz) analysis of the crude reaction mixture.

\section{Data for (-)-57:}

bp: $\quad 150{ }^{\circ} \mathrm{C}\left(6.5 \times 10^{-5} \mathrm{mmHg}, \mathrm{ABT}\right)$

${ }^{1} \mathrm{H}$ NMR: $\quad\left(500 \mathrm{MHz}, \mathrm{CDCl}_{3}\right)$

$7.28(\mathrm{dt}, J=7.5,1.8,2 \mathrm{H}, \mathrm{HC}(10)), 7.21-7.17$ (m, $3 \mathrm{H}, \mathrm{HC}(9,11)), 6.93$ (dt, $J=$ 15.1, 7.1, $1 \mathrm{H}, \mathrm{HC}(3)), 6.28$ (dt, $J=15.1,1.2,1 \mathrm{H}, \mathrm{HC}(2)), 3.79$ (dp, $J=5.9,1.0$, $1 \mathrm{H}, \mathrm{HC}(5)), 3.43-3.38$ (m, $\left.4 \mathrm{H}, \mathrm{H}_{2} \mathrm{C}(12)\right), 2.83$ (dt, $J=13.7,7.7,1 \mathrm{H}, \mathrm{HC}(7)$ ), 2.69 (dt, $J=13.8,8.2,1 \mathrm{H}, \mathrm{HC}(7)), 2.47-2.33$ (m, $\left.3 \mathrm{H}, \mathrm{H}_{2} \mathrm{C}(4), \mathrm{OH}\right), 1.84-1.80$ $\left(\mathrm{m}, 2 \mathrm{H}, \mathrm{H}_{2} \mathrm{C}(6)\right), 1.25-1.18\left(\mathrm{~m}, 6 \mathrm{H}, \mathrm{H}_{3} \mathrm{C}(13)\right)$

${ }^{13} \mathrm{C} \mathrm{NMR}: \quad\left(126 \mathrm{MHz}, \mathrm{CDCl}_{3}\right)$

165.7 (C(1)), 142.3 (C(3)), 142.0 (C(8)), 128.4 (C(9)), 128.2 (C(10)), 125.6 (C(11)), 123.0 (C(12)), 69.6 (C(2)), 42.0 (C(12)), 40.72 (C(4)), 40.65 (C(12)), 38.6 (C(6)), 31.9 (C(7)), 14.7 (C(13)), 13.0 (C(13))

IR: (neat)

3391 (m), 3085 (w), 3061 (w), 3026 (w), 2976 (m), 2933 (m), 1951 (w), 1875 (w), 1810 (w), 1659 (m), 1602 (m), 1484 (m), 1454 (m), 1434 (m), 1380 (m), 1362 (m), 1326 (w), 1271 (m), 1219 (w), 1144 (m), 1081 (m), 1052 (w), 1032 
(w), $976(\mathrm{w}), 934(\mathrm{w}), 842(\mathrm{w}), 814(\mathrm{w}), 777(\mathrm{w}), 748(\mathrm{w}), 701(\mathrm{~m}), 622(\mathrm{w})$

MS: $\quad\left(\mathrm{CI}, \mathrm{CH}_{4}\right)$

$$
277 \text { (20), } 276\left(\mathrm{M}^{+}+\mathrm{H}, 100\right), 258 \text { (26), } 141 \text { (13), } 126 \text { (14), } 91 \text { (18), } 59 \text { (11) }
$$

Opt. Rot.: $\quad[\alpha]_{\mathrm{D}}^{24}-8.36(\mathrm{c}=0.94, \mathrm{EtOH})$

TLC: $\quad R_{f} 0.28$ (EtOAc) [UV $\left.(254 \mathrm{~nm})\right]$

SFC: $\quad(S)-57, t_{\mathrm{R}} 10.18 \min (84.5 \%) ;(R)-57, t_{\mathrm{R}} 11.10 \mathrm{~min}(15.2 \%)$ (Chiralpak AD, 150 psi, $40{ }^{\circ} \mathrm{C}, 3.0 \% \mathrm{MeOH}$ in $\mathrm{CO}_{2}, 3.0 \mathrm{~mL} / \mathrm{min}, 220 \mathrm{~nm}$ )

HRMS: $\quad$ Calcd for $\mathrm{C}_{17} \mathrm{H}_{26} \mathrm{NO}_{2}: 276.1964$, found: 276.1972

Preparation of (-)-1-[(5S,2E)-1-Oxo-7-phenyl-5-hydroxy-2-heptenyl]piperidine (59) (Table 9, entry 4)

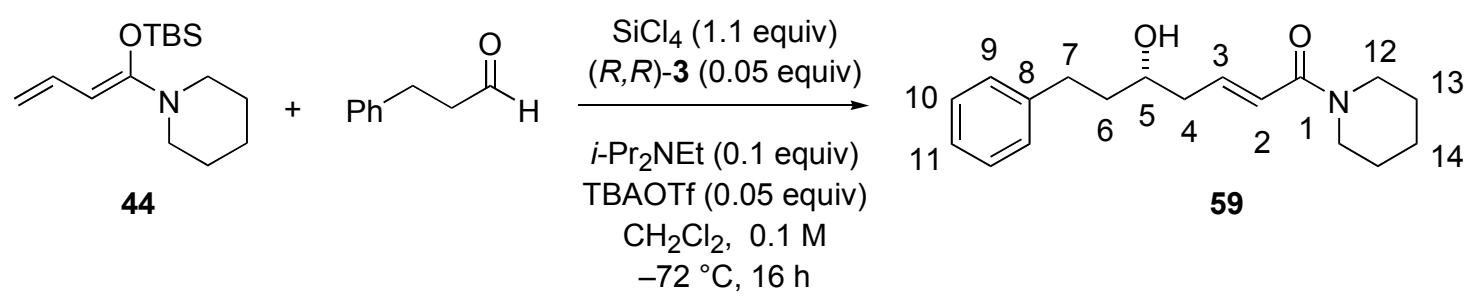

Following Representative Procedure 9, $132 \mu \mathrm{L}(1.0 \mathrm{mmol})$ of hydrocinnamaldehyde, was combined with $42 \mathrm{mg}$ ( $0.05 \mathrm{mmol}, 0.05$ equiv) of bisphosphoramide $(R, R)-3,20 \mathrm{mg}(0.05 \mathrm{mmol}$, 0.05 equiv) of tetrabutylammonium triflate, $18 \mu \mathrm{L} \quad(0.1 \mathrm{mmol}, 0.1$ equiv $)$ of diisopropylethylamine, $126 \mu \mathrm{L}\left(1.1 \mathrm{mmol}, 1.1\right.$ equiv) of $\mathrm{SiCl}_{4}$ and $321 \mathrm{mg}(1.2 \mathrm{mmol}, 1.2$ equiv) of 44 to yield after silica gel column chromatography $\left(\mathrm{SiO}_{2}(30 \mathrm{~g}), 3 \mathrm{~cm}\right.$ diam., EtOAc $(200 \mathrm{~mL})$ to EtOAc/MeOH, 19/1(150 mL)), $201 \mathrm{mg}(70 \%)$ of $(-)-59$ as a colorless oil. ${ }^{17}$ The ratio of $\gamma / \alpha-$ addition products was determined to be $93 / 7$ by ${ }^{1} \mathrm{H}$ NMR $(500 \mathrm{MHz})$ analysis of the crude reaction mixture.

Data for (-)-59:

bp: $\quad 170{ }^{\circ} \mathrm{C}\left(4.5 \times 10^{-5} \mathrm{mmHg}, \mathrm{ABT}\right)$

${ }^{1} \mathrm{H} \mathrm{NMR}: \quad\left(500 \mathrm{MHz}, \mathrm{CDCl}_{3}\right)$

$7.28(\mathrm{dt}, J=7.4,1.8,2 \mathrm{H}, \mathrm{HC}(10)), 7.20-7.17$ (m, $3 \mathrm{H}, \mathrm{HC}(9,11)), 6.82$ (dt, $J=$ 15.0, 7.5, $1 \mathrm{H}, \mathrm{HC}(3)), 6.34$ (dt, $J=14.9,1.2,1 \mathrm{H}, \mathrm{HC}(2))$ ) 3.80-3.75 (m, $1 \mathrm{H}$, $\mathrm{HC}(5)), 3.59-2.88\left(\mathrm{~m}, 4 \mathrm{H}, \mathrm{H}_{2} \mathrm{C}(12)\right), 2.82$ (dt, $\left.J=13.9,7.8,1 \mathrm{H}, \mathrm{HC}(7)\right), 2.68$ 
(m, $J=13.9,8.2,1 \mathrm{H}, \mathrm{HC}(7)), 2.45-2.32$ (m, $\left.2 \mathrm{H}, \mathrm{H}_{2} \mathrm{C}(4)\right)$ ), 2.02 (br s, $1 \mathrm{H}, \mathrm{OH}$ ), 1.83-1.77 (m, 2 H, $\left.\mathrm{H}_{2} \mathrm{C}(6)\right)$ ) 1.68-1.63 (m, $\left.2 \mathrm{H}, \mathrm{H}_{2} \mathrm{C}(14)\right)$, 1.58-1.55 (m, $4 \mathrm{H}$, $\left.\mathrm{H}_{2} \mathrm{C}(13)\right)$

${ }^{13} \mathrm{C} \mathrm{NMR}: \quad\left(126 \mathrm{MHz}, \mathrm{CDCl}_{3}\right)$

165.3 (C(1)), 142.1 (C(8)), 141.9 (C(3)), 128.4 (C(9)), 128.2 (C(10)), 125.6 (C(11)), 123.0 (C(12)), 69.5 (C(2)), 46.8 (C(12)), 43.0 (C(12)), 40.8 (C(4)), 38.6 (C(6)), 31.9 (C(7)), 26.4 (C(13)), 25.4 (C(13)), 24.4 (C(14))

IR: $\quad$ (neat)

3391 (s), 3084 (m), 3061 (m), 3025 (m), 3003 (m), 2935 (s), 2856 (s), 2668 (w), 2362 (w), 2341 (w), 1947 (w), 1871 (w), 1808 (w), 1652 (s), 1600 (s), 1495 (s), 1454 (s), 1367 (m), 1352 (s), 1253 (s), 1224 (s), 1162 (m), 1140 (s), 1125 (m), 1085 (s), 1052 (s), 1017 (s), 975 (s), 954 (m), 928 (m), 853 (m), 829 (m), 807 (m), 749 (s), $701(\mathrm{~s}), 668(\mathrm{~m}), 634(\mathrm{~m})$

MS: $\quad\left(\mathrm{CI}, \mathrm{CH}_{4}\right)$

289 (17), $288\left(\mathrm{M}^{+}+\mathrm{H}, 100\right), 276$ (10), 270 (24), 153 (13), 138 (15), 91 (17), 63

Opt. Rot.: $\quad[\alpha]_{\mathrm{D}}{ }^{24}-10.49(\mathrm{c}=1.18, \mathrm{EtOH})$

TLC: $\quad R_{f} 0.21(\mathrm{EtOAc})[\mathrm{UV}(254 \mathrm{~nm})]$

SFC: $\quad(S)-59, t_{\mathrm{R}} 5.11 \min (96.0 \%) ;(R)-59, t_{\mathrm{R}} 5.67 \mathrm{~min}(4.0 \%)$ (Chiralpak AD, 125 psi, $40{ }^{\circ} \mathrm{C}, 12.5 \% \mathrm{MeOH}$ in $\mathrm{CO}_{2}, 3.0 \mathrm{~mL} / \mathrm{min}, 220 \mathrm{~nm}$ )

HRMS: $\quad$ Calcd for $\mathrm{C}_{18} \mathrm{H}_{26} \mathrm{NO}_{2}: 288.1964$, found: 288.1966

Preparation of (-)-4-[(5S,2E)-1-Oxo-7-phenyl-5-hydroxy-2-heptenyl]morpholine (60) (Table 9, entry 5 and Table 10, entry 1)

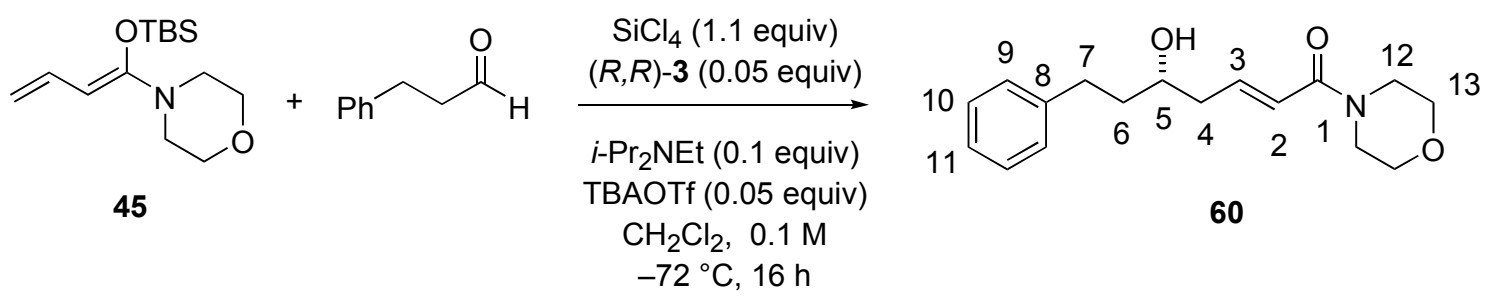

Following Representative Procedure 9, $132 \mu \mathrm{L}(1.0 \mathrm{mmol})$ of hydrocinnamaldehyde, was combined with $42 \mathrm{mg}(0.05 \mathrm{mmol}, 0.05$ equiv) of bisphosphoramide $(R, R)-3,20 \mathrm{mg}(0.05 \mathrm{mmol}$, 
0.05 equiv) of tetrabutylammonium triflate, $18 \mu \mathrm{L} \quad(0.1 \mathrm{mmol}, \quad 0.1$ equiv $)$ of diisopropylethylamine, $126 \mu \mathrm{L}\left(1.1 \mathrm{mmol}, 1.1\right.$ equiv) of $\mathrm{SiCl}_{4}$ and $324 \mathrm{mg}(1.2 \mathrm{mmol}, 1.2$ equiv) of 45 to yield after column chromatography $\left(\mathrm{SiO}_{2}(30 \mathrm{~g}), 3 \mathrm{~cm}\right.$ diam., EtOAc $(200 \mathrm{~mL})$ to EtOAc/MeOH, 19/1 (150 mL)), $230 \mathrm{mg}(80 \%)$ of $(-)-60$ as a colorless oil. ${ }^{17}$ The ratio of $\gamma / \alpha-$ addition products was determined to be $>99 / 1$ by ${ }^{1} \mathrm{H}$ NMR $(500 \mathrm{MHz})$ analysis of the crude reaction mixture.

Data for (-)-60:

bp: $\quad 170{ }^{\circ} \mathrm{C}\left(6.5 \times 10^{-5} \mathrm{mmHg}, \mathrm{ABT}\right)$

${ }^{1}$ H NMR: $\quad\left(500 \mathrm{MHz}, \mathrm{CDCl}_{3}\right)$

7.27 (t, $J=7.4,2 \mathrm{H}, \mathrm{HC}(10)), 7.21-7.18$ (m, $3 \mathrm{H}, \mathrm{HC}(9,11)), 6.90$ (dt, $J=15.0$, 7.8, $1 \mathrm{H}, \mathrm{HC}(3)), 6.29$ (dt, $J=15.0,1.3,1 \mathrm{H}, \mathrm{HC}(2))$, 3.81-3.77 (m, $1 \mathrm{H}, \mathrm{HC}(5))$, 3.68-3.64 (m, $\left.8 \mathrm{H}, \mathrm{H}_{2} \mathrm{C}(12,13)\right), 2.82(\mathrm{dt}, J=13.9,7.4,1 \mathrm{H}, \mathrm{HC}(7)), 2.69$ (dt, $J=$ 13.9, 8.1, $1 \mathrm{H}, \mathrm{HC}(7)), 2.47-2.33$ (m, $2 \mathrm{H}, \mathrm{H}_{2} \mathrm{C}(4)$ ), 2.19 (br s, $1 \mathrm{H}, \mathrm{OH}$ ), 1.84$1.79\left(\mathrm{~m}, 2 \mathrm{H}, \mathrm{H}_{2} \mathrm{C}(6)\right)$

${ }^{13} \mathrm{C} \mathrm{NMR}: \quad\left(126 \mathrm{MHz}, \mathrm{CDCl}_{3}\right)$

165.5 (C(1)), 143.3 (C(3)), 141.9 (C(8)), 128.3 (C(9)), 128.3 (C(10)), 125.7 (C(11)), 121.9 (C(2)), 69.5 (C(5)), 66.6 (C(13)), 66.5 (C(13)), 45.9 (C12)), 42.1 (C(12)), 40.7 (C(4)), $38.6(\mathrm{C}(6)), 31.8(\mathrm{C}(7))$

IR: (neat)

3401 (s), 3084 (m), 3060 (m), 3026 (m), 3001 (m), 2921 (s), 2857 (s), 2761 (w), 2714 (w), 1958 (w), 1878 (w), 1813 (w), 1660 (s), 1652 (s), 1663 (s), 1614 (s), 1495 (s), 1463 (s), 1455 (s), 1434 (s), 1362 (s), 1301 (s), 1267 (s), 1192 (s), 1117 (s), 1069 (s), 1043 (s), 977 (s), 930 (m), 854 (s), 810 (m), 750 (s), 701 (s)

MS: $\quad\left(\mathrm{CI}, \mathrm{CH}_{4}\right)$

291 (20), $290\left(\mathrm{M}^{+}+\mathrm{H}, 100\right), 289$ (10), 272 (32), 155 (21), 91 (21), 63 (11)

Opt. Rot.: $\quad[\alpha]_{\mathrm{D}}{ }^{24}-9.86(\mathrm{c}=1.10, \mathrm{EtOH})$

TLC: $\quad R_{f} 0.11(\mathrm{EtOAc})[\mathrm{UV}(254 \mathrm{~nm})]$

SFC: $\quad(S)-60, t_{\mathrm{R}} 4.31 \mathrm{~min}(99.0 \%) ;(R)-60, t_{\mathrm{R}} 5.08 \mathrm{~min}(1.0 \%)$ (Chiralpak OB, 125 psi, $40{ }^{\circ} \mathrm{C}, 8.0 \% \mathrm{MeOH}$ in $\mathrm{CO}_{2}, 3.0 \mathrm{~mL} / \mathrm{min}, 220 \mathrm{~nm}$ )

HRMS: $\quad$ Calcd for $\mathrm{C}_{17} \mathrm{H}_{24} \mathrm{NO}_{3}: 290.1756$, found: 290.1750 
Preparation of (-)-4-[(5S,2E)-1-Oxo-7-methyl-5-hydroxy-2-octenyl]morpholine (61) (Table 10, entry 2)

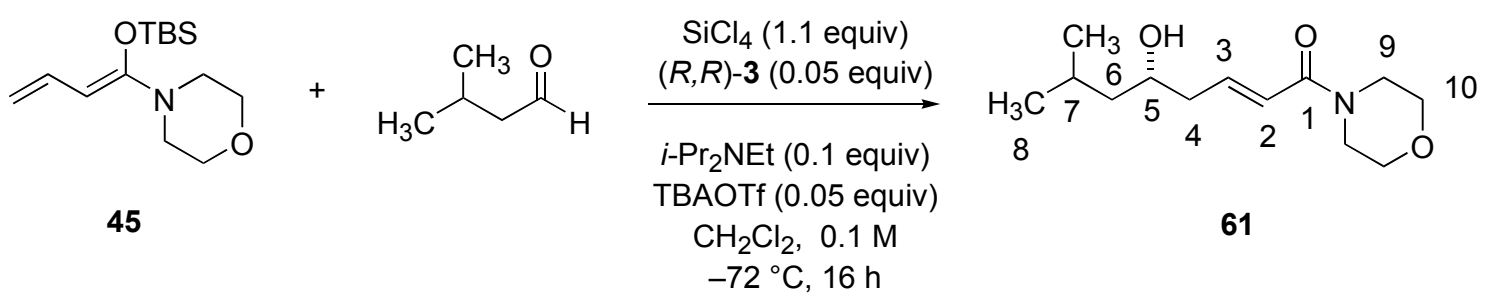

Following Representative Procedure 9, $107 \mu \mathrm{L}(1.0 \mathrm{mmol})$ of isovaleraldehyde, was combined with $42 \mathrm{mg}$ (0.05 mmol, 0.05 equiv) of bisphosphoramide $(R, R)-3,20 \mathrm{mg}(0.05 \mathrm{mmol}$, 0.05 equiv) of tetrabutylammonium triflate, $18 \mu \mathrm{L} \quad(0.1 \mathrm{mmol}, 0.1$ equiv $)$ of diisopropylethylamine, $126 \mu \mathrm{L}\left(1.1 \mathrm{mmol}, 1.1\right.$ equiv) of $\mathrm{SiCl}_{4}$ and $324 \mathrm{mg}(1.2 \mathrm{mmol}, 1.2$ equiv) of 45 to yield after column chromatography $\left(\mathrm{SiO}_{2}(30 \mathrm{~g}), 3 \mathrm{~cm}\right.$ diam., EtOAc $(200 \mathrm{~mL})$ to EtOAc/MeOH, 19/1 (150 mL)), $203 \mathrm{mg}(84 \%)$ of (-)-61 as a colorless oil. ${ }^{17}$ The ratio of $\gamma / \alpha-$ addition products was determined to be $>99 / 1$ by ${ }^{1} \mathrm{H}$ NMR $(500 \mathrm{MHz})$ analysis of the crude reaction mixture.

Data for (-)-61:

bp: $\quad 140{ }^{\circ} \mathrm{C}\left(6.5 \times 10^{-5} \mathrm{mmHg}, \mathrm{ABT}\right)$

${ }^{1}$ H NMR: $\quad\left(500 \mathrm{MHz}, \mathrm{CDCl}_{3}\right)$

$6.94(\mathrm{dt}, J=15.0,7.4,1 \mathrm{H}, \mathrm{HC}(3)), 6.30(\mathrm{dt}, J=15.1,1.3,1 \mathrm{H}, \mathrm{HC}(2)), 3.88$ 3.83 (m, $1 \mathrm{H}, \mathrm{HC}(5))$ ) 3.71-3.63 (m, $\left.8 \mathrm{H}, \mathrm{H}_{2} \mathrm{C}(9,10)\right)$, 2.44-2.29 (m, $\left.2 \mathrm{H}, \mathrm{H}_{2} \mathrm{C}(4)\right)$ ), 2.04 (br s, 1 H, OH), 1.79 (d, hept., $J=6.6,2.2,1$ H, HC(7)), 1.48-1.43 (m, 1 H, $\mathrm{HC}(6))$, 1.42-1.24 (m, H, HC(6)), 0.93 (d, $J=6.8,3$ H, $\left.\mathrm{H}_{3} \mathrm{C}(8)\right), 0.91$ (d, J = 6.8, $3 \mathrm{H}, \mathrm{H}_{3} \mathrm{C}(8)$ )

${ }^{13} \mathrm{C} \mathrm{NMR}: \quad\left(126 \mathrm{MHz}, \mathrm{CDCl}_{3}\right)$ $165.5(\mathrm{C}(1)), 143.4(\mathrm{C}(3)), 121.8(\mathrm{C}(2)), 68.2$ (C(5)), 66.7 (C(10)), 66.6 (C(10)), 46.1 (C(6)), 46.0 (C(9)), 42.1 (C(9)), 41.1 (C(4)), 24.4 (C(7)), 23.3 (C(8)), 21.8 $(\mathrm{C}(8))$

IR: (neat)

3402 (s), 3059 (m), 2955 (s), 2922 (s), 2867 (s), 2761 (w), 2718 (w), 2349 (w), 2229 (w), 2107 (w), 1962 (w), 1660 (s), 1614 (s), 1434 (s), 1385 (s), 1366 (s), 
1301 (s), 1267 (s), 1237 (s), 1189 (s), 1139 (s), 1116 (s), 1069 (s), 1037 (s), 979 (s), $920(\mathrm{~m}), 855(\mathrm{~s}), 814(\mathrm{~m}), 702(\mathrm{~m})$

MS: $\quad\left(\mathrm{CI}, \mathrm{CH}_{4}\right)$ 243 (15), $242\left(\mathrm{M}^{+}+\mathrm{H}, 100\right), 244$ (38), 155 (42), 140 (11), 69 (19),

Opt. Rot.: $\quad[\alpha]_{\mathrm{D}}{ }^{24}-4.80(\mathrm{c}=1.21, \mathrm{EtOH})$

TLC: $\quad R_{f} 0.12(\mathrm{EtOAc})[\mathrm{UV}(254 \mathrm{~nm})]$

SFC: $\quad(S)-61, t_{\mathrm{R}} 2.23 \min (99.8 \%) ;(R)-61, t_{\mathrm{R}} 2.54 \min (0.2 \%)$ (Chiralpak AD, 125 psi, $40{ }^{\circ} \mathrm{C}, 12.5 \% \mathrm{MeOH}$ in $\mathrm{CO}_{2}, 3.0 \mathrm{~mL} / \mathrm{min}, 220 \mathrm{~nm}$ )

HRMS: Calcd for $\mathrm{C}_{13} \mathrm{H}_{24} \mathrm{NO}_{3}: 242.1756$, found: 242.1753

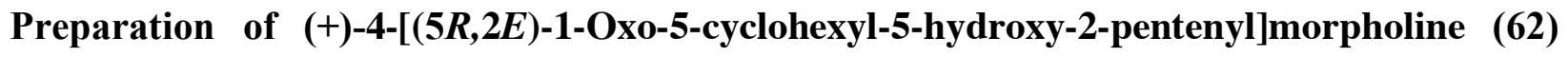
(Table 10, entry 3)

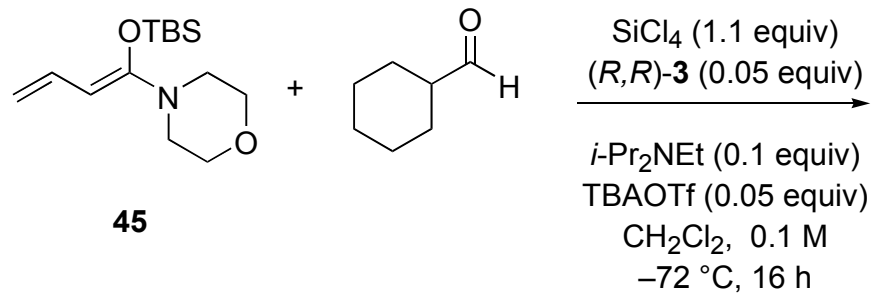

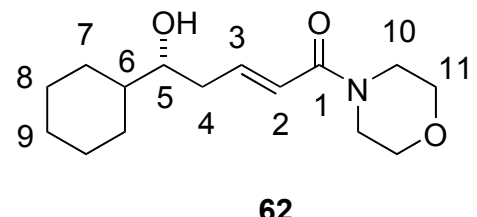

62

Following Representative Procedure 9, $121 \mu \mathrm{L} \quad\left(\begin{array}{llll}1.0 & \mathrm{mmol}\end{array}\right)$ of cyclohexanecarboxaldehyde was combined with $42 \mathrm{mg}(0.05 \mathrm{mmol}, 0.05$ equiv) of bisphosphoramide $(R, R)-3,20 \mathrm{mg}(0.05 \mathrm{mmol}, 0.05$ equiv) of tetrabutylammonium triflate, 18 $\mu \mathrm{L}\left(0.1 \mathrm{mmol}, 0.1\right.$ equiv) of diisopropylethylamine, $126 \mu \mathrm{L}\left(1.1 \mathrm{mmol}, 1.1\right.$ equiv) of $\mathrm{SiCl}_{4}$ and $324 \mathrm{mg}$ (1.2 mmol, 1.2 equiv) of 45 to yield after column chromatography $\left(\mathrm{SiO}_{2}(30 \mathrm{~g}), 3 \mathrm{~cm}\right.$ diam., EtOAc $(200 \mathrm{~mL})$ to EtOAc/MeOH, 19/1 (150 mL), a solid which was recrystallized by precipitation from hot EtOAc $(4 \mathrm{~mL})$ with minimal amounts of hexanes to yield $168 \mathrm{mg}(63 \%)$ of (+)-62 as white crystals. The ratio of $\gamma / \alpha$-addition products was determined to be $>99 / 1$ by ${ }^{1} \mathrm{H}$ NMR (500 MHz) analysis of the crude reaction mixture.

Data for $(+)-62$ :

mp: $\quad 85-86^{\circ} \mathrm{C}($ EtOAc/hexanes $)$

${ }^{1}$ H NMR: $\quad\left(500 \mathrm{MHz}, \mathrm{CDCl}_{3}\right)$

$6.91(\mathrm{dt}, J=15.0,7.4,1 \mathrm{H}, \mathrm{HC}(3)), 6.30$ (dt, $J=15.1,1.2,1 \mathrm{H}, \mathrm{HC}(2)), 3.68$ 3.49 (m, $9 \mathrm{H}, \mathrm{HC}(5), \mathrm{H}_{2} \mathrm{C}(12,13)$ ), 2.46-2.28 (m, $2 \mathrm{H}, \mathrm{H}_{2} \mathrm{C}(4)$ ), 1.90 (br s, $1 \mathrm{H}$, 
$\mathrm{OH}), 1.85-1.82(\mathrm{~m}, 1 \mathrm{H}),, 1.78-1.73$ (m, $2 \mathrm{H},), 1.68-1.65$ (m, $2 \mathrm{H},), 1.41-1.33$ (m, $1 \mathrm{H}, \mathrm{HC}(6)), 1.28-0.97(\mathrm{~m}, 5 \mathrm{H}$ )

${ }^{13} \mathrm{C} \mathrm{NMR}: \quad\left(126 \mathrm{MHz}, \mathrm{CDCl}_{3}\right)$

165.7 (C(1)), 144.4 (C(3)), 121.9 (C(2)), 74.7 (C(5)), 66.93 (C(12)), 66.85 (C(12)), 46.2 (C(13)), 43.4 (C(6)), 42.3 (C(13)), 37.6 (C(4)), 29.3, 28.1, 26.6, $26.3,26.2$

IR: $\quad\left(\mathrm{CHCl}_{3}\right)$

3431 (w), 3017 (m), 2971 (w), 2928 (m), 2856 (m), 2672 (w), 2438 (w), 2400 (w), 2349 (w), 2233 (w), 1962 (w), 1657 (m), 1608 (m), 1461 (m), 1438 (m), 1362 (w), 1300 (m), 1259 (m), 1236 (m), 1216 (s), 1173 (m), 1115 (m), 1087 (w), $1069(\mathrm{w}), 1036(\mathrm{~m}), 976(\mathrm{~m}), 950(\mathrm{w}), 926(\mathrm{w}), 893$ (w), $854(\mathrm{w}), 758(\mathrm{~s}), 668$ (m), $640(\mathrm{w})$

MS: $\quad\left(\mathrm{CI}, \mathrm{CH}_{4}\right)$ 269 (18), $268\left(\mathrm{M}^{+}+\mathrm{H}, 100\right), 266$ (25), 251 (14), 250 (75), 234 (10), 156 (29), 155 (52), 140 (13), 114 (10), 95 (30), 88 (21), 86 (10), 69 (20), 63 (28), 57 (16), 55 (18)

Opt. Rot.: $\quad[\alpha]_{\mathrm{D}}{ }^{24}+10.84(\mathrm{c}=0.90, \mathrm{EtOH})$

TLC: $\quad R_{f} 0.11(\mathrm{EtOAc})[\mathrm{UV}(254 \mathrm{~nm})]$

SFC: $\quad(R)-62, t_{\mathrm{R}} 1.88 \min (99.4 \%) ;(S)-62, t_{\mathrm{R}} 2.15 \min (0.6 \%)$ (Chiralpak OJ, 125 psi, $40{ }^{\circ} \mathrm{C}, 9.0 \% \mathrm{MeOH}$ in $\mathrm{CO}_{2}, 3.0 \mathrm{~mL} / \mathrm{min}, 220 \mathrm{~nm}$ )

Analysis: $\quad \mathrm{C}_{15} \mathrm{H}_{25} \mathrm{NO}_{3}(267.36)$

Calcd: $\quad$ C, 67.38; H, 9.42; $\quad$ N, 5.24\%

Found: $\quad \mathrm{C}, 67.25 ; \quad \mathrm{H}, 9.63 ; \quad \mathrm{N}, 5.40 \%$ 


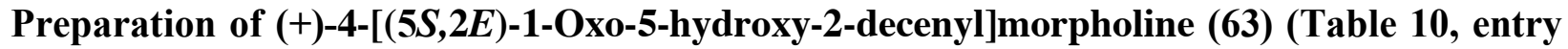
4)
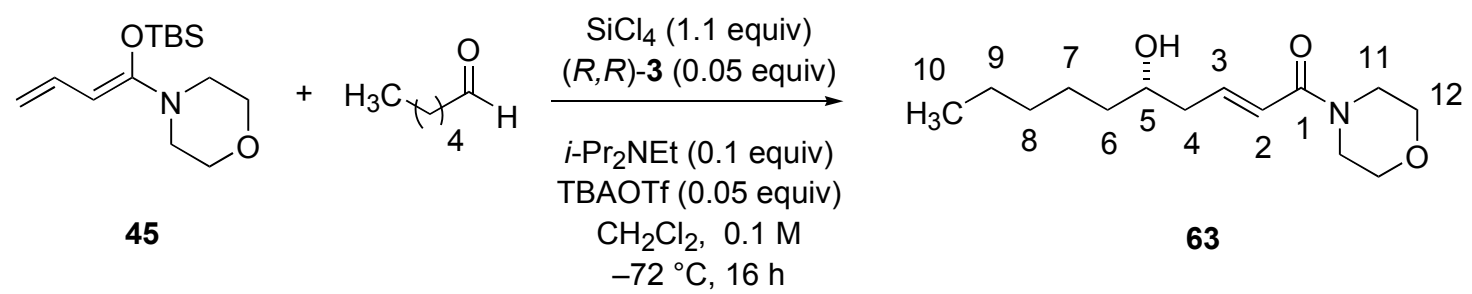

Following Representative Procedure 9, $120 \mu \mathrm{L}(1.0 \mathrm{mmol})$ of hexanal, was combined with $42 \mathrm{mg}$ (0.05 mmol, 0.05 equiv) of bisphosphoramide $(R, R)-3,20 \mathrm{mg}(0.05 \mathrm{mmol}, 0.05$ equiv) of tetrabutylammonium triflate, $18 \mu \mathrm{L}(0.1 \mathrm{mmol}, 0.1$ equiv) of diisopropylethylamine, $126 \mu \mathrm{L}$ (1.1 mmol, 1.1 equiv) of $\mathrm{SiCl}_{4}$ (1.2 mmol, 1.2 equiv) and $324 \mathrm{mg}$ of 45 to yield after column chromatography $\left(\mathrm{SiO}_{2}(30 \mathrm{~g}), 3 \mathrm{~cm}\right.$ diam., EtOAc $(200 \mathrm{~mL})$ to EtOAc/MeOH, 19/1 (150 $\mathrm{mL})$ ), $201 \mathrm{mg}(79 \%)$ of $(+)-63$ as a colorless oil. ${ }^{17}$ The ratio of $\gamma / \alpha$-addition products was determined to be $>99 / 1$ by ${ }^{1} \mathrm{H}$ NMR $(500 \mathrm{MHz})$ analysis of the crude reaction mixture.

Data for $(+)-63$ :

bp: $\quad 125^{\circ} \mathrm{C}\left(5.0 \times 10^{-5} \mathrm{mmHg}, \mathrm{ABT}\right)$

${ }^{1} \mathrm{H}$ NMR: $\quad\left(500 \mathrm{MHz}, \mathrm{CDCl}_{3}\right)$

$6.92(\mathrm{dt}, J=15.1,7.4,1 \mathrm{H}, \mathrm{HC}(3)), 6.30$ (dt, $J=15.1,1.3,1 \mathrm{H}, \mathrm{HC}(2)), 3.78-3.74$ (m, $1 \mathrm{H}, \mathrm{HC}(5))$, 3.70-3.62 (m, $\left.8 \mathrm{H}, \mathrm{H}_{2} \mathrm{C}(11,12)\right)$, 2.45-2.29 (m, $\left.2 \mathrm{H}, \mathrm{H}_{2} \mathrm{C}(4)\right)$, 1.93-1.85 (m, $1 \mathrm{H}, \mathrm{OH}), 1.51-1.42\left(\mathrm{~m}, 4 \mathrm{H}, \mathrm{H}_{2} \mathrm{C}(6,7)\right)$, 1.36-1.25 (m, $4 \mathrm{H}$, $\left.\mathrm{H}_{2} \mathrm{C}(8,9)\right), 0.89$ (t, $\left.J=7.0,3 \mathrm{H}, \mathrm{H}_{3} \mathrm{C}(10)\right)$

${ }^{13} \mathrm{C} \mathrm{NMR}: \quad\left(126 \mathrm{MHz}, \mathrm{CDCl}_{3}\right)$

165.5 (C(1)), 143.5 (C(3)), 121.7 (C(2)), 70.2 (C(5)), 66.6 (C(11)), 45.9 (C(12)), $42.1(\mathrm{C}(12)), 40.5(\mathrm{C}(4)), 36.9(\mathrm{C}(6)), 31.6(\mathrm{C}(8)), 25.1(\mathrm{C}(7)), 22.4(\mathrm{C}(9)), 13.9$ (C(10))

IR: (neat)

3412 (s), 2956 (s), 2929 (s), 2857 (s), 2760 (w), 2718 (w), 2360 (w), 1658 (s), 1607 (s), 1435 (s), 1378 (m), 1361 (m), 1301 (s), 1267 (s), 1236 (s), 1194 (m), 1116 (s), 1070 (s), 1035 (s), 977 (s), 929 (w), 854 (m), 812 (w), 762 (w), 699 (w), $668(\mathrm{w})$

MS: $\quad\left(\mathrm{CI}, \mathrm{CH}_{4}\right)$

257 (16), $256\left(\mathrm{M}^{+}+\mathrm{H}, 100\right), 254$ (15), 238 (41), 156 (21), 155 (42), 140 (13), 88, 


$$
\text { (11), } 83(10), 69(21)
$$

Opt. Rot.: $\quad[\alpha]_{\mathrm{D}}^{24}+2.26(\mathrm{c}=1.20, \mathrm{EtOH})$

TLC: $\quad R_{f} 0.13(\mathrm{EtOAc})[\mathrm{UV}(254 \mathrm{~nm})]$

SFC: $\quad(S)-63, t_{\mathrm{R}} 2.92 \min (94.3 \%) ;(R)-63, t_{\mathrm{R}} 3.33 \mathrm{~min}(5.7 \%)$ (Chiralpak OB, $125 \mathrm{psi}$, $40{ }^{\circ} \mathrm{C}, 3.5 \% \mathrm{MeOH}$ in $\mathrm{CO}_{2}, 3.0 \mathrm{~mL} / \mathrm{min}, 220 \mathrm{~nm}$ )

HRMS: $\quad$ Calcd for $\mathrm{C}_{14} \mathrm{H}_{26} \mathrm{NO}_{3}: 256.1913$, found: 256.1905

Preparation of (-)-4-[(5S,2E)-1-Oxo-7-benzyloxy-5-hydroxy-2-heptenyl]morpholine (67) (Table 11, entry 4)

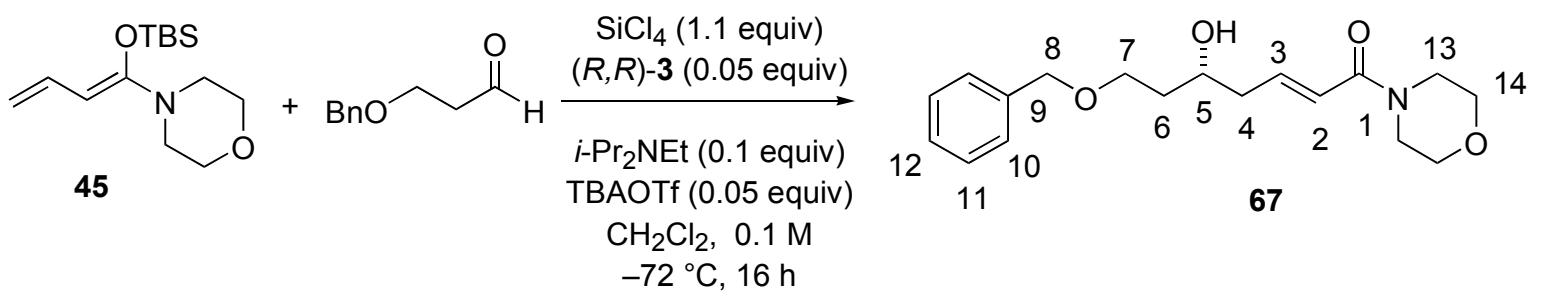

Following Representative Procedure 9, $164 \mathrm{mg}$ (1.0 mmol) of 3-benzyloxypropanal, was combined with $42 \mathrm{mg}$ (0.05 mmol, 0.05 equiv) of bisphosphoramide $(R, R)-3,20 \mathrm{mg}(0.05 \mathrm{mmol}$, 0.05 equiv) of tetrabutylammonium triflate, $18 \mu \mathrm{L} \quad(0.1 \mathrm{mmol}, \quad 0.1$ equiv $)$ of diisopropylethylamine, $126 \mu \mathrm{L}\left(1.1 \mathrm{mmol}, 1.1\right.$ equiv) of $\mathrm{SiCl}_{4}$ and $324 \mathrm{mg}(1.2 \mathrm{mmol}, 1.2$ equiv) of 45 to yield after column chromatography $\left(\mathrm{SiO}_{2}(30 \mathrm{~g}), 3 \mathrm{~cm}\right.$ diam., EtOAc $(200 \mathrm{~mL})$ to EtOAc/MeOH, 19/1 (150 mL)), $155 \mathrm{mg}(49 \%)$ of (-)-67 as a colorless oil. ${ }^{17}$ The ratio of $\gamma / \alpha-$ addition products was determined to be $>99 / 1$ by ${ }^{1} \mathrm{H}$ NMR $(500 \mathrm{MHz})$ analysis of the crude reaction mixture.

Data for (-)-67:

${ }^{1} \mathrm{H}$ NMR: $\quad\left(500 \mathrm{MHz}, \mathrm{CDCl}_{3}\right)$

7.37-7.26 (m, 5 H, HC(10,11,12)), 6.89 (dt, $J=14.9,7.3,1$ H, HC(3)), 6.29 (dd, $J$

$=15.1,1.2,1 \mathrm{H}, \mathrm{HC}(2)), 4.52$ (s, $\left.2 \mathrm{H}, \mathrm{H}_{2} \mathrm{C}(8)\right)$, 4.01-3.96 (m, $\left.1 \mathrm{H}, \mathrm{HC}(5)\right), 3.75-$

3.55 (m, $\left.10 \mathrm{H}, \mathrm{H}_{2} \mathrm{C}(7,12,13)\right), 3.03$ (br s, $\left.1 \mathrm{H}, \mathrm{OH}\right), 2.45-2.35$ (m, $2 \mathrm{H}, \mathrm{H}_{2} \mathrm{C}(4)$ ),

1.81-1.76 (m, $\left.2 \mathrm{H}, \mathrm{H}_{2} \mathrm{C}(6)\right)$

${ }^{13} \mathrm{C} \mathrm{NMR}: \quad\left(126 \mathrm{MHz}, \mathrm{CDCl}_{3}\right)$

165.3 (C(1)), 142.9 (C(3)), 137.8 (C(9)), 128.3 (C(11)), 127.6 (C(12)), 127.5 (C(10)), 121.7 (C(2)), 73.1 (C(8)), 69.5 (C(5)), 68.4 (C(14)), 66.6 (C(7)), 45.9 (C13)), 42.1 (C(13)), 40.4 (C(4)), $36.0(\mathrm{C}(6))$ 
IR: (neat)

3413 (s), 3087 (w), 3062 (w), 3030 (m), 2919 (s), 2858 (s), 2715 (w), 2239 (w), 1960 (w), 1878 (w), 1815 (w), 1659 (s), 1614 (s), 1496 (m), 1434 (s), 1363 (s), 1301 (s), 1267 (s), 1238 (s), 1115 (s), 1029 (s), 978 (s), 918 (m), 853 (m), 809 (m), $739(\mathrm{~s}), 700(\mathrm{~s}), 639(\mathrm{~m})$

MS: $\quad\left(\mathrm{CI}, \mathrm{CH}_{4}\right)$ 321 (21) $320\left(\mathrm{M}^{+}+\mathrm{H}, 100\right), 213$ (10), 91 (26), 86 (43), 85 (19), 84 (69), 83 (28)

Opt. Rot.: $\quad[\alpha]_{\mathrm{D}}{ }^{24}-2.15(\mathrm{c}=1.01, \mathrm{EtOH})$

TLC: $\quad R_{f} 0.11(\mathrm{EtOAc})[\mathrm{UV}(254 \mathrm{~nm})]$

SFC: $\quad(S)-67, t_{\mathrm{R}} 3.29 \min (83.7 \%) ;(R)-67 t_{\mathrm{R}} 3.73 \min (16.3 \%)$ (Chiralpak OB, 125 psi, $40{ }^{\circ} \mathrm{C}, 10.0 \% \mathrm{MeOH}$ in $\mathrm{CO}_{2}, 3.0 \mathrm{~mL} / \mathrm{min}, 220 \mathrm{~nm}$ )

HRMS: $\quad$ Calcd for $\mathrm{C}_{18} \mathrm{H}_{26} \mathrm{NO}_{4}: 320.1862$, found: 320.1856

\section{Preparation of (-)-4-[(5S,2E)-1-Oxo-7-(2-propenyl)-5-hydroxy-2-heptenyl]morpholine (68)} (Table 11, entry 5)

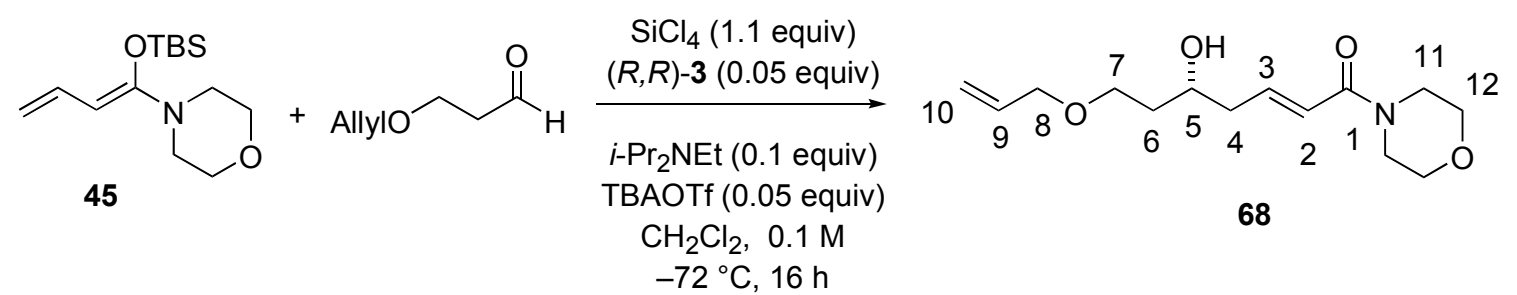

Following Representative Procedure 9, $31 \mu \mathrm{L}(0.25 \mathrm{mmol})$ of 3-allyloxypropanal, was combined with $11 \mathrm{mg}(0.0125 \mathrm{mmol}, 0.05$ equiv) of bisphosphoramide $(R, R)-3,5 \mathrm{mg}(0.0125$ mmol, 0.05 equiv) of tetrabutylammonium triflate, $32 \mu \mathrm{L}\left(0.275 \mathrm{mmol}, 1.1\right.$ equiv) of $\mathrm{SiCl}_{4}$ and $81 \mathrm{mg}\left(0.3 \mathrm{mmol}, 1.2\right.$ equiv) of 45 to yield after column chromatography $\left(\mathrm{SiO}_{2}(14 \mathrm{~g}), 2 \mathrm{~cm}\right.$ diam., EtOAc (150 mL) to EtOAc/MeOH, 19/1 (100 mL)), $20 \mathrm{mg}(30 \%)$ of (-)-68 as a colorless oil. The ratio of $\gamma / \alpha$-addition products was determined to be $>99 / 1$ by ${ }^{1} \mathrm{H}$ NMR $(500 \mathrm{MHz})$ analysis of the crude reaction mixture.

Data for (-)-68

${ }^{1} \mathrm{H}$ NMR: $\quad\left(500 \mathrm{MHz}, \mathrm{CDCl}_{3}\right)$

$6.92(\mathrm{dt}, J=15.1,7.2,1 \mathrm{H}, \mathrm{HC}(3)), 6.31$ (dt, $J=15.0,1.4,1 \mathrm{H}, \mathrm{HC}(2)), 5.93-5.85$ 
(m, $1 \mathrm{H}, \mathrm{HC}(9)), 5.27$ (dq, $J=17.2,1.6,1 \mathrm{H}, \mathrm{HC}(10)), 5.19$ (dq, $J=10.3,1.5,1$ $\mathrm{H}, \mathrm{HC}(10))$, 4.01-3.96 (m, $\left.3 \mathrm{H}, \mathrm{HC}(5), \mathrm{H}_{2} \mathrm{C}(8)\right), 3.71-3.60$ (m, $10 \mathrm{H}$, $\left.\mathrm{H}_{2} \mathrm{C}(7,11,12)\right), 2.52-2.38$ (m, $\left.3 \mathrm{H}, \mathrm{OH}, \mathrm{H}_{2} \mathrm{C}(4)\right)$, 1.79-1.75 (m, $\left.2 \mathrm{H}, \mathrm{H}_{2} \mathrm{C}(6)\right)$

${ }^{13} \mathrm{C} \mathrm{NMR}: \quad\left(126 \mathrm{MHz}, \mathrm{CDCl}_{3}\right)$

$165.4(\mathrm{C}(1)), 142.9$ (C(3)), 134.2 (C(9)), 122.0 (C(2)), 117.2 (C(10)), $72.1(\mathrm{C}(8))$, 70.3 (C(5)), 68.9 (C(7)), 66.8 (C(12)), 46.1 (C11)), 42.2 (C(11)), 40.5 (C(4)), 36.0 $(\mathrm{C}(6))$

MS: $\quad\left(\mathrm{CI}, \mathrm{CH}_{4}\right)$

298 (16), $271(17), 270\left(\mathrm{M}^{+}+\mathrm{H}, 100\right), 252$ (11), 155 (10)

Opt. Rot.: $\quad[\alpha]_{\mathrm{D}}{ }^{24}-0.76(\mathrm{c}=0.66, \mathrm{EtOH})$

TLC: $\quad R_{f} 0.07($ EtOAc) [UV $(254 \mathrm{~nm})]$

SFC: $\quad(S)-68, t_{\mathrm{R}} 6.51 \mathrm{~min}(83.5 \%) ;(R)-68, t_{\mathrm{R}} 6.87 \mathrm{~min}(16.5 \%)$ (Chiralpak AD, $175 \mathrm{psi}$, $40{ }^{\circ} \mathrm{C}, 8.0 \% \mathrm{MeOH}$ in $\mathrm{CO}_{2}, 2.0 \mathrm{~mL} / \mathrm{min}, 220 \mathrm{~nm}$ )

HRMS: $\quad$ Calcd for $\mathrm{C}_{14} \mathrm{H}_{24} \mathrm{NO}_{4}: 270.1705$, found: 270.1703

Preparation of (-)-4-[(5S,2E)-1-Oxo-7-benzoate-5-hydroxy-2-heptenyl]morpholine (69) (Table 11, entry 6)

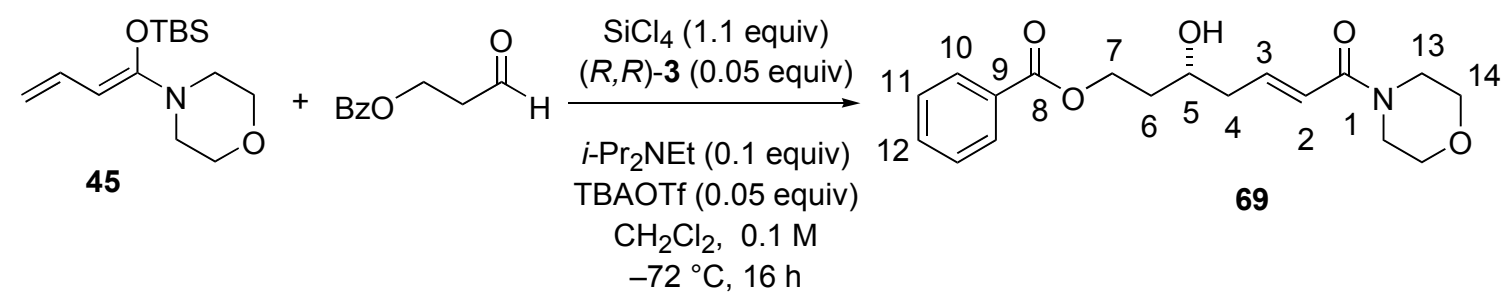

Following Representative Procedure 9, $45 \mathrm{mg}(0.25 \mathrm{mmol})$ of 3-benzoyloxypropanal, was combined with $11 \mathrm{mg}$ (0.0125 mmol, 0.05 equiv) of bisphosphoramide $(R, R)-3,5 \mathrm{mg}$ ( $0.0125 \mathrm{mmol}, 0.05$ equiv) of tetrabutylammonium triflate, $32 \mu \mathrm{L}(0.275 \mathrm{mmol}, 1.1$ equiv) of $\mathrm{SiCl}_{4}$ and $81 \mathrm{mg}\left(0.3 \mathrm{mmol}, 1.2\right.$ equiv) of 45 to yield after column chromatography $\left(\mathrm{SiO}_{2}(14 \mathrm{~g})\right.$, $2 \mathrm{~cm}$ diam., EtOAc (150 mL) to EtOAc/MeOH, 19/1 (100 mL)), $34 \mathrm{mg}(41 \%)$ of (-)-69 as a colorless oil. The ratio of $\gamma / \alpha$-addition products was determined to be $>99 / 1$ by ${ }^{1} \mathrm{H}$ NMR (500 $\mathrm{MHz}$ ) analysis of the crude reaction mixture. 
Data for (-)-69:

${ }^{1} \mathrm{H}$ NMR: $\quad\left(500 \mathrm{MHz}, \mathrm{CDCl}_{3}\right)$

8.04 (dt, $J=8.3,1.6,2$ H, HC(10)), 7.57 (tt, $J=7.4,1.4,1 \mathrm{H}, \mathrm{HC}(12)), 7.45$ (dt, $J$ =8.1, 1.6, 2 H, HC(11)), 6.91 (dt, $J=15.1,7.6,1 \mathrm{H}, \mathrm{HC}(3)), 6.29$ (dt, $J=15.0$, 1.4, $1 \mathrm{H}, \mathrm{HC}(2))$, 4.65-4.60 (m, $1 \mathrm{H}, \mathrm{HC}(7))$, 4.43-4.39 (m, $1 \mathrm{H}, \mathrm{HC}(7))$, 3.95$3.90(\mathrm{~m}, 1 \mathrm{H}, \mathrm{HC}(5)), 3.67-3.54\left(\mathrm{~m}, 8 \mathrm{H}, \mathrm{H}_{2} \mathrm{C}(12,13)\right), 2.49(\mathrm{~m}, 3 \mathrm{H}, \mathrm{OH}$, $\left.\mathrm{H}_{2} \mathrm{C}(4)\right), 2.03-2.00$ (m, $\left.1 \mathrm{H}, \mathrm{HC}(6)\right), 1.86-1.82$ (m, $\left.1 \mathrm{H}, \mathrm{HC}(6)\right)$

${ }^{13} \mathrm{C} \mathrm{NMR}: \quad\left(126 \mathrm{MHz}, \mathrm{CDCl}_{3}\right)$

166.9 (C(8)), 165.4 (C(1)), 142.7 (C(3)), 133.1 (C(12)), 130.0 (C(9)), 129.6 (C(10)), $128.4(\mathrm{C}(11)), 122.3(\mathrm{C}(2)), 67.2$ (C(5)), 66.7 (C(14)), $61.8(\mathrm{C}(7)), 46.1$ (C13)), 42.3 (C(13)), 40.5 (C(4)), 36.2 (C(6))

MS: $\quad\left(\mathrm{CI}, \mathrm{CH}_{4}\right)$ $334\left(\mathrm{M}^{+}+\mathrm{H}, 50\right), 123$ (100), 122 (10), 105 (29), 79 (16)

Opt. Rot.: $\quad[\alpha]_{\mathrm{D}}^{24}-3.81(\mathrm{c}=0.75, \mathrm{EtOH})$

TLC: $\quad R_{f} 0.11(\mathrm{EtOAc})[\mathrm{UV}(254 \mathrm{~nm})]$

SFC: $\quad(S)-69, t_{\mathrm{R}} 3.53 \min (70.0 \%) ;(R)-69, t_{\mathrm{R}} 4.00 \min (30.0 \%)$ (Chiralpak OB, 125 psi, $40{ }^{\circ} \mathrm{C}, 9.0 \% \mathrm{MeOH}$ in $\mathrm{CO}_{2}, 3.0 \mathrm{~mL} / \mathrm{min}, 220 \mathrm{~nm}$ )

HRMS: $\quad$ Calcd for $\mathrm{C}_{18} \mathrm{H}_{24} \mathrm{NO}_{5}: 334.1654$, found: 334.1656

Preparation of (+)-4-[(5S,2E)-1-Oxo-10-benzyloxy-5-hydroxy-2-decenyl]morpholine (71) (Table 11, entry 8)
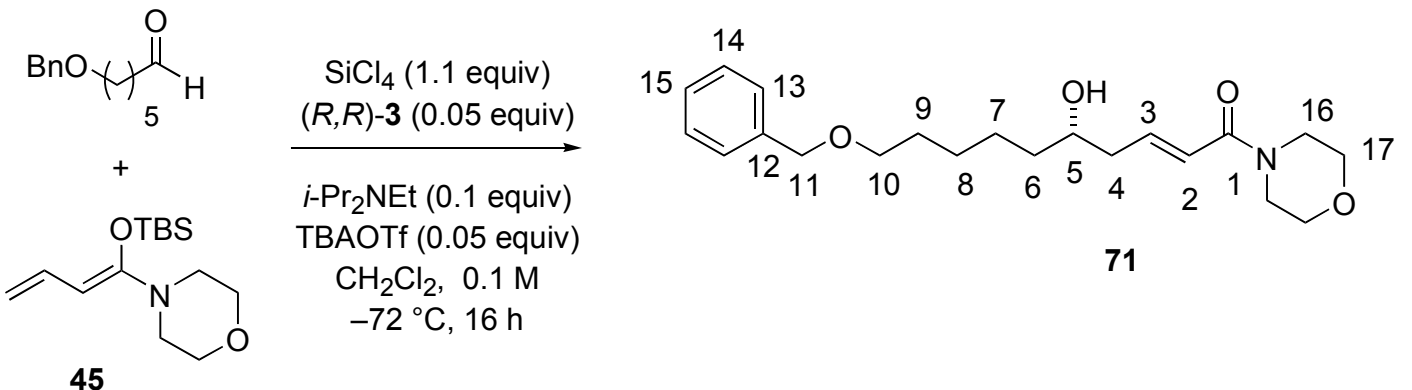

Following Representative Procedure 9, $206 \mathrm{mg}$ (1.0 mmol) of 6-benzyloxypropanal, was combined with $42 \mathrm{mg}$ (0.05 mmol, 0.05 equiv) of bisphosphoramide $(R, R)-3,20 \mathrm{mg}(0.05 \mathrm{mmol}$, 0.05 equiv) of tetrabutylammonium triflate, $18 \mu \mathrm{L} \quad(0.1 \mathrm{mmol}, 0.1$ equiv $)$ of 
diisopropylethylamine, $126 \mu \mathrm{L}\left(1.1 \mathrm{mmol}, 1.1\right.$ equiv) of $\mathrm{SiCl}_{4}$ and $324 \mathrm{mg}(1.2 \mathrm{mmol}, 1.2$ equiv) of 45 to yield after column chromatography $\left(\mathrm{SiO}_{2}(30 \mathrm{~g}), 3 \mathrm{~cm}\right.$ diam., EtOAc $(200 \mathrm{~mL})$ to EtOAc/MeOH, 19/1 (200 mL)), $308 \mathrm{mg}(85 \%)$ of $(+)-71$ as a colorless oil. ${ }^{17}$ The ratio of $\gamma / \alpha-$ addition products was determined to be $>99 / 1$ by ${ }^{1} \mathrm{H}$ NMR $(500 \mathrm{MHz})$ analysis of the crude reaction mixture.

Data for $(+)-71$ :

${ }^{1}$ H NMR: $\quad\left(500 \mathrm{MHz}, \mathrm{CDCl}_{3}\right)$

7.36-7.32 (m, 4 H, HC(13,14)), 7.29-7.26 (m, 1 H, HC(15)), 6.93 (dt, $J=15.1$, 7.1, $1 \mathrm{H}, \mathrm{HC}(3)), 6.31$ (d, $J=15.1,1 \mathrm{H}, \mathrm{HC}(2)), 4.50$ (s, $\left.2 \mathrm{H}, \mathrm{H}_{2} \mathrm{C}(11)\right), 3.78-3.64$ (m, 9 H, HC(5), $\left.\mathrm{H}_{2} \mathrm{C}(16,17)\right), 3.47$ (t, $J=6.5,2$ H, $\left.\mathrm{H}_{2} \mathrm{C}(10)\right)$ ) 2.45-2.30 (m, $2 \mathrm{H}$, $\left.\mathrm{H}_{2} \mathrm{C}(4)\right), 2.17$ (br s, $\left.1 \mathrm{H}, \mathrm{OH}\right), 1.63$ (p, $\left.J=6.8,2 \mathrm{H}, \mathrm{H}_{2} \mathrm{C}(9)\right)$ ) 1.52-1.35 (m, $6 \mathrm{H}$, $\left.\mathrm{H}_{2} \mathrm{C}(6,7,8)\right)$

${ }^{13} \mathrm{C} \mathrm{NMR}: \quad\left(126 \mathrm{MHz}, \mathrm{CDCl}_{3}\right)$

165.4 (C(1)), 143.4 (C(3)), 138.4 (C(12)), 128.1 (C(14)), 127.4 (C(13)), 127.2 (C(15)), $121.6(\mathrm{C}(2)), 72.6$ (C(11)), 70.1 (C(10)), 70.0 (C(5)), 66.5 (C(17)), 45.9 (C16)), 42.0 (C(16)), 40.4 (C(4)), 36.8 (C(6)), 29.5 (C(9), 26.0 (C(8)), 25.3 (C(7))

IR: (neat)

3415 (m), 3087 (w), 3062 (w), 3030 (w), 2932 (s), 2857 (s), 2361 (w), 2341 (w), 1959 (w), 1812 (w), 1657 (s), 1606 (s), 1496 (m), 1454 (s), 1435 (s), 1362 (m), 1267 (s), 1237 (s), 1163 (m), 1116 (s), 1070 (s), 1031 (s), 978 (s), 917 (w), 854 (m), $817(\mathrm{w}), 739(\mathrm{~s}), 699(\mathrm{~s}), 640(\mathrm{~m})$

MS: $\quad\left(\mathrm{CI}, \mathrm{CH}_{4}\right)$

$362\left(\mathrm{M}^{+}+\mathrm{H}, 40\right), 156$ (14), 107 (12), 91 (19), 63 (100), 62 (24)

Opt. Rot.: $\quad[\alpha]_{\mathrm{D}}^{24}+0.35(\mathrm{c}=1.15, \mathrm{EtOH})$

TLC: $\quad R_{f} 0.12(\mathrm{EtOAc})$ [UV $\left.(254 \mathrm{~nm})\right]$

SFC: $\quad(S)-71, t_{\mathrm{R}} 2.36 \min (92.5 \%) ;(R)-71, t_{\mathrm{R}} 3.41 \mathrm{~min}(7.5 \%)$ (Chiralpak OB, 150 psi, $40{ }^{\circ} \mathrm{C}, 20.0 \% \mathrm{MeOH}$ in $\mathrm{CO}_{2}, 3.0 \mathrm{~mL} / \mathrm{min}, 220 \mathrm{~nm}$ )

HRMS: Calcd for $\mathrm{C}_{21} \mathrm{H}_{32} \mathrm{NO}_{4}: 362.2331$, found: 362.2326 
Preparation of 4-[(5S,2E)-1-Oxo-7-phenyl-5-hydroxy-2-methyl-2-heptenyl]morpholine (75) (Table 12, entry 1)

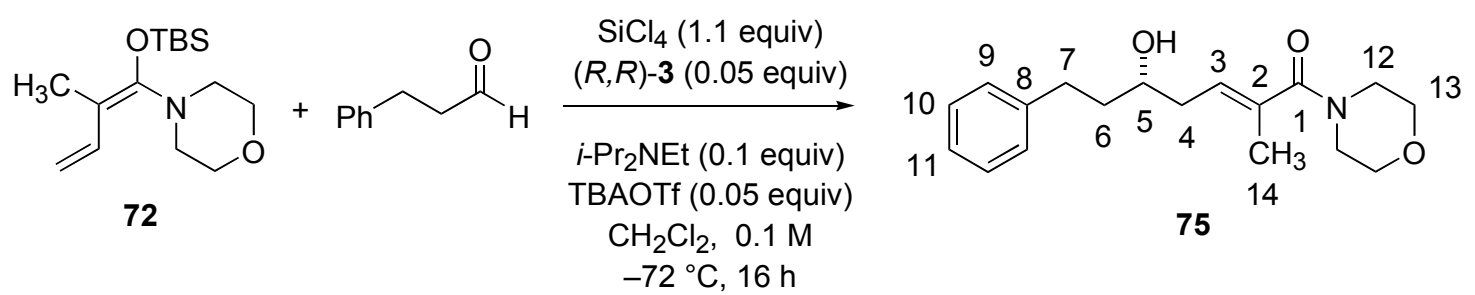

Following Representative Procedure $9,33 \mu \mathrm{L}(0.25 \mathrm{mmol})$ of hydrocinnamaldehyde, was combined with $11 \mathrm{mg}(0.0125 \mathrm{mmol}, 0.05$ equiv) of bisphosphoramide $(R, R)-3,5 \mathrm{mg}(0.0125$ mmol, 0.05 equiv) of tetrabutylammonium triflate, $4 \mu \mathrm{L}(0.025 \mathrm{mmol}, 0.1$ equiv) of diisopropylethylamine, $32 \mu \mathrm{L}\left(0.275 \mathrm{mmol}, 1.1\right.$ equiv) of $\mathrm{SiCl}_{4}$ and $85 \mathrm{mg}(0.3 \mathrm{mmol}, 1.2$ equiv) of 72 to yield after column chromatography $\left(\mathrm{SiO}_{2}(10 \mathrm{~g}), 2 \mathrm{~cm}\right.$ diam., EtOAc $(100 \mathrm{~mL})$ to EtOAc/MeOH, 19/1 (100 mL)), $24 \mathrm{mg}(32 \%)$ of 75 as a colorless oil. The ratio of $\gamma / \alpha$-addition products was determined to be $>99 / 1$ by ${ }^{1} \mathrm{H}$ NMR $(500 \mathrm{MHz})$ analysis of the crude reaction mixture.

Data for 75:

${ }^{1} \mathrm{H}$ NMR: $\quad\left(500 \mathrm{MHz}, \mathrm{CDCl}_{3}\right)$

$7.29(\mathrm{t}, J=7.5,2 \mathrm{H}, \mathrm{HC}(10)), 7.23-7.19$ (m, $3 \mathrm{H}, \mathrm{HC}(9,11)), 5.61(\mathrm{dt}, J=7.3,1.5$, $1 \mathrm{H}, \mathrm{HC}(3))$, 3.76-3.56 (m, $\left.9 \mathrm{H}, \mathrm{HC}(5), \mathrm{H}_{2} \mathrm{C}(12,13)\right), 2.81$ (dt, $J=13.9,7.6,1 \mathrm{H}$, $\mathrm{HC}(7)), 2.68$ (dt, $J=13.9,8.1,1 \mathrm{H}, \mathrm{HC}(7)), 2.31$ (t, $\left.J=6.6,2 \mathrm{H}, \mathrm{H}_{2} \mathrm{C}(4)\right), 1.85$ (s, $\left.3 \mathrm{H}, \mathrm{H}_{3} \mathrm{C}(14)\right)$, 1.82-1.78 (m, $\left.2 \mathrm{H}, \mathrm{H}_{2} \mathrm{C}(6)\right)$

TLC: $\quad R_{f} 0.10(\mathrm{EtOAc})[\mathrm{UV}(254 \mathrm{~nm})]$

SFC: $\quad(R)-75, t_{\mathrm{R}} 9.27 \min (1.0 \%) ;(S)-75, t_{\mathrm{R}} 9.97 \min (99.0 \%)$ (Chiralpak OJ, 200 psi, 40 ${ }^{\circ} \mathrm{C}, 4.0 \% \mathrm{MeOH}$ in $\mathrm{CO}_{2}, 2.25 \mathrm{~mL} / \mathrm{min}, 220 \mathrm{~nm}$ ) 
Preparation of (-)-4-[(5S,2E)-1-Oxo-7-phenyl-5-hydroxy-2-methyl-2-heptenyl]morpholine (75) (Table 12, entry 2)

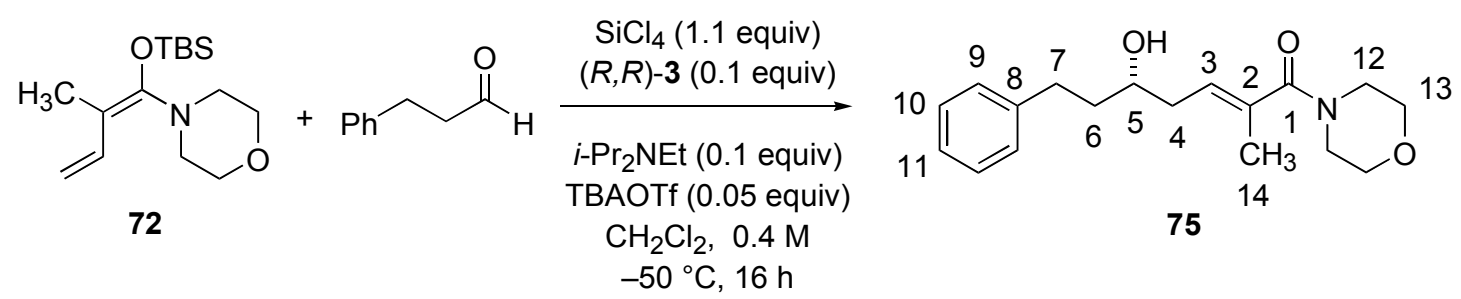

Diisopropylethylamine (18 $\mu \mathrm{L}, 0.1 \mathrm{mmol}, 0.1$ equiv) was added via syringe to a flamedried, 20-mL, Schlenk flask under Ar containing a solution of $84 \mathrm{mg}$ ( $0.1 \mathrm{mmol}, 0.1$ equiv) of bisphosphoramide $(R, R)-3$ and $20 \mathrm{mg}(0.05 \mathrm{mmol}, 0.05$ equiv) of tetrabutylammonium triflate in $\mathrm{CH}_{2} \mathrm{Cl}_{2}$ (1.25 mL). To this solution was added $132 \mu \mathrm{L}(1.0 \mathrm{mmol}, 1.0$ equiv) of hydrocinnamaldehyde in one portion and the reaction mixture was cooled to $-50{ }^{\circ} \mathrm{C}$ over $15 \mathrm{~min}$. To the resulting solution was added $126 \mu \mathrm{L}$ (1.1 mmol, 1.1 equiv) of $\mathrm{SiCl}_{4}$ in one portion. Then, a solution of $340 \mathrm{mg}$ (1.2 mmol, 1.2 equiv) of 72 in $1.25 \mathrm{~mL}$ of $\mathrm{CH}_{2} \mathrm{Cl}_{2}$ was added dropwise over 5 min via syringe. The resulting mixture was stirred at $-50{ }^{\circ} \mathrm{C}$ for $16 \mathrm{~h}$ whereupon $3.0 \mathrm{~mL}$ of chilled $\mathrm{CH}_{2} \mathrm{Cl}_{2}$ was added before the cold reaction mixture was poured into a rapidly stirring solution of $1 / 1$ sat. aq. $\mathrm{NaHCO}_{3} /$ sat. aq. $\mathrm{KF}(25 \mathrm{~mL})$ at $0{ }^{\circ} \mathrm{C}$. This biphasic mixture was stirred vigorously for $3 \mathrm{~h}$ after which the organic layer was removed and the aqueous layer was washed with $\mathrm{CH}_{2} \mathrm{Cl}_{2}(3 \times 50 \mathrm{~mL})$. The combined organic extracts were dried over $\mathrm{Na}_{2} \mathrm{SO}_{4}(5 \mathrm{~g})$, filtered and the filtrate was concentrated in vacuo. The ratio of $\gamma / \alpha$-addition products was determined to be $>99 / 1$ by ${ }^{1} \mathrm{H}$ NMR $(500 \mathrm{MHz})$ analysis of the crude reaction mixture. The residue was purified by column chromatography $\left(\mathrm{SiO}_{2}(25 \mathrm{~g}), 3 \mathrm{~cm}\right.$ diam., EtOAc $(150 \mathrm{~mL})$ to EtOAc/MeOH, 19/1 (200 mL)) to yield $199 \mathrm{mg}(66 \%)$ of $(-)-75$ as a colorless oil. ${ }^{17}$

\section{Data for (-)-75:}

bp: $\quad 160^{\circ} \mathrm{C}\left(5.0 \times 10^{-5} \mathrm{mmHg}, \mathrm{ABT}\right)$

${ }^{1} \mathrm{H}$ NMR: $\quad\left(500 \mathrm{MHz}, \mathrm{CDCl}_{3}\right)$

7.29 (t, $J=7.6,2 \mathrm{H}, \mathrm{HC}(10)), 7.21-7.18$ (m, $3 \mathrm{H}, \mathrm{HC}(9,11)), 5.60$ (dt, $J=7.3,1.5$, $1 \mathrm{H}, \mathrm{HC}(3))$, 3.74-3.56 (m, $\left.9 \mathrm{H}, \mathrm{HC}(5), \mathrm{H}_{2} \mathrm{C}(12,13)\right), 2.81$ (dt, $J=13.9,7.6,1 \mathrm{H}$, HC(7)), 2.69 (dt, $J=13.9,8.1,1 \mathrm{H}, \mathrm{HC}(7)), 2.30$ (t, $\left.J=6.7,2 \mathrm{H}, \mathrm{H}_{2} \mathrm{C}(4)\right), 1.90$ (br s, $1 \mathrm{H}, \mathrm{OH}), 1.85$ (s, $\left.3 \mathrm{H}, \mathrm{H}_{3} \mathrm{C}(14)\right), 1.82-1.78$ (m, $2 \mathrm{H}, \mathrm{H}_{2} \mathrm{C}(6)$ ) 
NOE ${ }^{1} \mathrm{H}$ NMR: $\left(500 \mathrm{MHz}, \mathrm{CDCl}_{3}\right)$

Irradiation at $5.61 \mathrm{ppm}(\mathrm{HC}(3))$ enhanced signal at 3.72-3.67 ppm $(\mathrm{HC}(5)), 3.62-$ $3.54\left(\mathrm{H}_{2} \mathrm{C}(12,13)\right)$ and $2.28 \mathrm{ppm}\left(\mathrm{H}_{2} \mathrm{C}(4)\right)$

${ }^{13} \mathrm{C} \mathrm{NMR}: \quad\left(126 \mathrm{MHz}, \mathrm{CDCl}_{3}\right)$

172.2 (C(1)), 141.9 (C(8)), 132.4 (C(2)), 128.0 (C(9), C(10)), 127.7 (C(3)), 125.5

(C(11)), 69.8 (C(5)), 66.5 (C(13)), 47.1 (C12)), 41.9 (C(12)), 38.5 (C(6)), 35.4 (C(4)), 31.7 (C(7)), 14.3 (C(14))

IR: $\quad$ (neat)

3402 (s), 3084 (w), 3061 (w), 3026 (m), 2921 (s), 2857 (s), 2759 (w), 2683 (w), 1952 (w), 1877 (w), 1810 (w), 1614 (s), 1495 (m), 1455 (s), 1434 (s), 1380 (m), 1363 (m), 1300 (s), 1278 (s), 1258 (s), 1210 (m), 1157 (m), 1115 (s), 1068 (s), 1031 (s), 973 (m), 934 (m), 904 (m), 840 (m), 749 (m), 701 (s), 639 (m), 606 (m)

MS: $\quad\left(\mathrm{CI}, \mathrm{CH}_{4}\right)$ 305 (23), $304\left(\mathrm{M}^{+}+\mathrm{H}, 100\right), 286$ (28), 169 (23), 91 (11), 86 (21), 84 (30)

Opt. Rot.: $\quad[\alpha]_{\mathrm{D}}{ }^{24}-6.08(\mathrm{c}=1.30, \mathrm{EtOH})$

TLC: $\quad R_{f} 0.10($ EtOAc) [UV $(254 \mathrm{~nm})]$

SFC: $\quad(R)-75, t_{\mathrm{R}} 5.90 \min (3.0 \%) ;(S)-75, t_{\mathrm{R}} 6.26 \min (97.0 \%)$ (Chiralpak AD, 150 psi, $40{ }^{\circ} \mathrm{C}, 8.0 \% \mathrm{MeOH}$ in $\mathrm{CO}_{2}, 3.0 \mathrm{~mL} / \mathrm{min}, 220 \mathrm{~nm}$ )

HRMS: $\quad$ Calcd for $\mathrm{C}_{18} \mathrm{H}_{26} \mathrm{NO}_{3}: 304.1913$, found: 304.1908

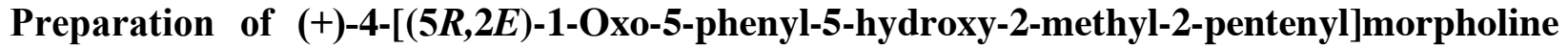
(76) (Table 12, entry 3)<smiles>C=CC(C)=C([OH2+])N1CCOCC1</smiles>

72

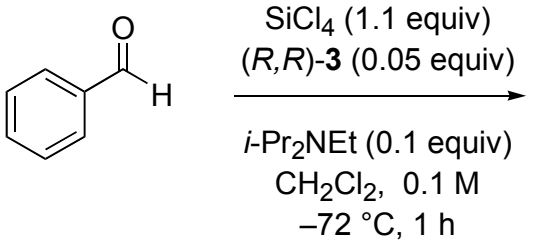

$-72{ }^{\circ} \mathrm{C}, 1 \mathrm{~h}$

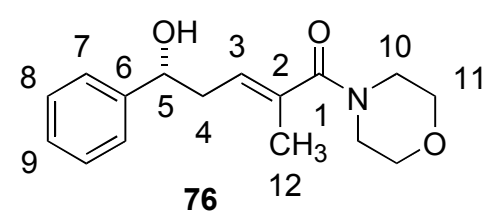

76

Following Representative Procedure 8, $102 \mu \mathrm{L}(1.0 \mathrm{mmol})$ of benzaldehyde was combined with $42 \mathrm{mg}$ (0.05 mmol, 0.05 equiv) of bisphosphoramide $(R, R)-3,18 \mu \mathrm{L}(0.1 \mathrm{mmol}$, 0.1 equiv) of diisopropylethylamine, $126 \mu \mathrm{L}\left(1.1 \mathrm{mmol}, 1.1\right.$ equiv) of $\mathrm{SiCl}_{4}$ and $340 \mathrm{mg}(1.2$ mmol, 1.2 equiv) of 72 to yield, after column chromatography $\left(\mathrm{SiO}_{2}(30 \mathrm{~g}), 3 \mathrm{~cm}\right.$ diam., EtOAc 
$(200 \mathrm{~mL})$ to EtOAc/MeOH, 19/1 (150 mL)) $270 \mathrm{mg}(98 \%)$ of $(+)-76$ as a clear oil. ${ }^{17}$ The ratio of $\gamma / \alpha$-addition products was determined to be $>99 / 1$ by ${ }^{1} \mathrm{H}$ NMR $(500 \mathrm{MHz})$ analysis of the crude reaction mixture.

Data for $(+)-76$ :

${ }^{1} \mathrm{H}$ NMR: $\quad\left(500 \mathrm{MHz}, \mathrm{CDCl}_{3}\right)$

7.35-7.26 (m, $5 \mathrm{H}, \mathrm{HC}(7,8,9)), 5.53(\mathrm{dt}, J=7.3,1.5,1 \mathrm{H}, \mathrm{HC}(3)), 4.81(\mathrm{t}, J=6.6$,

$1 \mathrm{H}, \mathrm{HC}(5)), 3.56$ (br s, $\left.8 \mathrm{H}, \mathrm{H}_{2} \mathrm{C}(10,11)\right), 2.67-2.54$ (m, $\left.2 \mathrm{H}, \mathrm{H}_{2} \mathrm{C}(4)\right), 2.26$ (br s,

$1 \mathrm{H}, \mathrm{OH}), 1.77$ (s, $\left.3 \mathrm{H}, \mathrm{H}_{3} \mathrm{C}(14)\right)$

${ }^{13} \mathrm{C} \mathrm{NMR}: \quad\left(126 \mathrm{MHz}, \mathrm{CDCl}_{3}\right)$

$172.2(\mathrm{C}(1)), 144.0(\mathrm{C}(6)), 132.3(\mathrm{C}(2)), 128.2$ (C(8), $127.3 \mathrm{C}(3)), 127.2(\mathrm{C}(9))$, 125.7 (C(7)), 72.8 (C(5)), 66.6 (C(11)), 47.0 (C10)), 41.7 (C(10)), $37.0(\mathrm{C}(4))$, $14.3(\mathrm{C}(12))$

IR: (neat)

3390 (s), 3061 (m), 3029 (m), 2966 (s), 2856 (s), 1955 (w), 1891 (w), 1814 (w), 1660 (s), 1633 (s), 1455 (s), 1362 (s), 1301 (s), 1278 (s), 1153 (m), 1114 (s), 1033 (s), $978(\mathrm{~m}), 907(\mathrm{~m}), 838(\mathrm{~m}), 757$ (s), 702 (s)

MS: $\quad\left(\mathrm{CI}, \mathrm{CH}_{4}\right)$

$276\left(\mathrm{M}^{+}+\mathrm{H}, 34\right), 259$ (19), 258 (100), 169 (19), 86 (11), 84 (17)

Opt. Rot.: $\quad[\alpha]_{\mathrm{D}}{ }^{24}+11.00(\mathrm{c}=1.22, \mathrm{EtOH})$

TLC: $\quad R_{f} 0.20($ EtOAc) [UV $(254 \mathrm{~nm})$ ]

SFC: $\quad(S)-76, t_{\mathrm{R}} 4.12 \min (1.5 \%) ;(S)-76, t_{\mathrm{R}} 4.61 \min (98.5 \%)$ (Chiralpak OB, $200 \mathrm{psi}, 40$ ${ }^{\circ} \mathrm{C}, 7.0 \% \mathrm{MeOH}$ in $\mathrm{CO}_{2}, 2.5 \mathrm{~mL} / \mathrm{min}, 220 \mathrm{~nm}$ )

HRMS: Calcd for $\mathrm{C}_{16} \mathrm{H}_{22} \mathrm{NO}_{3}: 276.1600$, found: 276.1601 
Preparation of 4-[(2E)-1-Oxo-5-phenyl-5-hydroxy-2-methyl-2-pentenyl]morpholine (Table 12, entry 4)
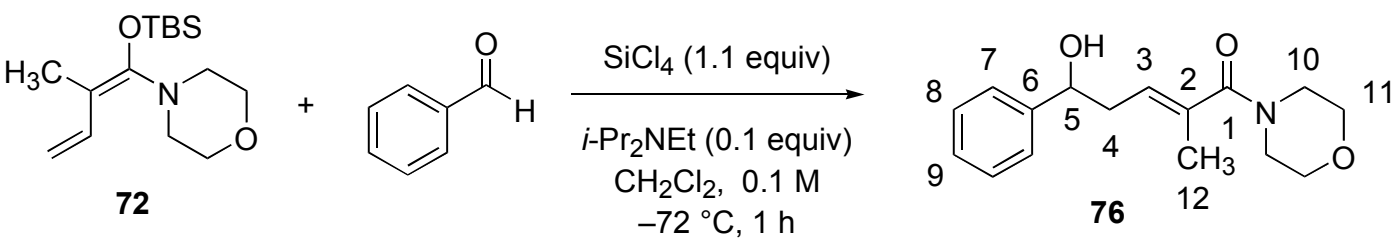

Following Representative Procedure 8, $25 \mu \mathrm{L}(0.25 \mathrm{mmol})$ of benzaldehyde was combined with $4 \mu \mathrm{L}(0.025 \mathrm{mmol}, 0.1$ equiv) of diisopropylethylamine, $32 \mu \mathrm{L}(0.275 \mathrm{mmol}, 1.1$ equiv) of $\mathrm{SiCl}_{4}$ and $85 \mathrm{mg}$ ( $0.3 \mathrm{mmol}, 1.2$ equiv) of 72 to yield, after column chromatography $\left(\mathrm{SiO}_{2}(10 \mathrm{~g}), 2 \mathrm{~cm}\right.$ diam., EtOAc $(100 \mathrm{~mL})$ to EtOAc/MeOH, 19/1 (100 mL)) $24 \mathrm{mg}(35 \%)$ of 76 as a clear oil. The ratio of $\gamma / \alpha$-addition products was determined to be $>99 / 1$ by ${ }^{1} \mathrm{H}$ NMR (500 $\mathrm{MHz}$ ) analysis of the crude reaction mixture.

Data for 76:

${ }^{1} \mathrm{H}$ NMR: $\quad\left(500 \mathrm{MHz}, \mathrm{CDCl}_{3}\right)$

7.37-7.26 (m, $5 \mathrm{H}, \mathrm{HC}(7,8,9)), 5.52(\mathrm{dt}, J=7.3,1.5,1 \mathrm{H}, \mathrm{HC}(3)), 4.81(\mathrm{t}, J=6.5$, $1 \mathrm{H}, \mathrm{HC}(5)), 3.56-3.31$ (m, $\left.8 \mathrm{H}, \mathrm{H}_{2} \mathrm{C}(10,11)\right), 2.67-2.54$ (m, $\left.2 \mathrm{H}, \mathrm{H}_{2} \mathrm{C}(4)\right), 2.25$ (br s, $1 \mathrm{H}, \mathrm{OH}), 1.77$ (s, $3 \mathrm{H}, \mathrm{H}_{3} \mathrm{C}(14)$ )

TLC: $\quad R_{f} 0.20(\mathrm{EtOAc})[\mathrm{UV}(254 \mathrm{~nm})]$

Preparation of $\quad(-)-4-[(5 R, 2 E, 6 E)-1-0 x 0-7-p h e n y l-5-h y d r o x y-2-m e t h y l-2,6-$ heptadienyl]morpholine (77) (Table 12, entry 5)

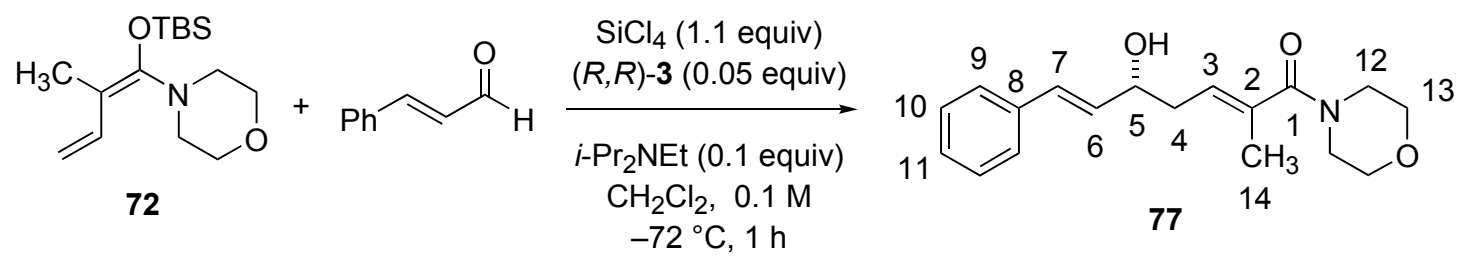

Following Representative Procedure 8, $126 \mu \mathrm{L}(1.0 \mathrm{mmol})$ of cinnamaldehyde was combined with $42 \mathrm{mg}$ ( $0.05 \mathrm{mmol}, 0.05$ equiv) of bisphosphoramide $(R, R)-3,18 \mu \mathrm{L}(0.1 \mathrm{mmol}$, 0.1 equiv) of diisopropylethylamine, $126 \mu \mathrm{L}\left(1.1 \mathrm{mmol}, 1.1\right.$ equiv) of $\mathrm{SiCl}_{4}$ and $340 \mathrm{mg}$ (1.2 mmol, 1.2 equiv) of $\mathbf{7 2}$ to yield, after column chromatography $\left(\mathrm{SiO}_{2}(30 \mathrm{~g}), 3 \mathrm{~cm}\right.$ diam., EtOAc 
$(200 \mathrm{~mL})$ to EtOAc/MeOH, 19/1 (150 mL)) $274 \mathrm{mg}(91 \%)$ of $(-)-77$ as a clear oil. ${ }^{17}$ The ratio of $\gamma / \alpha$-addition products was determined to be $>99 / 1$ by ${ }^{1} \mathrm{H}$ NMR $(500 \mathrm{MHz})$ analysis of the crude reaction mixture.

Data for (-)-77:

개 NMR: $\quad\left(500 \mathrm{MHz}, \mathrm{CDCl}_{3}\right)$

$7.36(\mathrm{dd}, J=7.1,1.5,2 \mathrm{H}, \mathrm{HC}(9)), 7.32$ (dt, $J=7.0,1.8,2 \mathrm{H}, \mathrm{HC}(10))$, 7.27-7.24 $(\mathrm{m}, 1 \mathrm{H}, \mathrm{HC}(11)), 6.58$ (d, $J=15.9,1 \mathrm{H}, \mathrm{HC}(7)), 6.23$ (dd, $J=15.9,6.8,1 \mathrm{H}$, $\mathrm{HC}(6)), 5.62$ (dt, $J=7.3,1.5,1 \mathrm{H}, \mathrm{HC}(3)), 4.43$ (dq, $J=6.1,1.0,1 \mathrm{H}, \mathrm{HC}(5))$, 3.53 (br s, 8 H, $\mathrm{H}_{2} \mathrm{C}(12,13)$ ), 2.54-2.44 (m, 2 H, $\mathrm{H}_{2} \mathrm{C}(4)$ ), 2.05 (br s, $1 \mathrm{H}, \mathrm{OH}$ ), 1.87 (s, $\left.3 \mathrm{H}, \mathrm{H}_{3} \mathrm{C}(14)\right)$

${ }^{13} \mathrm{C} \mathrm{NMR}: \quad\left(126 \mathrm{MHz}, \mathrm{CDCl}_{3}\right)$ 172.2 (C(1)), 136.2 (C(8)), 132.2 (C(2)), 131.6 (C(6)), 129.8 (C(7), 128.3 (C(10), 127.4 C(11)), 127.1 (C(3)), 126.0 (C(9)), 71.3 (C(5)), 66.4 (C(13)), 47.2 (C12)), 41.7 (C(12)), 35.3 (C(4)), 14.4 (C(14))

IR: (neat)

3390 (m), 3026 (w), 2965 (w), 2918 (m), 2921 (s), 2856 (m), 1732 (w), 1660 (m), 1614 (m), 1494 (m), 1463 (m), 1434 (m), 1361 (m), 1300 (m), 1279 (m), 1257 (w), 1114 (m), 1068 (m), 1033 (m), 970 (m), 907 (m), 840 (m), 752 (m), 696 (m)

MS: $\quad\left(\mathrm{CI}, \mathrm{CH}_{4}\right)$

$302\left(\mathrm{M}^{+}+\mathrm{H}, 6\right), 285$ (22), 284 (100), 198 (13), 197 (28), 170 (13), 169 (70), 154

(17), 133 (40), $114(28)$

Opt. Rot.: $\quad[\alpha]_{\mathrm{D}}{ }^{24}-14.62(\mathrm{c}=0.85, \mathrm{EtOH})$

TLC: $\quad R_{f} 0.18(\mathrm{EtOAc})$ [UV $(254 \mathrm{~nm})$ ]

SFC: $\quad(R)-77, t_{\mathrm{R}} 1.66 \min (99.2 \%) ;(S)-77, t_{\mathrm{R}} 2.10 \min (0.8 \%)$ (Chiralpak OB, 125 psi, $40{ }^{\circ} \mathrm{C}, 20.0 \% \mathrm{MeOH}$ in $\mathrm{CO}_{2}, 3.0 \mathrm{~mL} / \mathrm{min}, 220 \mathrm{~nm}$ )

HRMS: $\quad$ Calcd for $\mathrm{C}_{18} \mathrm{H}_{24} \mathrm{NO}_{3}: 302.1756$, found: 302.1757 
Preparation of 4-[(2E,6E)-1-Oxo-7-phenyl-5-hydroxy-2-methyl-2,6-heptadienyl]morpholine (77) (Table 12, entry 6)

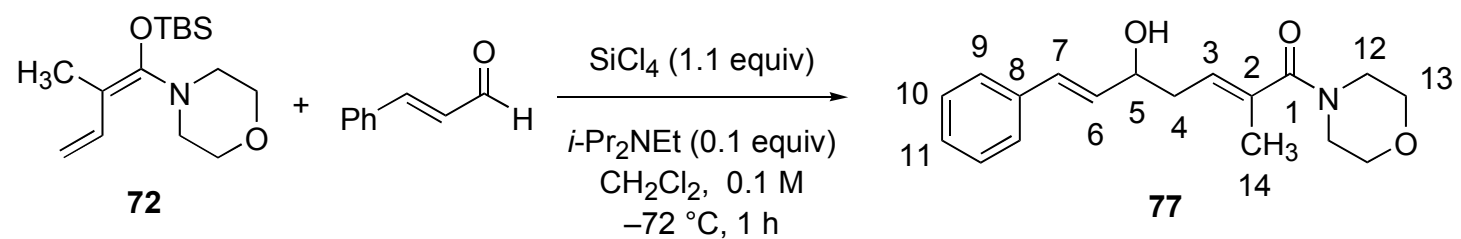

Following Representative Procedure 8, $32 \mu \mathrm{L}(0.25 \mathrm{mmol})$ of cinnamaldehyde was combined with $4 \mu \mathrm{L}(0.025 \mathrm{mmol}, 0.1$ equiv) of diisopropylethylamine, $32 \mu \mathrm{L}(0.275 \mathrm{mmol}, 1.1$ equiv) of $\mathrm{SiCl}_{4}$ and $85 \mathrm{mg}(0.3 \mathrm{mmol}, 1.2$ equiv) of 72 to yield, after column chromatography $\left(\mathrm{SiO}_{2}(10 \mathrm{~g}), 2 \mathrm{~cm}\right.$ diam., EtOAc $(100 \mathrm{~mL})$ to EtOAc/MeOH, 19/1 (100 mL)) $42 \mathrm{mg}(56 \%)$ of 77 as a clear oil. The ratio of $\gamma / \alpha$-addition products was determined to be $>99 / 1$ by ${ }^{1} \mathrm{H}$ NMR (500 $\mathrm{MHz}$ ) analysis of the crude reaction mixture.

Data for 77:

${ }^{1} \mathrm{H}$ NMR: $\quad\left(500 \mathrm{MHz}, \mathrm{CDCl}_{3}\right)$

7.38-7.24 (m,5 H, HC(9,10,11)), $6.58(\mathrm{~d}, J=15.8,1 \mathrm{H}, \mathrm{HC}(7)), 6.22(\mathrm{dd}, J=$ 15.9, 6.7, $1 \mathrm{H}, \mathrm{HC}(6)), 5.61$ (dt, $J=7.4,1.5,1 \mathrm{H}, \mathrm{HC}(3)), 4.42$ (dq, $J=6.0,1.0,1$ $\mathrm{H}, \mathrm{HC}(5)), 3.53$ (br s, $\left.8 \mathrm{H}, \mathrm{H}_{2} \mathrm{C}(12,13)\right), 2.53-2.43$ (m, $\left.2 \mathrm{H}, \mathrm{H}_{2} \mathrm{C}(4)\right), 1.98$ (d, $J=$ 3.7, $1 \mathrm{H}, \mathrm{OH}), 1.87$ (s, $\left.3 \mathrm{H}, \mathrm{H}_{3} \mathrm{C}(14)\right)$

TLC: $\quad R_{f} 0.18($ EtOAc) [UV $(254 \mathrm{~nm})]$

Preparation of (-)-4-[(5S,2E)-1-Oxo-7-phenyl-5-hydroxy-3-methyl-2-heptenyl]morpholine (78) (Table 13, entry 1)

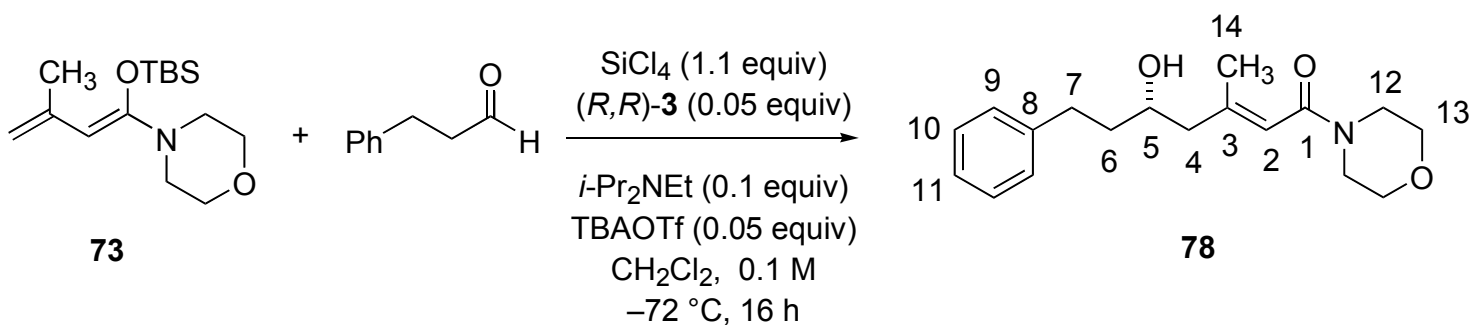

Following Representative Procedure 9, $132 \mu \mathrm{L}$ (1.0 mmol) of hydrocinnamaldehyde, was combined with $42 \mathrm{mg}$ (0.05 mmol, 0.05 equiv) of bisphosphoramide $(R, R)-3,20 \mathrm{mg}(0.05 \mathrm{mmol}$, 0.05 equiv) of tetrabutylammonium triflate, $18 \mu \mathrm{L} \quad(0.1 \mathrm{mmol}, 0.1$ equiv) of 
diisopropylethylamine, $126 \mu \mathrm{L}\left(1.1 \mathrm{mmol}, 1.1\right.$ equiv) of $\mathrm{SiCl}_{4}$ and $340 \mathrm{mg}(1.2 \mathrm{mmol}, 1.2$ equiv) of 73 to yield after column chromatography (( $\mathrm{SiO}_{2}(30 \mathrm{~g}), 3 \mathrm{~cm}$ diam., EtOAc $(150 \mathrm{~mL})$ to EtOAc/MeOH, 19/1 (200 mL)) $205 \mathrm{mg}(68 \%)$ of $(-)-(2 E)-78$ as a colorless oil. ${ }^{17}$ The $(2 E)-$ 78/(2Z)-78 ratio was determined to be $88 / 12$ by ${ }^{1} \mathrm{H}$ NMR (500 MHz) analysis of the crude reaction mixture. The ratio of $\gamma / \alpha$-addition products was determined to be $>99 / 1$ by ${ }^{1} \mathrm{H}$ NMR $(500 \mathrm{MHz})$ analysis of the crude reaction mixture.

Data for $(-)-(2 E)-78$ :

bp: $\quad 140{ }^{\circ} \mathrm{C}\left(5.0 \times 10^{-5} \mathrm{mmHg}, \mathrm{ABT}\right)$

${ }^{1}$ H NMR: $\quad\left(500 \mathrm{MHz}, \mathrm{CDCl}_{3}\right)$

7.29 (t, $J=7.4,2$ H, HC(10)), 7.21-7.18 (m, 3 H, HC(9,11)), 5.84 (s, 1 H, HC(2)), 3.86-3.81 (m, $1 \mathrm{H}, \mathrm{HC}(5))$, 3.68-3.59 (m, $8 \mathrm{H}, \mathrm{H}_{2} \mathrm{C}(12,13)$ ), 2.83 (dt, $J=13.7$, 7.7, $1 \mathrm{H}, \mathrm{HC}(7)), 2.71(\mathrm{dt}, J=13.9,8.1,1 \mathrm{H}, \mathrm{HC}(7)), 2.29\left(\underline{\mathrm{ABX}}, J_{\mathrm{AB}}=13.5, J_{\mathrm{AX}}\right.$ $\left.=3.5,1 \mathrm{H}, \mathrm{H}_{\mathrm{a}} \mathrm{C}(4)\right), 2.22\left(\mathrm{ABX}, J_{\mathrm{AB}}=13.5, J_{\mathrm{BX}}=9.2,1 \mathrm{H}, \mathrm{H}_{\mathrm{b}} \mathrm{C}(4)\right), 1.92(\mathrm{~s}, 3 \mathrm{H}$, $\left.\mathrm{H}_{3} \mathrm{C}(14)\right), 1.82-1.78$ (m, $\left.2 \mathrm{H}, \mathrm{H}_{2} \mathrm{C}(6)\right)$

NOE ${ }^{1} \mathrm{H}$ NMR: $\left(500 \mathrm{MHz}, \mathrm{CDCl}_{3}\right)$

Irradiation at $5.80 \mathrm{ppm}(\mathrm{HC}(2))$ enhanced signal at 3.82-3.80 ppm $(\mathrm{HC}(5)), 3.63-$ $3.47\left(\mathrm{H}_{2} \mathrm{C}(12,13)\right)$ and 2.27-2.18 ppm $\left(\mathrm{H}_{2} \mathrm{C}(4)\right)$

${ }^{13} \mathrm{C} \mathrm{NMR}: \quad\left(126 \mathrm{MHz}, \mathrm{CDCl}_{3}\right)$

167.2 (C(1)), $146.3(\mathrm{C}(3)), 141.9$ (C(8)), 128.3 (C(9), C(10)), 125.8 (C(11)), 119.7 (C(2)), 68.3 (C(5)), 66.8 (C(13)), 47.7 (C(4)), 46.5 (C12)), 41.6 (C(12)), $39.0(\mathrm{C}(6)), 32.0(\mathrm{C}(7)), 18.9$ (C(14))

IR: (neat)

3402 (m), 3084 (w), 3061 (w), 3026 (m), 2919 (m), 2857 (m), 1958 (w), 1605 (m), 1495 (w), 1435 (m), 1381 (m), 1362 (w), 1329 (w), 1300 (w), 1272 (m), 1242 (m), 1180 (m), 1115 (m), 1038 (m), $975(\mathrm{w}), 931$ (w), 852 (w), $750(\mathrm{~m}), 701$ (m)

MS: $\quad\left(\mathrm{CI}, \mathrm{CH}_{4}\right)$

305 (23), $304\left(\mathrm{M}^{+}+\mathrm{H}, 100\right), 286$ (26), 169 (15), 91 (15), 83 (12)

Opt. Rot.: $[\alpha]_{\mathrm{D}}^{24}-0.84(\mathrm{c}=1.75, \mathrm{EtOH})$

TLC: $\quad R_{f} 0.09$ (EtOAc) [UV $\left.(254 \mathrm{~nm})\right]$

SFC: $\quad(S)-78, t_{\mathrm{R}} 1.51 \min (97.1 \%) ;(R)-78, t_{\mathrm{R}} 1.85 \min (2.9 \%)$ (Chiralpak OB, 125 psi, 
$40{ }^{\circ} \mathrm{C}, 15.0 \% \mathrm{MeOH}$ in $\left.\mathrm{CO}_{2}, 3.0 \mathrm{~mL} / \mathrm{min}, 220 \mathrm{~nm}\right)$

HRMS: $\quad$ Calcd for $\mathrm{C}_{18} \mathrm{H}_{26} \mathrm{NO}_{3}: 304.1913$, found: 304.1905

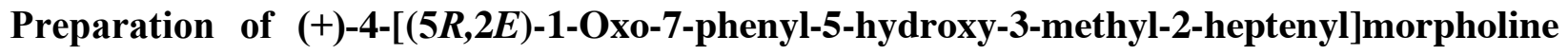
(79) (Table 13, entry 2)
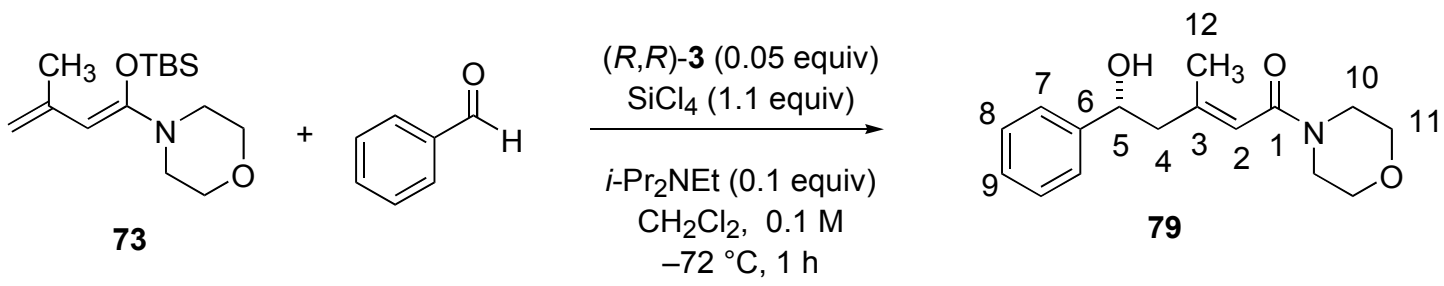

Following Representative Procedure 8, $102 \mu \mathrm{L}(1.0 \mathrm{mmol})$ of benzaldehyde was combined with $42 \mathrm{mg}(0.05 \mathrm{mmol}, 0.05$ equiv) of bisphosphoramide $(R, R)-3,18 \mu \mathrm{L}(0.1 \mathrm{mmol}$, 0.1 equiv) of diisopropylethylamine, $126 \mu \mathrm{L}\left(1.1 \mathrm{mmol}, 1.1\right.$ equiv) of $\mathrm{SiCl}_{4}$ and $340 \mathrm{mg}(1.2$ mmol, 1.2 equiv) of 73 to yield after column chromatography $\left(\mathrm{SiO}_{2}(30 \mathrm{~g}), 3 \mathrm{~cm}\right.$ diam., EtOAc $(200 \mathrm{~mL})$ to EtOAc/MeOH, 19/1 (150 mL)) $30 \mathrm{mg}(10 \%)$ of (2Z)-79 as clear oil and (2E)-79 as an oil which was crystallized from $\mathrm{Et}_{2} \mathrm{O}(3 \mathrm{~mL})$ to yield $245 \mathrm{mg}(89 \%)$ of white crystals. The (2E)-79/(2Z)-79 ratio was determined to be $88 / 12$ by ${ }^{1} \mathrm{H}$ NMR (500 MHz) analysis of the crude reaction mixture. The ratio of $\gamma / \alpha$-addition products was determined to be $>99 / 1$ by ${ }^{1} \mathrm{H}$ NMR $(500 \mathrm{MHz})$ analysis of the crude reaction mixture.

Data for $(+)-(2 E)-79$ :

mp: $\quad 81-82^{\circ} \mathrm{C}\left(\mathrm{Et}_{2} \mathrm{O}\right)$

${ }^{1} \mathrm{H} \mathrm{NMR}: \quad\left(500 \mathrm{MHz}, \mathrm{CDCl}_{3}\right)$

7.35-7.32 (m, $4 \mathrm{H}, \mathrm{HC}(7,8))$, 7.29-7.25 (m, $1 \mathrm{H}, \mathrm{HC}(9))$ ), 5.69 (s, $1 \mathrm{H}, \mathrm{HC}(2))$, $3.86(\mathrm{dd}, J=8.1,5.6,1 \mathrm{H}, \mathrm{HC}(5)), 3.55-3.17$ (m, 8 H, $\left.\mathrm{H}_{2} \mathrm{C}(10,11)\right)$, 2.63-2.46 (m, $\left.3 \mathrm{H}, \mathrm{OH}, \mathrm{H}_{2} \mathrm{C}(4)\right), 1.91$ (s, $\left.3 \mathrm{H}, \mathrm{H}_{3} \mathrm{C}(12)\right)$

${ }^{13} \mathrm{C} \mathrm{NMR}: \quad\left(126 \mathrm{MHz}, \mathrm{CDCl}_{3}\right)$

$167.1(\mathrm{C}(1)), 144.8$ (C(3)), 144.0 (C(6)), 128.2 (C(8), 127.3 (C(9)), 125.8 (C(7)), 120.4 (C(2)), 71.7 (C(5)), 66.6 (C(11)), 66.5 (C(11)), 49.2 (C(4)), 46.1 (C10)), $41.3(\mathrm{C}(10)), 18.5(\mathrm{C}(12))$

IR: $\quad\left(\mathrm{CHCl}_{3}\right)$

3392 (m), 3086 (w), 3063 (w), 3030 (w), 2969 (w), 2918 (m), 2858 (m), 2759 (w), $2683(\mathrm{w}), 2244(\mathrm{w}), 1955(\mathrm{w}), 1881(\mathrm{w}), 1814(\mathrm{w}), 1651(\mathrm{~m}), 1614(\mathrm{~s}), 1494$ 
(w), 1440 (m), 1382 (m), 1362 (w), 1330 (w), 1301 (m), 1273 (m), 1244 (m), 1202 (w), 1181 (m), 1115 (s), 1085 (w), 1067 (w), 1029 (m), 974 (m), 912 (m), $852(\mathrm{w}), 835(\mathrm{w}), 821(\mathrm{w}), 733(\mathrm{~s}), 702(\mathrm{~m}), 646(\mathrm{~m})$

MS: $\quad\left(\mathrm{CI}, \mathrm{CH}_{4}\right)$

304 (15), $276\left(\mathrm{M}^{+}+\mathrm{H}, 31\right), 270$ (11), 259 (19), 258 (100), 170 (10), 169 (22), 153

(12), 151 (10), 114 (31), 107 (20), 83 (16), 59 (11)

Opt. Rot.: $\quad[\alpha]_{\mathrm{D}}{ }^{24}+28.41(\mathrm{c}=1.07, \mathrm{EtOH})$

TLC: $\quad R_{f} 0.16($ EtOAc) [UV $(254 \mathrm{~nm})$ ]

SFC: $\quad(5 R, 2 E)-79, t_{\mathrm{R}} 1.70 \min (98.4 \%) ;(5 S, 2 E)-79, t_{\mathrm{R}} 1.98 \mathrm{~min}(1.6 \%)$ (Chiralpak OB, $125 \mathrm{psi}, 40^{\circ} \mathrm{C}, 14.0 \% \mathrm{MeOH}$ in $\mathrm{CO}_{2}, 3.0 \mathrm{~mL} / \mathrm{min}, 220 \mathrm{~nm}$ )

Analysis: $\quad \mathrm{C}_{16} \mathrm{H}_{21} \mathrm{NO}_{3}(275.34)$

Calcd: $\quad$ C, 69.79; H, 7.69; N, 5.09\%

Found: $\quad$ C, 69.65; H, 7.69; N, 5.16\%

Data for (2Z)-79:

${ }^{1} \mathrm{H}$ NMR: $\quad\left(500 \mathrm{MHz}, \mathrm{CDCl}_{3}\right)$

$7.44(\mathrm{~d}, J=7.3,2 \mathrm{H}, \mathrm{HC}(7)), 7.34$ (t, $J=7.3,2 \mathrm{H}, \mathrm{HC}(8)), 7.24$ (t, $J=7.3,1 \mathrm{H}$, HC(9)), 6.10 (d, $J=1.0,1 \mathrm{H}, \mathrm{HC}(2)), 5.81$ (br s, 1H, OH), 4.87 (dd, $J=10.5,2.9$, $1 \mathrm{H}, \mathrm{HC}(5)), 3.71-3.47$ (m, $\left.8 \mathrm{H}, \mathrm{H}_{2} \mathrm{C}(12,13)\right), 3.00(\mathrm{dd}, J=12.9,10.6,1 \mathrm{H}$, $\mathrm{HC}(4)), 2.33$ (dd, $J=12.8,2.9,1 \mathrm{H}, \mathrm{HC}(4)), 1.99$ (d, $\left.J=1.2,3 \mathrm{H}, \mathrm{H}_{3} \mathrm{C}(14)\right)$

MS: $\quad\left(\mathrm{CI}, \mathrm{CH}_{4}\right)$

$276\left(\mathrm{M}^{+}+\mathrm{H}, 17\right), 259$ (18), 258 (100), 189 (18), 171 (12), 170 (33), 169 (14), 114 (21), 107 (10), 88 (14), 58 (43)

TLC: $\quad R_{f} 0.34$ (EtOAc) [UV $\left.(254 \mathrm{~nm})\right]$

SFC: $\quad(2 Z)-79, t_{\mathrm{R}} 3.47 \min (42.8 \%) ;(2 Z)-79, t_{\mathrm{R}} 3.98 \mathrm{~min}(57.2 \%)$ (Chiralpak AD, 125 psi, $40{ }^{\circ} \mathrm{C}, 15.0 \% \mathrm{MeOH}$ in $\left.\mathrm{CO}_{2}, 3.0 \mathrm{~mL} / \mathrm{min}, 220 \mathrm{~nm}\right)$

HRMS: $\quad$ Calcd for $\mathrm{C}_{16} \mathrm{H}_{22} \mathrm{NO}_{3}: 276.1600$, found: 276.1598 
Preparation of 4-[(2E)-1-Oxo-7-phenyl-5-hydroxy-3-methyl-2-heptenyl]morpholine (79) (Table 13, entry 3)

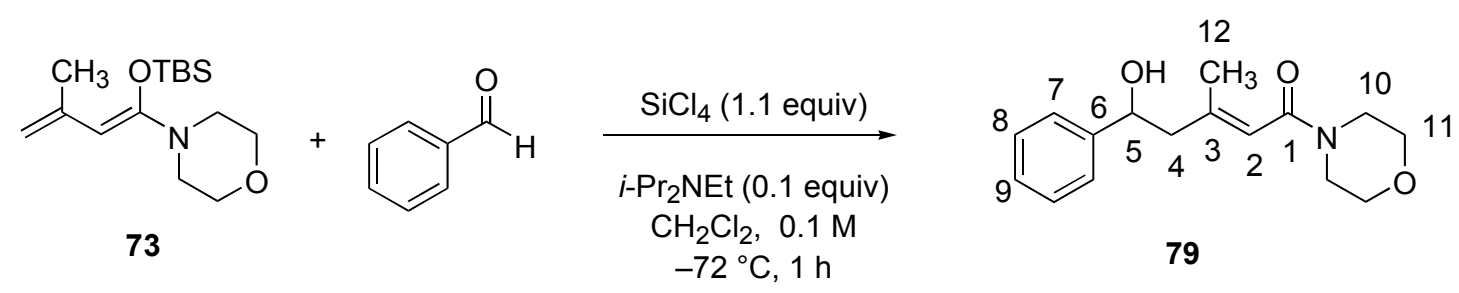

Following Representative Procedure 8, $25 \mu \mathrm{L}(0.25 \mathrm{mmol})$ of benzaldehyde was combined with $4 \mu \mathrm{L}(0.025 \mathrm{mmol}, 0.1$ equiv) of diisopropylethylamine, $32 \mu \mathrm{L}(0.275 \mathrm{mmol}, 1.1$ equiv) of $\mathrm{SiCl}_{4}$ and $85 \mathrm{mg}(0.3 \mathrm{mmol}, 1.2$ equiv) of 73 to yield after column chromatography $\left(\mathrm{SiO}_{2}(10 \mathrm{~g}), 2 \mathrm{~cm}\right.$ diam., EtOAc)) $35 \mathrm{mg}$ (51\%) of (2Z)-79 as clear, colorless oil and $34 \mathrm{mg}$ (49\%) of (2E)-79 as clear, colorless oil. The (2E)-79/(2Z)-79 ratio was determined to be $48 / 52$ by ${ }^{1} \mathrm{H}$ NMR $(500 \mathrm{MHz})$ analysis of the crude reaction mixture. The ratio of $\gamma / \alpha$-addition products was determined to be $>99 / 1$ by ${ }^{1} \mathrm{H}$ NMR $(500 \mathrm{MHz})$ analysis of the crude reaction mixture.

Data for $(2 E)-79$ :

${ }^{1} \mathrm{H} \mathrm{NMR}: \quad\left(500 \mathrm{MHz}, \mathrm{CDCl}_{3}\right)$

7.35-7.31 (m, 4 H, HC(7,8)), 7.29-7.25 (m, $1 \mathrm{H}, \mathrm{HC}(9))$ ), 5.68 (s, $1 \mathrm{H}, \mathrm{HC}(2))$, $3.87(\mathrm{dd}, J=8.2,5.6,1 \mathrm{H}, \mathrm{HC}(5)), 3.55-3.17$ (m, 8 H, $\left.\mathrm{H}_{2} \mathrm{C}(10,11)\right), 2.63-2.44$ (m, $\left.3 \mathrm{H}, \mathrm{OH}, \mathrm{H}_{2} \mathrm{C}(4)\right), 1.91$ (s, $\left.3 \mathrm{H}, \mathrm{H}_{3} \mathrm{C}(12)\right)$

TLC: $\quad R_{f} 0.16(\mathrm{EtOAc})[\mathrm{UV}(254 \mathrm{~nm})]$

Data for (2Z)-79:

${ }^{1} \mathrm{H} \mathrm{NMR}: \quad\left(500 \mathrm{MHz}, \mathrm{CDCl}_{3}\right)$

$7.46(\mathrm{~d}, J=7.3,2 \mathrm{H}, \mathrm{HC}(7)), 7.34$ (t, $J=7.2,2 \mathrm{H}, \mathrm{HC}(8)), 7.25(\mathrm{t}, J=7.3,1 \mathrm{H}$, $\mathrm{HC}(9)), 6.10$ (d, $J=1.0,1 \mathrm{H}, \mathrm{HC}(2)), 5.81$ (br s, 1H, OH), 4.87 (dd, $J=10.5,2.9$, $1 \mathrm{H}, \mathrm{HC}(5)), 3.71-3.47$ (m, $\left.8 \mathrm{H}, \mathrm{H}_{2} \mathrm{C}(12,13)\right), 3.01$ (dd, $J=12.9,10.6,1 \mathrm{H}$, $\mathrm{HC}(4)), 2.33$ (dd, $J=12.8,2.9,1 \mathrm{H}, \mathrm{HC}(4)), 1.99$ (d, $\left.J=1.2,3 \mathrm{H}, \mathrm{H}_{3} \mathrm{C}(14)\right)$

TLC: $\quad R_{f} 0.30($ EtOAc) [UV $(254 \mathrm{~nm})]$ 
Preparation of $\quad(-)-4-[(5 R, 2 E)-1-0 x 0-7-p h e n y l-5-h y d r o x y-3-m e t h y l-2,6-$ heptdienyl]morpholine (80) (Table 13, entry 4)

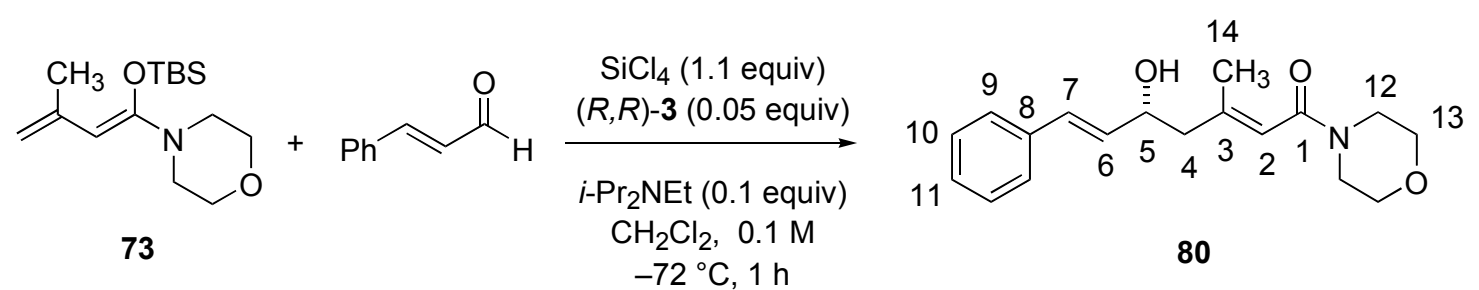

Following Representative Procedure 8, $126 \mu \mathrm{L}(1.0 \mathrm{mmol})$ of cinnamaldehyde was combined with $42 \mathrm{mg}$ ( $0.05 \mathrm{mmol}, 0.05$ equiv) of bisphosphoramide $(R, R)-3,18 \mu \mathrm{L}(0.1 \mathrm{mmol}$, 0.1 equiv) of diisopropylethylamine, $126 \mu \mathrm{L}\left(1.1 \mathrm{mmol}, 1.1\right.$ equiv) of $\mathrm{SiCl}_{4}$ and $340 \mathrm{mg}(1.2$ mmol, 1.2 equiv) of 73 to yield after column chromatography $\left(\mathrm{SiO}_{2}(30 \mathrm{~g}), 3 \mathrm{~cm}\right.$ diam., EtOAc $(200 \mathrm{~mL})$ to EtOAc/MeOH, 19/1 $(150 \mathrm{~mL}))$ to yield $24 \mathrm{mg}(8 \%)$ of $(2 Z)-80$ as a clear oil and $(-)-(2 E)-80$ as a solid which was recrystallized by precipitation from hot EtOAc $(5 \mathrm{~mL})$ with minimal amounts of hexanes to yield $271 \mathrm{mg}(90 \%)$ of white needles. The $(2 E)-\mathbf{8 0} /(2 Z)-80$ ratio was determined to be $88 / 12$ by ${ }^{1} \mathrm{H}$ NMR (500 MHz) analysis of the crude reaction mixture. The ratio of $\gamma / \alpha$-addition products was determined to be $>99 / 1$ by ${ }^{1} \mathrm{H}$ NMR (500 MHz) analysis of the crude reaction mixture.

Data for $(-)-(2 E)-\mathbf{8 0}$ :

mp: $\quad 69-70{ }^{\circ} \mathrm{C}\left(\mathrm{Et}_{2} \mathrm{O}\right)$

${ }^{1} \mathrm{H}$ NMR: $\quad\left(500 \mathrm{MHz}, \mathrm{CDCl}_{3}\right)$

7.36 (d, $J=7.1,2 \mathrm{H}, \mathrm{HC}(9)), 7.31$ (t, $J=7.6,2 \mathrm{H}, \mathrm{HC}(10)), 7.25$ (t, $J=7.3,1 \mathrm{H}$, $\mathrm{HC}(11)), 6.58(\mathrm{~d}, J=15.9,1 \mathrm{H}, \mathrm{HC}(7)), 6.22$ (dd, $J=15.9,6.6,1 \mathrm{H}, \mathrm{HC}(6)), 5.83$ (s, 1 H, HC(2)), 4.52-4.48 (m, 1 H, HC(5)), 3.59-3.44 (m, 8 H, $\mathrm{H}_{2} \mathrm{C}(12,13)$ ), 2.462.38 (m, $\left.3 \mathrm{H}, \mathrm{OH}, \mathrm{H}_{2} \mathrm{C}(4)\right), 1.93$ (s, $\left.3 \mathrm{H}, \mathrm{H}_{3} \mathrm{C}(14)\right)$

${ }^{13} \mathrm{C} \mathrm{NMR}: \quad\left(126 \mathrm{MHz}, \mathrm{CDCl}_{3}\right)$ 167.2 (C(1)), 144.7 (C(3)), 136.3 (C(8)), 131.7 (C(6), 130.0 (C(7)), 128.5 C(10)), 127.6 (C(11)), 126.2 (C(9)), 120.3 (C(2)), 70.2 (C(5)), 66.5 (C(13)), 47.4 (C(4)), 46.4 (C12)), 41.4 (C(12)), 18.8 (C(14))

IR: $\quad\left(\mathrm{CHCl}_{3}\right)$

3352 (s), 3081 (m), 3057 (m), 3027 (m), 2968 (m), 2952 (m), 2898 (m), 2857 (s), 2710 (w), 2243 (m), 1952 (w), 1822 (w), 1651 (s), 1601 (s), 1494 (m), 1460 (s), 
1440 (s), 1380 (s), 1362 (s), 1318 (m), 1301 (m), 1271 (s), 1242 (s), 1176 (m), 1154 (m), 1113 (s), 1069 (s), 1033 (s), 1006 (m), 971 (s), 919 (s), 872 (m), 851 (m), $750(\mathrm{~s}), 732(\mathrm{~s}), 696(\mathrm{~s}), 662(\mathrm{~m}), 646(\mathrm{~m})$

MS: $\quad\left(\mathrm{CI}, \mathrm{CH}_{4}\right)$

330 (12), $302\left(\mathrm{M}^{+}+\mathrm{H}, 7\right), 285$ (20), 284 (100), 170 (18), 169 (22), 133 (36), 114 (20), 83 (11)

Opt. Rot.: $\quad[\alpha]_{\mathrm{D}}{ }^{24}-6.05(\mathrm{c}=1.09, \mathrm{EtOH})$

TLC: $\quad R_{f} 0.18($ EtOAc) [UV $(254 \mathrm{~nm})]$

SFC: $\quad(5 R, 2 E)-80, t_{\mathrm{R}} 1.74 \min (98.6 \%) ;(5 S, 2 E)-80, t_{\mathrm{R}} 2.85 \min (1.4 \%)$ (Chiralpak OB, $125 \mathrm{psi}, 40^{\circ} \mathrm{C}, 20.0 \% \mathrm{MeOH}$ in $\mathrm{CO}_{2}, 3.0 \mathrm{~mL} / \mathrm{min}, 220 \mathrm{~nm}$ )

Analysis: $\quad \mathrm{C}_{18} \mathrm{H}_{23} \mathrm{NO}_{3}(301.38)$

$\begin{array}{llll}\text { Calcd: } & \text { C , 71.73; } & \text { H, 7.69; } & \text { N, 4.65\% } \\ \text { Found: } & \text { C , 71.64; } & \text { H, 7.73; } & \text { N, 4.73\% }\end{array}$

Data for (2Z)-80:

${ }^{1} \mathrm{H}$ NMR: $\quad\left(500 \mathrm{MHz}, \mathrm{CDCl}_{3}\right)$ 7.39 (d, $J=7.3,2 \mathrm{H}, \mathrm{HC}(9)), 7.29$ (t, $J=7.7,2 \mathrm{H}, \mathrm{HC}(10)), 7.21$ (dt, $J=7.3,0.6$, $1 \mathrm{H}, \mathrm{HC}(11)), 6.71(\mathrm{dd}, J=15.9,0.7,1 \mathrm{H}, \mathrm{HC}(7)), 6.30(\mathrm{dd}, J=15.9,5.6,1 \mathrm{H}$, $\mathrm{HC}(6)), 6.07$ (d, $J=1.2,1 \mathrm{H}, \mathrm{HC}(2)), 4.48-4.44$ (m, $1 \mathrm{H}, \mathrm{HC}(5)), 3.79-3.35$ (m, 9 H, OH, $\left.\mathrm{H}_{2} \mathrm{C}(12,13)\right), 2.86(\mathrm{dd}, J=12.7,10.0,1 \mathrm{H}, \mathrm{HC}(4)), 2.32$ (dd, $J=12.9,3.4$, $1 \mathrm{H}, \mathrm{HC}(4)), 1.99$ (s, $\left.3 \mathrm{H}, \mathrm{H}_{3} \mathrm{C}(14)\right)$

MS: $\quad\left(\mathrm{CI}, \mathrm{CH}_{4}\right)$ $302\left(\mathrm{M}^{+}+\mathrm{H}, 5\right), 285$ (20), 284 (100), 215 (10), 170 (51), 169 (15), 133 (26), 114 (22), $88(16), 58(24)$

TLC: $\quad R_{f} 0.31(\mathrm{EtOAc})[\mathrm{UV}(254 \mathrm{~nm})]$

SFC: $\quad(2 E)-80, t_{\mathrm{R}} 3.21 \min (53.2 \%) ;(2 E)-80, t_{\mathrm{R}} 3.98 \mathrm{~min}(46.8 \%)$ (Chiralpak OD, 125 psi, $40{ }^{\circ} \mathrm{C}, 20.0 \% \mathrm{MeOH}$ in $\mathrm{CO}_{2}, 3.0 \mathrm{~mL} / \mathrm{min}, 220 \mathrm{~nm}$ )

HRMS: $\quad$ Calcd for $\mathrm{C}_{18} \mathrm{H}_{23} \mathrm{NO}_{3}: 301.1678$, found: 301.1679 
Preparation of 4-[(2E,6E)-1-Oxo-7-phenyl-5-hydroxy-3-methyl-2,6-heptdienyl]morpholine (80) (Table 13, entry 5)

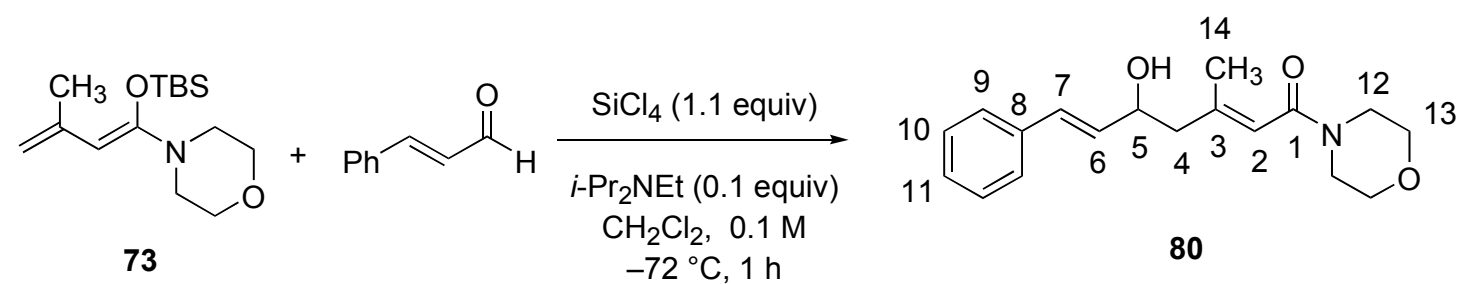

Following Representative Procedure 8, $32 \mu \mathrm{L}(0.25 \mathrm{mmol})$ of cinnamaldehyde was combined with $4 \mu \mathrm{L}$ (0.025 mmol, 0.1 equiv) of diisopropylethylamine, $32 \mu \mathrm{L}$ (0.3 mmol, 1.1 equiv) of $\mathrm{SiCl}_{4}$ and $85 \mathrm{mg}(0.3 \mathrm{mmol}, 1.2$ equiv) of 73 to yield after column chromatography $\left(\mathrm{SiO}_{2}(10 \mathrm{~g}), 2 \mathrm{~cm}\right.$ diam., EtOAc $(100 \mathrm{~mL})$ to EtOAc/MeOH, 19/1 (100 mL)) $52 \mathrm{mg}(69 \%)$ of (2Z)-80 as a clear, colorless oil and $19 \mathrm{mg}(25 \%)$ of (2E)-80 as a clear, colorless oil. The (2E)80/(2Z)-80 ratio was determined to be $32 / 68$ by ${ }^{1} \mathrm{H}$ NMR $(500 \mathrm{MHz})$ analysis of the crude reaction mixture. The ratio of $\gamma / \alpha$-addition products was determined to be $>99 / 1$ by ${ }^{1} \mathrm{H}$ NMR (500 MHz) analysis of the crude reaction mixture.

Data for $(2 E)-80$ :

${ }^{1} \mathrm{H}$ NMR: $\quad\left(500 \mathrm{MHz}, \mathrm{CDCl}_{3}\right)$

$7.36(\mathrm{~d}, J=7.1,2 \mathrm{H}, \mathrm{HC}(9)), 7.31(\mathrm{t}, J=7.6,2 \mathrm{H}, \mathrm{HC}(10)), 7.25$ (t, $J=7.3,1 \mathrm{H}$, $\mathrm{HC}(11)), 6.58(\mathrm{~d}, J=15.9,1 \mathrm{H}, \mathrm{HC}(7)), 6.22(\mathrm{dd}, J=15.9,6.6,1 \mathrm{H}, \mathrm{HC}(6)), 5.83$ (s, $1 \mathrm{H}, \mathrm{HC}(2)), 4.52-4.48$ (m, $1 \mathrm{H}, \mathrm{HC}(5)), 3.59-3.44$ (m, 8 H, $\left.\mathrm{H}_{2} \mathrm{C}(12,13)\right)$, 2.462.38 (m, $\left.3 \mathrm{H}, \mathrm{OH}, \mathrm{H}_{2} \mathrm{C}(4)\right), 1.93$ (s, $3 \mathrm{H}, \mathrm{H}_{3} \mathrm{C}(14)$ )

TLC: $\quad R_{f} 0.18(\mathrm{EtOAc})$ [UV $\left.(254 \mathrm{~nm})\right]$

\section{Data for (2Z)-80:}

${ }^{1} \mathrm{H}$ NMR: $\quad\left(500 \mathrm{MHz}, \mathrm{CDCl}_{3}\right)$ 7.38 (d, $J=7.2,2 \mathrm{H}, \mathrm{HC}(9)), 7.28$ (t, $J=7.5,2 \mathrm{H}, \mathrm{HC}(10)), 7.22$ (t, $J=7.4,1 \mathrm{H}$, $\mathrm{HC}(11)), 6.71(\mathrm{dd}, J=15.8,0.7,1 \mathrm{H}, \mathrm{HC}(7)), 6.30(\mathrm{dd}, J=15.9,5.7,1 \mathrm{H}$, $\mathrm{HC}(6)), 6.05$ (d, $J=1.1,1 \mathrm{H}, \mathrm{HC}(2))$, 4.48-4.45 (m, $1 \mathrm{H}, \mathrm{HC}(5)), 3.79-3.50$ (m, 8 $\left.\mathrm{H}, \mathrm{H}_{2} \mathrm{C}(12,13)\right), 2.86(\mathrm{dd}, J=12.7,10.1,1 \mathrm{H}, \mathrm{HC}(4)), 2.34(\mathrm{dd}, J=12.9,3.5,1 \mathrm{H}$, $\mathrm{HC}(4)), 1.99$ (s, $3 \mathrm{H}, \mathrm{H}_{3} \mathrm{C}(14)$ )

TLC: $\quad R_{f} 0.31(\mathrm{EtOAc})$ [UV $(254 \mathrm{~nm})$ ] 
Preparation of 4-[(5R,2E)-1-Oxo-7-phenyl-5-hydroxy-3-methyl-2,6-heptdienyl]morpholine (80) (Table 14, entry 2)

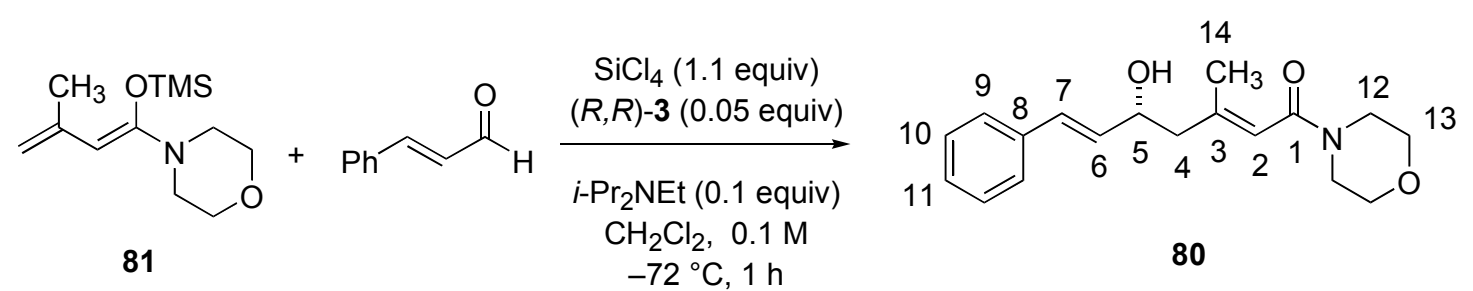

Following Representative Procedure 8, $32 \mu \mathrm{L}(0.25 \mathrm{mmol})$ of cinnamaldehyde was combined with $11 \mathrm{mg}(0.0125 \mathrm{mmol}, 0.05$ equiv) of bisphosphoramide $(R, R)-3,4 \mu \mathrm{L}(0.025$ mmol, 0.1 equiv) of diisopropylethylamine, $32 \mu \mathrm{L}\left(0.3 \mathrm{mmol}, 1.1\right.$ equiv) of $\mathrm{SiCl}_{4}$ and $72 \mathrm{mg}(1.2$ mmol, 1.2 equiv) of $\mathbf{8 1}$ to yield after column chromatography $\left(\mathrm{SiO}_{2}(10 \mathrm{~g}), 2 \mathrm{~cm}\right.$ diam., EtOAc $(100 \mathrm{~mL})$ to $\mathrm{EtOAc} / \mathrm{MeOH}, 19 / 1(100 \mathrm{~mL})) 6 \mathrm{mg}(8 \%)$ of $(2 \mathrm{Z})-80$ as a clear, colorless oil and 50 $\mathrm{mg}(67 \%)$ of $(2 E)-\mathbf{8 0}$ as a clear, colorless oil. The $(2 E)-\mathbf{8 0} /(2 Z)-\mathbf{8 0}$ ratio was determined to be $82 / 18$ by ${ }^{1} \mathrm{H}$ NMR $(500 \mathrm{MHz})$ analysis of the crude reaction mixture. The ratio of $\gamma / \alpha$-addition products was determined to be $>99 / 1$ by ${ }^{1} \mathrm{H}$ NMR $(500 \mathrm{MHz})$ analysis of the crude reaction mixture.

Data for $(2 E)-\mathbf{8 0}$ :

${ }^{1}$ H NMR: $\quad\left(500 \mathrm{MHz}, \mathrm{CDCl}_{3}\right)$

7.35 (d, $J=7.2,2 \mathrm{H}, \mathrm{HC}(9)), 7.32$ (t, $J=7.4,2 \mathrm{H}, \mathrm{HC}(10)), 7.24$ (t, $J=7.3,1 \mathrm{H}$, HC(11)), $6.58(\mathrm{~d}, J=15.8,1 \mathrm{H}, \mathrm{HC}(7)), 6.22$ (dd, $J=15.7,6.6,1 \mathrm{H}, \mathrm{HC}(6)), 5.84$ (s, $1 \mathrm{H}, \mathrm{HC}(2))$, 4.54-4.50 (m, $1 \mathrm{H}, \mathrm{HC}(5)), 3.66-3.41$ (m, 8 H, $\left.\mathrm{H}_{2} \mathrm{C}(12,13)\right)$, 2.472.39 (m, 2 H, $\left.\mathrm{H}_{2} \mathrm{C}(4)\right), 1.93$ (s, $\left.3 \mathrm{H}, \mathrm{H}_{3} \mathrm{C}(14)\right), 1.91$ (d, $\left.J=3.4,1 \mathrm{H}, \mathrm{OH}\right)$

TLC: $\quad R_{f} 0.18(\mathrm{EtOAc})[\mathrm{UV}(254 \mathrm{~nm})]$

SFC: $\quad(5 R, 2 E)-80, t_{\mathrm{R}} 1.72 \mathrm{~min}(97.4 \%) ;(5 S, 2 E)-80, t_{\mathrm{R}} 2.83 \mathrm{~min}(2.6 \%)$ (Chiralpak OB, $125 \mathrm{psi}, 40^{\circ} \mathrm{C}, 20.0 \% \mathrm{MeOH}$ in $\mathrm{CO}_{2}, 3.0 \mathrm{~mL} / \mathrm{min}, 220 \mathrm{~nm}$ )

Data for (2Z)-80:

${ }^{1} \mathrm{H}$ NMR: $\quad\left(500 \mathrm{MHz}, \mathrm{CDCl}_{3}\right)$

7.39 (d, $J=7.3,2 \mathrm{H}, \mathrm{HC}(9)), 7.29$ (t, $J=7.7,2 \mathrm{H}, \mathrm{HC}(10)), 7.21$ (dt, $J=7.3,0.6$, $1 \mathrm{H}, \mathrm{HC}(11)), 6.71(\mathrm{dd}, J=15.9,0.7,1 \mathrm{H}, \mathrm{HC}(7)), 6.30(\mathrm{dd}, J=15.9,5.6,1 \mathrm{H}$, $\mathrm{HC}(6)), 6.07$ (d, $J=1.2,1 \mathrm{H}, \mathrm{HC}(2))$, 4.48-4.44 (m, $1 \mathrm{H}, \mathrm{HC}(5)), 3.79-3.35$ (m, 9 $\left.\mathrm{H}, \mathrm{OH}, \mathrm{H}_{2} \mathrm{C}(12,13)\right), 2.86(\mathrm{dd}, J=12.7,10.0,1 \mathrm{H}, \mathrm{HC}(4)), 2.32(\mathrm{dd}, J=12.9,3.4$, 
$1 \mathrm{H}, \mathrm{HC}(4)), 1.99$ (s, $\left.3 \mathrm{H}, \mathrm{H}_{3} \mathrm{C}(14)\right)$

TLC: $\quad R_{f} 0.31(\mathrm{EtOAc})[\mathrm{UV}(254 \mathrm{~nm})]$

SFC: $\quad(2 Z)-80, t_{\mathrm{R}} 3.24 \mathrm{~min}(88.1 \%) ;(2 Z)-80, t_{\mathrm{R}} 4.00 \mathrm{~min}(11.9 \%)$ (Chiralpak OD, 125 psi, $40{ }^{\circ} \mathrm{C}, 20.0 \% \mathrm{MeOH}$ in $\mathrm{CO}_{2}, 3.0 \mathrm{~mL} / \mathrm{min}, 220 \mathrm{~nm}$ )

\section{Preparation of 4-[(5R,2E)-1-Oxo-7-phenyl-5-hydroxy-3-methyl-2,6-heptdienyl]morpholine} (80) (Table 14, entry 3)

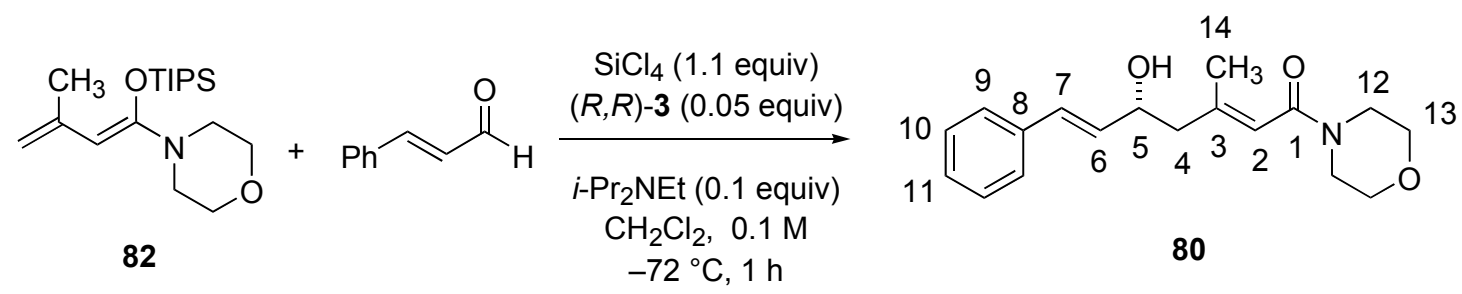

Following Representative Procedure 8, $32 \mu \mathrm{L}(0.25 \mathrm{mmol})$ of cinnamaldehyde was combined with $11 \mathrm{mg}(0.0125 \mathrm{mmol}, 0.05$ equiv) of bisphosphoramide $(R, R)-3,4 \mu \mathrm{L}(0.025$ mmol, 0.1 equiv) of diisopropylethylamine, $32 \mu \mathrm{L}\left(0.3 \mathrm{mmol}, 1.1\right.$ equiv) of $\mathrm{SiCl}_{4}$ and $72 \mathrm{mg}(1.2$ mmol, 1.2 equiv) of $\mathbf{8 2}$ to yield after column chromatography $\left(\mathrm{SiO}_{2}(10 \mathrm{~g}), 2 \mathrm{~cm}\right.$ diam., EtOAc $(100 \mathrm{~mL})$ to $\mathrm{EtOAc} / \mathrm{MeOH}, 19 / 1(100 \mathrm{~mL}))$ to yield $5 \mathrm{mg}(7 \%)$ of $(2 Z)-80$ as a clear, colorless oil and $56 \mathrm{mg}(75 \%)$ of $(2 E)-\mathbf{8 0}$ as a clear, colorless oil. The $(2 E)-\mathbf{8 0} /(2 Z)-\mathbf{8 0}$ ratio was determined to be $87 / 13$ by ${ }^{1} \mathrm{H}$ NMR $(500 \mathrm{MHz})$ analysis of the crude reaction mixture. The ratio of $\gamma / \alpha$-addition products was determined to be $>99 / 1$ by ${ }^{1} \mathrm{H}$ NMR (500 MHz) analysis of the crude reaction mixture.

Data for $(2 E)-\mathbf{8 0}$ :

${ }^{1} \mathrm{H} \mathrm{NMR}: \quad\left(500 \mathrm{MHz}, \mathrm{CDCl}_{3}\right)$

7.36 (d, $J=7.1,2 \mathrm{H}, \mathrm{HC}(9)), 7.31$ (t, $J=7.6,2 \mathrm{H}, \mathrm{HC}(10)), 7.24$ (t, $J=7.3,1 \mathrm{H}$, $\mathrm{HC}(11)), 6.38(\mathrm{~d}, J=15.7,1 \mathrm{H}, \mathrm{HC}(7)), 6.22$ (dd, $J=15.8,6.6,1 \mathrm{H}, \mathrm{HC}(6)), 5.84$ (s, $1 \mathrm{H}, \mathrm{HC}(2)), 4.52-4.48$ (m, $1 \mathrm{H}, \mathrm{HC}(5)), 3.60-3.44$ (m, 8 H, $\left.\mathrm{H}_{2} \mathrm{C}(12,13)\right)$, 2.462.38 (m, 2 H, $\left.\mathrm{H}_{2} \mathrm{C}(4)\right), 1.93$ (s, 3 H, $\mathrm{H}_{3} \mathrm{C}(14)$ )

TLC: $\quad R_{f} 0.18($ EtOAc) [UV $(254 \mathrm{~nm})]$

SFC: $\quad(5 R, 2 E)-80, t_{\mathrm{R}} 1.72 \mathrm{~min}(99.5 \%) ;(5 S, 2 E)-80, t_{\mathrm{R}} 2.82 \mathrm{~min}(0.5 \%)$ (Chiralpak OB, $125 \mathrm{psi}, 40^{\circ} \mathrm{C}, 20.0 \% \mathrm{MeOH}$ in $\mathrm{CO}_{2}, 3.0 \mathrm{~mL} / \mathrm{min}, 220 \mathrm{~nm}$ ) 
Data for (2Z)-80:

${ }^{1} \mathrm{H}$ NMR: $\quad\left(500 \mathrm{MHz}, \mathrm{CDCl}_{3}\right)$

7.40 (d, $J=7.3,2 \mathrm{H}, \mathrm{HC}(9)), 7.29$ (t, $J=7.7,2 \mathrm{H}, \mathrm{HC}(10)), 7.21$ (t, $J=7.4,1 \mathrm{H}$, $\mathrm{HC}(11)), 6.72(\mathrm{dd}, J=15.8,0.7,1 \mathrm{H}, \mathrm{HC}(7)), 6.30(\mathrm{dd}, J=15.9,5.6,1 \mathrm{H}$, $\mathrm{HC}(6)), 6.07$ (d, $J=1.2,1 \mathrm{H}, \mathrm{HC}(2))$, 4.48-4.44 (m, 1 H, HC(5)), 3.79-3.35 (m, 9 $\left.\mathrm{H}, \mathrm{OH}, \mathrm{H}_{2} \mathrm{C}(12,13)\right), 2.86(\mathrm{dd}, J=12.7,10.0,1 \mathrm{H}, \mathrm{HC}(4)), 2.32(\mathrm{dd}, J=12.9,3.4$, $1 \mathrm{H}, \mathrm{HC}(4)), 1.99$ (s, $\left.3 \mathrm{H}, \mathrm{H}_{3} \mathrm{C}(14)\right)$

TLC: $\quad R_{f} 0.31$ (EtOAc) [UV $(254 \mathrm{~nm})$ ]

SFC: $\quad(2 Z)-80, t_{\mathrm{R}} 3.11 \mathrm{~min}(86.6 \%) ;(2 Z)-80, t_{\mathrm{R}} 4.21 \mathrm{~min}(13.4 \%)$ (Chiralpak OD, 125 psi, $40{ }^{\circ} \mathrm{C}, 20.0 \% \mathrm{MeOH}$ in $\mathrm{CO}_{2}, 3.0 \mathrm{~mL} / \mathrm{min}, 220 \mathrm{~nm}$ )

Preparation of $\quad(+)-4-[(4 R, 5 R, 2 E)-1-0 x 0-5-p h e n y l-5-h y d r o x y-4-m e t h y l-2-$ pentenyl]morpholine (84) (Table 15, entry 2)
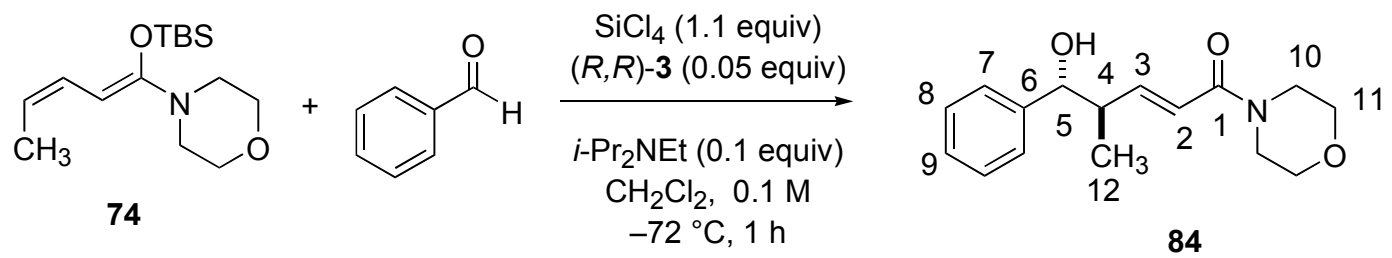

Following Representative Procedure 8, $102 \mu \mathrm{L}(1.0 \mathrm{mmol})$ of benzaldehyde was combined with $42 \mathrm{mg}$ ( $0.05 \mathrm{mmol}, 0.05$ equiv) of bisphosphoramide $(R, R)-3,18 \mu \mathrm{L}(0.1 \mathrm{mmol}$, 0.1 equiv) of diisopropylethylamine, $126 \mu \mathrm{L}\left(1.1 \mathrm{mmol}, 1.1\right.$ equiv) of $\mathrm{SiCl}_{4}$ and $340 \mathrm{mg}(1.2$ mmol, 1.2 equiv) of $\mathbf{7 4}$ to yield, after column chromatography $\left(\mathrm{SiO}_{2}(30 \mathrm{~g}), 3 \mathrm{~cm}\right.$ diam., EtOAc $(200 \mathrm{~mL})$ to $\mathrm{EtOAc} / \mathrm{MeOH}, 19 / 1(150 \mathrm{~mL}))$ an oil which was crystallized from $\mathrm{Et}_{2} \mathrm{O}(3 \mathrm{~mL})$ to yield $270 \mathrm{mg}(98 \%)$ of $(+)-84$ as white crystals. The ratio of $\gamma / \alpha$-addition products was determined to be $>99 / 1$ by ${ }^{1} \mathrm{H}$ NMR $(500 \mathrm{MHz})$ analysis of the crude reaction mixture.

Data for $(+)-84$ :

mp: $\quad 84-86^{\circ} \mathrm{C}\left(\mathrm{Et}_{2} \mathrm{O}\right)$

${ }^{1}$ H NMR: $\quad\left(500 \mathrm{MHz}, \mathrm{CDCl}_{3}\right)$

7.36-7.26 (m, $5 \mathrm{H}, \mathrm{HC}(7,8,9)), 6.89$ (dd, $J=15.1,8.5,1 \mathrm{H}, \mathrm{HC}(3)), 6.23$ (d, $J=$ 15.1, $1 \mathrm{H}, \mathrm{HC}(2)), 4.52$ (d, $J=7.6,1 \mathrm{H}, \mathrm{HC}(5)), 3.66-3.47$ (m, $8 \mathrm{H}, \mathrm{H}_{2} \mathrm{C}(10,11)$ ), 2.68-2.64 (m, 2 H, HC(4)), 2.42 (br s, $1 \mathrm{H}, \mathrm{OH}), 0.94$ (d, $\left.J=6.8,3 \mathrm{H}, \mathrm{H}_{3} \mathrm{C}(12)\right)$ 
${ }^{13} \mathrm{C}$ NMR: $\quad\left(126 \mathrm{MHz}, \mathrm{CDCl}_{3}\right)$

$165.6(\mathrm{C}(1)), 148.5(\mathrm{C}(3)), 142.6(\mathrm{C}(6)), 128.1(\mathrm{C}(8), 127.4$ (C(9)), 126.6 (C(7)), $120.4(\mathrm{C}(2)), 77.5(\mathrm{C}(5)), 66.5$ (C(11)), 45.9 (C(10)), 44.9 (C4)), 42.0 (C(10)), $16.3(\mathrm{C}(12))$

IR: $\quad\left(\mathrm{CHCl}_{3}\right)$

3401 (w), $3086(w), 3063$ (w), $3030(\mathrm{~m}), 2968$ (w), 2926 (w), $2901(\mathrm{w}), 2861(\mathrm{w})$, 2760 (w), 2717 (w), 2244 (w), 1955 (w), 1813 (w), 1656 (s), 1606 (s), 1493 (w), 1455 (m), 1438 (s), 1362 (w), 1301 (w), 1271 (m), 1241 (m), 1194 (w), 1116 (s), $1069(\mathrm{w}), 1044(\mathrm{~m}), 1001(\mathrm{w}), 975(\mathrm{~m}), 911(\mathrm{~s}), 851(\mathrm{w}), 826(\mathrm{w}), 792(\mathrm{w}), 762$ (m), $732(\mathrm{~s}), 703(\mathrm{~s}), 647(\mathrm{~m})$

MS: $\quad\left(\mathrm{CI}, \mathrm{CH}_{4}\right)$

305 (11), $276\left(\mathrm{M}^{+}+\mathrm{H}, 25\right), 259$ (18), 258 (100), 170 (43), 169 (26), 114 (19), 107 (46), 88 (12), 79 (11), 59 (11)

Opt. Rot.: $\quad[\alpha]_{\mathrm{D}}^{24}+50.30(\mathrm{c}=1.09, \mathrm{EtOH})$

TLC: $\quad R_{f} 0.15$ (EtOAc) [UV $\left.(254 \mathrm{~nm})\right]$

SFC: $\quad \operatorname{syn-84,~} 4.63 \mathrm{~min}(3.4 \%) ;(4 R, 5 R)-84, t_{\mathrm{R}} 5.27 \mathrm{~min}(85.2 \%) ;(4 S, 5 S)-84, t_{\mathrm{R}} 6.51 \mathrm{~min}$ (11.4\%) (Chiralpak OJ, $125 \mathrm{psi}, 40^{\circ} \mathrm{C}, 7.0 \% \mathrm{MeOH}$ in $\mathrm{CO}_{2}, 3.0 \mathrm{~mL} / \mathrm{min}, 220 \mathrm{~nm}$ ) Analysis: $\quad \mathrm{C}_{16} \mathrm{H}_{21} \mathrm{NO}_{3}(275.34)$
Calcd:
C, 69.79;
$\mathrm{H}, 7.69$;
$\mathrm{N}, 5.09 \%$
Found:
C, 69.64;
$\mathrm{H}, 7.67$;
$\mathrm{N}, 5.15 \%$

\section{Preparation of 4-[(2E)-1-Oxo-5-phenyl-5-hydroxy-4-methyl-2-pentenyl]morpholine
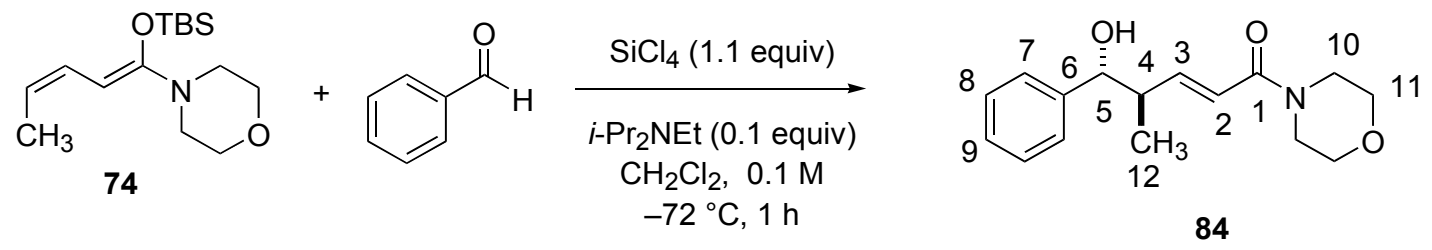

Following Representative Procedure 8, $25 \mu \mathrm{L}(0.25 \mathrm{mmol})$ of benzaldehyde was combined with $4 \mu \mathrm{L}(0.025 \mathrm{mmol}, 0.1$ equiv) of diisopropylethylamine, $32 \mu \mathrm{L}(0.275 \mathrm{mmol}, 1.1$ 
equiv) of $\mathrm{SiCl}_{4}$ and $85 \mathrm{mg}(0.3 \mathrm{mmol}, 1.2$ equiv) of 74 to yield, after column chromatography $\left(\mathrm{SiO}_{2}(10 \mathrm{~g}), 3 \mathrm{~cm}\right.$ diam., EtOAc/hexanes, $1 / 1(100 \mathrm{~mL})$ to EtOAc $\left.(200 \mathrm{~mL})\right)$ to yield $60 \mathrm{mg}$ (87\%, anti/syn 66/37) of 84 as clear, colorless oil. The ratio of $\gamma / \alpha$-addition products was determined to be $95 / 5$ by ${ }^{1} \mathrm{H}$ NMR $(500 \mathrm{MHz})$ analysis of the crude reaction mixture.

Data for 84:

${ }^{1}$ H NMR: $\quad\left(500 \mathrm{MHz}, \mathrm{CDCl}_{3}\right)$

7.36-7.24 (m, $5 \mathrm{H}, \mathrm{HC}(7,8,9)), 6.87$ (dd, $J=15.3,8.6,1 \mathrm{H}, \mathrm{HC}(3)), 6.24$ (d, $J=$ 15.0, $1 \mathrm{H}, \mathrm{HC}(2)), 4.51$ (d, $J=7.7,1 \mathrm{H}, \mathrm{HC}(5)), 3.66-3.48\left(\mathrm{~m}, 8 \mathrm{H}, \mathrm{H}_{2} \mathrm{C}(10,11)\right)$, 2.68-2.64 (m, 2 H, HC(4)), 2.42 (br s, 1 H, OH), 0.94 (d, $J=6.8,3$ H, $\mathrm{H}_{3} \mathrm{C}(12)$ ) TLC: $\quad R_{f} 0.15(\mathrm{EtOAc})[\mathrm{UV}(254 \mathrm{~nm})]$

Preparation of 4-[(4R,5R,2E,6E)-1-Oxo-7-phenyl-5-hydroxy-4-methyl-2,6heptadienyl]morpholine (85) (Scheme 7)<smiles>O=C/C=C/c1ccccc1</smiles>

$\mathrm{SiCl}_{4}(1.1$ equiv) $\stackrel{(R, R)-3 \text { ( } 0.05 \text { equiv) }}{\longrightarrow}$<smiles>C/C=C\C=C(/O[Sb])N1CCOCC1</smiles>
74

$$
\text { i- } \mathrm{Pr}_{2} \mathrm{NEt} \text { (0.1 equiv) }
$$

$\mathrm{CH}_{2} \mathrm{Cl}_{2}, 0.1 \mathrm{M}$

$-72{ }^{\circ} \mathrm{C}, 1 \mathrm{~h}$

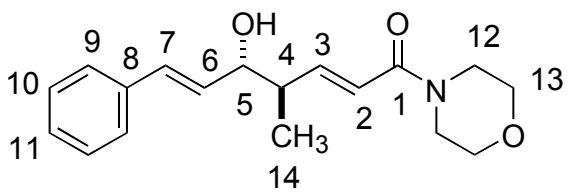

$\gamma-1,2-85$

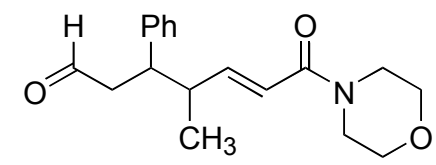

$\gamma-1,4-85$<smiles>C/C=C/C(C(=O)N1CCOCC1)C(O)/C=C/c1ccccc1</smiles>

$\alpha-1,2-85$<smiles>C/C=C/C(C(=O)N1CCOCC1)C(CC=O)c1ccccc1</smiles>

$\alpha-1,4-85$

Following Representative Procedure 8, $25 \mu \mathrm{L}(0.25 \mathrm{mmol})$ of benzaldehyde was combined with $11 \mathrm{mg}(0.0125 \mathrm{mmol}, 0.05$ equiv) of bisphosphoramide $(R, R)-3,4 \mu \mathrm{L}(0.025$ mmol, 0.1 equiv) of diisopropylethylamine, $32 \mu \mathrm{L}\left(0.275 \mathrm{mmol}, 1.1\right.$ equiv) of $\mathrm{SiCl}_{4}$ and $85 \mathrm{mg}$ ( $0.3 \mathrm{mmol}, 1.2$ equiv) of 74 to yield after column chromatography $\left(\mathrm{SiO}_{2}(10 \mathrm{~g}), 3 \mathrm{~cm}\right.$ diam., EtOAc/hexanes, $1 / 1(100 \mathrm{~mL})$ to EtOAc $(200 \mathrm{~mL})) 41 \mathrm{mg}(55 \%)$ of $\alpha-1,4-85$ and $30 \mathrm{mg}(40 \%)$ of a 69/31 mixture of $\gamma-1,2-85 / \gamma-1,4-85$ as clear, colorless oil. The diastereomeric ratio of $\gamma-1,2-$ 85 was determined to be anti/syn, $82 / 18$ by SFC analysis. The ratio of $\gamma-1,2-85 / \alpha-1,2-85 / \gamma-1,4-$ 85/ $\alpha-1,4-85$ was determined to be $31 / 0 / 14 / 55$ by ${ }^{1} \mathrm{H}$ NMR $(500 \mathrm{MHz})$ analysis. 
Data for $\alpha-1,4-85$ :

${ }^{1} \mathrm{H}$ NMR: $\quad\left(500 \mathrm{MHz}, \mathrm{CDCl}_{3}\right)$

$9.59(\mathrm{~d}, J=1.5,1 \mathrm{H})$ 7.31-7.21 (m, $5 \mathrm{H})$, 5.76-5.69 (m, $1 \mathrm{H})$, 5.61-5.56 (m, $1 \mathrm{H})$,

3.85-3.76 (m, $2 \mathrm{H}), 3.59-3.50(\mathrm{~m}, 1 \mathrm{H}), 3.45-3.41$ (m, $1 \mathrm{H}), 3.30-3.15(\mathrm{~m}, 4 \mathrm{H})$,

2.93-2.84 (m, 2 H), 2.72-2.67 (m, $1 \mathrm{H}), 1.65(\mathrm{dd}, J=6.8,1.7,3 \mathrm{H})$

MS: $\quad\left(\mathrm{CI}, \mathrm{CH}_{4}\right)$

303 (20), $302\left(\mathrm{M}^{+}+\mathrm{H}, 100\right), 284$ (16), 170 (34), 169 (16), 168 (11), 161 (10), 133

(23), $114(18), 88(13)$

TLC: $\quad R_{f} 0.30($ EtOAc) [UV $(254 \mathrm{~nm})]$

Data for $\gamma-1,2-85$ :

${ }^{1} \underline{\mathrm{H} N M R}: \quad\left(500 \mathrm{MHz}, \mathrm{CDCl}_{3}\right)$

$7.38(\mathrm{dd}, J=7.3,1.2,2 \mathrm{H}, \mathrm{HC}(9)), 7.32$ (dt, $J=7.8,1.7,2 \mathrm{H}, \mathrm{HC}(10)), 7.25$ (t, $J$ $=7.3,1 \mathrm{H}, \mathrm{HC}(11)), 6.89(\mathrm{dd}, J=15.1,8.3,1 \mathrm{H}, \mathrm{HC}(3)), 6.60(\mathrm{dd}, J=15.9,5.4,1$ H, HC(7)), $6.29(\mathrm{dd}, J=15.2,1.0,1 \mathrm{H}, \mathrm{HC}(2)), 6.20(\mathrm{dd}, J=15.9,6.8,1 \mathrm{H}$, $\mathrm{HC}(6))$, 4.20-4.17 (m, $1 \mathrm{H}, \mathrm{HC}(5))$, 3.67-3.53 (m, 8 H, $\left.\mathrm{H}_{2} \mathrm{C}(12,13)\right), 2.59-2.52$ $(\mathrm{m}, 1 \mathrm{H}, \mathrm{HC}(4)), 2.15(\mathrm{~d}, J=3.4,1 \mathrm{H}, \mathrm{OH}), 1.12\left(\mathrm{~d}, J=6.8,3 \mathrm{H}, \mathrm{H}_{3} \mathrm{C}(12)\right)$

TLC: $\quad R_{f} 0.13$ (EtOAc) [UV (254 nm)]

SFC: $\quad(4 R, 5 R)-85, t_{\mathrm{R}} 2.49 \min (65.2 \%) ;(4 S, 5 S)-85, t_{\mathrm{R}} 3.17 \mathrm{~min}(34.8 \%)$ (Chiralpak AD, $125 \mathrm{psi}, 40^{\circ} \mathrm{C}, 25.0 \% \mathrm{MeOH}$ in $\mathrm{CO}_{2}, 3.0 \mathrm{~mL} / \mathrm{min}, 220 \mathrm{~nm}$ )

Preparation of 4-[(2E)-1-Oxo-7-phenyl-5-hydroxy-4-methyl-2,6-heptadienyl]morpholine (85) (Scheme 7)
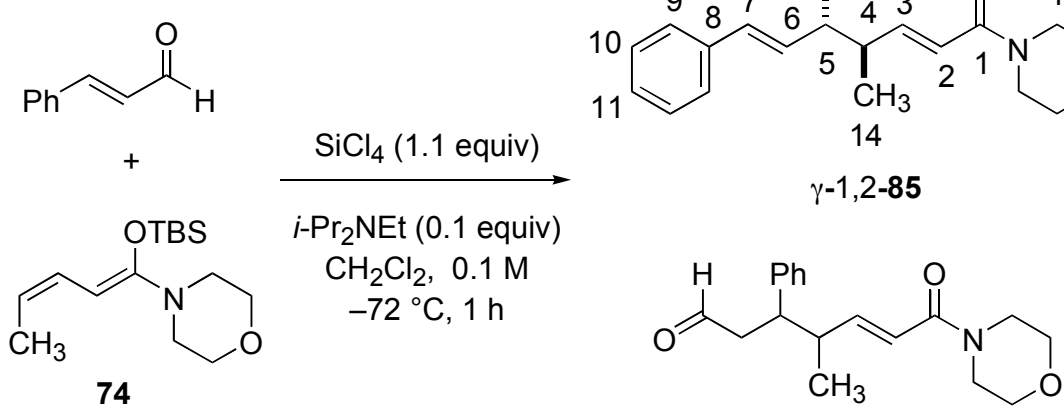

$\gamma-1,4-85$<smiles>C/C=C\C(C(=O)N1CCOCC1)C(O)/C=C/c1ccccc1</smiles><smiles>CC=CC(C(=O)N1CCOCC1)C(CC=O)c1ccccc1</smiles>

$\alpha-1,4-85$

Following Representative Procedure 8, $25 \mu \mathrm{L}(0.25 \mathrm{mmol})$ of benzaldehyde was 
combined with $4 \mu \mathrm{L}(0.025 \mathrm{mmol}, 0.1$ equiv) of diisopropylethylamine, $32 \mu \mathrm{L}(0.275 \mathrm{mmol}, 1.1$ equiv) of $\mathrm{SiCl}_{4}$ and $85 \mathrm{mg}(0.3 \mathrm{mmol}, 1.2$ equiv) of 74 to yield after column chromatography $\left(\mathrm{SiO}_{2}(10 \mathrm{~g}), 3 \mathrm{~cm}\right.$ diam., EtOAc/hexanes, $1 / 1(100 \mathrm{~mL})$ to EtOAc $\left.(200 \mathrm{~mL})\right) 71 \mathrm{mg}(95 \%)$ of a 98/2 mixture of $\gamma-1,2-85 / \gamma-1,4-85$ as clear, colorless oil. The ratio of $\gamma-1,2-85 / \alpha-1,2-85 / \gamma-1,4-$ 85/ $\alpha-1,4-85$ was determined to be $87 / 0 / 2 / 11$ by ${ }^{1} \mathrm{H}$ NMR (500 MHz) analysis of the crude reaction mixture.

Data for $\gamma-1,2-85$ :

${ }^{1}$ H NMR: $\quad\left(500 \mathrm{MHz}, \mathrm{CDCl}_{3}\right)$

$7.38(\mathrm{dd}, J=7.3,1.2,2 \mathrm{H}, \mathrm{HC}(9)), 7.32$ (dt, $J=7.8,1.7,2 \mathrm{H}, \mathrm{HC}(10)), 7.25$ (t, $J$ $=7.3,1 \mathrm{H}, \mathrm{HC}(11)), 6.89(\mathrm{dd}, J=15.1,8.3,1 \mathrm{H}, \mathrm{HC}(3)), 6.60(\mathrm{dd}, J=15.9,5.4,1$ H, HC(7)), $6.29(\mathrm{dd}, J=15.2,1.0,1 \mathrm{H}, \mathrm{HC}(2)), 6.20(\mathrm{dd}, J=15.9,6.8,1 \mathrm{H}$, $\mathrm{HC}(6))$, 4.20-4.17 (m, $1 \mathrm{H}, \mathrm{HC}(5))$, 3.67-3.53 (m, 8 H, $\left.\mathrm{H}_{2} \mathrm{C}(12,13)\right), 2.59-2.52$ $(\mathrm{m}, 1 \mathrm{H}, \mathrm{HC}(4)), 2.15(\mathrm{~d}, J=3.4,1 \mathrm{H}, \mathrm{OH}), 1.12\left(\mathrm{~d}, J=6.8,3 \mathrm{H}, \mathrm{H}_{3} \mathrm{C}(12)\right)$

TLC: $\quad R_{f} 0.13(\mathrm{EtOAc})[\mathrm{UV}(254 \mathrm{~nm})]$

\section{Preparation of Silyl Ether 86}

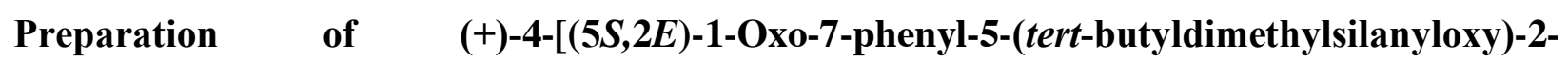
heptenyl]morpholine (86) (Scheme 8)

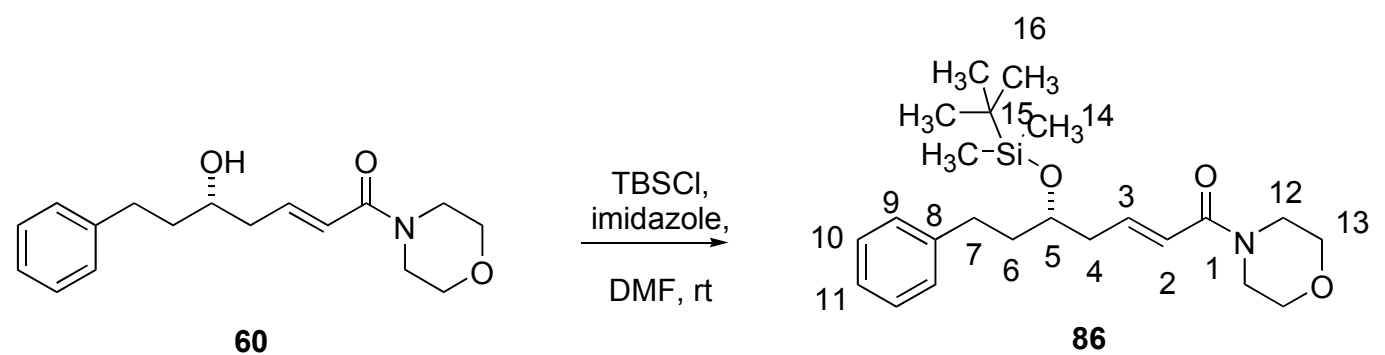

To a stirred solution of $302 \mathrm{mg}(1.04 \mathrm{mmol})$ of $(S)-60$ in $1.21 \mathrm{~mL}$ of DMF in a $25 \mathrm{~mL} 1$ neck, round bottom flask was added $170 \mathrm{mg}$ ( $2.5 \mathrm{mmol}, 2.4$ equiv) of imidazole, and $181 \mathrm{mg}$ (1.2 mmol, 1.15 equiv) of $\mathrm{TBSCl}$ at room temperature under argon. After the addition was complete, the solution was allowed to stir at room temperature for $18 \mathrm{~h}$. The reaction mixture was then poured into a stirring sat. aq. $\mathrm{NaHCO}_{3}$ solution $(25 \mathrm{~mL})$. The organic layer was removed from the biphasic mixture and the aqueous layer was washed with $\mathrm{CH}_{2} \mathrm{Cl}_{2}(3 \mathrm{x} 50 \mathrm{~mL})$. The combined organic extracts were dried over $\mathrm{Na}_{2} \mathrm{SO}_{4}(5 \mathrm{~g})$, filtered and the filtrate was 
concentrated in vacuo. The residue was purified by column chromatography $\left(\mathrm{SiO}_{2}(30 \mathrm{~g}), 3 \mathrm{~cm}\right.$ diam., EtOAc/ hexanes, 1/1) to yield $392 \mathrm{mg}(93 \%)$ of (+)-86 as a colorless oil. ${ }^{17}$

Data for $(+)-86$ :

bp: $\quad 180{ }^{\circ} \mathrm{C}\left(2.5 \times 10^{-5} \mathrm{mmHg}, \mathrm{ABT}\right)$

${ }^{1} \mathrm{H}$ NMR: $\quad\left(500 \mathrm{MHz}, \mathrm{CDCl}_{3}\right)$

$7.26(\mathrm{t}, J=7.7,2 \mathrm{H}, \mathrm{HC}(10)), 7.17-7.15(\mathrm{~m}, 3 \mathrm{H}, \mathrm{HC}(9,11)), 6.91(\mathrm{dt}, J=15.1$, 7.6, $1 \mathrm{H}, \mathrm{HC}(3)), 6.23$ (d, $J=14.9,1 \mathrm{H}, \mathrm{HC}(2)), 3.86$ (p, $J=5.7,1 \mathrm{H}, \mathrm{HC}(5))$, 3.64-3.51 (m, $\left.8 \mathrm{H}, \mathrm{H}_{2} \mathrm{C}(12,13)\right), 2.71$ (dt, $\left.J=13.7,8.3,1 \mathrm{H}, \mathrm{HC}(7)\right), 2.59$ (dt, $J=$ 13.7, 8.8, 1 H, HC(7)), 2.42-2.40 (m, 2 H, $\left.\mathrm{H}_{2} \mathrm{C}(4)\right)$, 1.79-1.75 (m, $2 \mathrm{H}, \mathrm{H}_{2} \mathrm{C}(6)$ ), 0.92 (s, 9 H, $\left.\mathrm{H}_{3} \mathrm{C}(16)\right), 0.07$ (s, $\left.3 \mathrm{H}, \mathrm{H}_{3} \mathrm{C}(14)\right), 0.07$ (s, $3 \mathrm{H}, \mathrm{H}_{3} \mathrm{C}(14)$ )

${ }^{13} \mathrm{C} \mathrm{NMR}: \quad\left(126 \mathrm{MHz}, \mathrm{CDCl}_{3}\right)$

165.0 (C(1)), 142.9 (C(3)), 141.9 (C(8), 128.11 (C(9), 128.05 (C(10)), 125.5 (C(11)), 121.4 (C(2)), 70.6 (C(5)), 66.5 (C(13)), 45.8 (C12)), 41.9 (C(12)), 40.3 $(\mathrm{C}(4)), 38.7(\mathrm{C}(6)), 31.5(\mathrm{C}(7)), 25.6(\mathrm{C}(16)), 17.7(\mathrm{C}(15)),-4.6(\mathrm{C}(14)),-4.8$ (C(14))

IR: (neat)

3085 (w), 3062 (w), 3027 (w), 3955 (m), 2929 (s), 2897 (m), 2857 (s), 2709 (w), 1958 (w), 1804 (w), 1661 (s), 1622 (s), 1496 (w), 1472 (m), 1455 (m), 1434 (s), $1388(\mathrm{w}), 1361$ (m), 1301 (w), 1256 (m), 1236 (m), 1192 (m), 1155 (w), 1117 (s), 1090 (m), 1070 (m), 1044 (m), 1005 (m), 981 (m), 940 (w), 921 (w), 881 (w), 837 (s), $812(\mathrm{~m}), 776(\mathrm{~s}), 749(\mathrm{~m}), 700(\mathrm{~m}), 664(\mathrm{w})$

MS: $\quad\left(\mathrm{CI}, \mathrm{CH}_{4}\right)$ 405 (30), $404\left(\mathrm{M}^{+}+\mathrm{H}, 100\right), 388$ (27), 347 (22), 246 (84), 300 (10), 272 (42), 249 (25), 212 (13), 91 (11), 73 (11)

Opt. Rot.: $\quad[\alpha]_{\mathrm{D}}^{24}+3.42(\mathrm{c}=1.21, \mathrm{EtOH})$

TLC: $\quad R_{f} 0.49$ (EtOAc) [UV $(254 \mathrm{~nm})$ ]

HRMS: Calcd for $\mathrm{C}_{23} \mathrm{H}_{38} \mathrm{NO}_{3} \mathrm{Si}$ : 404.2621, found: 404.2622 


\section{Preparation of Methyl Ketone 87}

Preparation of $(+)-(6 S, 3 E)-6-($ tert-Butyldimethylsilanyloxy)-8-phenyl-3-octen-2-one (87) (Scheme 8)

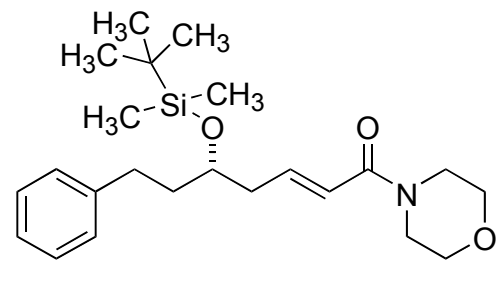

86

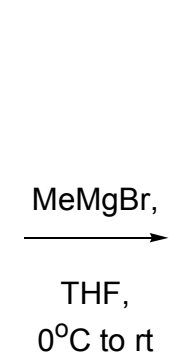

A $25 \mathrm{~mL}, 2$-necked, round-bottomed flask fitted with a magnetic stir bar, gas inlet tube and septum containing a stirring solution of $130 \mathrm{mg}(0.32 \mathrm{mmol})$ of $(S)-86$ in $3.20 \mathrm{~mL}$ of THF under Ar was cooled to $0{ }^{\circ} \mathrm{C}$ (bath temperature) in an ice water bath and then $0.21 \mathrm{~mL}$ of a solution of $\mathrm{MeMgBr}$ in $\mathrm{Et}_{2} \mathrm{O}$ (3.0 M, 0.64 mmol, 2.0 equiv) was added slowly over 2 min via syringe. After the addition was complete, the ice water bath removed and the solution was allowed to stir at room temperature for $3 \mathrm{~h}$. The reaction mixture was then poured into a stirring sat. aq. $\mathrm{NH}_{4} \mathrm{Cl}$ solution $(30 \mathrm{~mL})$. The layers separated and the aqueous layer was washed with $\mathrm{CH}_{2} \mathrm{Cl}_{2}(3 \times 30 \mathrm{~mL})$. The combined organic extracts were dried over $\mathrm{Na}_{2} \mathrm{SO}_{4}(5 \mathrm{~g})$, filtered and the filtrate was concentrated in vacuo. The residue was purified by column chromatography $\left(\mathrm{SiO}_{2}\right.$ (15 g), $2 \mathrm{~cm}$ diam., hexanes/EtOAc, 10/1) to yield, after Kugelrohr distillation, $89 \mathrm{mg}$ $(84 \%)$ of $(+)-87$ as a colorless oil.

Data for $(+)-87$ :

bp: $\quad 100^{\circ} \mathrm{C}\left(5.5 \times 10^{-5} \mathrm{mmHg}, \mathrm{ABT}\right)$

${ }^{1} \mathrm{H} \mathrm{NMR}: \quad\left(500 \mathrm{MHz}, \mathrm{CDCl}_{3}\right)$

7.28 (t, $J=7.4,2$ H, HC(11)), 7.20-7.16 (m, 3 H, HC(10,12)), 6.82 (dt, $J=16.0$, 7.4, $1 \mathrm{H}, \mathrm{HC}(4)), 6.09$ (d, $J=16.1,1 \mathrm{H}, \mathrm{HC}(3)), 3.87$ (p, $J=5.6,1 \mathrm{H}, \mathrm{HC}(6))$, 2.73-2.58 (m, $2 \mathrm{H}, \mathrm{H}_{2} \mathrm{C}(8)$ ), 2.47-2.39 (m, $\left.2 \mathrm{H}, \mathrm{H}_{2} \mathrm{C}(5)\right), 2.25$ (s, $3 \mathrm{H}, \mathrm{H}_{3} \mathrm{C}(1)$ ), $1.77\left(\mathrm{dq}, J=5.9,2.0,2 \mathrm{H}, \mathrm{H}_{2} \mathrm{C}(7)\right), 0.91$ (s, $\left.9 \mathrm{H}, \mathrm{H}_{3} \mathrm{C}(15)\right), 0.07$ (s, $3 \mathrm{H}$, $\left.\mathrm{H}_{3} \mathrm{C}(13)\right), 0.05$ (s, $\left.3 \mathrm{H}, \mathrm{H}_{3} \mathrm{C}(13)\right)$

${ }^{13} \mathrm{C} \mathrm{NMR}: \quad\left(126 \mathrm{MHz}, \mathrm{CDCl}_{3}\right)$

198.2 (C(2)), 144.7 (C(4)), 141.9 (C(9)), 133.3 (C(3)), 128.3 (C(10)), 128.2 (C(11)), 125.8 (C(12)), 70.7 (C(6)), 40.1 (C(5)), 39.0 (C(7)), 31.5 (C(8)), 26.6 
(C(1)), $25.7(\mathrm{C}(15)), 17.9(\mathrm{C}(14)),-4.58(\mathrm{C}(13)),-4.62(\mathrm{C}(13))$

IR: $\quad$ (neat)

$3086(\mathrm{w}), 3063$ (w), 3028 (m), 3003 (w), 2953 (s), 2930 (s), 2895 (m), 2857 (s), 2803 (w), 1943 (w), 1871 (w), 1803 (w), 1699 (s), 1678 (s), 1630 (m), 1604 (w), 1585 (w), 1496 (m), 1472 (m), 1462 (m), 1455 (m), 1430 (m), 1388 (m), 1361 (s), 1320 (w), 1254 (s), 1180 (m), 1155 (w), 1091 (s), 1063 (s), 1031 (m), 1004 (m), 984 (s), 939 (m), 920 (w), 880 (w), 836 (s), 810 (m), 775 (s), 748 (m), 700 (s), $666(w), 618(w), 604(w)$

MS: (ESI)

$333\left(\mathrm{M}^{+}+\mathrm{H}, 48\right), 250$ (32), 249 (100), 193 (12)

Opt. Rot.: $\quad[\alpha]_{\mathrm{D}}{ }^{24}+10.30(\mathrm{c}=0.95, \mathrm{EtOH})$

TLC: $\quad R_{f} 0.45$ (hexanes/EtOAc, 10/1) [UV (254 nm)]

Analysis: $\quad \mathrm{C}_{20} \mathrm{H}_{32} \mathrm{O}_{2} \mathrm{Si}(332.55)$

Calcd: $\quad$ C, $72.23 ; \quad H, 9.70 \%$

Found: $\quad$ C, $72.06 ; \quad H, 10.02 \%$

Preparation of $(+)-(6 S, 3 E)-6-($ tert-Butyldimethylsilanyloxy)-8-phenyl-3-octen-2-one (87) (Scheme 8)

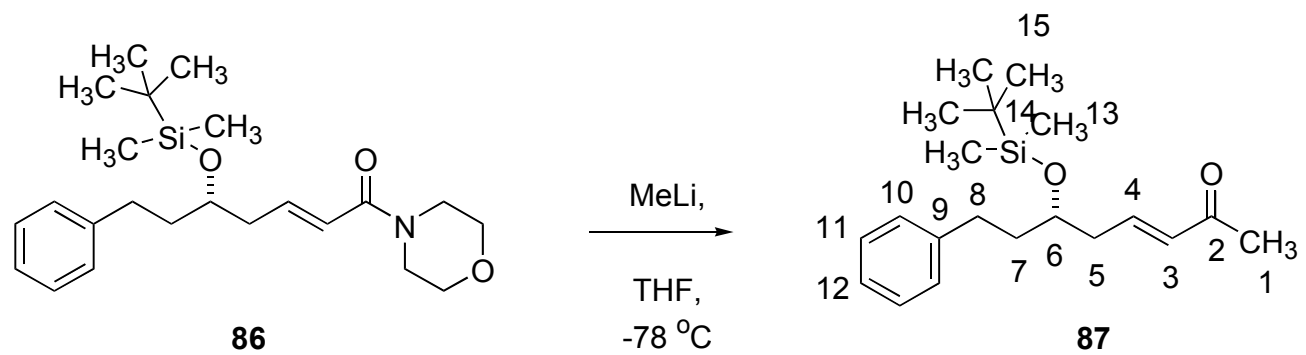

A 5-mL, Schlenk flask containing a stirring solution of $36 \mathrm{mg}(0.09 \mathrm{mmol})$ of $(S)-86$ in $1.0 \mathrm{~mL}$ of THF under $\mathrm{Ar}$ was cooled to $-78{ }^{\circ} \mathrm{C}$ (bath temperature) and then $0.066 \mathrm{~mL}$ of a solution of $\mathrm{MeMgBr}$ in hexanes (1.5 M, $0.099 \mathrm{mmol}, 1.1$ equiv) was added slowly over $2 \mathrm{~min}$ via syringe. After the addition was complete, the solution was allowed to stir at $-78^{\circ} \mathrm{C}$ for 30 min. The reaction mixture was then poured into a stirring sat. aq. $\mathrm{NH}_{4} \mathrm{Cl}$ solution $(30 \mathrm{~mL})$. The layers separated and the aqueous layer was washed with $\mathrm{CH}_{2} \mathrm{Cl}_{2}(3 \times 20 \mathrm{~mL})$. The combined organic extracts were dried over $\mathrm{Na}_{2} \mathrm{SO}_{4}(5 \mathrm{~g})$, filtered and the filtrate was concentrated in vacuo. The residue was purified by column chromatography $\left(\mathrm{SiO}_{2}(10 \mathrm{~g}), 2 \mathrm{~cm}\right.$ diam., hexanes/EtOAc, 
10/1) to yield $28 \mathrm{mg}(93 \%)$ of (+)-87 as a clear, colorless oil.

Data for $(+)-87$ :

${ }^{1} \mathrm{H} \mathrm{NMR}: \quad\left(500 \mathrm{MHz}, \mathrm{CDCl}_{3}\right)$

7.27 (t, $J=7.3,2$ H, HC(11)), 7.20-7.17 (m, 3 H, HC(10,12)), 6.87 (dt, $J=16.0$, 7.6, $1 \mathrm{H}, \mathrm{HC}(4)), 6.10$ (d, $J=16.2,1 \mathrm{H}, \mathrm{HC}(3)), 3.88$ (p, $J=5.5,1 \mathrm{H}, \mathrm{HC}(6))$, 2.74-2.58 (m, $2 \mathrm{H}, \mathrm{H}_{2} \mathrm{C}(8)$ ), 2.46-2.38 (m, $\left.2 \mathrm{H}, \mathrm{H}_{2} \mathrm{C}(5)\right), 2.26$ (s, $3 \mathrm{H}, \mathrm{H}_{3} \mathrm{C}(1)$ ), $1.78\left(\mathrm{dq}, J=5.9,2.2,2 \mathrm{H}, \mathrm{H}_{2} \mathrm{C}(7)\right), 0.92$ (s, $\left.9 \mathrm{H}, \mathrm{H}_{3} \mathrm{C}(15)\right), 0.07$ (s, $3 \mathrm{H}$, $\left.\mathrm{H}_{3} \mathrm{C}(13)\right), 0.05$ (s, $\left.3 \mathrm{H}, \mathrm{H}_{3} \mathrm{C}(13)\right)$

TLC: $\quad R_{f} 0.45$ (hexanes/EtOAc, 10/1) [UV (254 nm)]

\section{Determination of the Absolute Configuration of the Vinylogous Aldol Adducts.}

Representative Procedure 10. Ozonolysis of an $\alpha, \beta$-Unsaturated Ketones or Amides. Preparation of $(+)-(3 R)-1-P h e n y l p r o p a n e-1,3-d i o l ~((3 R)-25)$ from $(+)-(R)-5-h y d r o x y-1,5-$ diphenyl-pent-2-en-1-on ((5R,2E)-11) (Figure 2)

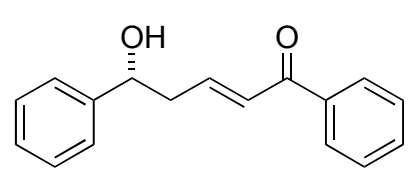

11

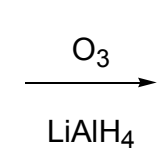

$\mathrm{AlH}_{4}$

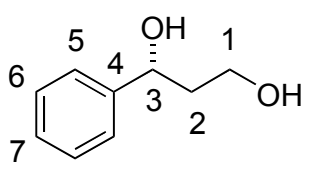

25

A 25-mL, 1-necked, round-bottomed flask containing a solution of $70 \mathrm{mg}$ of $11(0.28$ $\mathrm{mmol}$ ) in $5 \mathrm{~mL}$ of $\mathrm{CH}_{2} \mathrm{Cl}_{2}$ was cooled to $-78{ }^{\circ} \mathrm{C}$ (bath temperature) and a solution of ozone in oxygen was passed through it using a gas dispersion tube for $20 \mathrm{~min}$. The solution was sparged with $\mathrm{N}_{2}$ (to remove residual ozone) and then $0.56 \mathrm{~mL}$ of a solution of $\mathrm{LiAlH}_{4}$ in THF $(2.0 \mathrm{M}$, 1.12 mmol, 4 equiv) was added slowly at $-78{ }^{\circ} \mathrm{C}$. The flask was then fitted with a reflux condenser and was heated at $65{ }^{\circ} \mathrm{C}$ for $1.5 \mathrm{~h}$. The mixture was cooled to room temperature and 5 $\mathrm{mL}$ of sat. aq. sodium potassium tartrate solution was added and the mixture was stirred to break up the resulting precipitate. The organic layer was separated and the aqueous layer was washed $\mathrm{CH}_{2} \mathrm{Cl}_{2}(3 \times 10 \mathrm{~mL})$. The combined organic extracts were washed with brine $(25 \mathrm{~mL})$, then were dried over $\mathrm{Na}_{2} \mathrm{SO}_{4}$, filtered and was concentrated in vacuo. The residue was purified by column chromatography $\left(\mathrm{SiO}_{2}(15 \mathrm{~g}), 2 \mathrm{~cm}\right.$ diam., EtOAc/hexanes, $\left.2 / 1\right)$ to yield $30 \mathrm{mg}(71 \%)$ of (3R)-25 as a clear, colorless oil. The spectroscopic data for $\mathbf{2 5}$ matched those in the literature. ${ }^{18}$ 
Data for $(+)-(3 R)-25$ :

${ }^{1} \mathrm{H}$ NMR: $\quad\left(500 \mathrm{MHz}, \mathrm{CDCl}_{3}\right)$

7.39-7.27 (m, $5 \mathrm{H}, \mathrm{HC}(5,6,7)), 4.98(\mathrm{dd}, J=8.9,3.7,1 \mathrm{H}, \mathrm{HC}(3)), 3.88(\mathrm{t}, J=5.5$,

$\left.2 \mathrm{H}, \mathrm{H}_{2} \mathrm{C}(1)\right), 2.20$ (br s, $\left.2 \mathrm{H}, \mathrm{OH}\right) ; 2.08-1.92$ (m, $\left.2 \mathrm{H}, \mathrm{H}_{2} \mathrm{C}(2)\right)$

TLC: $\quad R_{f} 0.28($ EtOAc/hexanes, $2 / 1)$ [p-anisaldehyde]

Opt. Rot.: $[\alpha]_{\mathrm{D}}{ }^{24}+61.80^{\circ}\left(\mathrm{c}=0.97, \mathrm{CHCl}_{3}\right)$, lit. $[\alpha]_{\mathrm{D}}{ }^{24}-63.0\left(\mathrm{c}=0.958, \mathrm{CHCl}_{3}\right)$ for $(3 S)-25^{18}$

Preparation of $(+)-(3 R)-1-P h e n y l p r o p a n e-1,3-d i o l ~((3 R)-25)$ from $(+)-(R)-7-H y d r o x y-2,2-$ dimethyl-7-phenyl-4-hepten-3-one ((7R,4E)-12) (Figure 2)

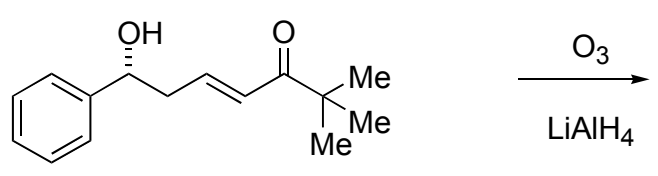

12

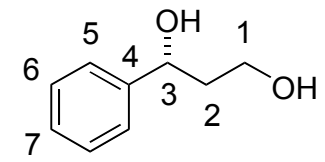

25

Following Representative Procedure 10, a solution of $75 \mathrm{mg}(0.32 \mathrm{mmol})$ of 12 in $5 \mathrm{~mL}$ of $\mathrm{CH}_{2} \mathrm{Cl}_{2}$ at $-78{ }^{\circ} \mathrm{C}$ (bath temperature) in was treated with a solution of ozone in oxygen followed by reduction with $0.64 \mathrm{~mL}$ of a solution of $\mathrm{LiAlH}_{4}$ in THF $(2.0 \mathrm{M}, 1.28 \mathrm{mmol}, 4.0$ equiv) to yield, after column chromatography $\left(\mathrm{SiO}_{2}(20 \mathrm{~g}), 2 \mathrm{~cm}\right.$ diam., EtOAc/hexanes, 2/1) 37 mg (76\%) of (3R)-25 as a colorless oil. The spectroscopic data for $\mathbf{2 5}$ matched those in the literature. $^{18}$

Data for $(+)-(3 R)-25:$

${ }^{1} \mathrm{H}$ NMR: $\quad\left(500 \mathrm{MHz}, \mathrm{CDCl}_{3}\right)$

7.41-7.26 (m, $5 \mathrm{H}, \mathrm{HC}(5,6,7)), 4.99(\mathrm{dd}, J=8.9,3.7,1 \mathrm{H}, \mathrm{HC}(3)), 3.88(\mathrm{t}, J=5.6$, $\left.2 \mathrm{H}, \mathrm{H}_{2} \mathrm{C}(1)\right), 2.17$ (br s, $\left.1 \mathrm{H}\right), 2.08-1.92$ (m, $\left.2 \mathrm{H}, \mathrm{H}_{2} \mathrm{C}(2)\right)$

TLC: $\quad R_{f} 0.28$ (EtOAc/hexanes, 2/1) [p-anisaldehyde]

Opt. Rot.: $[\alpha]_{\mathrm{D}}{ }^{24}+66.39^{\circ}\left(\mathrm{c}=1.0, \mathrm{CHCl}_{3}\right)$, lit. $[\alpha]_{\mathrm{D}}{ }^{24}-63.0\left(\mathrm{c}=0.958, \mathrm{CHCl}_{3}\right)$ for $(3 S)-\mathbf{2 5} 5^{18}$ 
Preparation of $(+)-(4 R, 7 R)-4-(H y d r o x y(p h e n y l) m e t h y l)-2-c y c l o h e x e n-1-o n e ~((4 R, 7 R)-20)$

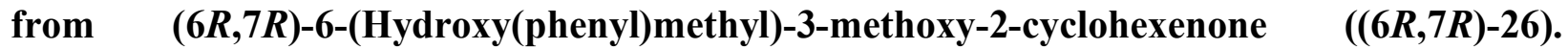
(Figure 2)

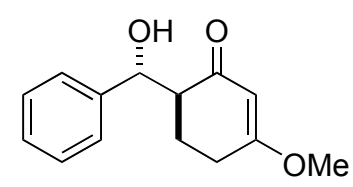

26

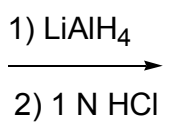

2) $1 \mathrm{NHCl}$

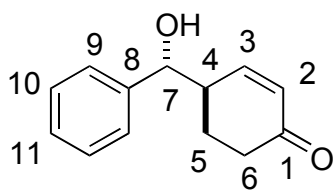

20

A 25-mL, 1-necked, round-bottomed flask fitted with a magnetic stir bar and septum containing a solution of $70 \mathrm{mg}$ of $26^{19}$ (99 mg, $\left.0.43 \mathrm{mmol}\right)$ in $5 \mathrm{~mL}$ of $\mathrm{Et}_{2} \mathrm{O}$ was cooled to $0{ }^{\circ} \mathrm{C}$ (bath temperature). A solution of $\mathrm{LiAlH}_{4}$ in THF $(2.0 \mathrm{M}, 1.12 \mathrm{mmol}, 4$ equiv) was then added via syringe. The flask was then fitted with a reflux condenser and was heated at $45^{\circ} \mathrm{C}$ for $1.0 \mathrm{~h}$. The mixture was cooled to room temperature and $1 \mathrm{~mL}$ of $\mathrm{H}_{2} \mathrm{O}$ was added followed by $5 \mathrm{~mL}$ of 1 $\mathrm{N} \mathrm{HCl}$ and the resulting biphasic mixture was stirred for $30 \mathrm{~min}$. The layers were then separated and the aqueous layer was extracted twice with $25 \mathrm{~mL}$ of $\mathrm{Et}_{2} \mathrm{O}$. The combined organic extracts were washed with a sat. aq. $\mathrm{NaHCO}_{3}$ solution $(25 \mathrm{~mL})$, then were dried over $\mathrm{NaSO}_{4}$, filtered and was concentrated in vacuo. The residue was purified by column chromatography ( $\mathrm{SiO}_{2}(15 \mathrm{~g})$, $2 \mathrm{~cm}$ diam., pentane/ $\left.\mathrm{Et}_{2} \mathrm{O}, 1 / 1\right)$ to give $75 \mathrm{mg}(86 \%$, anti/syn 93.5/6.5) of 20 as thick oil, which solidified upon standing. The spectroscopic data for $\mathbf{2 0}$ matched those in the literature. ${ }^{15}$

Data for $(+)-(4 R, 7 R)-\mathbf{2 0}$ :

${ }^{1}$ H NMR: $\quad\left(500 \mathrm{MHz}, \mathrm{CDCl}_{3}\right)$

7.43-7.32 (m, 5H, HC(9,10,11)); 7.25 (dt, $J=10.3,1.7,1 \mathrm{H}, \mathrm{HC}(3)) ; 6.09$ (dd, $J=$ 10.3, 2.4, $1 \mathrm{H}, \mathrm{HC}(2))$; 4.59 (dd, J = 7.8, 3.2, $1 \mathrm{H}, \mathrm{HC}(7)) ; 2.78-2.73$ (m, $1 \mathrm{H}$, $\mathrm{HC}(4))$; 2.49-2.21 (m, $1 \mathrm{H}, \mathrm{HC}(6))$; 2.35-2.28 (m, $1 \mathrm{H}, \mathrm{HC}(6)) ; 2.03$ (br s, 1H, $\mathrm{OH}) ; 1.75-1.68$ (m, $\left.2 \mathrm{H}, \mathrm{H}_{2} \mathrm{C}(5)\right)$

${ }^{13} \mathrm{C} \mathrm{NMR}: \quad\left(125 \mathrm{MHz}, \mathrm{CDCl}_{3}\right)$

199.5 (C(1)), 151.1 (C(3)), 142.1 (C(8)), 130.1 (C(2)), 128.7 (C(10)), 128.3 (C(11)), 126.3 (C(9)), 76.7 (C(7)), 43.7 (C(4)), 36.9 (C(6)), 26.0 (C(5))

Opt. Rot.: $\quad[\alpha]_{\mathrm{D}}^{24}+54.49^{\circ}(\mathrm{c}=1.15, \mathrm{EtOH})$

TLC: $\quad R_{f} 0.10$ (pentane/Et $\left.{ }_{2} \mathrm{O}, 1 / 1\right)$ [UV $\left.(254 \mathrm{~nm})\right]$ 
Preparation of $(+)-(5 R)-4-(H y d r o x y(p h e n y l) m e t h y l) c y c l o h e x a n-1-o n e ~((5 R)-27 a)$ from $(+)-$ $(4 R, 7 R)-4-(H y d r o x y(p h e n y l) m e t h y l)-2-c y c l o h e x e n-1-o n e ~((4 R, 7 R)-20)$ (Figure 2)

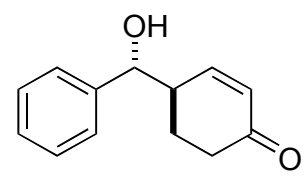

20

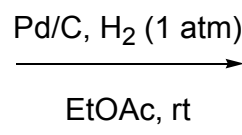

EtOAc, rt

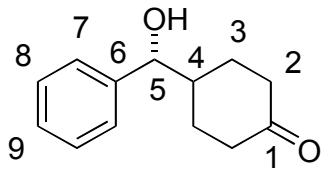

$27 a$

A $25 \mathrm{~mL}, 1$-necked, round-bottomed flask containing a suspension of $112 \mathrm{mg}$ of $\mathbf{2 0}(0.55$ $\mathrm{mmol}$ ) and $8.0 \mathrm{mg}$ of $10 \% \mathrm{Pd}-\mathrm{C}$ in $10 \mathrm{~mL}$ of EtOAc was stirred for $3 \mathrm{~h}$ at $23{ }^{\circ} \mathrm{C}$ under $1 \mathrm{~atm}$ of $\mathrm{H}_{2}$. After briefly evacuating the flask and venting with $\mathrm{N}_{2}$, the suspension was then filtered through Celite on a glass frit and the filtrate was concentrated in vacuo. The residue was purified by column chromatography $\left(\mathrm{SiO}_{2}(13 \mathrm{~g}), 2 \mathrm{~cm}\right.$ diam., hexanes/EtOAc, 2/1) to yield $90 \mathrm{mg}(88 \%)$ of (5R)-27a as a white solid.

Data for $(+)-(5 R)-\mathbf{2 7} \mathbf{a}$ :

${ }^{1} \mathrm{H}$ NMR: $\quad\left(500 \mathrm{MHz}, \mathrm{CHCl}_{3}\right)$

7.39-7.29 (m, $5 \mathrm{H}, \mathrm{HC}(7,8,9)), 4.50$ (d, $J=7.3,1 \mathrm{H}, \mathrm{HC}(5)), 2.46-2.23$ (m, $5 \mathrm{H}$, $\left.\mathrm{H}_{2} \mathrm{C}(2), \mathrm{HC}(4)\right), 2.12-2.05$ (m, $\left.1 \mathrm{H}, \mathrm{HC}(3)\right), 1.95$ (br s, $\left.1 \mathrm{H}, \mathrm{OH}\right), 1.75-1.70$ (m, 1 H, HC(3)), 1.61-1.52 (m, 1 H, HC(3)), 1.48-1.42 (m, 1 H, HC(3))

${ }^{13} \mathrm{C} \mathrm{NMR}: \quad\left(125 \mathrm{MHz}, \mathrm{CDCl}_{3}\right)$

212.4 (C(1)), 143.1 (C(6)), 128.3 (C(7)), 127.7 (C(9)), 126.3 (C(8)), 77.5 (C(5)), $42.9(\mathrm{C}(4)), 40.3$ (C(2)); 40.2 (C(2)), 28.7 (C(3)), 28.4 (C(3))

IR: $\quad\left(\mathrm{CHCl}_{3}\right)$

3459 (s), 3085 (m), 3062 (s), 3028 (s), 2933 (m), 2875 (s), 1964 (m), 1892 (m), 1828 (m), 1760 (s), 1733 (s), 1682 (s), 1602 (m), 1494 (s), 1462 (s), 1453 (s), 1428 (s), 1416 (s), 1367 (s), 1336 (s), 1323 (s), 1301 (s), 1288 (s), 1244 (s), 1211 (s), 1161 (s), 1112 (s), 1091 (s), 1061 (s), 1027 (s), 1006 (s), 977 (s), 955 (s), 937 (s), $917(\mathrm{~s}), 858(\mathrm{~m}), 834(\mathrm{~m}), 816(\mathrm{~m}), 767$ (s), $716(\mathrm{~s}), 700(\mathrm{~s}), 659(\mathrm{~s}), 630(\mathrm{~m})$

MS: $\quad(\mathrm{EI}, 70 \mathrm{eV})$ $204\left(\mathrm{M}^{+}, 4\right), 108$ (10), 107 (100), 98 (67), 83 (14), 79 (50), 88 (27)

Opt. Rot.: $\quad[\alpha]_{\mathrm{D}}{ }^{24}+22.31(\mathrm{c}=0.73, \mathrm{EtOH})$

TLC: $\quad R_{f} 0.13$ (hexanes/EtOAc, 2/1) [UV (254 nm)] 
HRMS: $\quad$ Calcd for $\mathrm{C}_{13} \mathrm{H}_{16} \mathrm{O}_{2}: 204.1150$, found: 204.1154

Preparation of $\quad(+)-(5 R)$-cyclohexyl(phenyl)methanol $\quad((1 R)-27) \quad$ from $\quad(+)-(5 R)-4-$ (Hydroxy(phenyl)methyl)cyclohexan-1-one ((5R)-27a) (Figure 2)<smiles>O=C1CCC([C@@H](O)c2ccccc2)CC1</smiles>

$27 a$

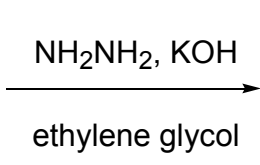

thylene glycol

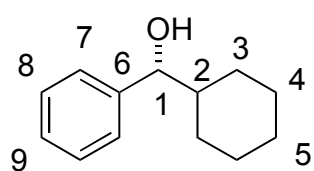

27

A $25 \mathrm{~mL}, 1$-necked, round-bottomed flask fitted with a magnetic stir bar and septum containing a solution of $101 \mathrm{mg}$ of $27 \mathbf{a}(0.49 \mathrm{mmol})$, and $350 \mathrm{mg}$ of $\mathrm{KOH}(6.2 \mathrm{mmol}, 1.7 \mathrm{equiv})$ in $2 \mathrm{~mL}$ of ethylene glycol was added $71 \mu \mathrm{L}$ of $\mathrm{N}_{2} \mathrm{H}_{4}-\mathrm{H}_{2} \mathrm{O}(1.47 \mathrm{mmol}, 3.0$ equiv). The flask was then fitted with a reflux condenser and was heated at $110^{\circ} \mathrm{C}$ for $13 \mathrm{~h}$ while rapidly stirring. The reaction was then warmed to $180{ }^{\circ} \mathrm{C}$ and stirred for $3 \mathrm{~h}$ while rapidly stirring. The mixture was cooled to room temperature and poured into $50 \mathrm{~mL}$ of $\mathrm{H}_{2} \mathrm{O}$. The solution was then extracted $3 \mathrm{x}$ $30 \mathrm{~mL}$ of $\mathrm{CH}_{2} \mathrm{Cl}_{2}$. The combined organic layers were washed with $\mathrm{H}_{2} \mathrm{O}$, dried over $\mathrm{Na}_{2} \mathrm{SO}_{4}(5$ $\mathrm{g}$ ), filtered and the filtrate was concentrated in vacuo. The residue was purified by column chromatography $\left(\mathrm{SiO}_{2}(14 \mathrm{~g}), 2 \mathrm{~cm}\right.$ diam., pentane/Et $\left.2 \mathrm{O}, 4 / 1\right)$ to yield $58 \mathrm{mg}(62 \%)$ of $(1 R)-27$ as a white solid. The spectroscopic data for 27 matched those in the literature. ${ }^{20}$

Data for $(+)-(1 R)-27$ :

11 H NMR: $\quad\left(500 \mathrm{MHz}, \mathrm{CHCl}_{3}\right)$

7.36-7.26 (m, $5 \mathrm{H}, \mathrm{HC}(7,8,9)), 4.38$ (d, $J=7.3,1 \mathrm{H}, \mathrm{HC}(1)), 2.00-1.98(\mathrm{~m}, 1 \mathrm{H})$ 1.79-1.75 (m, 2 H), 1.69-1.59 (m, 3 H), 1.40-1.37 (m, 1 H), 1.28-0.89 (m, 5 H)

${ }^{13} \mathrm{C} \mathrm{NMR}: \quad\left(125 \mathrm{MHz}, \mathrm{CDCl}_{3}\right)$ $143.6(\mathrm{C}(6)), 128.2$ (C(7)), $127.4(\mathrm{C}(9)), 126.6(\mathrm{C}(8)), 79.4(\mathrm{C}(1)), 43.7,29.2$, $28.8,26.3,26.0,26.0$

Opt. Rot.: $[\alpha]_{\mathrm{D}}{ }^{24}+25.98(\mathrm{c}=0.99$, benzene $)$ lit. $[\alpha]_{\mathrm{D}}{ }^{24}-28.27\left(\mathrm{c}=3.29, \mathrm{CHCl}_{3}\right)$ for $(1 S)-27^{20}$

TLC: $\quad R_{f} 0.44$ (hexanes/EtOAc, 2/1) [UV(254 nm)] 
Preparation of (-)-(3S)-5-Phenylpentane-1,3-diol ((3S)-88) from (-)-4-[(5S,2E)-1-Oxo-7phenyl-5-hydroxy-2-heptenyl]morpholine ((5S,2E)-60) (Figure 6)<smiles>O=C(/C=C/CC(O)CCc1ccccc1)N1CCOCC1</smiles>

60

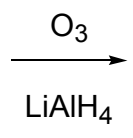

$\mathrm{LiAlH}_{4}$

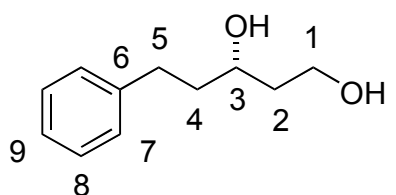

88

Following Representative Procedure 10, a solution of $62 \mathrm{mg}(0.22 \mathrm{mmol})$ of 60 in $5 \mathrm{~mL}$ of $\mathrm{CH}_{2} \mathrm{Cl}_{2}$ at $-78{ }^{\circ} \mathrm{C}$ (bath temperature) in was treated with a solution of ozone in oxygen followed by reduction with $0.42 \mathrm{~mL}$ of a solution of $\mathrm{LiAlH}_{4}$ in THF $(2.0 \mathrm{M}, 0.84 \mathrm{mmol}, 4.0$ equiv) to yield, after column chromatography $\left(\mathrm{SiO}_{2}(5 \mathrm{~g}), 2 \mathrm{~cm}\right.$ diam., EtOAc/hexanes, 2/1) 34 $\mathrm{mg}(85 \%)$ of $(3 S)-\mathbf{8 8}$ as a colorless oil. The spectroscopic data for $\mathbf{8 8}$ matched those in the literature. $^{18}$

Data for $(-)-(3 S)-88$ :

${ }^{1} \mathrm{H} \mathrm{NMR}: \quad\left(500 \mathrm{MHz}, \mathrm{CDCl}_{3}\right)$

7.31-7.18 (m, $5 \mathrm{H}, \mathrm{HC}(7,8,9))$ ) 3.93-3.88 (m, $\left.2 \mathrm{H}, \mathrm{H}_{2} \mathrm{C}(1)\right)$ ) 3.86-3.82 (m, $1 \mathrm{H}$, $\mathrm{HC}(3)), 2.82-2.66$ (m, $\left.2 \mathrm{H}, \mathrm{H}_{2} \mathrm{C}(5)\right), 2.21$ (br s, $\left.2 \mathrm{H}, \mathrm{OH}\right), 1.89-1.69$ (m, $4 \mathrm{H}$, $\left.\mathrm{H}_{2} \mathrm{C}(2,4)\right)$

Opt. Rot.: $\quad[\alpha]_{\mathrm{D}}{ }^{24}-11.69(\mathrm{c}=1.07$, EtOH $)$, lit. $[\alpha]_{\mathrm{D}}{ }^{24}-7.21(\mathrm{c}=1.52, \mathrm{EtOH})$ for $(3 S)-88^{18}$

TLC: $\quad R_{f} 0.22($ EtOAc/hexanes, $2 / 1)$ [p-anisaldehyde]

Preparation of (-)-4-[(5R)-1-Oxo-5-hydroxy-7-phenylheptyl]morpholine ((5R)-89) from (-)4-[(5R,2E)-1-Oxo-7-phenyl-5-hydroxy-2,6-heptadienyl]morpholine ((5R,2E)-60) (Figure 6)

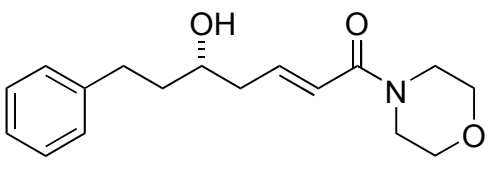

60
$\stackrel{\mathrm{Pd} / \mathrm{C}, \mathrm{H}_{2}}{\longrightarrow}$

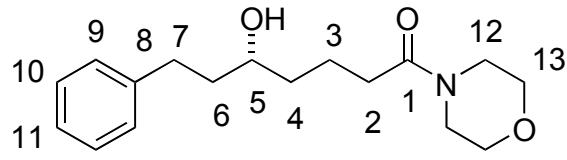

89

A $50 \mathrm{~mL}, 1$-necked, round-bottomed flask containing a suspension of $58 \mathrm{mg}$ of $\mathbf{6 0}(0.2$ $\mathrm{mmol}$ ) and $7.0 \mathrm{mg}$ of $10 \% \mathrm{Pd}-\mathrm{C}$ in $5 \mathrm{~mL}$ of EtOAc was stirred for $3 \mathrm{~h}$ at $23{ }^{\circ} \mathrm{C}$ under 1 atm of $\mathrm{H}_{2}$. After briefly evacuating the flask and venting with $\mathrm{N}_{2}$, the suspension was then filtered through Celite on a glass frit and the filtrate was concentrated in vacuo. The residue was purified by column chromatography $\left(\mathrm{SiO}_{2}(7 \mathrm{~g}), 2 \mathrm{~cm}\right.$ diam., EtOAc) to yield $55 \mathrm{mg}(95 \%)$ of $(5 R)-89$ as 
a colorless oil.

Data for $(-)-(5 R)-89$ :

${ }^{1} \mathrm{H}$ NMR: $\quad\left(500 \mathrm{MHz}, \mathrm{CDCl}_{3}\right)$

7.29-7.21 (m, 2 H, HC(10)), 7.19-7.17 (m, 3 H, HC(9,11)), 3.67-3.45 (m, 9 H, $\left.\mathrm{HC}(5), \mathrm{H}_{2} \mathrm{C}(12,13)\right), 2.83-2.77$ (m, $\left.1 \mathrm{H}, \mathrm{HC}(7)\right)$, 2.71-2.65 (m, $\left.1 \mathrm{H}, \mathrm{HC}(7)\right), 2.40-$ 2.29 (m, 2 H, $\left.\mathrm{H}_{2} \mathrm{C}(2)\right)$, 1.88-1.73 (m, $\left.5 \mathrm{H}, \mathrm{OH}, \mathrm{H}_{2} \mathrm{C}(6), \mathrm{H}_{2} \mathrm{C}(3)\right)$, 1.58-1.46 (m, 2 $\left.\mathrm{H}, \mathrm{H}_{3} \mathrm{C}(4)\right)$

Opt. Rot.: $\quad[\alpha]_{\mathrm{D}}^{24}-7.53(\mathrm{c}=1.01, \mathrm{EtOH})$

TLC: $\quad R_{f} 0.11($ EtOAc) [UV $(254 \mathrm{~nm})]$

Preparation of (-)-4-[(5R)-1-Oxo-5-hydroxy-7-phenylheptyl]morpholine $((5 R)-89)$ from (-)-4-[(5R,2E,6E)-1-Oxo-7-phenyl-5-hydroxy-2,6-heptadienyl]morpholine $\quad((5 R, 2 E, 6 E)-51)$ (Figure 6)

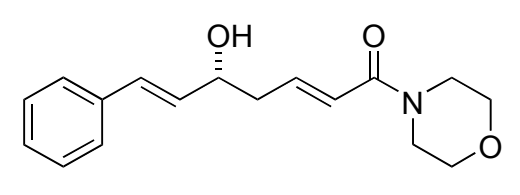

51

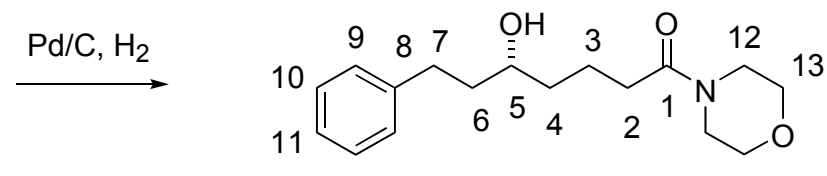

89

A $50 \mathrm{~mL}, 1$-neck round-bottom flask containing a suspension of $172 \mathrm{mg}$ of $\mathbf{6 0}(0.6$ $\mathrm{mmol}$ ) and $7.0 \mathrm{mg}$ of $5 \% \mathrm{Pd}-\mathrm{C}$ in $15 \mathrm{~mL}$ of EtOAc was stirred for $3 \mathrm{~h}$ at $23{ }^{\circ} \mathrm{C}$ under 1 atm of $\mathrm{H}_{2}$. After briefly evacuating the flask and venting with $\mathrm{N}_{2}$, the suspension was then filtered through Celite on a glass frit and the filtrate was concentrated in vacuo. The residue was purified by column chromatography $\left(\mathrm{SiO}_{2}(12 \mathrm{~g}), 2 \mathrm{~cm}\right.$ diam., EtOAc) to yield $161 \mathrm{mg}(92 \%)$ of $(5 R)-89$ as a colorless oil.

Data for $(-)-(5 R)-89$ :

bp: $\quad 130^{\circ} \mathrm{C}\left(4.0 \times 10^{-5} \mathrm{mmHg}, \mathrm{ABT}\right)$

${ }^{1} \mathrm{H} \mathrm{NMR}: \quad\left(500 \mathrm{MHz}, \mathrm{CDCl}_{3}\right)$

7.29-7.21 (m, 2 H, HC(10)), 7.19-7.17 (m, 3 H, HC(9,11)), 3.67-3.47 (m, 9 H, $\left.\mathrm{HC}(5), \mathrm{H}_{2} \mathrm{C}(12,13)\right)$, 2.83-2.77 (m, $\left.1 \mathrm{H}, \mathrm{HC}(7)\right), 2.71-2.65$ (m, $\left.1 \mathrm{H}, \mathrm{HC}(7)\right)$, 2.402.30 (m, $\left.2 \mathrm{H}, \mathrm{H}_{2} \mathrm{C}(2)\right)$, 1.81-1.74 (m, $\left.4 \mathrm{H}, \mathrm{H}_{2} \mathrm{C}(6), \mathrm{H}_{2} \mathrm{C}(3)\right)$ ) 1.58-1.46 (m, $2 \mathrm{H}$, $\left.\mathrm{H}_{3} \mathrm{C}(4)\right)$ 


\section{${ }^{13}$ C NMR: $\quad\left(126 \mathrm{MHz}, \mathrm{CDCl}_{3}\right)$}

$171.7(\mathrm{C}(1)), 142.2(\mathrm{C}(8)), 128.3(\mathrm{C}(9)), 128.2$ (C(10)), 125.5 (C(11)), 70.0 (C(5)), 66.7 (C(13)), 66.4 (C(13)), 45.7 (C(12)), 41.7 (C(12)), 39.0 (C(6)), 36.9 $(\mathrm{C}(4)), 32.5(\mathrm{C}(2)), 31.9(\mathrm{C}(7)), 20.6(\mathrm{C}(3))$

IR: (neat)

3418 (s), 3084 (w), 3060 (w), 3025 (m), 2921 (s), 2858 (s), 2760 (w), 2714 (w), 2683 (w), 2362 (w), 1956 (w), 1877 (w), 1810 (w), 1633 (s), 1495 (m), 1455 (s), 1435 (s), 1362 (m), 1330 (m), 1301 (m), 1272 (s), 1238 (s), 1196 (m), 1177 (m), 1116 (s), 1069 (s), 1032 (s), 974 (m), 915 (m), 848 (m), 818 (w), 750 (m), 701 (s)

MS: $\quad\left(\mathrm{CI}, \mathrm{CH}_{4}\right)$

$292\left(\mathrm{M}^{+}+\mathrm{H}, 34\right), 275$ (20), 274 (100), 186 (12), 88 (10)

Opt. Rot.: $\quad[\alpha]_{\mathrm{D}}{ }^{24}-7.32(\mathrm{c}=1.03, \mathrm{EtOH})$

TLC: $\quad R_{f} 0.11$ (EtOAc) [UV $\left.(254 \mathrm{~nm})\right]$

HRMS: Calcd for $\mathrm{C}_{17} \mathrm{H}_{25} \mathrm{NO}_{3}$ : 292.1913, found: 292.1914

Preparation of $(+)-(3 R)-1-P h e n y l p r o p a n e-1,3-d i o l ~((3 R)-25)$ from $(+)-4-[(5 R, 2 E)-1-0 x 0-5-$ phenyl-5-hydroxy-2-pentenyl]morpholine ((5R,2E)-50) (Figure 6)<smiles>O=C(/C=C/C[C@H](O)c1ccccc1)N1CCOCC1</smiles>

50

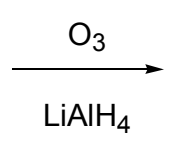

$\mathrm{LiNH}_{4}$

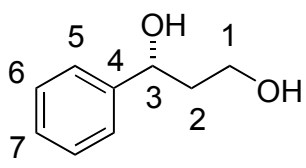

25

Following Representative Procedure 10, a solution of $65 \mathrm{mg}(0.25 \mathrm{mmol})$ of (50) in $5 \mathrm{~mL}$ of $\mathrm{CH}_{2} \mathrm{Cl}_{2}$ at $-78{ }^{\circ} \mathrm{C}$ (bath temperature) in was treated with a solution of ozone in oxygen followed by reduction with $0.50 \mathrm{~mL}$ of a solution of $\mathrm{LiAlH}_{4}$ in THF $(2.0 \mathrm{M}, 1.0 \mathrm{mmol}, 4.0$ equiv) to yield, after column chromatography $\left(\mathrm{SiO}_{2}(10 \mathrm{~g}), 2 \mathrm{~cm}\right.$ diam., EtOAc/hexanes, 1/1) 36 mg (95\%) of (3R)-25 as a clear, colorless oil. The spectroscopic data for $\mathbf{2 5}$ matched those in the literature. $^{18}$

Data for $(+)-(3 R)-25:$

${ }^{1}$ H NMR: $\quad\left(500 \mathrm{MHz}, \mathrm{CDCl}_{3}\right)$

7.39-7.26 (m, $5 \mathrm{H}, \mathrm{HC}(5,6,7)), 4.98$ (dd, $J=9.0,3.6,1 \mathrm{H}, \mathrm{HC}(3)), 3.88$ (t, $J=5.5$, 2 H, $\left.\mathrm{H}_{2} \mathrm{C}(1)\right), 2.28$ (br s, $\left.2 \mathrm{H}, \mathrm{OH}\right), 2.08-1.93$ (m, $2 \mathrm{H}, \mathrm{H}_{2} \mathrm{C}(2)$ ) 
Opt. Rot.: $[\alpha]_{\mathrm{D}}{ }^{24}+56.30\left(\mathrm{c}=1.00, \mathrm{CHCl}_{3}\right)$, lit. $[\alpha]_{\mathrm{D}}{ }^{24}-63.0\left(\mathrm{c}=0.958, \mathrm{CHCl}_{3}\right)$ for $(3 S)-\mathbf{2 5}^{18}$ TLC: $\quad R_{f} 0.28($ EtOAc/hexanes, $2 / 1)$ [p-anisaldehyde]

\section{Preparation of $(+)-(3 R)-1-P h e n y l p r o p a n e-1,3-d i o l ~((3 R)-25)$ from $(+)-4-[(5 R, 2 E)-1-O x 0-5-$} phenyl-5-hydroxy-2-methyl-2-pentenyl]morpholine ((5R,2E)-76) (Figure 6)<smiles>CC(=CC[C@@H](O)c1ccccc1)C(=O)N1CCOCC1</smiles>

76

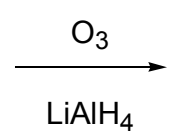

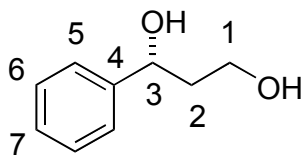

25

Following Representative Procedure 10, a solution of $41 \mathrm{mg}(0.15 \mathrm{mmol})$ of 76 in $5 \mathrm{~mL}$ of $\mathrm{CH}_{2} \mathrm{Cl}_{2}$ at $-78{ }^{\circ} \mathrm{C}$ (bath temperature) in was treated with a solution of ozone in oxygen followed by reduction with $0.3 \mathrm{~mL}$ of a solution of $\mathrm{LiAlH}_{4}$ in THF $(2.0 \mathrm{M}, 0.60 \mathrm{mmol}, 4.0$ equiv) to yield, after column chromatography $\left(\mathrm{SiO}_{2}(10 \mathrm{~g}), 2 \mathrm{~cm}\right.$ diam., EtOAc/hexanes, 2/1) 18 $\mathrm{mg}(\mathbf{7 8 \%})$ of (3R)-25 as a colorless oil. The spectroscopic data for $\mathbf{2 5}$ matched those in the literature. $^{18}$

Data for $(+)-(3 R)-\mathbf{2 5}$ :

${ }^{1}$ H NMR: $\quad\left(500 \mathrm{MHz}, \mathrm{CDCl}_{3}\right)$

7.40-7.26 (m, 5 H, HC(5,6,7)), 4.99 (dd, $J=9.0,3.7,1 \mathrm{H}, \mathrm{HC}(3)), 3.89$ (t, $J=5.5$, $\left.2 \mathrm{H}, \mathrm{H}_{2} \mathrm{C}(1)\right), 2.08-1.93$ (m, $\left.4 \mathrm{H}, \mathrm{OH}, \mathrm{H}_{2} \mathrm{C}(2)\right)$

Opt. Rot.: $\quad[\alpha]_{\mathrm{D}}{ }^{24}+66.22\left(\mathrm{c}=0.59, \mathrm{CHCl}_{3}\right)$, lit. $[\alpha]_{\mathrm{D}}{ }^{24}-63.0\left(\mathrm{c}=0.958, \mathrm{CHCl}_{3}\right)$ for $(3 S)-25^{18}$ TLC: $\quad R_{f} 0.28($ EtOAc/hexanes, 2/1) [p-anisaldehyde]

Preparation of $(+)-(4 R)-4-($ Acetyloxy)-4-phenyl-2-butanone $((4 R)-90)$ from $(+)-4-[(5 R, 2 E)-1-$ Oxo-5-phenyl-5-hydroxy-3-methyl-2-pentenyl]morpholine ((5R,2E)-79) (Figure 6)<smiles>C/C(=C\C(=O)N1CCOCC1)C[C@@H](O)c1ccccc1</smiles>

79

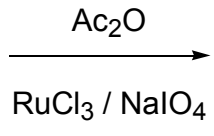

To a 25-mL, 1-necked, round-bottomed flask fitted with a magnetic stir bar containing a solution of $55 \mathrm{mg}$ of $79(0.2 \mathrm{mmol})$ in $0.44 \mathrm{~mL}$ of acetic anhydride (4.6 mmol, 23 equiv) was 
slowly added $0.44 \mathrm{~mL}$ of pyridine (5.4 mmol, 27 equiv). The solution was allowed to stir at room temperature for $2 \mathrm{~h}$ before the addition of $10 \mathrm{~mL}$ of $\mathrm{Et}_{2} \mathrm{O}$. The cloudy solution was then washed with $0.1 \mathrm{M}$ aq. $\mathrm{HCl}(20 \mathrm{~mL})$ followed by washing with brine $(20 \mathrm{~mL})$. The organic layer was then separated and dried over $\mathrm{Na}_{2} \mathrm{SO}_{4}(5 \mathrm{~g})$, filtered through Celite on a glass frit and the filtrate was concentrated in vacuo. The resulting residue was then dissolved in a mixture of 2 $\mathrm{mL} \mathrm{CH}_{2} \mathrm{Cl}_{2}, 2 \mathrm{~mL} \mathrm{CH} \mathrm{CH}_{3} \mathrm{CN}$, and $2 \mathrm{~mL} \mathrm{H} \mathrm{H}_{2} \mathrm{O}$. To this solution was added $1 \mathrm{mg}$ of $\mathrm{RuCl}_{3}-\mathrm{H}_{2} \mathrm{O}$ ( $0.0046 \mathrm{mmol}, 0.023$ equiv) and $180 \mathrm{mg}$ of $\mathrm{NaIO}_{4}(0.84 \mathrm{mmol}, 4.2$ equiv). The biphasic mixture was stirred at room temperature for $2 \mathrm{~h}$ prior to the addition of $10 \mathrm{~mL}$ of $0.1 \mathrm{M} \mathrm{HCl}$. The solution was then extracted with $\mathrm{CH}_{2} \mathrm{Cl}_{2}(2 \times 10 \mathrm{~mL})$. The combined organic layers were washed with brine $(10 \mathrm{~mL})$, dried over $\mathrm{Na}_{2} \mathrm{SO}_{4}(5 \mathrm{~g})$, filtered through Celite on a glass frit and the filtrate was concentrated in vacuo. The residue was purified by column chromatography $\left(\mathrm{SiO}_{2}(10 \mathrm{~g}), 2\right.$ $\mathrm{cm}$ diam., hexanes/EtOAc, 4/1) to yield $11 \mathrm{mg}(27 \%)$ of (4R)-90 as a colorless oil. The spectroscopic data for $\mathbf{9 0}$ matched those in the literature. ${ }^{21}$

Data for $(+)-(4 R)-90$ :

${ }^{1} \mathrm{H} \mathrm{NMR}: \quad\left(500 \mathrm{MHz}, \mathrm{CDCl}_{3}\right)$

7.36-7.26 (m, $5 \mathrm{H}, \mathrm{HC}(6,7,8)), 6.19$ (dd, $J=8.8,4.9,1 \mathrm{H}, \mathrm{HC}(4)), 3.12(\mathrm{dd}, J=$ 16.6, 8.8, $1 \mathrm{H}, \mathrm{HC}(3)), 2.82(\mathrm{dd}, J=16.6,8.8,1 \mathrm{H}, \mathrm{HC}(3)), 2.15$ (s, $\left.3 \mathrm{H}, \mathrm{H}_{3} \mathrm{C}(1)\right)$, $2.04\left(\mathrm{~s}, 3 \mathrm{H}, \mathrm{H}_{3} \mathrm{C}(10)\right)$

Opt. Rot.: $\quad[\alpha]_{\mathrm{D}}{ }^{24}+56.19\left(\mathrm{c}=0.57, \mathrm{CHCl}_{3}\right)$, lit. $[\alpha]_{\mathrm{D}}{ }^{24}+64.6\left(\mathrm{c}=0.71, \mathrm{CHCl}_{3}\right)$ for $(4 R)-90^{21}$ TLC: $\quad R_{f} 0.36$ (hexanes/EtOAc, $\left.4 / 1\right)\left[\mathrm{UV}(254) / \mathrm{KMNO}_{4}\right]$

Preparation of $(+)-(2 R, 3 R)-2-M e t h y l-1-p h e n y l p r o p a n e-1,3-d i o l ~((2 R, 3 R)-91)$ from (+)-4[(4R,5R,2E)-1-Oxo-5-phenyl-5-hydroxy-4-methyl-2-pentenyl]morpholine

$((4 R, 5 R, 2 E)-84)$

(Figure 6)<smiles>CC(/C=C/C(=O)N1CCOCC1)[C@H](O)c1ccccc1</smiles>

84

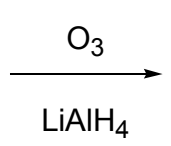

$\mathrm{LiAlH}_{4}$

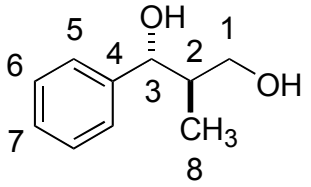

91

Following Representative Procedure 10, a solution of $45 \mathrm{mg}(0.16 \mathrm{mmol})$ of 84 in $5 \mathrm{~mL}$ of $\mathrm{CH}_{2} \mathrm{Cl}_{2}$ at $-78{ }^{\circ} \mathrm{C}$ (bath temperature) in was treated with a solution of ozone in oxygen 
followed by reduction with $0.32 \mathrm{~mL}$ of a solution of $\mathrm{LiAlH}_{4}$ in THF $(2.0 \mathrm{M}, 0.64 \mathrm{mmol}, 4.0$ equiv) to yield, after column chromatography $\left(\mathrm{SiO}_{2}(10 \mathrm{~g}), 2 \mathrm{~cm}\right.$ diam., EtOAc/hexanes, 2/1) 21 $\mathrm{mg}(78 \%)$ of $(2 R, 3 R)-91$ as a colorless oil. The spectroscopic data for 91 matched those in the literature. $^{18}$

Data for $(+)-(2 R, 3 R)-91$ :

${ }^{1} \mathrm{H}$ NMR: $\quad\left(500 \mathrm{MHz}, \mathrm{CDCl}_{3}\right)$

7.40-7.26 (m, $5 \mathrm{H}, \mathrm{HC}(5,6,7)), 4.99(\mathrm{dd}, J=9.0,3.7,1 \mathrm{H}, \mathrm{HC}(3)), 3.89$ (t, $J=5.5$, $\left.2 \mathrm{H}, \mathrm{H}_{2} \mathrm{C}(1)\right), 2.08-1.93$ (m, $4 \mathrm{H}, \mathrm{OH}, \mathrm{H}_{2} \mathrm{C}(2)$ )

Opt. Rot.: $\quad[\alpha]_{\mathrm{D}}{ }^{24}+34.74\left(\mathrm{c}=1.8, \mathrm{CHCl}_{3}\right)$, lit. $[\alpha]_{\mathrm{D}}{ }^{24}-46.8\left(\mathrm{c}=0.35, \mathrm{CHCl}_{3}\right)$ for $(2 S, 3 S)-91^{18}$

TLC: $\quad R_{f} 0.46$ (EtOAc/hexanes, $\left.2 / 1\right)$ [ $p$-anisaldehyde]

\section{Calculated Structure of the Aldehyde-Silyl Cation Complex (Figure 7)}

Model created using the PC version of GAMESS(US) QC package at the PM3 level. The structure was visualized using Chem3D with some hydrogens omitted for clarity.

\begin{tabular}{|c|cc|c|c|}
\hline \multicolumn{5}{|c|}{ RESULTS FROM SUCCESSFUL RHF GEOMETRY SEARCH } \\
COORDS, ORBS, GRADIENT, AND APPROX. HESSIAN \\
COORDINATES OF SYMMETRY UNIQUE ATOMS (ANGS) \\
Atom & Charge & X & Y & Z \\
\hline C & 6 & 7.08576704 & -4.5424505 & 1.57103129 \\
C & 6 & 6.08218144 & -4.0270331 & 2.34543123 \\
C & 6 & 7.58284018 & -3.8025013 & 0.4749762 \\
N & 7 & 3.09338375 & 2.87554011 & -0.9171932 \\
C & 6 & 4.38728795 & 3.56600712 & -0.7167774 \\
C & 6 & 7.08350719 & -2.5599204 & 0.19138778 \\
C & 6 & 1.92993776 & 3.7958594 & -0.9008909 \\
C & 6 & -7.2085942 & -3.4755011 & -2.1077765 \\
C & 6 & 6.05483553 & -1.9853507 & 0.98920839 \\
\hline
\end{tabular}




\begin{tabular}{|c|c|c|c|c|}
\hline $\mathrm{C}$ & 6 & -6.1601344 & -2.956205 & -2.8182928 \\
\hline $\mathrm{C}$ & 6 & 5.5376727 & -2.7467525 & 2.05815336 \\
\hline $\mathrm{C}$ & 6 & -7.6321253 & -2.8499385 & -0.9136188 \\
\hline $\mathrm{C}$ & 6 & 4.44903291 & -2.2436369 & 2.81991553 \\
\hline $\mathrm{C}$ & 6 & 3.89064544 & -1.0383337 & 2.51255091 \\
\hline $\mathrm{N}$ & 7 & -2.3332423 & 2.99282974 & 1.34782975 \\
\hline $\mathrm{C}$ & 6 & 4.42341075 & -0.2434609 & 1.45625281 \\
\hline $\mathrm{N}$ & 7 & 3.8325934 & 1.05664464 & 1.17831691 \\
\hline $\mathrm{P}$ & 15 & 2.98423692 & 1.19529317 & -0.369194 \\
\hline $\mathrm{C}$ & 6 & 3.14900452 & 1.69617355 & 2.32357157 \\
\hline $\mathrm{C}$ & 6 & 5.51289579 & -0.6842203 & 0.71804805 \\
\hline $\mathrm{C}$ & 6 & 6.0835264 & 0.11188875 & -0.3844739 \\
\hline $\mathrm{C}$ & 6 & 5.31651495 & 0.46432015 & -1.4871189 \\
\hline $\mathrm{C}$ & 6 & 5.92328216 & 1.05520637 & -2.6348737 \\
\hline $\mathrm{C}$ & 6 & 7.24848938 & 1.37708094 & -2.6267067 \\
\hline $\mathrm{C}$ & 6 & 8.02977845 & 1.16572693 & -1.4572445 \\
\hline $\mathrm{C}$ & 6 & 7.45173738 & 0.53917565 & -0.332999 \\
\hline $\mathrm{N}$ & 7 & 3.8915398 & 0.19019543 & -1.4901711 \\
\hline $\mathrm{C}$ & 6 & 3.28534912 & -0.1521728 & -2.7909756 \\
\hline $\mathrm{C}$ & 6 & 8.24509409 & 0.37740293 & 0.83604997 \\
\hline $\mathrm{C}$ & 6 & 9.54559151 & 0.80514202 & 0.8640058 \\
\hline $\mathrm{C}$ & 6 & 10.1256877 & 1.41077288 & -0.2729728 \\
\hline $\mathrm{C}$ & 6 & 9.38480434 & 1.58773717 & -1.4106807 \\
\hline $\mathrm{O}$ & 8 & 1.43829019 & 0.8459831 & -0.2343668 \\
\hline $\mathrm{C}$ & 6 & -3.5073538 & 3.89364582 & 1.34410533 \\
\hline $\mathrm{C}$ & 6 & -7.0111372 & -1.7152737 & -0.4653716 \\
\hline $\mathrm{C}$ & 6 & -1.0291729 & 3.70053866 & 1.37850526 \\
\hline $\mathrm{C}$ & 6 & -5.9293722 & -1.1395062 & -1.1886361 \\
\hline $\mathrm{C}$ & 6 & -5.4942699 & -1.7855505 & -2.3648527 \\
\hline
\end{tabular}




\begin{tabular}{|c|c|c|c|c|}
\hline $\mathrm{C}$ & 6 & -4.3731716 & -1.2772519 & -3.0754057 \\
\hline $\mathrm{C}$ & 6 & -3.7023782 & -0.1830386 & -2.614299 \\
\hline $\mathrm{C}$ & 6 & -4.1386783 & 0.48869015 & -1.4353189 \\
\hline $\mathrm{N}$ & 7 & -3.4203128 & 1.66442233 & -0.9709396 \\
\hline $\mathrm{P}$ & 15 & -2.5163114 & 1.43970645 & 0.53509634 \\
\hline $\mathrm{C}$ & 6 & -2.7179272 & 2.43939767 & -2.0178926 \\
\hline $\mathrm{C}$ & 6 & -5.2582695 & 0.04797492 & -0.7436125 \\
\hline $\mathrm{C}$ & 6 & -5.7350767 & 0.73251409 & 0.47215967 \\
\hline $\mathrm{C}$ & 6 & -4.9267832 & 0.84520687 & 1.59538953 \\
\hline $\mathrm{C}$ & 6 & -5.4548627 & 1.35797418 & 2.81693834 \\
\hline $\mathrm{C}$ & 6 & -6.7348392 & 1.82568815 & 2.87587216 \\
\hline $\mathrm{C}$ & 6 & -7.5448992 & 1.84770351 & 1.70775565 \\
\hline $\mathrm{C}$ & 6 & -7.047356 & 1.31001446 & 0.50198775 \\
\hline $\mathrm{N}$ & 7 & -3.5426296 & 0.4026807 & 1.53451516 \\
\hline $\mathrm{C}$ & 6 & -2.9660842 & -0.1082445 & 2.7946377 \\
\hline $\mathrm{C}$ & 6 & -7.8610444 & 1.38839779 & -0.6617041 \\
\hline $\mathrm{C}$ & 6 & -9.1062855 & 1.95555341 & -0.608108 \\
\hline $\mathrm{C}$ & 6 & -9.6088062 & 2.46920802 & 0.60844805 \\
\hline $\mathrm{C}$ & 6 & -8.8452813 & 2.41718157 & 1.7437368 \\
\hline $\mathrm{O}$ & 8 & -1.1077169 & 0.78398494 & 0.27987444 \\
\hline $\mathrm{C}$ & 6 & 1.77335343 & 4.61231188 & 0.38236941 \\
\hline $\mathrm{C}$ & 6 & 0.4974222 & 5.43758389 & 0.35940293 \\
\hline $\mathrm{C}$ & 6 & -0.7624381 & 4.60701199 & 0.17756687 \\
\hline $\mathrm{Si}$ & 14 & 0.16093784 & -0.2901569 & -0.1590629 \\
\hline $\mathrm{Cl}$ & 17 & 1.65015594 & -1.9801939 & -0.6569166 \\
\hline $\mathrm{C}$ & 6 & -3.8744603 & -4.7385572 & -0.7390823 \\
\hline $\mathrm{C}$ & 6 & -2.9764927 & -3.6869722 & -0.5995046 \\
\hline $\mathrm{C}$ & 6 & -3.6753199 & -5.9271124 & -0.0442317 \\
\hline $\mathrm{C}$ & 6 & -2.5728252 & -6.0682579 & 0.79672271 \\
\hline
\end{tabular}




\begin{tabular}{|c|c|c|c|c|}
\hline $\mathrm{C}$ & 6 & -1.6722593 & -5.0234167 & 0.94444001 \\
\hline $\mathrm{C}$ & 6 & -1.8708786 & -3.8212407 & 0.24794536 \\
\hline $\mathrm{C}$ & 6 & -0.882289 & -2.7613019 & 0.43127183 \\
\hline $\mathrm{O}$ & 8 & -1.0141064 & -1.6489997 & -0.1172918 \\
\hline $\mathrm{Cl}$ & 17 & -0.332367 & 0.01412551 & -2.3465979 \\
\hline $\mathrm{H}$ & 1 & 7.50778321 & -5.5297699 & 1.78662992 \\
\hline $\mathrm{H}$ & 1 & 5.67937416 & -4.5947499 & 3.19217981 \\
\hline $\mathrm{H}$ & 1 & 8.37324461 & -4.2365027 & -0.1469472 \\
\hline $\mathrm{H}$ & 1 & 4.55258745 & 3.8781661 & 0.32622329 \\
\hline $\mathrm{H}$ & 1 & 4.42363112 & 4.46553184 & -1.3481828 \\
\hline $\mathrm{H}$ & 1 & 5.20963442 & 2.90316721 & -1.0243493 \\
\hline $\mathrm{H}$ & 1 & 7.47459334 & -1.9909497 & -0.6616107 \\
\hline $\mathrm{H}$ & 1 & 2.05317413 & 4.47800962 & -1.7683671 \\
\hline $\mathrm{H}$ & 1 & 1.00095639 & 3.21225118 & -1.096765 \\
\hline $\mathrm{H}$ & 1 & -7.7291413 & -4.3743424 & -2.4559593 \\
\hline $\mathrm{H}$ & 1 & -5.8208021 & -3.4311596 & -3.7467341 \\
\hline $\mathrm{H}$ & 1 & -8.4670763 & -3.283 & -0.3517147 \\
\hline $\mathrm{H}$ & 1 & 4.04781548 & -2.850567 & 3.64008225 \\
\hline $\mathrm{H}$ & 1 & 2.99322169 & -0.683301 & 3.05202645 \\
\hline $\mathrm{H}$ & 1 & 2.63456527 & 2.61100289 & 1.9815884 \\
\hline $\mathrm{H}$ & 1 & 3.9060297 & 1.97989419 & 3.06657863 \\
\hline $\mathrm{H}$ & 1 & 2.41246464 & 1.02687348 & 2.81255911 \\
\hline $\mathrm{H}$ & 1 & 5.30397866 & 1.22505132 & -3.5307543 \\
\hline $\mathrm{H}$ & 1 & 7.72453902 & 1.81397805 & -3.5126961 \\
\hline $\mathrm{H}$ & 1 & 3.61540486 & -1.1661222 & -3.0568319 \\
\hline $\mathrm{H}$ & 1 & 3.596459 & 0.53593268 & -3.5967975 \\
\hline $\mathrm{H}$ & 1 & 2.18561167 & -0.1655842 & -2.7018778 \\
\hline $\mathrm{H}$ & 1 & 7.79608535 & -0.1030063 & 1.71501439 \\
\hline $\mathrm{H}$ & 1 & 10.1504283 & 0.67928963 & 1.76873653 \\
\hline
\end{tabular}




\begin{tabular}{|c|c|c|c|c|}
\hline $\mathrm{H}$ & 1 & 11.1708397 & 1.73620315 & -0.2316536 \\
\hline $\mathrm{H}$ & 1 & 9.82356374 & 2.05842189 & -2.2983242 \\
\hline $\mathrm{H}$ & 1 & -3.6856804 & 4.37236442 & 0.36839182 \\
\hline $\mathrm{H}$ & 1 & -3.3592422 & 4.68909769 & 2.08851946 \\
\hline $\mathrm{H}$ & 1 & -4.4041629 & 3.32386687 & 1.6300928 \\
\hline $\mathrm{H}$ & 1 & -7.3478444 & -1.2304918 & 0.46016825 \\
\hline $\mathrm{H}$ & 1 & -1.0136067 & 4.29529785 & 2.31608622 \\
\hline $\mathrm{H}$ & 1 & -0.2358062 & 2.93070665 & 1.48008196 \\
\hline $\mathrm{H}$ & 1 & -4.0460068 & -1.7865202 & -3.9902654 \\
\hline $\mathrm{H}$ & 1 & -2.7934601 & 0.17692827 & -3.1335076 \\
\hline $\mathrm{H}$ & 1 & -2.0340438 & 3.16841843 & -1.546832 \\
\hline $\mathrm{H}$ & 1 & -3.4673021 & 2.98761173 & -2.6036034 \\
\hline $\mathrm{H}$ & 1 & -2.1303043 & 1.80000029 & -2.7073704 \\
\hline $\mathrm{H}$ & 1 & -4.817367 & 1.3545742 & 3.71605523 \\
\hline $\mathrm{H}$ & 1 & -7.1496912 & 2.20384779 & 3.81816037 \\
\hline $\mathrm{H}$ & 1 & -3.3865838 & -1.1061538 & 2.97951041 \\
\hline $\mathrm{H}$ & 1 & -3.2098129 & 0.52479694 & 3.66693259 \\
\hline $\mathrm{H}$ & 1 & -1.8701298 & -0.199569 & 2.70408964 \\
\hline $\mathrm{H}$ & 1 & -7.4736197 & 0.9826044 & -1.6051449 \\
\hline $\mathrm{H}$ & 1 & -9.7264919 & 2.01544693 & -1.5093816 \\
\hline $\mathrm{H}$ & 1 & -10.611732 & 2.90968257 & 0.63021091 \\
\hline $\mathrm{H}$ & 1 & -9.2228027 & 2.81612361 & 2.69270944 \\
\hline $\mathrm{H}$ & 1 & 2.63885458 & 5.2936438 & 0.51565653 \\
\hline $\mathrm{H}$ & 1 & 1.78665575 & 3.94558337 & 1.2763146 \\
\hline $\mathrm{H}$ & 1 & 0.5566113 & 6.18181015 & -0.4606421 \\
\hline $\mathrm{H}$ & 1 & 0.42716934 & 6.02861665 & 1.29479141 \\
\hline $\mathrm{H}$ & 1 & -0.6775895 & 3.99348215 & -0.7551649 \\
\hline $\mathrm{H}$ & 1 & -1.6181704 & 5.29299007 & 0.01034665 \\
\hline $\mathrm{H}$ & 1 & -4.7455983 & -4.618108 & -1.4001566 \\
\hline
\end{tabular}




\begin{tabular}{|ccccc|}
\hline $\mathrm{H}$ & 1 & -3.1433686 & -2.7556586 & -1.1618859 \\
$\mathrm{H}$ & 1 & -4.3849028 & -6.7545854 & -0.159032 \\
$\mathrm{H}$ & 1 & -2.4153423 & -7.0071483 & 1.33998442 \\
$\mathrm{H}$ & 1 & -0.801655 & -5.1390102 & 1.60289515 \\
$\mathrm{H}$ & 1 & 0.00262044 & -2.9457676 & 1.07499146 \\
$\mathrm{Cl}$ & 17 & 0.50006703 & -0.603103 & 2.12263458 \\
\hline
\end{tabular}

\section{References}

(1) Clarke, C.; Fleming, I.; Fortunak, J. M. D.; Gallagher, P. T.; Honan, M. C.; Mann, A.; Nubling, C. O.; Raithby, P. R; Wolff, J. J. Tetrahedron 1988, 44, 3931-3944.

(2) Denmark, S. E.; Wynn, T. J. Am. Chem. Soc. 2001, 123, 6199-6200.

(3) Denmark, S. E.; Su, X.; Nishigaichi, Y.; Coe, D. M.; Wong, K.-T.; Winter, S. B. D.; Choi, J. Y. J. Org. Chem. 1999, 64, 1958-1967.

(4) Ongoka, P.; Mauze, B.; Miginiac, L. J. Organomet. Chem. 1987, 322, 131-139.

(5) Lou, S.; Westbrook, J. A.; Schaus, S. E. J. Am. Chem. Soc. 2004, 126, 11440-11441.

(6) Pollex, A.; Millet, A.; Muller, J.; Hiersemann, M.; Abraham, L. J. Org. Chem. 2005, 70, 5579-5591.

(7) Conway, J. C.; Quayle, P.; Regan, A. C.; Urch, C. J. Tetrahedron, 2005, 61, 11910-11923.

(8) Zhou, X.T.; Carter, R. G. Chem. Comm. 2004, 2138-2140.

(9) Nakai, E.; Nakai, T. Tetrahedron Lett. 1988, 29, 5409-5412.

(10) Paterson, I.; Smith, J. D. Tetrahedron Lett. 1993, 34, 5351-5354.

(11) Cloarec, J.-M.; Charette, A. B. Org. Lett. 2004, 6, 4731-4734.

(12) Chen, H.; Feng, Y.; Xu, Z.; Ye, T. Tetrahedron 2005, 61, 11132-11140.

(13) Fleming, I.; Iqbal, J.; Tetradedron Lett. 1983, 24, 2913-2917.

(14) Konrad, K; Simchen, G. Synthesis 1981, 30-32.

(15) Saito, S.; Shiozawa, M.; Ito, M.; Yamamoto, H. J. Am. Chem. Soc. 1998, 120, 813.

(16) Yang, W.; Shang, D.; Liu, Y.; Du, Y.; Feng, X. J. Org. Chem. 2005, 70, 8533.

(17) Suitable microanalytical data could not be obtained. The purity was established as $>99 \%$ by both ${ }^{1} \mathrm{H}$ NMR and CSP-SFC analysis.

(18) (a) Masamune, S.; Sato, T.; Kim, B.; Wollman, T. A. J. Am. Chem. Soc. 1986, 108, 8279. 
(b) Nunez, M. T.; Martin, V. S. J. Org. Chem. 1990, 55, 1928.

(19) Torii, S.; Inokuchi, T.; Ogawa, H. Bull. Chem. Soc. Jpn. 1979, 52, 1233.

(20) Ojima, I.; Kogure, T.; Kumagai, M.; Horiuchi, S. Sata, T. J. Organomet. Chem. 1976, 122 (1), 83.

(21) Harrington, P.E.; Tius, M.A. Org. Lett. 2000, 2, 2447-2450.

(22) (a) from http://classic.chem.msu.su/gran/gamess/index.html by Granovsky, A. A. (b) Schmidt, M. W.; Baldridge, K. K.; Boatz, J. A.; Elbert, S. T.; Gordon, M. S.; Jensen, J. J.; Matsunaga, N.; Nguyen, K. A.; Su, S.; Windus, T. L.; Dupuis, M.; Montgomery, J. A. J. Comput. Chem. 1993, 14, 1347. 
Denmark and Heemstra

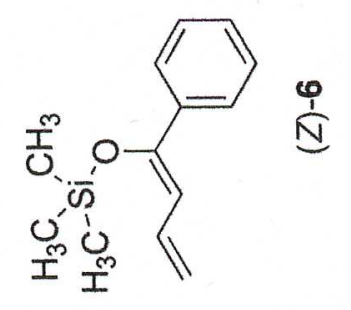

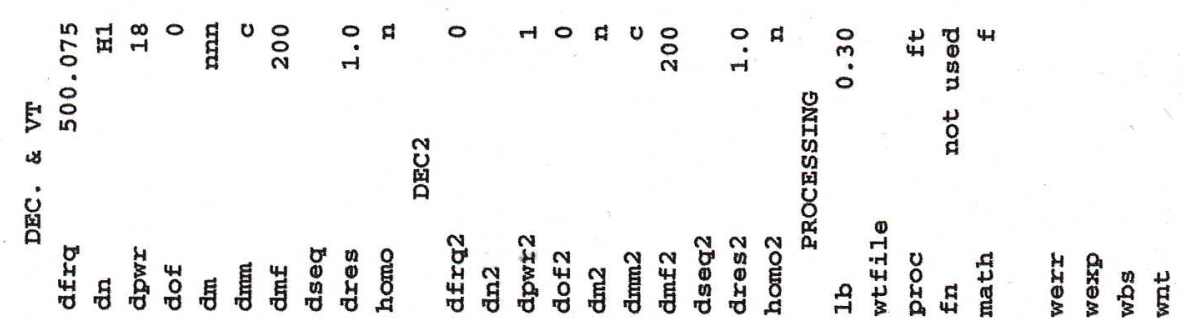

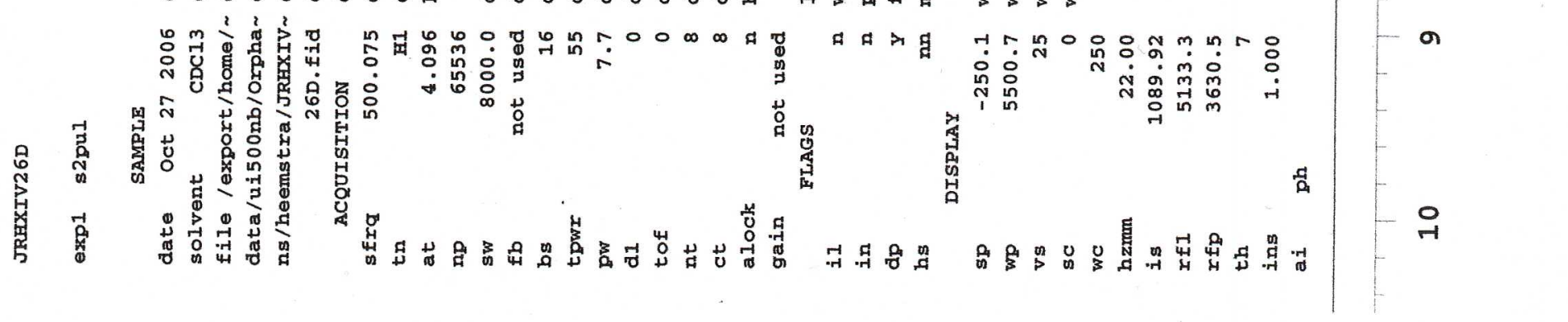


Denmark and Heemstra

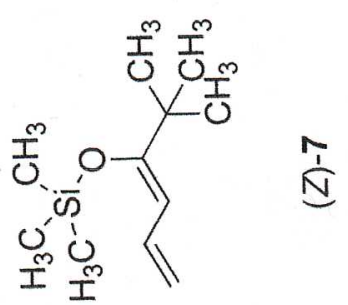

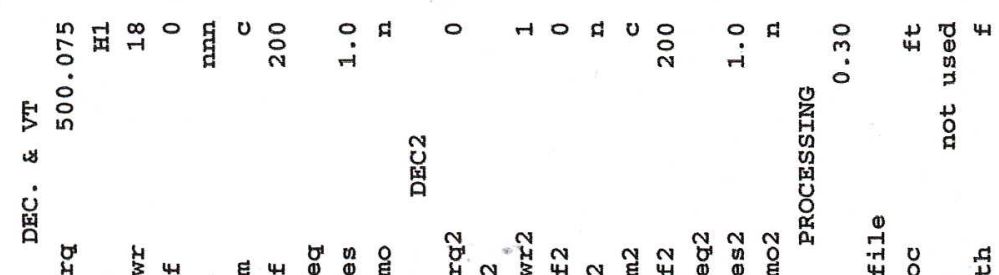
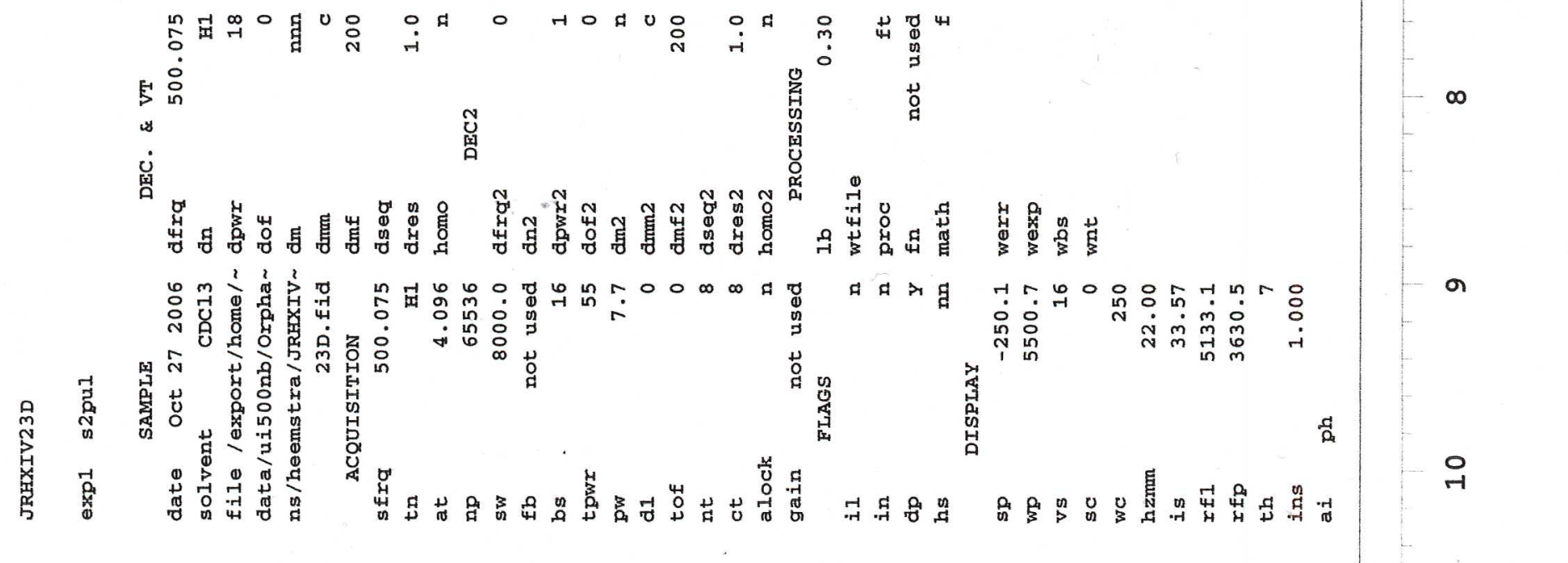

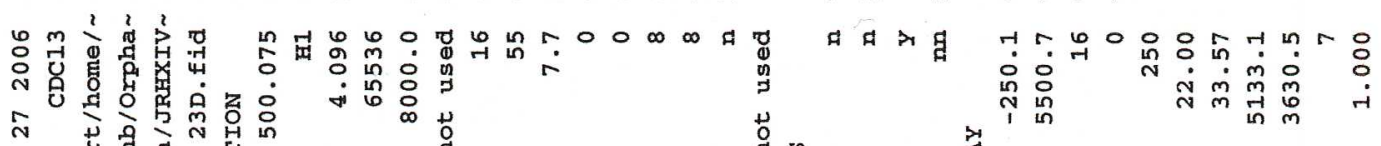

N

m

⿷匚⿱ 口,

-1
n 
Denmark and Heemstra

N
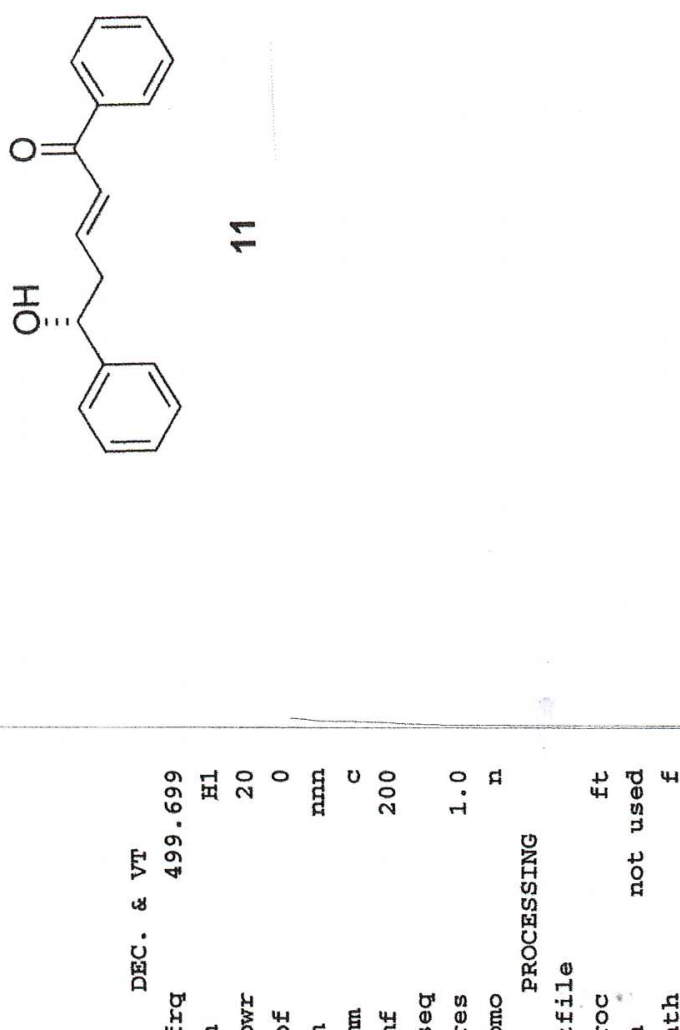

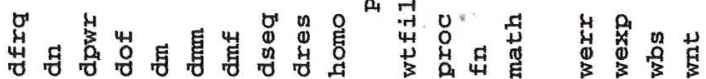

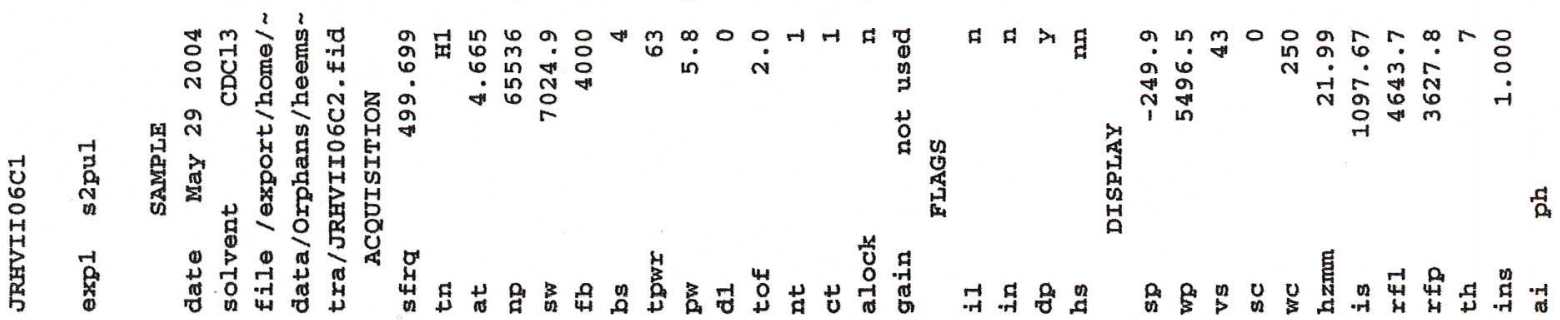

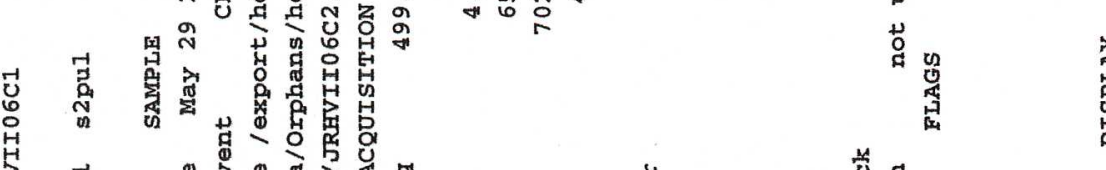

句

6

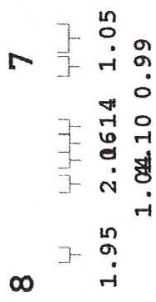

a

$\underset{-1}{\circ}$ 
Denmark and Heemstra

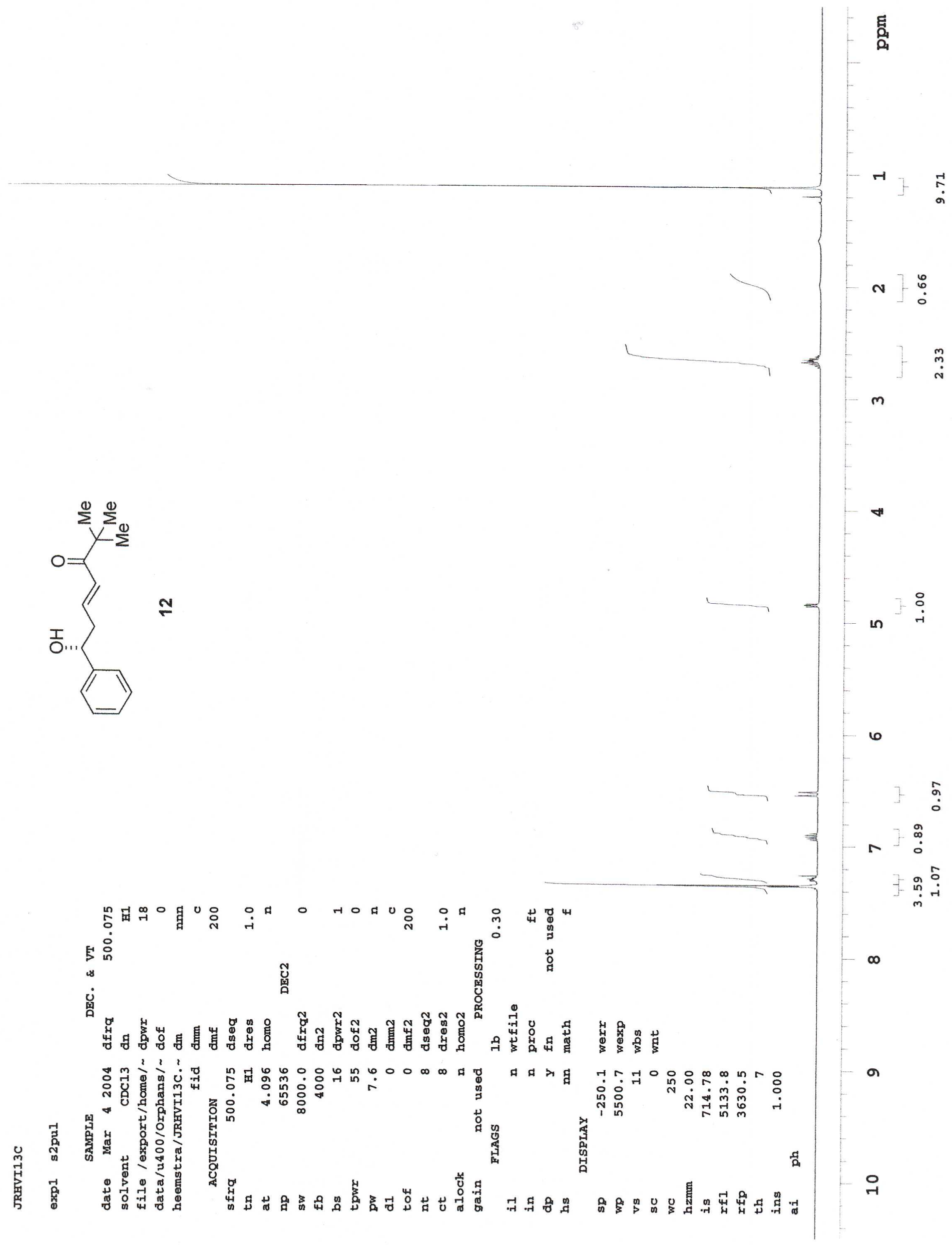




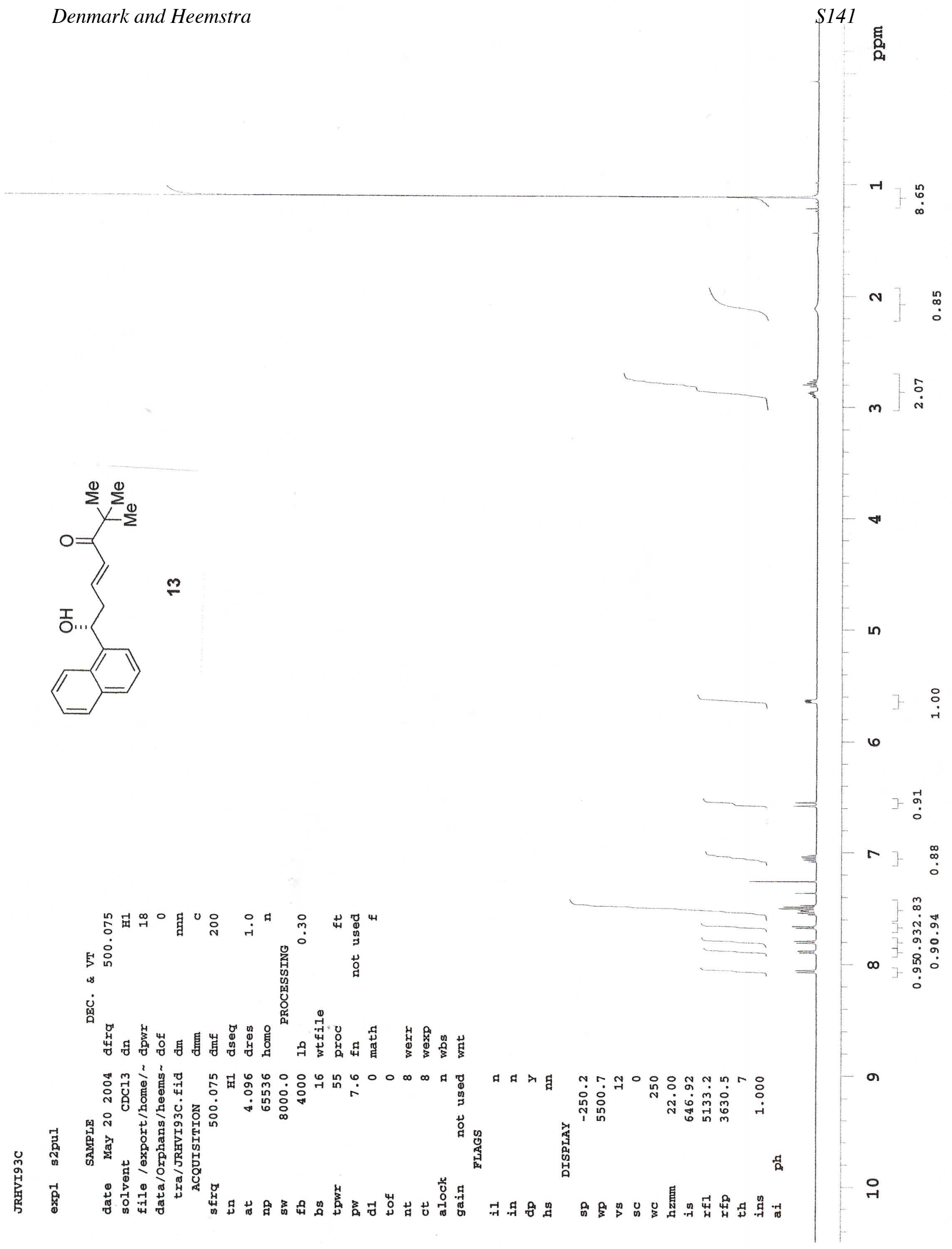


Denmark and Heemstra

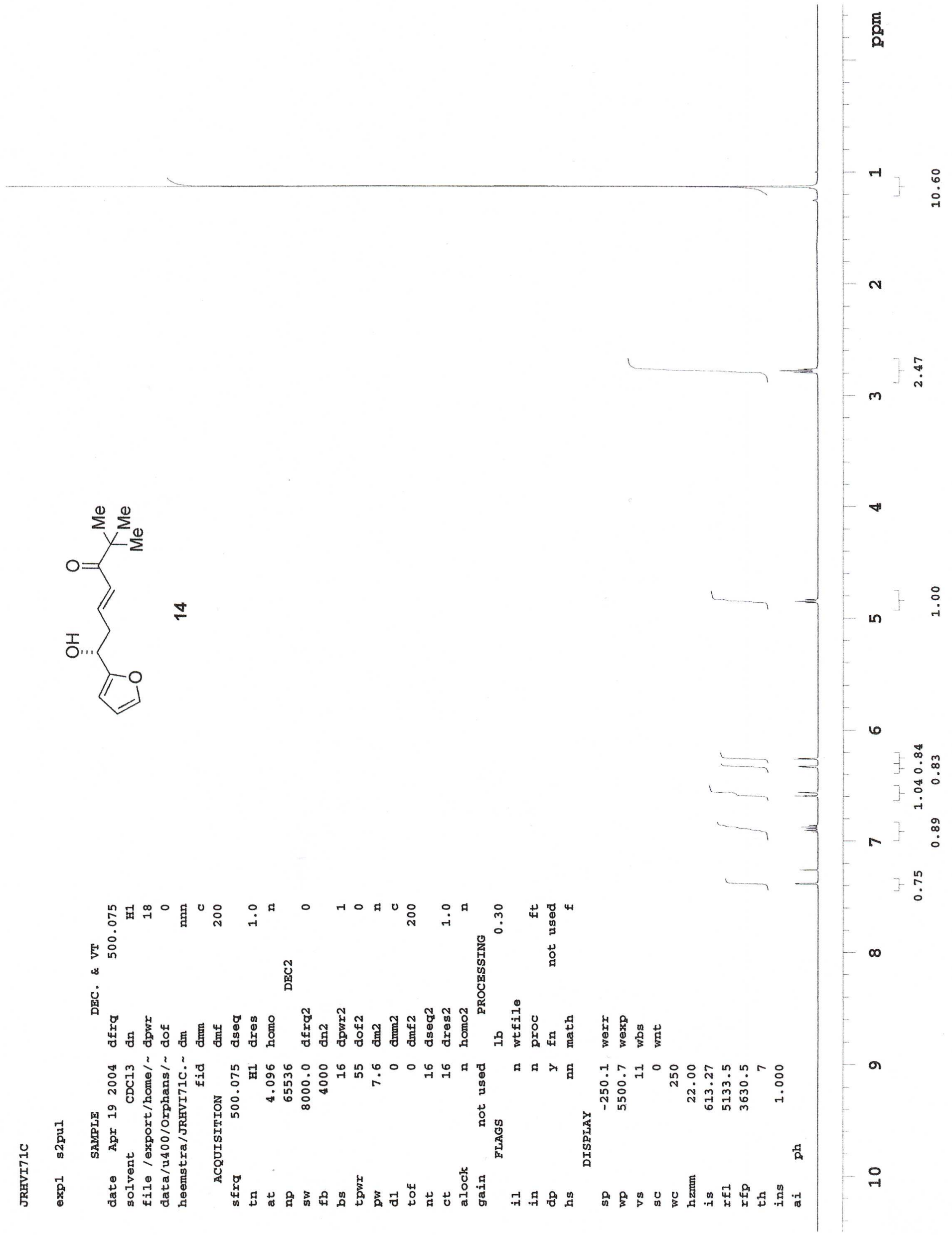



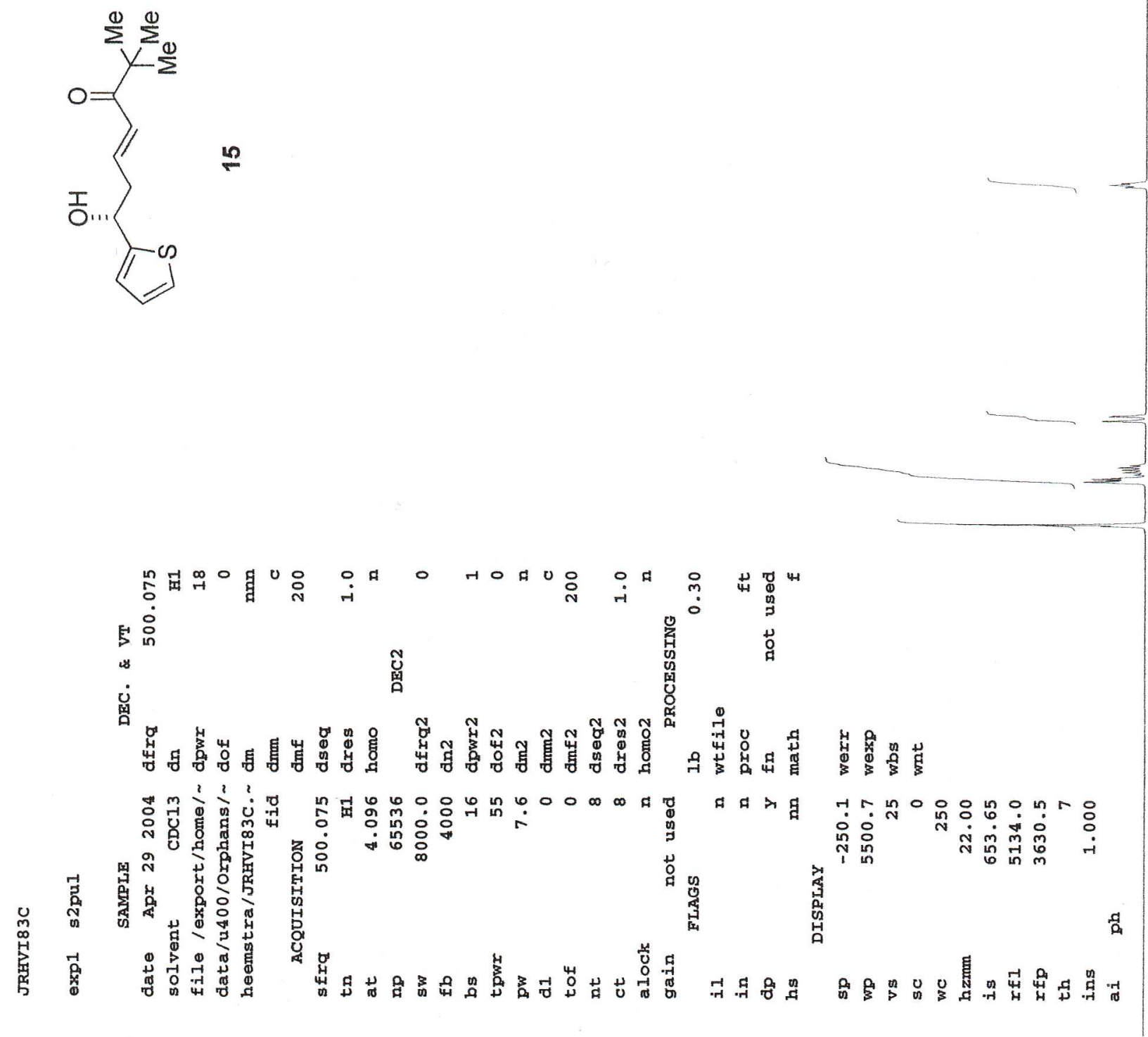
Denmark and Heemstra

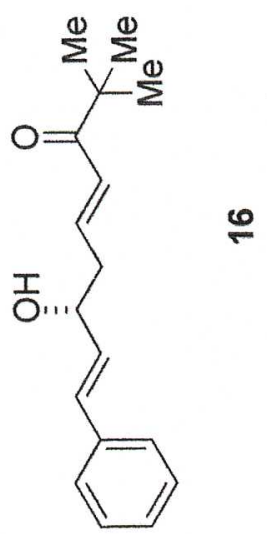

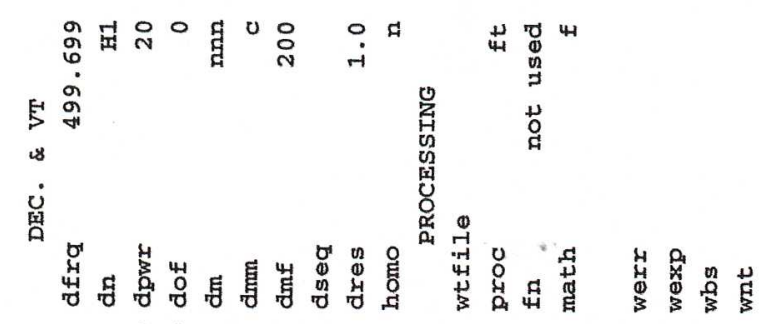

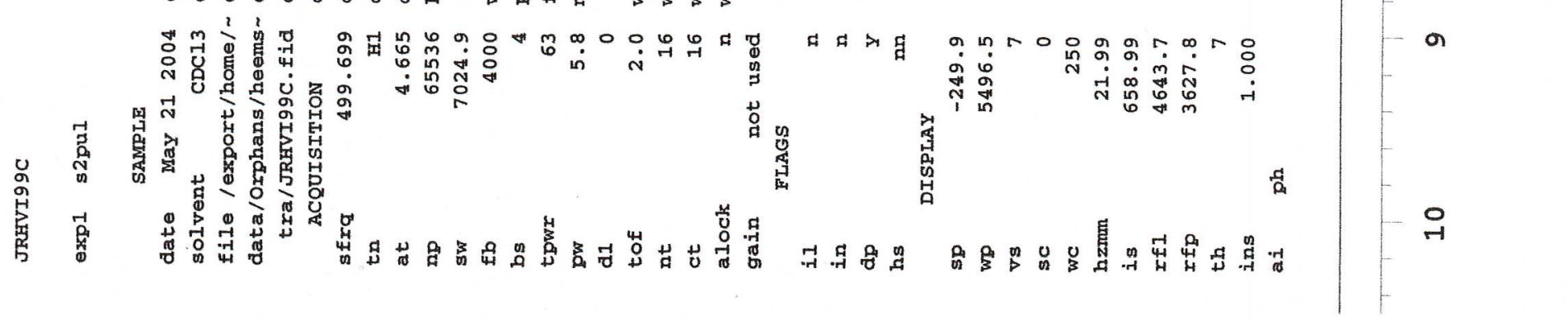




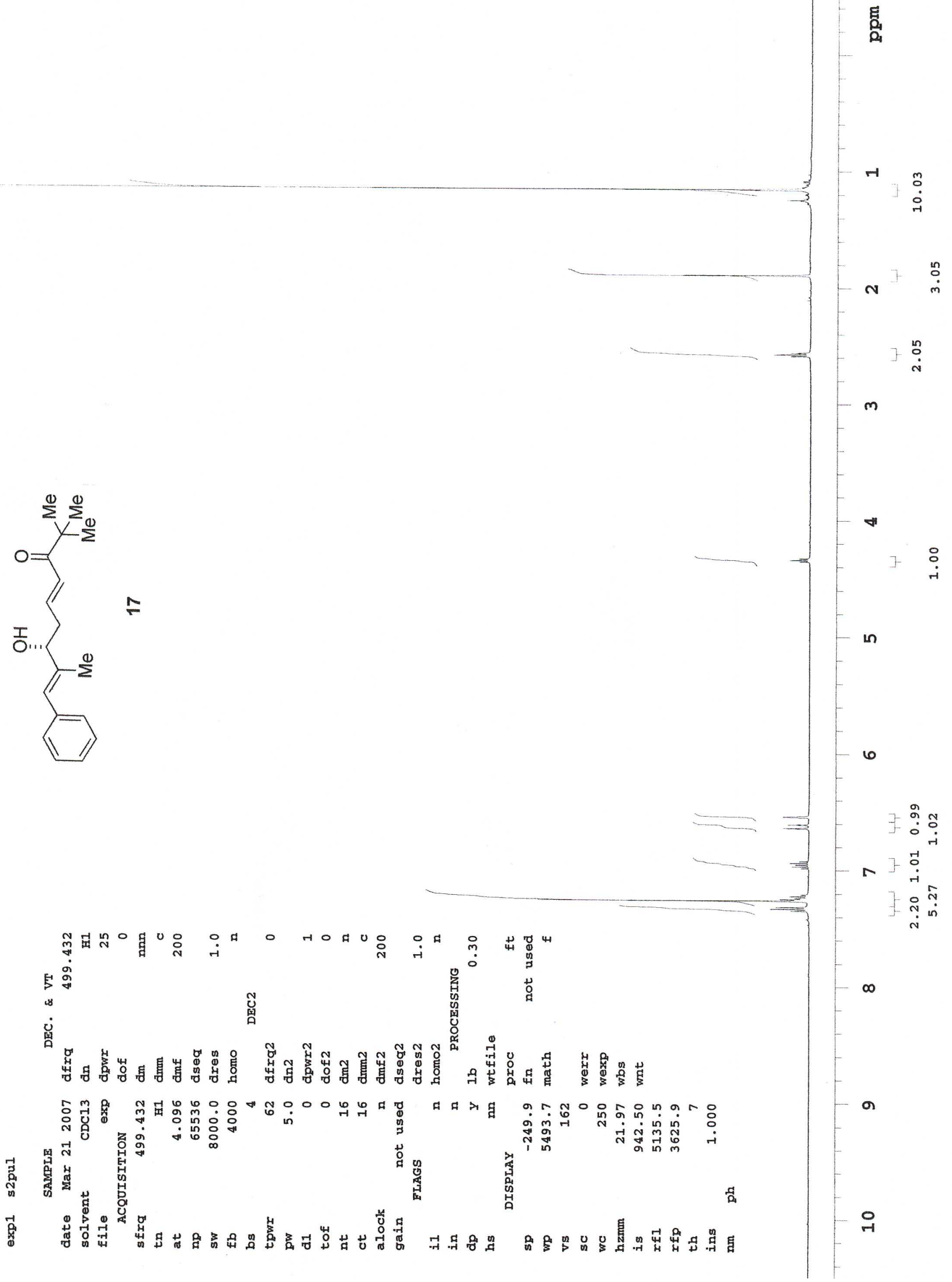


Denmark and Heemstra
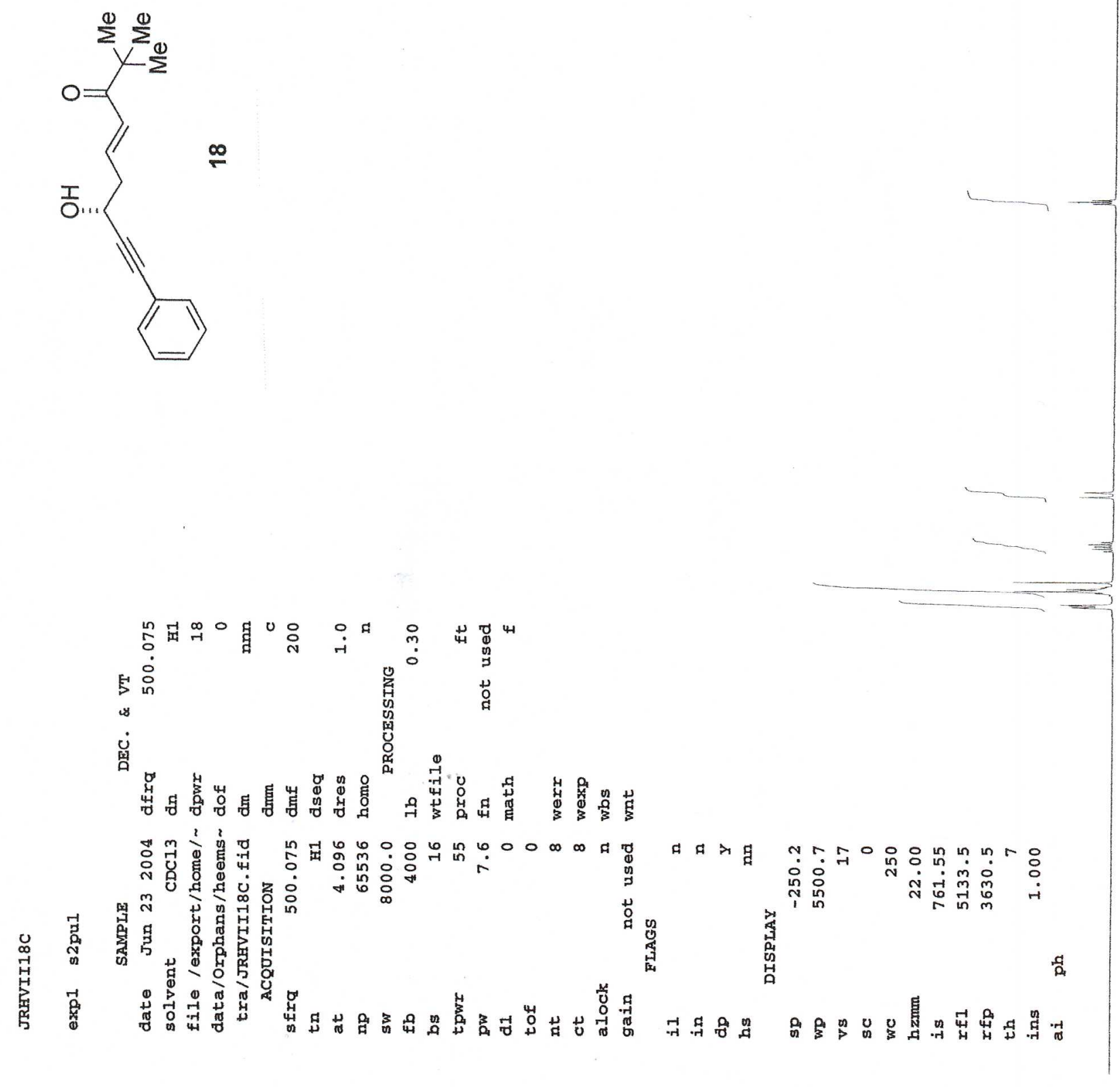

हี

+
0
0
0
$r$

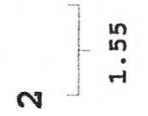

$m$

ᄀ $\stackrel{\text { ก }}{\mathfrak{4}}$

m

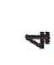

$7 \stackrel{0}{\circ}$

เก

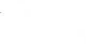

6

ᄀ.

[ ] 웅

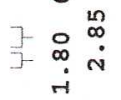

$\infty$

$a$

$\stackrel{0}{7}$ 


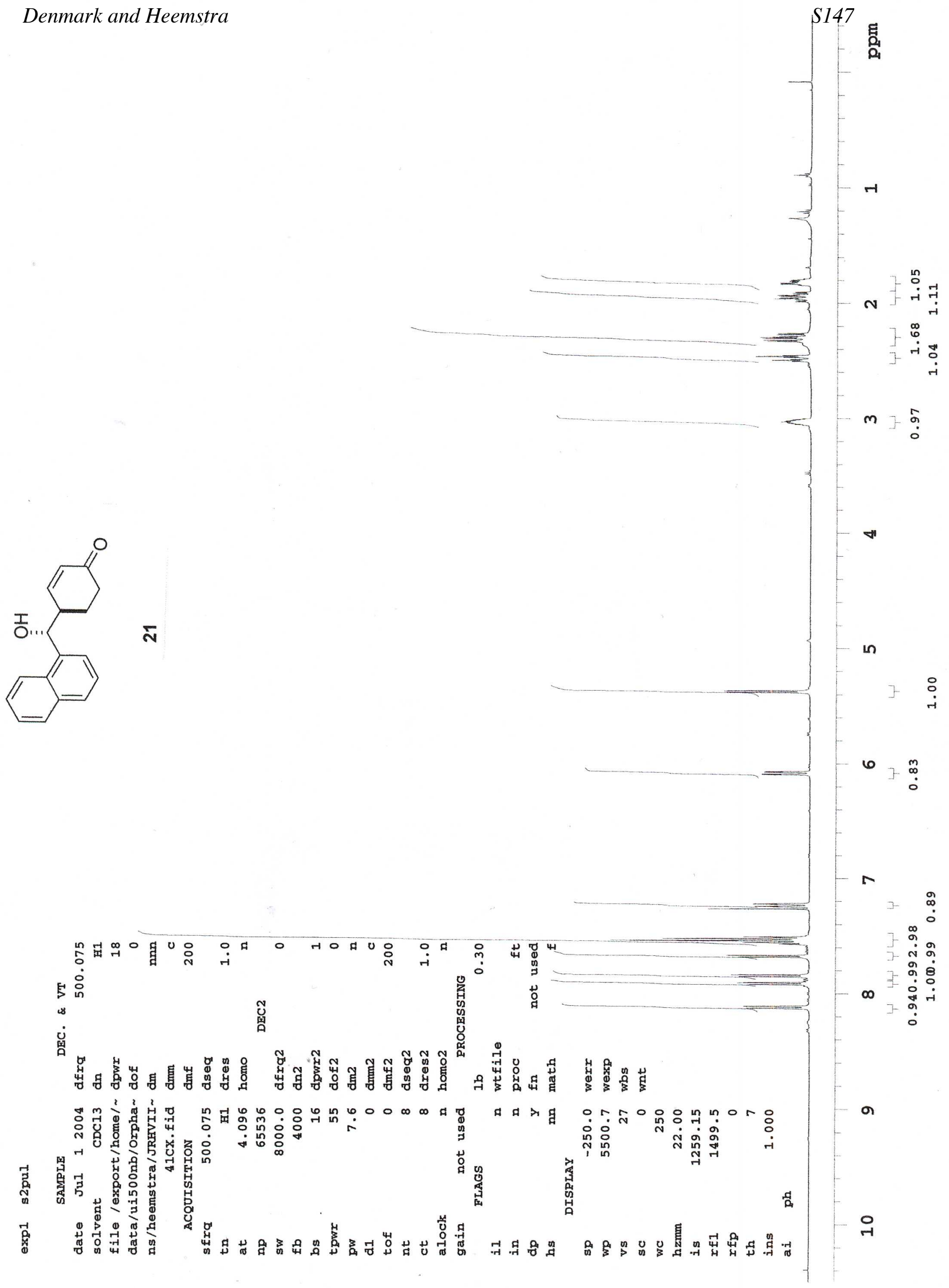


Denmark and Heemstra
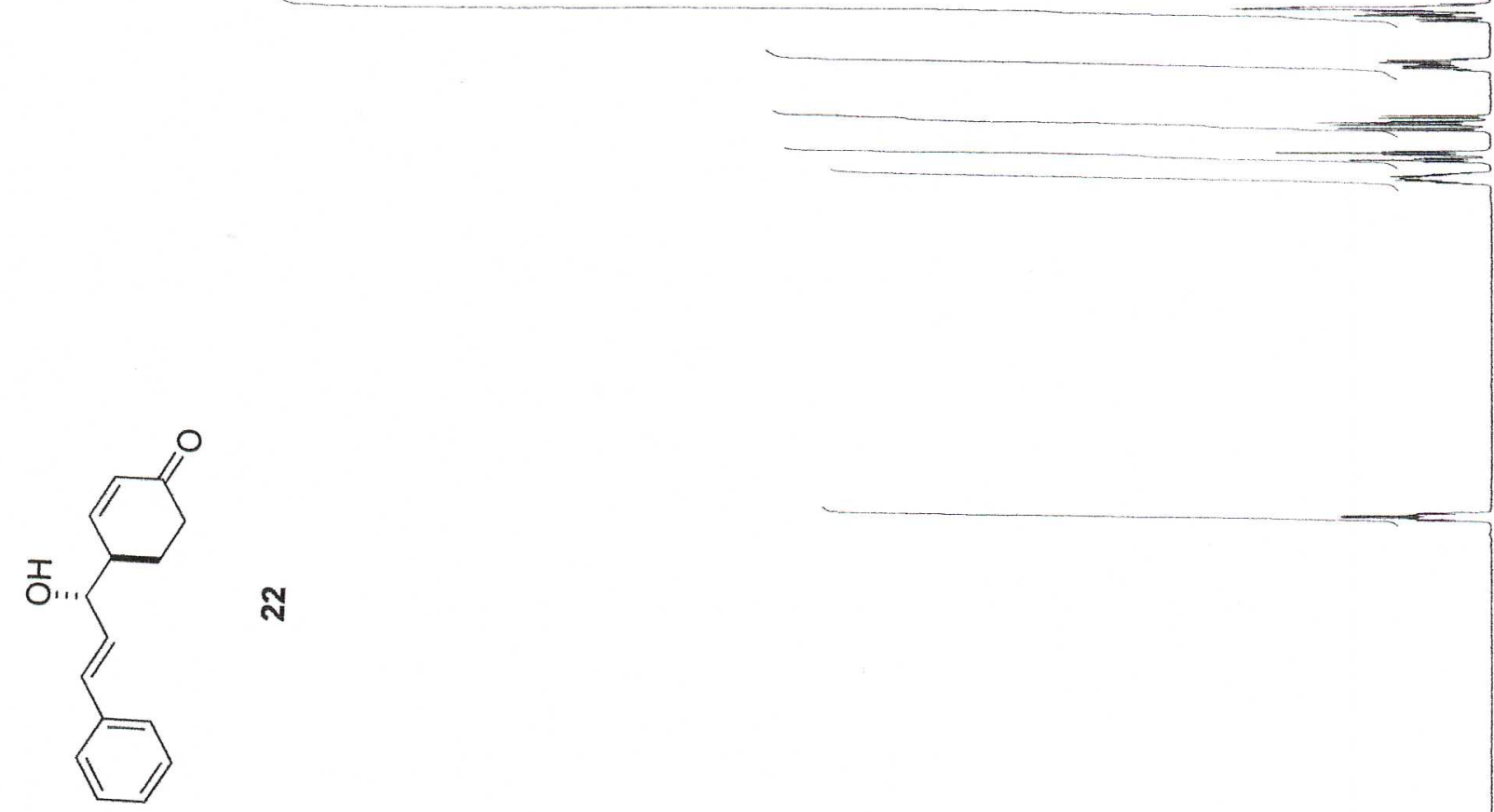

N

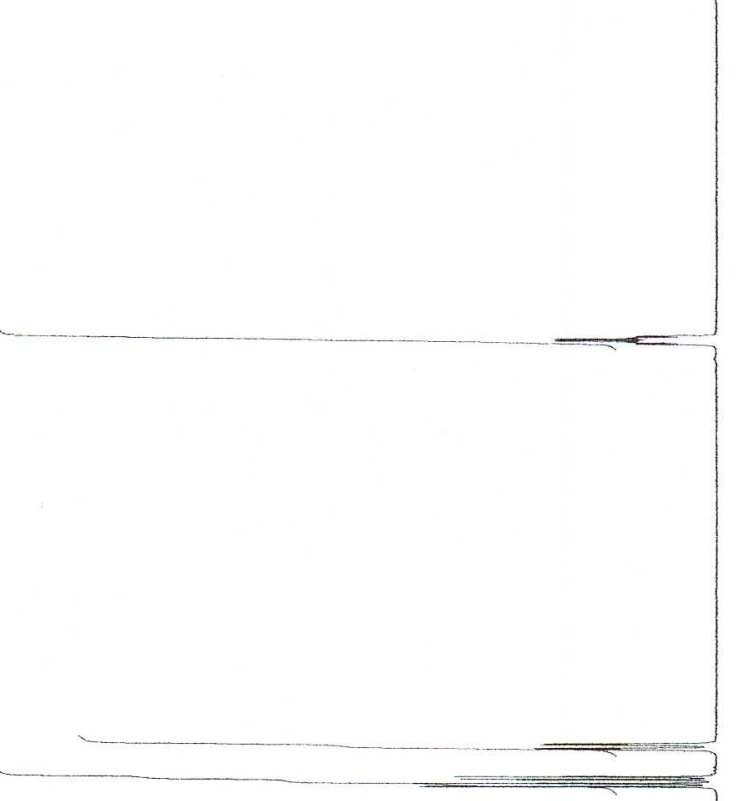

$m$

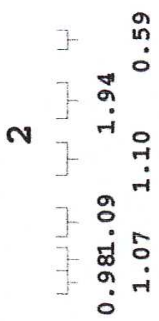

10

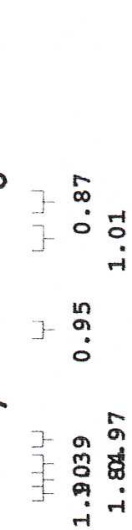

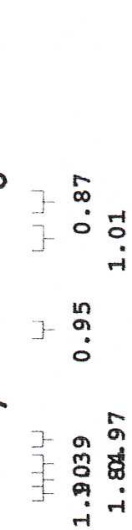

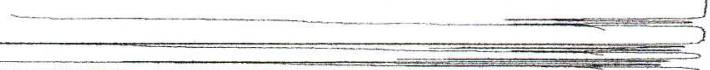

N

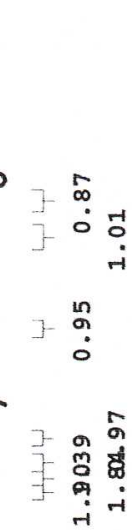

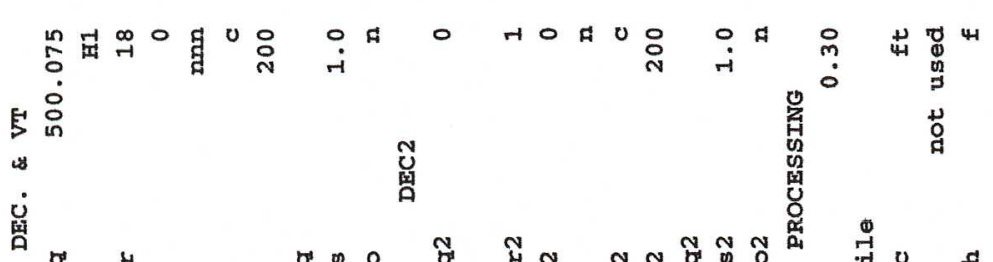

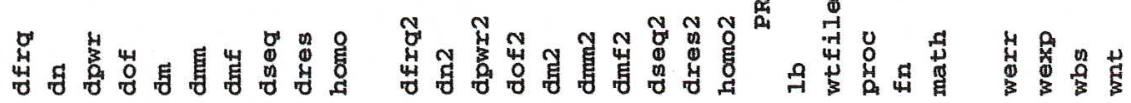

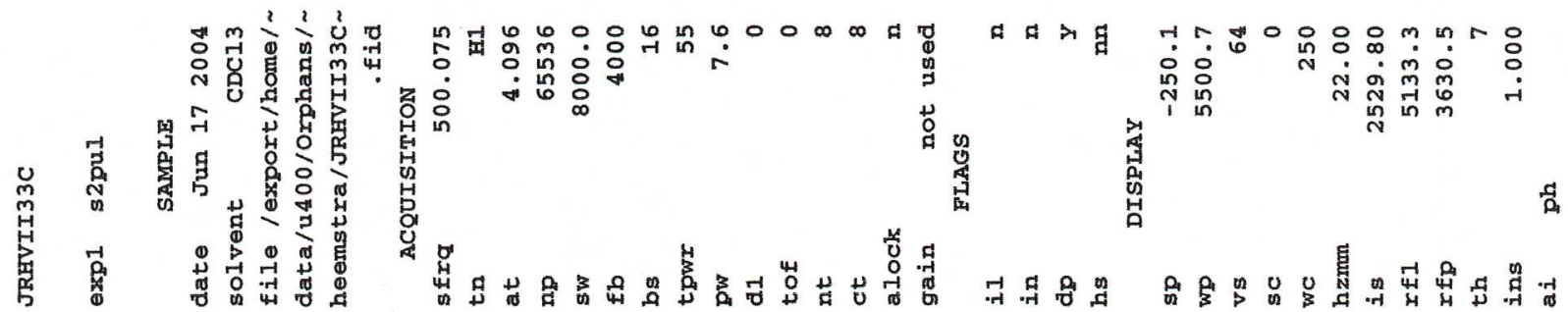

$\infty$

a

욱 
Denmark and Heemstra

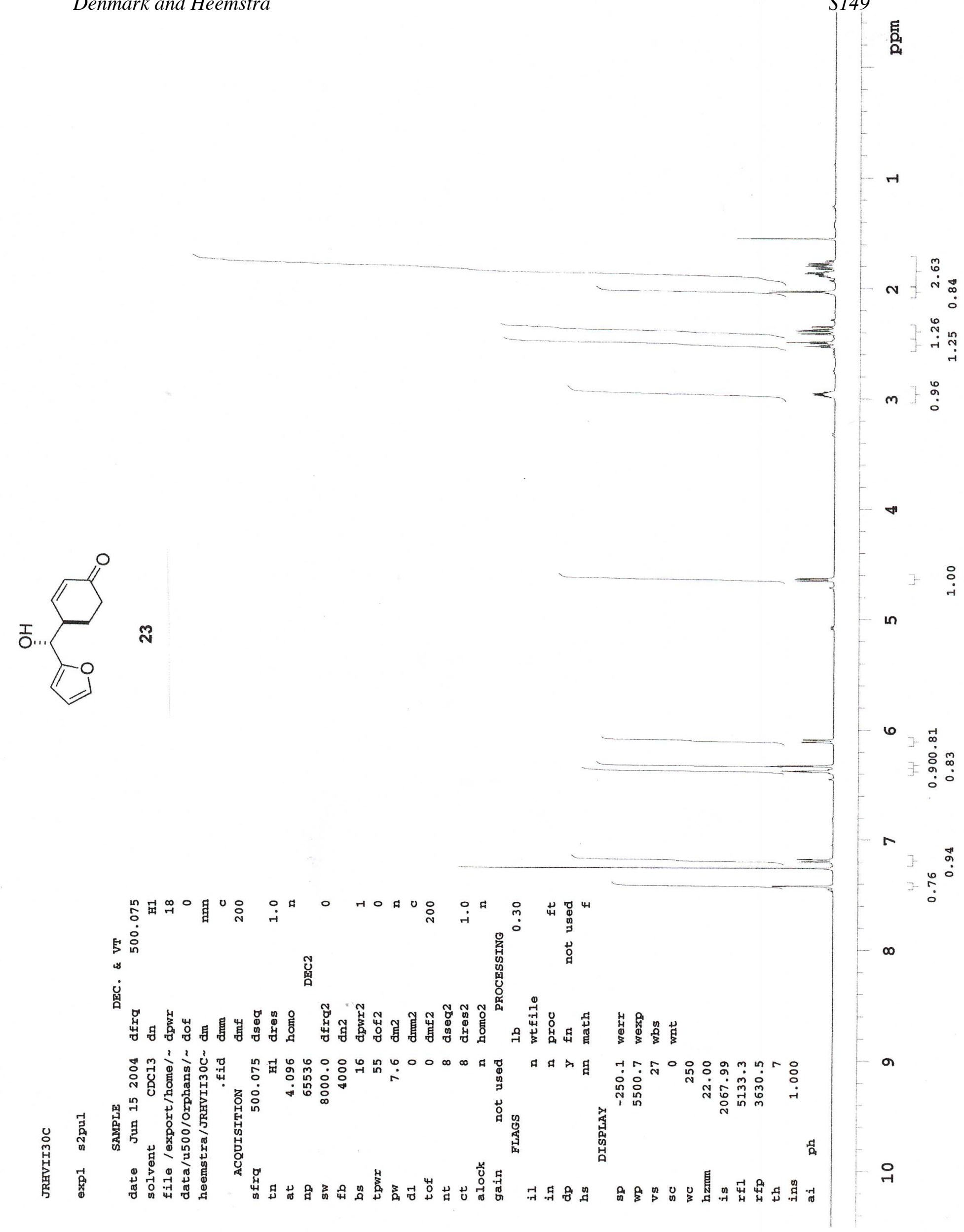




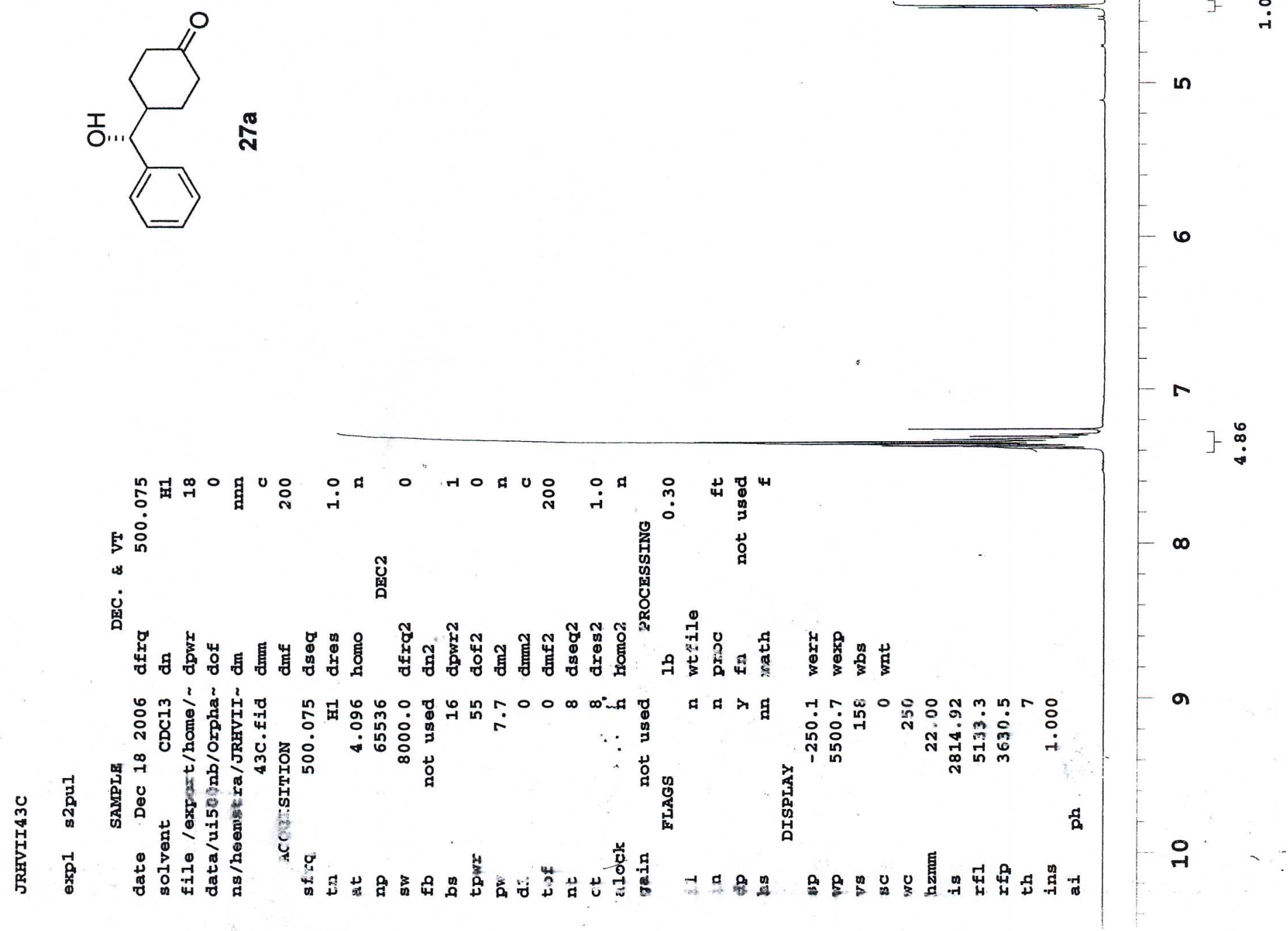




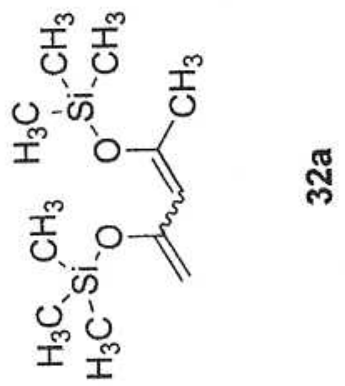

$\{151$ हू

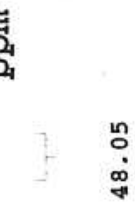

$-1$

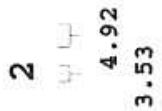

m

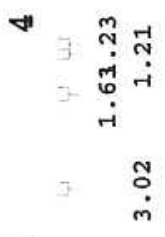

in $=\frac{O}{i}$

6

r

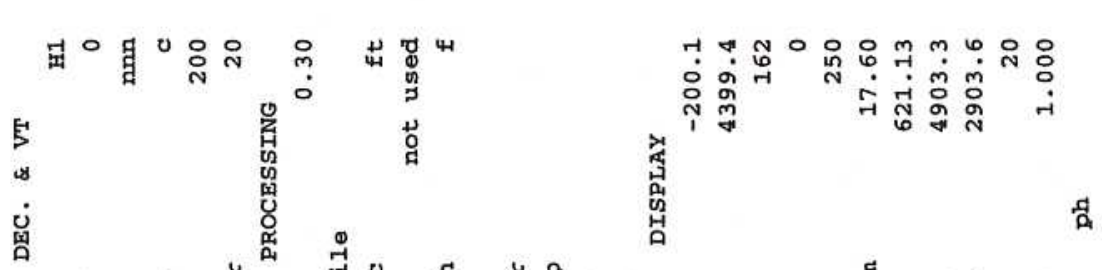

모ำ

$\infty$

$a$

욱 

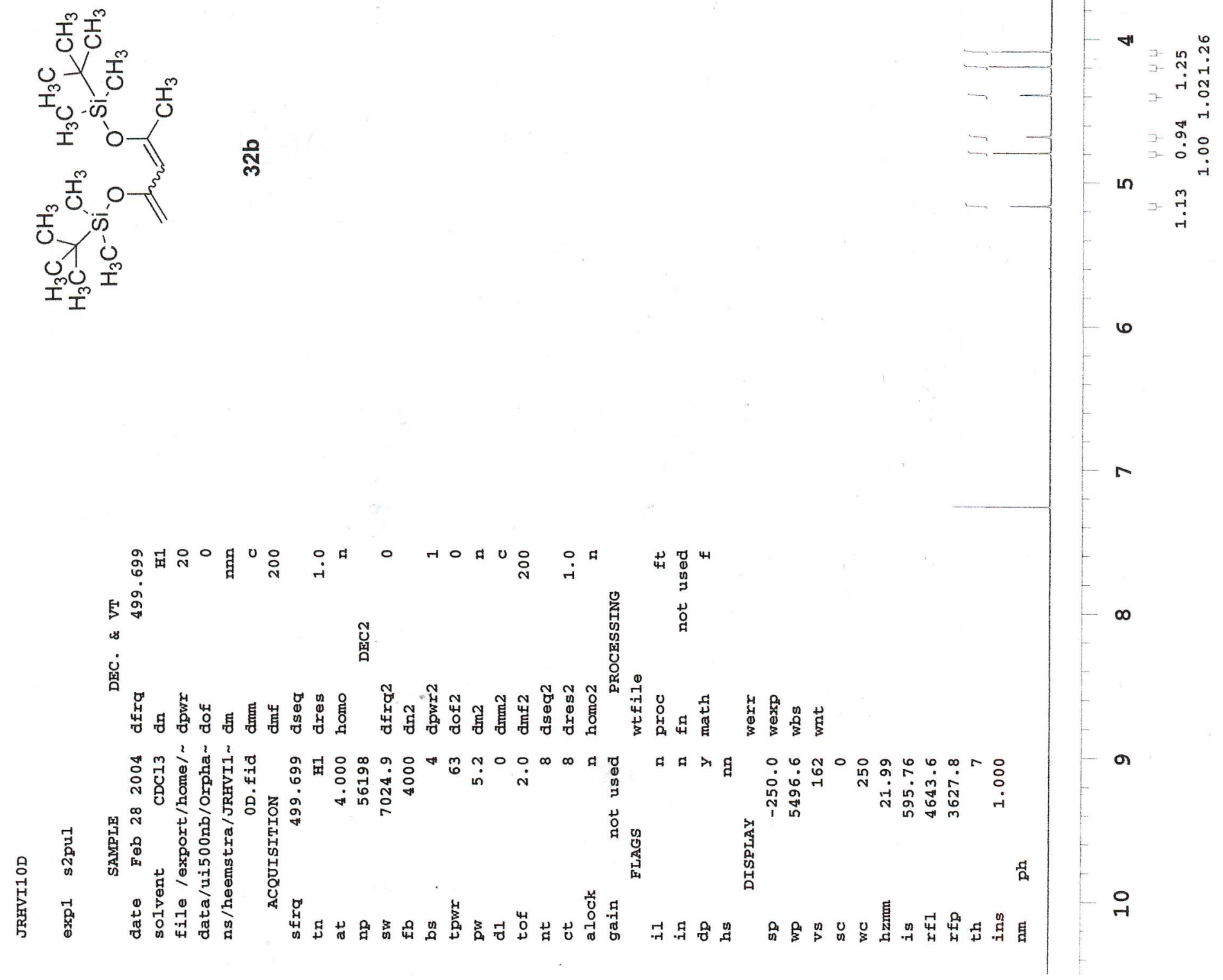


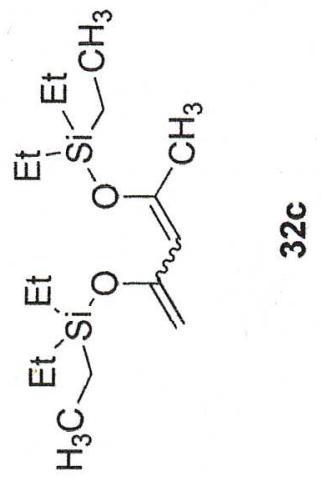


Denmark and Heemstra
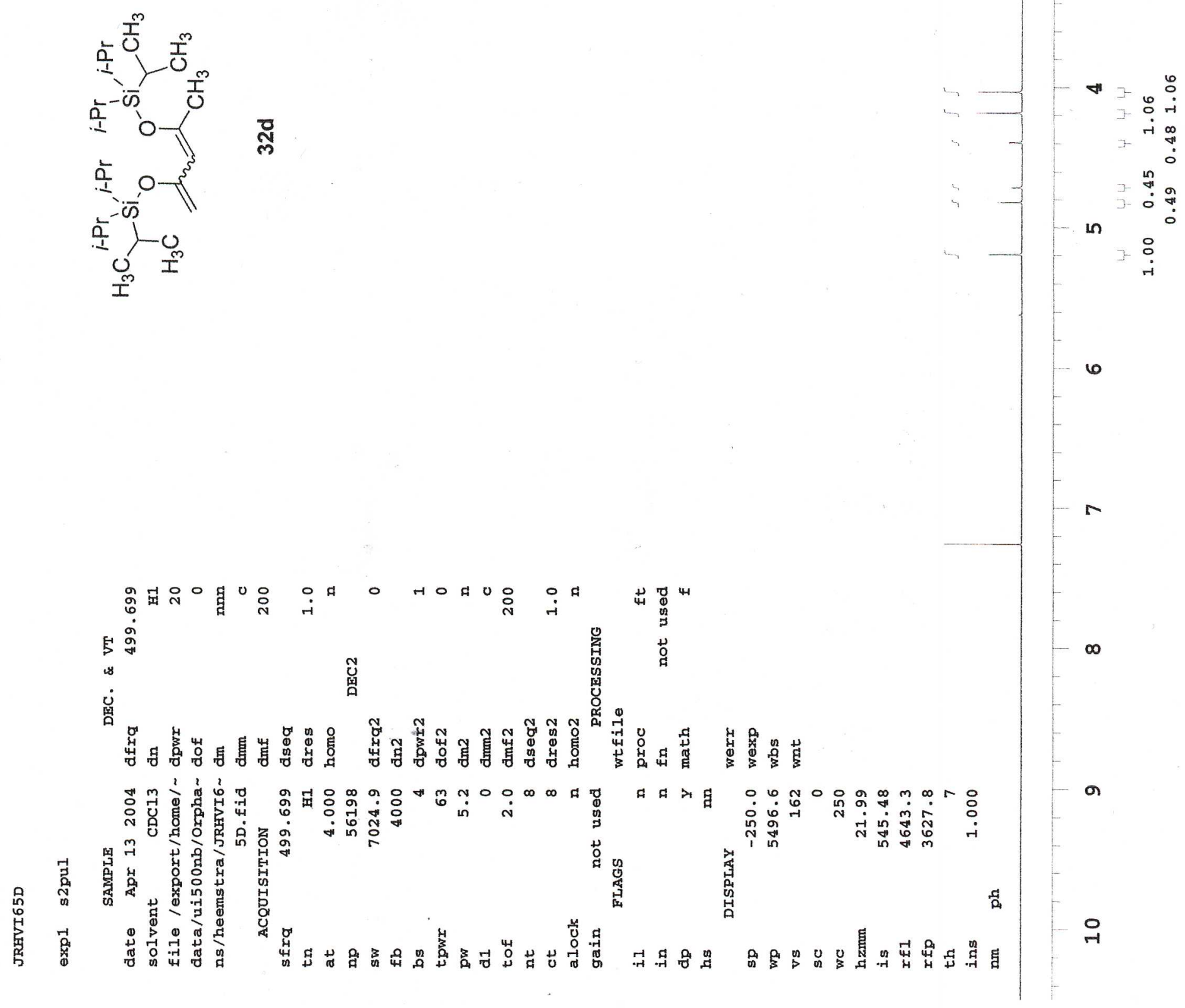
Denmark and Heemstra
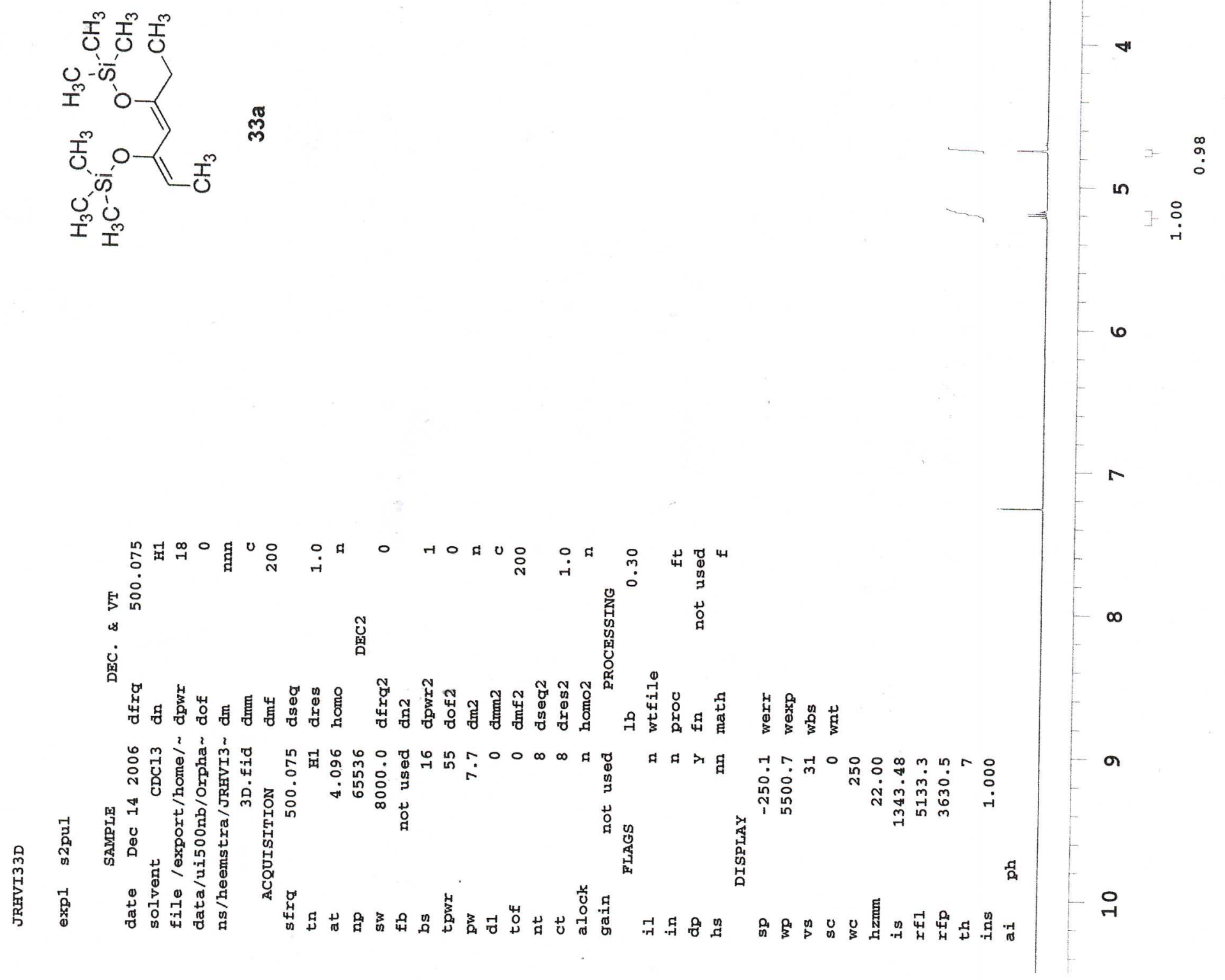


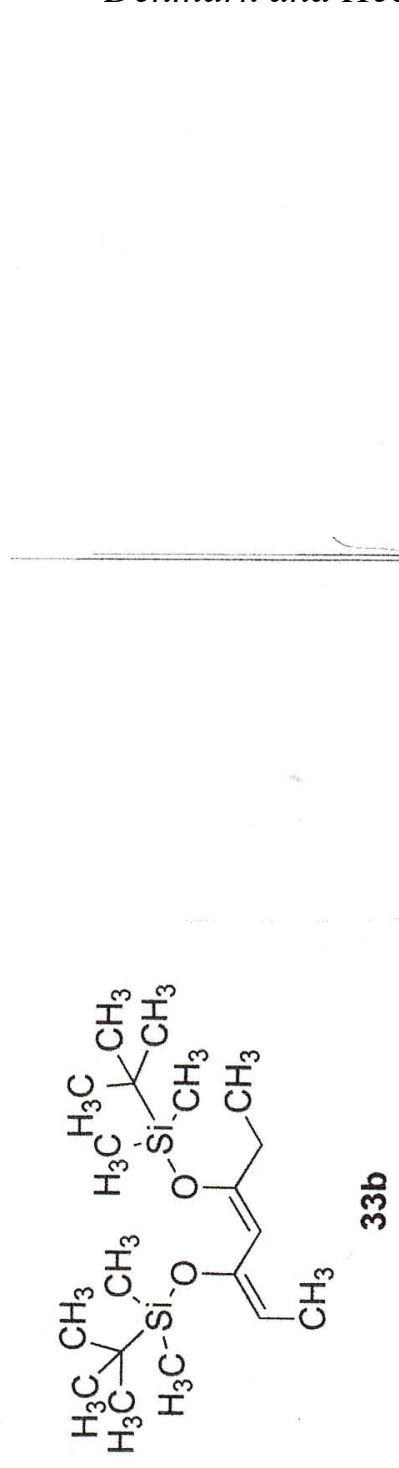

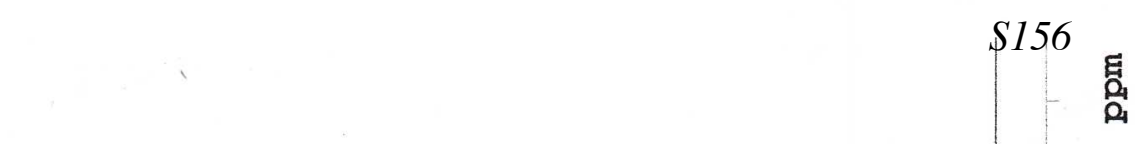

$\circ$

d̊․

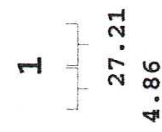

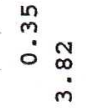

ง

in

m

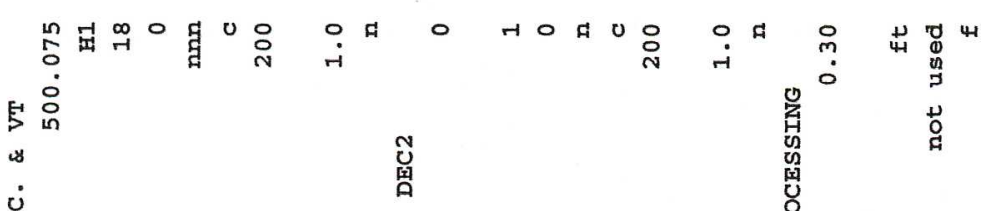

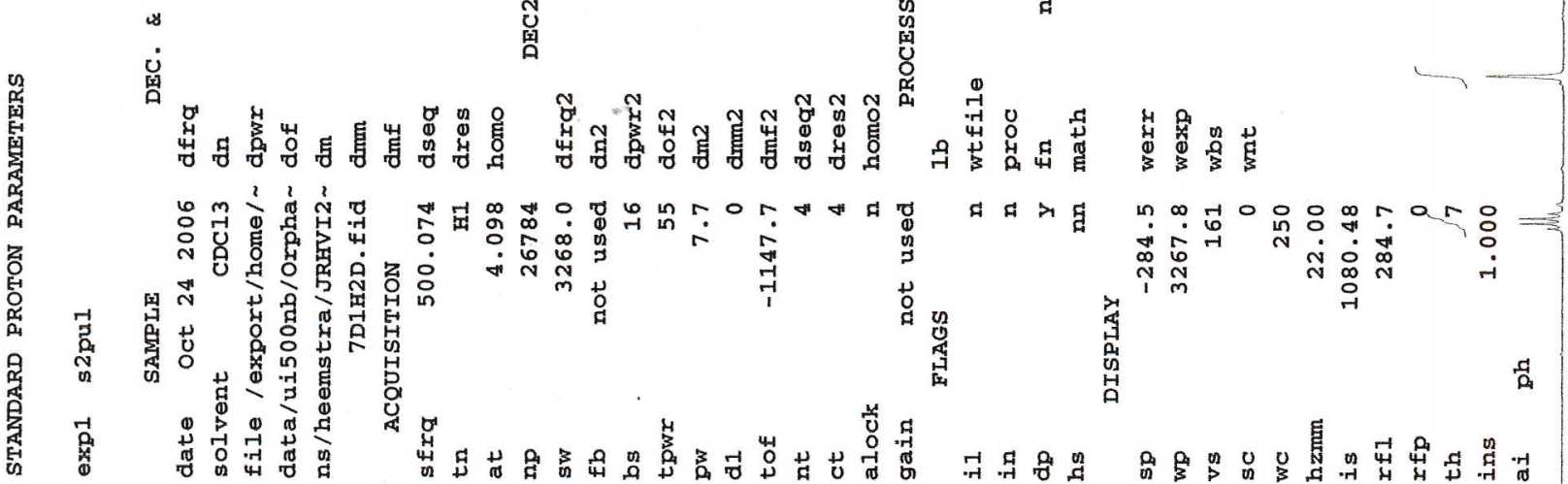


Denmark and Heemstra

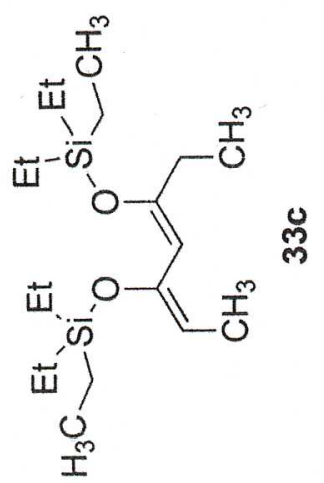

$m$

in

0
0
-1

6

n

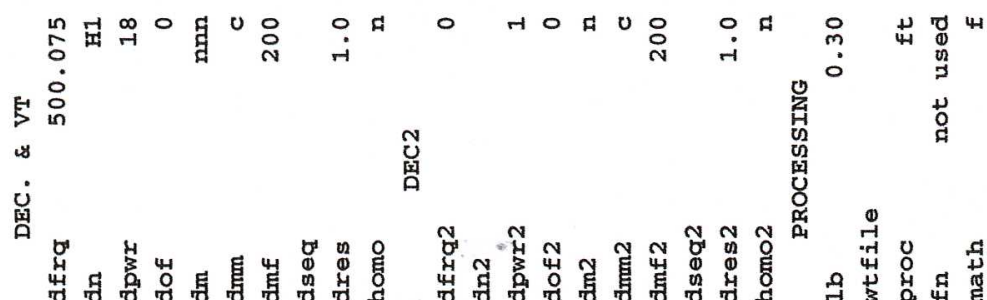

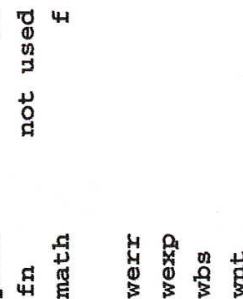

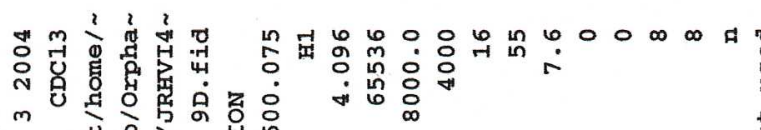

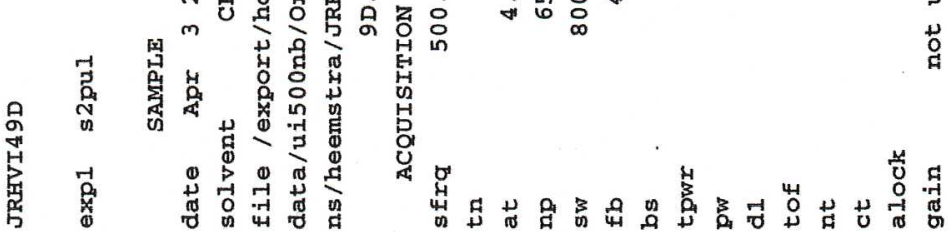
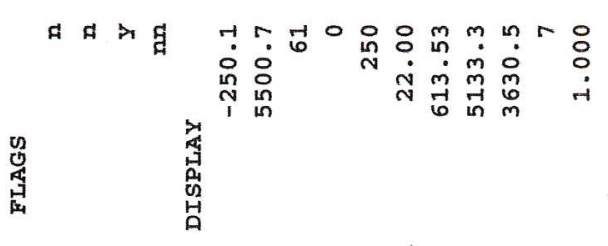

o

$\infty$ ఫั?

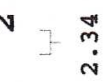

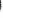
ำ 


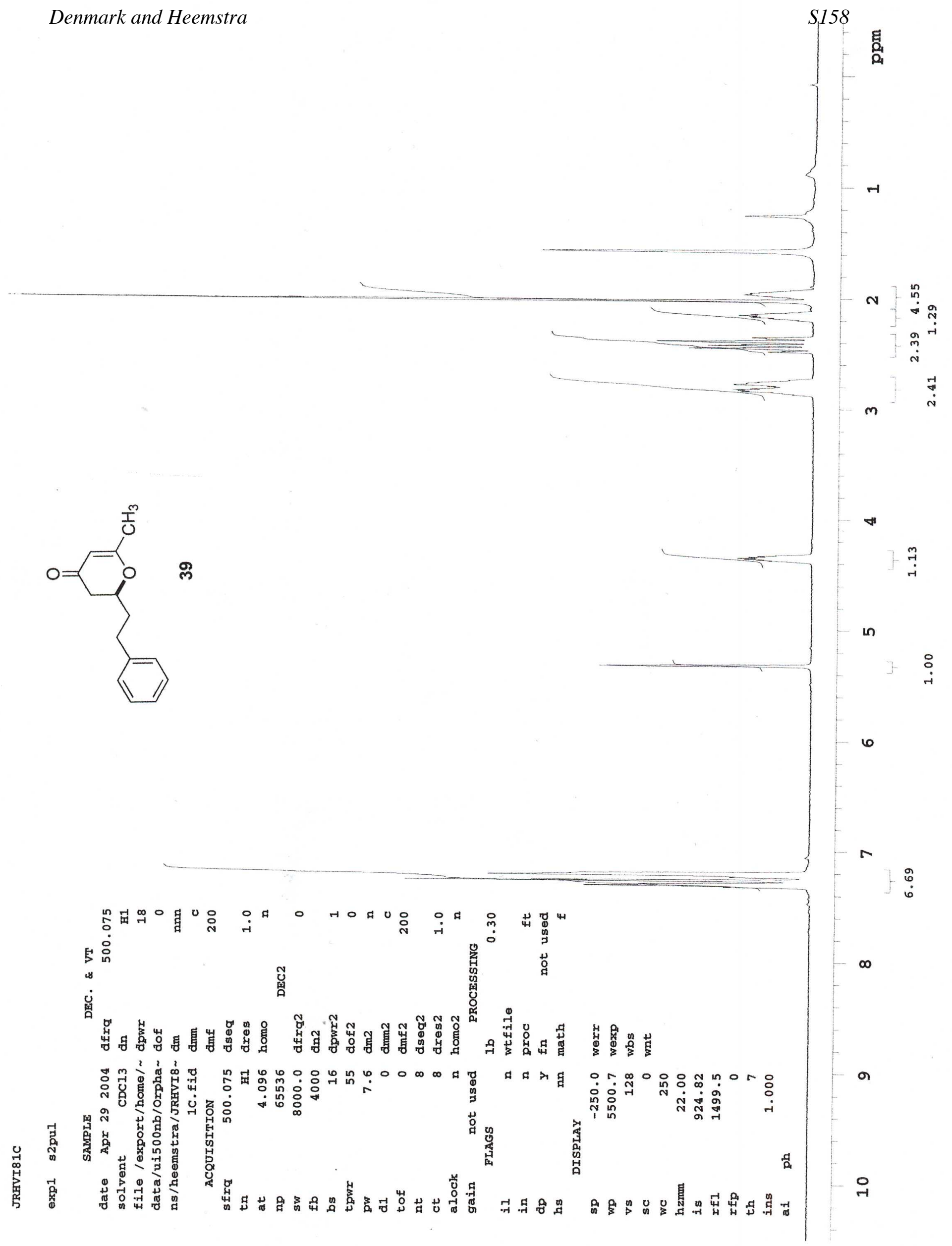




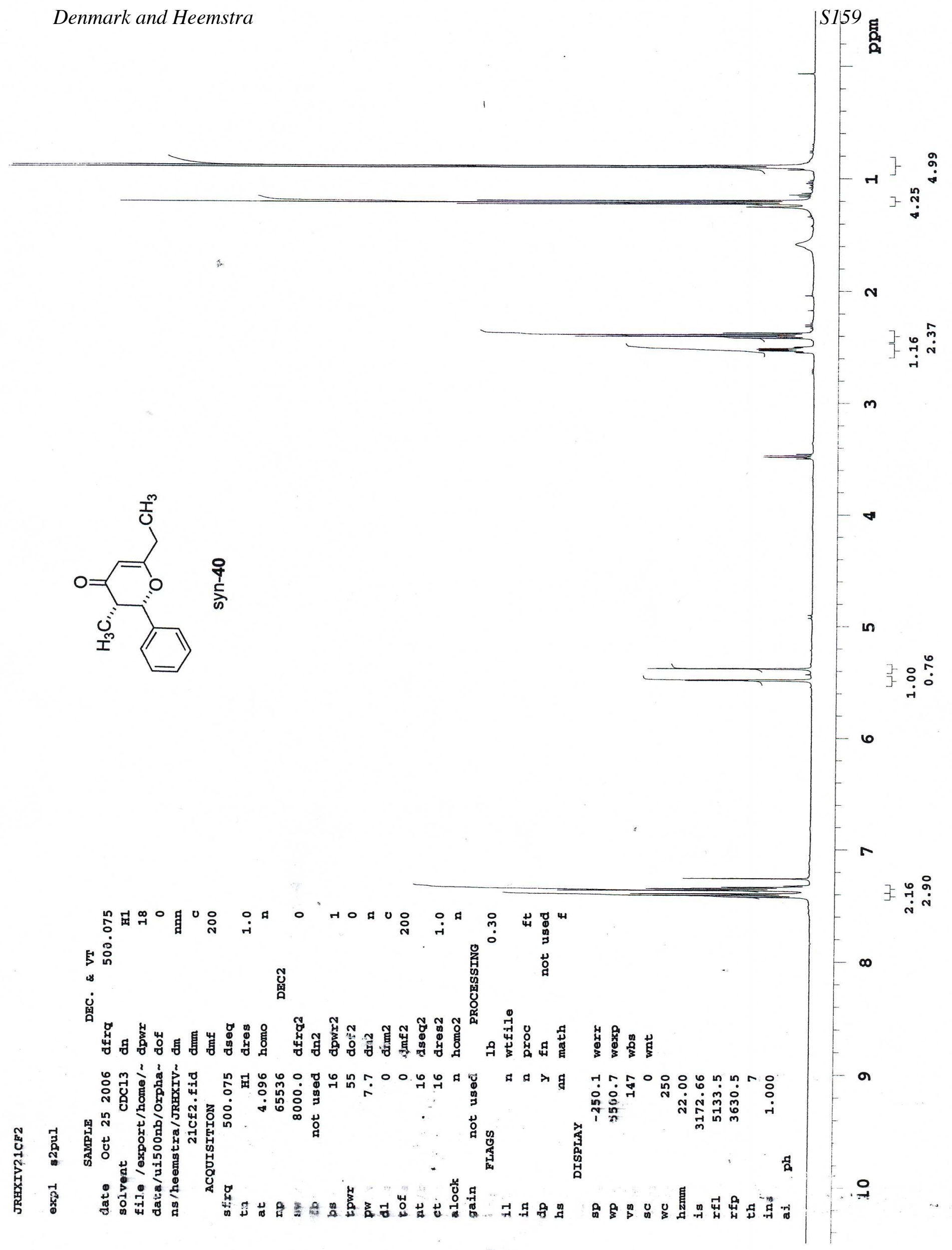




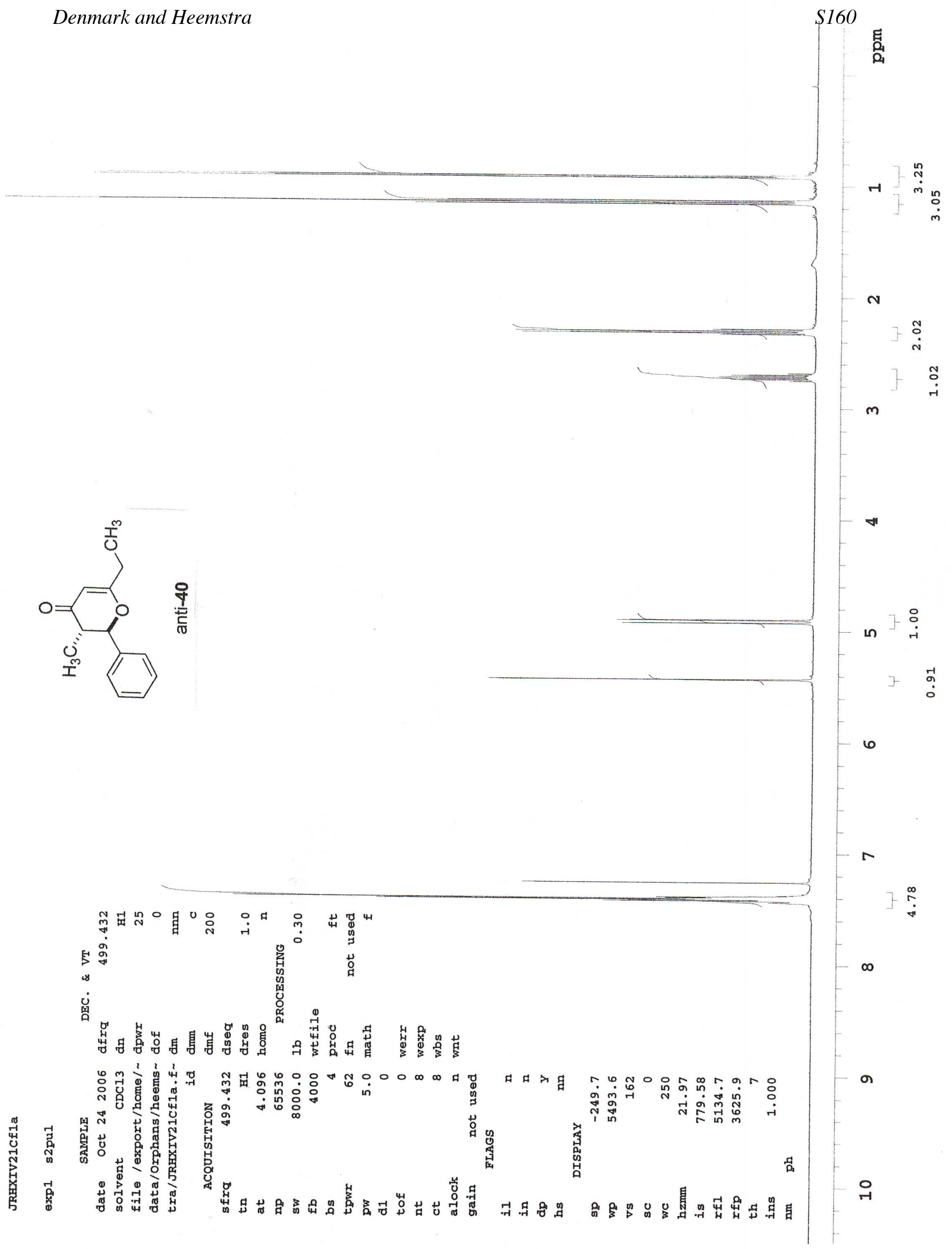




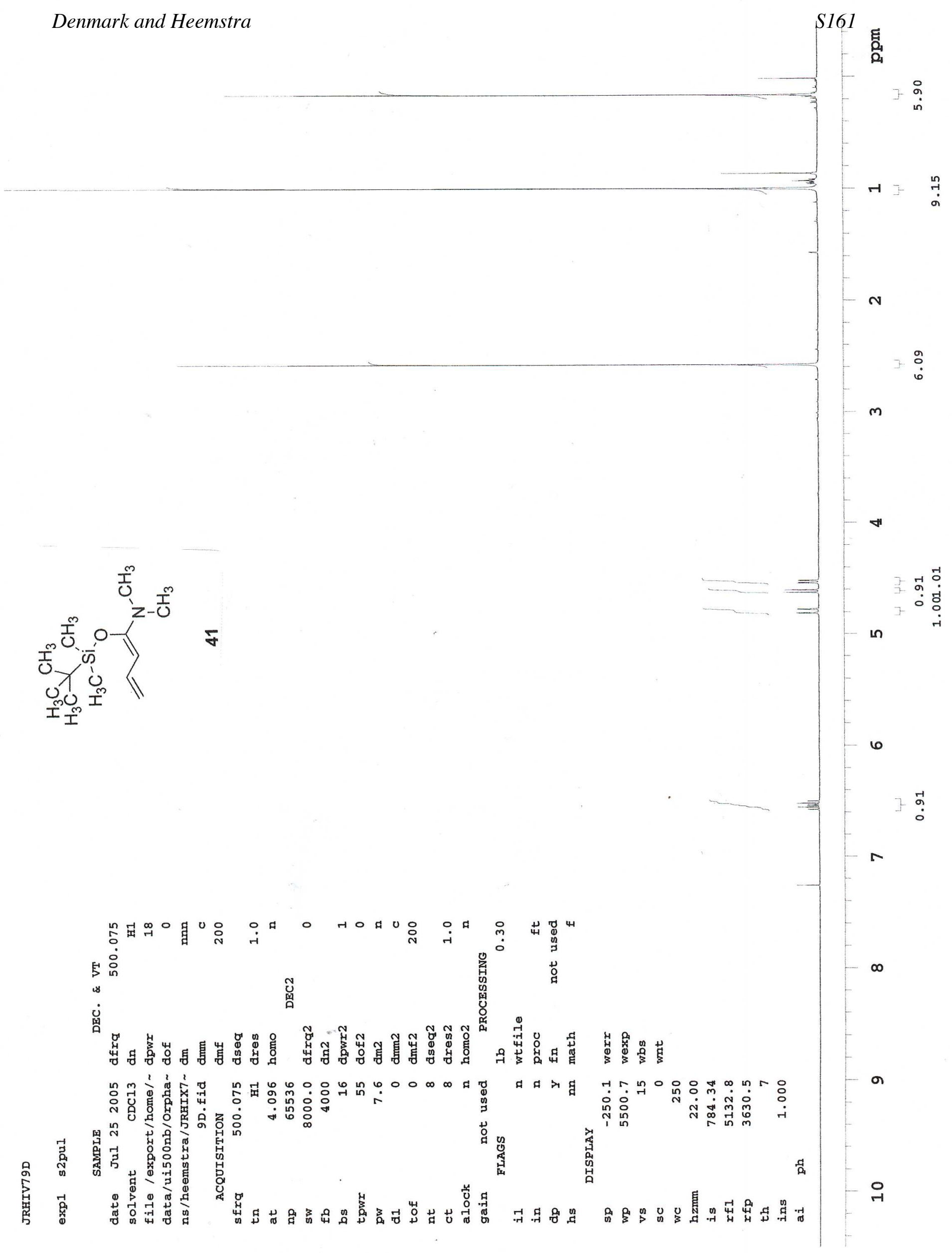




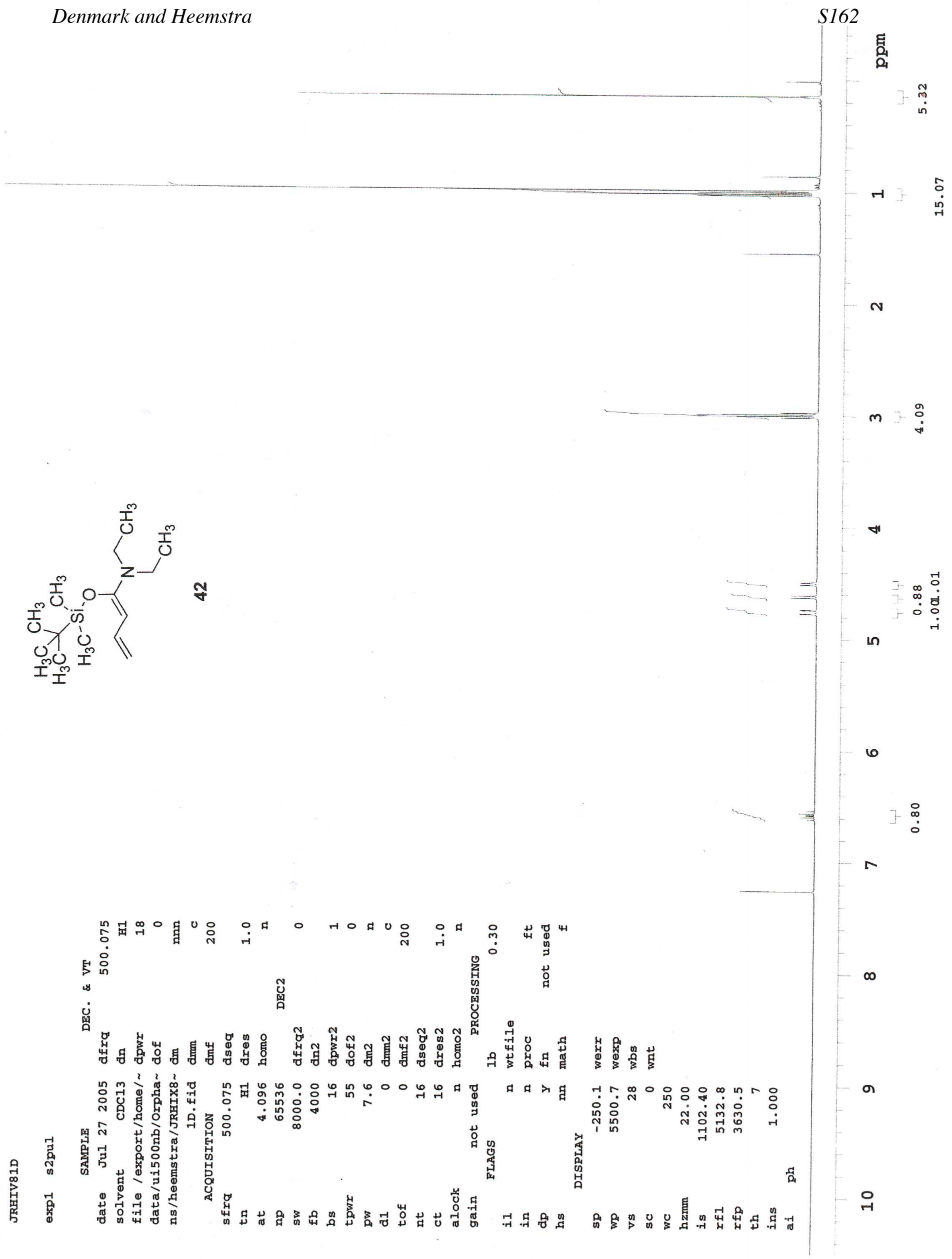


Denmark and Heemstra

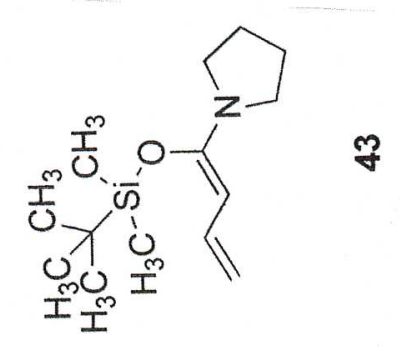

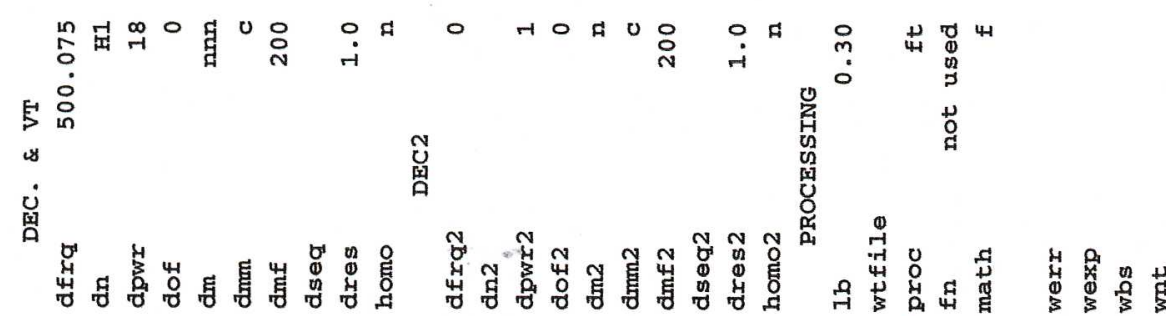

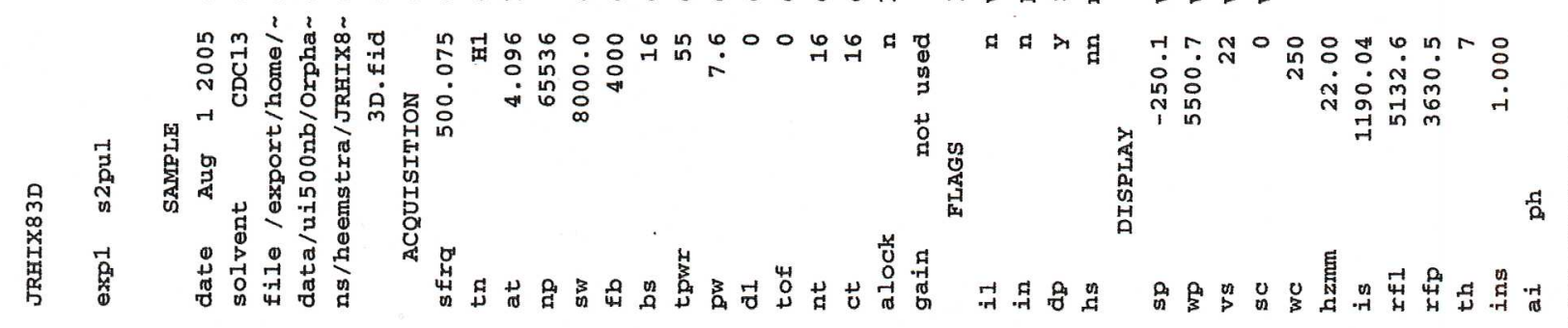


Denmark and Heemstra

疋

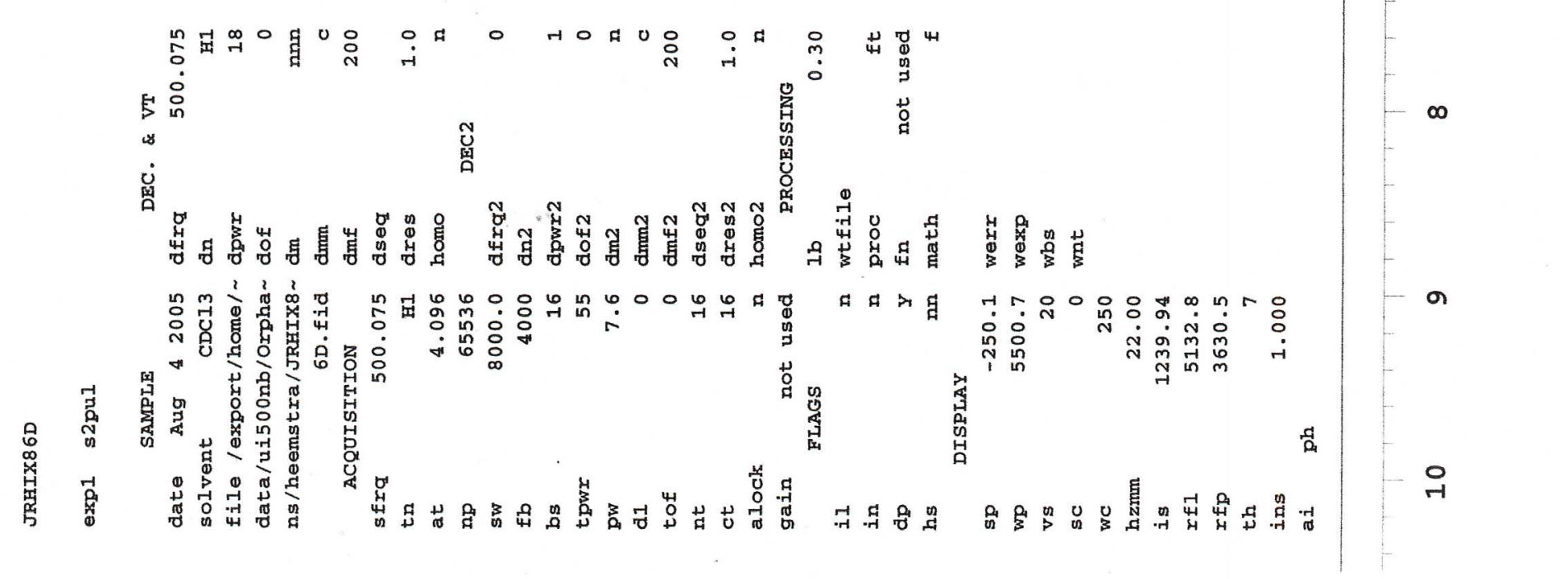




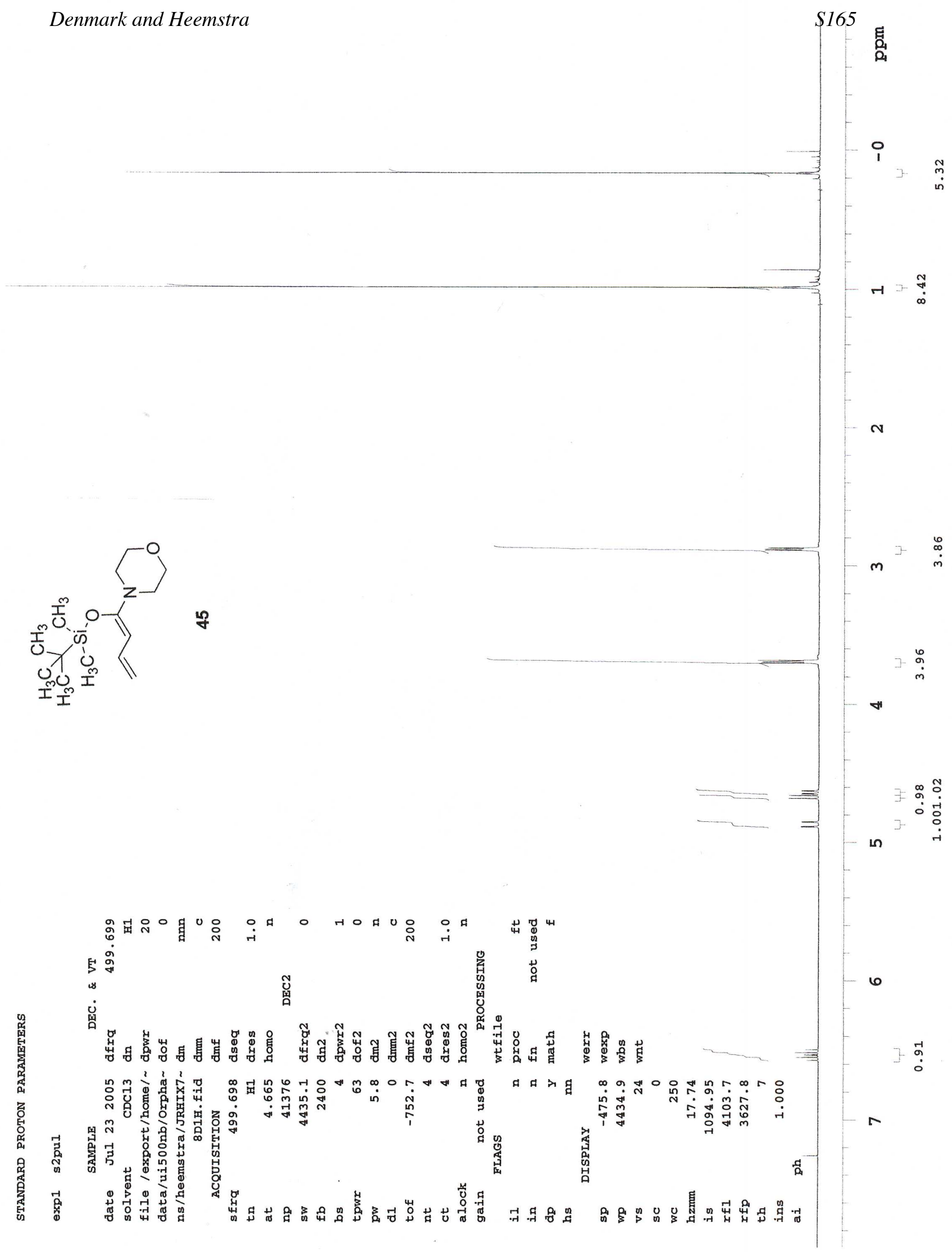


Denmark and Heemstra

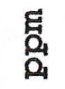

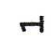

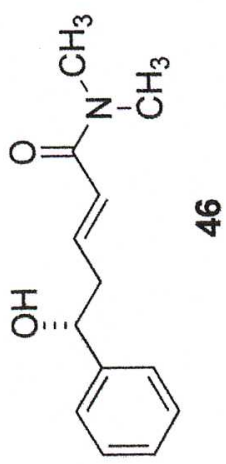

6

L $\begin{array}{ll}2 \\ 0\end{array}$

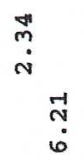
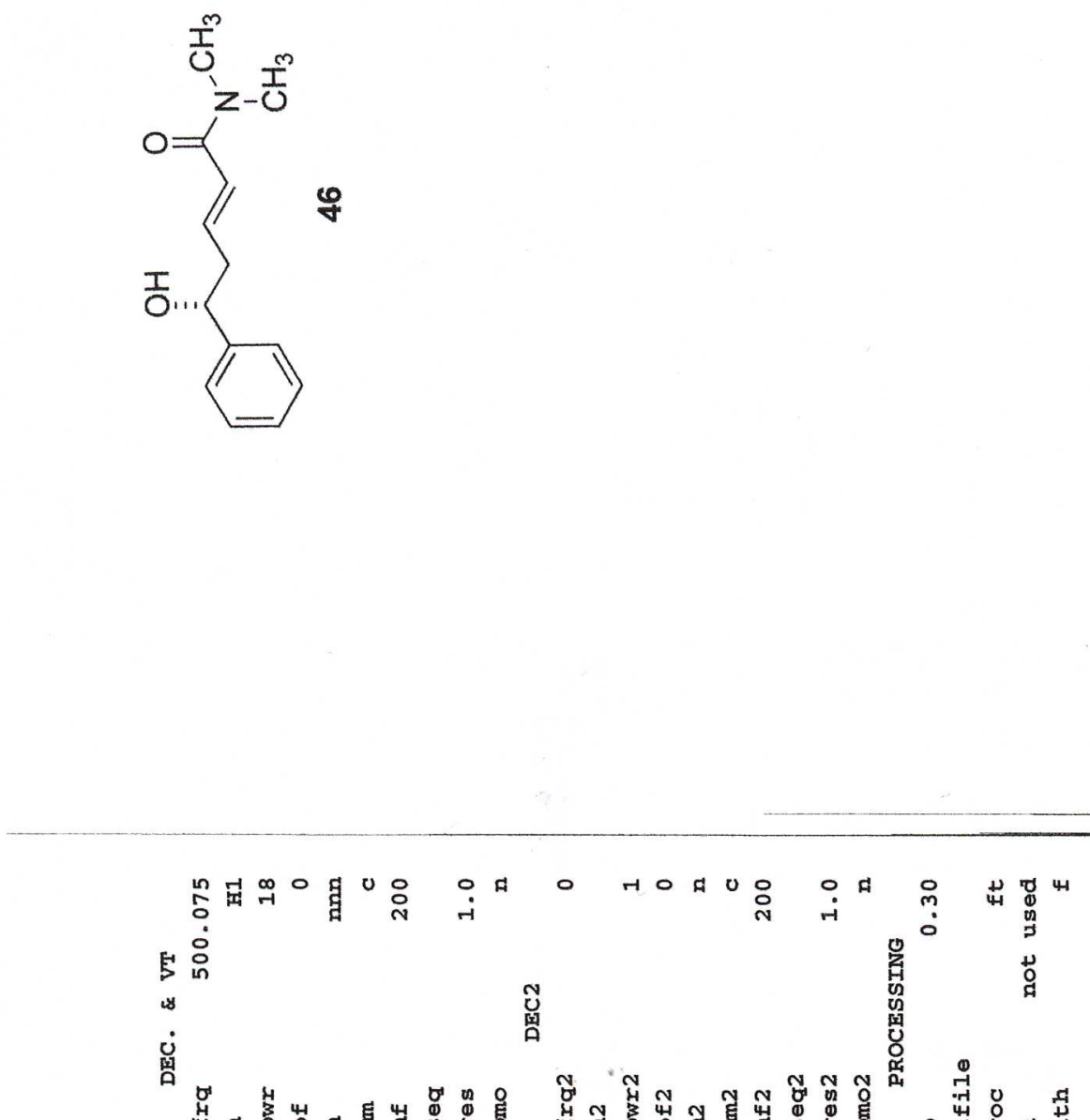

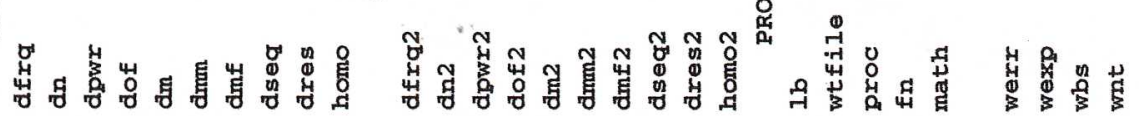

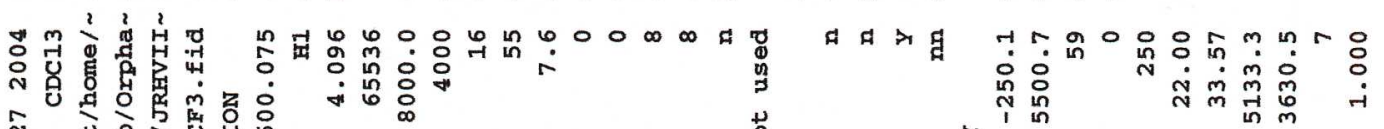




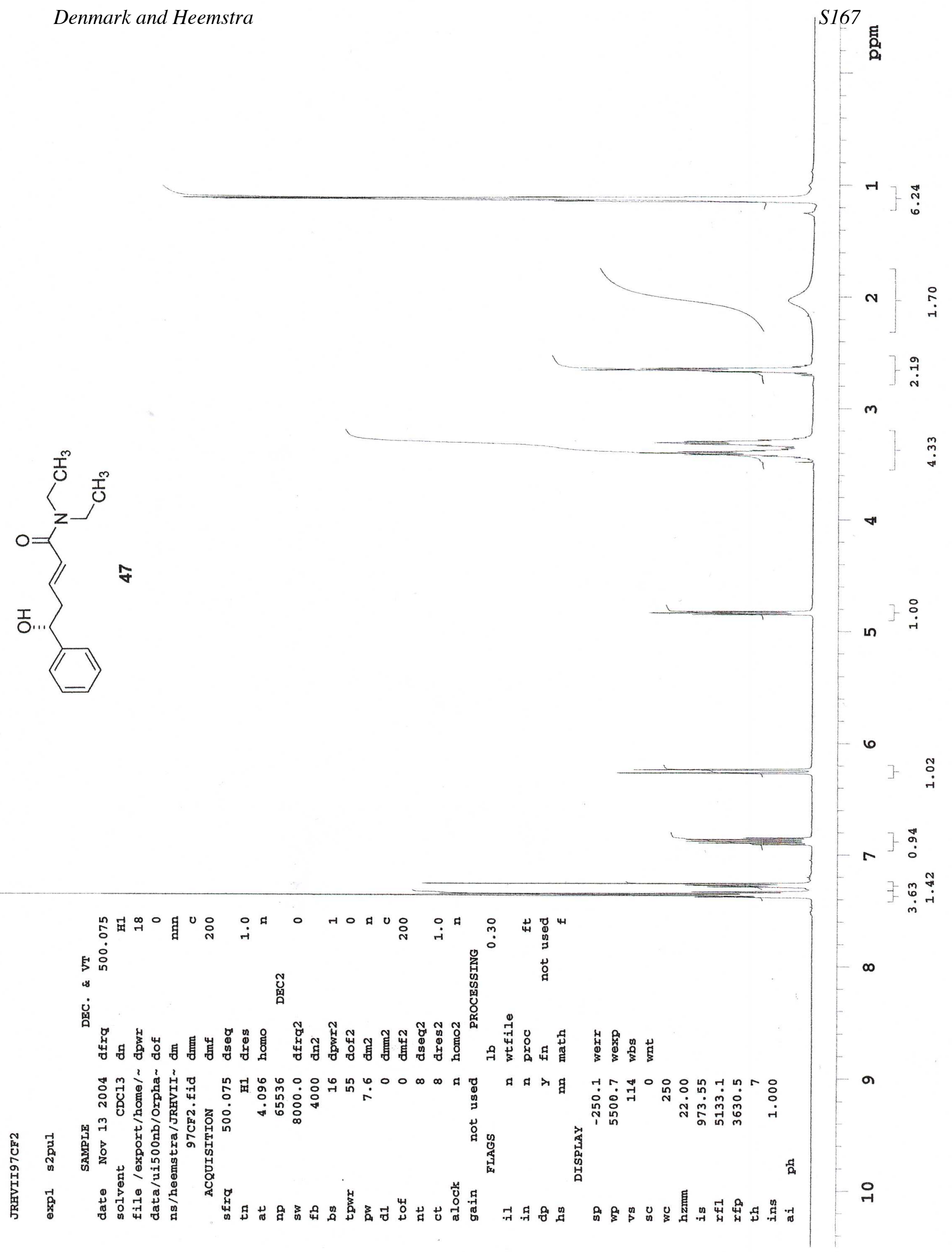


Denmark and Heemstra

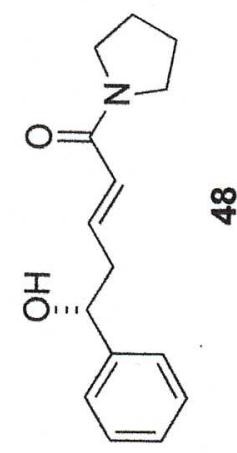

$\stackrel{\infty}{\forall}$

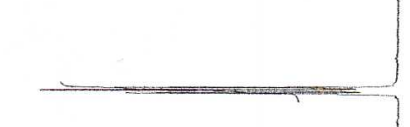

L $\begin{aligned} & \circ \\ & \therefore\end{aligned}$

6 $\stackrel{\mathbb{m}}{\stackrel{i}{i}}$

m

$r \quad \stackrel{m}{o}$ F.

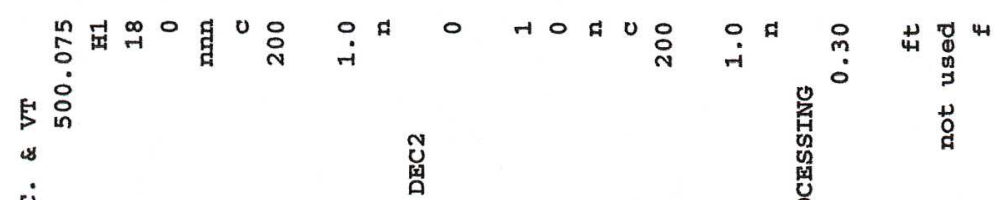

$\infty$

曾

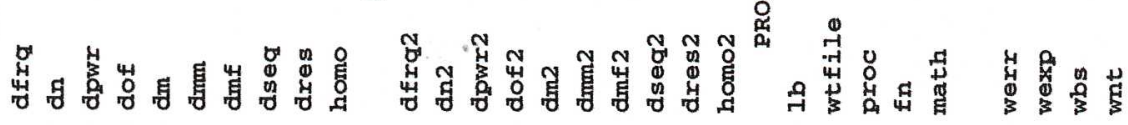

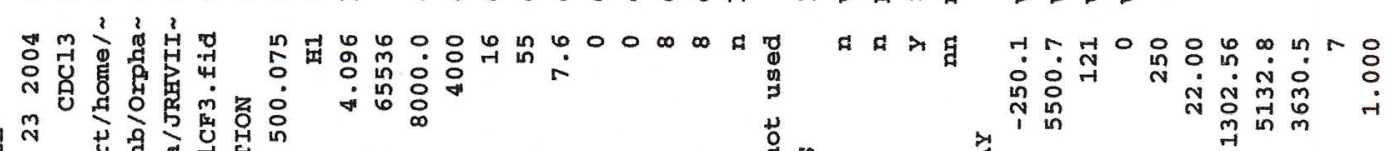

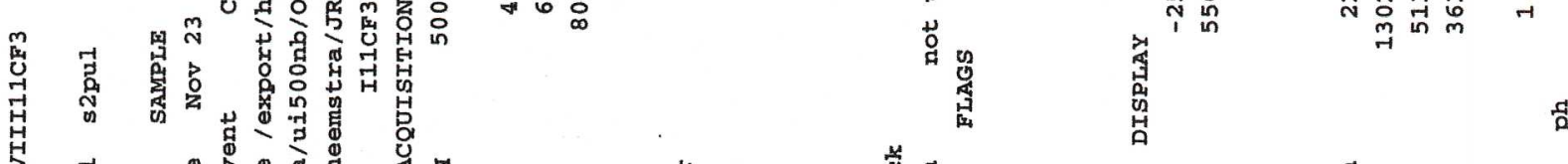

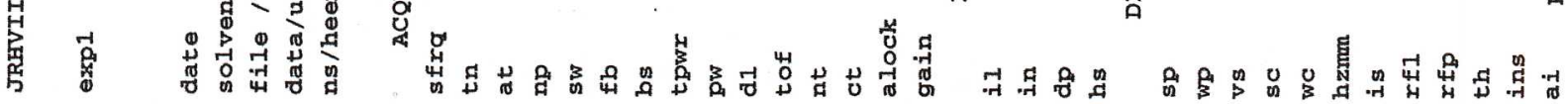


Denmark and Heemstra

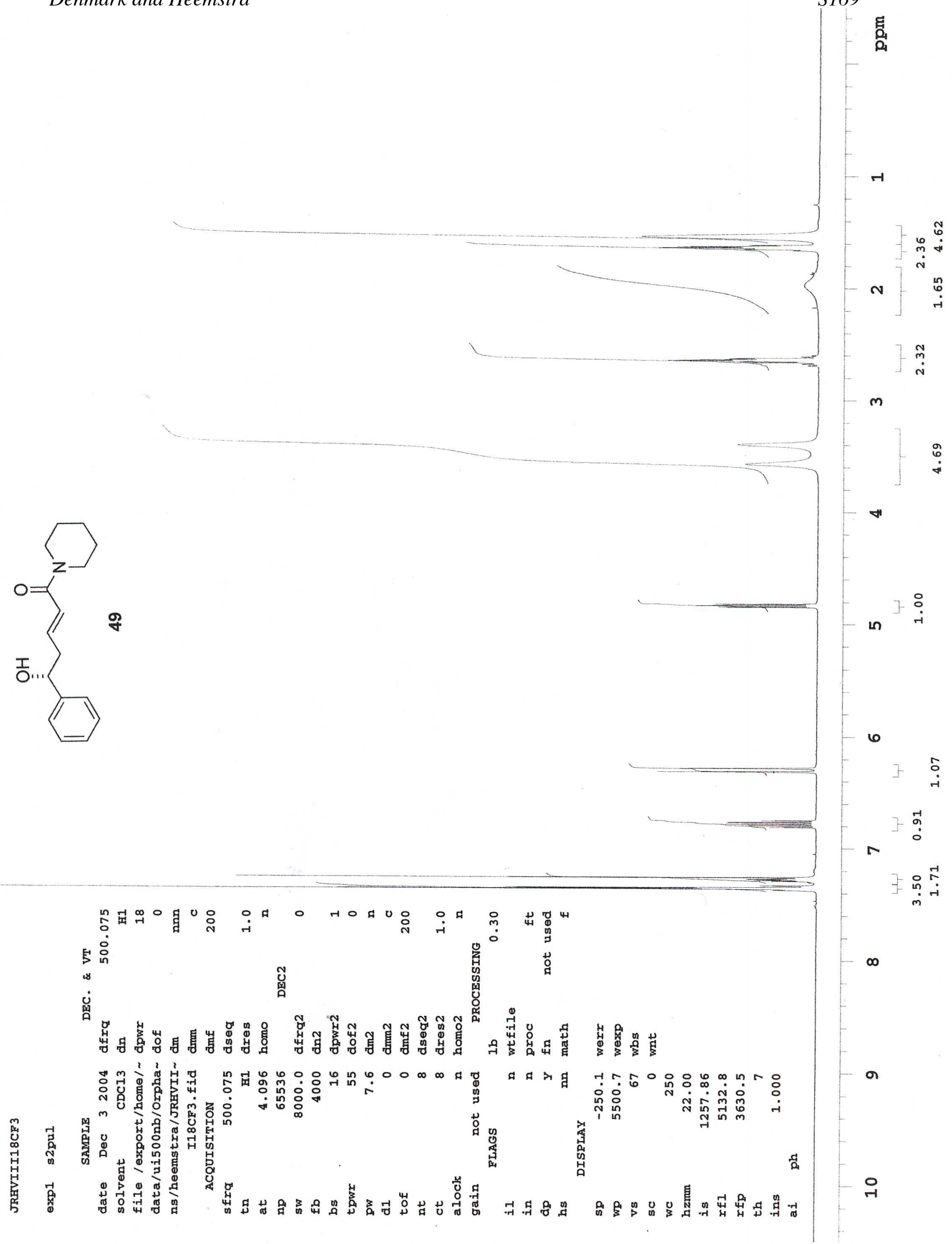




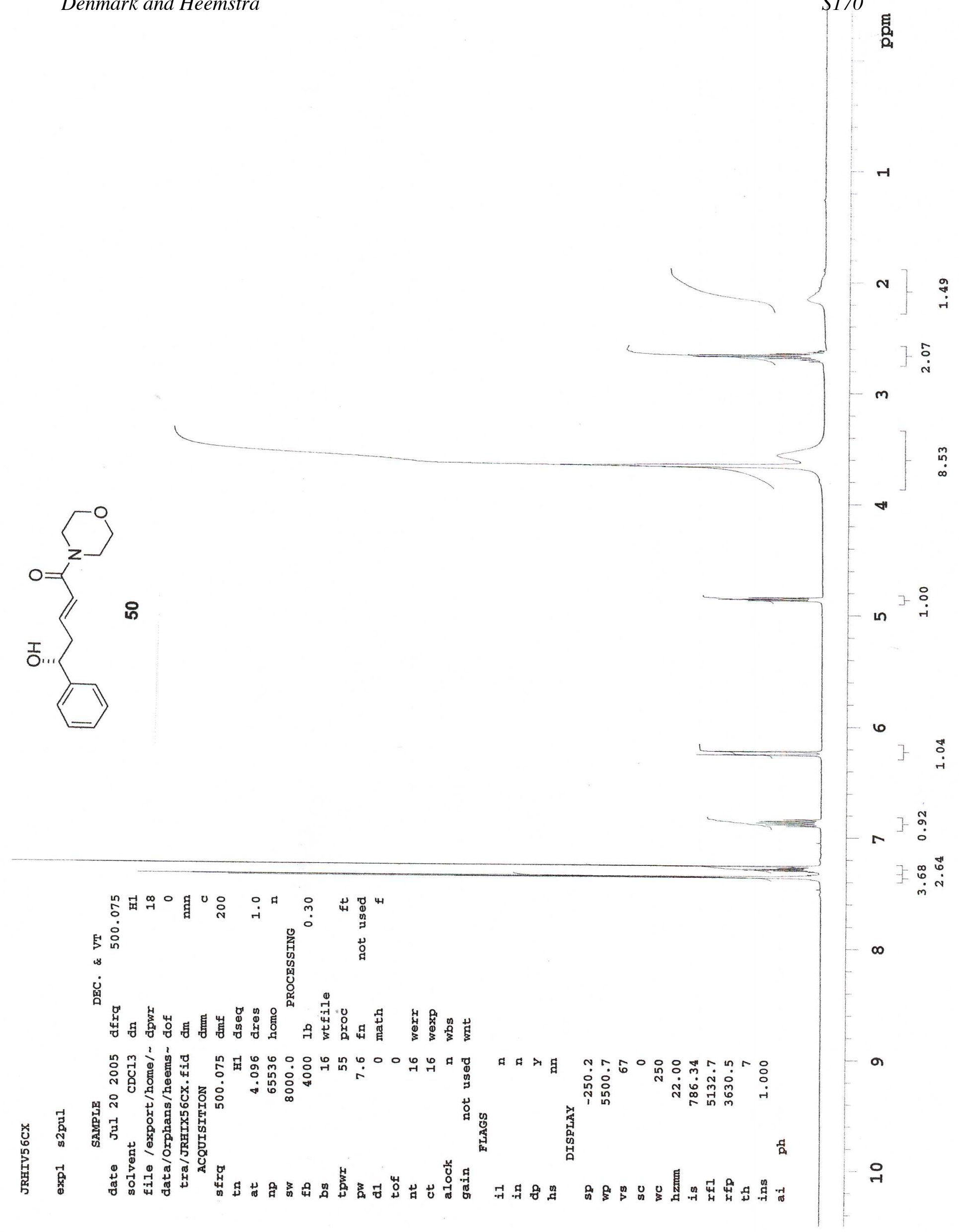


Denmark and Heemstra

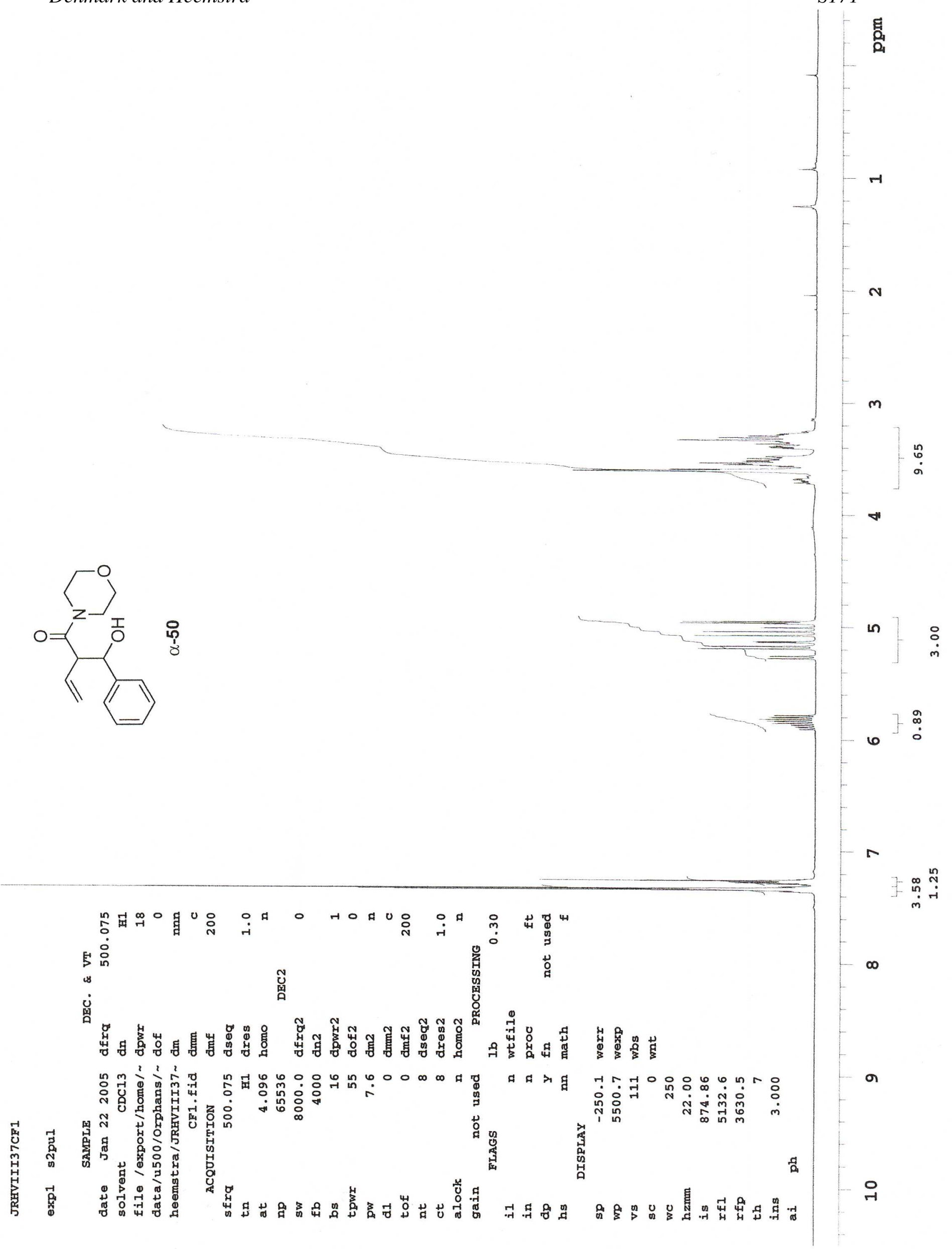


Denmark and Heemstra

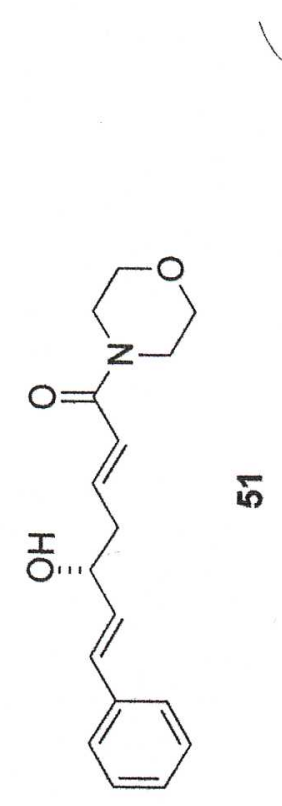

$S 172$

N

$J \dot{n}$

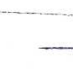

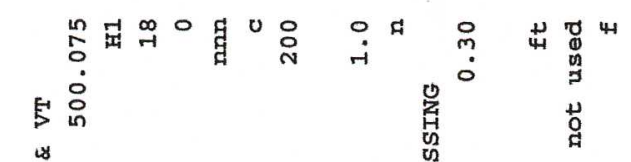

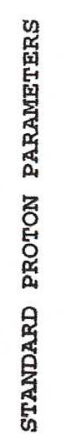

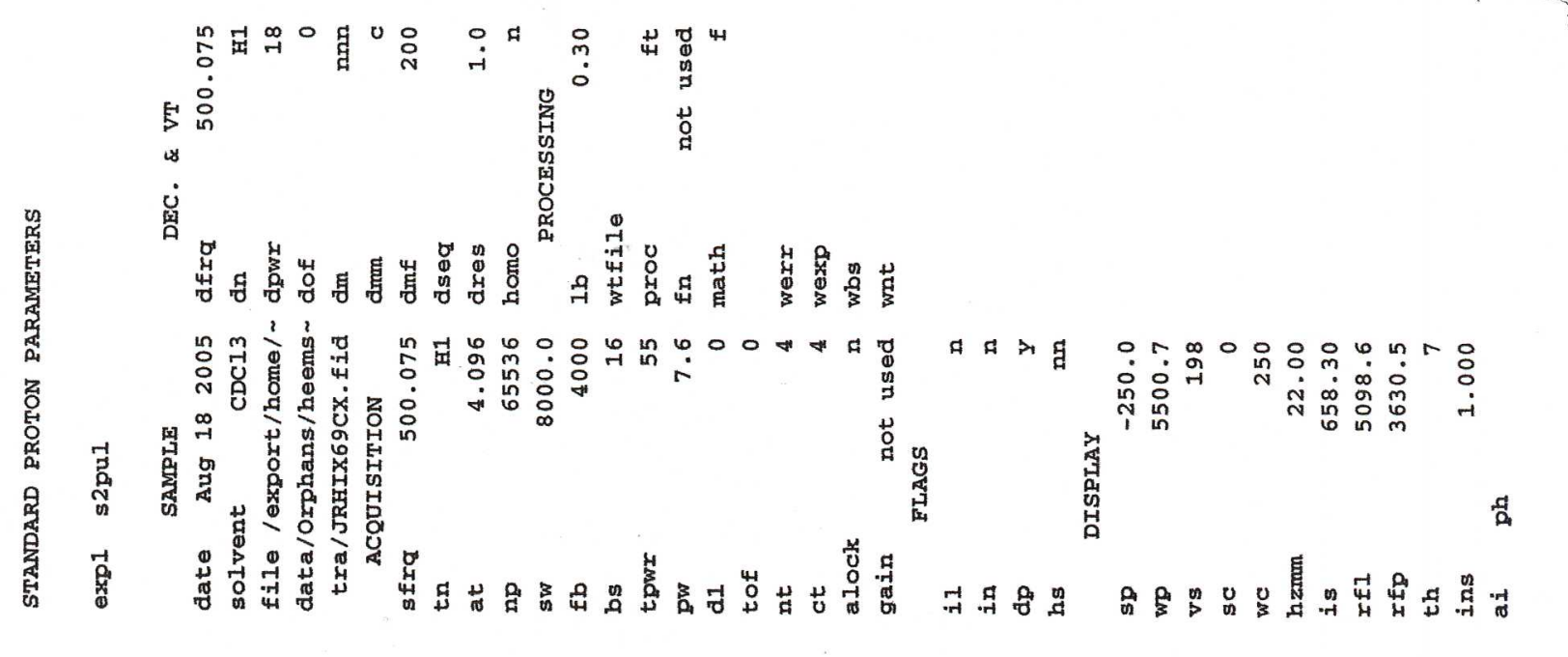

$m$

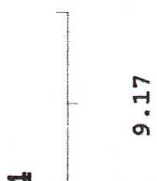

$7 \stackrel{0}{\circ}$

in

6

] $\begin{gathered}\text { क } \\ \text { के } \\ \text { \% } \\ 0 \\ 0\end{gathered}$

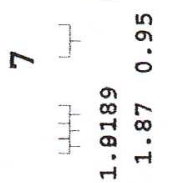

$\infty$

a

이 


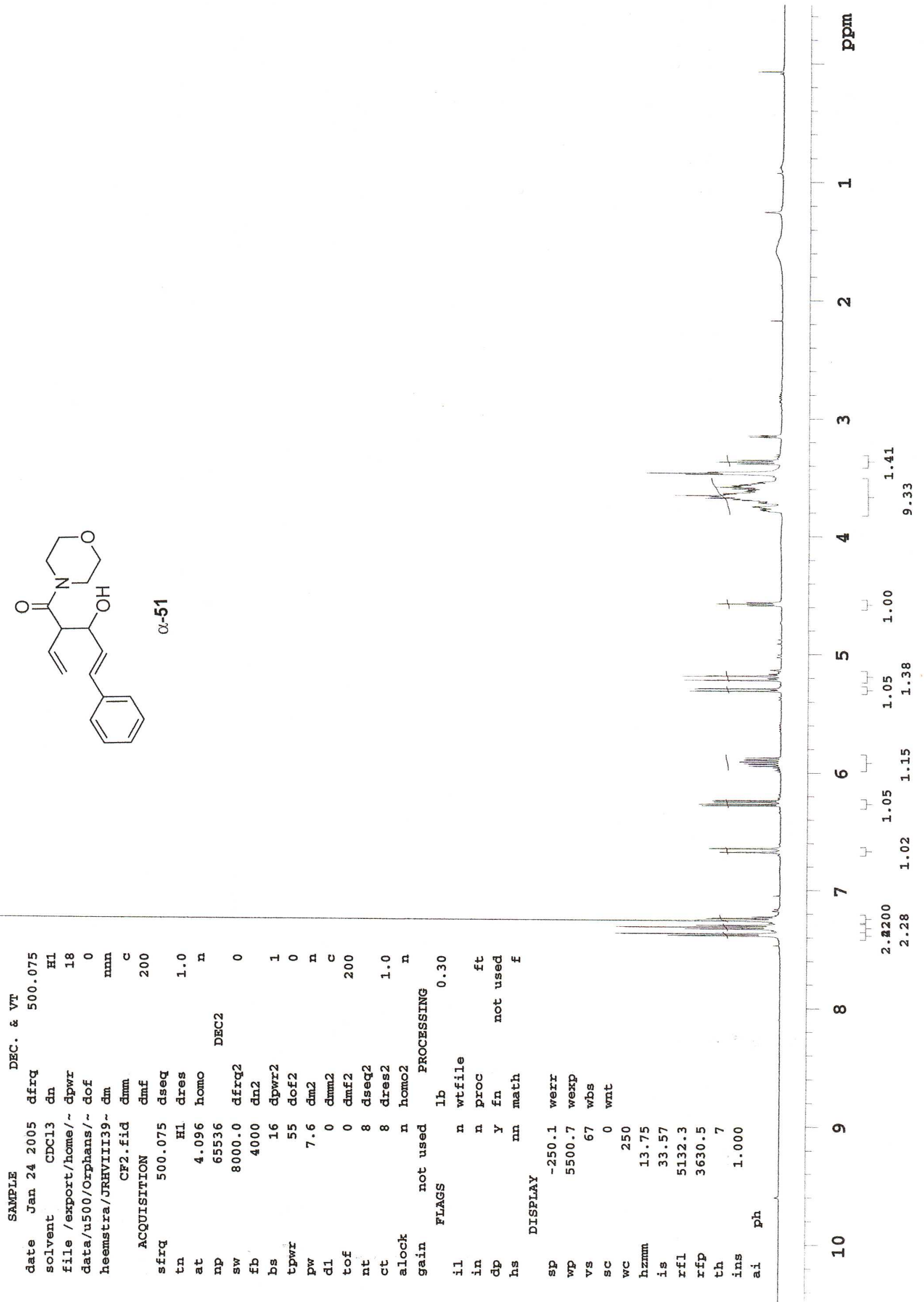



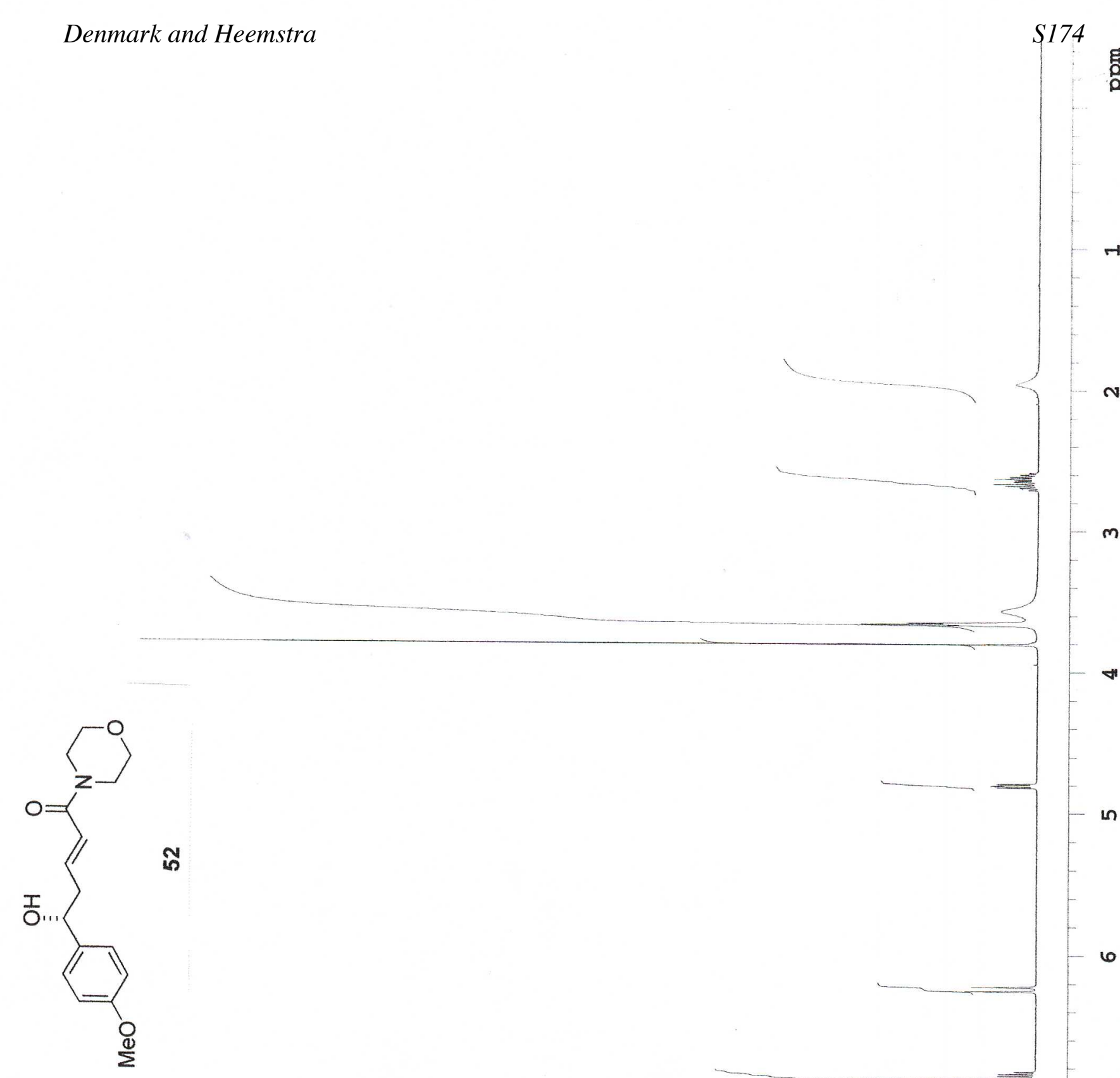

สู 

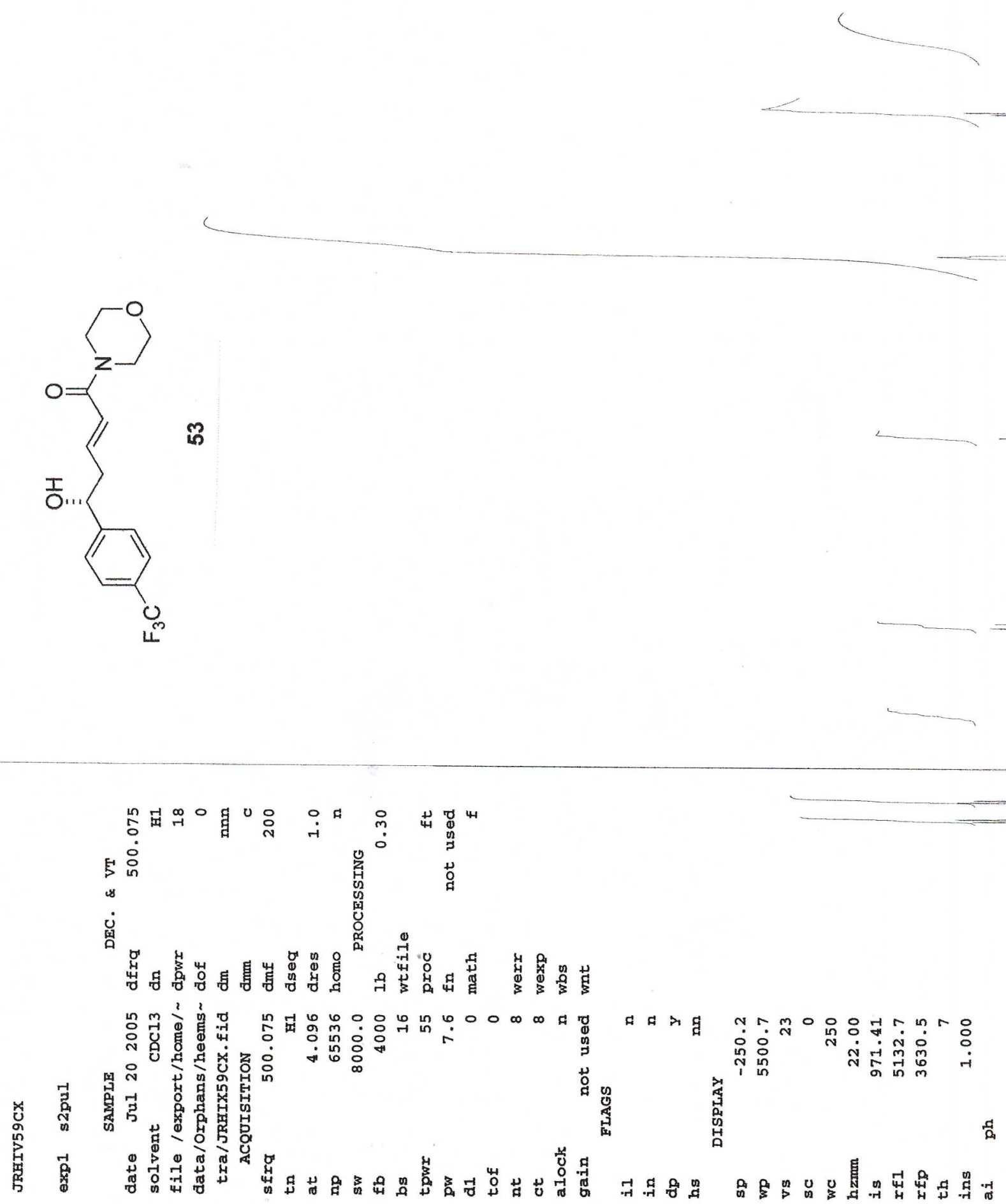

6

L) $1 \stackrel{0}{\circ}$ I $\quad \stackrel{0}{\dot{0}}$

N $1 \frac{\circ}{0}$

₹

$\infty$

$a$

욱 
Denmark and Heemstra
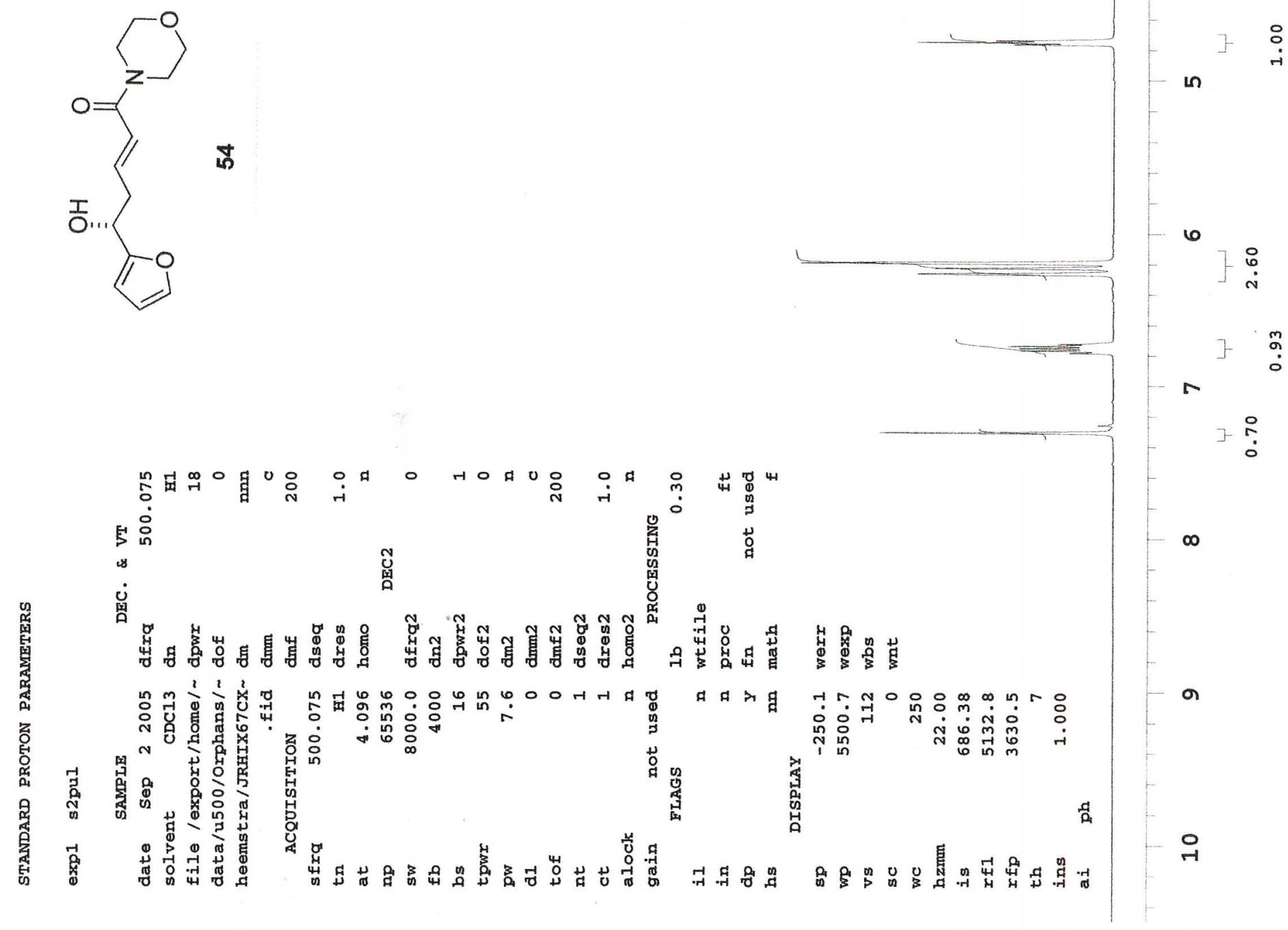


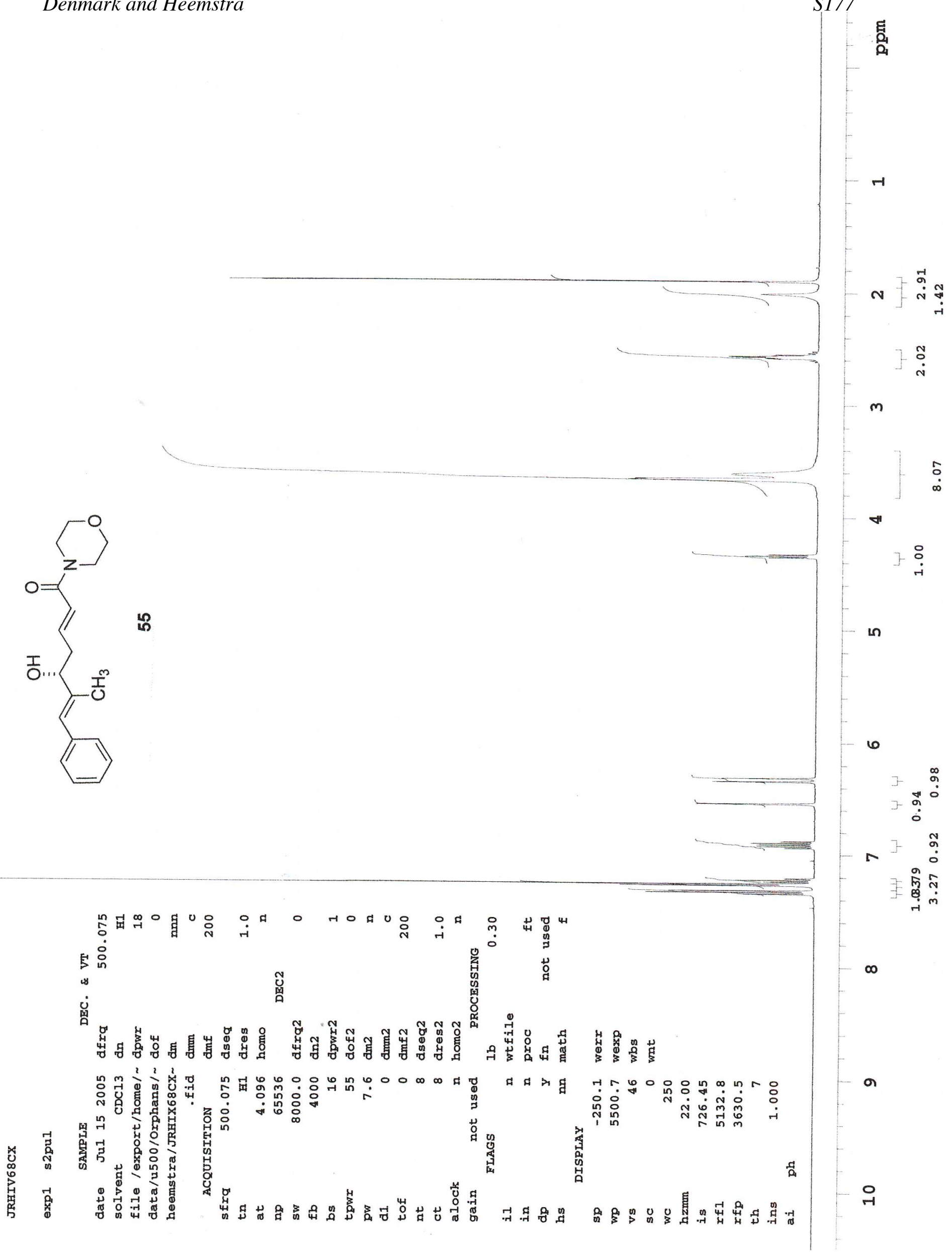


Denmark and Heemstra

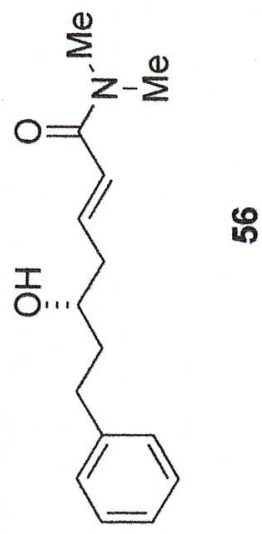


Denmark and Heemstra

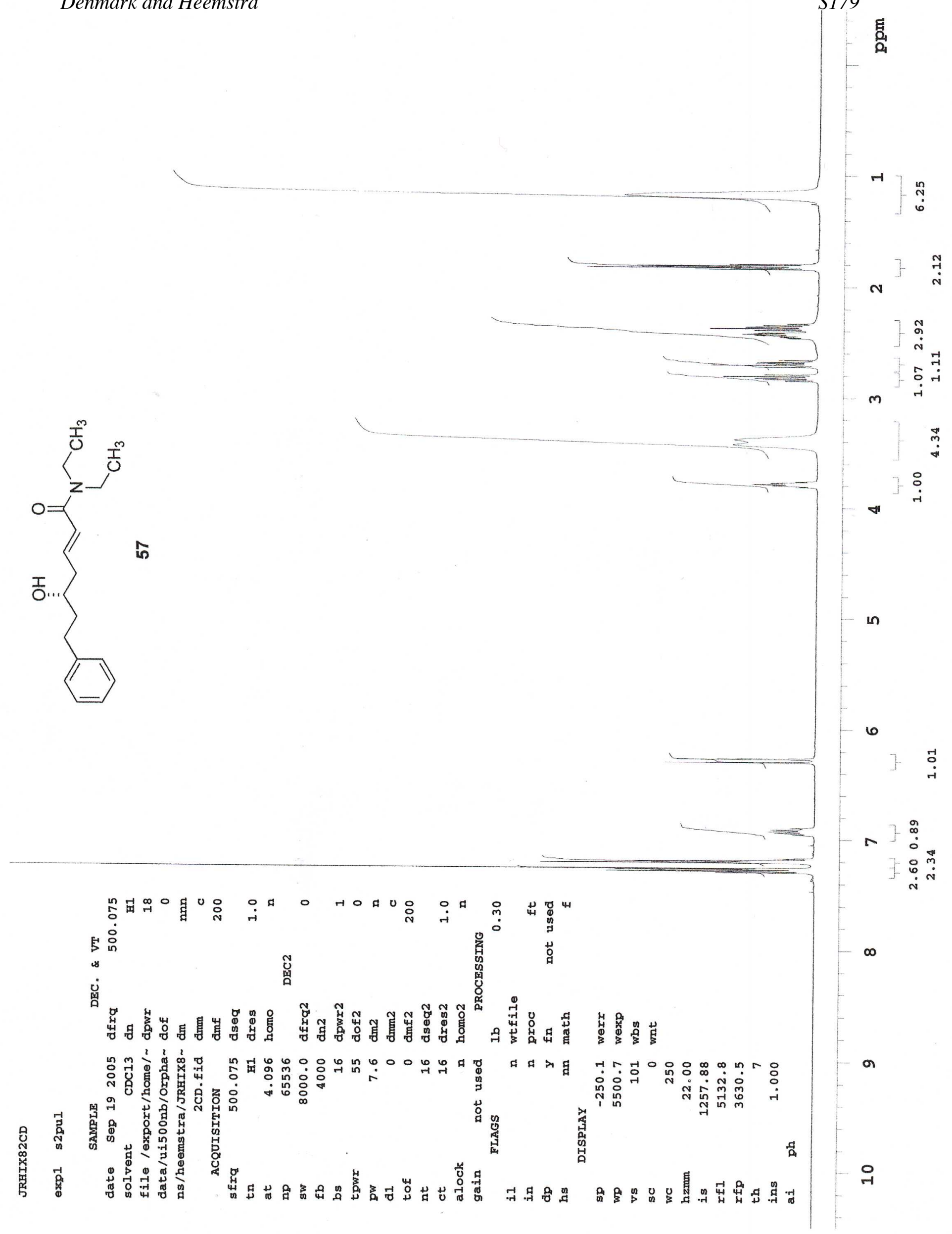


Denmark and Heemstra
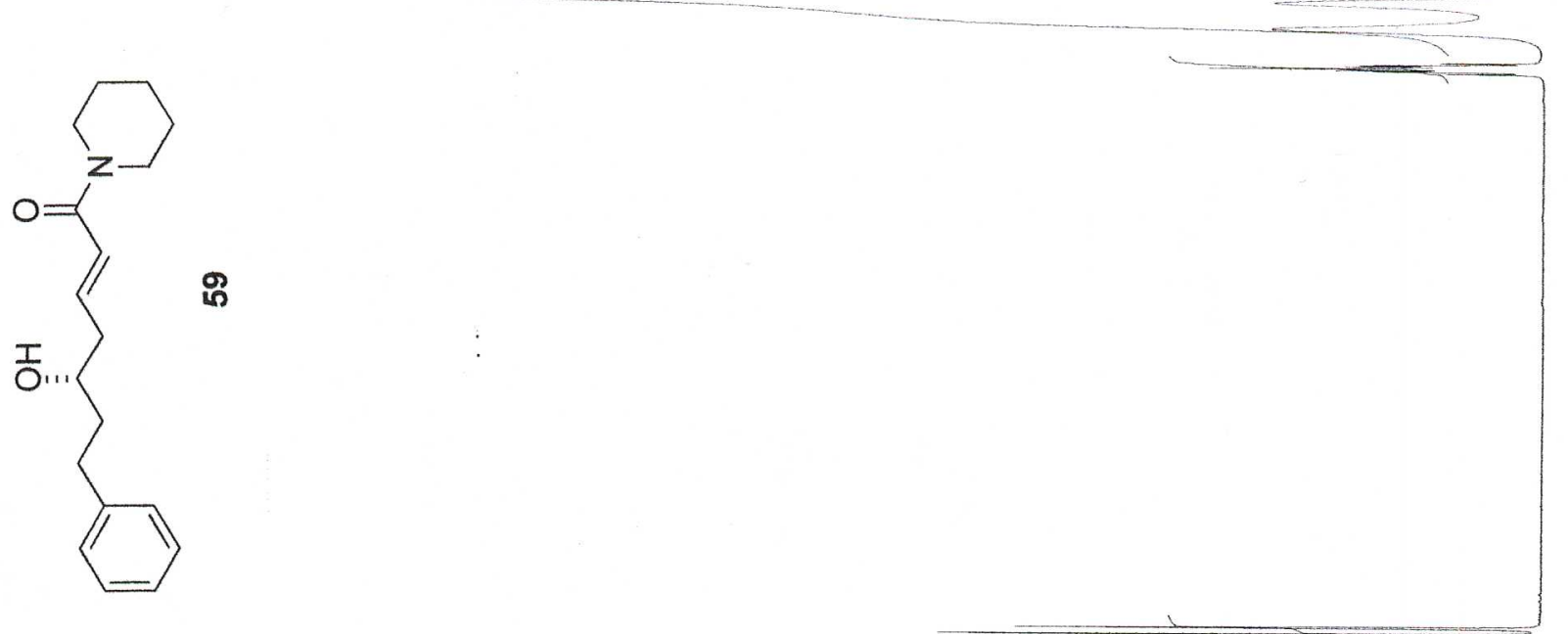

เก

0 茫

$m$

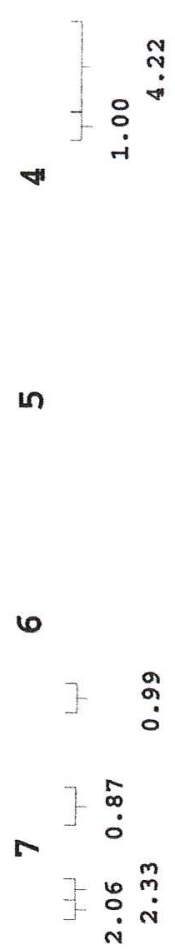

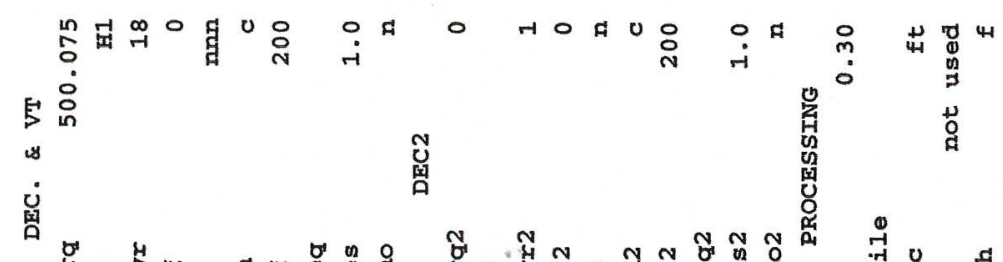

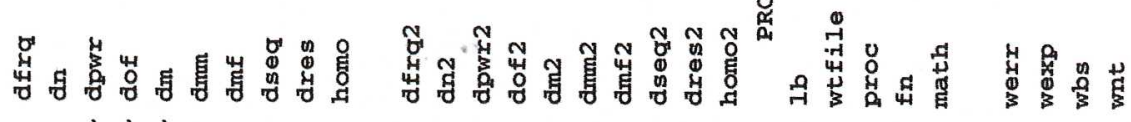

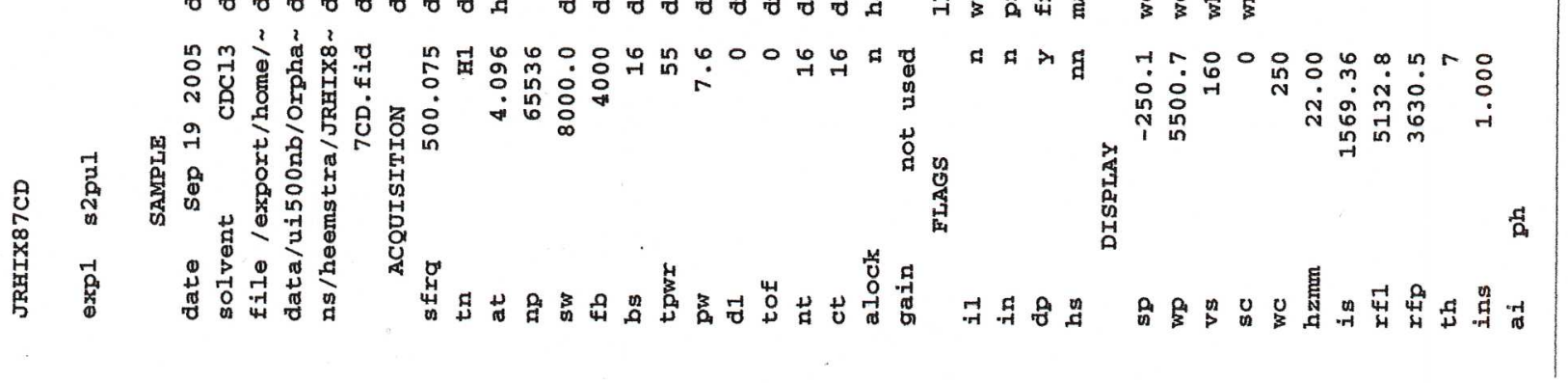


Denmark and Heemstra

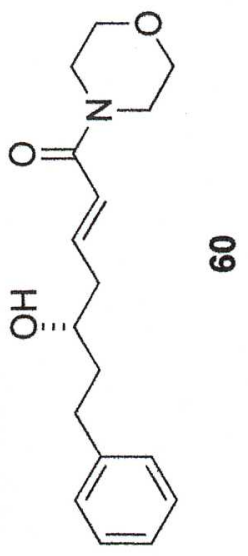

8

in

6 
Denmark and Heemstra

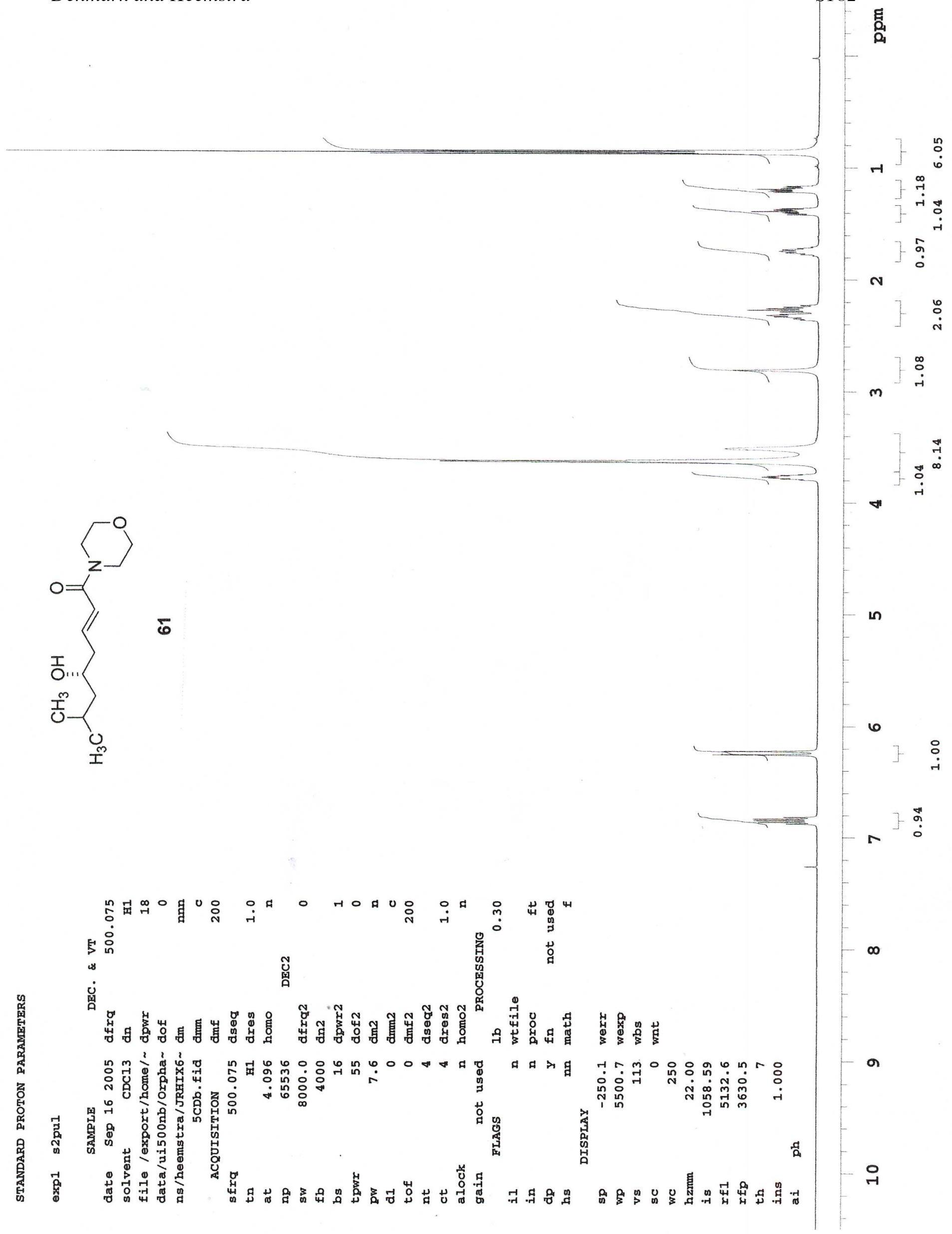




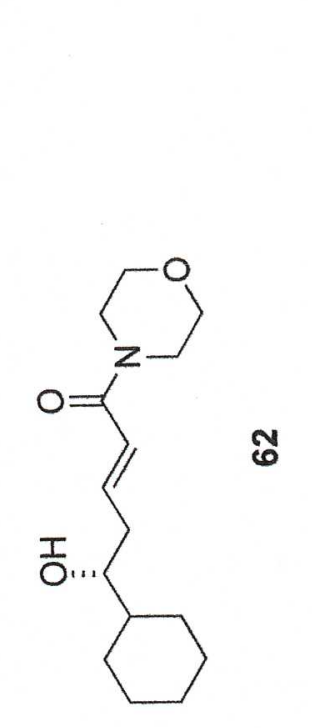

\section{ช}

Heemstra

$S 183$ 
Denmark and Heemstra

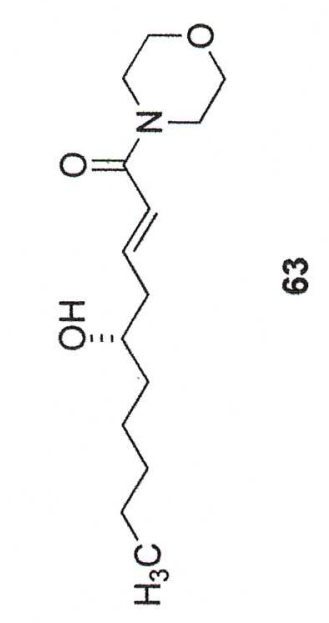

$a$

⿷匚
م,

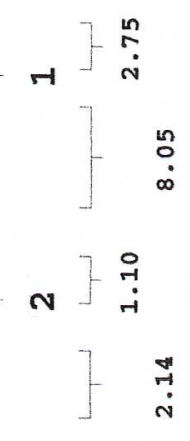

m

เก

6

$\stackrel{8}{\circ}$

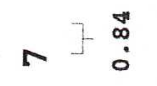

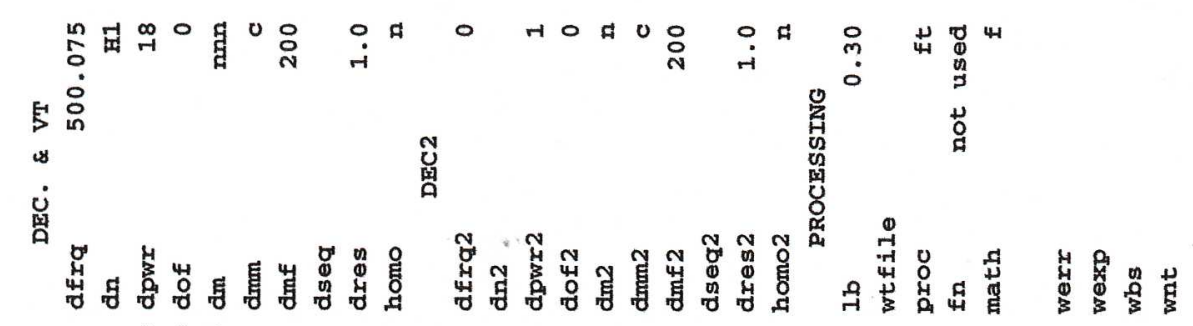

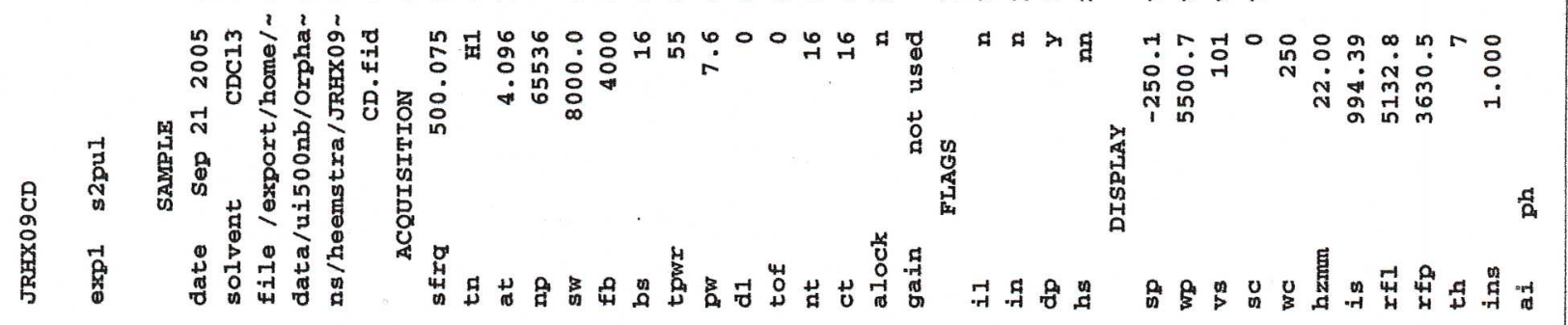



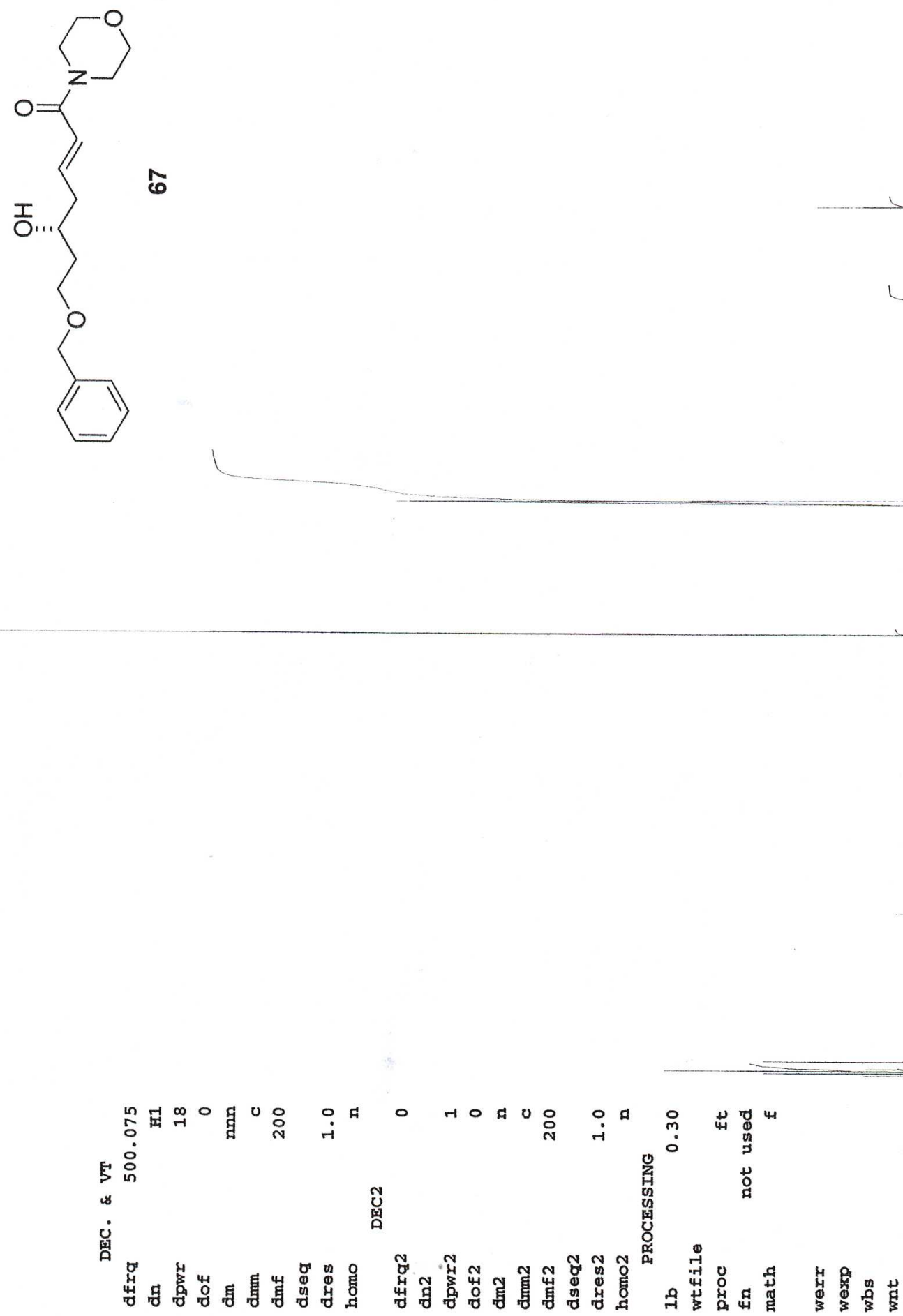

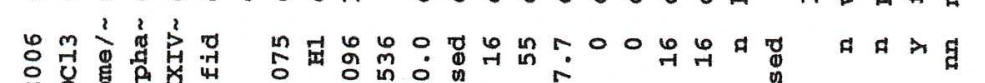

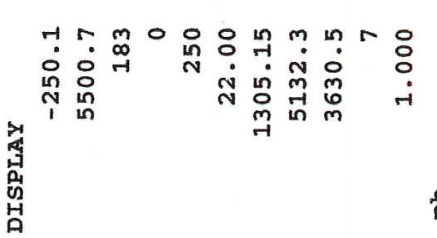

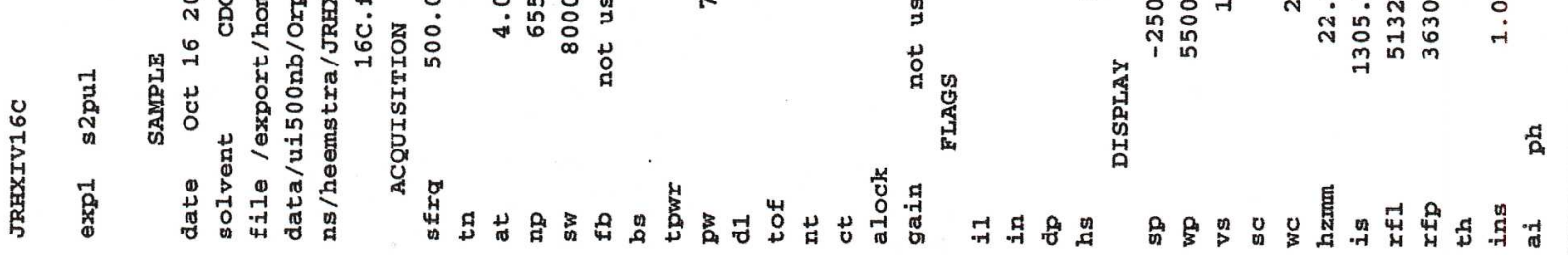


Denmark and Heemstra

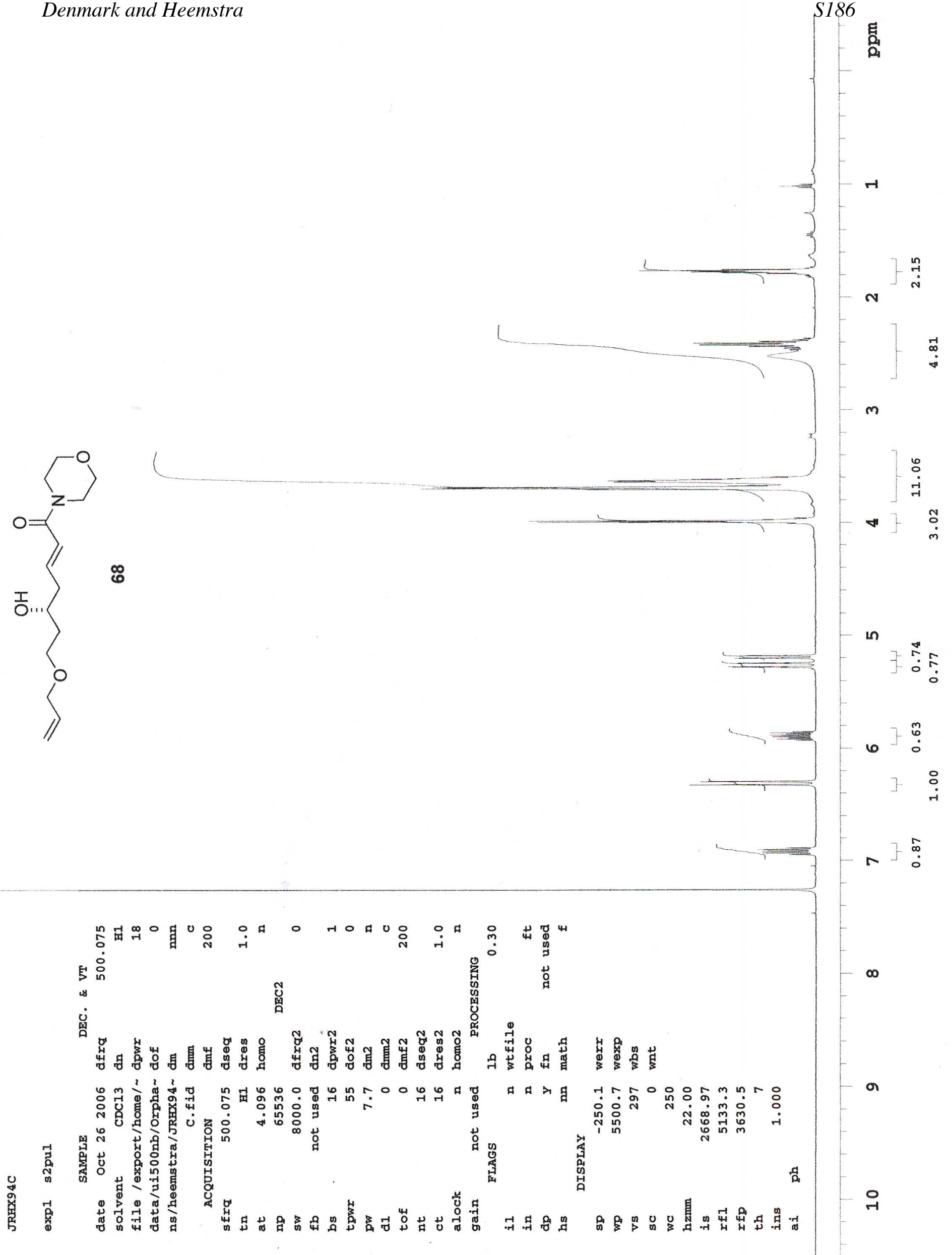




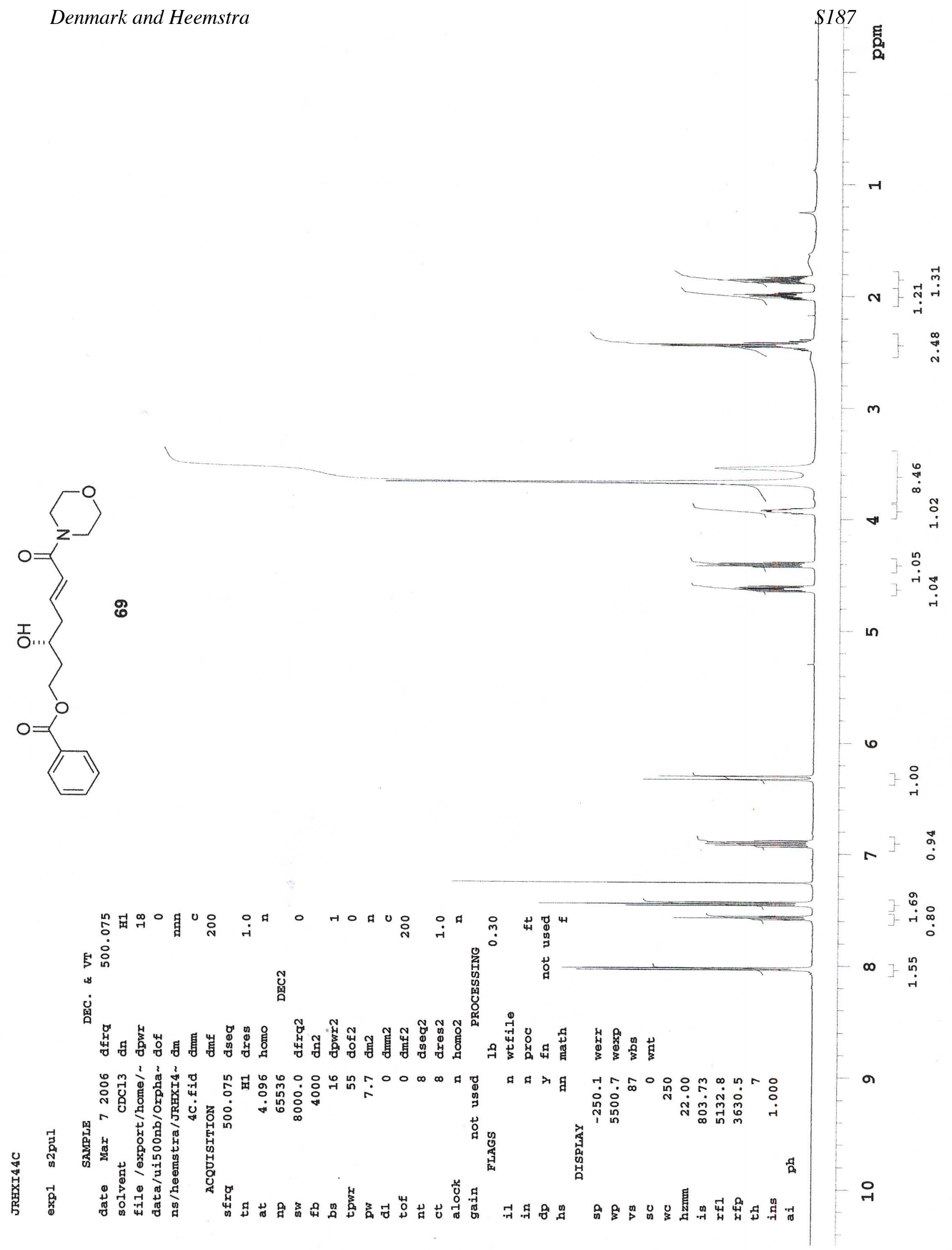


Denmark and Heemstra

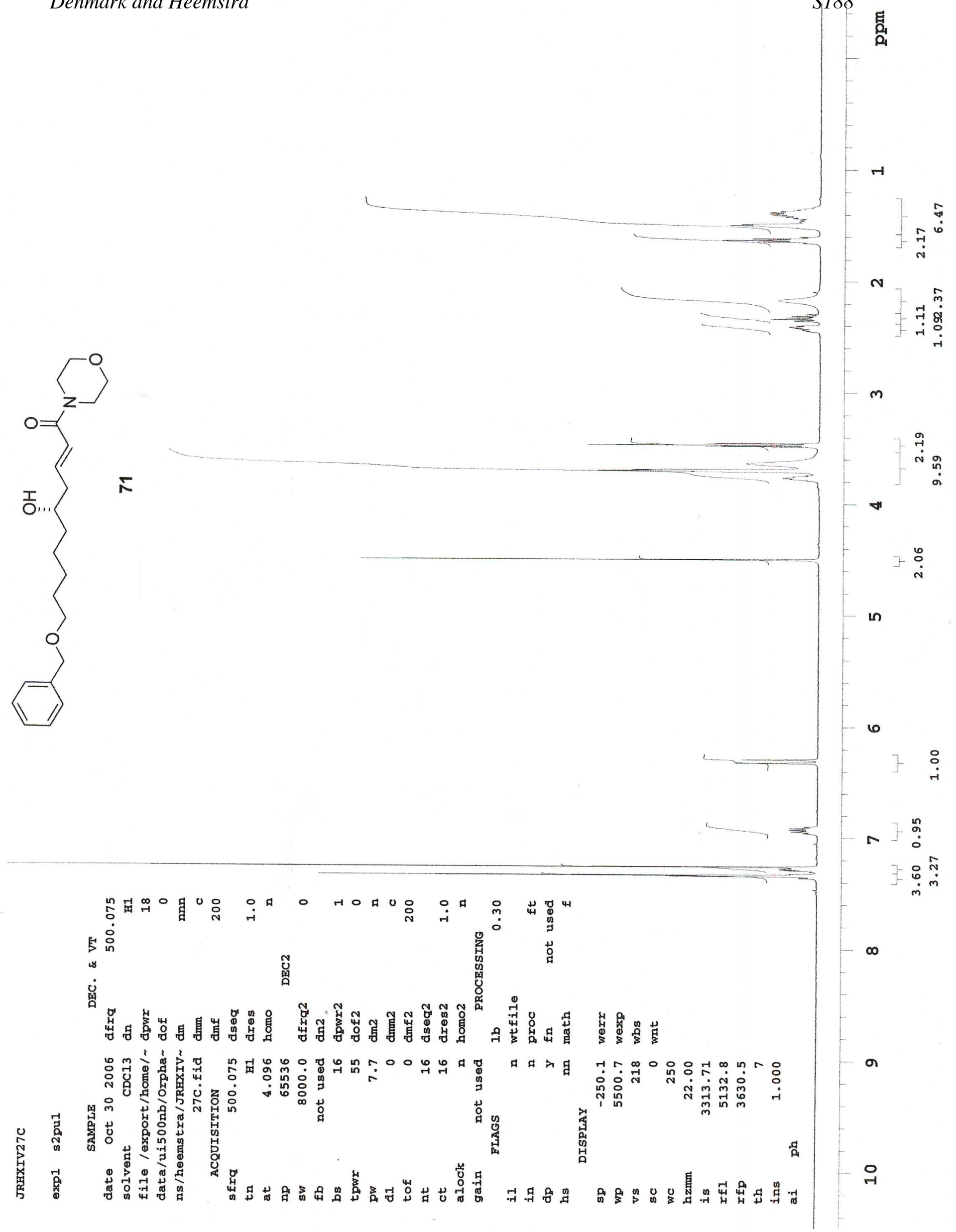

$S 188$ 


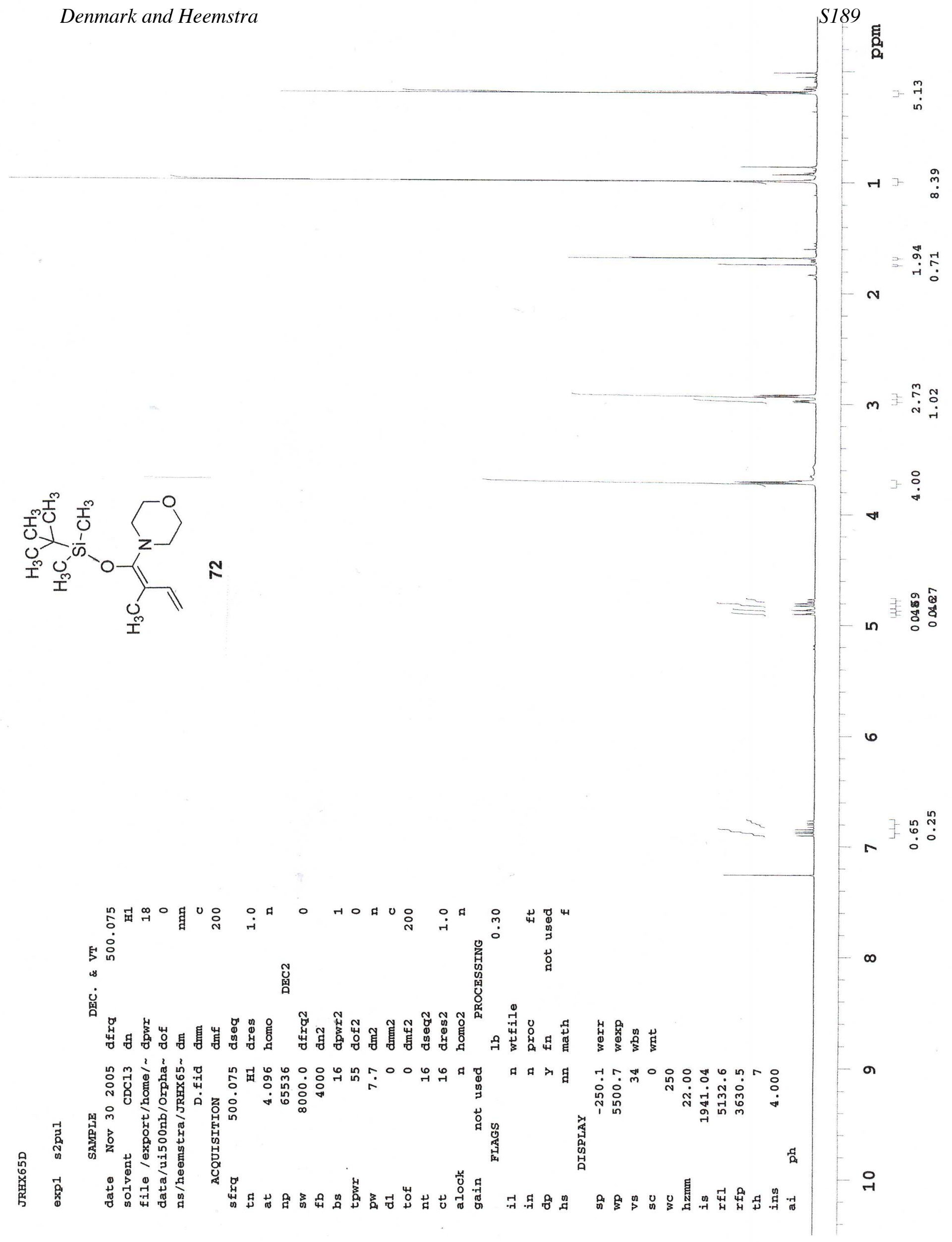


Denmark and Heemstra

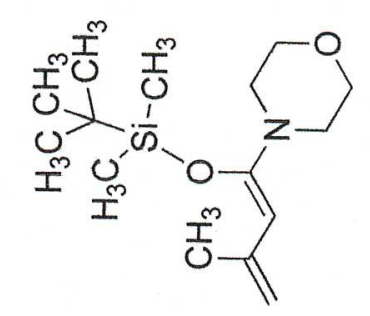

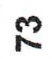

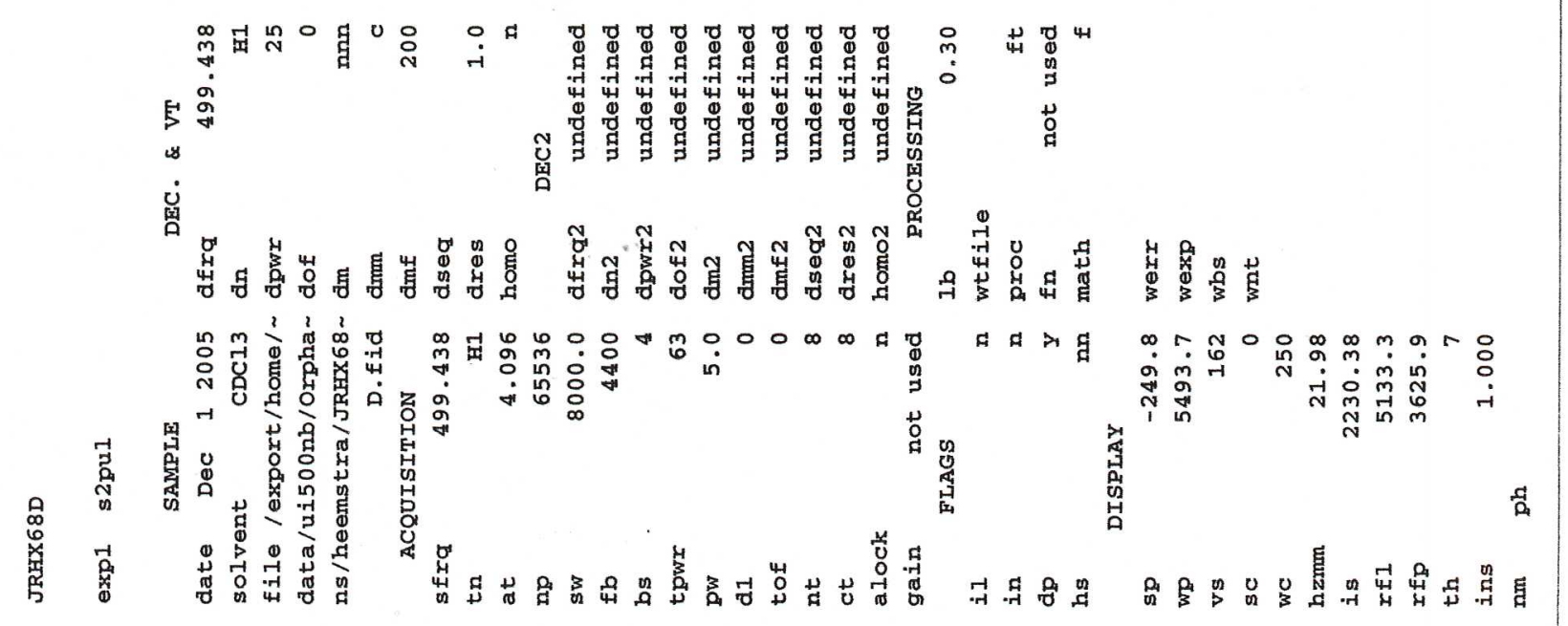

-

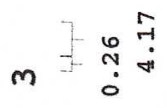

6

r

$\infty$

$a$

욱 


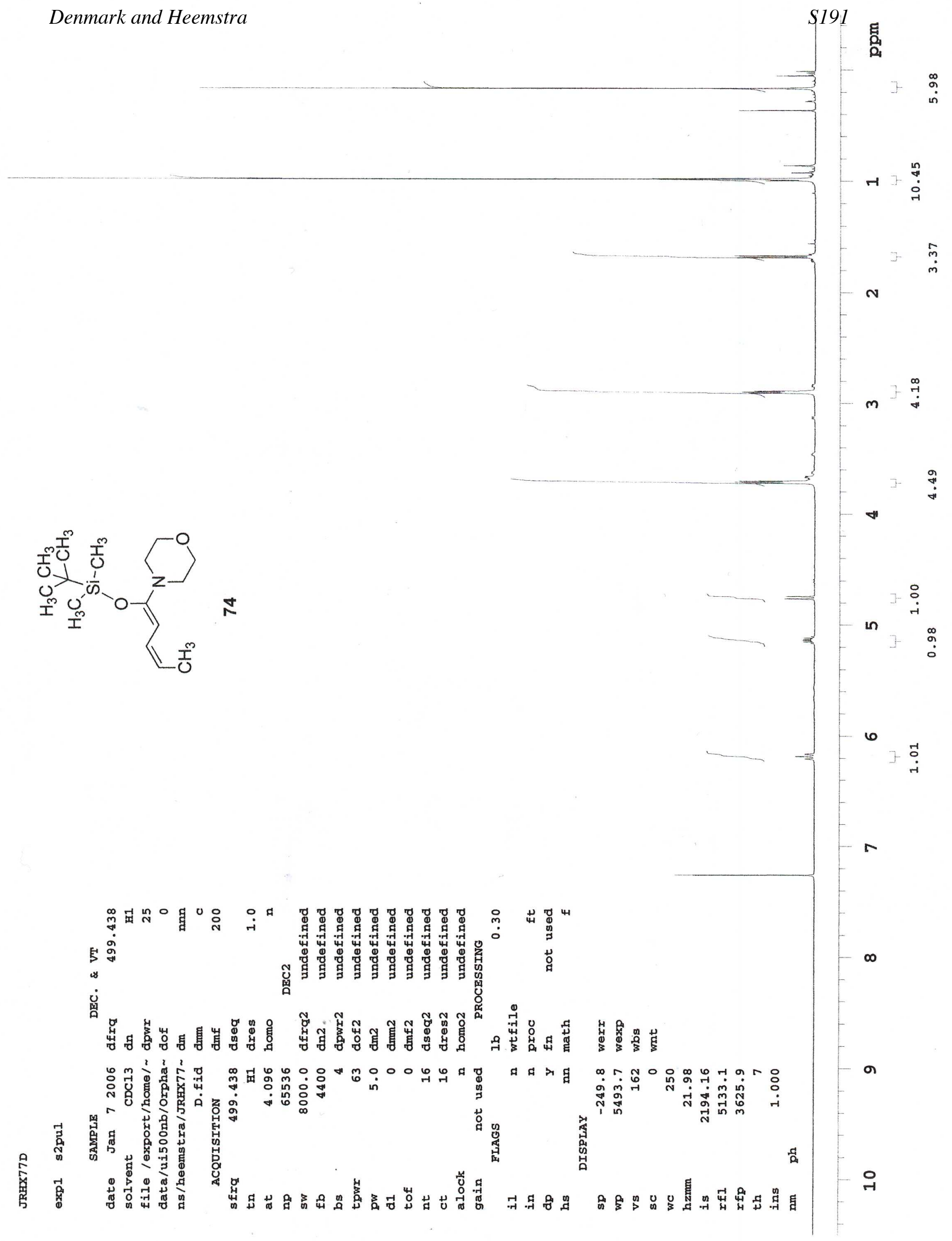




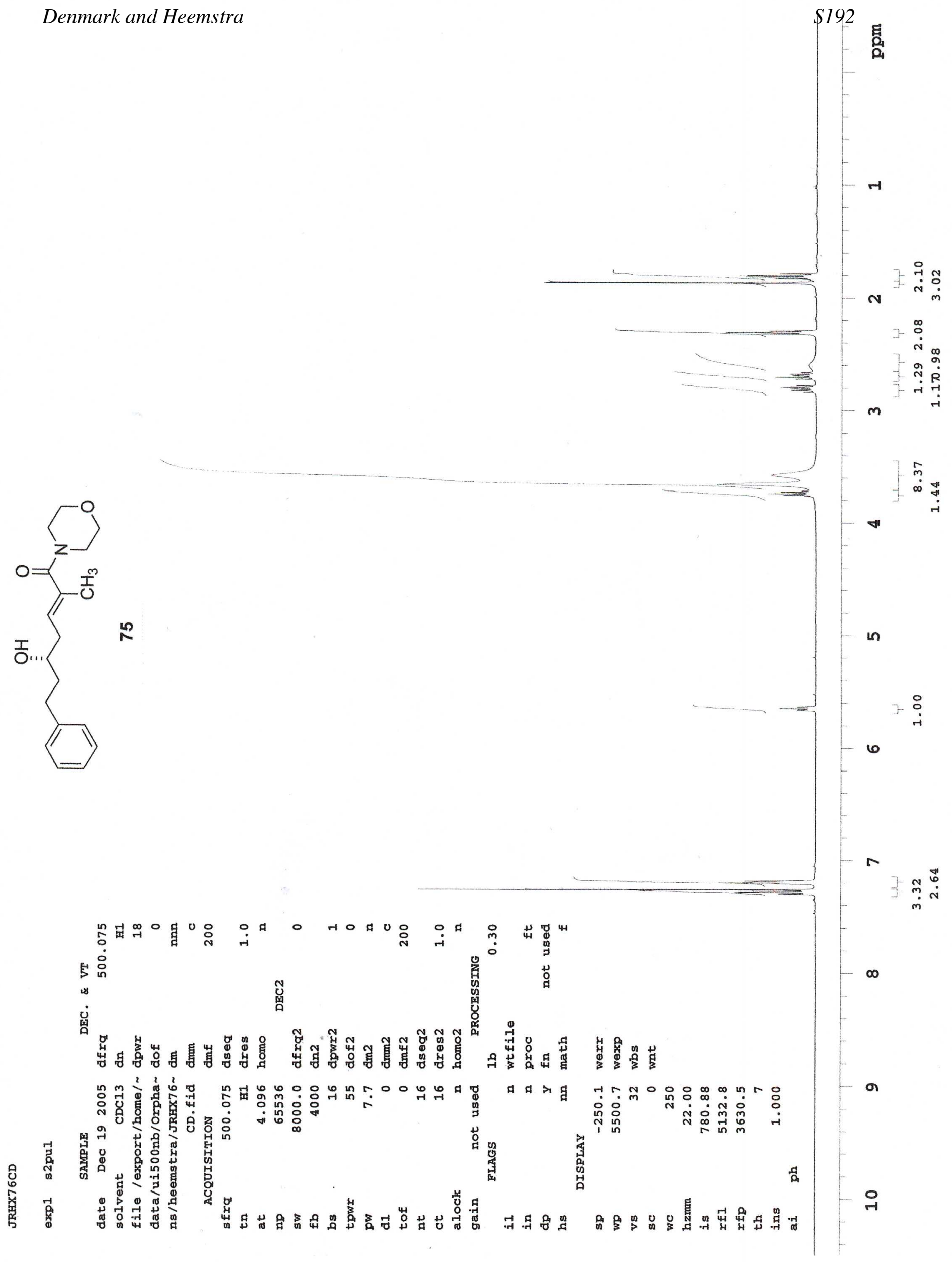


Denmark and Heemstra

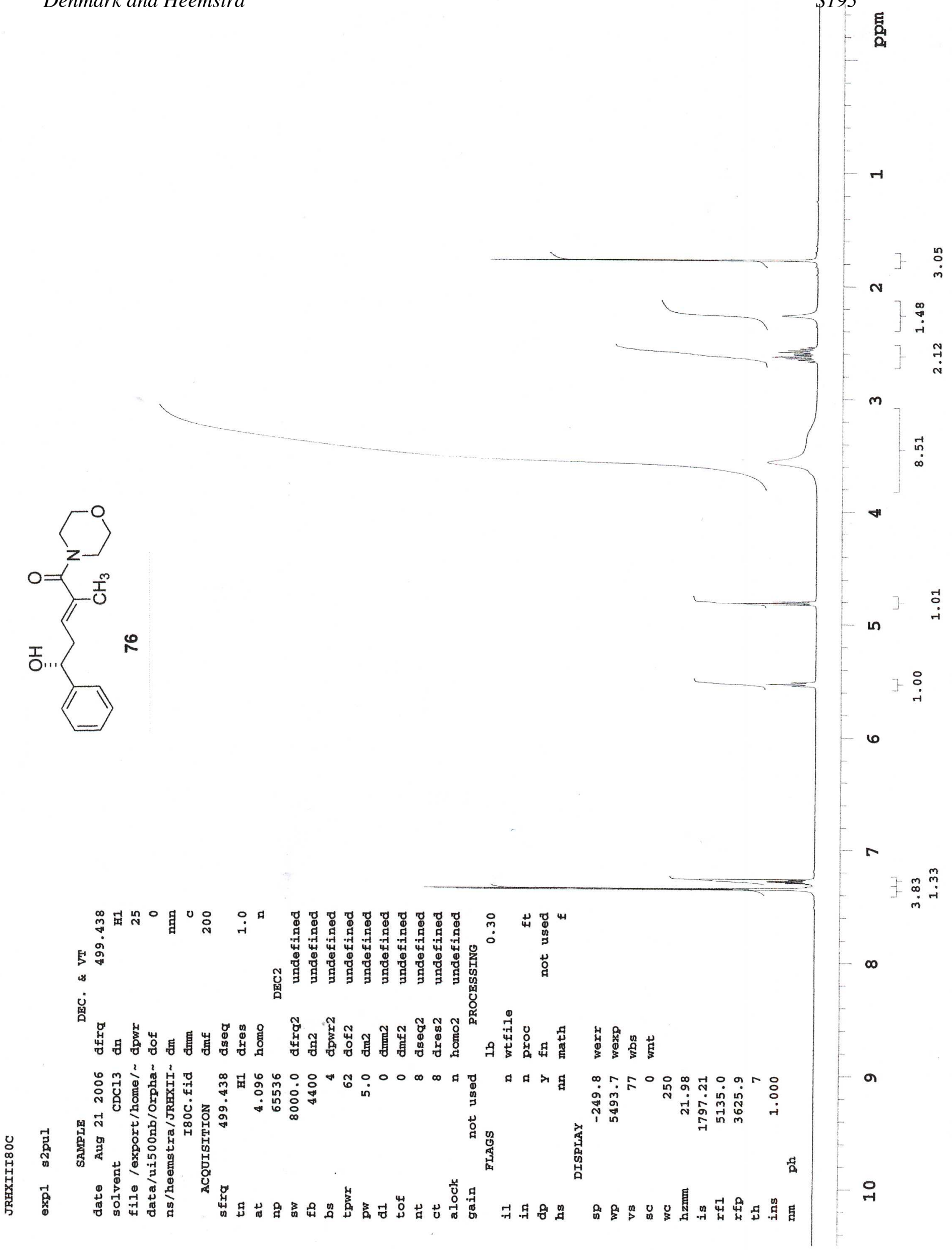

$\$ 193$ 
Denmark and Heemstra
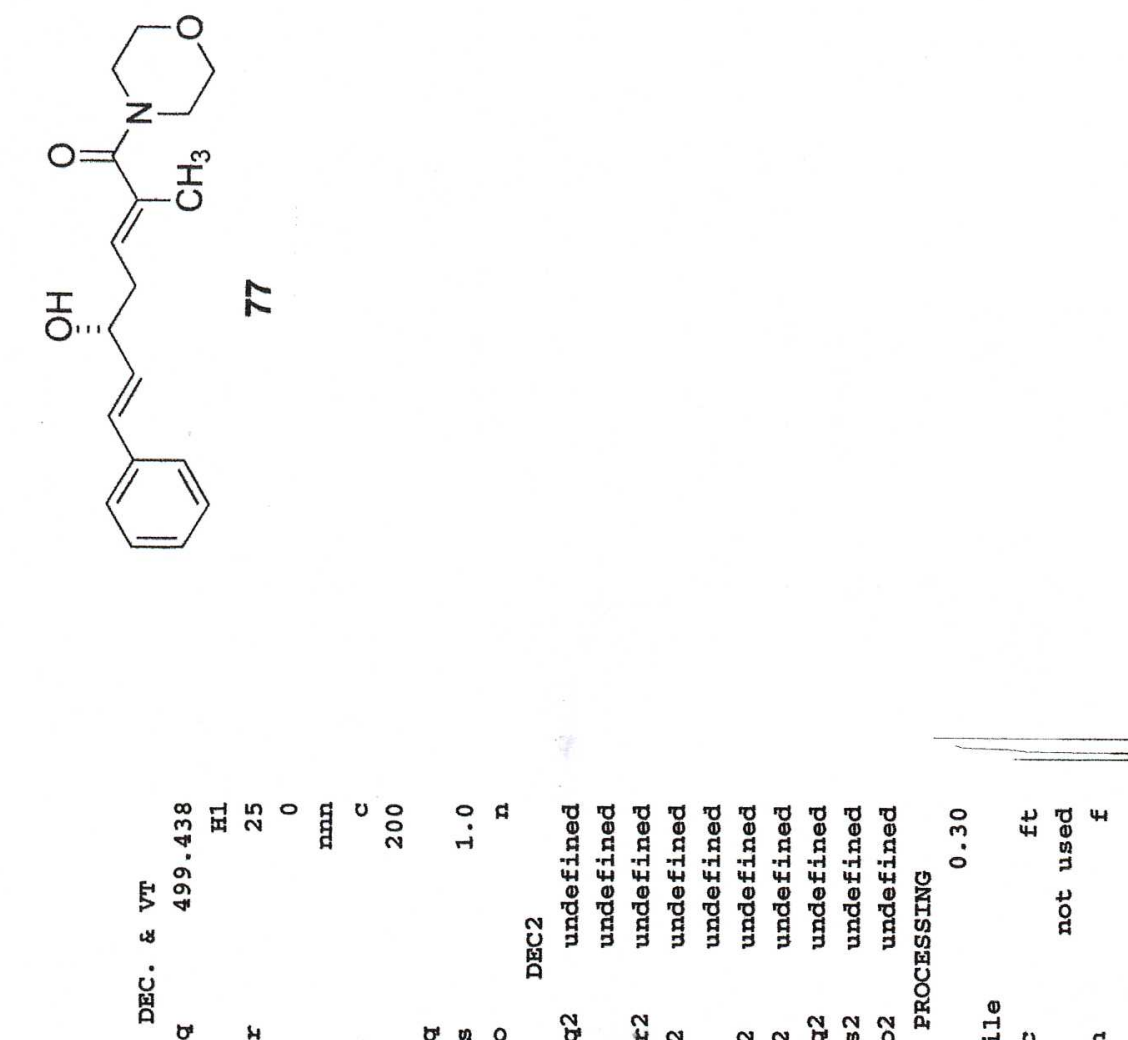

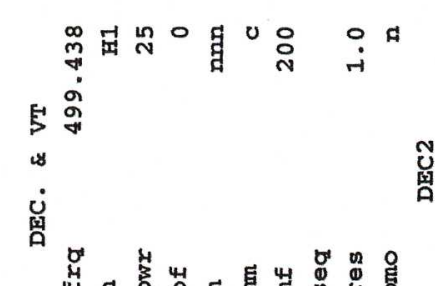

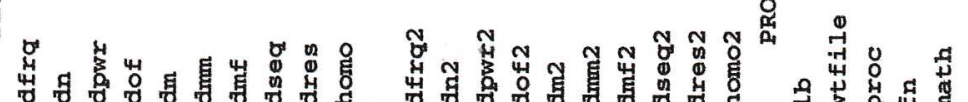

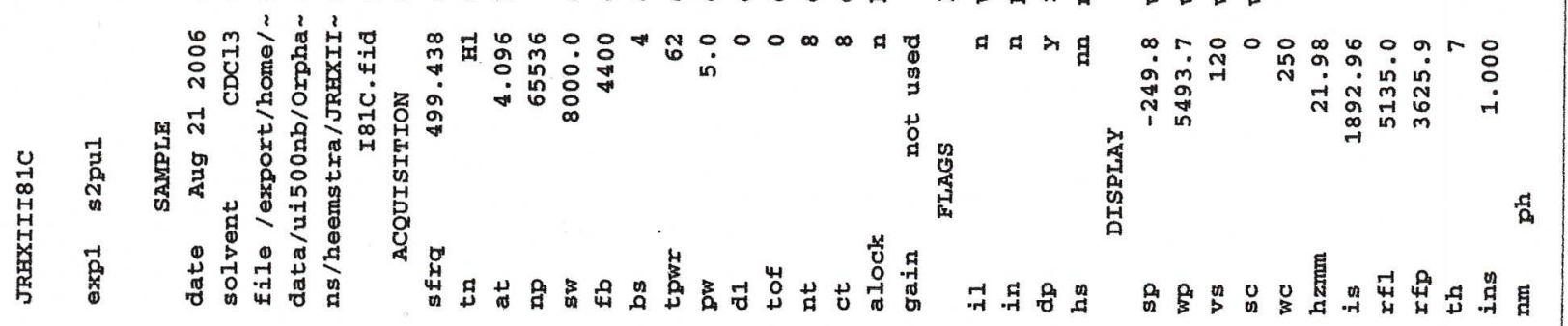

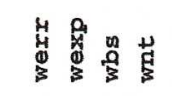

N]

7 웅

m

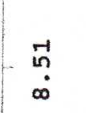

in

J

6

]

ᄀ ดे

n

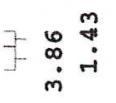

$\infty$

$a$

우 
Denmark and Heemstra

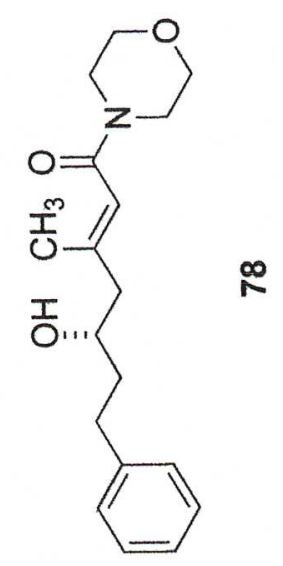

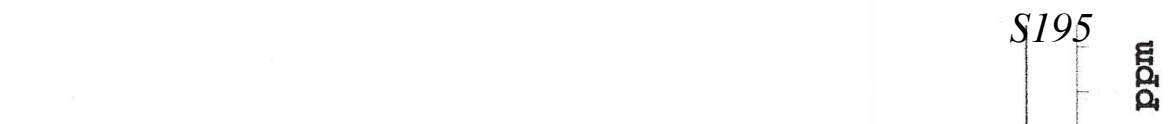

$H$

N

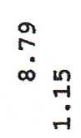

in

$r$

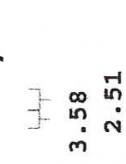

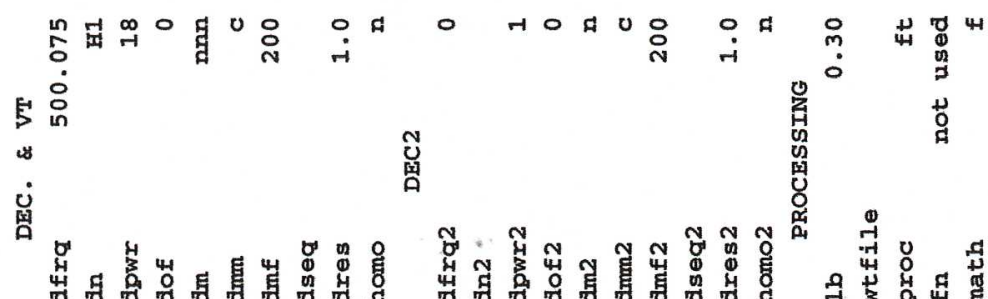

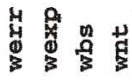

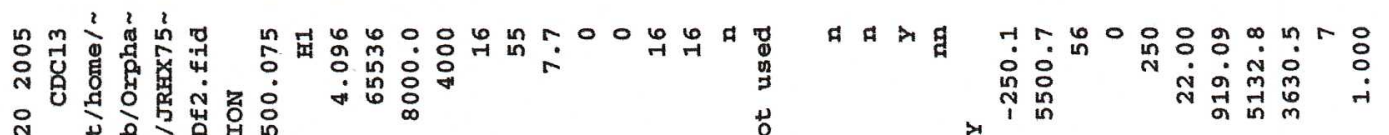

a

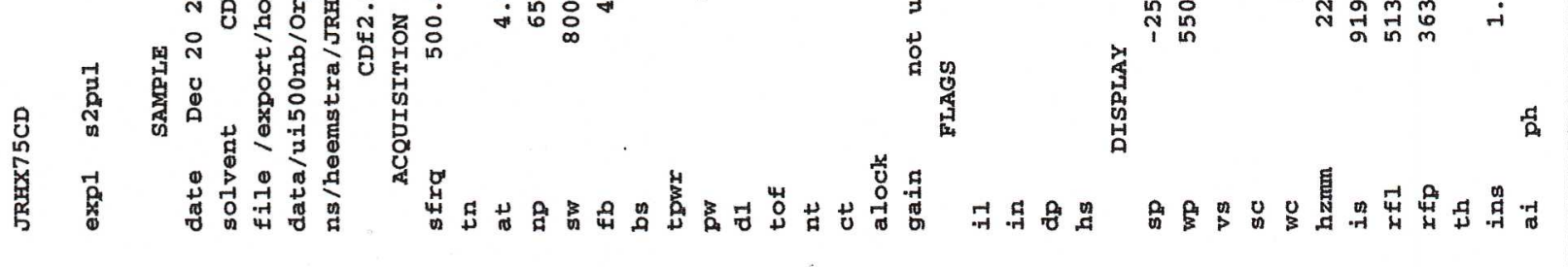

$\infty$

0
0

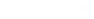


Denmark and Heemstra<smiles>O=C(O)C(=CC(=O)C1CCOCC1)CC[C@@H](O)c1ccccc1</smiles>

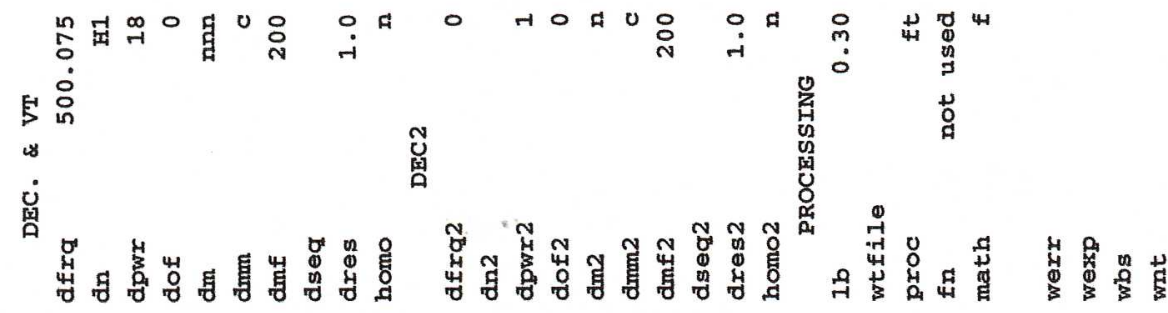




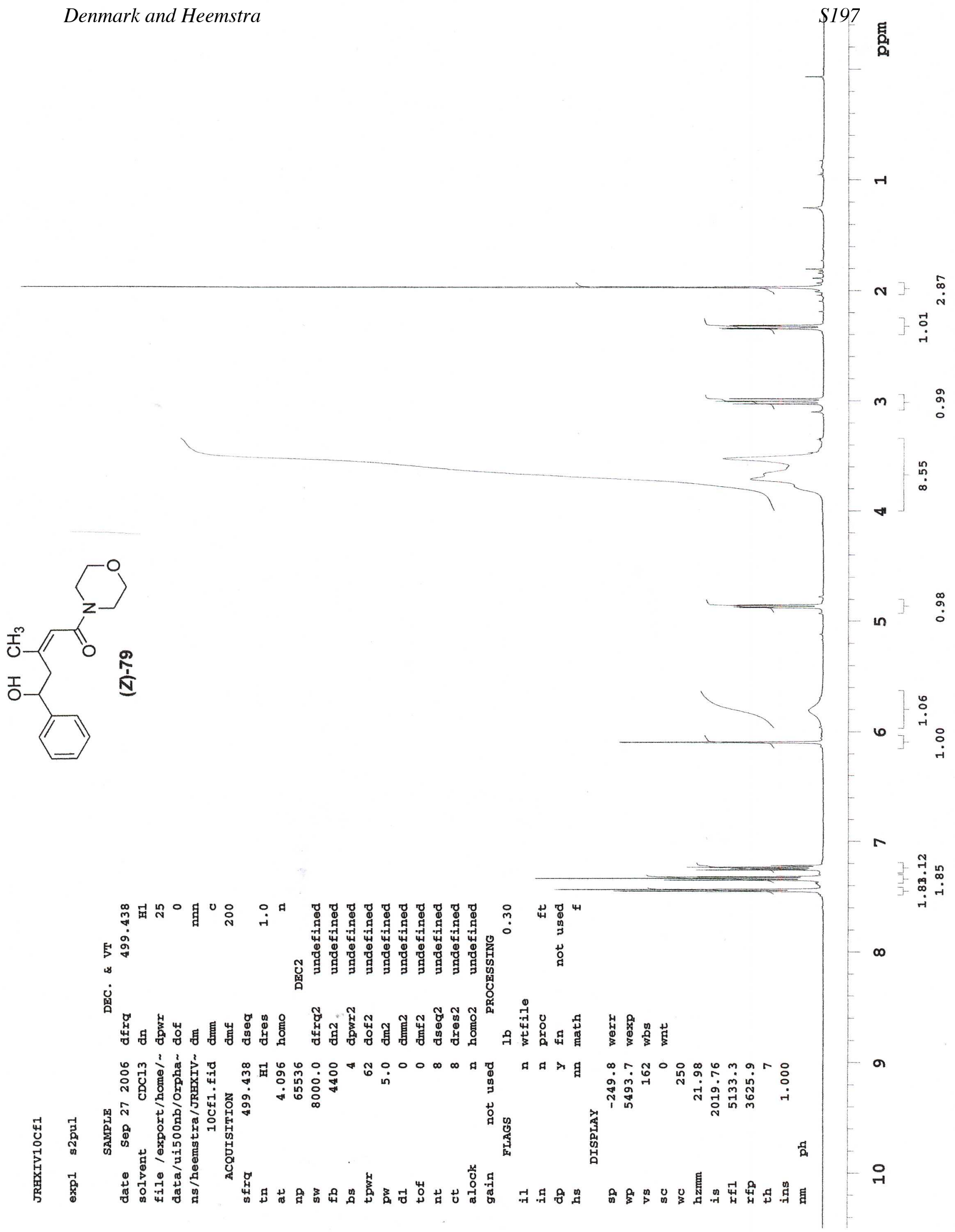




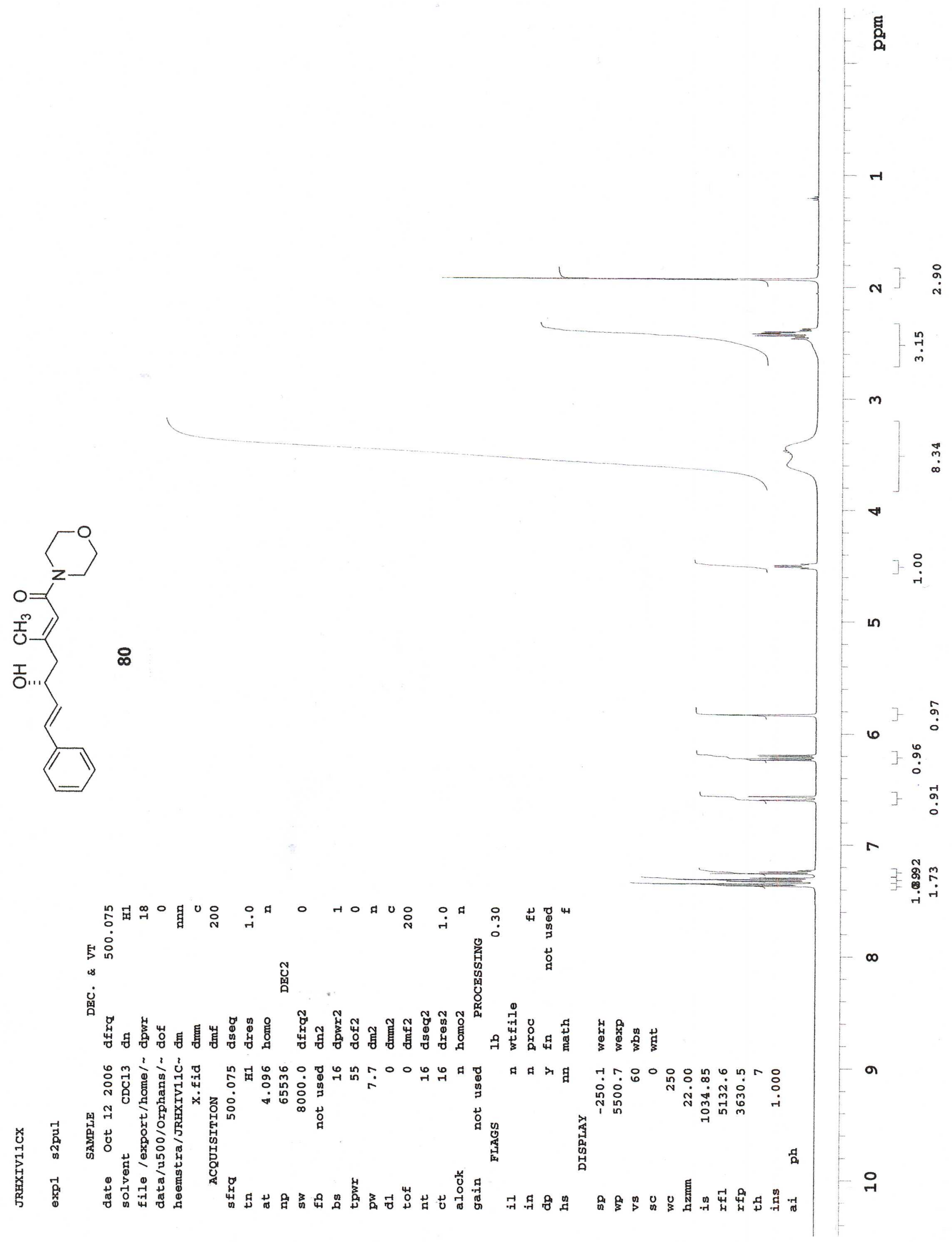




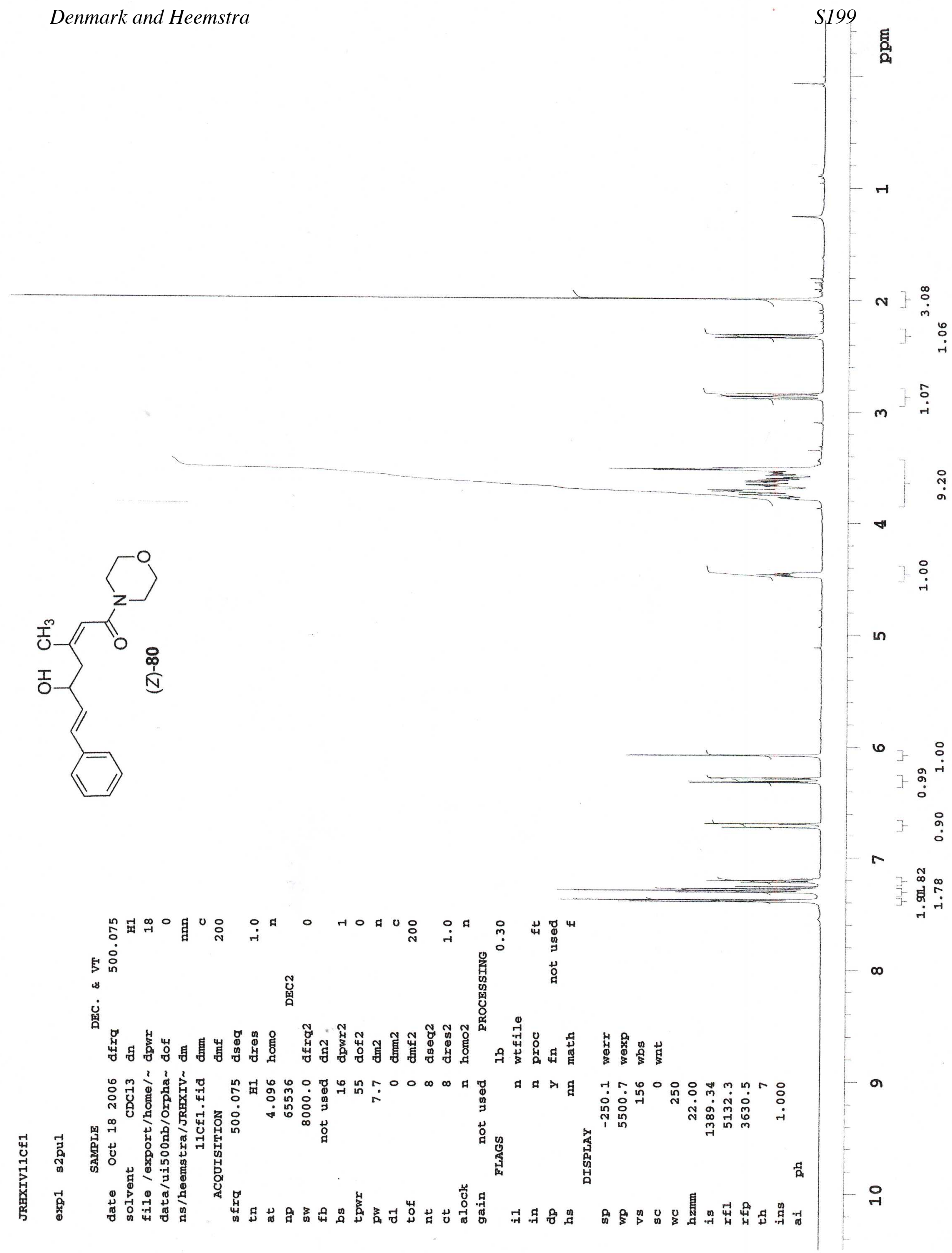


Denmark and Heemstra

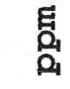

$\stackrel{m}{?}$

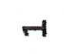

N $\stackrel{m}{\dot{m}}$

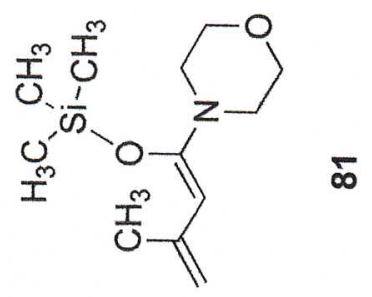

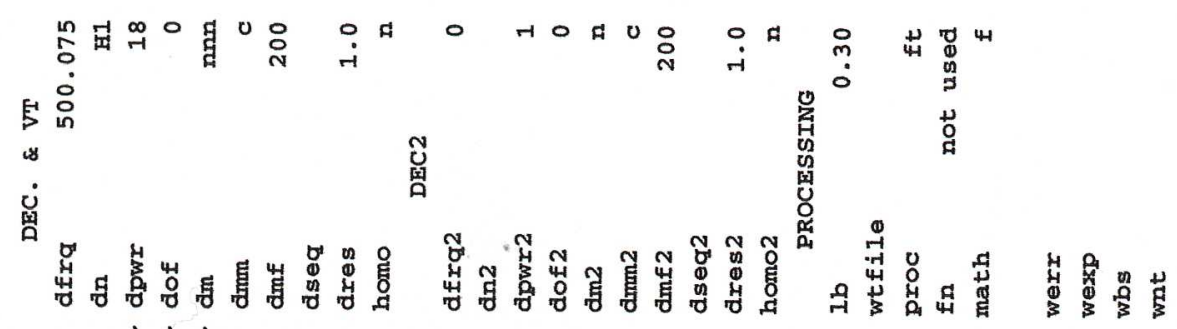

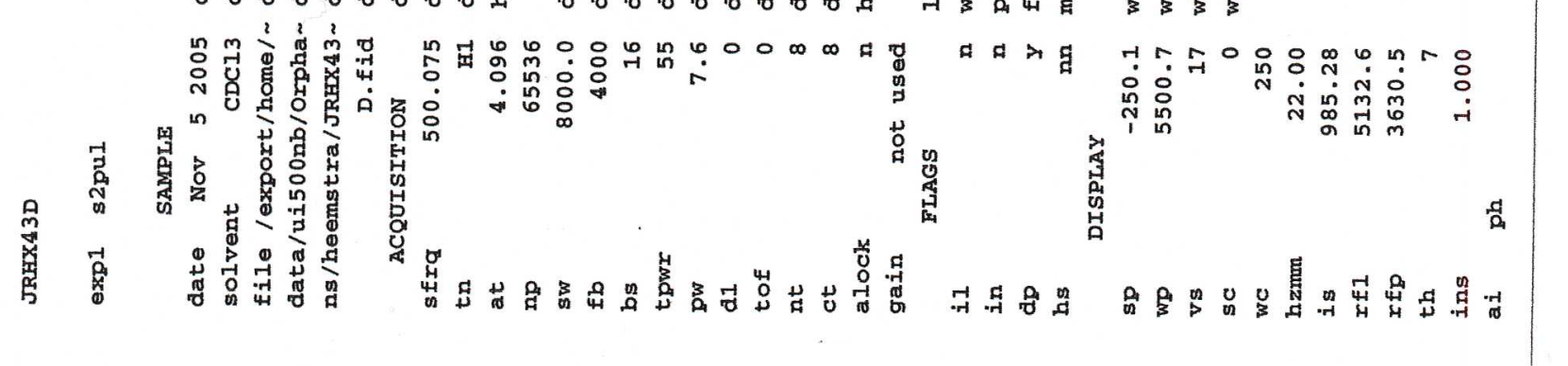




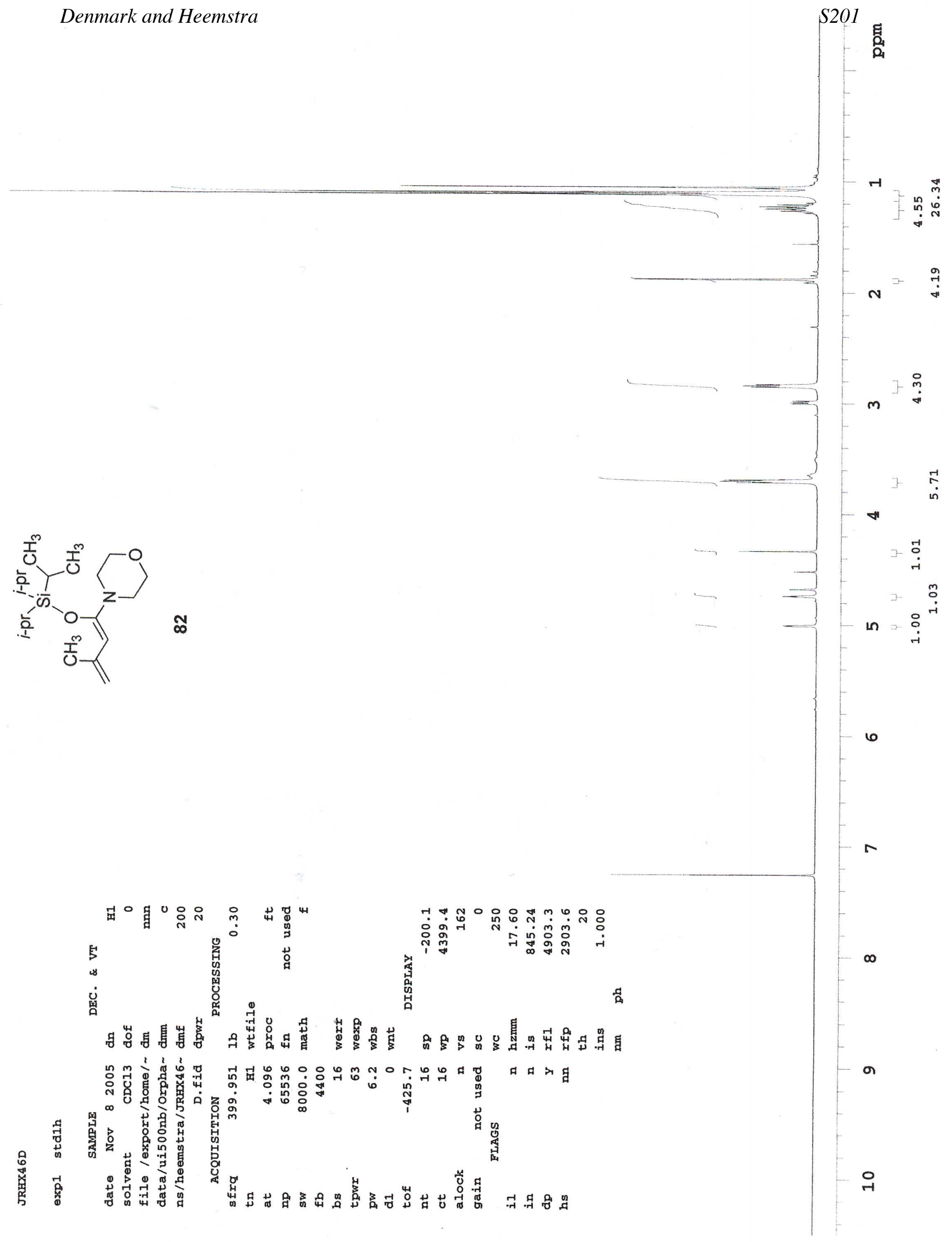


Denmark and Heemstra

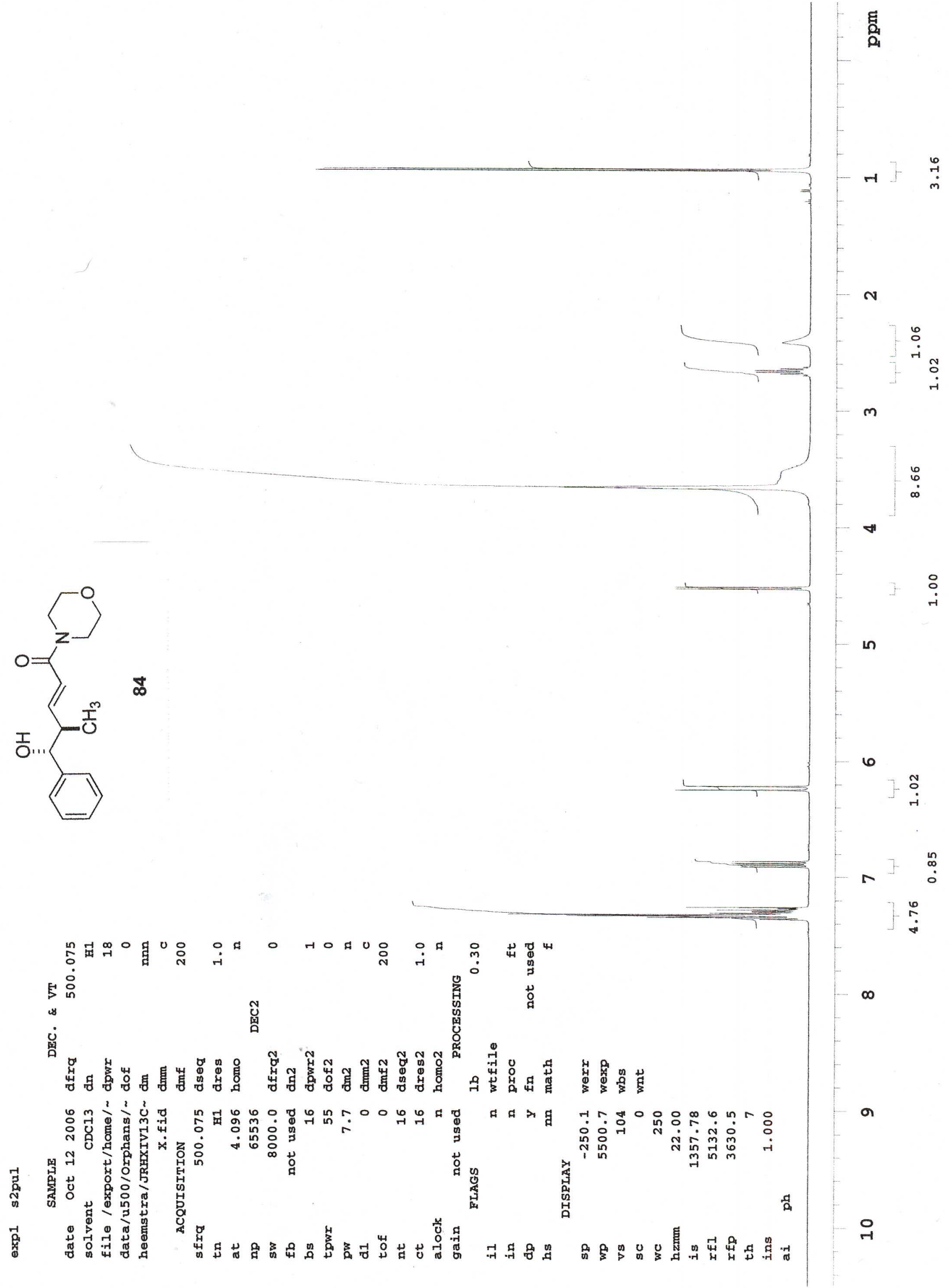


Denmark and Heemstra
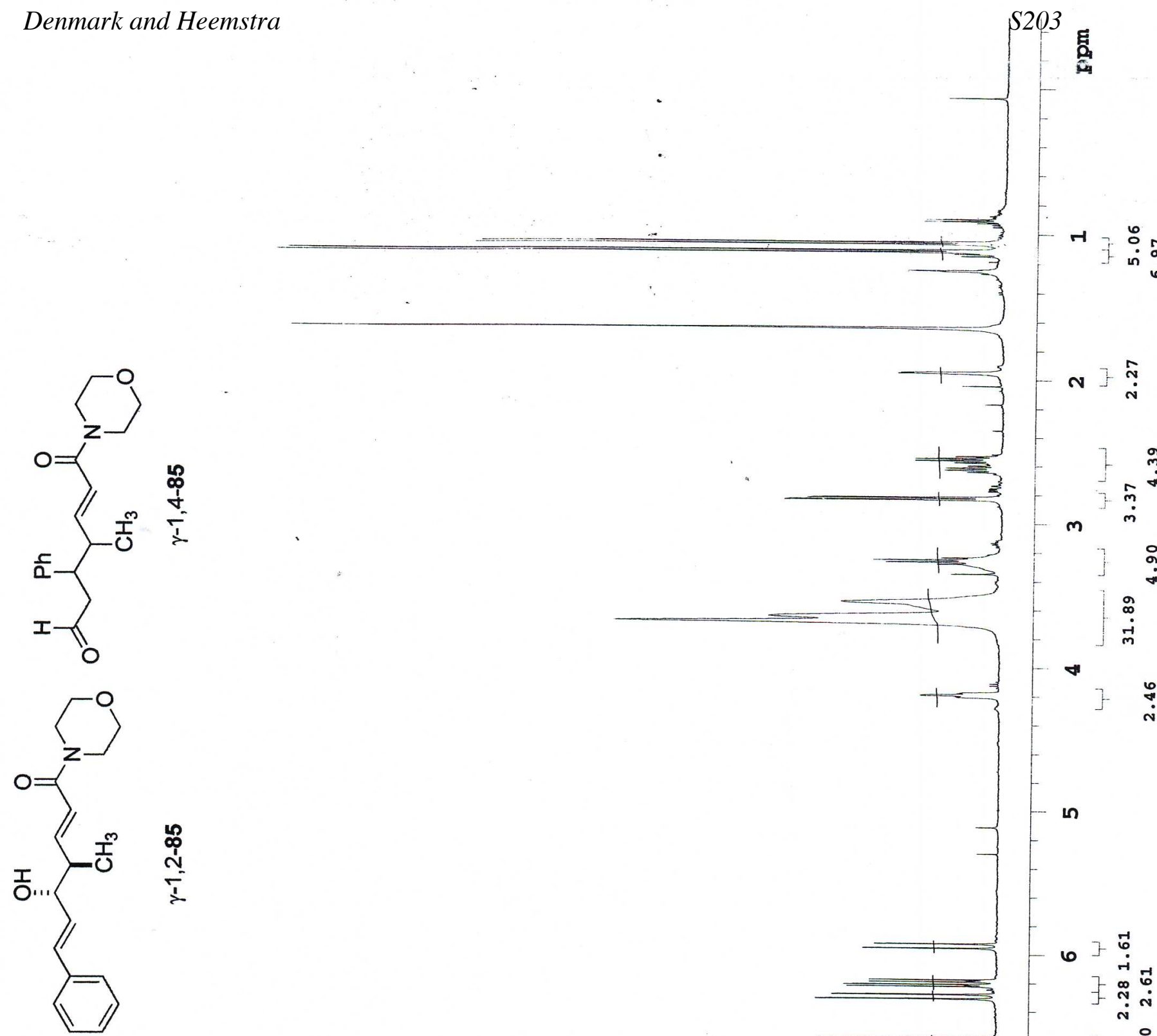
Denmark and Heemstra<smiles>C=CC(C(=O)[C]1CCOCC1)C([O-])C(=O)O</smiles>
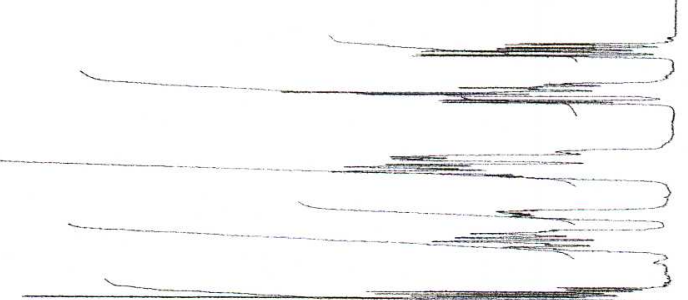

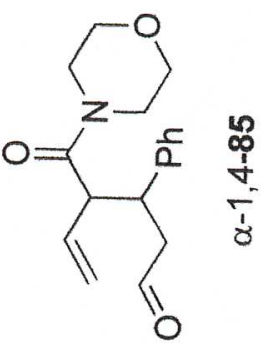

in
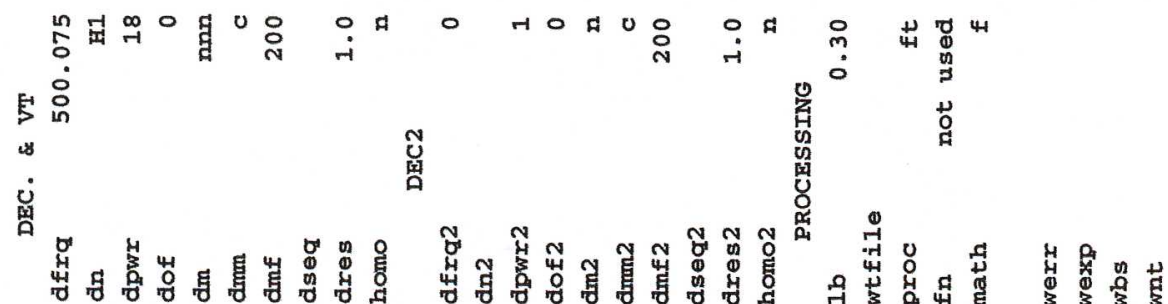

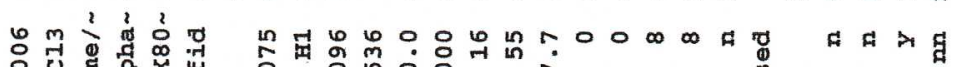

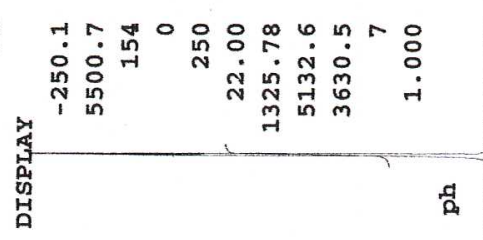

a

$\infty$ 


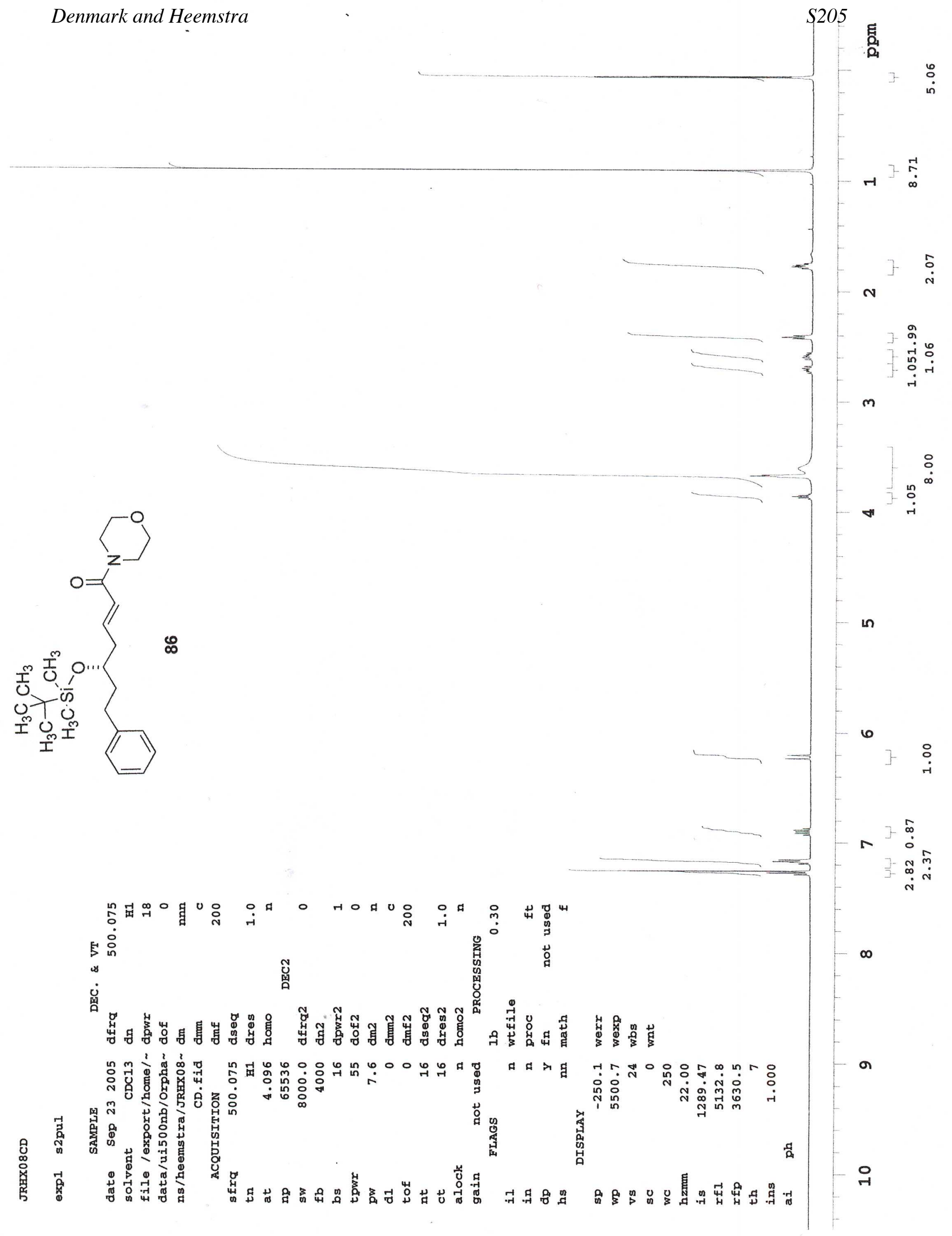


Denmark and Heemstra

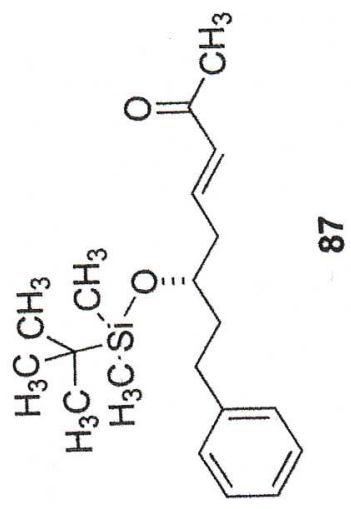

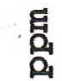

]$\stackrel{\substack{+0}}{0}$

तI

$N$

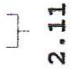

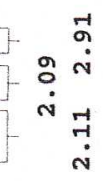

m

in

$6] \quad \frac{7}{0}$

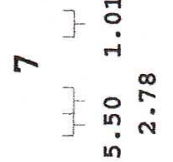

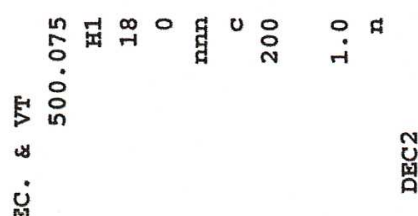

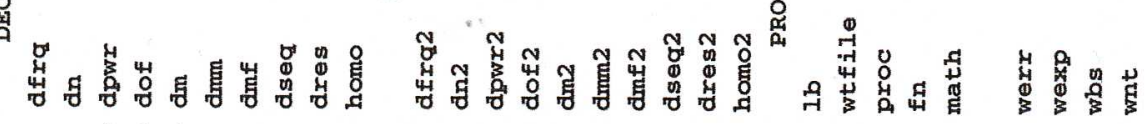

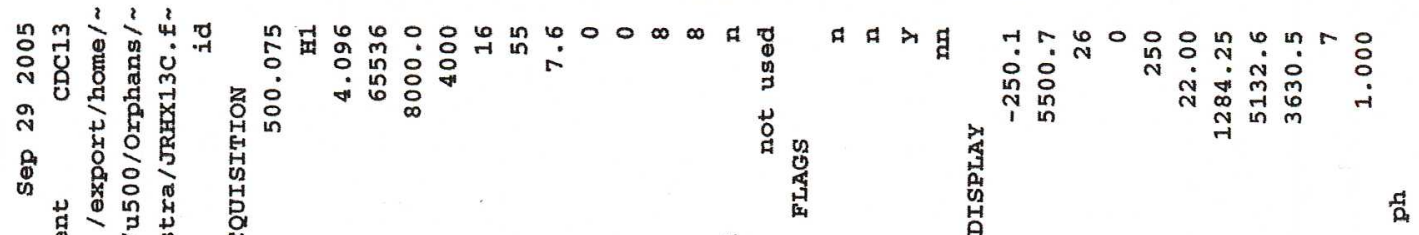

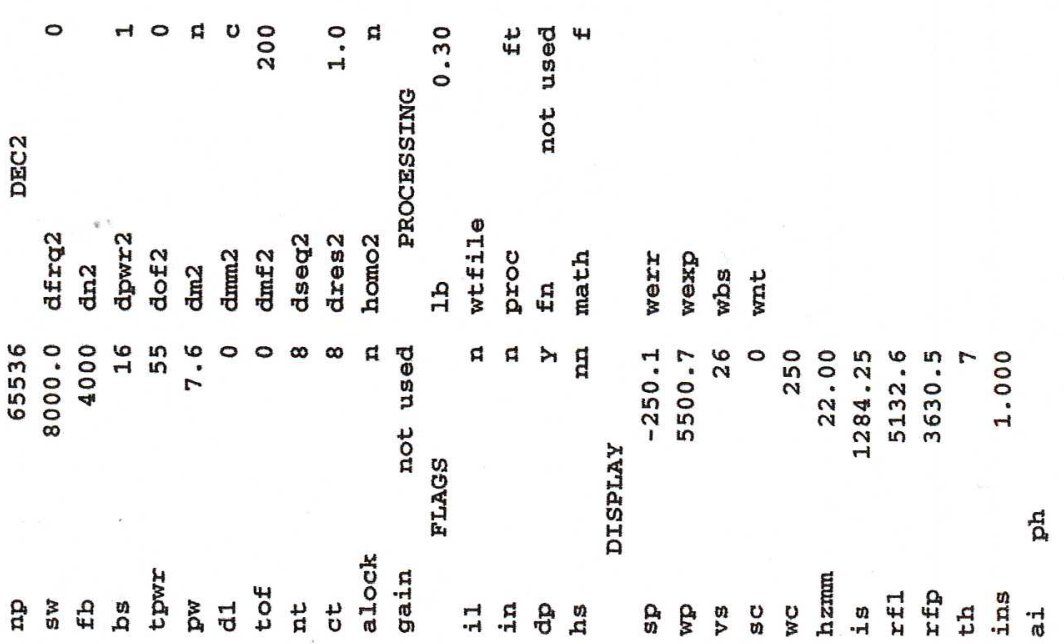

$\infty$ 
Denmark and Heemstra

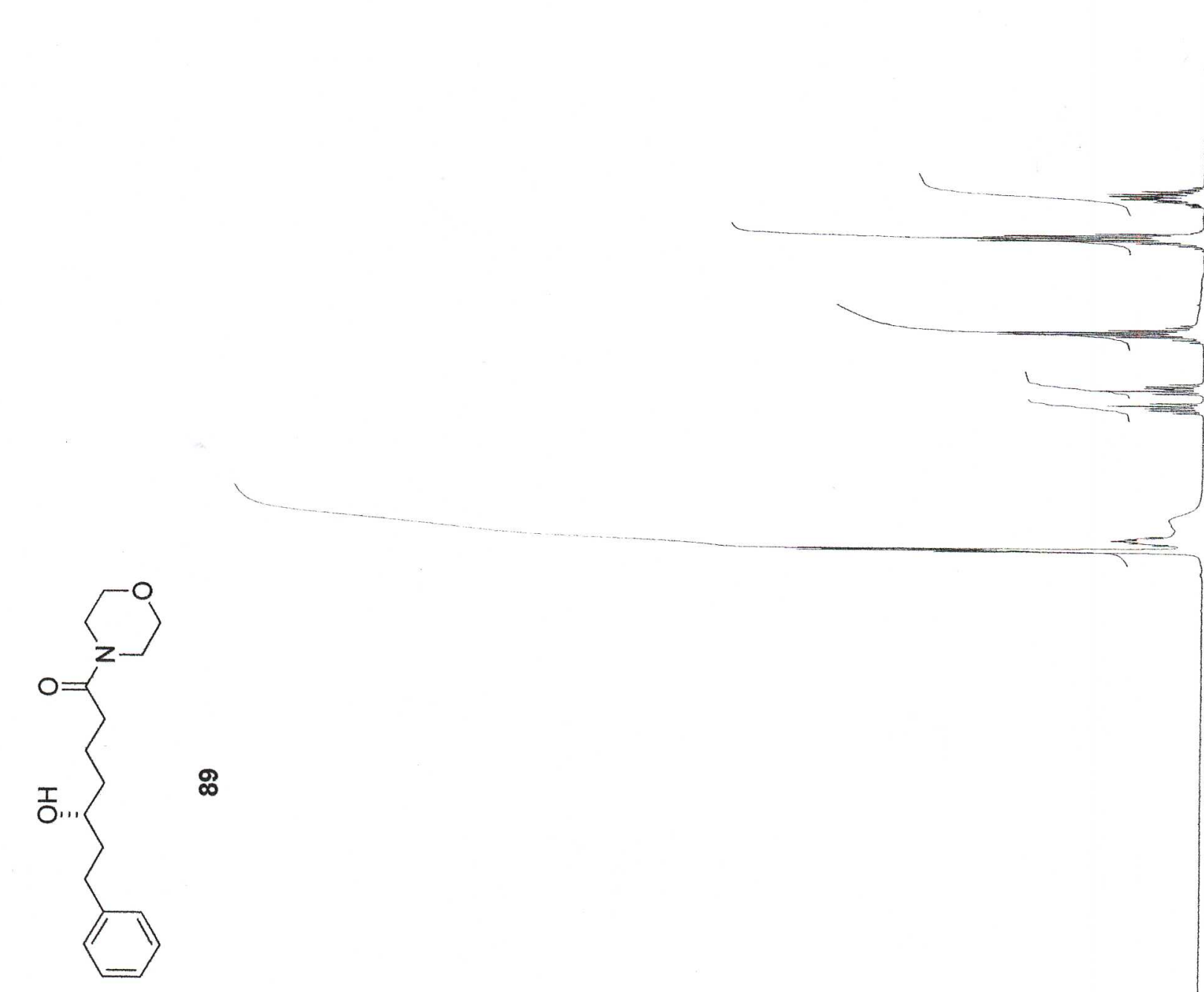

S207 